Дальневосточный федеральный университет

Школа биомедицины

\title{
ГЛИОБЛАСТОМА \\ И СТВОЛОВЫЕ КЛЕТКИ КОСТНОГО МОЗГА
}

Монография

Владивосток

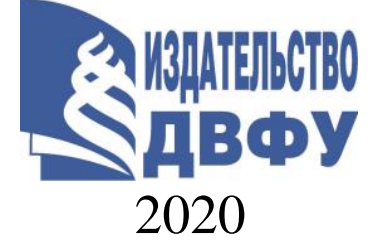




\author{
Aвmоры: \\ И.С. Брюховецкий (гл. 1-10), А.С. Брюховецкий (гл. 1-10), \\ Ю.С. Хотимченко (гл. 1-10), О.И. Пак (гл. 4-8), С.В. Зайцев (гл. 4-8), \\ В.Е. Шевченко (гл. 8), И.А. Ляхова (гл. 9)
}

\title{
Рецензенты:
}

А.В. Полевщиков, д-р биол. наук, профессор, руководитель отдела иммунологии НИИ эксперимент. медицины Северо-Западного отделения РАН (г. Санкт-Петербург); М.И. Давыдов, д-р мед. наук, профессор, академик РАН, заслуженный деятель науки РФ, гл. онколог МЦ Управления делами Президента РФ, зав. каф. онкологии Первого Моск. гос. мед. университета им. И.М. Сеченова (г. Москва).

Глиобластома и стволовые клетки костного мозга : монография /

Г54 И.С. Брюховецкий, А.С. Брюховецкий, Ю.С. Хотимченко, О.И. Пак, С.В. Зайцев, В.Е. Шевченко, И.А. Ляхова ; ДВФУ, Школа биомедицины ; предисл. М.И. Давыдова. - Владивосток : Изд-во Дальневост. федерал. ун-та, 2020. - 254 с. : ил.

ISBN 978-5-7444-4837-0.

DOI dx.doi.org/10.24866/7444-4837-0.

Монография посвящена проблемам применения стволовых клеток (СК) костного мозга $(\mathrm{KM})$ в комплексном лечении одной из самых смертоностных опухолей - мультиформной глиобластомы (МГБ). Основной акцент сделан на взаимодействии СК КМ с опухолевыми стволовыми клетками (ОСК). Изучены закономерности взаимодействия и взаимовлияния гемопоэтических стволовых клеток (ГСК) с опухолевыми клетками, показан противоопухолевый потенциал ГСК и предложены способы его усиления. Проведен анализ протеомных профилей СК и ОК, всесторонне изучена роль трансформирующего фактора роста $1 \beta$ в запуске эпителиально-мезенхимального перехода (ЭМП) в клетках МГБ, показана роль этого цитокина в формировании иммуносупрессивной среды, модулирующей свойства неопластической экосистемы, идентифицированы стратегически важные молекулярные мишени в ОСК глиобластомы человека и показана возможность воздействия на них с использованием биомедицинских клеточных продуктов, созданных на базе мобилизованных мононуклеарных CD45+ клеток КМ, обогащенных ГСК. Отмечены перспективные направления создания биомедицинских клеточных продутов для лечения МГБ с использованием противоопухолевого потенциала СК костного мозга.

Предназначена для онкологов, неврологов, гематологов и врачей других специальностей, а также для студентов вузов и сотрудников научно-исследовательских учреждений.

Ключевые слова: глиобластома, красный костный мозг, фактор роста, цитокины, стволовые клетки, гематоэнцефалический барьер, глиальная опухоль.

ББК 616

Glioblastoma and bone marrow stem cells: monograph / I. Bryukhovetskiy, A. Bryukhovetskiy, Y. Khotimchenko, O.I. Pak, S.V. Zaitsev, V.E. Shevchenko, I.A. Lyakhova ; FEFU, School of Biomedicine ; foreword M.I. Davydov. - Vladivostok : FEFU Publishing House, 2020. - 254 p. : il. - ISBN 978-5-7444-4837-0.

Keywords: glioblastoma, red bone marrow, growth factor, cytokines, stem cells, bloodbrain barrier, glial tumor. 


\section{ОГЛАВЛЕНИЕ}

СПИСОК СОКРАЩЕНИЙ И ОБОЗНАЧЕНИЙ........................................... 7

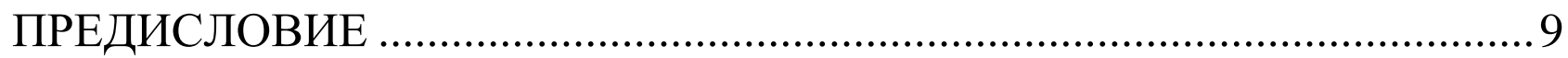

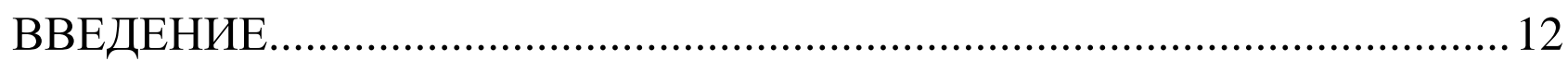

ГЛАВА 1. МУЛЬТИФОРМНАЯ ГЛИОБЛАСТОМА:

ОБЩАЯ ХАРАКТЕРИСТИКА ПРОБЛЕМЫ ............................................ 14

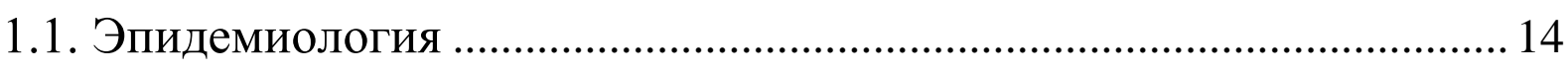

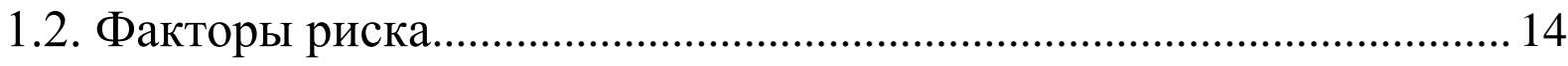

1.3. Классификация МГБ и других глиом

как узловая точка проблемы .................................................................... 15

1.4. Молекулярно-генетические нарушения в клетках МГБ ................. 17

1.5. Взгляды на этиологию и патогенез глиобластомы ........................... 18

1.6. Опухолевые стволовые клетки ............................................................ 20

1.7. Эпителиально-мезенхимальный переход

и трансформирующий фактор роста $\beta$.................................................... 24

1.8. Межклеточные взаимодействия в ангиогенезе и

иммуносупрессивная локальная микросреда........................................2 27

ГЛАВА 2. СУЩЕСТВУЮЩИЕ ПОДХОДЫ К ДИАГНОСТИКЕ

И ЛЕЧЕНИЮ ГЛИОБЛАСТОМЫ И ПУТИ ИХ ОПТИМИЗАЦИИ ......... 32

2.1. Нейровизуализационная картина МГБ ................................................ 33

2.2. Морфологическая характеристика МГБ............................................. 33

2.3. Лечение впервые диагностированной глиобластомы ...................... 34

2.4. Лечение рецидива глиобластомы..................................................... 36

2.5 Пути повышения эффективности генотоксической терапии

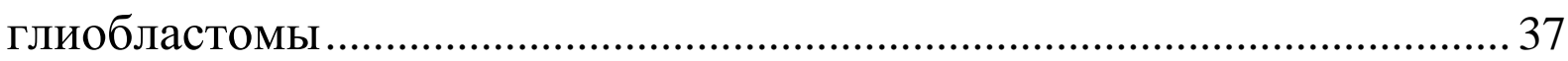

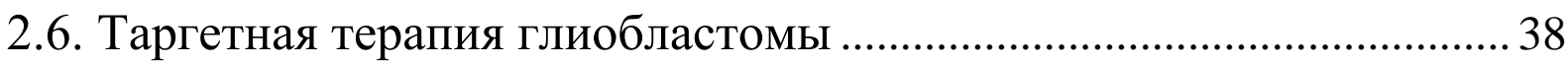

2.7. Перспективные молекулы для создания новых генотоксических средств ............................................................................ 41

2.8. Химиотерапия и гематоэнцефалический барьер ............................... 42

2.9. Иммунотерапия МГБ ........................................................................... 44

ГЛАВА 3. ПРОТИВООПУХОЛЕВЫЙ ПОТЕНЦИАЛ

ГЕМОПОЭТИЧЕСКИХ СТВОЛОВЫХ КЛЕТОК В ТЕРАПИИ

ГЛИОБЛАСТОМЫ . 
ГЛАВА 4. ФУНДАМЕНТАЛЬНЫЕ АСПЕКТЫ ПРОБЛЕМЫ:

ВЗАИМОДЕЙСТВИЕ ГЕМОПОЭТИЧЕСКИХ СТВОЛОВЫХ И ОПУХОЛЕВЫХ КЛЕТОК IN VITRO

4.1. Закономерности миграции гемопоэтических стволовых клеток к опухолевым клеткам различных линий in vitro

4.1.1. Миграция стволовых клеток млекопитающих

в сочетанных культурах с клетками различных линий in vitro.......54

4.1.2. Миграция стволовых клеток человека в сочетанных

культурах с клетками злокачественных опухолей

различных линий

4.2. Взаимодействие стволовых клеток человека с клетками

злокачественных опухолей in vitro.

4.2.1. Взаимодействие гемопоэтических стволовых клеток

на модели глиомы линии С6

4.2.2. Взаимодействие гемопоэтических стволовых клеток

с клетками злокачественных опухолей человека

4.3. Обсуждение полученных данных

ГЛАВА 5. ФУНДАМЕНТАЛЬНЫЕ АСПЕКТЫ ПРОБЛЕМЫ:

ВЗАИМОДЕЙСТВИЕ ГЕМОПОЭТИЧЕСКИХ СТВОЛОВЫХ И ОПУХОЛЕВЫХ КЛЕТОК НА МОДЕЛИ ГЛИОБЛАСТОМЫ

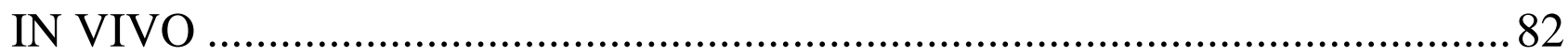

5.1. Создание экспериментальной модели глиобластомы in vivo ........ 82

5.2. Анализ миграции гемопоэтических стволовых клеток в опухолевый очаг.

5.3. Взаимодействие гемопоэтических стволовых клеток

с клетками глиомы С6 в опухолевом очаге.

5.3.1. Рекрутирование ГСК в системный кровоток

экспериментального животного с глиомой С6 96

5.3.2. Характеристика иммуногистохимических трансформаций опухолевого узла в мозге крыс с рекрутированными

в системный кровоток ГСК 96

5.4. Иммуноферментный анализ экспрессии цитокинов в вытяжке опухоли и прилежащей ткани мозга у контрольных

и экспериментальных животных

5.5. Обсуждение результатов главы 5 
ГЛАВА 6. ТРАНСФОРМИРУЮЩИЙ ФАКТОР РОСТА $\beta$

В ПРОЦЕССАХ ВЗАИМОДЕЙСТВИЯ ГЕМОПОЭТИЧЕСКИХ

СТВОЛОВЫХ И ОПУХОЛЕВЫХ КЛЕТОК IN VITRО ......................... 125

6.1. Влияние TGF- $\beta 1$ на клетки глиобластомы.................................... 125

6.2. Морфологические (ультраструктурные) особенности клеток

линии U87 глиобластомы после стимуляции TGF- $\beta 1$

6.3. Влияние TGF- $\beta 1$ на подвижность клеток глиобластомы

6.4. Закономерности взаимодействия ГСК с клетками глиобластомы, предобработанными TGF- $\beta 1$ in vitro

6.4.1. Изученеие общих закономерностей взаимодействия ГСК

с клетками глиобластомы, предобработанными TGF- $\beta 1$

6.4.2. Разработка методов повышения эффективности

взаимодействия ГСК с клетками глиобластомы, предобработанными TGF- $\beta 1$ in vitro

ГЛАВА 7. ТРАНСФОРМИРУЮЩИЙ ФАКТОР РОСТА $\beta$

В ПРОЦЕССАХ ВЗАИМОДЕЙСТВИЯ ГЕМОПОЭТИЧЕСКИХ

СТВОЛОВЫХ И ОПУХОЛЕВЫХ КЛЕТОК IN VIVO

7.1. Материалы и методы проведения иследования.

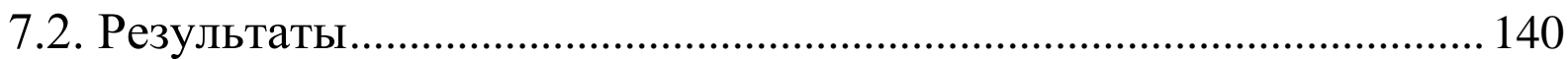

7.3. Обсуждение результатов главы......................................................... 152

\section{ГЛАВА 8. ПРОТЕОМИКА СТВОЛОВЫХ И ОПУХОЛЕВЫХ}

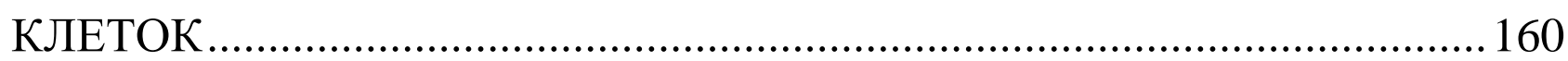

8.1. Сравнительный анализ протеомных профилей нормальных нейральных CD 133+ стволовых клеток человека, мезенхимальных CD29+, CD44+, CD73+, CD90+, CD34- стволовых клеток костного мозга человека и опухолевых (CD133+) стволовых клеток (OCK) глиобластомы человека

8.2. Сравнительное картирование стволовых $\mathrm{CD} 133+$ и

дифференцированных CD133- клеток глиобластомы. 165

8.3. Сравнительный анализ ключевых параметров протеома ОСК и ДКГ, обработанных TGF- $\beta 1$ 170

8.4. Сравнительный анализ ключевых параметров протеома CD133+

ОСК МГБ человека до и после экспериментального облучения 173 8.5. Обсуждение результатов главы 8 
8.5.1. Обсуждение результатов сравнительного картирования стволовых и опухолевых клеток

8.5.2. Обсуждение результатов сравнительного картирования ОСК и ДКГ

8.5.3. Обсуждение результатов сравнительного анализа ключевых параметров протеома ОСК и ДКГ обрабобанных TGF- $\beta 1$

8.5.4. Обсуждение результатов сравнительного анализа ключевых параметров протеома CD133+ ОСК МГБ человека до и после экспериментального облучения

ГЛАВА 9. ПРОТИВООПУХОЛЕВАЯ ЭФФЕКТИВНОСТЬ ПРОИЗВОДНЫХ МОРСКИХ АЛКАЛОИДОВ КАК ПОТЕНЦИАЛЬНЫХ ЛЕКАРСТВЕННЫХ СРЕДСТВ ДЛЯ АДРЕСНОЙ ДОСТАВКИ

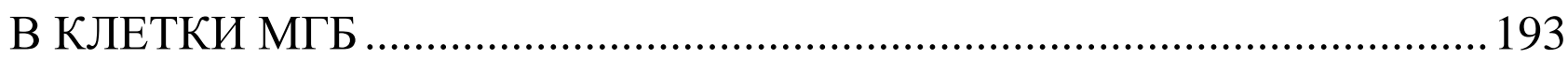

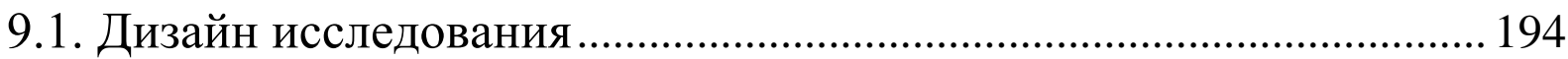

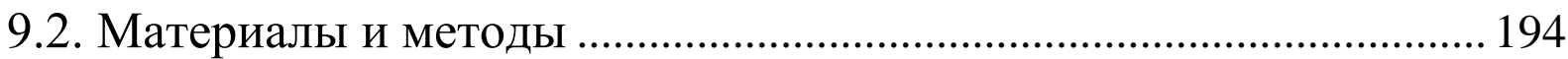

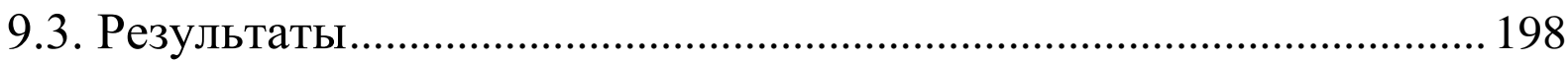

ГЛАВА 10. БИОМЕДИЦИНСКИЕ КЛЕТОЧНЫЕ ПРОДУКТЫ И ТЕХНОЛОГИИ ДЛЯ РЕГУЛЯЦИИ ФУНКЦИЙ СТВОЛОВЫХ КЛЕТОК В КОМПЛЕКСНОЙ ТЕРАПИИ МГБ: РЕАЛЬНОСТЬ

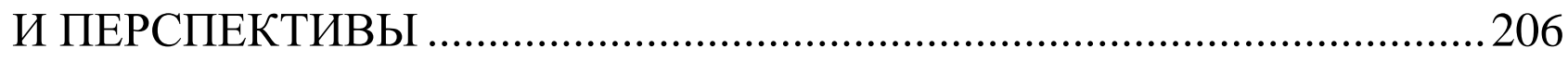

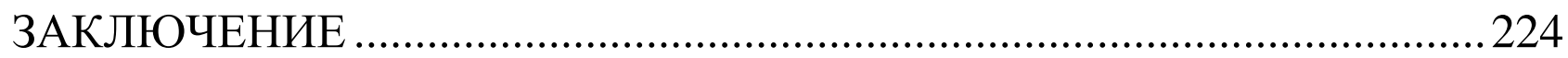

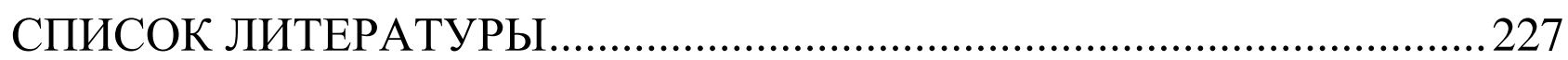




\section{СПИСОК СОКРАЩЕНИЙ И ОБОЗНАЧЕНИЙ}

БСА Бычй сывороточный альбумин

BO3 Всемирная организация здравоохранения

ВКМ Внеклеточный матрикс

ВЭЖХ-МС Высокоэффективная жидкостная хроматография масс-спектрометрия

ГО Глиальные опухоли

ГCК Гемопоэтические стволовые клетки

ГЭБ Гематоэнцефалический барьер

ДВ Дендритные вакцины

ДЭБ Дифференциально экспрессированные белки

МГБ Мультиформная глиобластома

МССК Мезенхимальные стромальные стволовые клетки

МНК Мононуклеарные клетки

MPT Магнитно-резонансная томография

НСК Нейральные стволовые клетки

ОК Опухолевые клетки

ОСК Опухолевые стволовые клетки

СК Стволовые клетки

ХT Химиотерапия

ЦНС Ц Центральная нервная система

ЭМП Эпителиально-мезенхимальный переход

CFDA SE Carboxyfluorescein diacetate, succinimidyl ester

(Карбоксифлуоресцеин диацетат сукцинимидил эфира)

DMEM Dulbecco's Modified Eagle Medium

(Модифицированная по способу Дульбекко среда Игла)

EGF Epidermal growth factor (Эпидермальный фактор роста)

FBS Fetal bovine serum (Эмбриональная телячья сыворотка)

FGF $\beta$ Fibroblast growth factor (Фактор роста фибробластов)

HGF Hepatocyte growth factor (Фактор роста гепатоцитов)

HMGP1 high-mobility group protein B1 (Амфотерин) 
MCP-1 Monocyte Chemoattractant Protein-1 (Белок-хемоатрактант моноцитов)

PBS Phosphate buffered saline

(Забуференныий фосфатом физиологическиий раствор, ЗФР)

PDGF Platelet-Derived Growth Factor (Тромбоцитарный ростовой фактор)

SDF-1 $\alpha$ Stromal cell-derived factor $1 \alpha$ (Фактор стромальных клеток)

TGF- $\beta$ Трансформирующий фактор роста- $\beta$

GFAP Глиальный фибриллярный кислый белок 


\section{ПРЕДИСЛОВИЕ}

Настоящая монография посвящена одному из фундаментальных вопросов онкологии, - взаимодействию нормальных стволовых и опухолевых клеток. Тема эта чрезвычайно сложная и глубокая. Нормальные стволовые клетки, а именно стволовые клетки костного мозга, вероятно, представляют ту самую третью силу, которая существует и осуществляет взаимодействие между системами врожденного и приобретенного иммунитета.

Именно стволовые клетки костного мозга способны наиболее тонко реагировать на сигналы со стороны патологически измененных компонентов внеклеточного матрикса опухолевого очага и, возможно, ремодулировать матрикс, ориентируясь на цитокиновый сигнал клеточного микроокружения, что итоге и определяет степень зрелости, характер роста и другие свойства новообразования.

В фокусе внимания достаточно известного коллектива авторов - миграция стволовых клеток костного мозга в неопластический очаг, причем объектом экспериментального исследования выбрана мультиформная глиобластома - одна из самых сложных форм и локализаций опухолевого процесса, которой уделяется мало внимания. Между тем проблема очень актуальная, так как число больных с опухолями мозга велико и, очевидно, будет только расти. Схемы лечения опухолей мозга, использующие лучевую и химиотерапию, отработаны до мелочей. К сожалению, для больного с таким диагнозом никакого спасения нет. Максимумальная продолжительнрость жизни человек с этим заболеванием - полтора года.

Однако наука не стоит на месте. В этой связи очень примечательно, что в данной работе проведен глубокий и систематизированный аналитический обзор самой современной литературы, результаты которого впервые публикуются на русском языке. Заслуживает внимания критическая подача материала, а также тот факт, что анализ рассматриваемой проблемы слагается из довольно большого количества материала, который ранее прошел рецензирование.

При построении экспериментального исследования основной акцент авторами был сделан на взаимоотношения в системе «опухолевая стволовая клетка и гемопоэтическая стволовая клетка костного мозга». Авторами проведено множество параллелей между этими живыми объектами, изучены их свойства, показана возможность взаимодействия между ними и 
установлены закономерности и особенности такого взаимодействия, проиллюстрированы факты, свидетельствующие о возможности сложных, атрактивных и взаимно ориентированных персмиссивных взаимовлияний между ними.

Особого внимания заслуживает описанная авторами возможность воздействия цитокинового сигнала, генерируемого опухолевыми клетками, а именно сигнала трансформирующего фактора роста $\beta$, на нормальные стволовые и на опухолевые клетки. Показано, что именно цитокиновый сигнал из опухолевого очага предопределяет позиции основных «игроков» на данном поле. Применительно к неопластическим клеткам он усиливает взаимодействие с внеклеточным матриксом, индуцирует миграцию и инвазию опухолевых клеток, а в случае с нормальными стволовыми клеткам играет детерминирующую роль и препятствует ремоделированию внеклеточного матрикса и запускает ангиогенные процессы.

С патогенетических позиций обоснована роль внутриопухолевой гипоксии, которая предопределяет основные свойства опухолевых клеток, служит фактором отбора, выживания и агрессии. Заслуживает пристального внимания ряд новых данных о различиях протеома дифференцированных и стволовых клеток глиобластомы, парадоксальный факт сглаживания этих различий после стимуляции TGF- $\beta$, а также феноменальные отличия стволовых клеток глиобластомы до и после облучения.

Очень важно, что в процессе ответа на чисто научные вопросы авторы не теряют из виду практические проблемы. В частности, экспериментально доказан факт снижения эффективности темозоломида в отношении клеток глиобластомы, подвергнутых экспериментальному облучению, при этом задана основная линия решения этой проблемы с использованием нового класса генотоксических средств, идентифицирован ряд совершенно новых мишеней в опухолевых клетках и обоснованы ожидаемые эффекты при воздействии на них.

Монография формирует некий новый, качественно другой подход к адъювантной терапии опухолей мозга, в которой акцент делается не только на хирургическую помощь и химиотерапию, но и на использование биотерапии в комплексном лечении глиобластомы. Биопрепараты, или биомедицинские клеточные продукты, на основе аутологических и аллогенных клеток костного мозга - это препараты сегодняшнего дня. Они уже много лет используются для лечения рака, однако авторами экспери- 
ментально обосновывается мысль их использования не столько для атаки на остаточную опухолевую ткань или в целях реконструкции кроветворной системы, а сколько для моделирования микроокружения опухолевой стволовой клетки, что довольно прогрессивно.

Биомедицинские клеточные подходы к лечению глиальных опухолей мозга и злокачественных новообразований других локализаций только начинают формироваться. Уверен, у этих подходов есть неплохое будущее, о чем наглядно свидетельствует эта монография.

Академик РАН М.И. Давыдов 


\section{ВВЕДЕНИЕ}

Мультиформная глиобластома (МГБ) - самая распространенная первичная опухоль головного мозга человека. Современный стандарт комплексного лечения МГБ (Stupp et al, 2005; Stupp et al, 2017) включает хирургическую операцию, высокие дозы облучения и химиотерапию. Прогноз неблагоприятный (Omuro\&DeAngelis, 2013; Lukas et al, 2019), медиана выживаемости больных - 15 месяцев, около 25\% больных способны прожить два года с момента диагноза (Touat et al, 2017). Низкую эффективность лечения связывают (Louis et al, 2016; Urhie et al, 2018) с инвазивным ростом, диффузной инфильтрацией мозга опухолевыми клетками (ОК), избирательной проницаемостью гематоэнцефалического барьера (ГЭБ) для большинства противоопухолевых препаратов, гетерогенностью клеточной популяции МГБ, высокой пластичностью ОК и наличием в составе клеточной популяции опухолевых стволовых клеток (ОСК).

ОСК играют главную роль в иерархии клеточной популяции МГБ (Inocencio et al, 2018; Pecchia, 2015; Gabrusiewicz et al, 2018), они обладают мультипотентностью, высокой пролиферативной активностью, способностью к самообновлению и максимальной туморогенностью. Уникальные способности к востановлению поврежденной ДНК делают ОСК не доступными для поражения с применением существующих методов и технологий, что требует разработки новых подходов к терапии МГБ, направленных не только на полное уничтожение ОК, но и на регуляцию сигнальных и морфогенных свойств ОСК. Одним из путей решения этой проблемы является использование противоопухолевого потенциала аллогенных гемопоэтических стволовых клеток (ГСК) и их потомков.

Гемопоэтические стволовые клетки (ГСК) открыты профессором Императорской военно-медицинской академии, профессором Петроградского и Чикагского университетов Александром Александровичем Максимовым в 1909 г.

По иронии судьбы величайшее из всех фундаментальных открытий, подобно изобретениям Леонардо да Винчи, оказалось почти не замеченным современниками. Понадобилось более 100 лет, две мировые войны и научнотехническая революция, прежде чем трансплантация ГСК стала эффективным способом излечения рака у детей и позволила добиться стойкой ремиссии при ряде других тяжелых заболеваний.

Сегодня мы вступили в эпоху ренессанса. Биомедицинские клеточные технологии стали магистральным трендом развития медицины, транспланта- 
ция ГСК превратилась в рутинную процедуру, которая используется для реконструкции кроветворной системы и коррекции иммунодефицитных состояний после высокодозной химиотерапии, генной терапии, иммунотерапии, а также для лечения тяжёлых заболеваний и травм ЦНС. Однако открытие профессора Максимова все еще недооценено.

Высокий противоопухолевый потенциал ГСК и их дифференцированных потомков позволяет использовать клетки этого типа для создания новой группы противоопухолевых средств - биомедицинских клеточных продуктов, целью которых является дестабилизация взаимоотношений ОСК с локальным микрокружением и внеклеточным матриксом (ВКМ), нарушение иерархических взаимоотношений между ОК, подавление инвазивного роста опухоли и продление жизни больного МГБ.

Все представленные нами теоретические и экспериментальные данные являются оригинальными, достоверными и направленными на поиск закономерностей, ключевых особенностей и механизмов изучаемых явлений.

Описанные нами исследования выполнены в Дальневосточном федеральном университете. Конечная цель исследований - создание новых биомедицинских технологий лечения МГБ, однако ни один из разделов исследования не может быть вырван из контекста и использовани для лечения больных без предварительных клинических исследований. Какой бы тяжелой ни была ситуация, пациенту с МГБ следует лечиться только у сертифицированного врача - онколога - и неотступно следовать его рекомендациям.

Авторы выражают благодарность коллективу клиники «НейроВита», коллективу лаборатории онкопротеомикии НИИ канцерогенеза ФГБУ НМИЦ онкологии им Н.Н. Блохина Минздрава России, коллективу Лаборатории фармакологии ННЦМБ имени А.В. Жирмунского ДВО РАН, принявшим самое активное участие в написании этой работы. Замечания и предложения читателей по поводу данной монографии просим высылать на электронный адрес: bruhovetsky@ mail.ru.

Особая благодарность - Миннистерству высшего образования и науки России (Соглашения № 14.575.21.0038 (RFMEF157514X0038), 14.584.21.0027 (RFMEFI58417Х0027), Российскому научному фонду (проект № 14-15-00084) и Российскому фонду фундаментальных исследований (проект 19-315-90077), которые оказали нам финансовую поддержу на различных этапах данной работыл. 


\section{МУЛЬТИФОРМНАЯ ГЛИОБЛАСТОМА: ОБЩАЯ ХАРАКТЕРИСТИКА ПРОБЛЕМЫ}

\section{1. Эпидемиология}

Мультиформная глиобластома (МГБ) - самая распространенная первичная опухоль головного мозга человека. Всемирная организация Здравоохранения классифицирует МГБ как низкодифференцированную астроцитому IV степени злокачественности. Она составляет более 50\% глиальных опухолей головного мозга и около $20 \%$ всех внутричерепных новообразований. В странах Северной Европы и Северной Америки МГБ встречается с частотой 3,2-5,2 на 100 тысяч жителей (Nam \&de Groot, 2017; Omuro \&DeAngelis, 2013). Однако эти цифры весьма относительны: ежегодно только в США регистрируется более 17 тысяч новых случае МГБ и других злокачественных глиом.

Ежегодно в России регистрируется более 8,8 тыс. новых случаев глиобластом (в Приморском крае - более 100 случаев), умирает от данной патологии более 7,6 тыс. пациентов. В 2017 г. в России интенсивный показатель заболеваемости глиобластомами составил 6,02 на 100 тысяч населения.

МГБ возникает в любом возрасте, но приобладает на возрастном отрезке 40-60 лет, несколько чаще у мужчин (Thakkar et al, 2014), средний возраст заболевших - 62 года. Прогноз крайне неблагоприятный, мединана выживаемости больных 15 месяцев, общая выживаемость 10-20 месяцев (Touat et al, 2017), около 27\% больных живут 2 года с момента диагноза, 5-летняя выживаемость до 5\%, что сомнительно и, вероятно, связано с точностью диагноза.

\section{2. Факторы риска}

Среди факторов риска МГБ описаны (Omuro \& DeAngelis, 2013) синдромом Коудена, Теркота, Ли-Фраумени, нейрофиброматоз I и II типа, семейный шваноматоз, туберозный склероз, астма, сенная лихорадка, экзема и малярия. Риск МГБ повышен у врачей, пожарных, фермеров, лиц, работающих с нефтепродуктами, соединениями мышьяка, ртути, резиной, 
свинцом, пластиком. Описана связь МГБ с полиомавирусом SV40, цитомегаловирусом, вирусом герпеса VI типа. Риск МГБ достоверно выше у людей, получавших профилактическое облучение мозга при различных типах лейкозов и занятых в работе с радиоактивными материалами. Проживание в высоких широтах, белая раса, высокий рост и высокий социальный статус (Kitahara et al, 2012) в числе факторов риска.

\section{3. Классификация МГБ и других глиом как узловая точка проблемы}

Причину отсутствия прогресса в лечении МГБ следует искать в исторических подходах к этой проблеме. Не секрет, что все попытки классификации опухолей мозга, предпринимаемые ВОЗ и другими авторитетными организациями до 1979 г., не имели очевидного успеха и фактически провалились (Scheithauer, 2008). Причина заключалась в неспособности предлагаемых систематик ответить на принципиальные для врача вопросы о необходимой лечебной тактике и судьбе больного.

Появление в 1979 г. первого издания классификации опухолей нервной системы, известного как "Blue book", связано с именами Dr Klaus J. Zulch - директора Института исследований мозга им. Макса-Планка в Германии - и Dr. Lucien J. Rubinstein - американца, выпускника Стэнфордского университета. Оба были прекрасными специалистами, однако Zulch - врач, которого интересовали вопросы лечебной тактики и прогноза, a Rubinstein - патолог и гистолог, сосредоточенный на механизмах клеточной дифференцировки.

Исходя из чисто практических целей Zulch выдвинул концепцию клинической злокачественности, присвоив I степень злокачественности всем, даже очень медленно растущим в полости черепа опухолям. Главным аргументом была постоянная угроза жизни больного, обусловленная возможностью механического сдавления жизненно важных центров мозга, опасностью обструкции путей оттока цереброспинальной жидкости, развития вторичной гидроцефалии и дислокации мозга. В свою очередь, со II по IV группы распределились более быстрорастущие опухоли, ассоциированные с выживаемостью 3-5 лет, 1-3 года и 6-12 мес.

Для Rubinstein было очевидно, что относительно гетерогенные опухоли, собранные в пределах этих групп, обладают примерно одинаковой скоростью роста, которая обратно пропорциональна степени дифференци- 
ровки их морфологических элементов. В этой связи Rubinstein сосредоточился не столько на систематизации опухолей по гистологическому признаку, сколько на морфологических критериях, объединивших опухоли внутри I-IV групп. C этого времени атипия ядер, клеточный плеоморфизм, митозы, микроваскулярная пролиферация и, самое главное, некрозы стали системообразующим ядром классификации Duma-Duport и последующих систематик.

В четвертой классификации опухолей мозга, опубликованной ВО3 в 2007 г., IV степень злокачественности была присвоена группе смертоносных опухолей, которые отличались быстрым ростом, активной микроваскулярной пролиферацией и развитием некрозов. В эту группу вошли глиобластомы, медуллобластомы и первичные саркомы. Для опухолей данной группы была характерна высокая степень анаплазии морфологических элементов (Scheithauer, 2008), что сближало их с глиобластомой.

Первые включения молекулярной генетики в систематику МГБ связаны с именами швейцарца Dr. Paul Kleihues и американца Dr. Webster K. Cavenee. Но, увы, эти работы вызывали больше вопросов, чем давали ответов (Louis et al, 2012). В 2010 г. на основании данных молекулярногеномного анализа была предпринята попытка (Verhaak et al, 2010) сепарации МГБ на отдельные изотипы: классический, пронейральный, нейральный и мезенхимальный. Классический субтип характеризовался высоким уровнем амплификации гена EGFR, моносомией 10 хромосомы с потерей гена PTEN, потерей хромосомного участка $9 \mathrm{p} 21$ с геном CDKN2A, отсутствием мутации гена TP53. Пронейральному субтипу соответствуют потеря или мутация гена TP53, мутации генов IDH1 и PI3KCA/PI3KR1, амплификация гена PDGFR. Нейральному субтипу присуща полиморфная картина мутаций, а признаком мезенхимального субтипа является потеря хромосомного региона 17q11.1 с геном NF1.

Хотя научная ценность такого подхода не вызывает сомнений, в сформировавшиеся алгоритмы лечения больных был внесен некоторый каламбур. Так, пронейральный субтип МГБ оказался самым резистентным к лечению, что дало основание ряду экспертов вообще усомниться в целесообразности проведения противоопухолевой терапии у этой категории больных. Однако дальнейшие исследования в этом направлении показали, что наличие в опухолевых клетках IDH-мутации (Guan et al, 2014) делает такие опухоли релевантными глиомам II-III степени злокачественности, 
которые имеют лучший прогноз. Последующие систематики (Crespo et al, 2011; Crespo et al, 2015) еще большее обогатили наши знания в области молекулярной генетики МГБ, но мало что дали в практическом смысле.

В этой связи в классификации опухолей мозга, анонсированной ВО3 в 2016 г. (Louis et al, 2016; Jakovlevs et al, 2019; Bhawe \&Aghi, 2016), был сохранен традиционный клинико-гистологический подход к определению степени злокачественности опухолей мозга, однако центральным механизмом систематизации стала IDH-мутация.

\section{4. Молекулярно-генетические нарушения в клетках МГБ}

Согласно рекомендациям BO3 (Louis et al, 2016) глиомы с IDHмутацией и 1p/19q коделецией стали классифицироваться как олигодендроглиомы, а глиомы с мутациями генов IDH1/2, TP53 и ATRX как астрацитомы. IDH-мутация разделила больных МГБ на две группы: IDHмутантный и дикий тип МГБ.

Первый развивается из астроцитомы II-III степени злокачественности, возникает в более молодом возрасте и составляет 6-10\% случаев МГБ. Более 70\% IDH-мутантных МГБ характеризуется мутациями генов TP53 и ATRX (Nam \& deGroot, 2017). Второй чаще возникает de поvо и составляет более 90\% случаев болезни, средний возраст заболевших 60 лет. Более 70\% IDH-диких МГБ содержит мутации TERT-промотора, менее 20\% несут мутации генов PDGFRA, MDM2 и CDK4 (Aldape et al, 2015). Другие мутации у больных МГБ встречаются реже, однако их значения не следует умалять.

Визитной карточкой МГБ являются мутации гена ретинобластомы $\mathrm{Rb}$, гена TP53 и группы генов, формирующих тирозинкиназную сигнальную ось (Wirsching et al, 2016). Более 40\% МГБ содержат мутацию гена PTEN. Этот ген регулирует онкогенез и через хроматин-ассоциированный комплекс DAXX подавляет гликолиз (Benitez et al, 2017). Гиперэкспрессия PTEN способствует гибели опухолевых клеток, инактивируя путь Akt (Bao et al, 2019). Мутация этого регулятора оказывает крайне негативное влияние на общую выживаемость больных.

Ген VHL (от немецкого Von Hippel-Lindau) - стратегический фактор канцерогенеза МГБ (Stadlbauer et al, 2017) - регулирует реакцию неопластических клеток на гипоксию. Мутация этого онкосупрессора является причиной более агрессивного фенотипа болезни. 
Мутация гена NF1 характерна для больных с нейрофиброматозом первого типа, что предопределяет (Fortunato et al, 2018) движение диференцированной астроцитарной глиомы в сторону МГБ. Мутация более характерна для мезенхимального субтипа МГБ (Verhaak et al, 2010). Ocoбоe внимание уделяется мутациям группы генов семейства HIF (Miska et al, 2019) и BRAF (Maraka \&Janku, 2018).

IDH-дикий тип МГБ характеризуется снижением общего уровня метилирования генов на 50\% ниже, чем в нормальной ткани мозга (Kondo et al, 2014), в рецидивных формах МГБ этот уровень еще ниже (Kreth et al, 2014). Причиной нарушения процесса метилирования ДНК являются мутации в генах группы DNMT1, DNMT3a, DNMT3b, кодирующих синтез специфических ферментов ( $\mathrm{Li} \& \mathrm{Wu}, 2017)$. Эти мутации повреждают механизмы эпигенетического контроля, способствуют экспрессии онкогенов SOCS3, Sox2, MAGEA1, MGM, подавляет активность онкосупрессоров SLC5A8, RB1, VHL, EMP3, RASSF1A, CITED 4, BIU, GATA4, NDRG2 и регуляторов клеточного цикла DAPK, TIMP3, TMKS1/ASK, WWOX. Нарушение экспрессии генов HDAC2, HDAC9, JMJD1A, JMJDIB , SET7, SETD7, MILL изменяет уровень активности гистоновых белков и порождает еще более сложные патологические каскады.

Итак, в отсутствие IDH-мутации опухоль классифицируется как МГБ дикого типа. Недостатком молекулярно-геномных классификаций является статичность декларируемых нарушений. Анализ молекулярногеномных ландшафтов клеток МГБ свидетельствует о большем полиморфизме картины генетических нарушений, чем принято считать. В одной из работ опубликованных в журнале "Science" (Patel et al, 2014), описывается полиморфизм молекулярно-геномных профилей одиночных клеток МГБ, полученных из одной опухоли.

Сегодня, в эпоху постгеномных технологий (Degl'Innocenti et al, 2020; Klughammer et al, 2018; Cai et al, 2020), различия молекулярногеномных и эпигенетических ландшафтов выявлены как в пределах клеток, полученных из различных биоптатов одной опухоли, так и в пределах клеток, выделенных из одного и того же участка опухоли.

\section{5. Взгляды на этиологию и патогенез глиобластомы}

Вопрос этиологии МГБ остается открытым. Общепринятой является мутационная теория, предложннная в 1914 г. Теодором Бовери. Согласно этой теории воздействие канцерогенов приводит к возникновению и 
накоплению мутаций, нарушению механизмов регуляции активности протоонкогенов и генов-онкосупрессоров с последующей глубокой реорганизацией и иммортализаций нормальных клеток, усилением их пролиферации. В качестве канцерогенов могут быть рассмотрены все вышеперечисленные физические, химические и биологические факторы.

Не менее актуальна теории анеуплоидии, в ней основное внимание уделяется нарушениям митоза, вследствие которых в клетке оказывается число хромосом, некратное основному набору, либо изменяется морфология хромосом, из-за чего доза генов в таких клетках оказывается резко завышенной. Нарушение дозового баланса генов ведет к нестабильности генома и предопределяет высокую частоту возникновения мутаций, роль которых в данном случае вторичная. Значительные отличия кариотипа таких клеток дали основание (Duesberg et al, 2003; Duesberg \&Li, 2003) pacсматривать их как клетки нового вида.

Мысль о том, что рак - не только болезнь, но и этап видообразования, высказывали в 1956 г. Джулиан Хаксли и ряд биологов-эволюционистов. Однако мутационная теория и теория анеуплоидии с момента своего появления подвергались критике. Они практически не обясняют гетерогенности МГБ, полиморфизма молекулярно-генетических нарушений в клетках МГБ, способность этой опухоли к быстрому инвазивному росту и резистентность к лечению. Некоторой квинтэссенцией стала концепция тканевого онкогенеза, которая усматривает основную причину появления ОК в нарушении пролиферации клоногенных клеток, обладающих активированными онкогенами, однако и она не дает ответов на все вопросы.

Вероятно, в формировании первичного клона опухолевых клеток задействованы сразу несколько механизмов, при этом из всей палитры генетических и эпигенетических нарушений ключевое значение имеют только те, которые ведут к усилению пролиферации, а последующие события вызваны давлением естественного отбора, системообразующим дейстием гипоксии, запуском эпителиально-мезенхимального перехода, формированием иммуносупрессивной среды, запуском ангиогенеза, повреждением гематоэнцефалического барьера (ГЭБ) и рекрутированием нормальных стволовых и дифференцированных клеток, в результате чего формируется опухолевая экосистема.

Согласно существующим представлениям главную роль в этой экосистеме играют раковые СК или опухолевые стволовые клетки (ОСК). 


\section{6. Опухолевые стволовые клетки}

О существовании ОСК стало известно в конце XX в. В 1997 г. журнал "Nature" опубликовал статью с описанием иерархии клеток острой миелоидной лейкемии (Bonnet \& Dick, 1997), в основе которой лежит примитивная опухолевая стволовая клетка. Позднее такие клетки были описаны при МГБ (Singh et al, 2003), раке молочной железы, яичников, простаты, поджелудочной железы и некоторых других опухолях. Принято считать (Brown et al, 2017; Lathia et al, 2015; Gimple et al, 2019; Bischof et al. 2017; Inocencio et al, 2018; Fiscon et al, 2018), что ОСК обладают самой большой скоростью пролиферации, исключительной туморогенностью, мультипотентностью, способностью к бесконечному самообновлению и играют главную роль в иерархии опухолевых клеток.

Множество данных (Doetsch et al, 1999; Aboody et al, 2000; ÁlvarezSatta al, 2019; Kawamura et al, 2018; Wang et al, 2019; Tuazon et al, 2019; Altmann et al, 2019) указывает в пользу происхождения ОСК от нейральных стволовых клеток (НСК), населяющих субвентрикулярную зону и другие герминативные центры мозга человека. Нормальные тканеспецифические стволовые клетки - идеальный объект мутагенеза и наиболее вероятная точка приложения внешних и внутренних канцерогенных факторов.

Нейрогенез в зрелом мозге млекопитающих был впервые описан Дж. Альтманом в 1960-х годах. Первоначально популяции постоянно пролиферирующих нейральных стволовых клеток были обнаружены (Eriksson et al, 1998; Doetsch et al, 1999) в субэпендимной зоне боковых желудочков зрелого мозга мышей и крыс, а затем выделены из гиппокампа взрослых приматов и человека. Типичная герминативная зона зрелого мозга также содержит нейральные прогениторные клетки, которые являются прямыми потомками нейральных стволовых клеток, обладают высокой скоростью пролиферации (Gage et al, 2000) и на протяжении всей жизни индивида мигрируют из субвентрикулярной зоны по ростральному миграционному тракту в обонятельную луковицу, где накапливаются и рассеиваются в ткани мозга.

Нейральные стволовые/прогениторные клетки обладают высокой подвижностью в отношении клеток МГБ, адгезируют к их поверхности в манере, описанной (Aboody et al, 2000) как "in piggy-back fashion" и активно взаимодействуют с ними. Прорастание опухоли в субвентрикулярную область резко ухудшает прогноз больного с МГБ (Goffart et al, 2017; 
Berendsen et al, 2019). Показана идентичность более 60\% внутриклеточных белков нормальной нейральной стволовой клетки и ОСК глиобластомы человека (Bryukhovetskiy et al, 2017), что является еще одним аргументом в пользу родства этих клеток.

Однако мысль о формировании ОСК из дифференцированных клеток центральной нервной системы не потеряла актуальности. Вероятно, в появлении ОСК задействованы оба механизма (Colwell et al, 2017; Sattiraju et al, 2017), однако сегодня этот вопрос имеет только теоретическое значение. Независимо от типа клеток, в которых под действием канцерогенов возникли мутации, материальным субстратом неопластического процесса они могут стать только в том случае, если ведут к уклонению от дифференцировки и усилению пролиферации, которая является основным двигателем неопластического роста.

Именно здесь целесообразно вернуться к истории вопроса. Огромный интерес к роли низкодифференцированных клеток в патогенезе МГБ, который мы наблюдаем сегодня, был фактически предопределен историческими работами Zulch и Rubinstein, сгруппировавшими самые быстрорастущие опухоли в одну группу. Наиболее высокая скорость пролиферации характерна для низкодифференцированных клеток, интенсивная репликация которых порождает конкуренцию за кислород и метаболические ресурсы, что, с одной стороны, ведет к масштабной гибели опухолевых клеток и раннему появлению в опухоли некрозов - признака, позволяющего сразу отнести опухоль к IV степени злокачественности согласно классификации ВО3; с другой стороны, запускает механизмы селекции опухолевых клеток, отбирающих клеточные клоны, наиболее резистентные к гипоксии, что неизбежно сопровождается снижением степени дифференцировки морфологических элементов опухоли (Mathieu et al, 2013).

Итак, пролиферация - главный двигатель опухолевого процесса (Colwell et al, 2017; Sharifzad et al, 2019; Linkous et al, 2019; Alcantara Llaguno et al 2016; Liu et al, 2018; Lizarte Neto et al, 2019), самой высокой скорость пролиферации обладают ОСК, а гипоксия (Tong et al, 2019) стратегически важный фактор, регулирующий пролиферативную активность этого типа клеток. При снижении в отдельных участках опухоли содержания кислорода менее $0,1-5 \%$ в клетках происходит арест клеточного цикла (Gardner et al, 2001), что сохраняет эти клетки в недифференцированном состоянии. Будучи извлеченными из опухоли (в условиях in vitro) при 
нормальном содержании кислорода такие клетки могут пролиферировать, порождая новые поколения неопластических клеток, что, вероятно, и дало некоторое основание поставить ОСК на вершину иерархической пирамиды клеток МГБ по аналогии с клетками острой миелоидной лейкемии.

Считается (Bradshaw et al, 2016), что подобно нормальным стволовым клеткам при ассиметричном делении ОСК порождает две клетки: первая сохраняет свойства ОСК, вторая становится дифференцированной клеткой, которыми представлены глиомы низкой II-III степени злокачественности. Но это положение становится неустойчивым, если учесть, что IDH-мутация и другие генетические маркеры, характеризующие более дифференцированные глиомы, едва ли могут спонтанно появиться в клетках-потомках, если они отсутствует в «диких» материнских клетках.

Безусловно, высокая скорость пролиферации генетически нестабильных клеток резко увеличивет вероятность анеуплоидии, полиплоидии и других хромосомных поломок, в этой связи всегда возможна спонтанная смена стволовой линии под влиянием локальных микроусловий, что объясняет гетерогенность клеточной популяции МГБ. Однако клетки, сформировавшие стволовую линию и обладающие относительно идентичным набором хромосом, являются генетически идентичными материнским клеткам. Конечно, потомки ОСК могут не обладать столь же высокой эффективностью эпигенетических механизмов (Lan et al, 2017; Gimple et al, 2019), например, предотвращающих истощение теломер. Клетки, лишенные этих привилегий, будут обладать меньшими темпами пролиферации, что отчасти может объяснить феномен дифференцировки клеток МГБ.

Другим вариантом репликации ОСК является симметричное деление, в результате которого образуются две клетки со свойствами стволовых клеток. В этой связи становится актуальным вопрос о колличестве OCK в опухоли. Свойства ОСК описаны (Inocencio et al, 2018) у клеток, иммунореактивных в отношении ряда цитоплазматических (CD 133, CD44, CD15 и ядерных Olig2, Sox2, Stat 3, Oct4) Nanog антигенов. Однако вопрос о том, можно ли считать эти клетки ОСК, остается открытым.

Если взять линию клеток глиомы С6, часто используемую для моделирования МГБ у крыс, то колличество CD133+ клеток в ее популяции составляет около 4\% (Zhou et al, 2009), при этом усиление экспрессии клетками глиомы этого антигена (Angelastro \&Lamé, 2010) сопровождается усилением лекарственной резистентности. Принципиально важно, что бе- 
лок-нестин - другой, не менее важный маркер ОСК клеток глиомы С6 (Zhou et al, 2009), выявлялся в наших исследованиях (Bryukhovetskiy et al, 2016) у большинства клеток этой линии.

Если обратиться к другой экспериментальной модели - клеточной линии U87 МГБ человека, особенно востребованной в онкологии, то колличество CD133+ элементов среди пролиферирующих клеток этой линии довольно велико (Wang et al, 2015). В свою очередь, среди клеток линии Т98G глиобластомы человека колличество CD 133+ исключительно велико, при этом далеко не все эти клетки пролиферируют. Для ответа на вопрос, являются ли эти клетки ОСК, целосообразно проанализировать другое, не менее важное свойство этого типа клеток - высокую туморогенность.

В 2004 г. журнал "Nature" опубликовал результаты исследования (Singh et al, 2004), согласно которым 100 клеток этого типа достаточно для быстрого формирования опухоли у экспериментальных животных. При имплантации экспериментальным животным CD133+ клетки МГБ формируют опухоли, близкие по структуре к метастазам (Brown et al, 2015). Клетки иммунофенотипа CD44 медленно пролиферируют (Brown et al, 2017), а клетки иммунофенотипа CD15 по степени туморогенности (Kenney-Herbert et al, 2015) не обнаруживают значимых отличий от других клеток МГБ. В свою очередь, клетки МГБ, иммунопозитивные в отношении эмбриональных ядерных антигенов Nanog, Stat3, Oct4 и Sox2, обладают некоторыми свойствами OCK (Seo et al, 2017), однако вопрос их высокой туморогенности остается открытым.

Не менее сложен вопрос предполагаемой мультипотентности ОСК. Во-первых, нет ни одной работы, в которой была бы убедительно показана возможность трансформации ОСК в иные типы клеток, кроме опухолевых. Существуют указания (Hambardzumyan et al, 2016) на возможность дифференцировки ОСК в клетки сосудистого эндотелия при построении кровеносного русла опухоли, что неудивительно, если учесть, что основным индуктором и регулятором их дифференцировочного потенциала является гипоксия. В этой связи представляется более уместным говорить не об мультипотентности, а скорее, о возможности ограниченной редифференцировки таких клеток.

И тем не менее в отличие от дифференцированных клеток МГБ человека в ОСК резко увеличен уровень синтеза белков внутриклеточных сигнальных путей гликолиза, сигнального пути - Wnt и сигнального пути 
рецепторного взаимодействия с внеклеточным матриксом (Shevchenko et al, 2020). Первый обеспечивает выживание опухолевых клеток в бескислородной среде, и это еще раз подтверждает мысль (Colwell et al, 2017), что именно гипоксия является основным фактором селекции опухолевых клеток. Второй, сигнальный путь - wnt - ключевой механизм регуляции дифференцировочного потенциала эукариотических клеток. В свою очередь, гиперпродукция белков сигнального пути рецепторного взаимодействия с внеклеточным матриксом (РВ-ВКМ) указывает на то, что именно взаимодействие с ВКМ является условием реализации этого потенциала.

Итак, нейральные стволовые клетки головного мозга человека являются наиболее вероятгным источником происхождения стволовых клеток МГБ. Клетки этого типа обладают широкой палитрой мембранных маркеров и ядерных антигенов, среди которых характеристикам ОСК больше всего соответствуют клетки иммунопозитивные в отношении антигена CD133 - общего с нормальными нейральными стволовыми клетками. Однако само по себе наличие этого маркера не означает обладание всей полнотой свойств ОСК. Весьма вероятно, понятие ОСК - понятие системное. Свойства этого типа клеток предопределяются гипоксией и наиболее полно проявляются в процессах межклеточного взаимодействия в формируемой гипоксией экосистеме, где ОСК принадлежит центральная роль в запусках процессов инвазии, ангиогенеза и выживания опухоли под воздействием облучения и химиотерапии.

\section{7. Эпителиально-мезенхимальный переход и трансформирующий фактор роста $\beta$}

Клеточная дифференцировка, миграция и пролиферация - взаимозависимые компоненты морфогенеза. Дифференцировка обусловлена координированной экспрессией и деактивацией генов, групп генов или генетических каскадов, определяющих способность клеток к выполнению определенных функций, соответствующих профилю их специализации. Дифференцированные клетки самоорганизуются в кластеры, синтезируют белки адгезии к внеклеточному матриксу (ВКМ) и белки межклеточных контактов, обеспечивающие максимальное межклеточное взаимодействие, согласованную регуляцию метаболизма и выполнение специализированных функций. 
Однако в ходе эмбрионального развития весьма часто наблюдается смена одного клеточного фенотипа на другой в результате процесса эпителиально-мезенхимального перехода (ЭМП), регулирующего морфогенетические изменения при росте, перемещении и дифференцировке клеток в ходе гаструляции (Iwadate et al, 2018). В результате ЭМП образуются зародышевые листки (эктодерма, мезодерма и энтодерма) - источники зачатков тканей и органов для органогенеза. В постнатальном периоде ЭМП участвует в регенерации тканей и органов млекопитающих и человека. Установлена роль ЭМП в развитии кардиосклероза, катаракты, фиброза почек (Boutet et al, 2006; Grande et al, 2015), болезнях органов дыхания. Однако роль этого механизма первостепенна в патогенезе МГБ.

ЭМП представляет собой комплексную морфогенетическую программу, в которой процессы пролиферации тесно интегрированы с другими, формально независимыми феноменами, такими как редукция клеточной полярности, изменение существующих взаимоотношений с ВКМ и модификация внутренней среды опухолевых клеток. Однако применительно к МГБ термин ЭМП представляется не совсем корректным, поскольку это опухоль нейроэктодермальной природы. Однако термин «пронейрально-мезенхимальный переход» (Segerman et al, 2016) и другие альтернативные названия представляются куда менее удачными.

В результате ЭМП эпителиальные клетки утрачивают свойственную им апикально-базальную полярность, теряют межклеточные контакты, реорганизуют цитоскелет и трансформируются в мезенхимально подобные подвижные клетки. Критически важная роль в реализации программы ЭМП принадлежит активации генов групп snail1 и 2, zeb1, twist и lef1 (Heerboth et al, 2015). Признаками ЭМП (Iwatsuki et al, 2010) служит снижение синтеза Е-кадгерина, окклюдина, клаудина 1, плакофилина 3 и усиление продукции $\mathrm{N}$-кадгерина виментина, фибронектина, актина, компонентов ВКМ и металлопротеаз.

Ведущим индуктором ЭМП является гипоксия - этот тезис доказан в эксперименте на моделях карциномы почек (Zhang et al, 2017), рака желудка (Yang et al, 2017), колоректальной аденокарциномы (Sun et al, 2016) и ряда других карцином (Lehmann et al, 2017). Не менее важными индукторами ЭМП являются облучение и антиангиогенная терапия с использованием препарата «Бевацизумаб» (Lee et al, 2017; Zhang, 2017; Iwadate, 2018; Huang \&Zong, 2017), но эти факторы лишь углубляют гипоксию, роль которой в данном случае первична. 
Гипоксия обеспечивает первичную селекцию опухолевых клеток и формирование пула стволовых клеток МГБ. Однако инвазивный рост главное свойство МГБ - обусловлен формированием особо агрессивного фенотипа ОК, возникающего в ходе сложных межклеточных взаимодействий при участии ряда паракринных факторов (Wang et al., 2017; Johansson et al., 2016), среди которых - активаторы рецепторов тирозинкиназы, wnt-белки и компоненты ВКМ, однако самое пристальное внимание уделяется трансформирующему фактору роста $\beta$ (TGF- $\beta$ ).

Описана (Rich et al., 2003; Wick et al., 2006; Caja et al., 2015) прямая связь между содержанием TGF- $\beta$ в сыворотке крови больных и степенью злокачественности глиальных опухолей мозга. Важнейшим источником TGF- $\beta$ в очаге МГБ являются опухолевые клетки, среди которых ведущая роль принадлежит ОСК. В ответ на стимуляцию гипоксией ОСК активизируют синтез TGF- $\beta$, в свою очередь, дифференцированные клетки МГБ располагают рецепторами к этому фактору и наращивают темпы его синтеза по принципу аутокринной индукции, формируя «секреторную петлю». TGF- $\beta$ секретируется в неактивном состоянии и активируется при низком $\mathrm{pH}$, чему сопутствует лактат-ацидоз - неизбежное следствие гликолитического типа метаболизма.

Роль TGF- $\beta$ в опухолевом процессе чрезвычайно сложна. С одной стороны, данный цитокин обладает сильной антителомеразной активностью, подавляет циклин-зависимые киназы Ink4 и Cip/Kip и препятствует активации ингибиторов циклинзависимых киназ р21W, AF1/CIP1, p15INK4b, p27KIP1a (Fabregat et al., 2014; Syed, 2016), способствует репрессии гена $\mathrm{MYC}$, что препятствует прохождению клеткой $\mathrm{G}_{1}$ фазы и входу в $\mathrm{S}$-фазу периода клеточного роста и является одним из ключевых индукторов апоптоза (Colak \& Ten Dijke, 2017; Futakuchi et al., 2019), активируя какой-либо их двух внутриклеточных сигнальных путей SMAD или DAXX.

Вероятно, именно мутации компонентов этих путей позволяют опухолевым клеткам избежать апоптоза, в связи с чем TGF- $\beta$ действует в синергизме c HIF (Lei et al., 2019; Nahomi et al., 2019) и индуцирует продукцию клетками МГБ многочисленных проопухолевых факторов, в частности, тромбоцитарного фактора роста (PDGF), эпидермального фактора роста (EGF) и т.д. Однако осевая роль TGF- $\beta$ в биологии МГБ сводится именно к запуску ЭМП.

Как показывают собственные исследования (Bryukhovetskiy et al., 2020; Shevchenko et al., 2020), стимуляция дифференцированных клеток 
глиобластомы TGF- $\beta$ достоверно уменьшает количество межклеточных контактов, увеличивает их подвижность и вызывает глубокую трансформацию молекулярного фенотипа опухолевых клеток в виде подавления синтеза адгезионного Е-кадгерина, оклюдина и клаудина 1, усиления продукции миграционного N-кадгерина, виментина, витронектина и других компонентов ВКМ, белков актин-миозинового комплекса и матриксных металлопротеаз MMP2, MMP9, MMP14, ADAMTS1.

В свете сказанного TGF- $\beta$ ведет к качественному перелому в течении опухолевого процесса и запускает процессы инвазивного роста. При этом важно, что стимуляция TGF- $\beta$ усиливает в дифференцированных клетках МГБ экспрессию белков сигнального пути РВ-ВКМ до значений, сопоставимых с OCK (Bryukhovetskiy et al., 2020), что, вероятно, является одной из критически важных точек в развитии опухолевого процесса. Кроме того, TGF- $\beta$ формирует локальную иммуносупрессивную микросреду, в которой становится возможен запуск ангиогенеза.

\section{8. Межклеточные взаимодействия в ангиогенезе и иммуносупрессивная локальная микросреда}

Ангиогенез - важнейшее событие в биологии МГБ, которое напрямую связано именно с ОСК. Гиперэкспрессия белков сигнального пути РВ-ВКМ позволяет ОСК легко взаимодействовать с ремоделированным противовоспалительными цитокинами ВКМ, а способность к продукции металлопротеиназы LOXL2 более чем в 9 раз превосходит дифференцированные клетки МГБ (Shevchenko et al., 2020), что позволяет исключительно быстро модифицировать ВКМ и запустить ангиогенные процессы.

Главенствующая роль ОСК в опухолевой иерархии и организации сложной системы межклеточных взаимодействий наиболее очевидны именно в процессах ангиогенеза, где ОСК непосредственно взаимодействуют с дифференцированными опухолевыми клетками через сложную сложную систему микротрубок, соединяющих отдельные клетки в сложно синхронизированный ансамбль.

В 2015 г. журнал "Nature" опубликовал результаты масштабного исследования (Osswald et al., 2015), напрямую связавшего сеть микротрубок между клетками МГБ с ангиогенезом и терапевтической резистентностью. Эти выводы нашли подтверждение в работах других авторов (Weil et al., 
2017). Наличие сложной коммуникационной сети между опухолевыми клетками позволяет ГБ свободно обмениваться белками и микроРНК.

В 2018 г. мы показали возможность свободного обмена между клетками МГБ флуоресцентной меткой, неразрывно связанной с внутриклеточными белками в процессе окраски. Помимо сети микротрубок между клетками МГБ мы идентифицировали множество межклеточных контактов с участками растворения цитолемы, делающих возможным обобществление цитоплазмы (Milkina et al., 2018).

Существование между клетками МГБ столь совершенной системы межклеточных взаимодействий в сочетании с хорошо описанной (Saadatpour et al., 2016; Quezada et al., 2018) системой коллаборации с помощью экзосом позволяет предположить, что ангиогенез в опухоли запускается синхронно и основной вектор этому процессу, вероятнее всего, задает именно гипоксия.

Очаги ангиогенеза появляются в ткани МГБ очень рано (Lathia et al., 2015). Гипоксия дифференцирует часть ОСК в клетки эндотелия и индуцирует продукцию этими клетками (Bao et al., 2006) фактора роста эндотелия кровеносных сосудов (VEGF), эпидермального фактора роста (EGF) и тромбоцитарного фактора роста (PDGF). Избыток VEGF ведет к гиперплазии кровеносных сосудов (Dvorak et al., 2015) и формирует особый, характерный для МГБ тип гломерулоидной микрососудистой пролиферации, при котором отростчатые клетки соединительной ткани, входящие в состав стенок кровеносных сосудов, назывемые клетками Руже, вместе с клетками эндотелия формируют дисфункциональные сосудистые структуры, напоминающие клубочковый аппарат почки.

Ангиогенез нарушает взаимоотношения между компонентами сосудистой сети мозга, а гиперплазия кровеносных сосудов в сочетании с отеком вещества мозга повреждает плотные контакты между эндотелиоцитами (Sharma et al., 2020), формирует патологические фенестрации и открывает гематоэнцефалический барьер (ГЭБ), позволяя рекрутировать в опухоль клетки красного костного мозга. Повреждение ГЭБ и рекрутирование опухолью клеток костного мозга можно считать главным событием патогенетической цепи МГБ.

Под влиянием гипоксии (Gabriely et al., 2017; Ahmed et al., 2018) клетки МГБ резко усиливают продукцию высоко активных молекул семейства факторов, индуцируемого гипоксией (HIFs)-1 $\alpha$ и $1 \beta$. Эти транскрипцион- 
ные факторы активируют экспрессию более 80 генов, ответственных за синтез хемоатрактантов (Dirkse et al., 2019; Zaytsev et al., 2020), индуцирующих миграцию и хоуминг в опухолевый очаг нормальных стволовых и дифференцированных клеток через соответствующего типа рецепторы. Особое значение для МГБ имеет рекрутирование микроглии, моноцитов/макрофагов, фибробластов и нормальных стволовых клеток.

Основную массу рекрутируемых опухолью клеток составляют микроглиоциты. При условии М1-поляризации (Poon et al., 2017; Matias et al., 2017; Prionisti et al., 2019; Sankowski et al., 2019) эти клетки продуцируют фактор некроза опухолей (TNF) $\alpha$, интерлейкины $1,2,6,8$, интерферон $\gamma$ и другие провоспалительные факторы, которые активируют цинкзависимые эндопептидазы, разрушающие внеклеточный матрикс, препятствуют процессам инвазии и ангиогенеза, подрывают энергетику и вызывают апоптоз опухолевых клеток.

Однако ресурс микроглии мозга не бесконечен. Клетки этого типа происходят из эмбрионального желточного мешка (Sasaki et al., 2017; Matias et al., 2017) и поддерживают свою популяцию в мозге путем пролиферации. Растущая опухоль быстро истощает ресурс клеток резидентной микроглии, а моноциты/макрофаги и стволовые клетки костного мозга в условиях сохранного гематоэнцефалического барьера (ГЭБ) восполнить этот дефицит не могут.

Повреждение ГЭБ вследствиие опухолевого ангиогенеза позволяет рекрутировать из кровеносного русла множество стволовых и дифференцированных клеток, среди которых множество клеток костного мозга предшественников тканевых макрофагов. Клетки этого типа обладают очень высоким противоопухолевым потенциалом. Однако основной вектор межклеточного взаимодействия в опухолевом очаге полностью задается локальной иммуносупрессивной микросредой, которая поляризует микроглию по альтернативному М2-типу (Hambardzumyan et al., 2016; da Fonseca et al., 2016; Schiffer et al., 2018), что сопровождается усилением синтеза TGF- $\beta$. В ответ клетки МГБ наращивают синтез этого цитокина по принципу «аутокринной индукции», что повторно замыкает «секреторную петлю», стимулирует ЭМП и генерацию новых клонов ОСК.

Другим не менее важным свойством микроглии является усиление продукции М2-поляризованной микроглией wnt-белков (Matias et al., 2016; Dijksterhuis et al., 2015), активизирующих wnt-сигнальный домен в 
ОСК. В ответ на подобную стимуляцию клетки МГБ начинают продуцировать wnt-лиганды, что замыкает новую «секреторную петлю» (Matias et al., 2019) и связанные с ними процессы пролиферации и ангиогенеза, который теперь становится лавинообразным.

Особую роль в ангиогенезе играют стволовые клетки костного мозга. При введении этих клеток в кровоток животных с перевитой низкодифференцированной глиальной опухолью мозга данные клетки мигрируют в опухоль, где накапливаются в наиболее гипоксических зонах опухоли - зонах инвазии и некроза. Под воздействием гипоксии в условиях иммуносупрессивной микросреды ГСК продуцируют экзосомы с высоким содержанием ангиогенных факторов (Gong et al., 2017; Sharma, 2018; Yang et al., 2018; Zhao et al., 2018), в первую очередь VEGF.

Но участие клеток костного мозга в опухолевом процессе не исчерпывается только паракринным взаимодействием. Описана (Mercapide et al., 2012) возможность слияния клеток МГБ, фибробластов и стволовых клеток костного мозга. Можно предположить, что в результате фузии и смешивания цитоплазмы между клетками происходит обмен белками и микроРНК, что ведет формированию гибридов (Bastida-Ruiz et al., 2016) совмещающих функции стволовых и опухолевых клеток. Однако этот вопрос нельзя рассматривать так однозначно. В эксперименте (Zeng et al., 2015) слияние ГСК с клетками рака печени приводило к формированию ОСК, при этом слияние (Fan \&Lu, 2014) ГCК с клетками карциномы пищевода к такому эффекту не приводило. Напротив, цитогибриды, полученные при слиянии МСК с клетками рака легких (Zhang et al., 2019) и глиальных опухолей (Sun et al., 2015), усиливают туморогенность и ангиогенные свойства ОК.

Таким образом, МГБ - одна из самых агрессивных опухолей головного мозга человека. Стратегически важная роль в биологии МГБ принадлежит ОСК, наиболее вероятным источником происходжения которых являются НСК. Будучи инструментом тканевого гомеостаза и восстановления эти клетки является главной мишенью для различных канцерогенных факторов и основным объектом процессов мутагенеза. По мере накопления генетических нарушений такая клетка приобретает независимость и способность преодолевать критически значимые, контрольные точки клеточного цикла и пролиферировать. Сформированный клон ОК идет по пути наращивания темпов деления, и с этого момента основным регулятором иерархии ОК становится гипоксия. 
Гипоксия компартментализирует опухолевую ткань. Описаны (Hambardzumyan \& Bergers, 2015) инвазивная, гипоксическая и периваскулярная ниши ОСК. Допустимо рассматривать как особые, созданные гипоксией кластеры, детерминирующие основные направления межклеточных взаимодействий в иммуносупрессивной среде: выживание, инвазию и ангиогенез. Повреждая ГЭБ, опухоль рекрутирует стволовые и дифференцированные клетки красного костного мозга, которые взаимодействуют с ОСК; результатом подобной коллаборации становится формирование стройной, иерархически организованной системы опухолевых клеток, обладающих высокой пластичностью.

Гетерогенность МГБ - это результат координированных гипоксией межклеточных взаимодействий в условиях локальной иммуносупрессивной среды, предоставляющей ОСК весь арсенал возможностей взаимодействия с клетками локального микроокружения и ВКМ, что является двигателем неопластического процесса. В этом ключе дезорганизация взаимоотношения ОСК с микрокружением и ВКМ путем проведения провоспалительной модификации микросреды - один из самых перспективных подходов к противоопухолевой терапии. 


\section{СУЩЕСТВУЮЩИЕ ПОДХОДЫ К ДИАГНОСТИКЕ И ЛЕЧЕНИЮ ГЛИОБЛАСТОМЫ И ПУТИ ИХ ОПТИМИЗАЦИИ}

Принцип ранней диагностики - одна из аксиом онкологии. Однако ранний диагноз при МГБ весьма затруднителен. Но существуют некоторые клинико-морфологические корреляции между локализацией опухоли и сопутствующей этому группы симптомов.

Супратенториальная локализация наиболее характерна для первичной МГБ, когда, как правило, поражаются теменные, височные или затылочные доли мозга. Опухоль растет в белом веществе, нередко распространяясь на глубинные структуры, включая мозолистое тело, подкорковые узлы и боковые желудочки. Ведущим симптомами в клинике заболевания являются стойкое повышение внутричерепного давления и очаговый неврологический дефицит, вызванный поражением мозговых структур. Взаимоотношения между этими симптомами определяются размером опухоли, выраженностью отека, степенью дисфункции соседних с опухолью структур, тяжестью нарушений ликвородинамики и других факторов.

Вторичная МГБ чаще локализуется в области лобных долей мозга, динамика развития клинических симптомов у этих больных представлена в нескольких вариантах. В одном случае развитию развернутой картины болезни предшествует длительный, до нескольких лет, период, проявляющийся только судорожными припадками, что требует детального нейровизуализационного обследования у данной категории неврологических больных. В другом случае клиническая картина разворачивается в относительно короткие сроки, от 3 до 6 месяцев, и проявляется грубыми очаговыми и общемозговыми нарушениями в сочетании со стойким повышением внутричерепного давления.

Молниеносное развитие симптомов в течение нескольких недель или часов связано с дислокацией мозга или кровоизлиянием в опухоль. Как правило, в этом случае симптомы имитируют инсульт или острое инфекционное заболевание ЦНС. Психопатологическая симптоматика крайне полиморфна и неспецифична, чаще всего она представлена астенией, патологией сна и сновидений, реакциями экзогенного типа, нарушениями мышления и эмоционально-личностными расстройствами. 


\section{1. Нейровизуализационная картина МГБ}

Магнитно-резонансная томография (МРТ) с контрастным усилением наиболее информативный метод диагностики глиобластомы. Характерным признаком МГБ является кольцевидная зона гетерогенного изменения плотности по гиподенсивному типу, что четко выявляется при контрастном усилении. Обычно контрастируемая часть опухоли окружена зоной перифокального отека, распространяющегося в белом веществе мозга на большом протяжении, при этом область отека не превышает размеров самой опухоли, что отличает ее от метастатических новообразований. В четверти случаев классический «кольцевидный» тип контрастного усиления может отсутствовать. У таких больных выявляется смешанный или гомогенный тип контрастирования опухоли.

МРТ позволяет визуализировать гетерогенность структуры опухоли. Томограммы в режиме Т1 выявляют объемное образование без четких границ, со смешанным (изо- и гипоинтенсивным) сигналом и центральным некрозом. В режиме Т2 картина опухоли представлена мозаикой разноинтенсивных сигналов от стромы опухоли, некроза, кист и кровоизлияний. Границы МГБ могут сливаться с перифокальным отеком, гипервентиляция улучшает визуализацию солидной части опухоли.

\section{2. Морфологическая характеристика МГБ}

Морфологическое исследование - ключевой компонент диагностики МГБ. Данный вид исследования возможен как после проведения биопсии опухоли, так и при изучении удаленной из мозга неопластической ткани. Опухоль локализуется в белом веществе мозга, имеет мягкую консистенцию и характерный пестрый вид на разрезе, что связано с наличием очагов некроза и кровоизлияний. Гистологически МГБ состоит из клеток различной формы и величины, отличающихся количеством ядер, их величиной и содержанием хроматина. Ядерно-цитоплазматическое соотношение резко нарушено, в клетках очень много гликогена. Ткань опухоли характеризуется высокой митотической активностью, границы опухоли нечеткие, иногда практически отсутствуют.

Как правило, участки перивазальной и периневральной инвазии сочетаются с зонами уплотнения опухолевых клеток, среди которых быстро появляются признаки микроваскулярной пролиферации и формируются 
кровеносные сосуды. В динамике на некотором удалении от кровеносных сосудов быстро развиваются некротические процессы, что ведет к уплотнению клеток вокруг кровеносных сосудов, которые имеют вид периваскулярных псевдорозеток, отграничивающих обширные зоны некроза с псевдопалисадными структурами. Опухоль может формировать вторичные очаги на некотором расстоянии от первичного узла.

\section{3. Лечение впервые диагностированной глиобластомы}

Согласно современному стандарту лечения (Stupp et al., 2014, Weller et al., 2019) всем больным МГБ в обязательном порядке рекомендована хирургическая операция. Использование фотосенсибилизирующих средств на основе аминолевулиновой кислоты и методов интраоперационного нейромониторинга повышает эффективность хирургического лечения и минимизирует риск повреждения функционально значимых зон мозга. Однако операция не решает проблемы, инфильтрация мозга опухолевыми клетками в процессе оппозиционного роста МГБ исключает возможность радикального удаления опухоли без необратимого неврологического ущерба пациенту, а в ряде случаев делает саму операцию невозможной.

Основная ставка в лечении ГБ делается на облучение (Bräutigam et al., 2019). Больному рекомендовано облучение в дозе 60 Гр, по 2 Гр ежедневно всего 30 фракций за 6 недель (Nam \& de Groot et al., 2017). Высокие дозы радиации (Wegner et al., 2019) в сочетании с терапией темозоломидом $\left(75 \mathrm{mg} / \mathrm{m}^{2} / \mathrm{d}\right)$ показаны большинству больных МГБ. Исключение возможны только для пожилых пациентов, лечение которых можно ограничить коротким курсом облучения в 40 Гр (15 фракций за 3 недели) и химиотерапией (Braun \& Ahluwalia, 2017). Но при допустимых значениях индекса Карновского (>70) выбор должен быть сделан в пользу стандартной методики.

Возможности лучевой терапии ограничены. Превышение суммарной дозы радиации от 66 до 84,9-96,6 Gy (Cammarata et al., 2019; Scartoni et al., 2020) не увеличивает выживаемость, но ведет к быстрому развитию лучевых некрозов. Технологии кибер-ножа, бор-нейтрон захватной терапии (БНЗТ), введения в мозг наноматериалов или применение комбинации облучения с протонной терапией (Mizumoto et al., 2016; Mizumoto et al., 2015) достоверно не увеличивают выживаемость больных.

Химиотерапия может увеличить длительность безрецидивного периода и является определяющей стратегией лечения больных ГБ. Препара- 
том выбора является темозоламид (TMZ). В организме он подвергается химическому превращению в активный метаболит, действие которого обусловлено алкилированием гуанина в положения О6 и N7 с последующим запуском механизма аберрантного восстановления метилового остатка.

Пациенту назначается 6 циклов химиотерапии TMZ (Gilbert et al., 2013). В первый цикл рекомендован прием 150 mg/m2/d TMZ с 1 по 5 день 28-дневного цикла с увеличением дозы TMZ до $200 \mathrm{mg} / \mathrm{m} 2 / \mathrm{d}$ в последующие циклы. Увеличение числа циклов от 6 до 12 и/или повышение частоты приема TMZ не сопровождается увеличением выживаемости больных (Blumenthal et al., 2017). Комбинации TMZ с цисплатином (Wang et al., 2017), ломустином (Stritzelberger et al., 2018; Herrlinger et al., 2019), прокарбазином, винкристином и другими цитотоксическими препаратами, равно как и с бевацизумабом (Stupp et al., 2019), онковакциной «Риндопепимут» (Weller et al., 2017; Gerstner et al., 2017) и иными таргетными средствами (Touat et al., 2019) не ведут к существенному увеличению выживаемости больных при резком ухудшении качества жизни пациентов.

Обсуждается возможность терапии переменным магнитным полем. Существуют данные о статистически значимом увеличении выживаемости в течение 2-3 и 4 лет (Stupp et al., 2016), однако для оценки итоговой эффективности этого метода пока еще слишком мало достоверных данных.

Пациенту, получившему полный курс стандартной «агрессивной» терапии, показан регулярный МРТ-контроль. Согласно рекомендациям "National Comprehensive Cancer Network" (Nabors et al., 2015) МРТ с контрастированием и без такового должно выполняться каждые 2-4 месяца с момента операции, что связано с необходимостью отличить раннее прогрессирование опухоли от псевдопрогрессирования. Важно, что клинические симптомы не являются надежным маркером раннего прогрессирования (Nam \& deGroot, 2016) и чаще вызваны развитием отека мозговых структур, который может быть следствием облучения или иммунотерапии. Информативным методом идентификации раннего прогрессирования является позитронно-эмиссионная томография, которая в сочетании с данными спиральной компьютерной и магнитно-резонансной томографии повышает вероятность ранней диагностики рецидива.

Неврологическая симптоматика в случае псевдопрогрессирования быстро отступает при использовании кортикостероидов и антиангиогенных средств, таких как бевацизумаб. 
Но нельзя не отметить, что использование кортикостероидов при МГБ крайне не желательно, они ухудшают выживаемость при МГБ (Pitter et al., 2016; Seidel \& Kortmann, 2016), что непосредственно связано как с увеличением уровня глюкозы крови (Weller et al., 2017), так и с усилением локальной иммуносупрессии, что создает условия для ремоделирования ВКМ и содействует инвазивному росту опухоли.

В этой связи кортикостероиды должны использоваться только в тех случаях, когда ожидаемая польза превосходит потенциальный риск от их применения. Современные шкалы RANO (Response Assessment in NeuroOncology) и iRANO (immunotherapy Response Assessment in NeuroOncology) рассматривают увеличение дозы кортикостероидов как исключительно неблагоприятный признак, указывающий на прогрессирование опухоли, что требует от врача решительных действий, направленных на подавление рецидива.

\section{4. Лечение рецидива глиобластомы}

Возможность реоперации оценивается исходя из общего состояния больного, размеров и локализации опухоли, наличия вторичных очагов, выраженности отека мозговых структур и тяжести неврологической симптоматики. При небольших опухолях у молодых больных с хорошим функциональным статусом возможна реоперация, которая носит паллиативный характер, способствуя снижению внутричерепного давления.

Не существует однозначных данных об эффективности повторного облучения у больных МГБ. Однако такую возможность следует обязательно рассмотреть у больных с хорошим функциональным статусом, при небольшом объеме опухоли при отсутствии выраженного отека мозговых структур. Облучение может применяться во время операции с акцентом на край опухоли, который невозможно иссечь без причинения больному тяжелого неврологического ущерба.

Основная ставка в лечении больных делается на химиотерапию TMZ. Как правило, больным рекомендуется (Weller et al., 2013; Nam \& deGroot, 2016) прием TMZ в ежедневной дозе от 40 до 100 мг $/ \mathrm{m}^{2}$ по схеме «21 день лечения /7 дней отдыха или 7 дней лечения /7 дней отдыха». Выбор режима химиотерапии сильно зависит от фактического состояния больного, но достоверная разница в выживаемости при применении этих двух способов приема препарата отсутствует. 
В качестве второй линии химиотерапии рецидивирующей МГБ используются производные нитрозомочевины в комбинации с антиангиогенными средствами, например, комбинация ломустина и бевацизумаба (Seystahl et al., 2016), способных увеличить среднюю выживаемость пациента с 6,5 до 9,2 месяцев. Комбинации бевацизумаба с карбоплатином, иринотеканом, этопозидом, эрлотинибом и цетуксимабом не имеют какихлибо преимуществ перед монотерапией этим препаратом (Duffau, 2017; Tabet et al., 2019).

\section{5. Пути повышения эффективности генотоксической терапии глиобластомы}

Сутью современных методов лучевой и химиотерапии (Erasimus et al., 2016) является повреждение ДНК опухолевых клеток. Среди механизмов такого действия описано (Kaina \& Christmann, 2019) алкилирование азотистых оснований, однонитевые и двуцепочечные разрывы ДНК. Повреждение генома активирует механизмы репарации ДНК, среди которых прямая репарация и базовая эксцизионная репарация ДНК, гомологичная рекомбинация, негомологическое соединение концов, SOS-репарация и другие способы. Не обеспечив репарации генома, ОК погибает в результате митотической катастрофы, критически высокого уровня геномной нестабильности (Kellner et al., 2017) или «эффекта свидетеля» (Widel et al., 2017).

Однако способности к репарации генома опухолевых клеток сильно различаются у разных больных. Пациенты с коделецией $1 \mathrm{p} / 19 \mathrm{q}$ или IDH мутацией в опухолевых клетках обладают более высокой чувствительностью к стандартной терапии, чем больные с IDH-диким типом МГБ (Nam \& de Groot, 2017; Diplas et al., 2018; Waitkus et al., 2018). В результате IDH мутации в клетке образуется избыток 2-гидроксиглутарата, что ведет к гиперметилированию промоторных сайтов гена MGMT, обеспечивающего прямую репарацию ДНК в клетках МГБ. Медиана выживаемости больных МГБ с высоким статусом метилирования MGMT - 23 месяца, с низким 13 месяцев (Bady et al., 2018).

Мутация генов BRCA1/2 препятствует репарации двунитевых разрывов ДНК путем гомологической рекомбинации, повышает уровень эндогенного стресса (Rasmussen et al., 2018), что увеличивает эффективность облучения и химиотерапии. В этой связи, например, больной с мутациями IDH1 и BRCA1/2 имеет большие шансы на успех химиотерапии. Однако 
эти мутации встречаются достаточно редко, пациенты с диким типом опухоли - это более 90\% больных МГБ. В этой связи одним из основных направлений оптимизации химиотерапии МГБ является комбинация TMZ с препаратами подавляющими процессы репарации ДНК или усиливающими генотоксическое действие химиотерапии.

Арсенал средств, подавляющих репарацию ДНК, невелик. Ломегуатриб ингибирует прямую репарацию ДНК, но попытки (Taspinar et al., 2013 ) его комбинации с TMZ к успеху не привели. Метоксиамин препятствует базовой эксцизионной репарации ДНК, но его комбинация с TMZ (Khoei et al., 2016) тоже не оправдала ожидания. Олапариб приводит к возникновению двунитевых разрывов ДНК (Fulton et al., 2017). В исследовании PARADIGM-2 он показал обнадеживающие результаты в комбинации с облучением и TMZ (Lesueur et al., 2019), но этот препарат потенциально эффективен при мутации генов BRCA1/2, частота которой в популяции больных ГБ тоже не велика (Umphlett et al., 2020).

Независимо от наличия в опухоли тех или иных мутаций наилучшей способностью к репарации генома обладают именно ОСК. Описана (Hirschmann-Jax et al., 2004) особая популяция CD133+ клеток, продуцирующих белки АТP-cassette transporters ABCG2 и ABCA3, недопускающие попадания лекарств в клетки МГБ или немедленно выводящих их обратно. Независимо от комбинации генотоксических веществ такие клетки практически не чувствительны к химиотерапии.

\section{6. Таргетная терапия глиобластомы}

Одним из путей повышения эффективности генотоксической противоопухолевой терапии стала комбинация химиотерапевтических средств с таргетными препаратами, подавляющими ключевые молекулярные мишени в опухолевых клетках всех типов, в том числе в ОСК.

Особо важная роль RTKs-сигнализации в биологии МГБ позволила предположить, что поражение рецепторов к EGF, FGF, PDGF и ряду других цитокинов приведет к прорыву в лечении больных МГБ за счет блокирования нижележащих сигнальных путей в опухолевых клетках. Однако первое поколение ингибиторов рецепторов эпидермального фактора роста (EGFR) - эрлотиниб и гефитиниб (Karpel-Massler et al., 2011; Goodwin et al., 2018) - показало низкую эффективность у больных МГБ. Онковакцина «Риндопепимут», направленная против ОК, экспрессирующих мутантный 
пептид EGFRvIII, показала низкую эффективность у больных МГБ (Gerstner, 2017), что отчасти может быть связано с уменьшением антигенной нагрузки, вызванной предшествующей операцией. Комбинация риндопепимута с бевацизумабом к успеху тоже не привела (Neagu \& Reardon, 2015; Weller et al., 2017), что можно сказать и про EGFR-ингибитор афатиниб (Reardon et al., 2015).

Не лучше обстоят дела с использованием других ингибиторов RTKsсигнализации. Мультикиназный ингибитор дазатиниб (Lassman et al., 2015) показал низкие результаты при лечении больных МГБ с гиперэкспрессией в опухоли рецепторов тромбоцитарного фактора роста (PDGFR). Отрицательные результаты получены (Cloughesy et al., 2016) при использовании онартузумаба - ингибитора рецепторов фактора роста гепатоцитов (HGFR), так и при применении множества потенциальных ингибиторов EGFR (Lasorella et al., 2017).

Низкая эффективность ингибиторов RTKs-сигнализации послужила основанием для попыток повысить эффективность лечения больных МГБ при воздействии на нижележащие компоненты этого внутриклеточного каскада - сигнальную ось PI3K/AKT/mTOR. Однако PI3K и mTOR-ингибитор воксталисиб и PI3K-ингибитор бипарлисиб показали низкую эффективность у больных МГБ (Massacesi et al., 2016), а ингибиторы mTOR - тимсиролимус и эверолимус - оказались не эффективны, как при монотерапии, так и в комбинации с RTKs-ингибиторами, бевацизумабом и TMZ.

Определенные ожидания были связаны с подавлением сигнализации TGF- $\beta$. Это не удивительно, учитывая роль TGF- $\beta$ в биологии МГБ. Блокада этой сигнализации усиливает эффективность онколитических вирусов (Esaki et al., 2017). Экспериментальный препарат трабедерсен - первое в своем классе антисмысловое соединение (Bogdahn et al., 2011), при внутриопухолевом введении в небольших дозах был эффективнее стандартной терапии. Но в ходе масштабного исследования SAPPHIRE, вопросов по применению этого препарата у больных МГБ возникло куда больше, чем получено ответов.

Экспериментальный TGF- $\beta$ ингибитор галунисертиб показал высокую противоопухолевую активность, но обладает ангиогенным эффектом и усиливает ангиогенную активность VEGF (Wick et al., 2020). Потенциальные лекарственные молкулы LY2109761 (Zhang et al., 2011), P144 (Gallo-Oller, et al., 2016), многочисленные растительные антоцианиды (Ouan- 
ouki et al., 2017) и препарат хлорохин, ранее используемый для лечения малярии (Roy et al., 2015), тоже показали обнадеживающие результаты, но дальше эксперимента распространение не получили.

Сигнальный путь Notch обеспечивает непосредственное контактное взаимодействие между посылающей и принимающей сигнал клетками. Этот сигнальный путь усиливает агрессивность клеток МГБ. Подавление сигнального пути Notch (Zhen et al., 2010; Wu et al., 2013) триоксидом мышьяка в свою очередь подавляет развитие ОСК в глиомаcфepax in vitro. K тому же подавление этого сигнального пути олеаноловой кислотой вызывает апоптоз клеток МГБ (Gao et al., 2007), но это только в эксперименте. Описана (Gersey et al., 2019) возможность воздействия на этот механизм при помощи дибензодиазепинов, никлозамида, ретиноевой куслоты, ресвератрола и других веществ, однако, опять же, только в эксперименте.

Сигнальный путь Wnt - одна из самых самых многообещающих целей для таргетной терапии МГБ. Уровень синтеза ключевых белков wntсигнального пути в ОСК значительно усилен по сравнению с дифференцированными клетками МГБ (Shevchenko et al., 2019; Shevchenko et al., 2020), что сближает их с клетками трижды-негативного рака молочной железы (Pohl et al., 2017). Однако об ингибиторах wnt-сигнального пути показавших высокую эффективность при лечении МГБ, известно мало, в этой связи представляют огромный интерес репозиционируемые лекарственные препараты, подавляющие Wnt-сигнализацию, среди которых клофазимин (Ahmed et al., 2019), сайкосапонид D (Wang et al., 2018), диклофенак и целекоксиб (Sareddy et al., 2013), никлозамид (Yin et al., 2016) и силибинин (Lu et al., 2012). Однако эти вещества и их комбинации еще на стадии эксперимента.

Репарация ДНК сопровождается резким снижением уровней метилирования ДНК и ацетилирования гистонов, но попытка повысить эффективность комбинации облучения и TMZ с ингибитором гистондеацетилазвориностатом (Galanis et al., 2018) и бевацизумабом (Peters et al., 2018) не показала увеличения выживаемости больных.

В свете сказанного, за редким исключением, таргетная терапия МГБ практически не эфективна. Причины заключаются в гетерогенности и высокой пластичности клеток МГБ. Однако разработка новых лекарств, сочетающих генотоксическое действие в отношении всех типов опухолевых 
клеток с обязательным воздействием на ключевые мишени в ОСК, - приоритетный путь увеличения выживаемости больных МГБ.

\section{7. Перспективные молекулы для создания новых генотоксических средств}

С 2014 г. в фокусе нашего внимания группа природных соединений, в основе которых лежит пентациклическая система пиридо[1,2-a:3,4b']дииндола, более известных как фаскаплизиновые алкалоиды, самым популярным представителем которых является красный пигмент фаскаплизин, выделенный из морской губки Fascaplysynopsis sp. в 1988 г.

Плоская структура фаскаплизина позволяет ему поместиться между азотистыми основаниями и интеркалировать ДНК, останавливая процессы транскрипции и трансляции (Hörmann A et al., 2001) и оказывая действие подобное доксорубицину, даунорубицину или дактиномицину. Но в отличие от этих веществ среди механизмов противоопухолевого действия морских алкалоидов описано (Bharate et al., 2012; Chen et al., 2017) подавление образования активных комплексов CDK4 и CDK6 с циклином D1; торможение процесса фосфорилирования белка ретинобластомы (Rb), арест клеточного цикла и активация каспаз 3, 8, 9 и запуск апоптоза (Hamilton et al., 2014); активизация рецепторов к лигандам семейства TNF $\alpha$, подавление антиапоптозных белков семейства Bcl-2, подавление TrkA и VEGFR2 (Chen et al., 2017; Kumar et al., 2015, Oh et al., 2017) и компонентов сигнального пути PI3K/AKT/mTOR.

Фаскаплизин представляет собой прообраз качественно нового противоопухолевого средства для лечения МГБ. Однако, как и большинство веществ природного происхождения, оно не лишено недостатков. Вещество обладает сильной ингибирующей активностью в отношении CDK4 (Bharate S.B. et al., 2012), но в отношении других CDK демонстрирует слабую активность, сродство к комплексу CDK4/циклин D1 выше, чем к CDK6/циклин D1. Фаскаплизин ингибирует комплекс CDK6/циклин D2, но не действует на комплексы CDK4/циклин D2 и CDK4/циклин D3.

Среди производных фаскаплизина встречаются соединения, противоопухолевая активность которых превосходит незамещенный алкалоид.

В частности, 10-бромфаскаплизин, 3-бромфаскаплизин, гомофаскаплизин намного активнее исходного соединения. Цитотоксическое действие 3-бромфаскаплизина и 3,10-дибромфаскаплизина демонстрирует 
высокую селективность по отношению к клеткам меланомы, рака кишечника и простаты (Zhidkov et al., 2019). Указанные свойства в сочетании со способностью проникать через ГЭБ позволяют рассматривать фаскаплизиновые алкалоиды как перспективные соединения для создания новых фармпрепаратов для лечения МГБ.

\section{8. Химиотерапия и гематоэнцефалический барьер}

Принято считать, что ГЭБ повсеместно нарушается при МГБ. Эти выводы основаны на экспериментах 1977 г. (Vick et al., 1977), показавших накопление гадолиниевого контраста в отдельных участках опухоли при нейровизуализационном обследовании. Однако получены новые данные, согласно которым осмотическое или ультразвуковое повреждение ГЭБ (Oberoi et al., 2016) увеличивает выживаемость больных МГБ по сравнению с монотерапией TMZ. Подавление белков лекарственной резистентности MRP1(Torres et al., 2018; Tong et al., 2018) BCRP, P-gp и других active-efflux транспортеров повышает эффективность лечения, доставка лекарств через ГЭБ улучшает результаты лечения МГБ.

Очевидно, что роль ГЭБ при построении современных схем химиотерапии МГБ критически недооценена (Sarkaria et al., 2018; Da Ros et al., 2018; Sharma et al., 2020). Опухолевые клетки, мигрирующие далеко за пределы опухолевого узла в участки мозга, тотально защищенные ГЭБ, остаются недоступными для химиопрепаратов. Решение данной проблемы не может быть тривиальным и требует отработки как минимум трех сценариев. Первый предусматривает интратекальное введение химиопрепаратов; второй непосредственно связан с введением лекарств в магистральные сосуды в сочетании с методиками и приемами, направленными на повышение проницаемости ГЭБ; третий основан на создании особых форм противоопухолевых препаратов, свободно проходящих через ГЭБ.

Интратекальный способ введения TMZ эффективен при лептоменингите, вызванном метастазами рака легких (Wang et al., 2018) и желудка (Liu, 2017), в сочетании с облучением мозга и таргетной терапией. К великому сожалению, такие формы вторичного опухолевого поражения ЦНС далеко не редкость, и подобный опыт можно использовать для лечения больных МГБ. Достаточно давно показано (Friedman, 2000), что интратекальное введение TMZ увеличивает выживаемость экспериментальных животных с глиомами. Такой способ особенно эф- 
фективен (Passarin et al., 2010) у больных с дессиминированными олигоастрацитомами с поражением мозговых оболочек.

Возможности интратекального введения TMZ не ограничиваются только случаями лептоменингита. Теоретически возможности этого способа химиотерапии могут быть расширены за счет суперселективного введения цитостатиков и TMZ во внутреннюю сонную артерию и ее дистальные ветви. Получены достаточно интерсеные данные (Kulason et al., 2018) о внутриартериальном введении цетуксимаба больным МГБ после осмотического повреждения ГЭБ манитолом в комбинации с комплексным лечением по стандартному протоколу (Stupp et al., 2017). Внутриартериальное введение TMZ (Muldoon et al., 2016) в сочетании с повреждением ГЭБ увеличивает эффективность доставки TMZ при лечении больных со вторичными или метастатическими опухолями. Проницаемость ГЭБ может быть повышена (Sharma et al., 2020) не только при введении манитола, но и путем повышения системного артериального давления или температуры; не исключена и возможность комбинации этих методик.

Использование нанотехнологий является одним из самых перспективных методов адресной доставки лекарств через ГЭБ. Наноразмерные частицы размером менее 200 нм способны самостоятельно проникать в мозг через адсорбционно-опосредованный трансцитоз, что позволяет использовать их для создания специальных систем доставки TMZ. Они могут быть получены из природных и синтетических полимеров, среди которых особые перспективы связаны с наночастицами на основе полимолочной гликолевой кислоты, полимолочной кислоты, хитозана, гиалуроновой кислоты, золота, серебра, оксида цинка и других компонентов.

Эффективность адресной доставки химиопрепаратов с использованием нанокапсул достаточно высока. Нанокапсулы на основе полимолочной гликолиевой кислоты с доксорубицином (Wohlfart et al., 2011) или TMZ (Ramalho et al., 2020) проникают через ГЭБ и эффективно уменьшают рост опухолей в эксперименте у крыс. Нанокапсулы на основе стеариновой кислоты и хитозана показали хорошие результаты для адресной доставки доксорубицина (Sahariah et al., 2017) через ГЭБ, в том числе после интраназального введения (Hefnawy et al., 2017). Однако только одной упаковки лекарств, помещенных в нанокапсулы, для успешной терапии недостаточно. 
Предложен способ адресной доставки паклитаксела с использованием наночастиц на основе полимолочной кислоты, конъюгированных с антителами против белка tLyp-1 (Hu et al., 2013), сверхэкспрессированного на клетках МГБ. Нанокапсулы на основе поли (этиленгликоль)-поли(саркапролактона), функционализированные белком LS10, который избирательно связывается с белком-мишенью NG2, сверхэкспрессируемым в клетках МГБ (Chi et al 2016), многократно увеличивают цитотоксичность паклитаксела в отношении ОСК. Наночастицы на основе гиалуроновой кислоты, функционализированные антителами против антигена CD44 к клеткам МГБ, обеспечивают адресную доставку паклитаксела (Sofias et al., 2017) или доксорубицина (Deng et al., 2017) в клетки МГБ, однако, опять же, только в эксперименте.

\section{9. Иммунотерапия МГБ}

Потенциал иммунной системы должен быть использован в комплексной терапии больных МГБ. Однако при построении конкретных схем иммунотерапии (ИТ) МГБ нужно учитывать стратегически важные системные факторы. Во-первых, МГБ локализована за ГЭБ и всегда дебютирует перед иммунной системой только в сопровождении пула иммуносупрессивных цитокинов (глава 1). Во-вторых, уничтожение ОК не является приоритетной задачей иммунной системы человека. На протяжении всего существования млекопитающих и человечества основную угрозу представляли инфекционные агенты, до рака большинство живых существ не доживало. Соответственно, совершенствование генетических и эпигенетических механизмов иммунной защиты организма от возникновения рака на протяжении всей истории развития млекопитающих не осуществлялось.

Механизмы инфекционной защиты отработаны в течение многих веков. Первая же встреча с инфекционным антигеном сопровождается первичным иммунным ответом в виде презентации антигенов на поверхности макрофагов и ДК, генерацией пула ЦТЛ (цитотоксических Т-лимфоцитов) и длительным сохранением информации в «клетках памяти» и выработкой антител к антигену. При повторной встрече с этим антигеном формируется вторичный иммунный ответ, который использует весь арсенал уже ранее сгенерированных и мобилизованных иммунных специальных средств для элиминирующего воздействия на инфекционные агенты. 
Безусловно, эволюцией сформированы механизмы элиминации измененных и трансформированных клеток, возникающих в процессе физиологической регенерации, при условии, что их количество не превышает определеннх пределов. После критического увеличения количества ОК $\left(>10^{5}\right)$, иммунная система не обеспечивает генерации необходимого пула ЦТЛ. По меткому выражению академика М.И. Давыдова, «однажды пропустив рак, иммунная система его никогда не догонит». Факты действительно парадоксальны (Rossi et al., 2019): 10 ЦТЛ способны убить 1 ОК, ситуация усугубляется продукцией ОК иммуносупрессивных цитокинов и развитием иммунотолерантности.

В свете сказанного прямолинейное решение проблемы ИТ у больного МГБ только методами стимуляции, мобилизации или активации иммунокомпетентных клеток (ИКК) практически не целесообразно. И тем не менее реставрация кроветворения и иммунного статуса пациента с МГБ отчасти может быть реализована путем применения Г-КСФ. Использование персонализированных (пЦТЛ), обладающих специфическими противоопухолевыми детерминантами, дендритно-клеточных вакцин (ДКВ) и ДВ способствует снижению числа ОК в организме больного, что важно, и этим нельзя пренебрегать.

В свете сказанного первой целью ИТ при МГБ является достижение состояния «минимальной остаточной болезни» за счет максимального снижения количества ОК в организме, что открывает «окно возможностей» для восстановления иммунного надзора. Второй целью является провоспалительная модификации микроокружения ОСК с целью ее декомпартментализации и нарушения взаимоотношений с ВКМ, что открывает возможность контроля над опухолевым процессом. Для этих целей применима стратегия комплементарной терапии (Wilcox et al., 2018; Jackson et al., 2019), которая заключается в потенцировании лечебного действия иммунотерапевтических методик при их системном применении и комбинации.

Одну из первых попыток применять персонализированную ИТ для лечения больных МГБ предприняли сотрудники НИИ детской онкологии и гематологии НМИНЦ онкологии им Н.Н. Блохина (Mentkevich et al., 2001; Yankelevich et al., 2017). Для лечения глиом у детей использовали ДКВ, нагруженные антигенами убитой опухоли больного, ЦТЛ и аллогенных ГСК родителей больных детей. Результаты можно назвать уникаль- 
ными. Несколько пациентов с МГБ жили до 5-6 лет, а один пациент прожил после лечения 14 лет.

Таким образом, диагноз МГБ сложен. Решающее значение здесь принадлежит МРТ и другим нейровизуализационным методам исследования. Комплексное лечение МГБ построено по стандартному протоколу, при этом основная ставка делается именно на химиотерапию TMZ. Прогноз крайне неблагоприятный, но комбинация цитотоксических веществ и таргетных препаратов может продлить жизнь больного МГБ. Среди молекулярно нацеленных препаратов достовено эффективным является комбинация TMZ + бевацизумаб, эффективность других таргетных средств не доказана. Одной из ведущих причин низкой эффективности лечения является недостаточная проницаемость ГЭБ. Попытки повысить эффективность химиотерапии путем интратекального и селективного внутриартериального введения лекарств следует признать принципиально правильными. Исключительно важно и перспективное использование наноконтейнеров с лекарствами, функционализированными против отдельных мишеней в ОСК. Возможно, такие мишени следует устанавливать индивидуально, используя функционал современных постгеномных технологий.

Основным средством подавления ОСК должны стать биомедицинские клеточные продукты (БМКП), созданные на основе клеток аутологичного и алогенного красного костного мозга (ККМ). 


\section{ПРОТИВООПУХОЛЕВЫЙ ПОТЕНЦИАЛ ГЕМОПОЭТИЧЕСКИХ СТВОЛОВЫХ КЛЕТОК В ТЕРАПИИ ГЛИОБЛАСТОМЫ}

Эффективных способов убивать ОСК в организме больного МГБ на сегодняшний день не существует. В этой связи пролонгация ремиссии, предотвращение рецидива и успех в лечении МГБ всецело определяются эффективностью регуляции ключевых функций ОСК. Одним из путей решения этой задачи являетя использованием противоопухолевого потенциала ГСК.

ГСК происходят от плюрипотентных клеток первичной эмбриональной мезодермы и при дальнейшей дифференцировке дают начало клеткам миелоидного и лимфоидного ростков красного костного мозга. Миелоидные клетки порождают моноциты/макрофаги, гранулоциты, эритроциты, мегакариоциты/тромбоциты и миелоидые дендритные клетки. Лимфоидные клетки являются источником Т- и В-лимфоцитов, NK-клеток и лимфоидных дендритных клеток. В красном костном мозге взрослого человека сохраняется некоторое количество плюрипотентных ГСК и клеток со свойствами прегемангиобластов. Эти клетки обладают высоким репаративным потенциалом, достаточным для быстрой реконструкции кроветворной системы.

Помимо зрелых гемопоэтических CD34+ CD45+ HLA DR CD38Gp130- стволовых клеток ККМ содержит гемопоэтические CD34+CD45+ HLA DR+ CD38+ Gp130+ прогениторные клетки, мультипотентные мезенхимальные стромальные CD10+ CD13+ CD34- CD44+ CD45- CD90+ (Thy-1) CD105+ CD117- клетки и мезенхимальные стромальные прогениторные CD10+ CD13+ CD34- CD44- CD45- CD90+ (Thy-1) CD105+ $\mathrm{CD} 117+$ клетки. Несмотря на широкую палитру поверхностных антигенов все клетки ККМ связаны сложной, иерархически организованной системой межклеточных взаимодействий, координирующих эпигенетические программы, предопределяющие их дальнейшую дифференцировку и регенераторный потенциал. Нарушение этой иерархиии крайне нежелательно, более того, выделение какого-то одного типа клеток резко снижает их регенераторные возможности.

В свете сказанного, с конца ХХ в. основным источником ГСК для целей трансплантации является периферическая кровь. ГСК рекрутируют 
в кровеносное русло путем введения пациенту гранулоцитарного колониестимулирующего фактора (Г-КСФ) и извлекают в составе пула CD45+ мононуклеарных клеток. Содержание CD34+ ГСК в таком пуле достигает 1,5$2 \%$ и более, а колличество мезенхимальных CD29+, CD44+, CD73+, CD90+, CD34- стволовых клеток не превышает 1-2 \% (Bryukhovetskiy et al., 2014).

Исключительно высокое содержание ГСК позволяет использовать лейкоконцентрат CD45+ мононуклеарных клеток для реконструкции кроветворной системы и коррекции миелосупрессии после высокодозной химиотерапии, а также для лечения аутоимунных заболеваний и адресной доставки генов. Предприняты успешные попытки применения предварительно консервированного лейкоконцентрата для лечения тяжелых неврологических заболеваний и травм ЦНС, а также для создания новых технологой омоложения и продления жизни.

Узловой точкой применения ГСК в онкологии и регенеративной медицине является их способность к хоумингу - фундаментальное свойство клеток ККМ, предопределяющее возможность самостоятельной миграции в зону повреждения и способность вернуться обратно в депо в ККМ. Среди множества цитокинов, регулирующих процессы хоуминга клеток ККМ, главная роль принадлежит фактору стромальных клеток (SDF)-1 $\alpha$ или хемокину CXCL12 (Lewellis \&Knaut, 2012). C-X-C chemokine receptor type 4 к SDF-1 $\alpha$ локализованы на мембране всех стволовых и прогениторных клеток костного мозга (Chute, 2006; Kavanagh\& Kalia, 2011), эмбриональных и СК, а также НСК и всех зрелых клеток крови.

Со способностью хоумингу связано другое свойство ГСК - направленная миграция в ткань МГБ. Поврежденные ткани мозга и опухолевые клетки активно продуцируют SDF-1 $\alpha$ в ответ на стммуляцию хемокинов семейства HIF - факторов, которые, с одной стороны, организуют иерархические межклеточные взаимоотношения в ККМ, с другой строны, являются главными модераторами межклеточных взаимодействий в патогенезе МГБ. В наших собственных экспериментах (Bryukhovetskiy et al., 2017) мононуклеарные клетки ККМ, обогащенные ГСК, при введении в кровоток крыс с глиомой С6 мигрировали в опухоль, проникали в неопластическую ткань и визуализировались в зонах инвазии и некроза. Вероятно, благодаря высокому содержанию SDF1 $\alpha$ и хемокинов семейства HIF клетки ККМ распознают гипоксичную опухоль как собственную нишу в костном мозге, в которую стремятся вернуться. 
Способность клеток ККМ, в том числе ГСК, к направленной миграции и хоумингу в ткань МГБ, открывает перспективы их использования для дестабилизации взаимоотношений ОСК с локальным микроокружением, ОСК и ВКМ, а также для эпигенетического перепрограмирования ОСК.

Как уже было сказано, вектор межклеточного взаимодействия задается локальной иммуносупрессивной микросредой, формируемой ОСК. На это указывает тот факт, что масштабное рекрутирование (Zaitsev et al., 2020) в кровоток мононуклеарных CD45+ клеток ККМ, обогащенных ГСК, с последующей провоспалительной стимуляцией увеличивает выживаемость крыс с глиомой С6 и сопровождается увеличением содержания в опухоли CD86+ клеток микроглии. Продукция этими клетками интерлейкина 1 , TNF $\alpha$ и других провоспалительных цитокинов дестабилизирует взаимоотношения между клетками МГБ и ВКМ.

Важнейшим компонентом лечения МГБ является облучение, индуцирующее в ОК процессы репарации ДНК и ведущее к критической экспрессии ряда генов (Crespo et al., 2015; Guan et al., 2016; Nguen et al., 2018; Noch et al., 2018). К таким генам следует отнести PARP1 (Murnyák et al., 2017), RBBP4 (Kitange et al., 2016), RAD 51 (King et al., 2017), NF-kB (Aasland et al., 2019), CXCL12 (Goffart et al., 2017), WISP1 (Jing et al., 2017), BIRC3 (Wang et al., 2018; Wang et al., 2016), NAMPT (Gujar et al., 2016), HIF (Wang et al., 2017), MET (De Bacco et al., 2016) ASAH1 (Doan et al., 2017) и т.д.

Воздействие на эти мишени возможно с использованием противоопухолевого потенциала мононуклеарных клеток КМ, обогащенных ГСК. Клетки этого типа (Mercatelli et al., 2017) способны к продукции 10 ключевых противоопухолевых микроРНК - MiR-302c-3p, MiR-592, MiR-484, MiR-1260a, MiR-493 - 3p, MiR-145 - 5p, MiR-30a - 5p, MiR483 - 5p, MiR-514a-3 и MiR-124 - 3p, а также микроРНК семейств Let7a, miR34, miR31, miR 451, miR145, семейств miR200/141 и $\mathrm{miR}$ 14/15, miR 23b, miR 223, miR224, MiR124, miR-145-5p, MiR200a, Mir451, Mir23b, которые подавляет процессы ЭМП, miR 181 и miR21, блокирующих сигнализацию NFкB в клетках МГБ, и MiR92a и miR145, подавляющих пролиферацию ОК. Эпигенетическое репрограмирование ОСК возможно с использованием экзосом, продуцируемых клетками ККМ, подавляющими активность NF-kB и HIF (Katakowski \& Chopp, 2016) и вызывающими другие противоопухолевые эффекты в условиях провоспалительной стимуляции. 
Итак, провоспалительная модификация микроокружения ОСК с использованием противоопухолевого потенциала мононуклеарных клеток КМ, обогащенных ГСК, является одним из самых обоснованных подходов к пролонгации ремиссии у больных МГБ. Среди практических подходов к решению данной проблемы следует выделить аутологическую и аллогенную трансплантацию ГСК.

Вопрос использования аутологичеких клеток КМ в первую очередь неразрывно связан с лечением иммуносупрессии. Системное иммуносупрессивное действие оказывают облучение, цитотоксические агенты и глюкокортикостероиды. Прием химиопрепаратов сопровождается угнетением кроветворных ростков костного мозга, развитием инфекционных и геморрагических осложнений. Современный протокол комплексного лечения МГБ игнорирует эту проблему, но, как показывает практика, без ее решения все остальные методы не эффективны.

Безусловно, коррекция лейкопении и сопутствующих инфекционных осложнений может быть проведена путем стимуляции пациента Г-КСФ, и для получения надежного противоопухолевого эффекта она может быть дополнена провоспалительной терапией. Подобное решение проблемы возможно, если больной хорошо перенес курс лечения по стандартному протоколу (Stupp et al., 2014), сохраняет высокий уровень функциональной активности и не имеет критически низкой лейкопении. Однако коррекция системной иммуносупрессии может быть более эффективной при введении больному предварительно собранного и криоконсервированного аутологического лейкоконцентрата клеток ККМ, обогащенного ГСК. В этом случае первичный курс биотерапии может быть дополнен персонализированными дендритно-клеточными вакцинами, что расширяет возможности лечения.

Для коррекции тяжелой системной иммуносупрессии в ряде случаев оправдано использование аллогенных клеток костного мозга, что, возможно, является методом выбора у больных МГБ. Длительность и качество ремиссии у онкогематологических больных, получивших высокодозную химиотерапию и аллотрансплантацию костного мозга, достоверно выше, чем у больных, получивших аутологический клеточный материал. В основе этого феномена - способность аллогенных лимфоцитов донора, являющихся неотъемлемой частью фракции CD45+ клеток костного мозга, атаковать остаточную опухолевую ткань в организме реципиента. Терапевтический эффект аллотрансплантации может быть усилен при по- 
следующем введении аллогенных лимфоцитов, активированных рекомбинантным интерлейкином 2, доза которых может быть как минимально эскалирующей, так и критически высокой.

Радикально удалить МГБ невозможно. Облучение и химиотерапия с этой задачей справляются плохо. В этой связи способность аллогенных лимфоцитов донора, являющихся неотъемлемой частью фракции CD45+ клеток костного мозга, атаковать остаточную опухолевую ткань в организме больного может и должна быть использована для лечения больных МГБ. Помимо Т-лимфоцитов противоопухолевый эффект аллогенных МК CD45+ клеток обусловлен участием моноцитов, макрофагов и NK-клеток (Or-Geva \& Reisner, 2015), способных подавлять ОК независимо от наличия антигенов главного комплекса гистосовместимости. Однако Т-клеток, агрессивных только против клеток МГБ, не существует, и даже при условии их трансдукции суицидальными генами риск такой терапии должен быть сопоставим с тяжестью состояния больного.

Очень привлекательные перспективы могут быть связаны с использованием эффекта «вето» ГСК (Sidik-Muskatel \&Reisner, 2019; Or-Geva \& Reisner, 2016; Reisner \& Or-Geva et al., 2019). Это исключительно сложный феномен, описанный при массированной трансплантации аллогенных ГСК. Он сопровождается индукцией билатеральной трансплантационной толерантности между клетками донора и реципиента, инактивацией агрессивных клонов Т-лимфоцитов и подавлением реакции «трансплантат против хозяина». Стратегическими условиями для этого феномена (Reisner et al., 2003, Or-Geva \& Reisner, 2015) является преобладание клеток трансплантата, контактное взаимодействие между клетками и присутствие ряда цитокинов.

Безусловно, этот феномен нуждается в дальнейшем изучении, однако эффект «вето» ГСК - концептуальное свидетельство стратегической, регуляторной функции СК ККМ, использование которой открывает грандиозные терапевтические перспективы в области иммунотерапии опухолей и регуляции функций ОСК.

Акцент на ГСК не случаен. Согласно традиционной точке зрения, только специализированные иммунокомпетентные клетки (ИКК) могут активировать иммунный ответ. На иммунизации периферических ИКК построена работа по созданию вакцин от вирусных и бактериальных инфекций во всем мире: в организм человека вводится антиген в ослабленной форме и организм сам формирует первичный иммунный ответ, который реализуется за счет ИКК и фиксируется в периферических 
клетках иммунной памяти. Роль ГСК в данном случае является неспецифической и состоит исключительно в генерации кроветворных и иммунных клеток.

Однако исследования последних лет указывают на существенную недооценку роли ГСК в регуляции иммунных реакций. Работы международной научной группы Майкла Сивеке (de Laval B et al., 2020) показывают, что ГСК могут «воспринимать» и хранить информацию о внешних факторах, чтобы специфически производить подтипы иммунных клеток «по требованию» для борьбы с инфекцией и любыми другими антигенами, а также указывают на центральную роль ГСК в механизмах иммунной памяти на любой антиген.

ГСК могут стимулировать быстрый и эффективный иммунный ответ (de Laval B et al., 2020), если они ранее подвергались воздействию компонентов бактериальной молекулы и память об этом хранится в ГСК как некий эпигенетический паттерн, позволяющие сформировать мгновенный иммунный ответ и сгенерировать достаточное количество специализированных ИКК (макрофагов, дендритных клеток, цитоксических лимфоцитов). Первое воздействие возбудителя приводит к тому, что в ДНК откладываются «метки», прямо вокруг генов, которые важны для иммунного ответа. «Метки» на ДНК гарантируют, что эти гены будут легко обнаружены, доступны и активированы для быстрого реагирования в случае появления второй волны инфекции подобным агентом. При этом эпигенетическая память активизируется C/EBP b-энхансерным белком - основным модератором неотложных иммунных реакций. Эти знания позволяют по-новому подойти к пониманию настройки иммунной системы для реагирования на опухолевые антигены, улучшить стратегию вакцинации и способность иммунной системы более эффективно бороться с опухолевой агрессией.

Таким образом, использование лейкоконцентрата мобилизованных CD45+ клеток KKM, обогащенных ГСК, открывает перспективы регуляции ОСК глиобластомы человека. Провоспалительная модификация микроокружения ОСК с использованием клеток ККМ позволяет дестабилизировать существущую иерархическую систему взаимодействия между клетками МГБ, нарушить взаимодействие с ВКМ, оказать репрограммирующее воздействие на эпигеном ОСК с применением факторов секретома ККМ и использовать феномен «вето» ГСК. Для достижения поставленной цели могут быть использованы аутологические и аллогенные клетки ККМ, причем последние обладают существенно большим противоопухолевым потенциалом. 


\section{ФУНДАМЕНТАЛЬНЫЕ АСПЕКТЫ ПРОБЛЕМЫ: ВЗАИМОДЕЙСТВИЕ ГЕМОПОЭТИЧЕСКИХ СТВОЛОВЫХ И ОПУХОЛЕВЫХ КЛЕТОК IN VITRO}

Одним из ключевых этапов эволюции многоклеточных организмов стало появление их способности к специфическому координированному межклеточному взаимодействию, что сделало возможным согласованную регуляцию метаболизма, дифференциацию клеток и проявление физиологических функций дифференцированных клеток. Вектор взаимодействия стволовой и дифференцированной клеток определяется локальными микроусловиями среды, однако только в патологии и клинике можно понять всю глубину адаптивных возможностей организма. В этой главе мы остановимся на закономерностях межклеточного взаимодействия ГСК с нормальными и патологически измененными, а именно опухолевыми клетками.

\section{1. Закономерности миграции гемопоэтических стволовых клеток к опухолевым клеткам различных линий in vitro}

Для обоснования феномена направленной миграции ГСК в неопластический очаг и выявления некоторых механизмов реализации этого феномена был выполнен эксперимент in vitro, который проходил в два этапа:

1) исследование миграции стволовых клеток в сочетанных культурах с клетками различных линий;

2) исследование миграции стволовых клеток человека в сокультурах с клетками злокачественных опухолей различных типов.

Использованы дермальные фибробласты человека (АTCC® PCS-201012тM), астроциты крысы (CTX TNA2 (ATCC® CRL-2006), клетки злокачественной крысиной глиомы линии C6 (ATCC® CCL-107), линии U-87MG (ATCC® HTB-14) и T-98G (ATCC® CRL-1690) глиобластомы человека, клетки линии МСА-7 аденокарциномы молочной железы (АТСС® НТВ22) и линии A549 (ATCC® CCL-185) карциномы легких человека, первичная культура CD34+ ГСК человека (АTCC® PCS-800-012 ${ }^{\mathrm{TM}}$ ). Перед началом эксперимента все клетки протестированы на контаминацию микоплазмой с помошью Universal Mycoplasma Detection Kit (ATCC® 30-1012K ${ }^{\mathrm{TM}}$ ). 
Для изучения закономерностей миграции СК и выявления некоторых механизмов и особенностей реализации этого феномена выполнен эксперимент in vitro, который проходил в два этапа. Задачей первого этапа было выявление особенностей взаимодействия ГСК с опухолевыми и нормальными высокодифференцированными клетками - фибробластами и астроцитами.

\subsection{1. Миграция стволовых клеток млекопитающих \\ в сочетанных культурах с клетками \\ и различных линий in vitro}

Для создания сочетанных культур использовали культуральные вставки с размером пор 12 мкм (Millipore, США). Дно лунок культурального планшета (Grinner BioOne, США) покрывали полиэтиленимином, а затем ламинином (Gibco, США). В каждую лунку планшета помещали пористую культуральную вставку с диаметром пор 12 мкм, которую фиксировали каплей стерильного парафина (рис. 1). Планшет заполняли средой DMEM (Dulbecco's modified Eagle's medium (DMEM); Gibco; Thermo Fisher Scientific, Inc., Waltham, MA, СШA) c пониженным содержанием глюкозы и добавлением 10\% эмбриональной телячьей сыворотки (FBS) и 100 U/ml пенициллина/стрептомицина. Все реагенты производства компании "Gibco" (Thermo Fisher Scientific, Inc., США).

Внутрь вставки вносили $0,5 \times 10^{4}$ клеток глиомы C6, астроцитов или фибробластов, предварительно окрашенных витальным трейсером Vybrant ${ }^{\mathrm{TM}}$ CFDA SE Cell Tracer (кат. № V12883 Invitrogen ${ }^{\mathrm{TM}}$ ). Планшет с культуральными вставками инкубировали в течение 24 ч, затем на дно лунки планшета снаружи культуральной вставки высаживали по 0,5×104 ГСК, предварительно окрашенных флуоресцентным маркером CellTracker ${ }^{\mathrm{TM}}$ Red CMTPX Dye (кат. № C34552, Invitrogen ${ }^{\mathrm{TM}}$ ).

Клетки культивировали 120 ч $\left(37^{\circ} \mathrm{C}, 5 \% \mathrm{CO}_{2}\right)$. Подсчет клеток, мигрировавших сквозь культуральную вставку, проводили с использованием высокоэффективной количественной микроскопии (Cell IQ, CM Technologies, Великобритания) с временными отрезками 24-48-72-96-120 ч; регистрировали количество Red CMTPX Dуе-позитивных объектов, как на границе, так и внутри культуральной вставки. Полученные результаты верифицировали методом цитофлуориметрии. 
Спустя 24 ч после начала совместного культивирования наблюдали формирование клеточного вала из флуоресцирующих клеток, располагающихся по периметру культуральной вставки с клетками глиомы. Этот феномен был отчетливо выражен в сокультурах, содержащих опухолевые клетки, и отсутствовал в лунках планшета, где стволовые клетки были совмещены с фибробластами и астроцитами (рис. 2, А-Г).

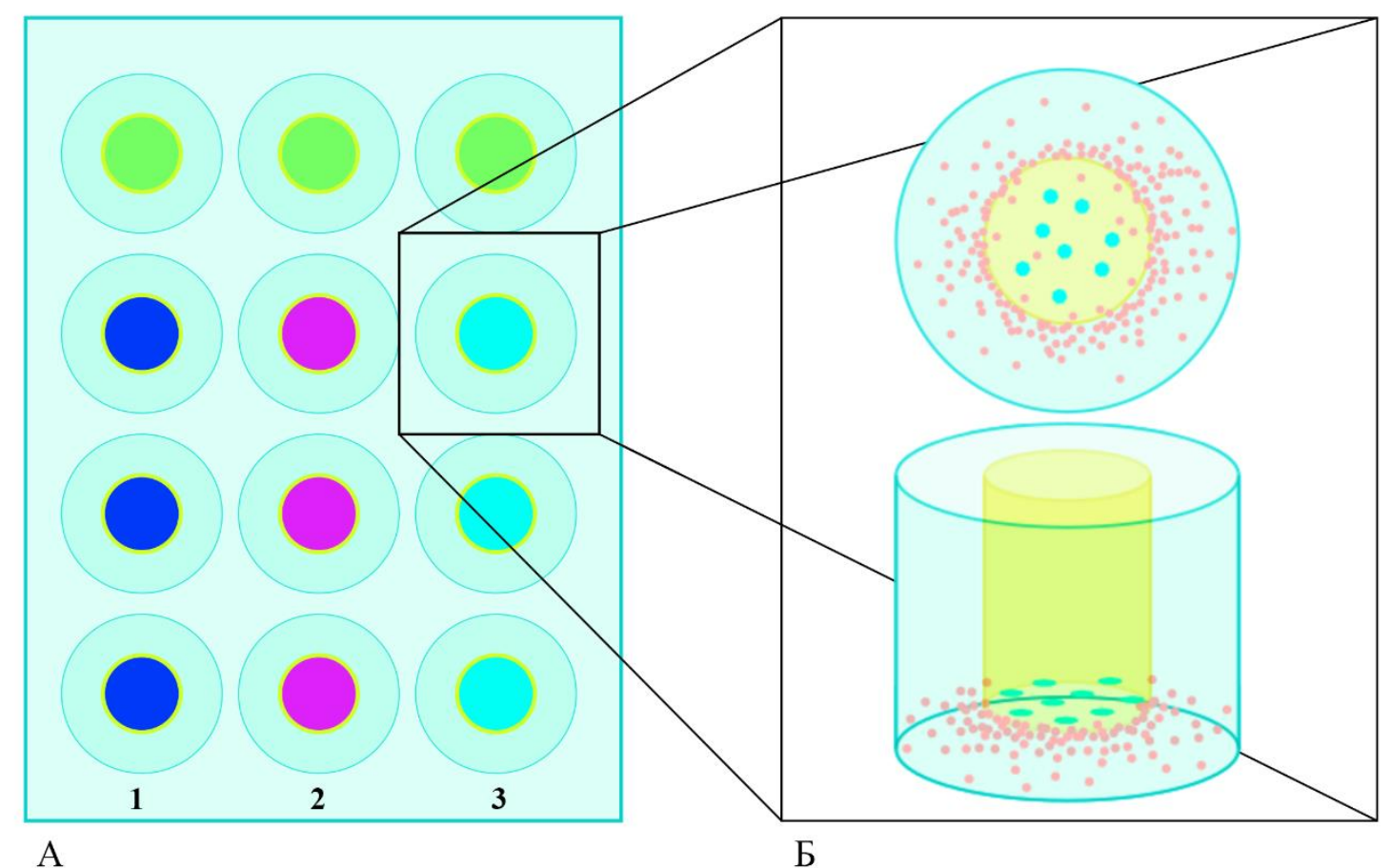

A

Б

Puc. 1. Схема эксперимента по изучению миграции СК in vitro. А.

Общая схема эксперимента: вставка содержит: 1 - клетки глиомы С6; 2 - астроциты; 3 - фибробласты. Зеленым выделены лунки, которые оставляли пустыми для оценки пассивной миграции клеток. Б. Схематическое изображение наблюдаемого явления: клетки глиомы линии С6 индуцируют миграцию ГСК, которые формируют вал вокруг и проникают внутрь культуральной вставки

В культурах, содержащих опухолевые клетки, ГСК мигрировали сквозь культуральную вставку и визуализировались среди неокрашенных клеток глиомы в форме округлых объектов, отвечающих на воздействие лазера устойчивым флуоресцентным сигналом, регистрируемым в спектре, соответствующем CMTPX Red (577/602 nm). В культурах, содержащих фибробласты и астроциты, регистрировались только единичные CMTPX Red-позитивные объекты. В культуральных вставках, оставленных пустыми, выявлялись только солитарные клетки, соответствующие спектру флуоресценции ГСК (табл. 1). 
Таблища 1

Количество ГСК, расположенных по периметру

и внутри культуральной вставки, через 24 ч культивирования

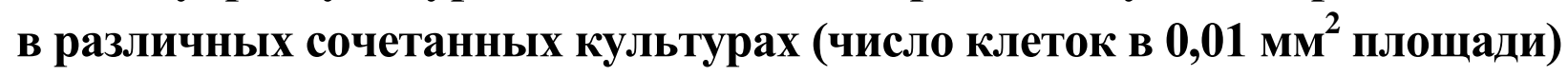

\begin{tabular}{|l|c|c|c|c|}
\hline \multicolumn{1}{|c|}{ ГСК } & С6 & Астроциты & Фибробласты & Контроль \\
\hline $\begin{array}{l}\text { Количество ГСК на границе } \\
\text { культуральной вставки }\end{array}$ & $33 \pm 4$ & $8 \pm 2$ & $14 \pm 2$ & $7 \pm 3$ \\
\hline $\begin{array}{l}\text { Количество ГСК внутри куль- } \\
\text { туральной вставки }\end{array}$ & $80 \pm 18$ & $73 \pm 6$ & $61 \pm 7$ & $10 \pm 3$ \\
\hline
\end{tabular}

Примечание. Данные представлены в виде $\mathrm{M} \pm$ s.e.m, $\mathrm{N}=12$ для каждой группы, по каждой точке.

$\mathbf{A}$
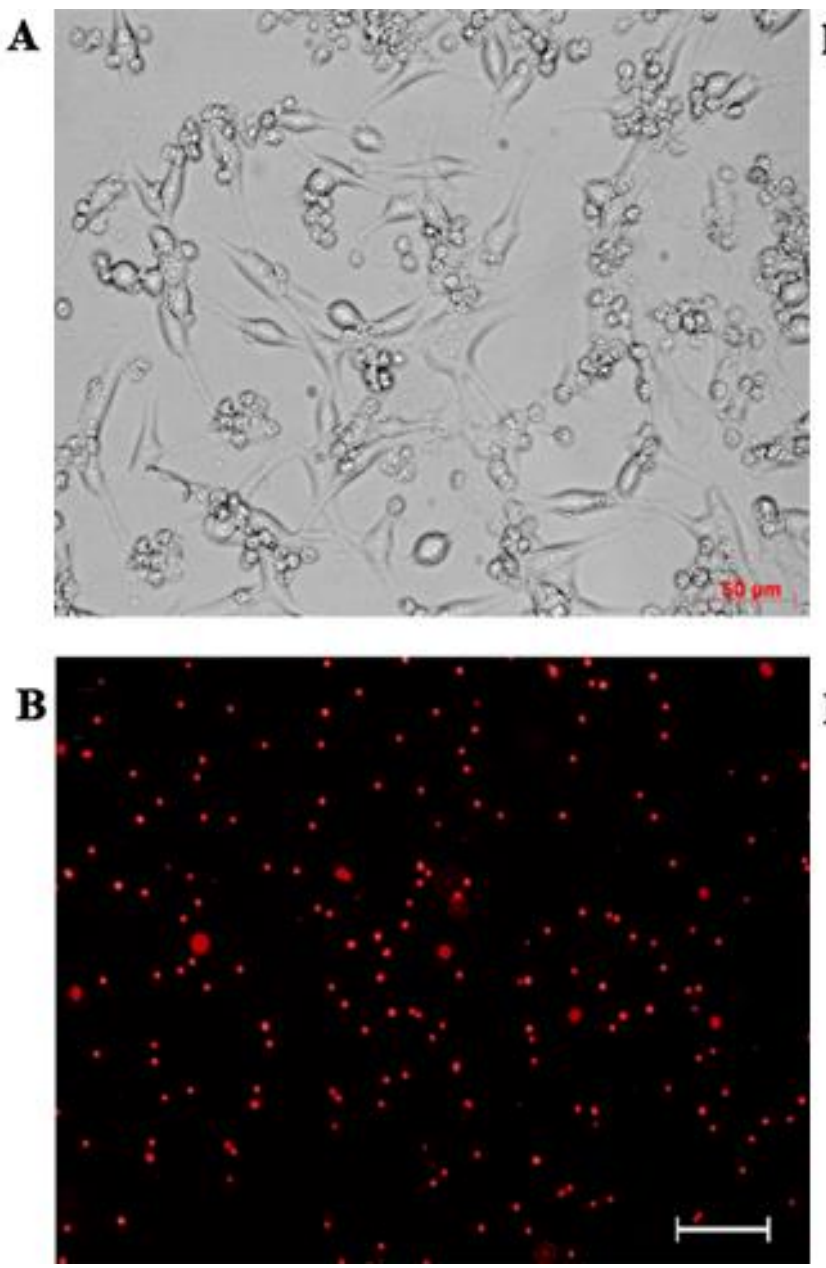

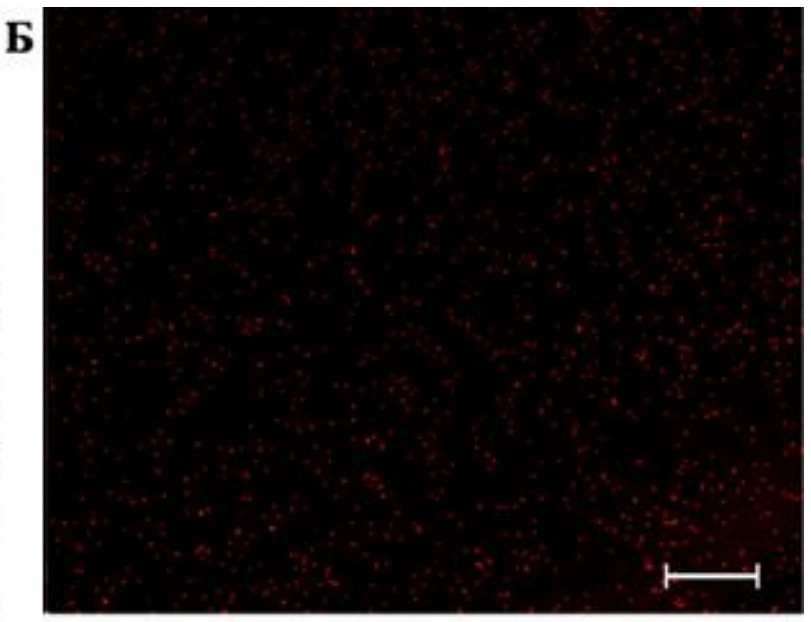

$\Gamma$

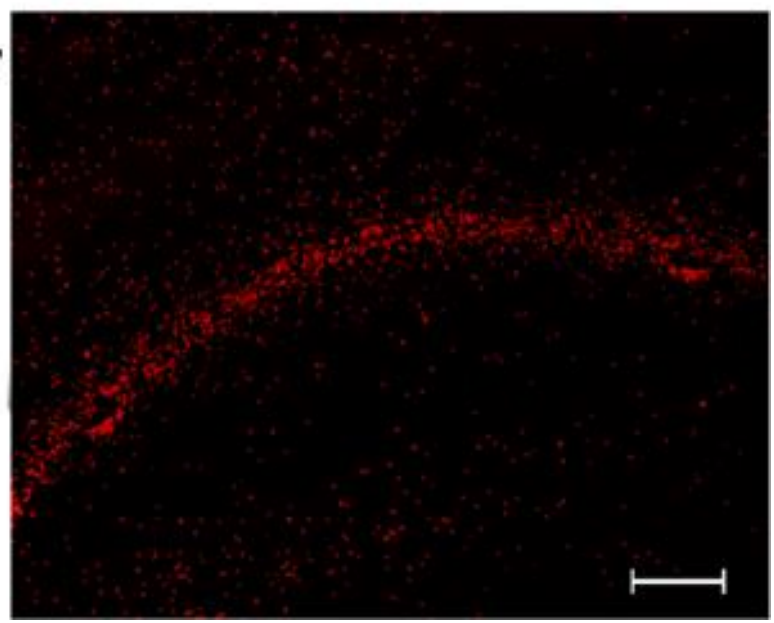

Puс. 2. Перераспределение ГСК в планшете при совместном культивировании через

24 ч. А. Опухолевые клетки внутри культуральной вставки. Б. Сокультура ГСК и фибробластов: формирование вала не наблюдается. Ув. 5X; В. Сокультура ГСК и астроцитов: формирование вала не наблюдается. Ув. 10Х. Г. Сочетанная культура ГСК и клеток глиомы С6 - формирование клеточного вала по периметру культуральной вставки, содержащей опухолевые клетки. Ув. 5Х 


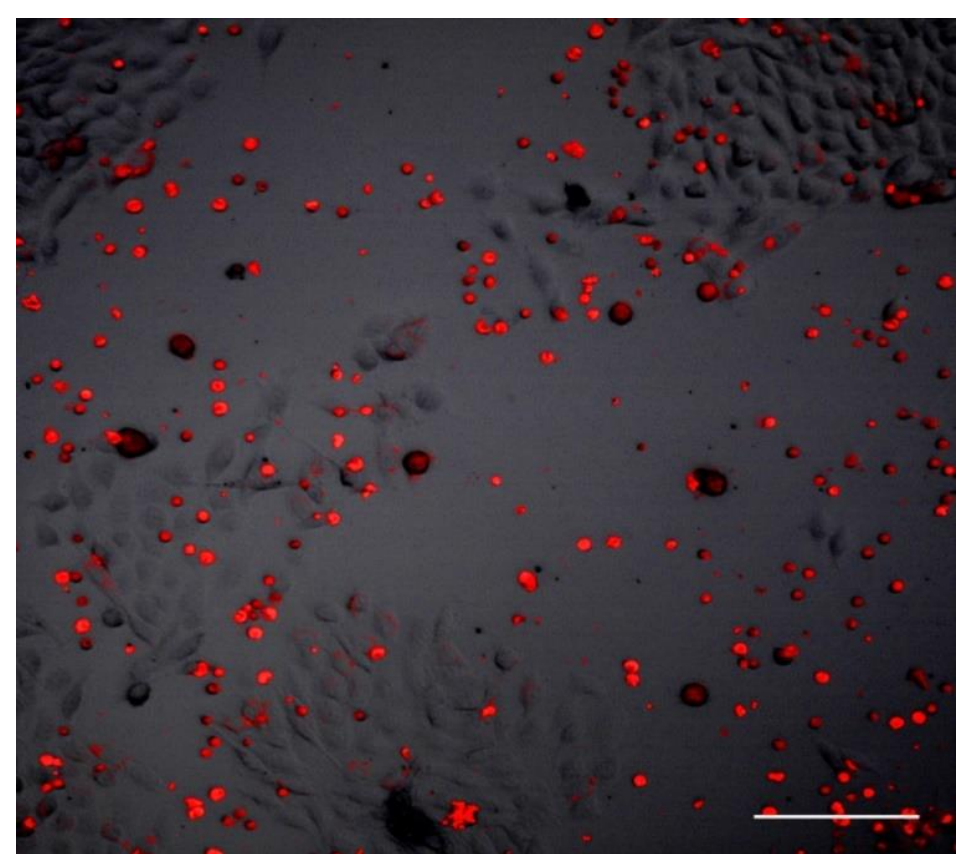

Puc. 3. ГСК человека, мигрировавшие в лунки с глиомой С6. Окраска CellTracker ${ }^{\mathrm{TM}} \operatorname{Red} \mathrm{CMTPX.} \mathrm{Конфокальная} \mathrm{микроскопия,}$ флуоресценция при воздействии лазера $\lambda=546 \mathrm{~nm}$; ув. 10x

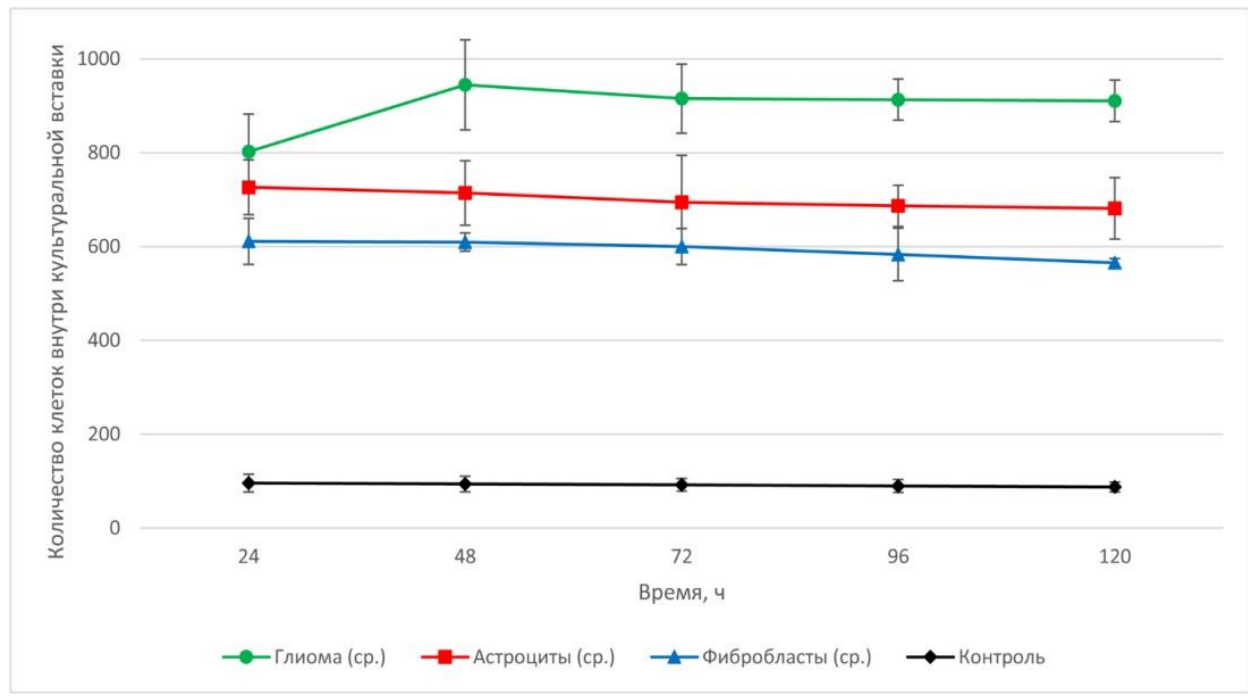

Puc. 4. Динамика накопления стволовых клеток в культуральных вставках, содержащих клетки глиомы линии С6, астроциты, фибробласты, и в контрольных вставках. По оси абсцисс - время со-культивирования (24-48-72-96-120 ч), по оси ординат - число флуоресцирующих клеток во вставке ( $\mathrm{M} \pm$ s.e.m, $\mathrm{N}=9$ по каждой точке)

Очевидно, что направленная миграция ГСК к клеткам глиомы обусловлена продукцией опухолевыми клетками сигнальных молекул. Поскольку в данном эксперименте были использованы клетки крысиной глиомы линии С6, способность ГСК мигрировать в отношении опухолевых клеток человека нуждалась в уточнении. 


\subsection{2. Миграция стволовых клеток человека в сочетанных культурах с клетками злокачественных опухолей различных линий}

В данном эксперименте использованы клетки аденокарциномы молочной железы и карциномы легких человека; кроме того, два типа клеток глиобластомы: а) клетки общего пула опухоли, б) опухолевые стволовые клетки (ОСК) глиобластомы.

Для получения ОСК клетки глиобластомы культивировались в среде DMEM (Gibco; Thermo Fisher Scientific, Inc.) без добавления сыворотки, с добавлением L-глутамина (2 мM), B-27 (0,5 мM), основного фактора роста фибробластов (20 нг/мл), эпидермального фактора роста (20 нг/мл), пенициллина/стрептомицина (100 ед/мл) и гепарина (5 мкг/мл). ОСК выделяли из глиомасфер на основании экспрессии антигена CD133, используя MicroBead (кат. № 130-100-857; Miltenyi Biotec, Inc.). Чистота популяции OCK, по данным проточной цитометрии (антитела CD133/1-VioBright FITC (кат. № 130-105-226; Miltenyi Biotec, Inc.), составила 96,72\%.

Все опухолевые клетки и фибробласты (контроль), используемые в эксперименте, окрашивали Vybrant ${ }^{\mathrm{TM}}$ CFDA SE Cell Tracer, вносили внутрь культуральной вставки в количестве $0,5 \times 10^{4}$. Пространство снаружи культуральной вставки планшета заполняли нейральными прогениторными клетками (НПК) человека (Neural Progenitor Cell Origin ATCCBXS0117 Normal; Human (ATCC® ACS-5003 ${ }^{\text {TM}) ~ и л и ~ Г С К ~ ч е л о в е к а ~ в ~ к о л и-~}$ честве $0,5 \times 10^{4}$. Клетки были окрашены флуоресцентным маркером CellTracker Red CMTPX Dye. Культивирование проводили в течение 120 ч при стандартных условиях. Результаты сравнительного анализа миграционной активности клеток в смешанных культурах представлены на рис. 5.

Нейральные прогениторные клетки (НПК) обладали существенно большей подвижностью при сокультивировании с CD133+ ОСК линий U87 и T98G (+926\% и +913,1\% от контроля). Атрактивность НПК в отношении общего пула клеток линий U87 и U251 была менее выраженной $(+598,7 \%$ и $+688,8 \%$ от контроля) и сопоставима с опухолевыми клетками иного происхождения. ГСК, несколько уступая НПК в способности мигрировать к CD133+ клеткам глиобластомы, тем не менее, активно мигрировали к этим клеткам $(+618,2 \%$ к OCK U87 и +623,8\% к OCK T98G по сравнению с контролем). Общий пул клеток глиобластомы обладал меньшей атрактивностью для ГСК (U87 +449,2\% и T98G +523,7\% в сравнении 
с контролем), что сопоставимо с миграцией ГСК к клеткам рака молочной железы (439,2\%) и рака легкого (516,8\%).

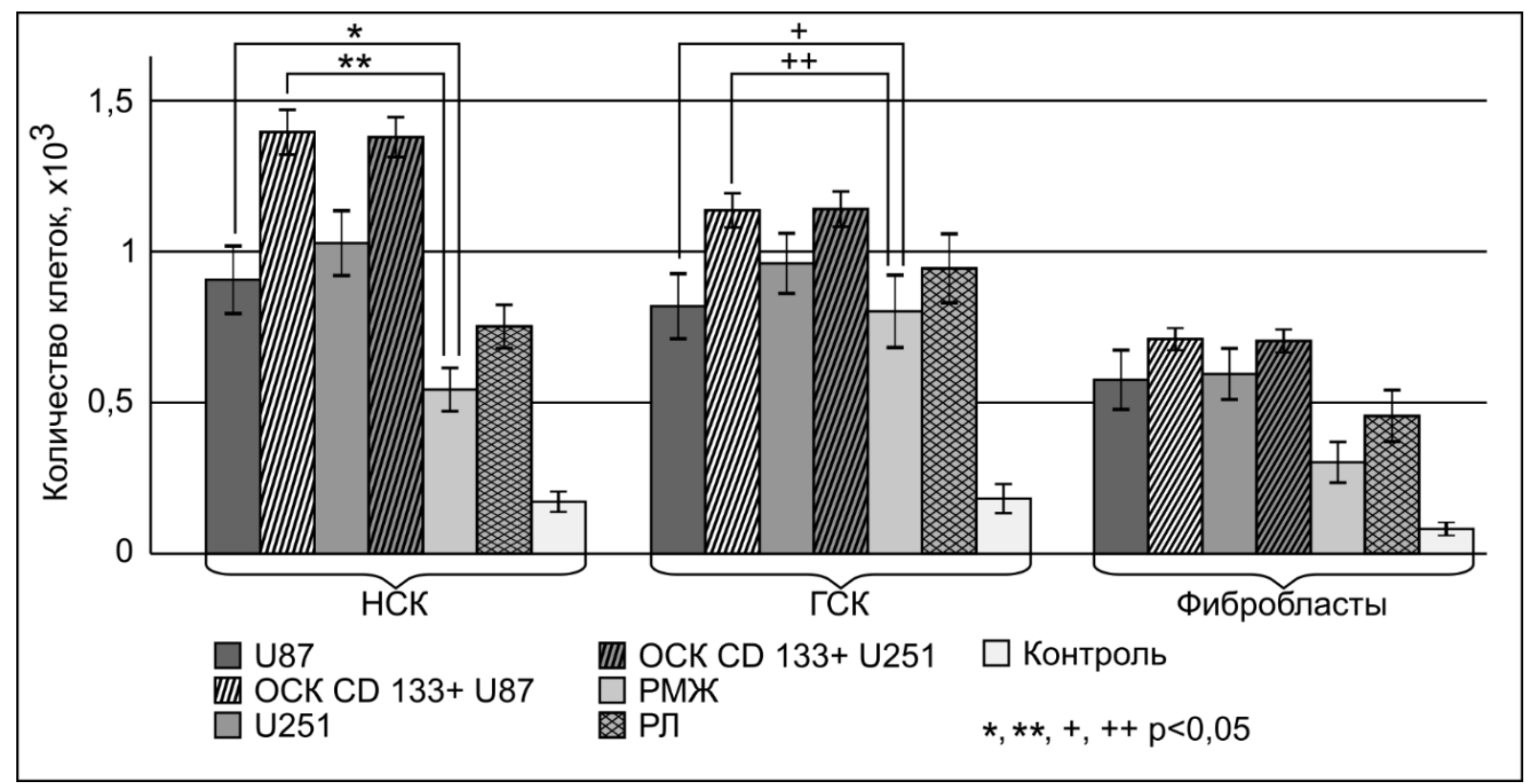

Puc. 5. Количество НПК, ГСК и фибробластов, мигрировавших через культуральную вставку, через 120 ч совместного культивирования. По оси ординат - количество клеток $\times 10^{3}$, данные представлены в виде $\mathrm{M} \pm$ s.e.m, $\mathrm{N}=15$ для каждой группы

Обращала внимание выраженная сильная способность глиобластомы привлекать высокодифференцированные клетки - фибробласты. При этом наилучшей подвижностью эти клетки обладали в отношении ОСК (U87 $+897,6$ и T98G +889\%. Клетки общего пула глиобластомы обладали несколько меньшей способностью индуцировать миграцию фибробластов, которая была сопоставима с неопластическими клетками рака молочной железы и $(380,9 \%)$ и легкого $(574,9 \%)$.

Итак, нейральные прогениторные клетки обладали существенно большей подвижностью к клеткам глиобластомы по сравнению с клетками других типов. Миграционная активность НПК зависела от типа опухолевых клеток в сокультуре, и они более активно мигрировали к ОСК двух типов глиобластомы. Дифференцированные клетки глиобластомы обладали несколько меньшей способностью индуцировать миграцию НПК, однако опухолевые клетки не нейронального происхождения существенно слабее индуцировали процессы миграции нейральных стволовых клеток. 
Следует отметить, что по мере приближения ГСК к культуральной вставке и их проникновения внутрь в популяции клеток глиобластомы индуцировалась высокая подвижность. В серии снимков, выполненных в режиме реального времени, с интервалом 3 ч (через 23, 26, 29 и 48 ч после начала эксперимента) видно, что клетки глиобластомы активно передвигались по дну планшета внутри культуральной вставки и как бы «собирали» мигрирующие к ним ГСК. Через 48 ч наблюдения практически все неопластические клетки были «облеплены» мигрирующими клетками (рис. 6).
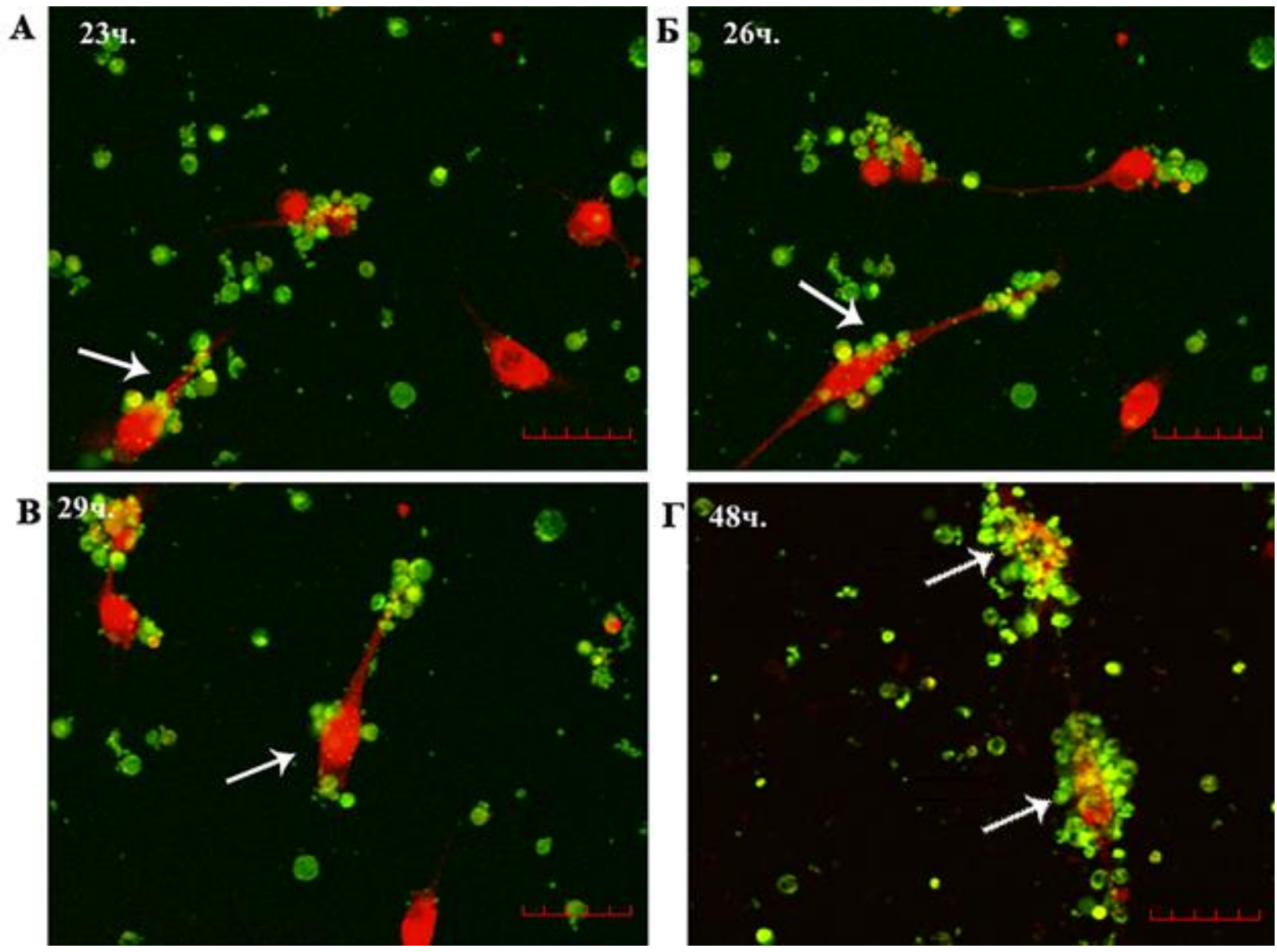

Puc. 6. Динамический ряд клеток U87 глиобластомы в сокультуре с CD34+ ГСК.

Опухолевые клетки окрашены CellTrackerTM Red CMTPX (красный), а ГСК -

Vybrant ${ }^{\circledR}$ CFDA SE (зеленый). Стрелкой показана активно перемещающаяся клетка глиобластомы, к поверхности которой адгезируют ГСК: А - 23 ч, Б - 26 ч, В - 29 ч, $\Gamma-48$ ч. Флуоресцентная лазерная микроскопия в режиме реального времени. Масштаб 400 мкм 


\section{2. Взаимодействие стволовых клеток человека \\ с клетками злокачественных опухолей in vitro}

Способность нормальных стволовых клеток мигрировать и взаимодействовать с опухолевыми клетками требует изучения закономерностей такого взаимодействия. Для ответа на эти вопросы была выполнена серия экспериментов in vitro, в которых использованы клетки глиомы линии С6, глиобластомы линии U87, аденокарциномы легкого линии А 549 и рака молочной железы MCF-7. Для каждой модели выполнены визуальное и цитометрическое изучение процесса взаимодействия ГСК с опухолевыми клетками и автоматизированный мониторинг процесса сокультивирования стволовых и опухолевых клеток в соотношении $3 / 1,1 / 1$ и 1/3 в режиме реального времени.

\subsection{1. Взаимодействие гемопоэтических стволовых клеток на модели глиомы линии С6}

В рамках подготовки экспериментов $0,5 \times 10^{6}$ клеток глиомы линии С6 после окраски витальным трейсером CFDA SE были внесены в лунки планшета, где инкубировались при стандартных условиях. Спустя 6 ч неприкрепившиеся опухолевые клетки были отобраны, и в культуру внесено 0,5×106 ГCК, окрашенных флуоресцентным трейсером Red CMTPX. В качестве контроля использовали фибробласты, которые после окраски маркером Red СМТРХ вносили в культуру опухолевых клеток в соотношении 1:1.

Через 6 ч клетки линии С6 визуализировались в виде веретеновидных или полигональных образований, отвечающих стойким флуоресцентным сигналом на воздействие лазера $(\lambda=488 \mathrm{~nm})$. В свою очередь, ГСК при воздействии лазера другого типа $(\lambda=546 \mathrm{~nm})$ формировали флуоресцентный сигнал, визуализируясь в форме округлых образований (рис. 7).

Спустя 12 ч ГСК адгезировали к клеткам глиобластомы и визуализировались на поверхности клеток глиомы С6 в виде красных флюоресцирующих объектов (рис. 8).

Спустя 24 ч наблюдения в цитоплазме клеток глиомы стали появляться включения красного флуорохрома, что означало присутствие красителя CMTPX Red, ковалентно связанного с белками цитоплазмы ГСК в процессе окраски (рис. 9). Это явление достигало максимума через 48 ч с начала эксперимента, сохранялось до конца исследования и отсутствовало в контрольной культуре с фибробластами. 

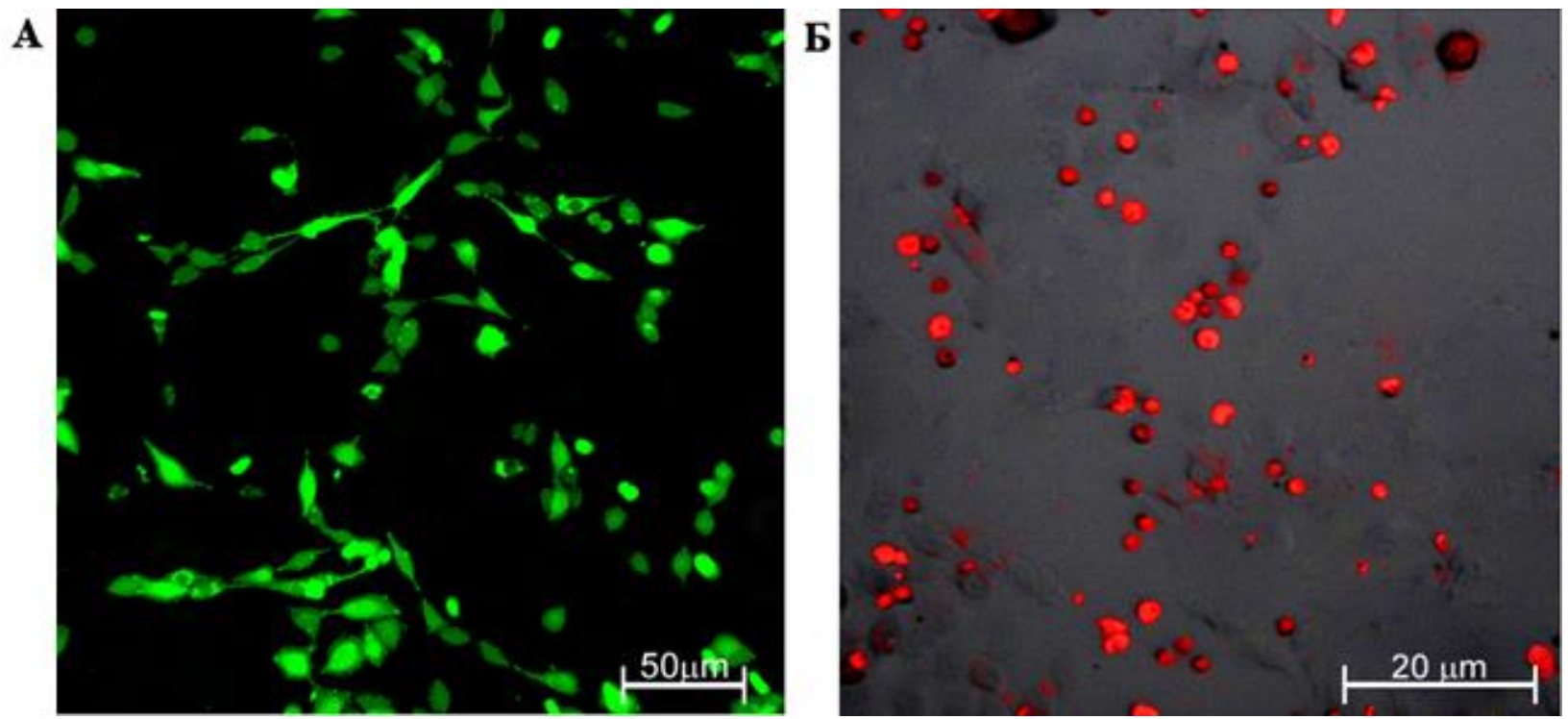

Puc. 7. Флуоресценция сокультивируемых клеток, 6 ч с начала эксперимента in vitro: A - клетки глиомы линии C6, окраска CFDA SE $(\lambda=488 \mathrm{~nm})$. Б - CD34+ стволовые клетки крысы, окраска СМТРХ $(\lambda=546 \mathrm{~nm})$. Флуоресцентная лазерная микроскопия

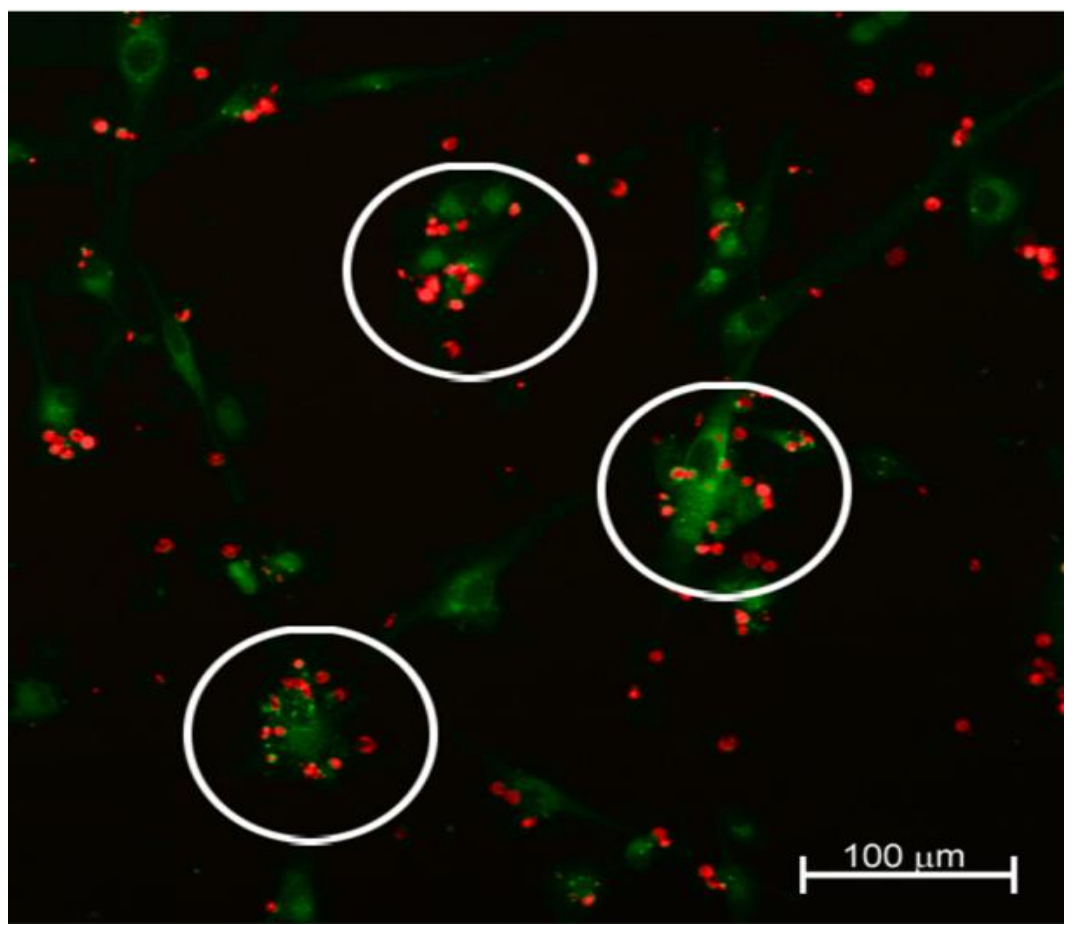

Puc. 8. Адгезия ГСК (СМТРХ, $\lambda=546 \mathrm{~nm})$ к поверхности клеток глиомы (CFDA SE, $\lambda=488 \mathrm{~nm}), 12$ ч. Мультифотонная флуоресцентная лазерная микроскопия. ГСК визуализируются в виде цилиндров красного цвета на поверхности клеток глиомы 


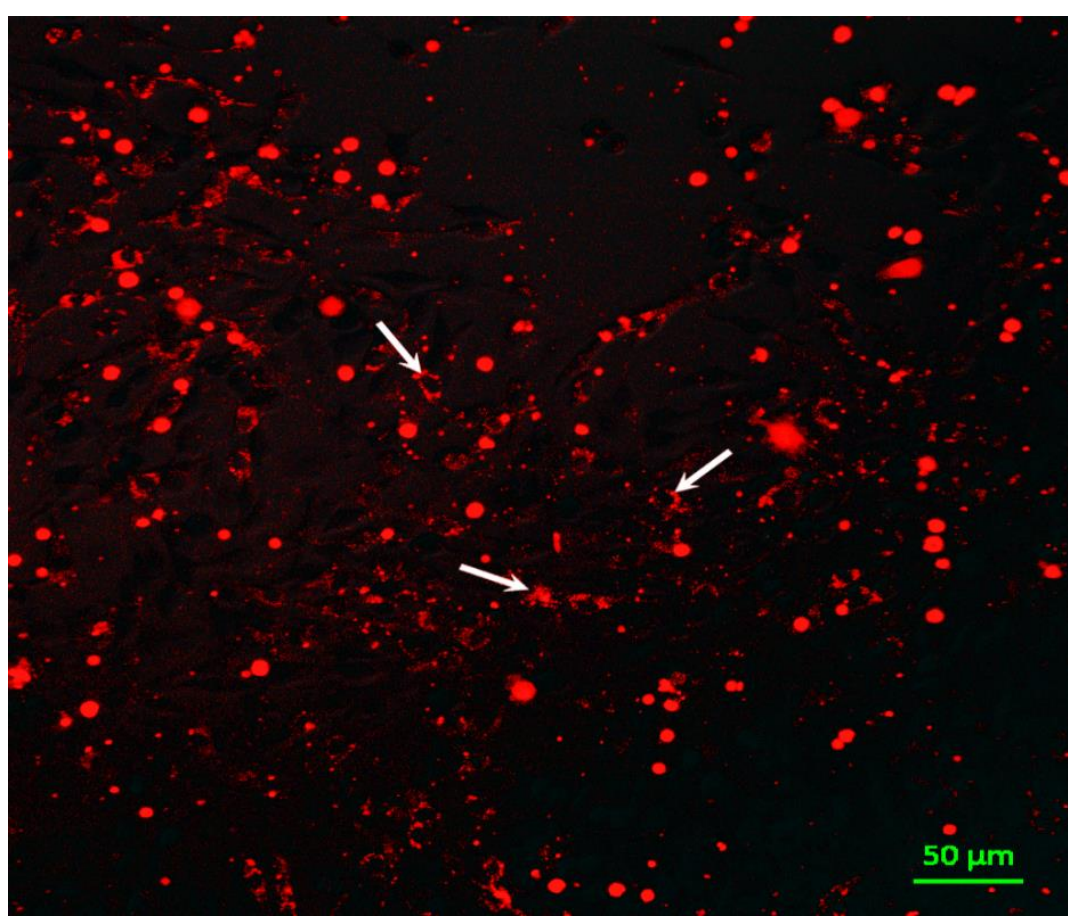

Pис. 9. Перенос флуоресцентной метки СМТРХ из ГСК в клетки линии С6. Флуоресцентная лазерная микроскопия in vitro. Стрелками показанно накопление красителя в сокультивируемых клетках

При визуальном наблюдении перенос флуоресцентной метки был заметен в направлении от ГСК к клеткам глиомы, поскольку через 48 ч накопление флуоресцентного красителя СМТРХ отмечено именно цитоплазме клеток линии С6.

Спустя 120 ч контрольная культура опухолевых клеток отвечала на воздействие лазера $(\lambda=488 \mathrm{~nm})$ устойчивым флуоресцентным сигналом, визуализируя четкую форму клеток глиомы без признаков обмена флуоресцентной меткой с ГСК (рис. 10).

Таким образом, при наблюдении взаимодействия двух популяций совместно культивируемых клеток, окрашенных разными красителями, было обнаружено, что клетки не только мигрируют и адгезируют друг к другу, но и осуществляют перенос флуорохрома в соседние клетки.

Результаты цитологического мониторинга подтверждаются при цитофлюориметрической оценке сокультуры на разных этапах эксперимента (24, 48, 72, 96 ч). Методом проточной цитофлуориметрии показано, что наиболее активное взаимодействие клеток происходит в период 24-48 ч (Рис. 11), что проявляется накоплением в неопластических клетках флуоресцентной метки. 

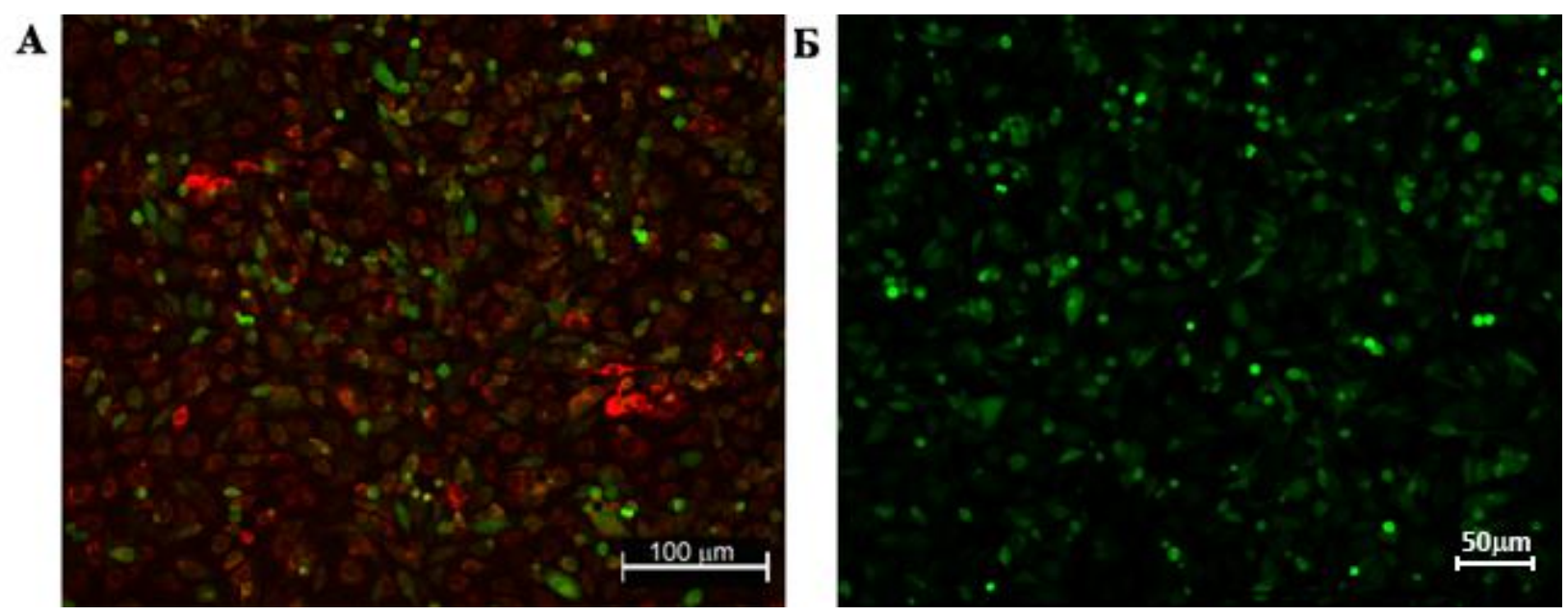

Puc. 10. Сокультура ГСК (СМТРХ, $\lambda=546$ nm) с клетками глиомы C6 (CFDA SE, $\lambda=488 \mathrm{~nm}):$ А - клетки линии С6 отвечают на воздействие лазеров двух типов; Б - клетки глиомы отвечают стойким флуоресцентным сигналом на воздействие лазера $\lambda=488 \mathrm{~nm}$, что свойственно красителю CFDA SE, которым они изначально окрашены. Флуоресцентная лазерная микроскопия, 120 ч эксперимента

Число клеток, содержащих двойную окраску, изменяется динамически: через 24 ч в культуре обнаруживается 25,8\% дважды меченых клеток, через 48 ч - 40,82\%, через 72 ч - 8,75\%, через 96 ч - 5,47\%. При этом по мере увеличения срока наблюдения тенденция к исчезновению ГСК в смешанной культуре становилась всё очевиднее. Так, на 24 ч количество ГСК в сокультуре составляло 47,45\%, к 48 ч эксперимента их количество сократилось до 9,01\%, критически уменьшилось - к 72 ч (1,18\%), а к 96 ч составило 0,73\% (рис. $11, \mathrm{~B}, \Gamma$ ). Важно отметить, что в контрольной группе количество клеток глиомы С6 закономерно уменьшалось, что, вероятно, следует объяснить ускоренными темпами пролиферации неопластических клеток, которые постепенно утрачивают флуоресцентную метку. Однако и в сокультуре С6/ГСК количество монопозитивных клеток линии С6 уменышается, при этом монопозитивных клеток на 96-м ч эксперимента в сокультуре с ГСК значительно меньше, чем в контроле. Сказанное выше свидетельствует в пользу переноса флуоресцентной метки из ГСК в опухолевые клетки на ранних сроках сокультивирования (до 48 ч). При этом на более поздних сроках (48-96 ч) клетки глиомы особенно интенсивно накапливали флуоресцентную метку от ГСК. Важно отметить, что в ходе сокультивирования популяция клеток ГСК практически исчезла на поздних сроках (120 ч).

Для изучения эффектов взаимодействия ГСК с опухолевыми клетками интеллектуальная система мониторинга Cell-IQ была настроена на распознавание образов и подсчет числа живых и мертвых клеток в режиме 
реального времени. Под живыми клетками понималась итоговая сумма образов интерфазы и митоза (рис. 12).

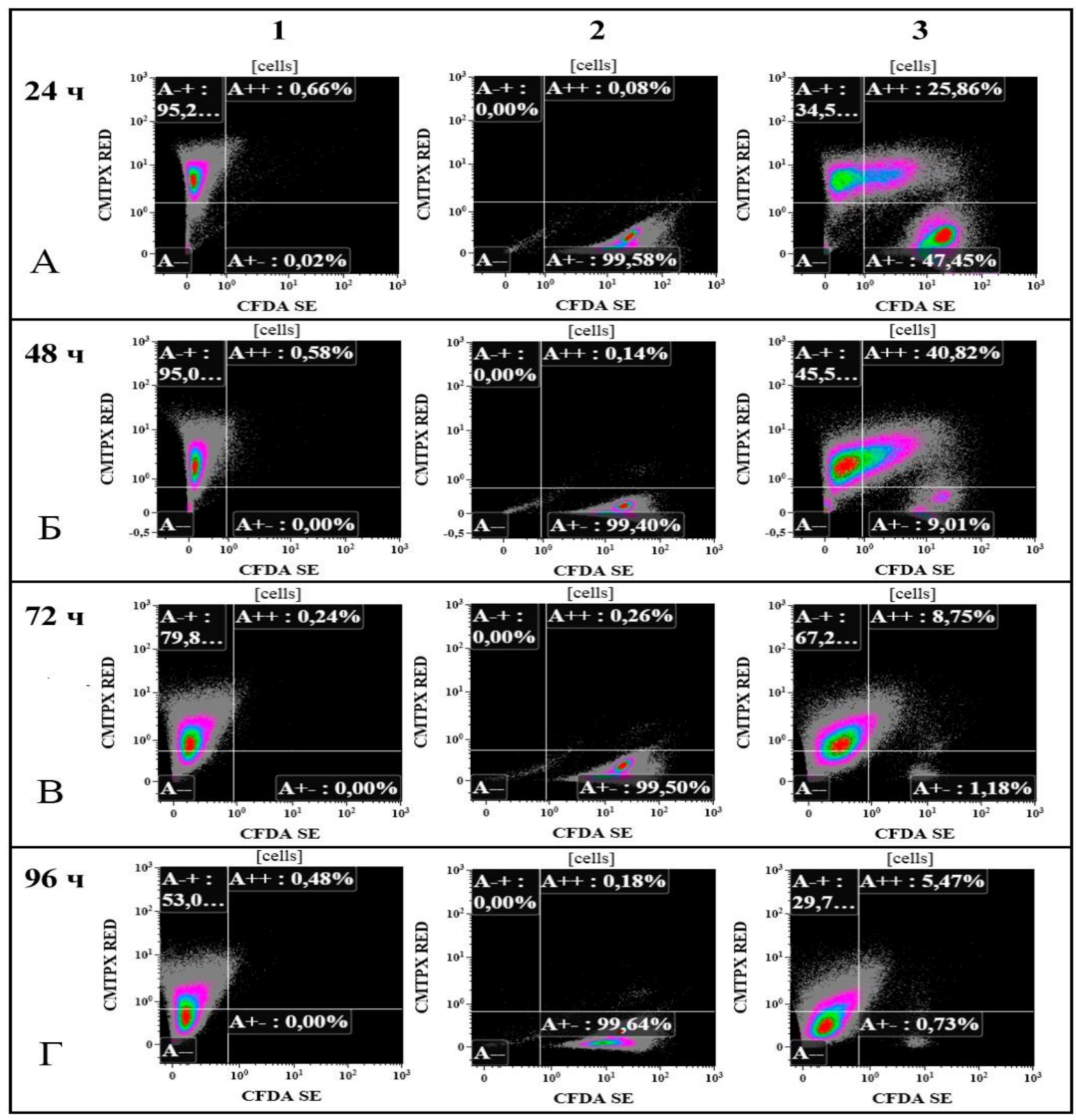

Puc. 11. Результаты сокультивирования ГСК (CFDA SE, $\lambda=488 \mathrm{~nm}$ ) и глиомы С6 (CMTPX Red, $\lambda=546 \mathrm{~nm}$ ) при исходном соотношении клеточных популяций 1:1: (A-+) - клетки, окрашенные CFDA SE, $\lambda=488 \mathrm{~nm},(\mathrm{~A}+-)$ - клетки, окрашенные CMTPX Red, $\lambda=546 \mathrm{~nm},(\mathrm{~A}-)$ - клетки, погибшие либо потерявшие окраску. (A++) -

область с клетками, включавшими окраску двумя красителями. Для контроля использованы чистые клеточные культуры ГСК и глиомы С6, окрашенные маркерами CMTPX Red, $\lambda=546 \mathrm{~nm}$ и CFDA SE, $\lambda=488 \mathrm{~nm}$ соответственно: А - анализ клеток через 24 ч; Б - анализ клеток через 48 ч; В - анализ клеток через 72 ч;

$$
\text { Г- анализ клеток через } 96 \text { ч }
$$



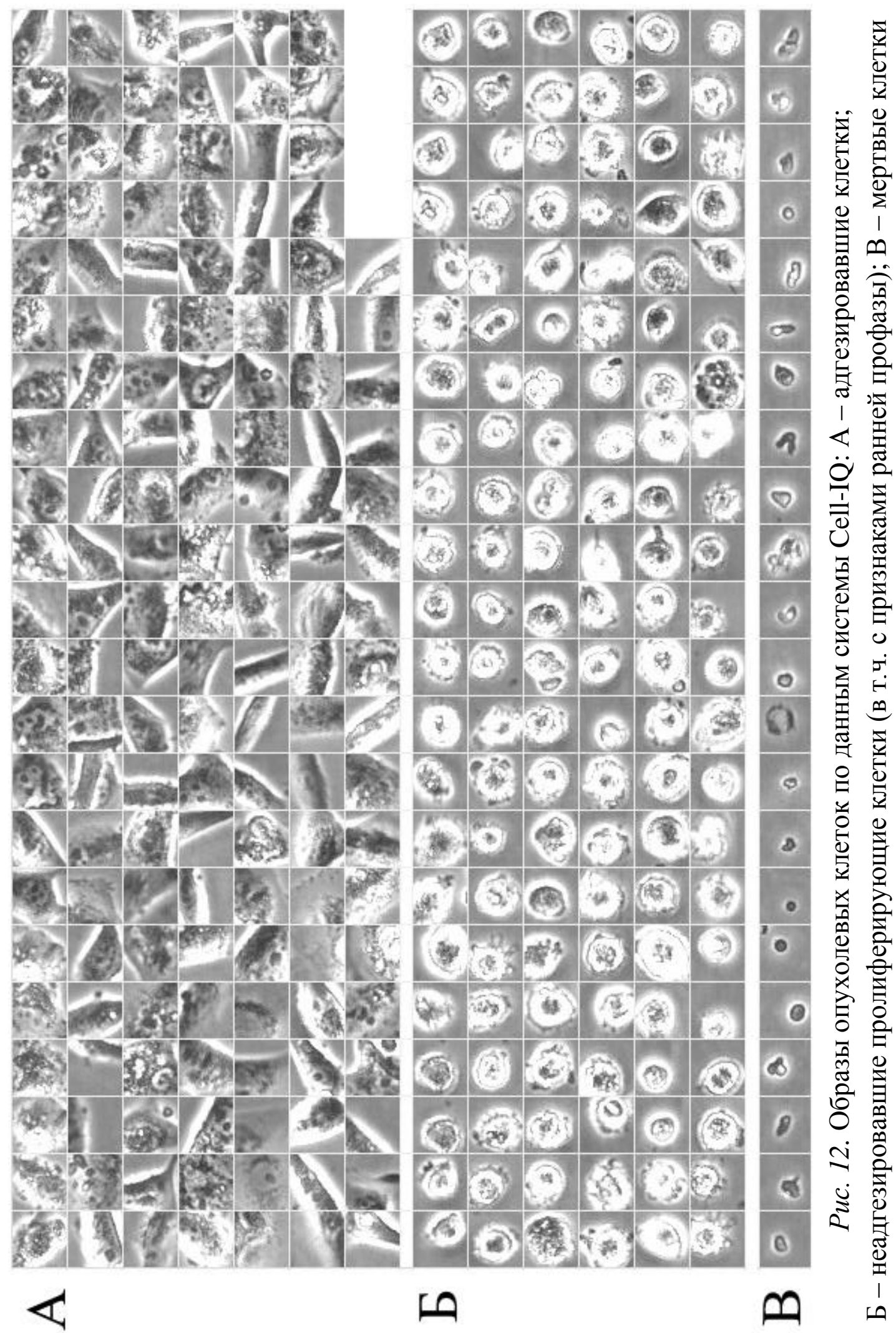
Термином «пролиферирующие» были обозначены клетки, обнаруживающие прекращение функциональной активности, имеющие отчетливые признаки открепления от субстрата и характеризующиеся увеличением объема ядра и клетки в целом, округлыми контурами клеточной мембраны и светлой цитоплазмой с отсутствием патологических включений, а также другими морфологическими признаками ранней профазы. При подсчете пролиферирующих клеток также учитывались клетки, находящиеся в митозе.

Динамическое наблюдение числа опухолевых клеток, сокультивируемых с ГСК, показало зависимость антипролиферативного эффекта от соотношения внесенных в культуру клеток. К концу эксперимента кривая нарастания числа живых клеток в сокультуре С6\ГСК при соотношении 3:1 не обнаруживала значительных отличий от контрольной культуры клеток линии С6 (рис. 13).

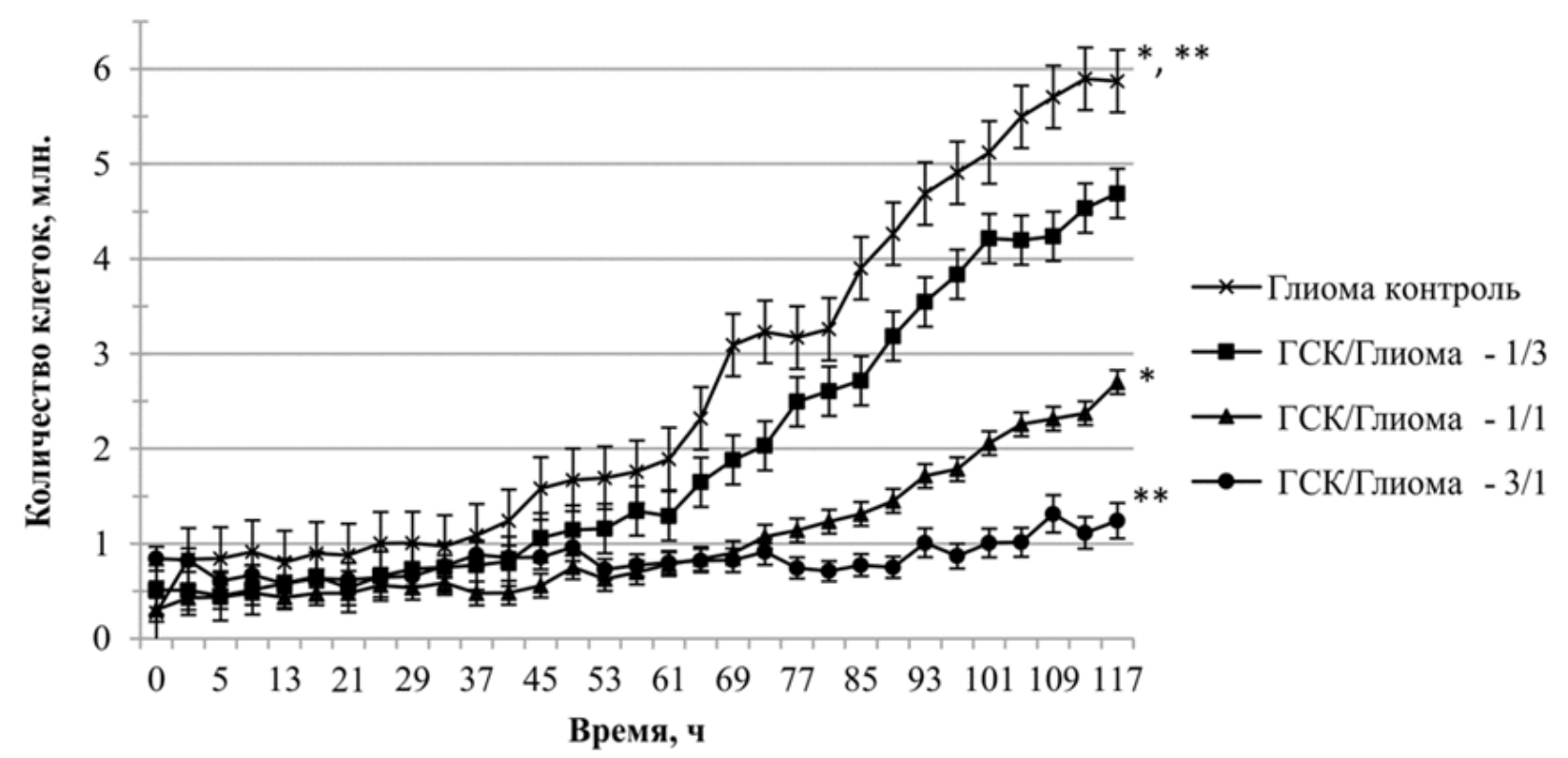

Pис. 13. Результаты сокультивирования клеток линии С6 с ГСК. По оси абсцисс указано время эксперимента (ч), по оси ординат - количество клеток линии С6 в сокультурах с ГСК. Данные приведены в виде $\mathrm{M} \pm$ s.e.m, $\mathrm{n}=30$ по каждой точке. Знаком * показаны достоверные $(\mathrm{P}<0,05)$ различия в количестве клеток линии С6 в сокультуре с ГСК /С6 в соотношениях $1 / 1$ и ** и 3/1 по сравнению с контрольной культурой С6

При сокультивировании клеток линии С6 /ГСК в соотношении 1:1 и более к 120 ч эксперимента сократилось как общее число опухолевых клеток, так и количество пролиферирующих клеток, определяемых с помощью иммуноцитохимической окраски на PCNA (рис. 14). 

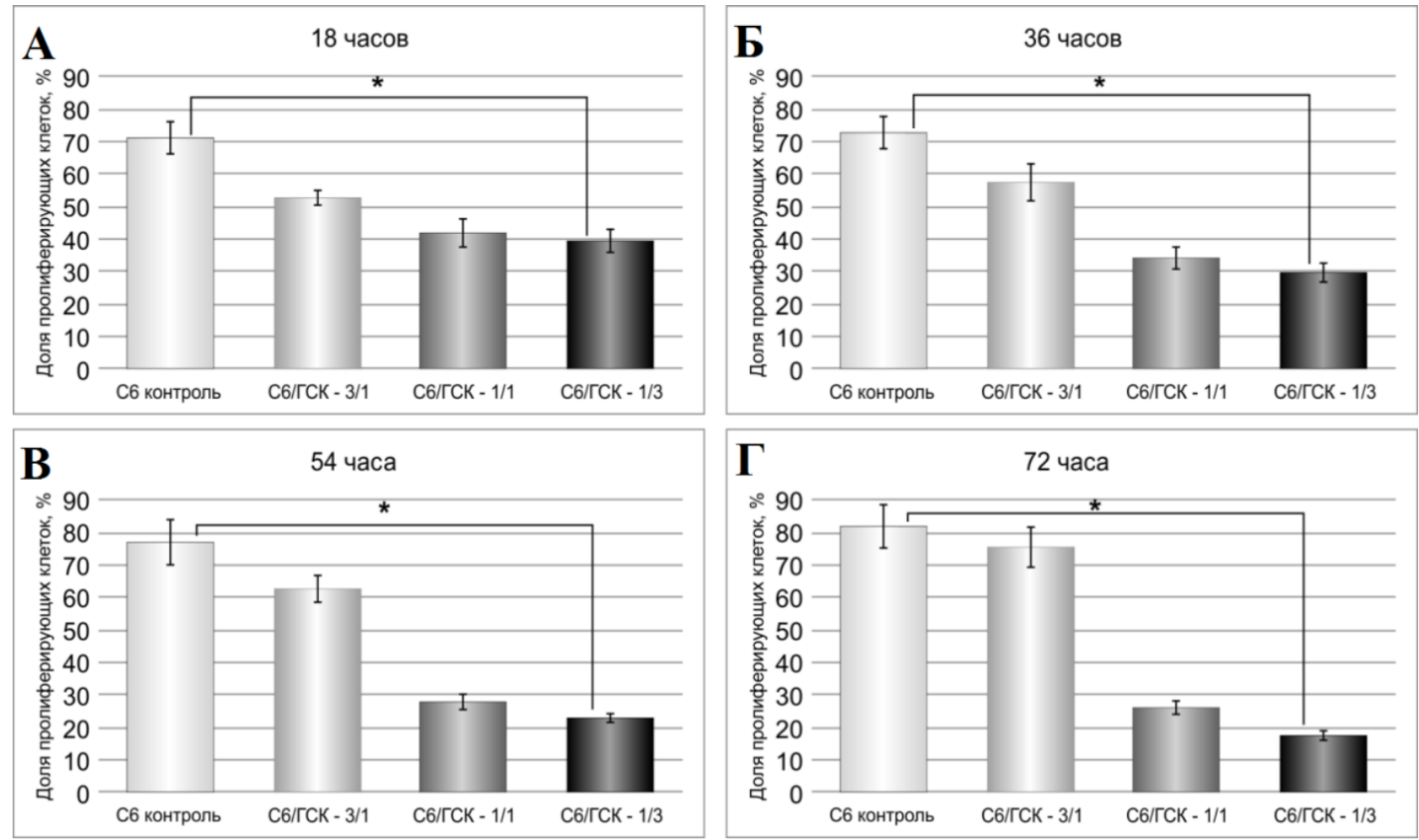

Puc. 14. Количество PCNA-позитивных клеток в сокультурах глиомы С6/ГСК, определяемых в ходе эксперимента: А - 18 ч, Б - 36 ч, В - 54 ч, Г - 72 ч. По оси ординат указано количество пролиферирующих клеток в \% от общего числа клеток

в сокультуре. Данные приведены в виде среднего \pm стандартное отклонение), $\mathrm{n}=18$ по каждой точке. Знаком * показаны достоверные $(\mathrm{P}<0,05)$ отличия между числом PCNA-позитивных клеток в сокультуре С6/ГСК в соотношении 1/3 в сравнении с контролем. Различия особенно очевидны на сроке 72 ч

При сокультивировании с клетками глиомы С6 в соотношении 1:1 ГСК оказывали на них цитостатический эффект. При увеличении количества ГСК в сочетанной культуре до 1:3 этот эффект был более очевидным, что свидетельствует о способности ГСК подавлять пролиферацию опухолевых клеток in vitro, зависящую от числа внесенных стволовых клеток (Рис. 15).

Таким образом, совместное культивирование ГСК с клетками глиомы линии С6 сопровождается адгезией ГСК к опухолевым клеткам, взаимодействием с ними, развитием антипролиферативного эффекта, при этом противоопухолевый потенциал таких взаимодействий возрастает по мере увеличения количества стволовых клеток в анализируемой системе. 

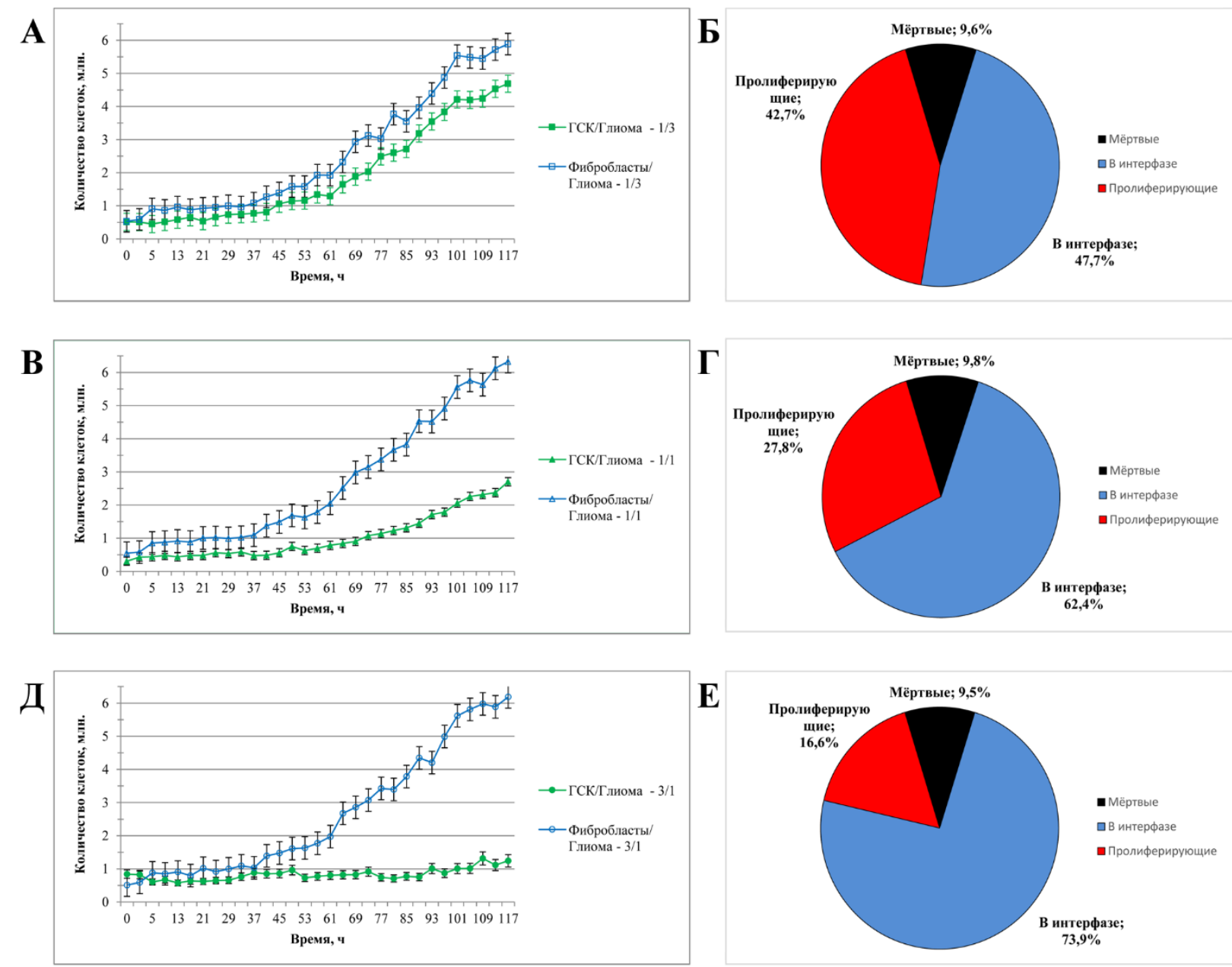

Puc. 15. Динамика количества клеток линии С6 при сокультивировании с ГСК по данным высокоэффективной количественной микроскопии в реальном времени. Сокультивирование клеток С6/ГСК: А - 1/3, Б - 1/1, В - 3/1. В качестве контроля использована культура фибробластов, по оси абсцисс указано время в ч, по оси ординат - количество клеток в млн. Данные приведены в виде среднего \pm стандартное отклонение), $\mathrm{N}=18$ по каждой точке. Б, Г, Е - указано распределение клеток глиомы

C6 на 117 ч наблюдения в соответствующих сокультурах по данным Cell-IQ

\subsection{2. Взаимодействие гемопоэтических стволовых клеток с клетками злокачественных опухолей человека}

Во второй части эксперимента изучалось in vitro взаимодействие ГСК с клетками линии U87 глиобластомы, линии A549 рака легких и линии MCF-7 рака молочной железы человека. Спустя 24 ч наблюдений отмечали адгезию ГСК к поверхности опухолевых клеток различных линий (рис. 16).

Спустя 48 ч в цитоплазме опухолевых клеток стали проявляться включения зеленого флуоресцентного красителя CFDA SE, которым предварительно были окрашены ГСК. Признаки обмена флуоресцентной мет- 
кой были заметны во всех сокультурах, однако были особенно очевидны в сокультуре ГСК с клетами рака легких А549/ГСК (рис. 17).
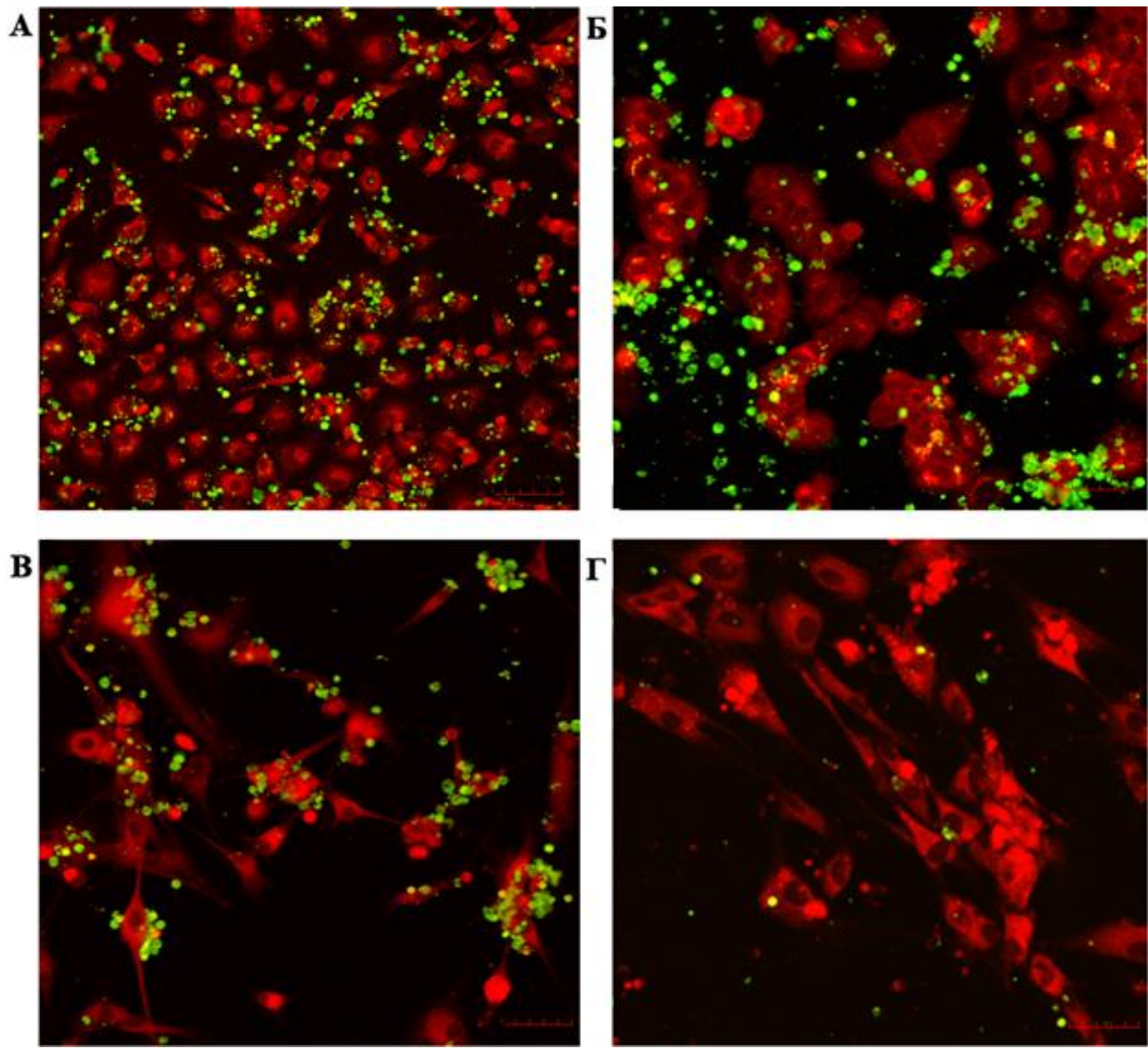

Puc. 16. Адгезия ГСК (окраска CFDA SE, $\lambda=488 \mathrm{~nm}$ ) к поверхности опухолевых клеток: А - рака легких; Б - аденокарциномы молочной железы; В - глиобластомы (окрашены CMPТХ, $\lambda=546 \mathrm{~nm}$ ); $\Gamma$ - сокультура фибробластов человека и ГСК, признаки адгезии отсутствуют. Флуоресцентная лазерная микроскопия, 24 ч эксперимента. Соотношения клеток 1:1. Масштаб 400 мкм

Описанный феномен был выражен среди всех линий опухолевых клеток и визуализировался с использованием мультифотонной микроскопии, что позволяет отличить транспорт флуоресцентной метки от возможного свечения ГСК, «распластавшихся» по поверхности опухолевых клеток. На данном сроке эксперимента транспорт флуоресцентной метки проходил только в направлении из ГСК в опухолевые клетки, однако с увеличением времени до 48-72 ч в спектре свечения ГСК, адгезировавших к поверхности клеток 
глиобластомы, начинали преобладать желтые тона (рис. 18 и 19), что отчасти может быть связанно с пересечением спектров флуоресцентного сигнала, отраженного от окрашенных SFDA $(\lambda=488 \mathrm{~nm})$ и «распластавшихся» по их поверхности ГСК, окрашенных красителем СMTPX Red $(\lambda=546 \mathrm{~nm})$.

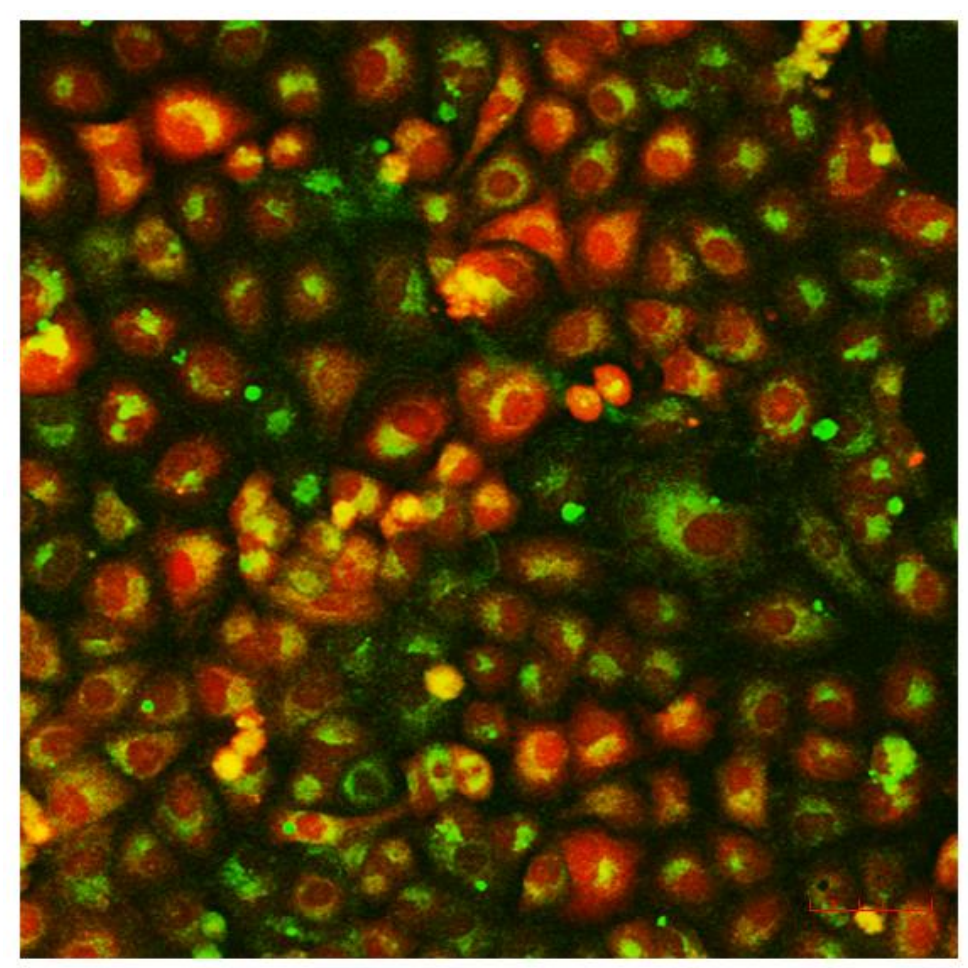

Рис. 17. Накопление зеленой флуоресцентной метки в клетках рака легких линии А 549 (изначально окрашены витальным трейсером CMPTX RED, $\lambda=546$ mm, красный) при сокультивировании с ГСК (CFDA SE, $\lambda=488 \mathrm{~nm}$, зеленый), 48 ч эксперимента. Лазерная сканирующая микроскопия в реальном времени. Масштаб 400 мкм

Анализ спектра флуоресценции ГСК, адгезировавших к поверхности клетки глиобластомы, свидетельствует об увеличении в нем количества оранжево-желтых оттенков, что может быть связанно с присутствием в ГСК красителя CMTPX Red, привнесенного из клеток глиобластомы в процессе межклеточного взаимодействия. Отметим, что с увеличением срока культивирования признаки переноса флуоресцентной метки не только из ГСК в ОК, но и наоборот, были отмечены во всех сокультурах, однако в контрольной культуре таких феноменов зарегистрировано не было. По результатам ЦФМ через 24 ч в сокультуре А-549/ГСК регистрировалось 9,6士1,3\% клеток, позитивных по двум красителям (рис. 20). 
Через 36 ч совместного культивирования число дважды позитивных клеток возросло до 13,3 $\pm 0,8 \%$. Через 48 ч с момента начала иссле-

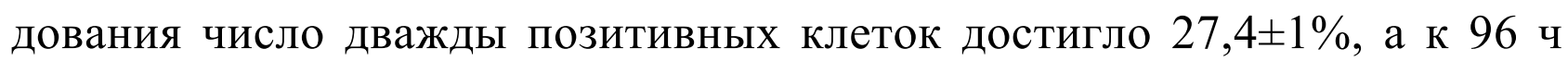

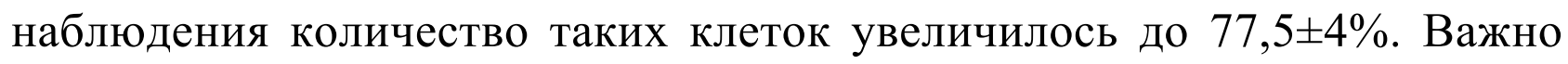
отметить, что параллельно увеличению количества дважды позитивных клеток уменьшалось число монопозитивных ГСК. По данным программы "Kaluza", увеличение числа дважды позитивных клеток происходило за счет клеток линии А549 (табл. 2).

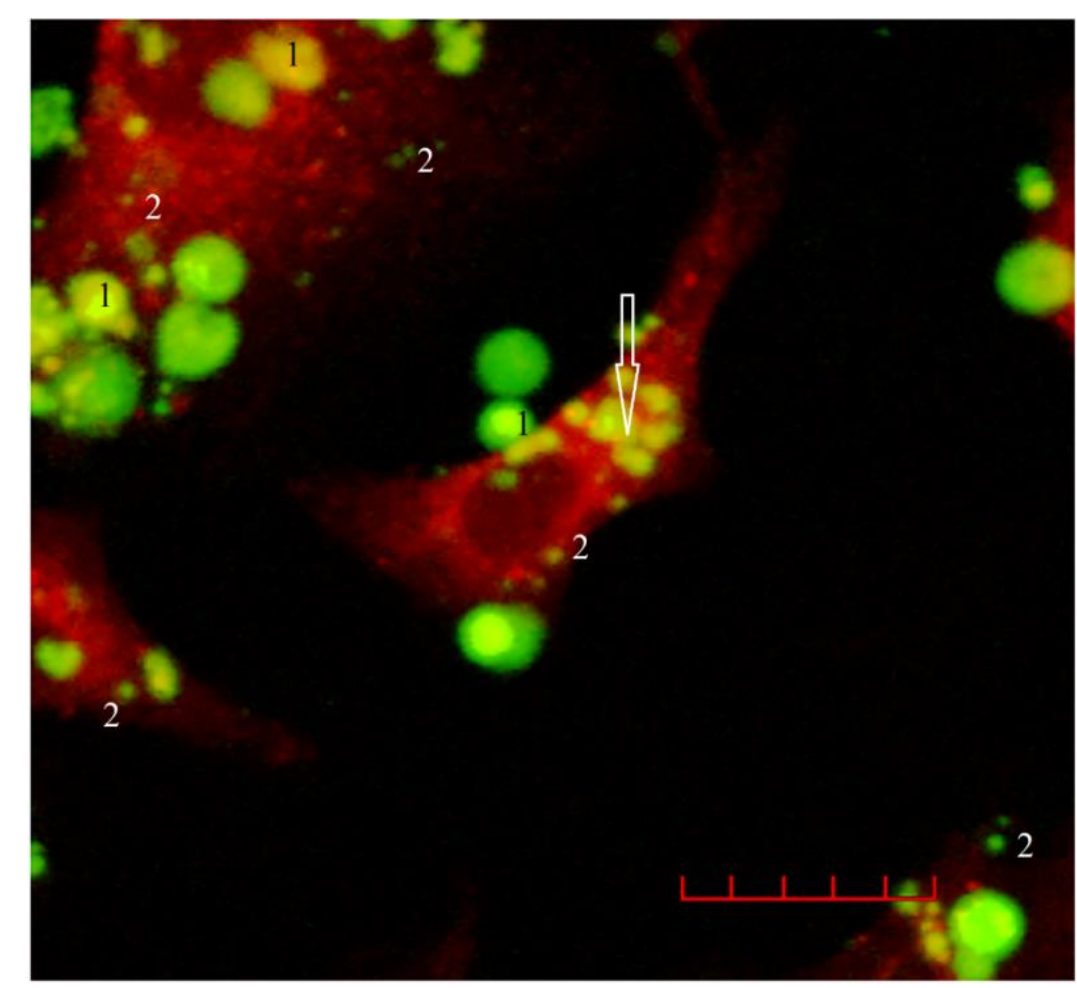

Рис. 18. Взаимодействие ГСК с опухолевыми клетками при сокультивировании в соотношении $1: 1$ в течение 48 ч: 1 - появление оранжево-желтого оттенка в цитоплазме ГСК, которые адгезировали к клеткам глиобластомы линии U87. Неопластические клетки изначально были окрашены витальным трейсером СМРТХ ( $\lambda=546 \mathrm{~nm}$, красный $), \Gamma \mathrm{CK}-\mathrm{CFDA}$

$\operatorname{SE}(\lambda=488 \mathrm{~nm}$, зеленый); 2 - при этом как на поверхности, так и, возможно, в цитоплазме (указанно стрелкой) клеток глиобластомы отчетливо

заметны флуоресцентные тельца диаметром значительно меньше ГСК. Флуоресцентная лазерная микроскопия. Масштаб 600 мкм 


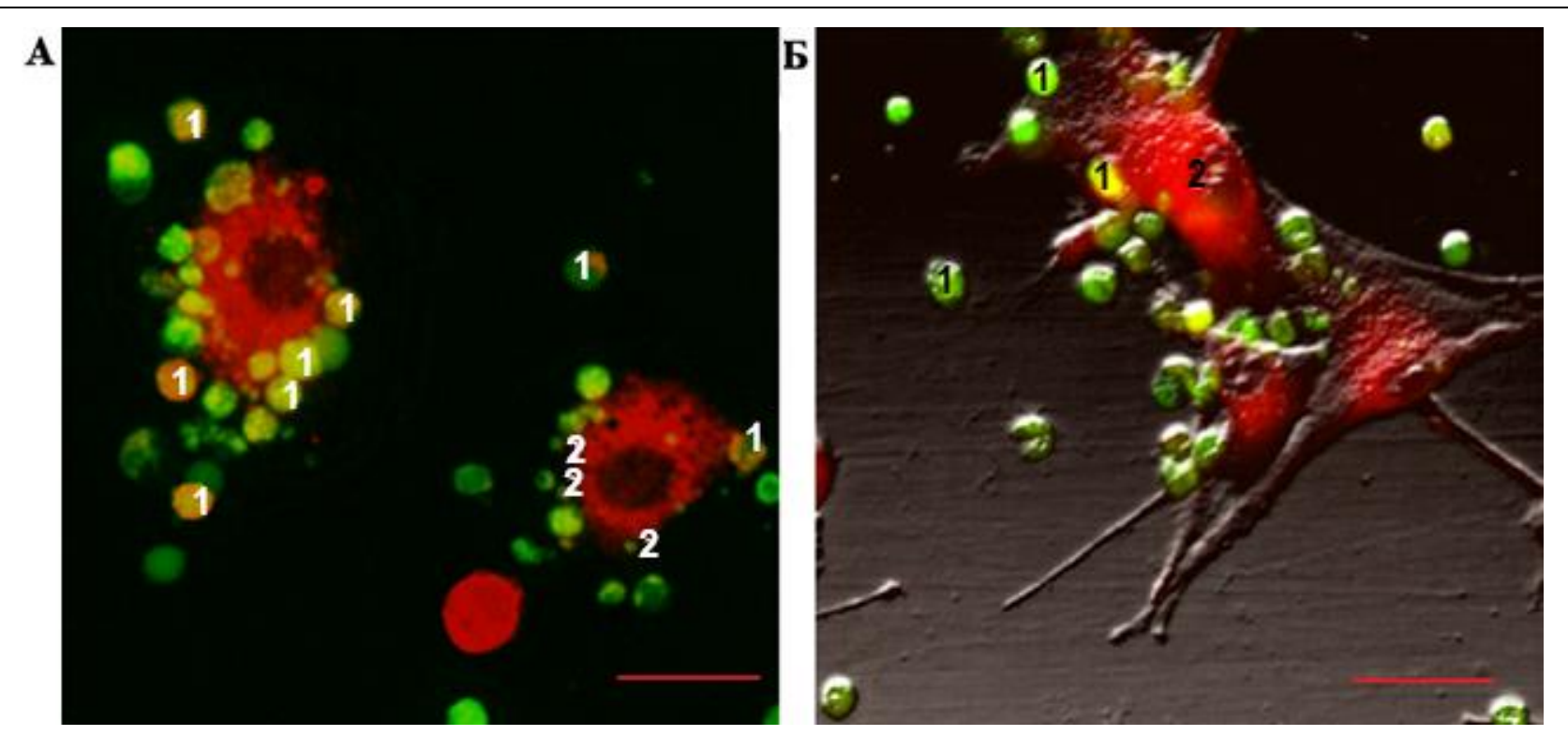

Puс. 19. Взаимодействие ГСК с опухолевыми клетками при сокультивировании в соотношении 1:1 в течение 72 ч: A - (1) накопление оранжево-желтого оттенка в цитоплазме ГСК, которые адгезировали к клеткам глиобластомы линии U87. Неопластические клетки изначально окрашены витальным трейсером СМРТХ ( $\lambda=546 \mathrm{~nm}$, красный) ГСК - CFDA SE ( $\lambda=488 \mathrm{~nm}$, зеленый); (2) на поверхности клеток глиобластомы видны флуоресцентные тельца диаметром значительно меньше ГСК; Б - взаимодействие ГСК (1) с клетками глиобластомы (2). Флуоресцентная лазерная микроскопия. Масштаб 600 мкм

Количество клеток, позитивных в отношении двух флуоресцентных меток, при совместном культивировании клеток рака легкого А549 с ГСК, по данным проточной цитофлуориметрии с использованием красителей CFDА и СМТРХ. Обработка данных программой "Kaluza"

\begin{tabular}{|c|c|c|}
\hline $\begin{array}{c}\text { Время, прошедшее } \\
\text { с начала эксперимента, } \\
\text { ч. }\end{array}$ & $\begin{array}{c}\text { Среднее число дважды } \\
\text { позитивных клеток } \\
\text { линии А549, \% }\end{array}$ & $\begin{array}{c}\text { Среднее число дважды } \\
\text { позитивных ГСК, } \\
\%\end{array}$ \\
\hline $\mathbf{2 4}$ ч & $12,62 \pm 0,64$ & $3,43 \pm 0,53$ \\
\hline $\mathbf{3 6}$ ч & $16,40 \pm 0,37$ & $2,46 \pm 0,12$ \\
\hline $\mathbf{4 8}$ ч & $30,8 \pm 2,70 *$ & $* 0,37 \pm 0,02$ \\
\hline
\end{tabular}

Примечание. Данные представлены в \% от общего числа клеток каждой группы, в $\mathrm{M} \pm$ s.e.m, $\mathrm{N}=9$ по каждой точке, * - число дважды позитивных опухолевых клеток, через 48 ч наблюдений достоверно $(\mathrm{P}<0,05)$ отличается от количества дважды позитивных ГСК. 


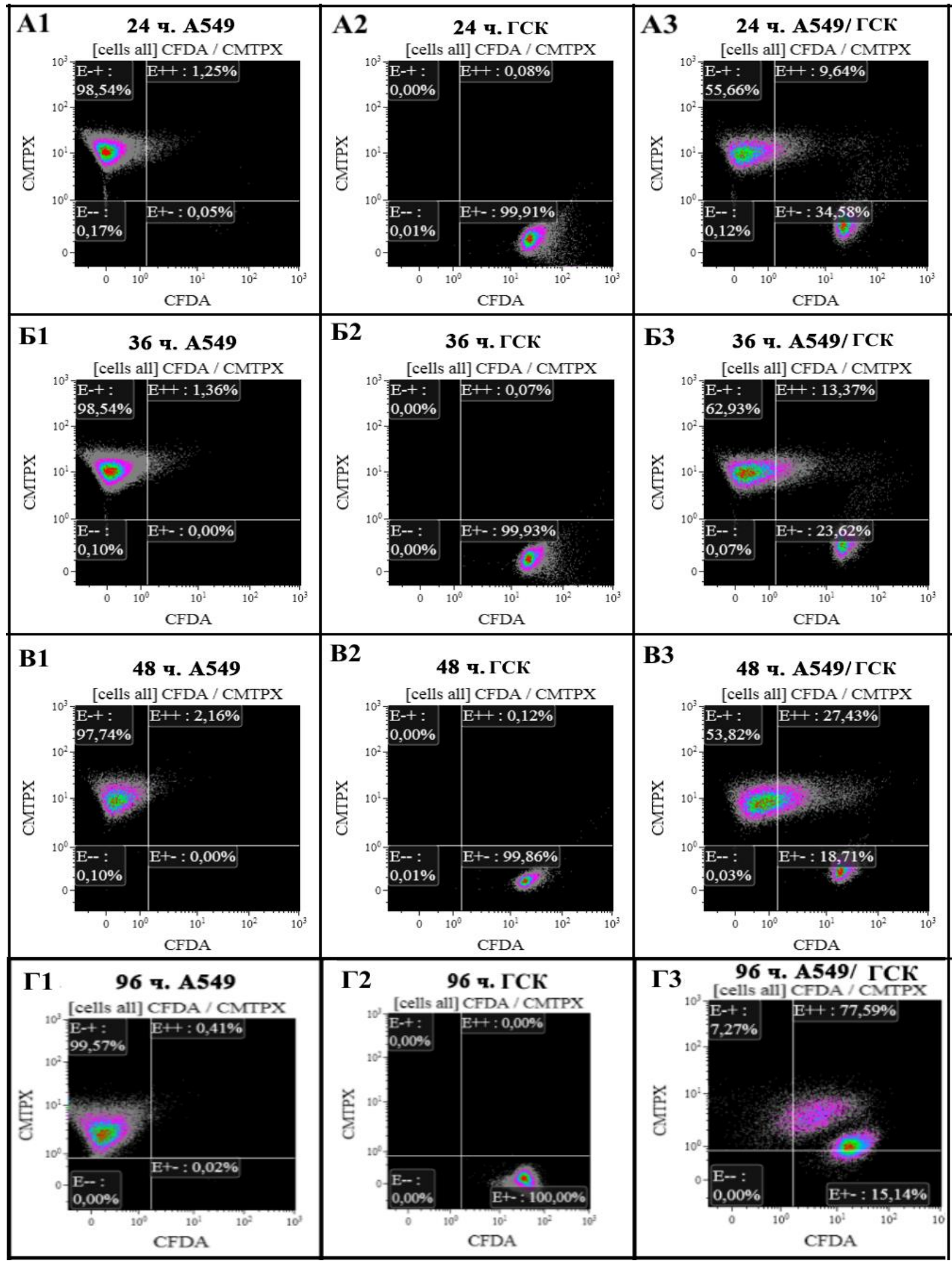

Puc. 20. Гистограммы распределения клеток в сокультуре рака легких с ГСК по данным цитофлуориметрии с использованием флуоресцентных красителей: Б - 36 ч с начала эксперимента; А1, Б1, В1, Г1 - клетки рака легкого, контроль; А2, Б2, В2, Г2 - гемопоэтические стволовые клетки, контроль; А3, Б3, В3, Г3 сокультура ГСК с клетками рака легкого линии А549 
В свою очередь, уменьшение числа монопозитивных стволовых клеток может быть связано гибелью части популяции ГСК под токсическим воздействием нарастающего количества продуктов жизнедеятельности неопластических клеток. Существенное увеличение количества дважды позитивных клеток наблюдалось к 96 ч эксперимента и в других сокультурах. Так, число клеток, позитивных в отношении двух красителей, составляло 47,5\% в сокультуре ГСК с клетками МСF-7 и 64,3\% в сокультуре ГСК с клетками глиобластомы (рис. 21). При этом в сокультуре ГСК с клетками глиобластомы к концу эксперимента практически не осталось монопозитивных ГСК.

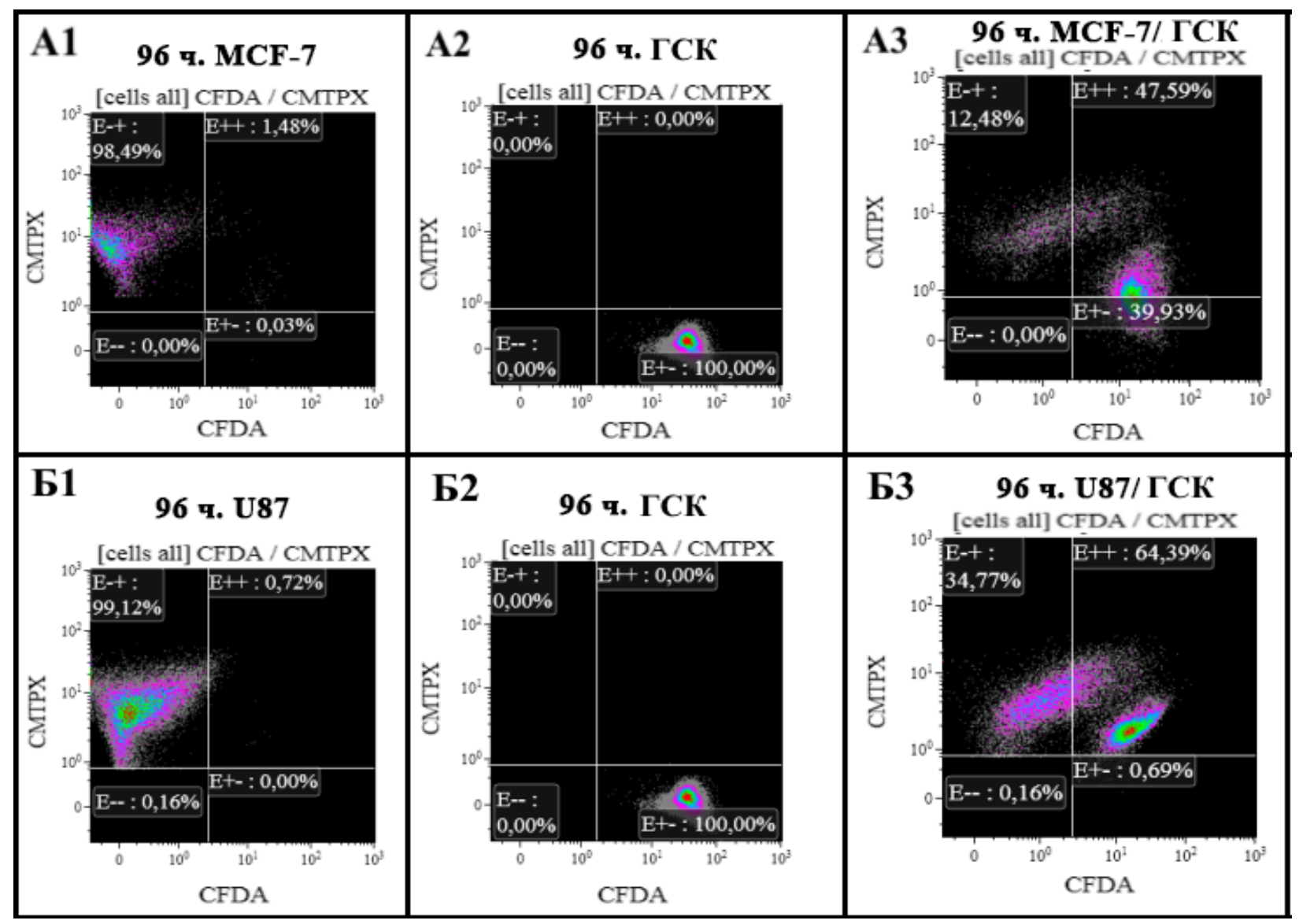

Puc. 21. Гистограммы распределения в сокультуре клеток рака молочной железы и глиобластомы с ГСК, по данным цитофлуориметрии с использованием флуоресцентных красителей: A1 - клетки рака молочной железы линии MCF-7, контроль; А2 гемопоэтические стволовые клетки, контроль; А3 - сокультура ГСК с клетками рака молочной железы линии MCF-7; Б1 - клетки глиобластомы линии U87, контроль; Б2 - гемопоэтические стволовые клетки, контроль; Б3 - сокультура ГСК с клетки глиобластомы линии U87 


\section{3. Обсуждение полученных данных}

Как следует из данных эксперимента in vitro, стволовые клетки обладают подвижностью по отношению к клеткам других типов, которая особо выражена по отношению к опухолевым клеткам. В свою очередь, миграционная активность СК нейрального и не нейрального происхождения сильно различается по отношению к опухолевым клеткам нейроглиального и не нейроглиального ряда. Очевидно, данный факт иллюстрирует важную закономерность: стволовые и опухолевые клетки, полученные из одного источника, обладают максимальной степенью аттракции по отношению друг к другу. Этот факт хорошо демонстрирует высокая подвижность клеток глиобластомы в пределах культуральной вставки по направлению к стволовым клеткам, мигрирующим сюда сквозь ее поры.

Однако особого внимания заслуживает тот факт, что продвижность НПК в отношении различных типов клеток линии глиобластомы тоже совсем не одинакова. Так, дифференцированные клетки двух типов глиобластомы в 5 и 6 раз соответственно превосходят их подвижность в контрольной группе, однако миграционная активность этого НПК в отношении ОСК превышает контроль практически на порядок.

Высокая подвижность НПК по отношению к различным типам опухолевых клеток не является неожиданностью. Способность к непрерывной миграции из первичных герминативных зон головного мозга одно из важнейших свойств нейральных стволовых клеток (Aboody et al., 2013) и их прямых потомков - нейральных прогениторных клеток. Мигрируя из субвентрикулярной зоны головного мозга, потоки НСК ориентируются по градиенту концентрации сигнальных молекул (Doetsch et al., 1999), продуцируемых эндотелием кровеносных сосудов, что позволяет провести некоторые параллели. Периваскулярный способ инвазии клеток МГБ также характеризуется миграцией опухолевых элементов по пространствам Вирхова-Робина, а также распространением вдоль пенетрирующих паренхиму мозга артерий, артериол и вен. В этой связи аргументом в пользу единства механизмов, определяющих специфические взаимоотношения НПК и ОСК, являются указания на способность растущей в мозге МГБ опустошать первичные герминативные центры мозга, что довольно подробно проиллюстрировано в работах (Zhao et al., 2008; Aboody et al., 2013; Kendall et al., 2008) и других авторов. 
Данное обстоятельство свидетельствует в пользу наличия прямой связи между ОСК глиобластомы и нормальными СК головного мозга человека и высших млекопитающих и, конечно, служит весомым аргументом, позволяющим рассматривать СК как важный фактор патогенеза глиом. Нельзя исключить, что способность опухоли привлекать СК наводит на мысль, что запуск и поддержание миграционной активности опухолевых клеток в значительной мере обеспечивается субпопуляцией стволовых клеток.

Относительно слабая способность культур клеток линии МСА-7 рака молочной железы и А 549 рака легкого привлекать СК не должна вводить в заблуждение. Рак молочной железы - гормонально зависимая опухоль, которая по распространенности и масштабу летальности уступает только раку легких, лидирующему в общемировой статистике онкологической смертности. Не исключено, что способность привлекать стволовые клетки может быть связана с многочисленными пассажами этих линий in vitro, приводящих к потере ряда важных сигнальных механизмов. В свете сказанного обращает на себя внимание тот факт, что НПК проявляли максимальную тропность в отношении опухолей нейроэпителиального происхождения и значительно уступали ГСК в активности по отношению к опухолям иного тканевого происхождения.

ГСК, несколько уступали НПК в способности мигрировать в направлении клеток злокачественных опухолей, тем не менее они активно мигрировали к неопластическим клеткам. Этот факт согласуется с данными литературы, указывающими на высокую подвижность СК КМ в отношении различных линий ОК (Nakamizo et al., 2005). Нельзя не отметить, что по способности привлекать ГСК сепарированные CD133+ клетки существенно превосходят другие клетки МГБ, что также является аргументом в пользу уже высказанного предположения, что в составе популяции клеток опухоли именно ОСК обеспечивают максимальный вклад в подачу специфического сигнала, запускающего процессы миграции ГСК и клеток других типов. Следуя этой логике, можно предполагать, что онкотехнологии, основанные на создании модифицированных СК, способны обеспечить эффективное управление ростом опухолевых стволовых клеток.

СК обладают способностью направленно мигрировать к опухолевым клеткам, но роль этого феномена в канцерогенезе МГБ практически не изучена. Идентифицировано множество хемоатрактантов, факторов роста 
и других сигнальных молекул, управляющих процессами миграции и хоуминга стволовых клеток, о чем сказано в разделе 2.4 литературного обзора. Однако роль описанных выше механизмов в патогенезе глиальных опухолей головного мозга неоднократно доказана.

Как следует из эксперимента, первичным источником сигнальных молекул, привлекающих СК, являются клетки опухоли. Способность клеток МГБ продуцировать коллаген 4-го IV типа, лектины и тенасцин доказана. Продукция клетками МГБ матриксных металлопротеаз (MМР 1, 2 и 9) способствует разрушению внеклеточного матрикса (ВКМ) и высвобождению фибронектина, витронектина и ряда других молекул, резко повышающих мотильность опухолевых клеток и их способность привлекать стволовые и дифференцированные клетки. Поскольку ангиогенные свойства МГБ ассоциированы именно с ОСК, то наблюдаемая в эксперименте лучшая подвижность ГСК и НПК относительно ОСК позволяет предположить, что способность привлекать СК не только находится в зависимости от ангиогенного потенциала опухоли, но и усиливается в процессе реализации этого потенциала.

Таким образом, в эксперименте in vitro изучены процессы направленной миграции СК к ОК различных типов. Установлено, что способность мигрировать к опухолевым клеткам в большей степени свойственна именно тканеспецифическим нейральным прогениторным клеткам. Наилучшей способностью индуцировать миграцию СК обладают ОСК, что свидетельствует о прямой зависимости этого феномена от ангиогенного потенциала опухоли. Вектор миграционной активности более выражен между клетками, имеющими единый гистогенетический источник.

ГСК обладают выраженной способностью к миграции в отношении клеток глиальных опухолей. В свою очередь, клетки МГБ также обладают высокой степенью мобильности и активно перемещаются в поле зрения, «собирая» стволовые клетки. На принципиальное значение адгезии стволовых и опухолевых клеток указывал (Greenbaum et al., 2013, Ding \&Morrison, 2013; Méndez-Ferrer et al., 2010; Anthony \& Link, 2014) и ряд других авторов, отметивших принципиальную возможность коллаборации между ними. При этом важно, что ГСК не являются сугубо адгезионной культурой и выявленная нами и описанная в литературе способность СК этого типа адгезировать к клеткам злокачественных опухолей - важное условие, определяющее их роль в опухолевом процессе. 
Мысли о противоопухолевых свойствах ГСК высказываются уже более 50 лет, однако механизмы этого явления не ясны. Показана способность ГСК подавлять процессы роста клеток рака поджелудочной, предстательной желез и ряда некоторых линий меланомы, клеток первичного лейкоза, саркомы Капоши, гепатомы и рака молочной железы. В качестве механизмов этого феномена указывается подавление CD34+ клетками процессов сигнальной трансдукции по внутриклеточному пути МАРК и подчеркивается особая роль ГСК при активизации лиганд-рецепторных осей CXCR4/SDF, VLA4/VCAM1, CD62L/PSGL, CD44/HA b Kit/KL (Nervi et al., 2006; de Lucas B et al., 2018) в ОК. Высказывается мнение, что активное привлечение ГСК в опухолевый очаг, осуществляемое через активацию этих сигнальных механизмов, имеет целью трансформацию их в резидентные макрофаги с последующей презентацией опухолевых антигенов (Ratajczak et al., 2003; Hambardzumyan et al., 2016; Chen \& Hambardzumyan, 2018). Как показанно в литературе (Aboody et al., 2000), адгезия ГСК к поверхности клеток опухоли снижает степень их мобильности, подавляя индуцированный TGF- $\beta$ синтез компонентов межклеточного матрикса и препятствуя метастазированию опухоли.

Важной особенностью процесса коммуникации ГСК с клетками опухолей является перенос флуоресцентной метки между ними. В настоящей работе использовались красители на основе сукцинимидного эфира 5,6карбоксилфлуоресцеин диацетата, обладающего липофильными свойствами, благодаря чему они легко проникают сквозь клеточную мембрану в процессе окрашивания. В цитоплазме клетки молекула красителя ковалентно взаимодействует с аминогруппами цитоплазматических белков (Gibson et al., 2012), благодаря чему метка не высвобождается из клеток и приобретает способность флуоресцировать. Это позволяет рассматривать сущность выявленного в настоящем фрагменте работы феномена переноса флуоресцентной метки именно как трансфер цитоплазматических белков, неразрывно связанных с клеточным красителем. При этом транспорт белков происходит преимущественно между ГСК и опухолевыми клетками разных линий, что, очевидно, представляет собой закономерность межклеточного взаимодействия.

Особый интерес обнаруживают механизмы указанного выше явления. Существуют данные о возможности клеточной фузии, или слиянии стволовой и неопластической клеток. Этот механизм играет важную роль 
в регуляции стволовыми клеками процессов детерминации, индукции и дифференциации, коррекции нарушений в поврежденных клетках, репарации и регуляции фенотипа стволовых клеток костного мозга (Wurmser \& Gage, 2002).

Обмен флуоресцентной меткой возможен через экзосомы (Gabrusiewicz et al., 2018), в пользу чего свидетельствует наличие большого количества флуоресцирующих объектов мелкого размера, существенно меньшего диаметра ГСК. Обмен экстрацеллюлярными везикулами с белками и микроРНК возможен также через особые дифференцировки цитоплазмы - наноразмерные микротрубки (Godlewski et al., 2015), образуемые между мембранами взаимодействующих клеток, либо путем формирования структурно-функционального синцития между стволовыми и опухолевыми клетками.

В ходе эксперимента при взаимодействии стволовых и опухолевых клеток мы наблюдали рад принципиальных моментов. Так, способность ГСК к подавлению ключевых функций опухолевых клеток носит дозозависимый характер, что в известном смысле объясняет конечный биологический смысл их миграции в опухолевую ткань. Резонно предположить, что существенная разница между количеством СК в молодом и пожилом возрасте является одной из причин преобладания злокачественных опухолей во второй половине жизни человека.

При сокультивировании ГСК и опухолевых клеток различных типов в соотношении 1:1 становится возможным описать другие принципиальные закономерности. Клетки рака легкого преимущественно накапливают флуоресцентную метку (цитоплазму), привнесенную из ГСК, что, вероятно, является одним из механизмов противоопухолевого действия этого типа клеток. Во втором случае при культивировании ГСК с клетками линии U87 и MCF-7 наблюдается увеличение количества дважды позитивных клеток при одновременном снижении количества ГСК. При этом важно, что к 96-му ч наблюдений в сокультуре ГСК с клетками глиобластомы практически не остается стволовых клеток, позитивных только в отношении одного из используемых красителей.

Направленная миграция ГСК к клеткам МГБ резко усиливается при активизации различного типа рецепторов лигандами, продуцируемыми как зоной повреждения, так и самими опухолевыми клетками. В ответ на эти стимулы ГСК мигрируют к опухолевым клеткам и адгезируют к ним. 
Безусловно, это явление носит регуляторный характер, но в процессе взаимодействия с неопластическими клетками ГСК подвергаются воздействию различных протеолитических ферментов, продуцируемых клетками опухоли. С одной стороны, такое воздействие запускает в них процессы апоптоза, что проявляется накоплением в цитоплазме соответствующих белков, с другой, позволяет опухолевым клеткам фагоцитировать фрагменты разрушенных клеток. Весьма вероятно, что накопление в опухолевых клетках проапоптотических и других белков вызывает серьезные сдвиги в эпигенетической регуляции экспрессии генов, что ведет к торможению пролиферации и угнетению жизненных функций опухолевых клеток. Именно следуя этой логике, становится понятным наблюдаемый нами дозозависимый противоопухолевый эффект ГСК.

Таким образом, при совместном культивировании гемопоэтические CD34+ стволовые клетки адгезируют к клеткам злокачественных опухолей, что сопровождается переносом флуоресцентной метки из ГСК в опухолевые клетки. Этот феномен наблюдается у 31\% клеток глиомы линии С6, у 47\% клеток рака легкого А 549 и аденокарциномы молочной железы и у 64\% клеток линии U87 глиобластомы человека. Увеличение числа ГСК в сокультуре сопровождается замедлением темпов пролиферации опухолевых клеток. 


\begin{tabular}{cc}
\hline ФУНДАМЕНТАЛЬНЫЕ АСПЕКТЫ ПРОБЛЕМЫ: \\
Ф \\
ВЗАИМОДЕЙСТВИЕ ГЕМОПОЭТИЧЕСКИХ \\
Сौ \\
СТВОЛОВЫХ И ОПУХОЛЕВЫХ КЛЕТОК \\
$\stackrel{5}{5}$ & НА МОДЕЛИ ГЛИОБЛАСТОМЫ IN VIVO \\
\hline
\end{tabular}

Последние 10 лет наша исследовательская группа занималась фундаментальными научными исследованиями в области изучения межклеточного взаимодействия стволовых клеток (СК) и различных типов опухолевых клеток (ОК) и опухолевых СК (ОСК) не только in vitro, но и in vivo. В соответствии с поставленной задачей исследование включало три этапа работ:

1) моделирование глиобластомы in vivo;

2) изучение феномена направленной миграции гемопоэтических стволовых клеток в опухолевый очаг;

3) изучение закономерностей процесса межклеточного взаимодействия в опухолевом очаге.

\section{1. Создание экспериментальной модели глиобластомы in vivo}

Прежде чем приступить к непосредственному описанию экспериментов, считаем необходимым сделать важную ремарку по поводу дизайна работы. Абсолютное большинство работ по изучению взаимодействия и взаимовлияния нормальных стволовых и опухолевых клеток in vivo выполнены с использованием особого типа экспериментальных животных, а именно иммунодефицитных крыс и мышей. Признавая методогическую обоснованность таких исследований, не можем не подчеркнуть, что разрыв между научной значимостью и практической ценностью таких данных весьма велик. В этой связи при планировании эксперимента мы отказались от использования иммунодефицитных животных, выбрав в качестве объекта исследования половозрелых крыс породы «Вистар» возрастом 10-12 недель массой 200-220 гр.

Использование (этих животных) одобрено Этическим комитетом Школы биомедицины ДВФУ (протокол № 1 и 2 от 05.03.2017). Животных содержали в условиях, соответствующих стандартам GLP и Хельсинкской декларации WMA об этических принципах лечения животных в экспериментах. Исследование проводилось в соответствии с требованиями зако- 
нодательства Великобритании (U.K. Animals Scientific Procedures), Директивы EC 2010/63/EU для экспериментов на животных и под руководством Национального института здравоохранения США по уходу и использованию лабораторных животных. Все исследования на животных соответствовали рекомендациям ARRIVE и AVMA 2013 г. по эвтаназии экспериментальных животных.

Для моделирования низкодифференцированной злокачественной опухоли головного мозга применялись клетки глиомы линии С6 (АТСС®) CCL-107). Клетки использованы в эксперименте после третьего пассажа с момента разморозки. Перед началом эксперимента все клетки были протестированы на контаминацию микоплазмой с помошью Universal Mycoplasma Detection Kit (ATCC® 30-1012K ${ }^{\mathrm{TM}}$ ). Для определения фенотипа опухолевых клеток выполняли предварительную иммуноцитохими-

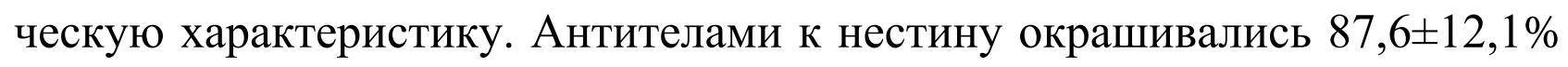

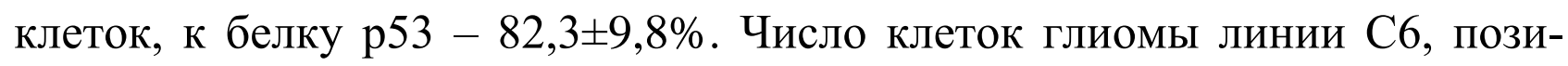
тивных в отношении к белкам CD133 $(3,7 \pm 2,8), \operatorname{S100}(7,4 \pm 4,3 \%)$, глиального фибриллярного кислого белка GFAP $(7,2 \pm 2,2 \%)$ и $\beta$ III-тубулина (9,3 $\pm 4,4 \%)$ было невелико (рис. 22).

Животных анестезировали внутрибрюшинной инъекцией 2 мг раствора, содержащего Zoletil 100 (Virbac, Франция) + Rometar (Bioveta a.s. Czech) в соотношении 1:4. Выполняли разрез кожи головы и накладывали фрезевое отверстие, используя Ideal Micro Drill (Harvard apparatus, US). $0,2 \times 10^{6}$ клеток глиомы вводили в $5 \mu 1$ стерильного $0,14 \mathrm{M}$ раствора $\mathrm{NaCl}$ со скоростью $1 \mu 1 / \mathrm{m}$, применяя гамильтоновский шприц (600 Series, Hamilton, US). Имплантацию выполняли, используя стереотаксический аппарат для крыс SR-5R-HT (Narishige, Japan) и ориентируясь по координатам атласа мозга крысы (Paxinos \&Watson, 2007): Ap-1; L-3,0; V4,5, TBS-2,4 mm. Верификацию опухоли выполняли на 14-й день, используя магнитно-резонансный томограф Bruker's $\quad$ PharmaScan ${ }^{\circledR}$ (Massachusetts, US).

Имплантация опухолевых клеток в мозг половозрелых крыс породы «Вистар» приводила к быстрому формированию опухолей, хорошо визуализируемых при МРТ головного мозга у оперированных животных спустя 7 суток с момента имплантации (рис. 23). К 20-му дню эксперимента опухоль была хорошо заметна на препаратах головного мозга крыс. При анализе морфологических изменений обращали на се- 
бя внимание гиперемия сосудов мозга в месте расположения опухоли, набухание и отечность мозгового вещества, наличие на поверхности мозга рельефных вдавлений от костей черепа, сглаженность основных борозд и извилин.
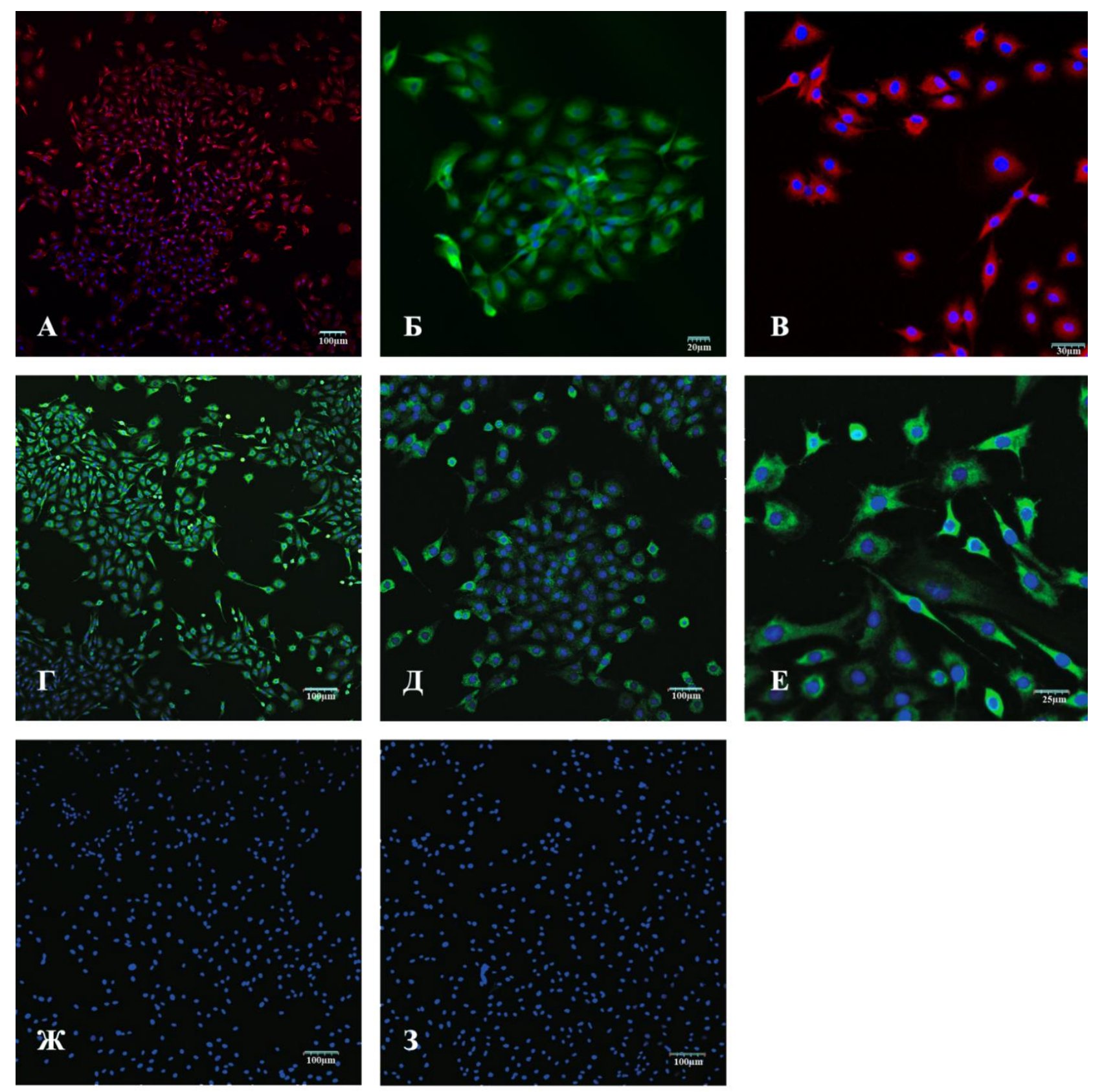

Puc. 22. Иммуноцитохимическая характеристика клеток линии С6, использованных для экспериментального моделирования глиобластомы in vivo. Иммуногистохимическая реакция на: А - нестин; Б - p53; В - CD133; Г - tubulin- $\beta$ III; Д-S100; E-GFAP; Ж, 3 - контрольное окрашивание вторичными антителами; Ж - Alexa 488, 3 - Alexa 633. Специфическая флуоресценция отсутствует.

Ядра докрашены DAPI 
Как правило, опухоль занимала больше половины полушария мозга, возвышалась над его конвекситальной поверхностью и была представлена на срезах мозга светло-красной или перстрой опалесцирующей тканью, контрастной цвету основных церебральных структур (рис. 23, А-В).
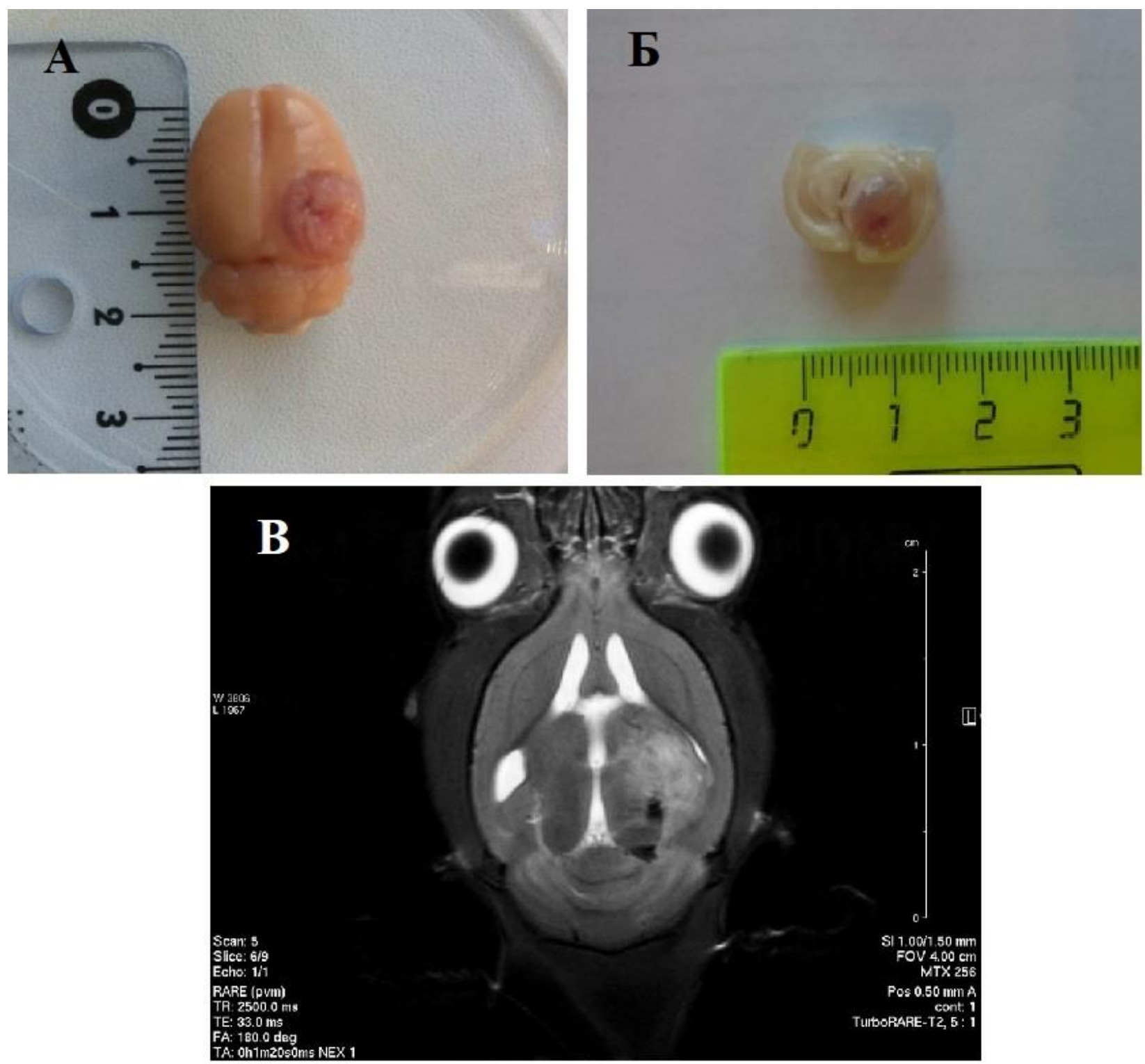

Рuc. 23. Опухоль в мозге крысы, 20-е сутки после введения клеток:

А - макропрепарат, опухоль возвышается над поверхностью полушария;

Б -фронтальный срез головного мозга, признаки сдавления опухолью мозговых структур; В - магнитно-резонансная томограмма мозга крысы, 20-е сутки эксперимента, режим N2 Turbo RARE

При гистологическом исследовании неопластическая ткань была представлена клетками разнообразной формы с различным количеством ядер (рис. 24, А, Б). 
К 14-му дню опухоль содержала множество микрососудов, что свидетельствовало о высокой скорости метаболических процессов. Очевидно, хорошая васкуляризация интенсифицировала метаболизм клеток глиомы, которые, образовывая вихревые очертания вокруг новообразованных сосудов, вторгались в дистрофически измененную паренхиму мозга, где формировали длинные клеточные тяжи, окруженные большим количеством солитарных клеток глиомы, инфильтрирующих мозговое вещество.

На некотором удалении от первичного неопластического узла клетки глиомы уплотнялись и образовывали конгломераты, из которых возникали сателлитные очаги. В центре такого очага быстро формировался питающий кровеносный сосуд, что значительно интенсифицировало процессы неопластического роста и инвазии. С появлением в кровеносном сосуде признаков эластической мембраны обнаруживалась тенденция к слиянию сателлитного очага с первичной опухолью. При этом клетки опухоли уплотнялись вокруг кровеносного сосуда, что формировало характерную картину псевдорозеол (рис. 24, В-Е).

С 28-го дня наблюдения в глубоких отделах опухолевой ткани начинались процессы гибели неопластических клеток, что указывало на принципиальную неспособность кровеносной сети обеспечить потребности быстро растущей клеточной массы опухоли. С этого времени в опухолевой ткани появлялись зоны разрежения, большая часть опухолевых клеток концентрировались вокруг питающего кровеносного сосуда, обнаруживая характерную картину псевдорозеол на фоне участков некроза, окруженных псевдопалисадными структурами и занимающих основное место в морфологической картине (рис. 25).

Таким образом, имплантация $0,2 \times 10^{6}$ клеток глиомы линии С6 данного иммунофенотипа быстро приводила к формированию опухоли, обладающей инвазивным ростом, высокими темпами пролиферации опухолевых клеток, ангиогенезом и формированием некрозов, что наряду с неизоморфностью образующих ее клеточных элементов позволяет считать ее аналогом МГБ человека. 

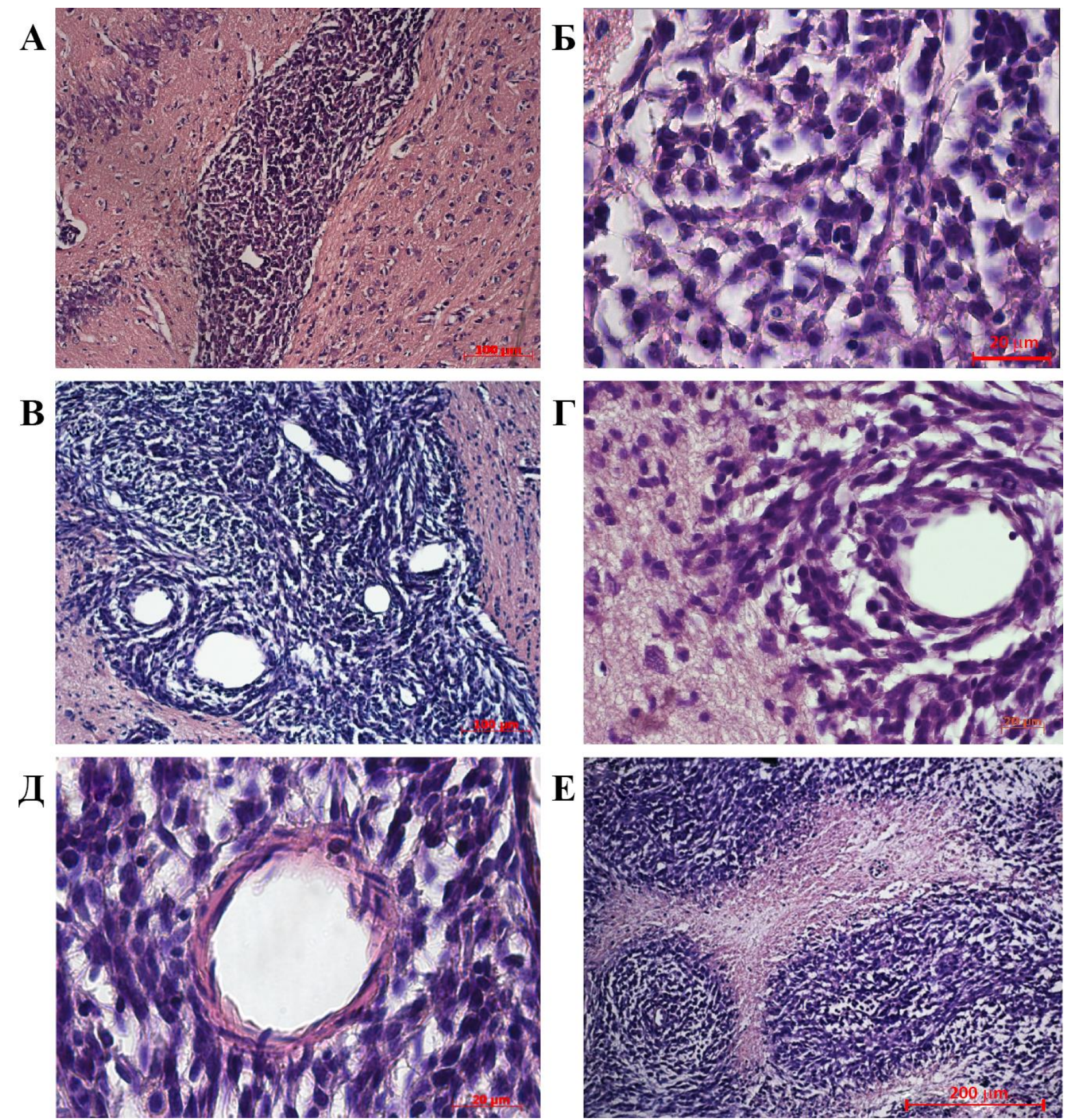

Puc. 24. Опухоль в головном мозге крыс. А, Б - 14-е сутки с момента имплантации (Б - масштаб 200 мкм); В, Г - 20-е сутки, опухолевая ткань с новообразованными кровеносными сосудами; Д - формирование кровеносного сосуда среди клеток сателлитного очага; E - 30-е сутки, ангиоцентрическая группировка опухолевых клеток и зоны некроза в опухолевой ткани. Окраска гематоксилин-эозином 

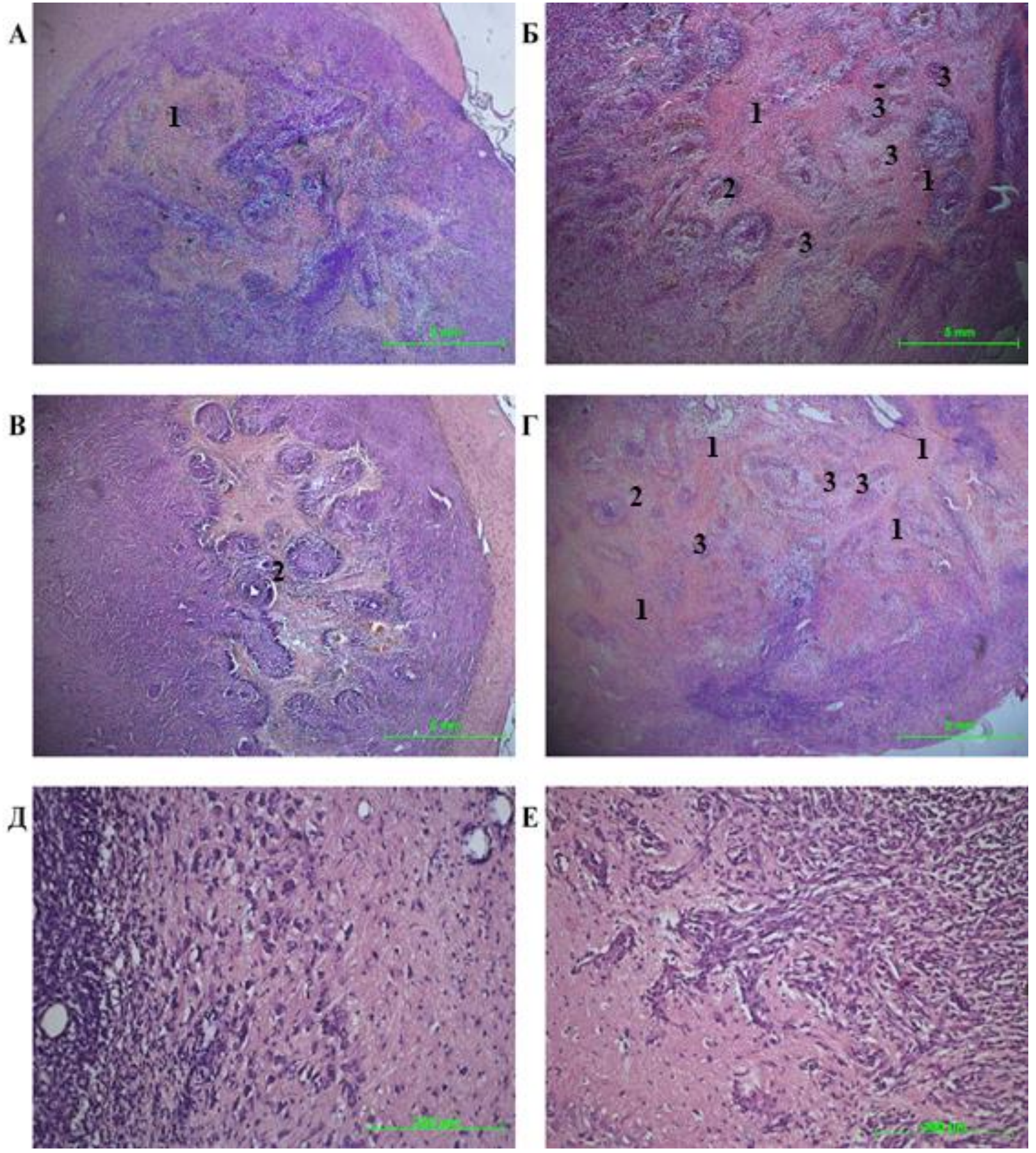

Puc. 25. Микропрепарат мозга крысы с перевитой глиомой С6.

Окраска гематоксиллин-эозином, 28-е сутки эксперимента: А-Г - некротические области в центре опухолевого узла (1), новообразованные кровеносные сосуды в окружении плотно сгруппированных опухолевых клеток, формирующих псевдопалисадные структуры (2), а также множество запустевающих новообразованных кровеносных сосудов в центре некротических областей (3); Д - множественные неопластические клетки, инфильтрирующие ткань мозга;

$$
\mathrm{E} \text { - участки инвазии по типу «языков пламени» }
$$




\section{2. Анализ миграции гемопоэтических \\ стволовых клеток в опухолевый очаг}

Для решения конкретной задачи, а именно для изучения закономерностей миграции нормальных ГСК в неопластический очаг, был использован биомедицинский препарат гемопоэтических стволовых клеток, предоставленный $3 \mathrm{AO}$ «Нейровита» (г. Москва, Россия). По данным сопроводительной документации, препарат был представлен лейкоконцентратом мононуклеарных клеток КМ, рекрутированных в системный кровоток после стимуляции больных гранулоцитарным колониестимулирующим фактором (Г-КСФ). Число клеток иммунофенотипа $\mathrm{CD} 34+$ в составе лейкоконцентрата варьировало от 1,5 до $3 \%$. Ксенотрансплантация согласована с Этическим комитетом Школы биомедицины ДВФУ (протокол № 2 от 05.03.2017).

На протяжении одной недели перед проведением эксперимента животным была проведена иммуносупрессивная терапия (бусульфан SigmaAldrich, кат. № BP403), дексаметазон (Sigma-Aldrich, кат. № D1159); циклофосфамид (Sigma-Aldrich, кат. № ВР1094). За 2 ч до введения животным ГСК были окрашены флуоресцентными трейсерами Red CMTPX Dye (C34552, Molecular Probes, спектр возбуждения/эмиссии 577/602nm) или Vybrant ${ }^{\circledR}$ CFDA SE (V12883, Molecular Probes, спектр возбуждения/эмиссии 492/517 nm) в соответствии с рекомендациями фирмыпроизводителя. Эти клетки в количестве $0,5 \times 10^{6}$ вводили в системный кровоток крыс через центральную хвостовую вену в условиях общей анестезии. Животных выводили из эксперимента на 3, 5, 8 и 15 сутки после введения клеток. Контролем служили крысы, получавшие инфузию меченых данными маркерами ГСК, но без предшествующей имплантации опухолевых клеток.

У животных экспериментальной группы появление единичных флуоресцирующих объектов в зоне расположения опухолевой ткани наблюдалось уже через 3 дня после введения клеток. В этот период местом их предпочтительной локализации является граница между опухолью и здоровой тканью мозга. Появление флуоресцирующих объектов в более глубоких зонах опухоли регистрируется в связи с походящими здесь кровеносными сосудами (рис. 26, А, указано стрелками).

На 5-е сутки с момента введения ГСК число флуоресцирующих клеток в зоне расположения опухоли заметно возрастает (рис. 26, Б). В этот 
период они формируют плотное скопление по периферии неопластического очага (рис. 26, Г) и в виде небольших группировок обнаруживаются в глубине опухолевой ткани (рис. 26, В). Как и на более ранних сроках наблюдения, они локализуются в непосредственной близости от кровеносных сосудов. Клетки, содержащие краситель, в этот период сохраняют четкие очертания перикарионов, гранулы флуорохрома распределены равномерно по их цитоплазме, оставляя свободной от окрашивания зону ядра (рис. 26, В, Г).

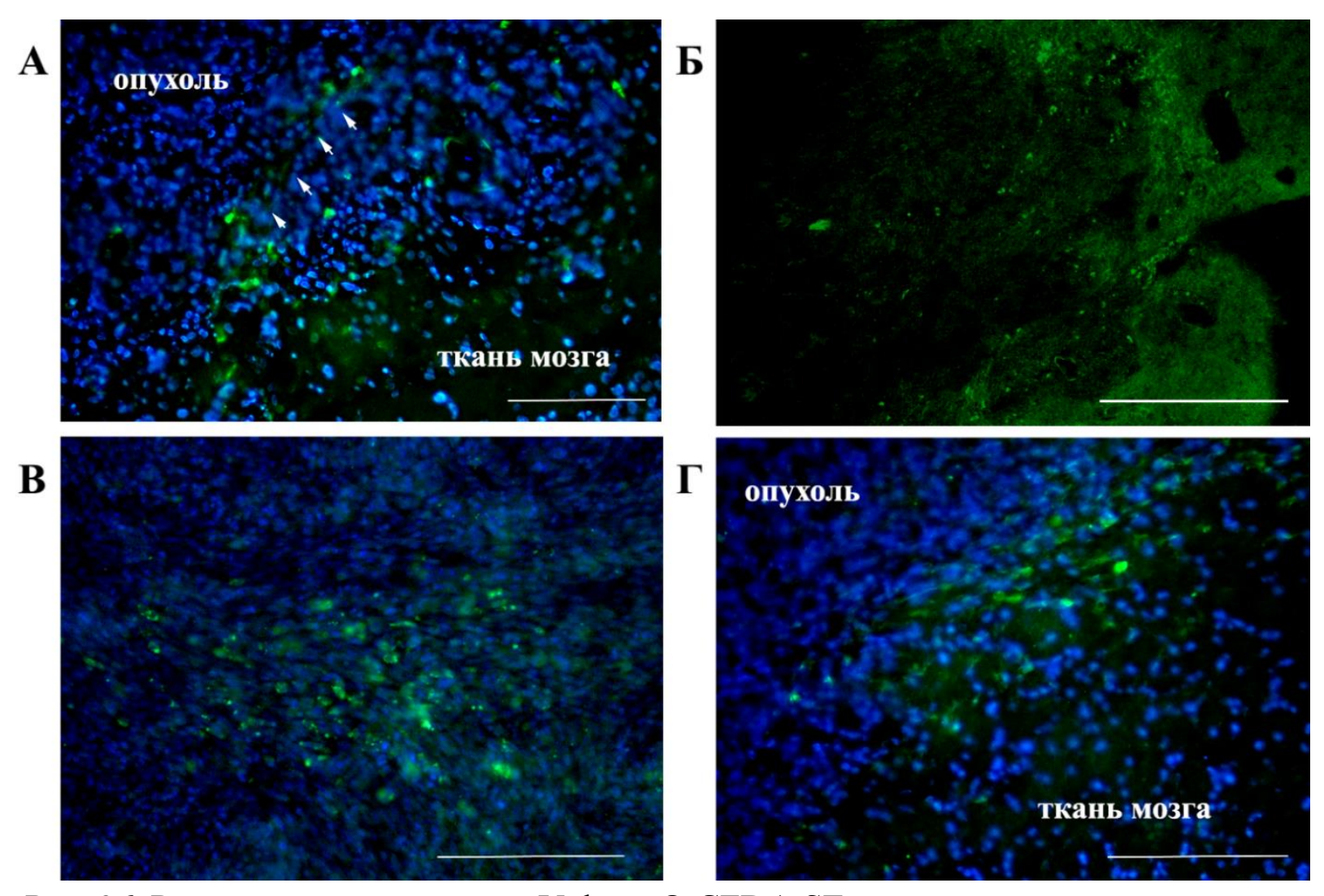

Puc. 26. Распределение меченых Vybrant® CFDA SE гемопоэтических стволовых клеток в мозге животных с привитой глиобластомой на 3 (А) и 5 (Б-Г) сутки после введения: А - на ранних сроках клетки локализуются вдоль границы опухоли или проникают вглубь неопластической ткани по ходу кровеносных сосудов (указаны стрелками); Б - плотное скопление флуоресцирующих клеток на 5-й день после инфузии. ГСК с сохранной морфологией группируются в глубине опухоли среди ее клеток (В) или на границе с интактной тканью мозга (Г). Ядра докрашены DAPI.

Масштаб 200 мкм

В течение 8-15 суток (рис. 27) продолжается дальнейшая инфильтрация опухолевой ткани мечеными ГСК с параллельным уменьшением их количества в краевой зоне опухоли. В этот период начинают регистрироваться признаки разрушения введенных клеток - флуоресцентный 
сигнал распределяется не только в цитоплазме, но и в межклеточном пространстве. На 8-е сутки после инфузии ГСК суммарная площадь флуоресцирующих объектов на границе опухолевого узла $(12,7 \pm 9,2 \%)$ усту-

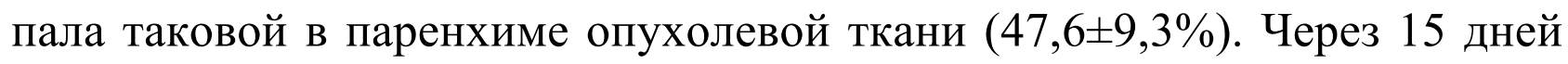
диффузный флуоресцентный сигнал регистрируется вдоль границ опухоли, которые к этому моменту имеют размытые очертания. Наибольшая интенсивность метки сохраняется в глубоких отделах опухоли, где регистрируются отдельные клеточные элементы, конгломераты клеток, а также большие зоны перицеллюлярного скопления флуоресцирующего материала. Обращает на себя внимание тот факт, что на поздних сроках наблюдения флуоресцентная метка доминирует на границе зон клеточного разряжения опухолевой ткани - зон некроза (рис. 27, отмечены звездочками).
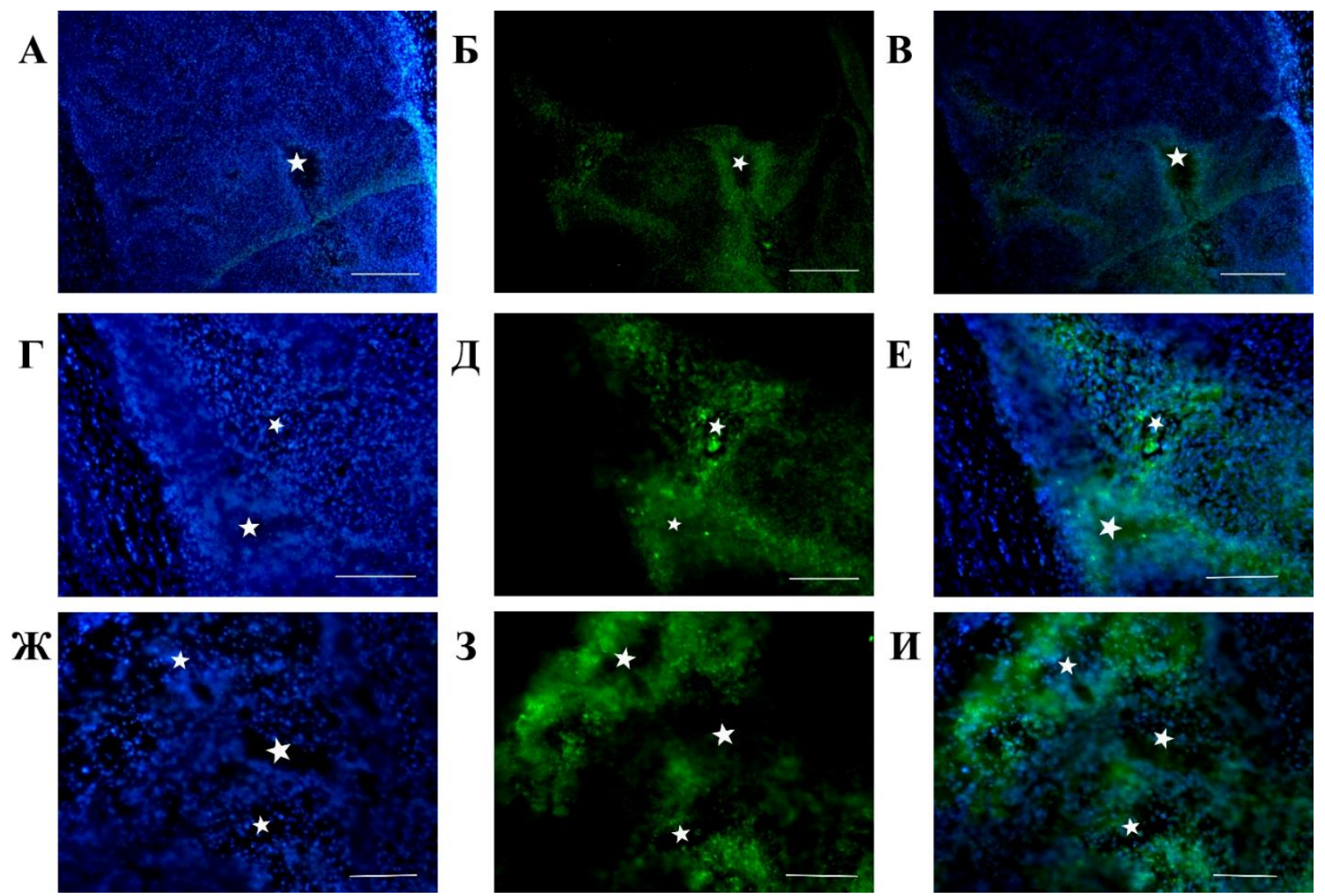

Pис. 27. Распределение меченых Vybrant® CFDA SE гемопоэтических стволовых клеток в мозге животных с привитой глиобластомой на 8-е (A-Е) и 15-е (Ж-И) сутки после введения. Клетки локализуются преимущественно в глубине опухолевой ткани вокруг зон некроза (обозначены звездочками). Флуоресцентная метка, особенно на поздних сроках наблюдения (Ж-И), распределена как в цитоплазме клеток, так и между ними: А, Г, Ж - DAPI; Б, Д, 3 - флуоресцентный сигнал CFDA SE; В, Е, И - объединенный сигнал. Масштаб: А-В - 500 мкм 
В головном мозге животных группы сравнения (введение ГСК без предварительного формирования опухоли) распределение введенных клеток носило иной характер. В течение первых 3-5 суток после трансплантации ГСК у крыс контрольной группы обнаружены солитарные флуоресцирующие объекты, соответствующие установленному диапазону свечения CFDA SE-позитивных ГСК. Клетки локализуются внутри кровеносных сосудов, в паренхиме мозга в непосредственной близости от них и в небольшом количестве встречаются в составе сосудистых сплетений мозговых желудочков (рис. 28).

На 8-15 сутки эксперимента на препаратах мозга крыс контрольной группы объекты, соответствующие форме и размеру ГСК и флуоресцирующие длине волн, соответствующих зеленому спектру (CFDA SE 492/517), не обнаруживались.

В паренхиматозных органах животных контрольной и экспериментальной групп (легкие, печень, почки, вилочковая железа) в течение 35 суток после введения лейкоконцентрата, обогащенного ГСК, обнаруживаются единичные флуоресцирующие клетки, достаточно сложно дифференцируемые от интенсивной аутофлуоресценции исследуемых органов (рис. 29).

Следует отметить, что в селезенке животных обеих групп в течение первых 3-5 суток после введения наблюдается повышение содержания флуоресцирующих клеток в области красной пульпы (Б). В этот же период солитарные флуоресцирующие объекты обнаруживаются в красном костном мозге животных, получавших гемотрансфузию ГСК (Рис. $30 \mathrm{~A}-Г$ ).

При изучении процесса миграции ГСК с использованием красителя Red CMTPX Dyе получены идентичные данные. Однако в отличие от клеток, окрашенных CFDA SE и сохраняющих активное свечение в течение двух недель после активации в клетках, краситель Red CMTPX Dye coxpaняет свою флуоресценцию в течение первых 3-5 дней.

Таким образом, гемопоэтические стволовые клетки, трансплантированные в организм экспериментальных животных с глиомой С6, направленно мигрируют в опухоль, где первоначально (3-5 сутки) накапливаются на границе неопластического очага и на последующих этапах (8-15 сутки) проникают в ткань глиомы и сосредотачиваются в 
участках некроза опухоли. Закономерностью этого процесса является накопление трансплантированных ГСК непосредственно в опухолевой ткани $(47,6 \pm 9,3 \%)$ и зонах инвазивного роста опухоли $(12,7 \pm 9,2 \%)$. При введении в организм крыс без опухоли ГСК не имеют конечной цели миграции, остаются в пределах капиллярного русла мозга и мозговых желудочков, что является существенной особенностью данного процесса. Трансплантированные клетки практически не обнаруживаются в паренхиматозных органах (легкие, печень, почка, вилочковая железа), а транзиторное повышение их количества в селезенке может свидетельствовать об их разрушении в красной пульпе при введении в системный кровоток.

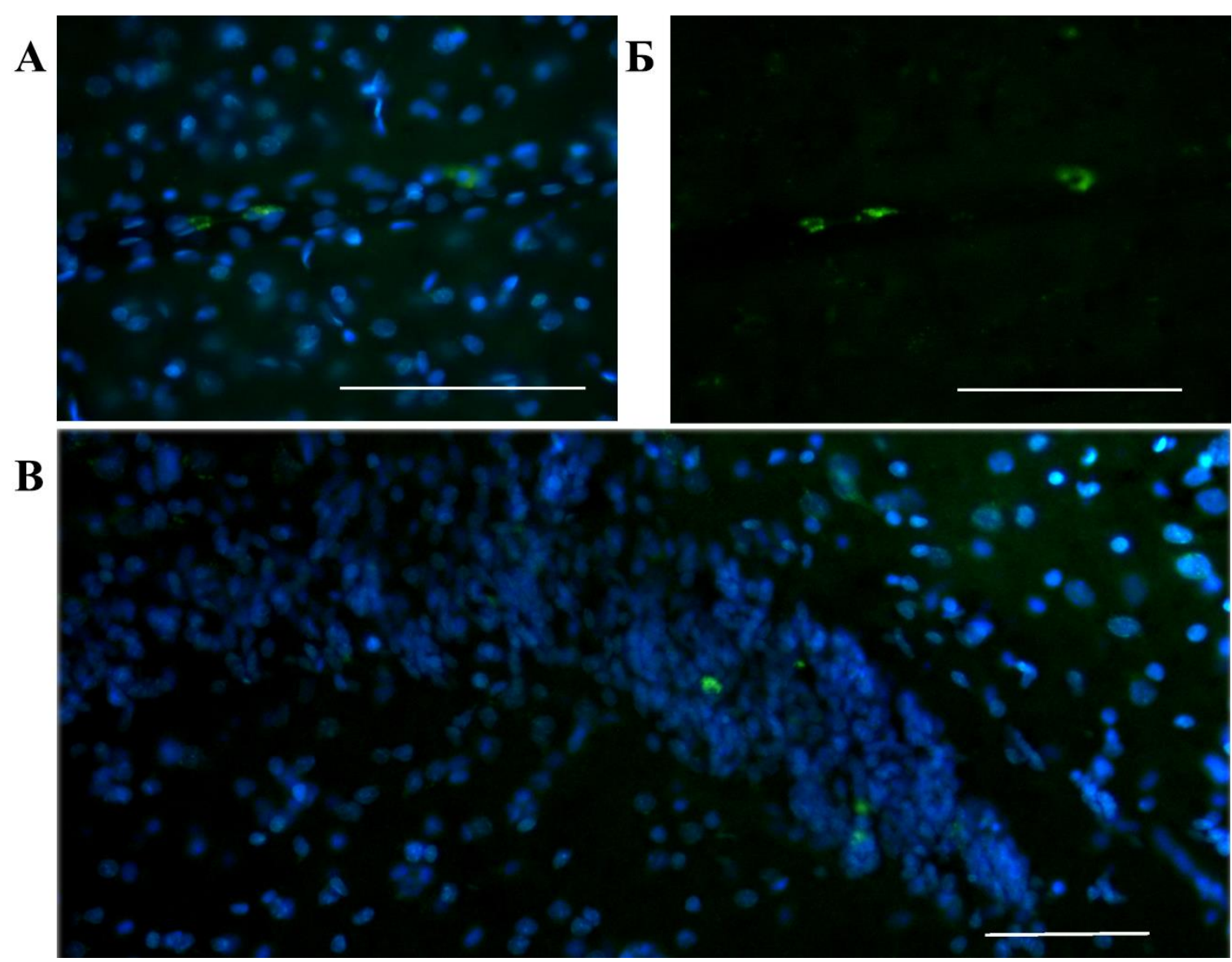

Рис. 28. Распределение трансплантированных ГСК в мозге животных без опухоли. Единичные клетки визуализируются в просвете кровеносного сосуда $(\mathrm{A}$, Б) и в сосудистом сплетении мозговых желудочков (B). Окраска Vibrant CFDA SE, $\lambda=488 \mathrm{~nm}$, Ex/Em 492/517 nm. Ядра окрашены DAPI. Флуресценция трансплантированных клеток контрастна аутосвечению мозговой ткани. Масштаб 100 мкм 
A

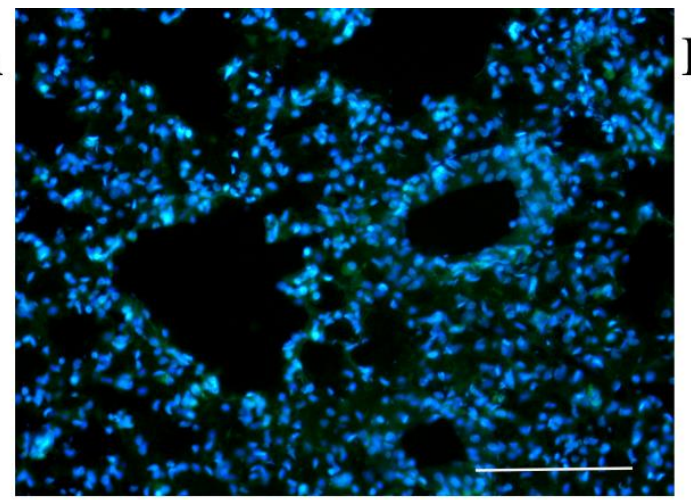

\section{Б}

легкое

B

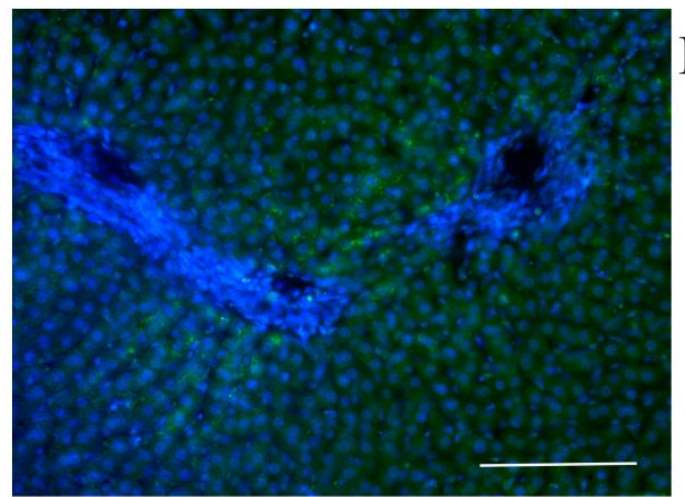

Д
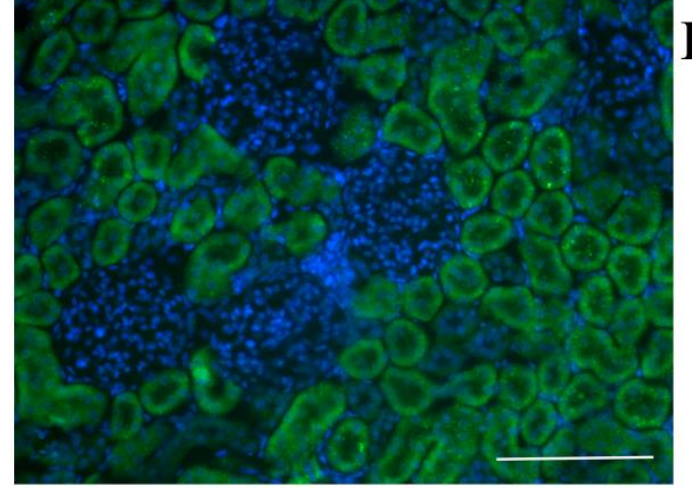

E

почка

печень

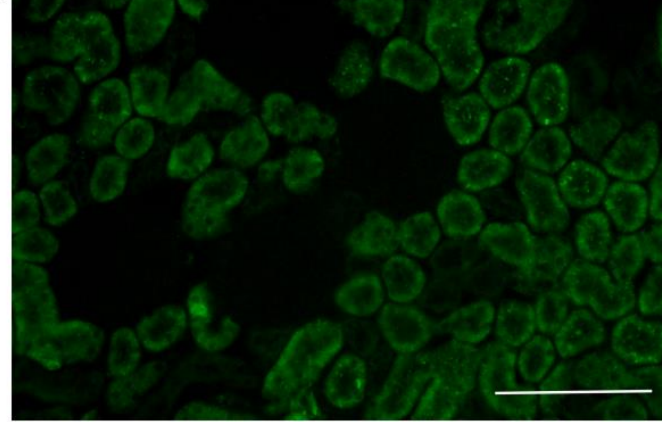

\section{K}

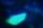

3

вилочковая железа
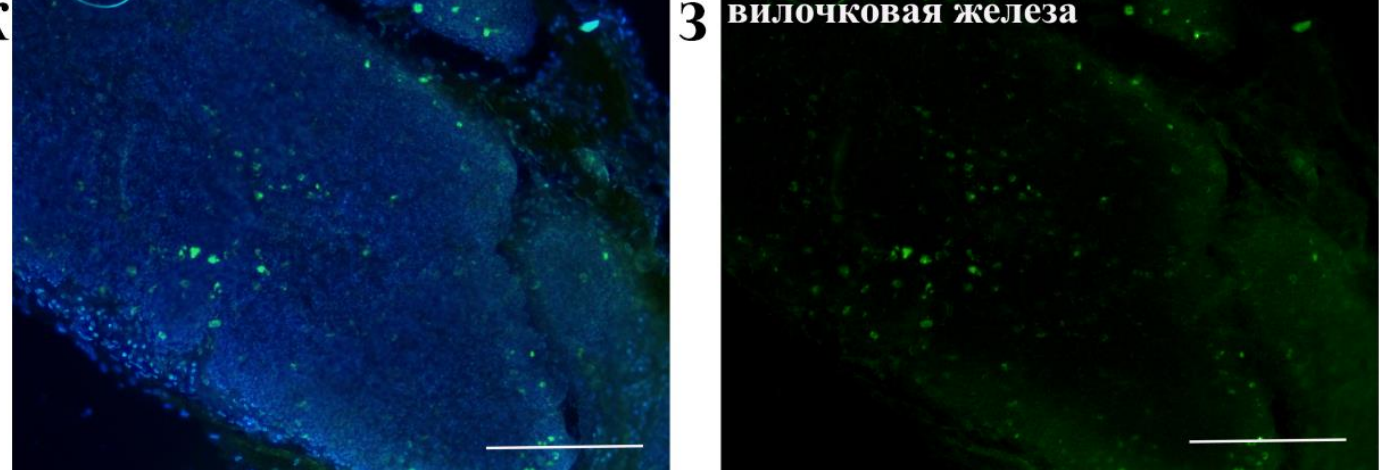

Puc. 29. Ткани паренхиматозных органов крыс контрольной группы

(без глиомы C6), получивших трансплантацию гаплоидентичных гемопоэтических (CD34+) стволовых клеток. Окраска CFDA SE, мультифотонная флуоресцентная лазерная микроскопия $(\lambda=488 \mathrm{~nm})$ : А, Б - легкие; В, Г - печень; Д, Е - почки, Ж, 3 - вилочковая железа; A, В, Д, Ж - ядра клеток докрашены DAPI. Масштаб 100 мкм 

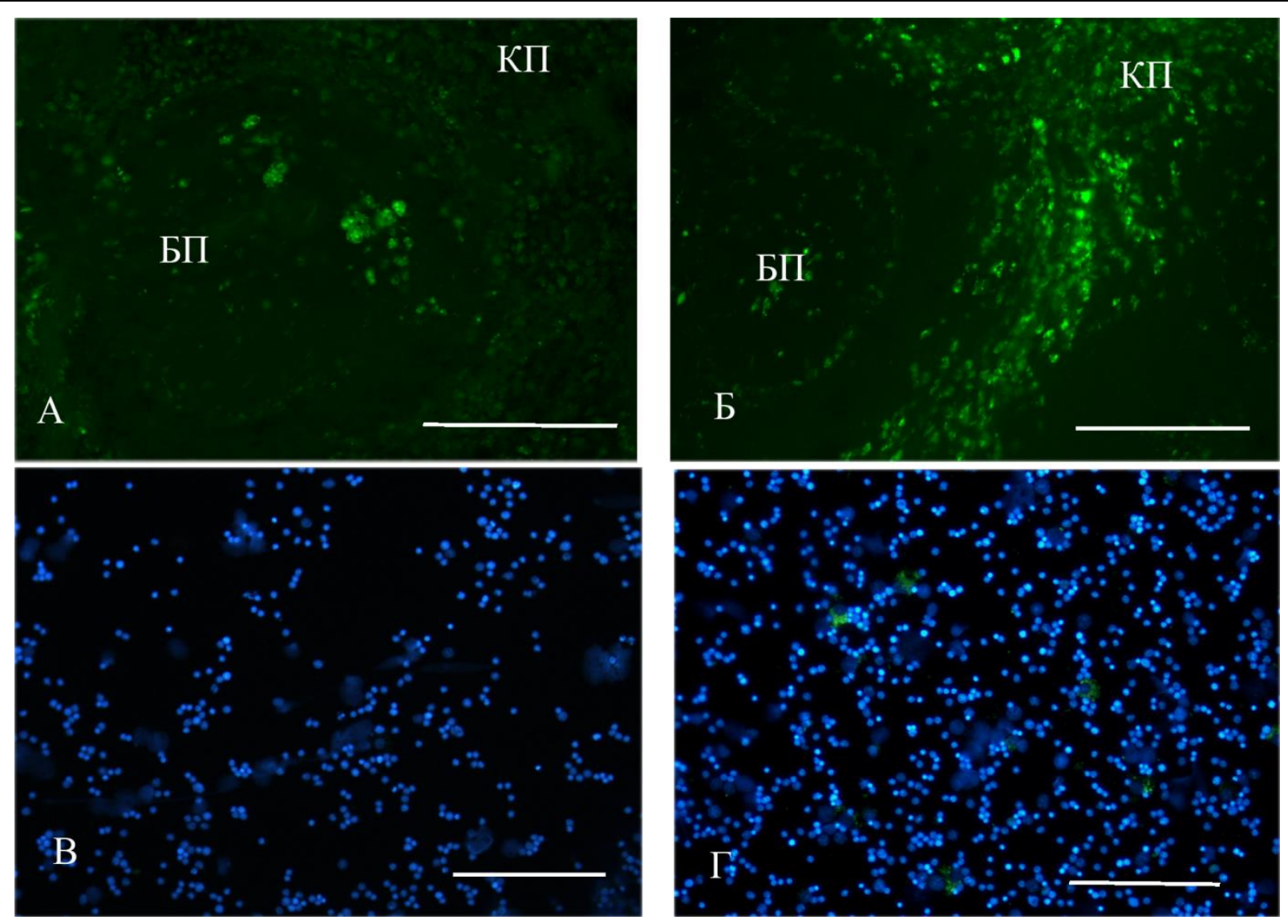

Puc. 30. Транзиторное повышение числа флуоресцирующих клеток в красной пульпе селезенки (Б) и в красном костном мозге (Г) на третьи сутки после введения ГСК, меченых CFDA SE: A - аутофлуоресценция в белой пульпе селезенки интактных животных; В - отсутствие специфического сигнала

в красном костном мозге интактных животных. Обозначения:

КП - красная пульпа, БП - белая пульпа. На рис. В и Г ядра докрашены DAPI. Масштаб 100 мкм

\section{3. Взаимодействие гемопоэтических стволовых клеток с клетками глиомы С6 в опухолевом очаге}

Целью данного этапа работ являлось изучение закономерностей и механизмов воздействия ГСК на течение опухолевого процесса в мозге in vivo. Поскольку в работах, описаных выше, была использована ксенотрансплантация клеток костного мозга человека в организм крыс с глиомой C6, получивших предварительную иммуносупрессивную терапию, для изучения закономерностей взаимодействаия ГСК с клетками глиобластомы in vivo мы отказались от этой модели.

Одним из ведущих способов получения клеток костного мозга для применения в онкологической практике является рекрутирование гемопоэтических стволовых клеток в системный кровоток путем стимуляции гра- 
нулоцитарным колониестимулирующим фактором (Г-КСФ) с последующим сбором лейкоконцентрата мононуклеарных CD45+ клеток, содержащих значительное колличество CD34+ ГСК. В этой связи план работ включал два принципиально значимых этапа: 1) иммобилизация аутологических ГСК в системный кровоток экспериментального животного с глиомой С6 и 2) характеристика иммуногистохимических трансформаций опухолевого узла в мозе крыс с рекрутированными в системный кровоток ГСК.

\subsection{1. Рекрутирование ГСК в системный кровоток экспериментального жсивотного с глиомой Сб}

Животным вводили подкожно Г-КСФ (Filgrastim, номер по каталогу YY0101173 Sigma-Aldrich, Сент-Луис, Миссури, США), 4 мг/день, в течение семи дней. Иммобилизацию мононуклеарных CD45+ клеток проверяли путем анализа крови экспериментальных животных с помощью проточного цитометра "Navios"тм (Beckman Coulter, США). В исследовании использовали антитела против крысиного CD45 (OX-1, конъюгированный с AРC/Су7, номер по каталогу 202216, Biolegend Inc., США). Данные цитофлуорометрии обрабатывали с помощью "Navios Software" v.1.2 и "Kaluza"тм v.1.2 (Beckman Coulter, США).

По данным проточной цитометрии, стимуляция животных Г-КСФ сопровождалась значительным увеличением числа CD45+ мононуклеарных клеток в периферической крови экспериментальных животных с глиомой С6 (рис. 31), при этом количество CD45+ клеток, экспрессирующих ГСК-ассоциированный мембранный антиген, возрастало до $30,0 \pm 1,3 \%$, что указывает на исключительно сильное иммобилизующее действие Г-КСФ. Важно, что мы не нашли коммерческие наборы для идентификации CD34+ клеток крысы, однако «боковая популяция» ГСКподобных клеток идентифицирована по методу "Telford" (2010).

\subsection{2. Характеристика иммуногистохимических трансформаций}

опухолевого узла в мозге крыс с рекрутированными

\section{в системный кровоток ГСК}

В данном фрагменте работы методами иммуногистохимиии выявлялись особенности распределения маркеров пролиферации, стволовости, астро- и микроглии, а также некоторых сигнальных молекул в мозге животных с привитой опухолью (контрольная группа) и после иммобизизации ГСК (группа «клетки»). 


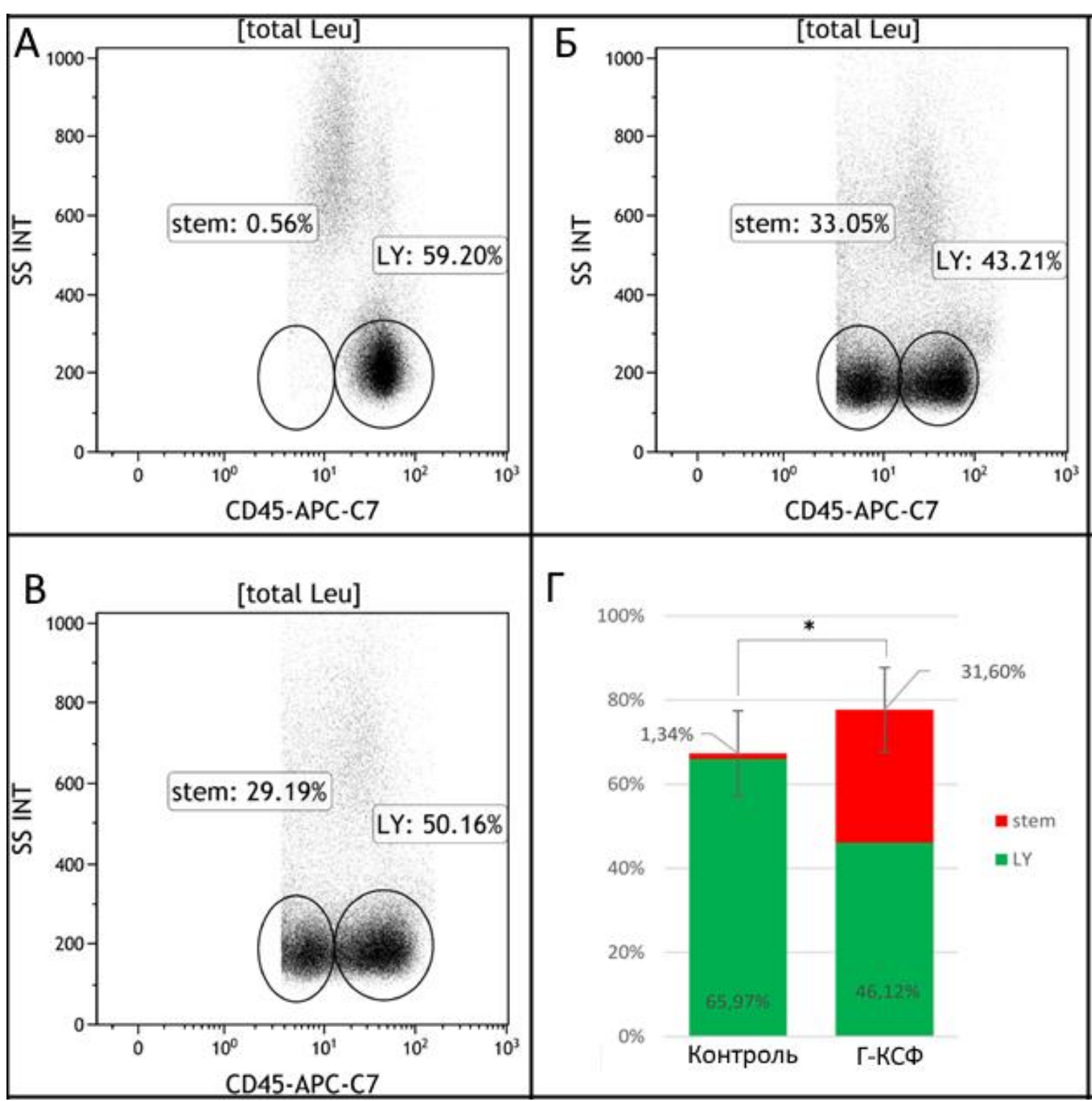

Puc. 31. Результаты цитометрического анализа образцов крови экспериментальных животных с глиомой С6, получивших стимуляцию Г-КСФ: A - доля CD45+ клеток в общем количестве лимфоцитов. При этом красным маркером выделено количество

ГСК подобные клетки в общем числе CD45+ мононуклеарных клеток; Б и В -

результаты цитометрического анализа популяции CD45+ клеток, «боковая популяция» ГСК-подобных клеток идентифицирована по методу "Telford" (2010)

\section{Контрольная группа}

Средняя продолжительность жизни контрольных животных составила $27,2 \pm 5,8$ дня. Средний объем опухолевого узла в головном мозге составил 202,1 \pm 19 мм³ $^{3}$. Для животных этой группы было характерно очень быстрое нарастание неврологических симптомов, снижение и полное исчезновение рефлексов на сгибание и переворачивание, появление одностороннего птоза на стороне опухоли с последующим присоединением признаков застоя на глазном дне, дискоординация между правыми и ле- 
выми лапами, возникновение манежных движений. По мере роста опухоли крысы становились вялыми, неохотно пили воду и отказывались от еды с последующим развитием комы и судорожных симптомов. При морфологическом исследовании тканей мозга выявлялась типичная морфологическая картина, детально описанная ранее.

При иммуногистохимическом окрашивании антителами к ядерному белку пролиферирующих клеток (PCNA) выявлялось резкое возрастание темпов пролиферации в ткани опухоли с 10 по 20 дни наблюдения, что, очевидно, связанно с интенсификацией процессов деления опухолевых клеток в связи с формированием неопластической кровеносной сети. Вне опухолевого очага максимальное количество РСNA-позитивных клеток было сосредоточено в прилегающих тканях, зонах лучеобразной инвазии клеток глиомы в ткань мозга и в кровеносных сосудах разного калибра (рис. 32-34).
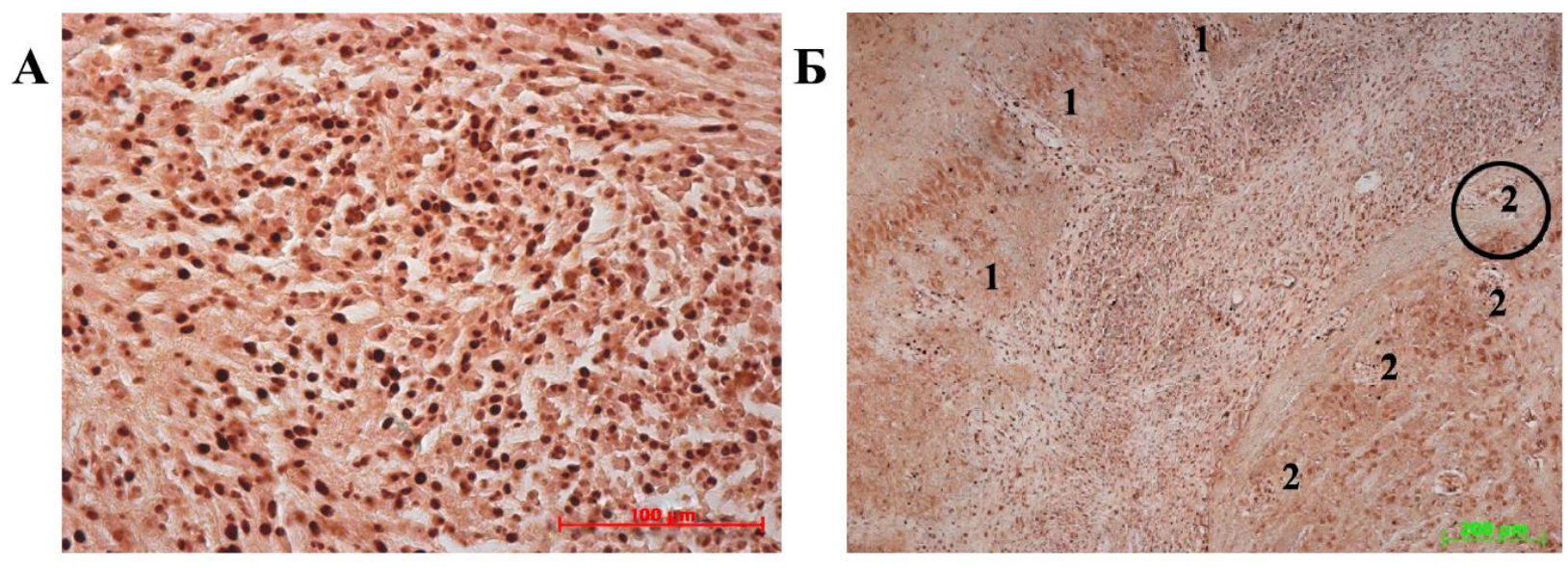

B
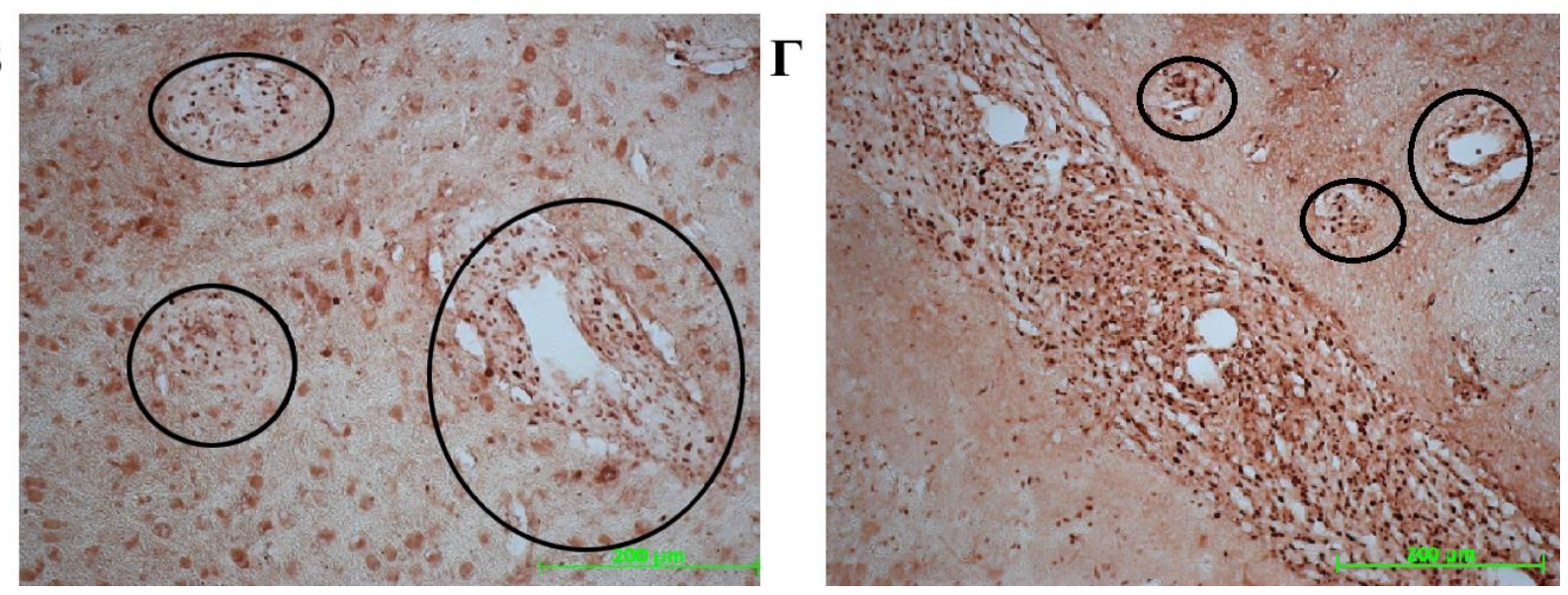

Puc. 32. Иммуногистохимическая реакция на антитела к PCNA. Опухолевый очаг, 20 суток с начала эксперимента: А - центр опухоли, видны скопления многочисленных

PCNA-позитивных элементов; Б - прилежащее у опухоли вещество мозга: 1 - зоны инвазии PCNA+ клеток в ткань мозга в сочетании с инфильтрацией ими окружающей ткани мозга (2); В и Г - скопление клеток PCNA+ в стенке и по периферии кровеносных сосудов (обведено эллипсом) 
С 20 по 30 дни исследования количество пролиферирующих клеток в опухолевой ткани уменьшалось. К этому времени в опухолевой ткани появлялись обширные зоны запустевания, некроза, а PCNAпозитивные клетки начинали уплотняться, обнаруживали отчетливую тенденцию к смещению к границам опухоли, где процессы пролиферации протекали особенно интенсивно и сочетались с активной миграцией иммунопозитивных клеток в прилегающие ткани мозга. Отдельные пролиферирующие клетки встречались в ткани мозга на значительном удалении от очага.
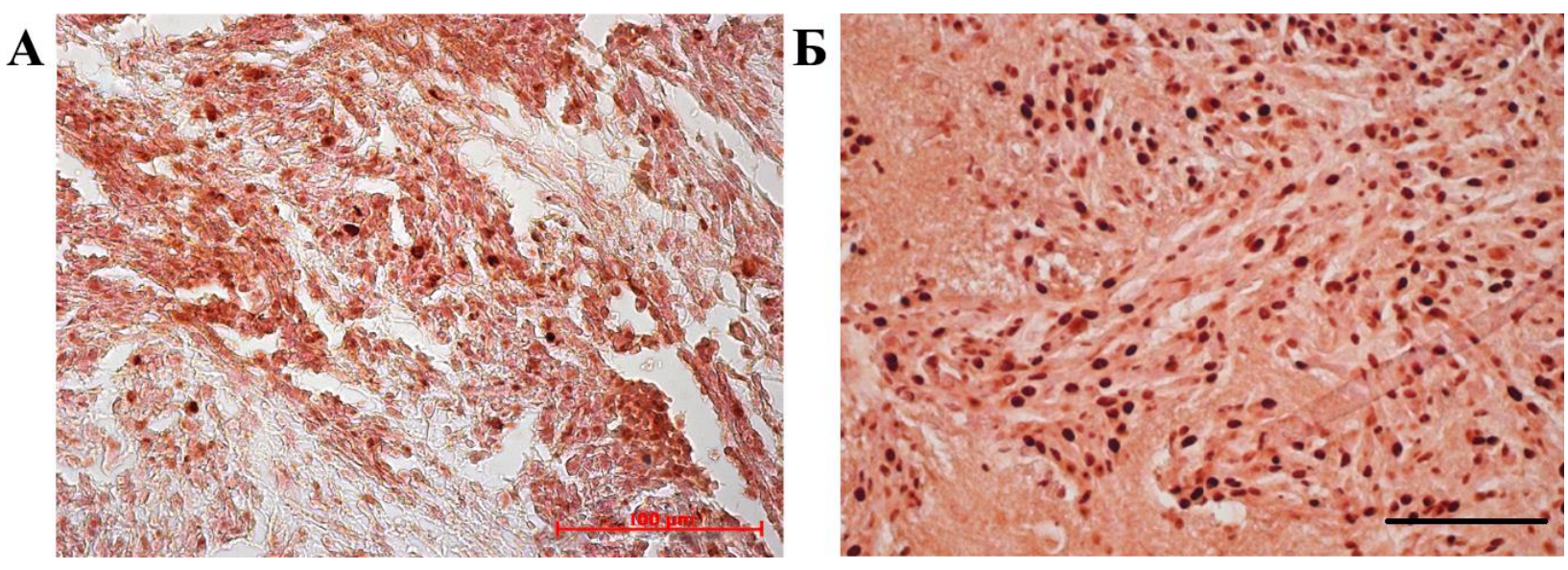

Puc. 33. Иммуногистохимическая реакция на антитела к PCNA через 30 суток развития опухоли: А - центральная часть опухолевого очага; Б - граница опухоли с интактной тканью мозга. Заметно увеличение количества PCNA- иммунореактивных клеток (ИР) в зонах инвазии опухоли. Масштаб 200 мкм

Динамика числа PCNA-позитивных клеток на различных сроках развития опухоли в контрольной группе представлена на рис. 34 .

Максимальное скопление микроглиальных клеток регистрировалось с 10 по 20 дни наблюдения непосредственно в опухолевой ткани и в прилегающих участках инвазии неопластических клеток в вещество мозга. Значительные скопления небольших, IBA1-позитивных клеток с телом вытянутой формы и короткими отростками были сосредоточены в паренхиме мозга на некотором расстоянии от опухоли в области гипертрофированных кровеносных сосудов. Очевидно, скопление микроглиальных клеток в неопластическом очаге с 10 по 20 день эксперимента вызвано их миграцией из кровеносных сосудов и окружающих тканей мозга. Число IBA1-позитивных клеток в паренхиме мозга на стороне расположения опухоли существенно превосходило их количество в тканях интактного полушария (рис. 35). 


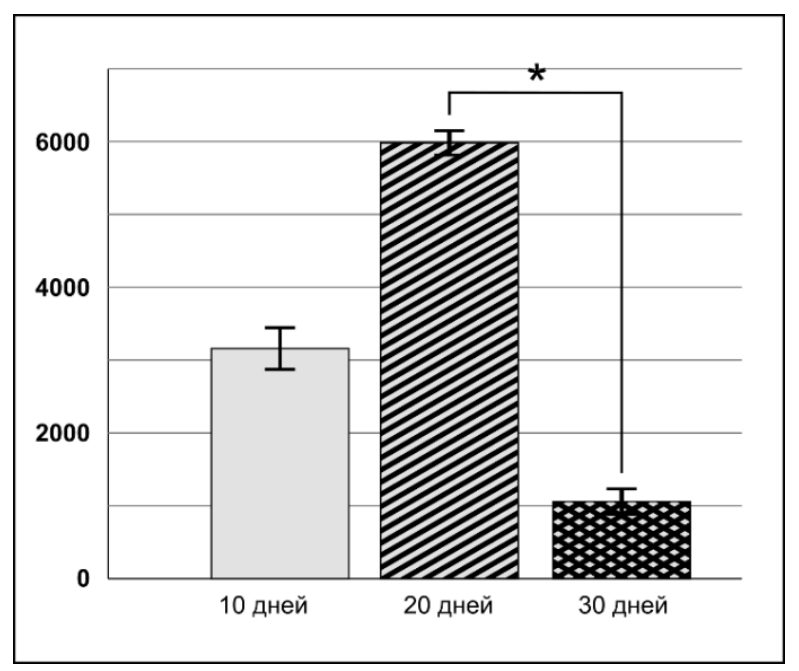

Рuc. 34. Динамика числа РCNA-ИР в ткани глиомы С6 у крыс контрольной группы. По оси ординат - количество ИР клеток в поле зрения микропрепаратов. Данные представлены в виде $\mathrm{M} \pm$ s.e.m, $\mathrm{N}=30$ для каждой группы; *указаны достоверные $(\mathrm{p}<0,05)$ отличия количества PCNA-ИР клеток между 20 и 30 сутками эксперимента

\section{A}
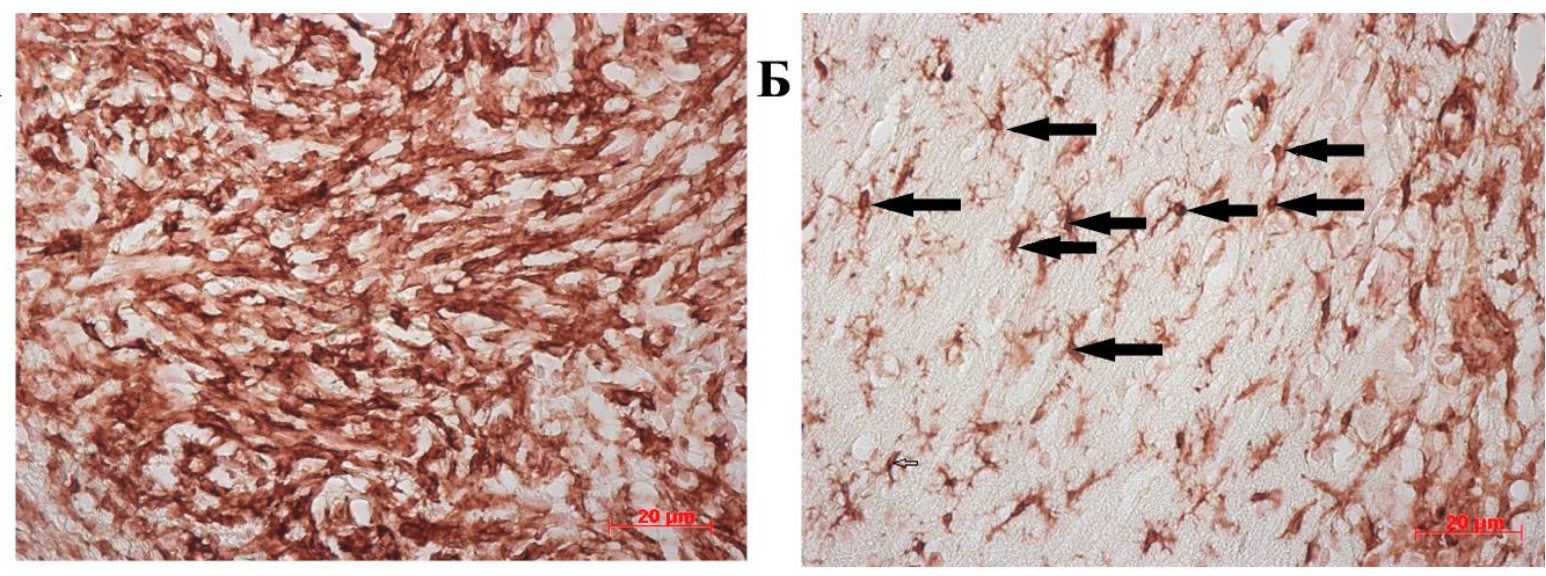

B

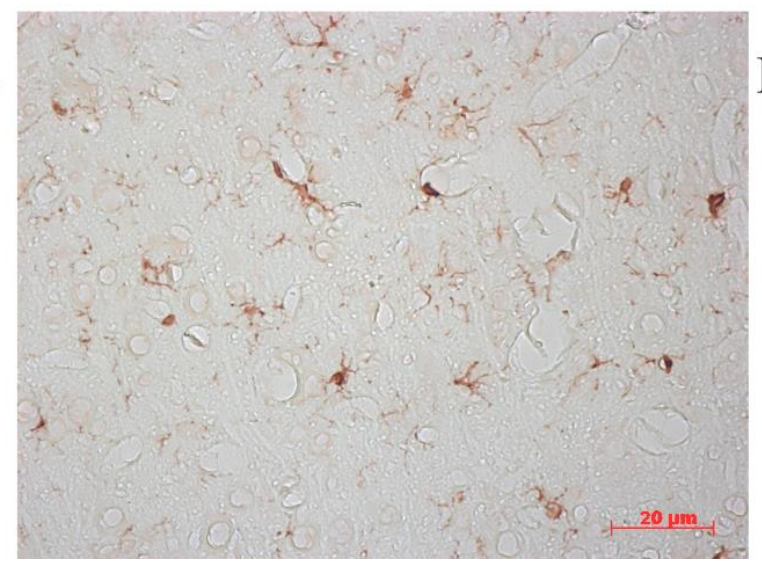

$\Gamma$

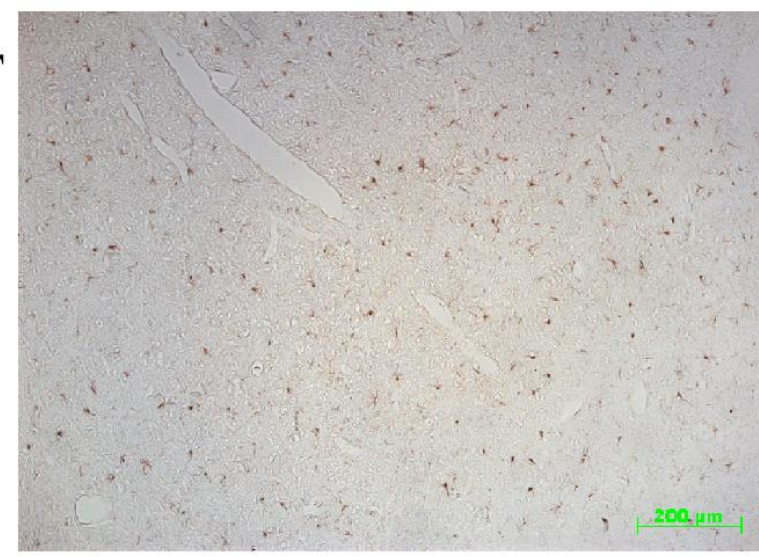

Puc. 35. Распределение микроглии в мозге животных контрольной группы на

15-20 сутки развития опухоли. Иммуногистохимическая реакция на антитела к специфическому белку микроглии/макрофагов (IBA1), 15-е сутки с момента начала эксперимента: А - центр; Б - ткань мозга, непосредственно прилегающая к опухоли. Видны клетки активированной микроглии с телами амебоидной формы и короткими отростками (указаны стрелками); В и Г - ткань противоположного опухоли головного мозга на 15-е (В) и 20-е (Г) сутки. Видны единичные IBA1 позитивные клетки

С 20-го по 30-й дни количество микроглиальных клеток в области опухолевого узла уменьшалось. В центре опухоли микроглиоциты уплотнялись, смещаясь к периферии, за счет чего зоны разрежения чередова- 
лись с участками скопления IBA1-позитивных клеток, как правило, окружающих кровеносные микрососуды. В участках перивазального скопления микроглиоциты округлой и амебоидной формы формировали плотные ряды, окружающие зоны некроза. Значительное количество микроглиоцитов было локализовано вдоль границ опухолевого очага (рис. 36, А-B).
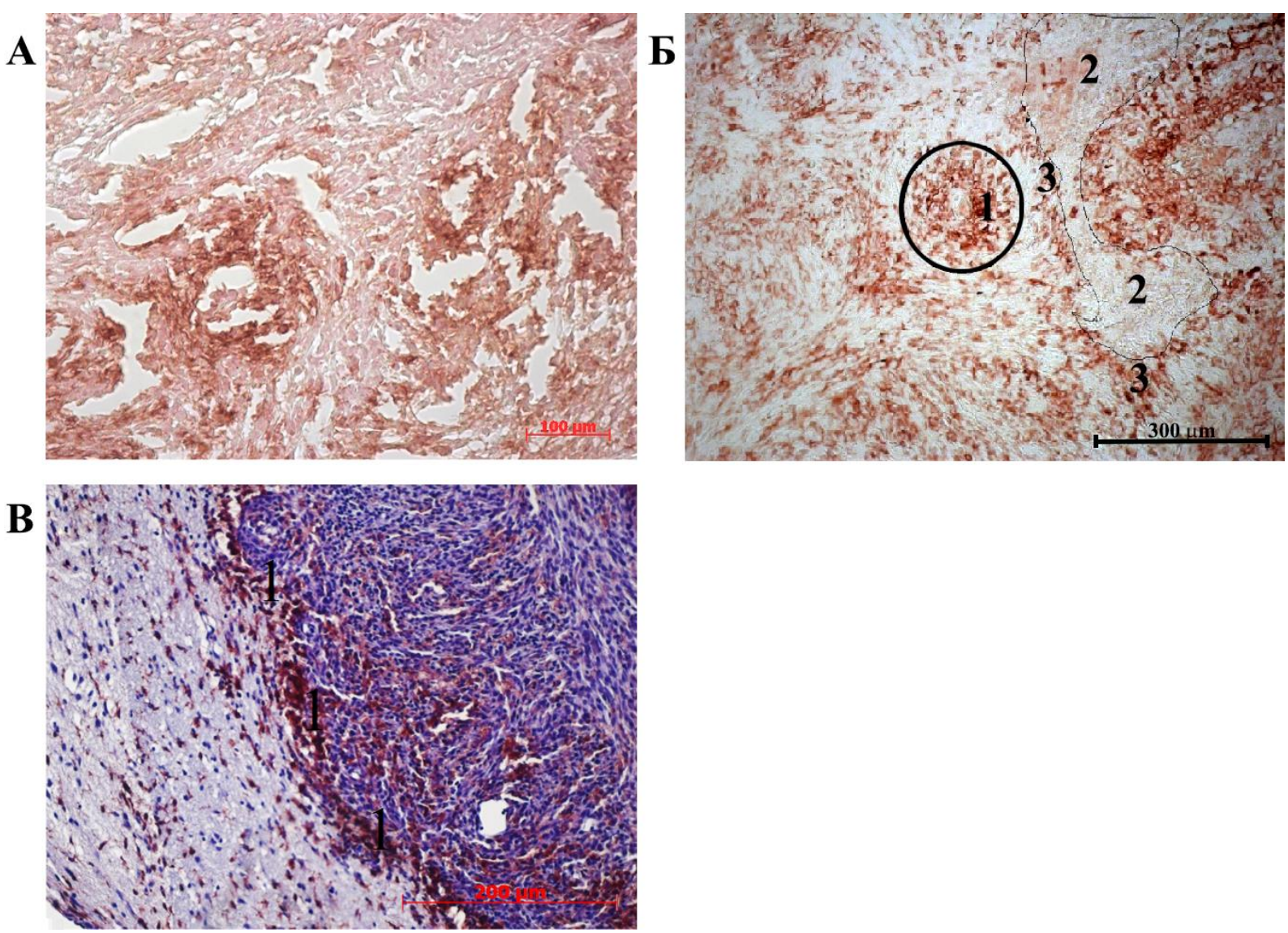

Рис. 36. Распределение IBA1-ИР клеток в мозге животных контрольной группы на 25-30 сутки развития опухоли: А - неоднородное распределение IBA1-ИР микроглиоцитов в очагах некроза и участках активного роста опухоли; Б - концентрация IBA1-ИР вокруг кровеносного сосуда (обведены в круг) и зоны запустевания (обведены маркерным карандашом), окруженные псевдодалисадными структурами (3); В - граница неопластического очага в мозге крыс контрольной группы. IBA1-ИР клетки образуют плотную кайму (1) на границе неопластического очага 30-й день эксперимента. Дополнительная окраска гематоксилином-эозином

При этом значительно возрастало количество клеток микроглии за пределами опухолевого очага и локализующихся в противоположной гемисфере, что, очевидно, связанно с миграцией этих клеток в опухолевый очаг.

К 30-м суткам микроглиальные клетки практически не обнаруживались в ткани опухолевого узла и были сосредоточены в виде плотной каймы на границе опухоли с тканью мозга. Следуя за клетками глиомы, инфиль- 
трирующими ткань мозга, основная масса микроглии локализовалась в дистрофически измененной паренхиме, окружающей опухолевый очаг. Очевидно, подобная картина обусловлена сложными, специфическими взаимоотношениями микроглии с опухолевыми клетками, в том числе с ОСК, что связанно с секрецией опухолевыми клетками и микроглией цитокинов, поскольку секреторная функция микроглии в данном случае имеет решающее значение. Динамика числа IBA1-позитивных клеток на различных сроках развития опухоли в контрольной группе представлена на рис. 37.

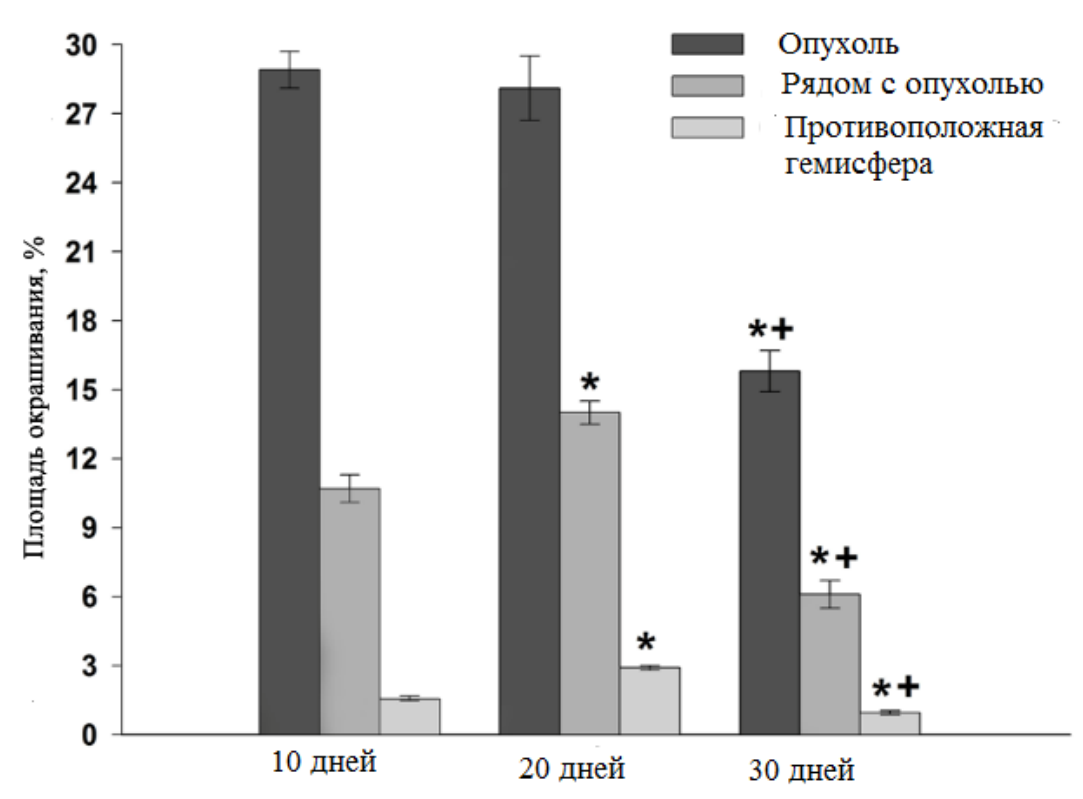

Puc. 37. Динамика числа IBA1-иммунореактивных (ИР) клеток в ткани глиомы С6 у крыс контрольной группы в ходе эксперимента. По оси ординат указано количество ИР клеток в поле зрения. Данные представлены в виде $\mathrm{M} \pm$ s.e.m, $\mathrm{N}=30$ для каждой группы; * указаны достоверные (p < 0,05) отличия количества IBA1 ИР клеток рядом с опухолью и в тканях противоположной гемисферы, знаком «*+» — различие в количестве IBA1-ИР клеток по всем точкам эксперимента между 20 и 30-ми сутками

На 20-е сутки эксперимента у крыс контрольной группы GFAPпозитивные звездчатые клетки концентрировались вокруг опухолевого очага, образуя контур в конгруэнтный зоне опухолевой инвазии (рис. 38, А), и практически не обнаруживались в неопластической ткани (рис. 38, Б). Подобная морфологическая картина сохранялась к 30-м суткам, однако группировка GFAP-позитивных астроцитов становилась более плотной и компактной (Рис. 38, B, Г). GFAР-ИР клетки окружали зону инвазии и отсутствовали в опухолевой ткани. При более предметном морфологическом ис- 
следовании тканей мозга крыс контрольной групп GFAP-ИР клетки с телом звездчатой формы с активно ветвящимися отростками образовывали скопления вдоль опухолевого очага и, очевидно, контактировали друг с другом (рис. 38, Д, Е), формируя барьер, противодействущий инвазивному процессу. При этом в ткани мозга противоположного полушария были обнаружены только единичные GFAP-позитивные клетки. При анализе рис. 36 и 38 становится очевидно, что двигаясь навстречу друг другу микро- и макроглия стремятся отграничить зону инвазии с двух сторон, что проявляется не только в виде локальных перестроек непосредственно на границе опухоли, но и в ткани мозга в целом.

На 30-е сутки после формирования опухоли участки перифокальной инвазии, содержащие максимальное скопление клеток микро- и макроглии (о чем будет сказано ниже), активно окрашивались антителами к нестину, CXCR4 и TGF- $\beta 1$ (Рис. 39). Нестин принято считать одним из ключевых маркеров нейральных стволовых и прогениторных клеток. Как было указано выше, абсолютное большинство клеток глиобластомы, использованных в эксперименте, окрашивалось антителами к этому белку, что служит признаком низкой степени дифференцировки и высокой агрессивности опухолевых клеток.

Ряд авторов относит нестин к одному из маркеров ОСК злокачественных глиом. Скопление нестин-позитивных клеток в области инвазивного роста свидетельствует об их прямом участии в этом процессе. Заслуживает внимание скопление в данном участке клеток, позитивных в отношении CXCR4 антигена. Этот цитоплазматический маркер локализован на поверхности стволовых клеток всех типов и играет ведущую роль в механизмах их миграции в опухолевый очаг. Присутствие маркера CXCR4 может означать наличие в области инвазивного роста нейральных стволовых клеток, мигрировавших из герминативных зон мозга.

Вместе с тем данный маркер локализован и на поверхности раковых или опухолевых стволовых клеток глиобластомы, что может свидетельствовать как об их прямом участии в механизмах инвазии при взаимодействии с микроглией, так и о взаимодействии с мигрировавшими сюда стволовыми клетками других типов, несущих на поверхности рецептор CXCR4. Кроме того, CXCR4 является компонентом клеточной мембраны микроглиальных клеток, привлекаемых опухолью. Вероятно, микросреда, создаваемая ОСК, селективно активирует мик- 
роглию М2 фенотипа, которая содействует процессам опухолевого роста и инвазии.

A

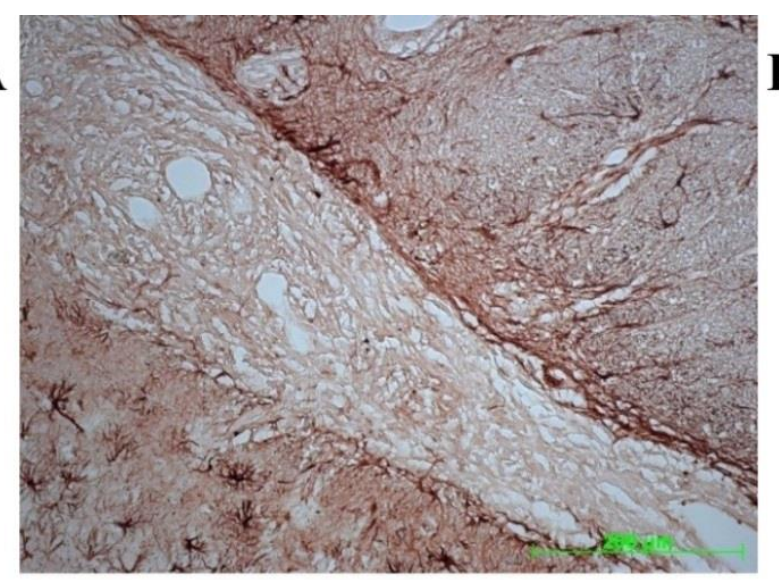

B

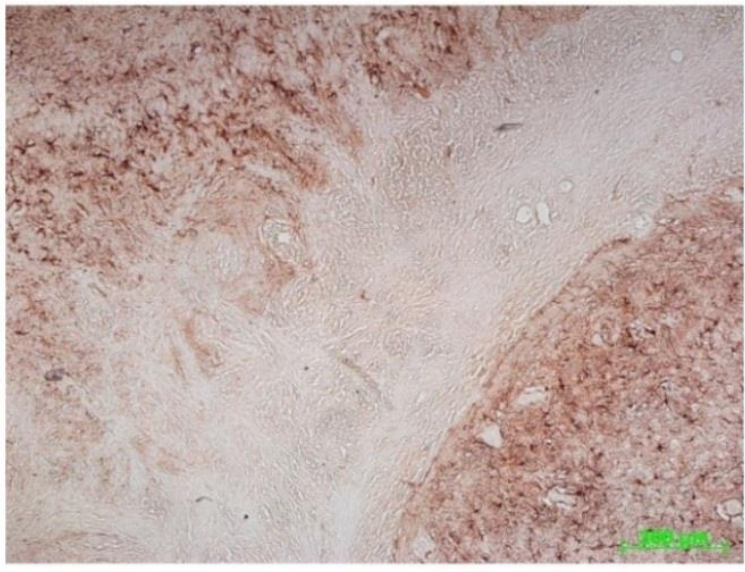

Д

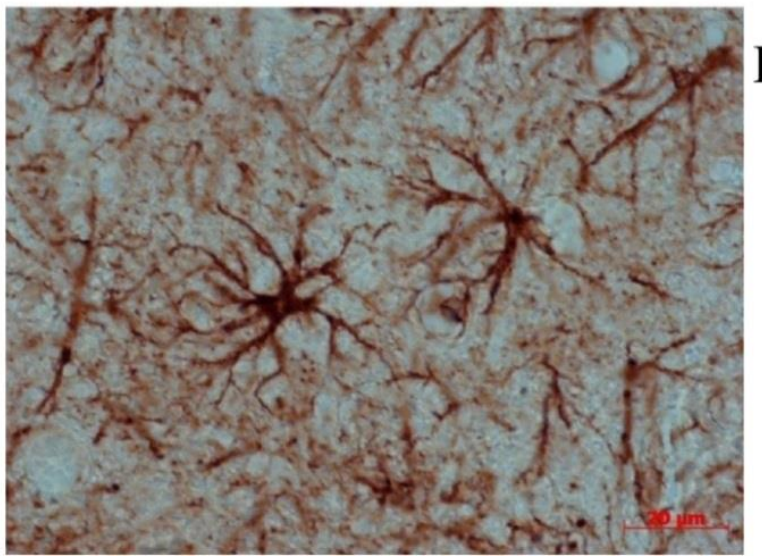

Б

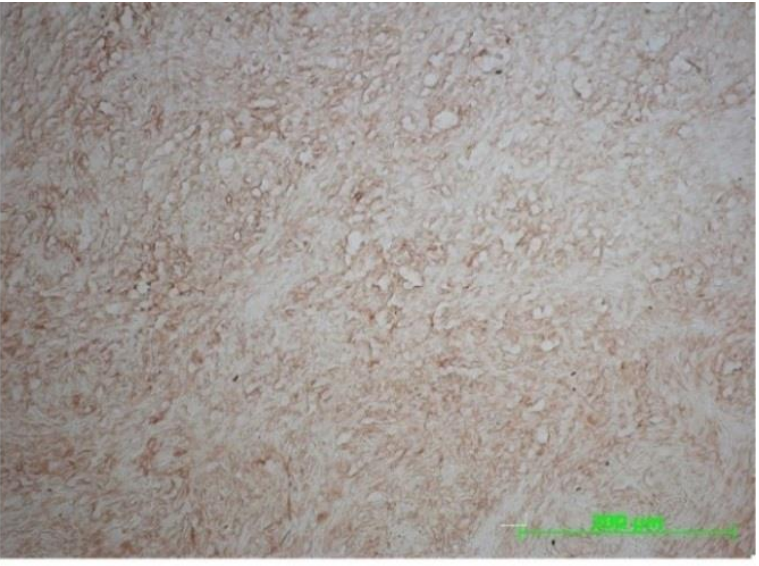

$\Gamma$

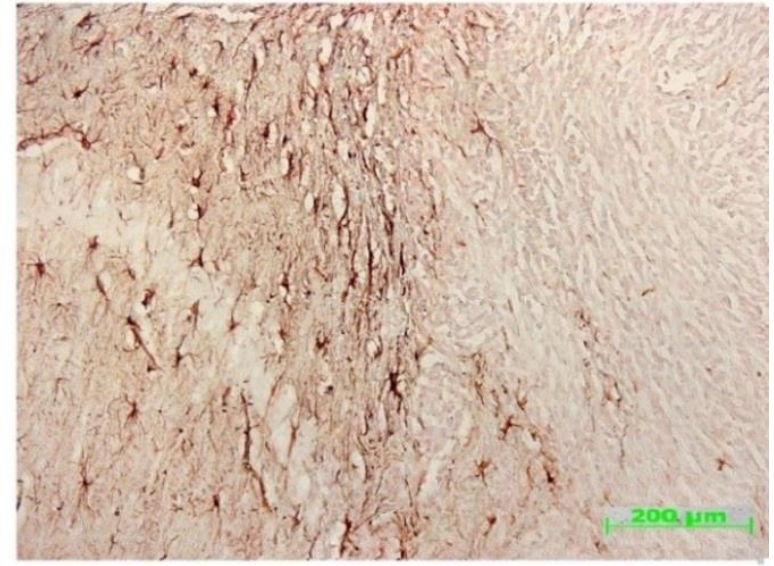

$\mathbf{E}$

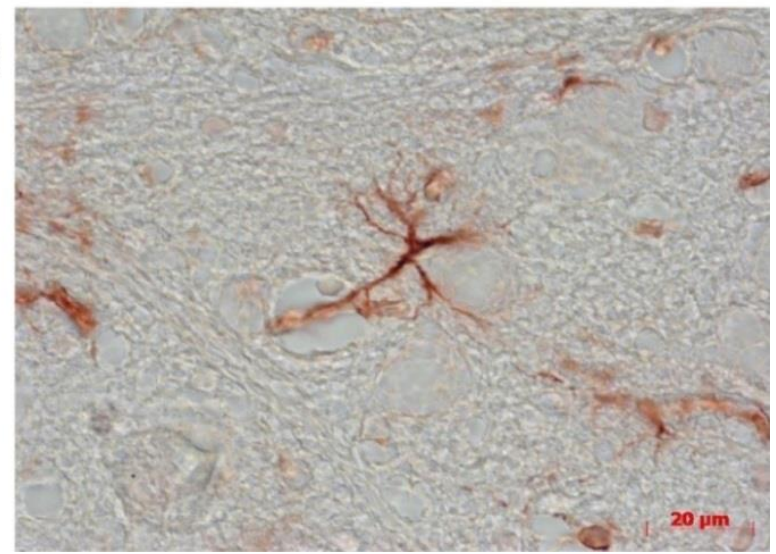

Puc. 38. Иммуноцитохимическая реакция на антитела к GFAP

у крыс контрольной группы: A - край опухоли в мозге контрольных крыс на 20-е сутки; Б - ткань опухоли в мозге контрольных животных, 20-е сутки; В - опухоль в мозге крыс контрольной группы, 30-е сутки; Г - край опухолевого очага в мозге крыс группы контрольной группы на 30-е сутки; Д - скопление GFAPИР клеток рядом с опухолью, 30-е сутки; Е - единичные GFAP-ИР клетки у контрольных крыс в ткани мозга противоположного полушария 

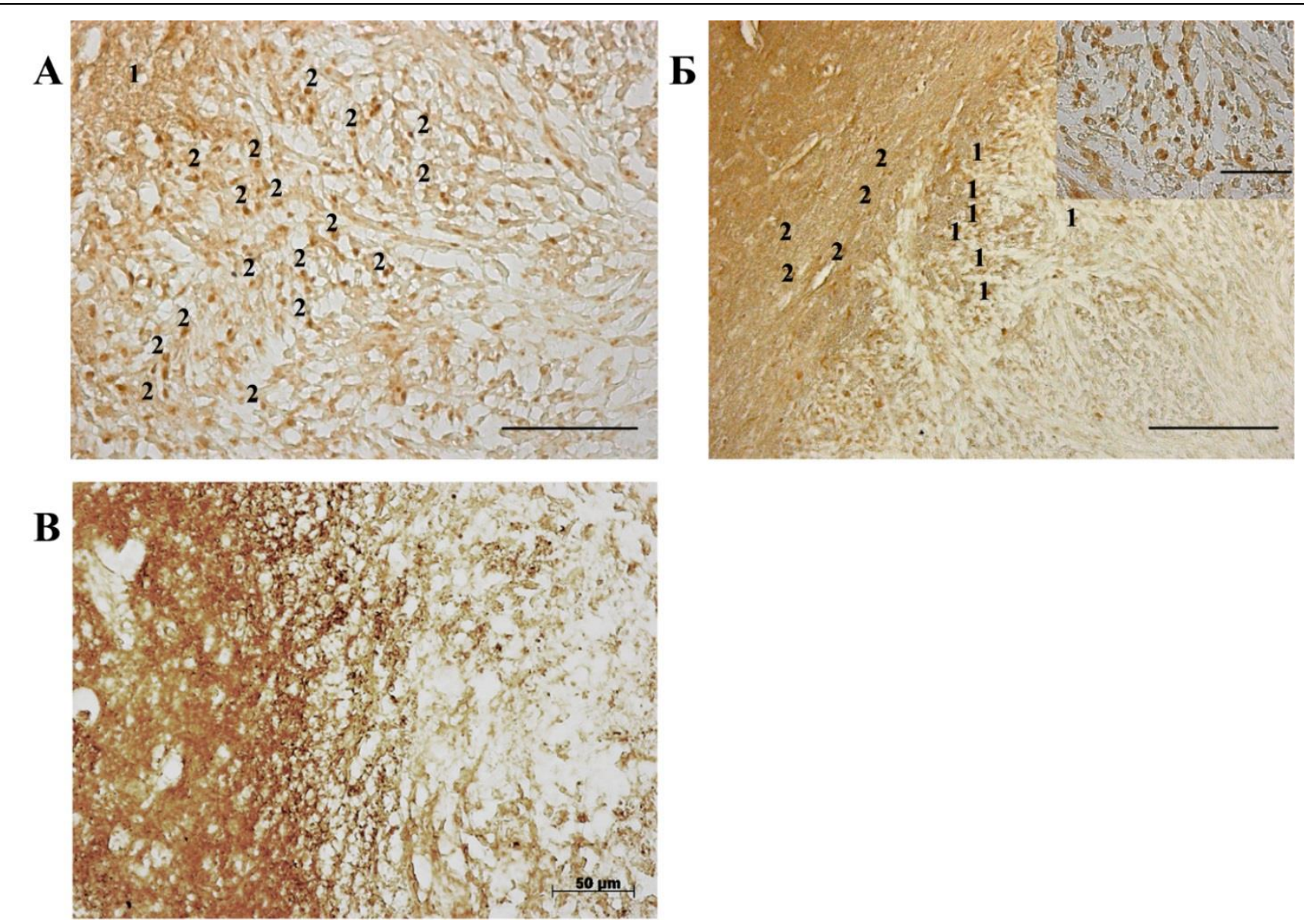

Puc. 39. Край опухоли в мозге крыс контрольной группы, 30-е сутки эксперимента: A - иммуноцитохимическая реакция на антитела к белку стволовых клеток - нестину. Нестин-позитивные клетки локализуются как на краю очага глиомы (1), так в области инвазии (2) неопластических элементов в вещество мозга. Масштаб 200 мкм. Б - иммуноцитохимическая реакция на рецепторный белок CXCR4. Клетки, несущие этот рецептор, а следовательно, мигрировавшие, локализуются как в области инвазии

(1 - показаны на вставке), так на периферии неопластической ткани (2). Масштаб

100 мкм, вставка 200 мкм. В - иммуноцитохимическая реакция на TGF- $\beta 1$.

Скопление белка выявлено вдоль границы зоны инвазии

Особого внимания заслуживает скопление в данной области клеток, секретирующих TGF- $\beta 1$ - лиганд, который запускает процесс эпителиально-мезенхимального перехода в опухолевых клетках и способствует обретению ими локомоторного фенотипа. Опубликованы данные о том, что TGF- $\beta$ может вызывать метастазы и прогрессию опухолевого процесса по аутокринному механизму. TGF- $\beta$ интенсифицирует пролиферацию клеток МГБ и усиливает процессы инвазии. Описана способность этого лиганда активизировать такие каскады, как Notch и Sonic Hedgehog в раковых клетках, кроме того, сигнальный домен TGF- $\beta$ идентифицирован на поверхности ОСК глиобластомы и гемопоэтических стволовых клеток. 
Анализируя данные локализации ряда маркеров в опухоли животных контрольной группы, необходимо отметить, что высокая скорость пролиферации клеток МГБ является главной составляющей неопластического процесса. К 20-му дню эксперимента скорость пролиферации клеток опухоли начинает опережать темпы ангиогенеза, что формирует гипоксическую микросреду. Роль гипоксии весьма многогранна. Гипоксия является главным фактором экспрессии генов, ответственных за биосинтез цитокинов, инициирующих процессы миграции в опухоль соматических и стволовых клеток. Главная роль в этом процессе принадлежит хемокину семейства CXC - фактору стромальных клеток (SDF-1 $\alpha$ ). Лиганд выделяется в ответ на гипоксическое повреждение тканей и активно привлекает в зону неоплазии стволовые клетки. В литературе описаны сложные секреторные ансамбли, образуемые ОСК со стволовыми и дифференцированными клетками других типов (Lourenco et al., 2015).

Например, клетки МГБ продуцируют колониестимулирующий фактор. Допустимо предположить (Revoltella et al., 2012), что синтез этого лиганда является ответом на суровые условия гипоксии, формируемые благодаря высокой скорости пролиферации клеток злокачественной глиомы. Гранулоцитарный колониестимулирующий фактор мобилизует стволовые клетки из депо в костном мозге, мигрирующие в опухолевый очаг, что позволяет глиоме их рекрутировать, вовлекая в секреторные ансамбли, модерируемые ОСК, индуцировать синтез трансформирующего фактора роста $\beta 1$, роль которого представляется весьма неоднозначной.

Таким образом, клетки глиомы С6 при имплантации в мозг быстро запускают пролиферативные процессы и формируют гипоксическую микросреду, индуцируют процессы направленной миграции различных типов соматических и стволовых клеток. Значительную часть привлекаемых опухолью клеток составляют микроглиоциты. Локальное скопление клеток, имеющих иммунофенотипические признаки ОСК на границах опухоли, сопровождается повышенной продукцией в этих областях TGF- $\beta 1$.

\section{Группа «клетки»}

Средняя продолжительность жизни крыс группы «клетки» составила $41 \pm 6,8$ дня, что больше подобного показателя в контрольной группе. Средний объем опухолевого узла в мозге этих животных $-197 \pm 14,2$ мм³ $^{3}$. В отличие от контрольной группы темп нарастания неврологических 
симптомов был медленным, крысы длительно сохраняли активность. На 20-е сутки отмечено появление птоза на стороне опухоли, снижение рефлексов на сгибание и переворачивание, дискоординация между передними и задними конечностями. К 30-40-м суткам эксперимента крысы становились вялыми и заторможенными, реагировали на прикосновение к вибрисам пронзительным визгом, при выкладывании на спину не могли перевернуться. По мере нарастания симптоматики до комы животные выводились из эксперимента.

На 10-й день наблюдения морфологическая картина не обнаруживала существенных отличий от контрольной группы. Однако к 30-м суткам признаки некроза в центре опухолевого узла в группе «клетки» были выражены в существенно меньшей степени (рис. 40).
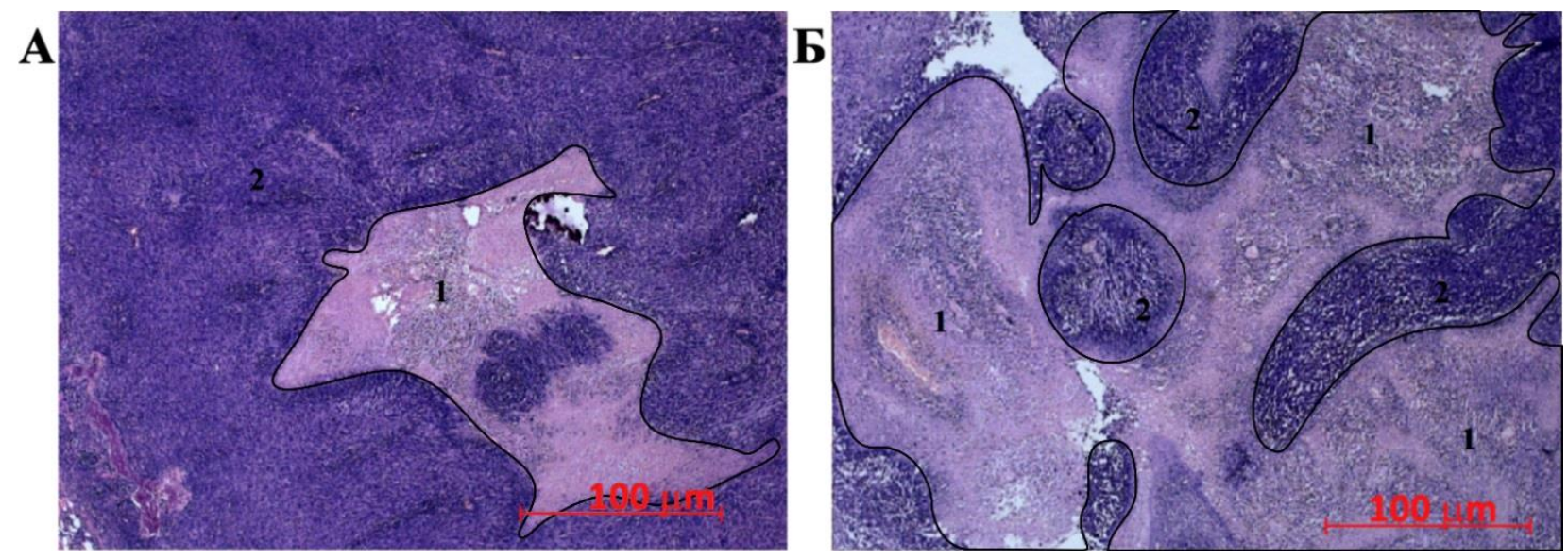

Puc. 40. Неопластическая ткань в мозге крыс сравниваемых групп, 30-е сутки эксперимента: А - группа «клетки»: 1 - область некроза (выделена маркером);

2 - активно растущая опухолевая ткань; Б - опухолевая ткань в мозге крыс контрольной группы: 1 - обширные зоны некроза (выделены маркером); 2 - фрагменты сохранной опухолевой ткань. Окраска гематоксилин-эозином

Данные сравнительной оценки площади некрозов в неопластической ткани крыс контрольной группы и группы «клетки» представлены на рис. 41.

Помимо этого опухолевая ткань из мозга крыс группы «клетки» содержала многочисленные инфильтраты в виде клеток округлой или овальной формы с эксцентрично расположенным несегментированным ядром. Локализация этих инфильтратов частично соответствовала зонам некроза опухолевой ткани, при этом они практически отсутствовали в участках инвазии неопластических клеток в паренхиму мозга (рис. 42). Нельзя исключить, что в составе данных образований присутствуют транспланти- 
рованные ГСК, которые мигрировали в опухолевую ткань и накапливались в участках максимальной гипоксии.

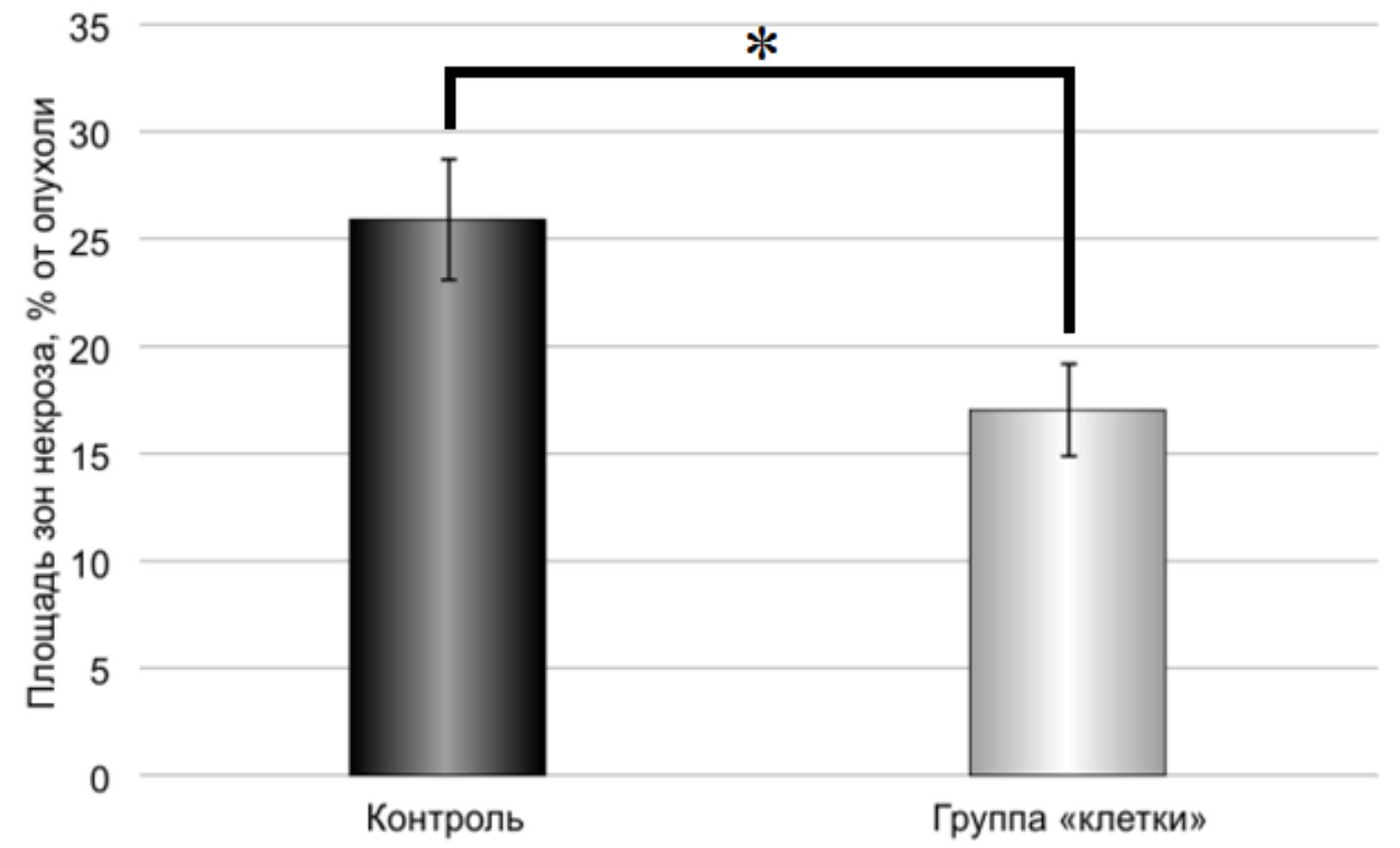

Puc. 41. Суммарная площадь некрозов в опухолевой ткани из головного мозга животных сравниваемых групп. По оси абсцисс указана площадь зон некроза в \% от суммарной площади микропрепаратов $\mathrm{M} \pm$ s.e.m, $\mathrm{N}=30$ для каждой группы. Значком * показаны достоверные отличия ( $<$ < 0,05$)$ группы «клетки» от контрольной

Сравнение результатов иммуногистохимической реакции на антитела к PCNA свидетельствовало о некотором усилении процессов пролиферации в области опухолевого узла к 30-му дню эксперимента по сравнению с контрольной группой (рис. 43, А, Б), что, вероятно, было связанно с трансформацией мигрировавших сюда ГСК. Подобная динамика сохранялась в группе клетки между 30-35-ми сутками эксперимента (рис. 43, В).

На рис. 44 представлены сравнительные данные о количестве PCNAИР клеток у животных контрольной группы и группы, получившей трансплантацию ГСК.

Важно отметить, что усиление пролиферации наблюлась именно в опухоли, вне очага глиомы встречаются только единичные PCNA-ИР клетки, сосредоточенные в кровеносных сосудах или участках мозга, подвергшихся инфильтрации опухолевыми клетками. В противоположном опухоли полушарии мозга крыс контрольной группы такие клетки прак- 
тически отсутствовали. В свою очередь, у крыс, получивших трансплантацию ГСК в ткани мозга на противоположные полушария, было отмечено транзиторное увеличение PCNA-ИР элементов.

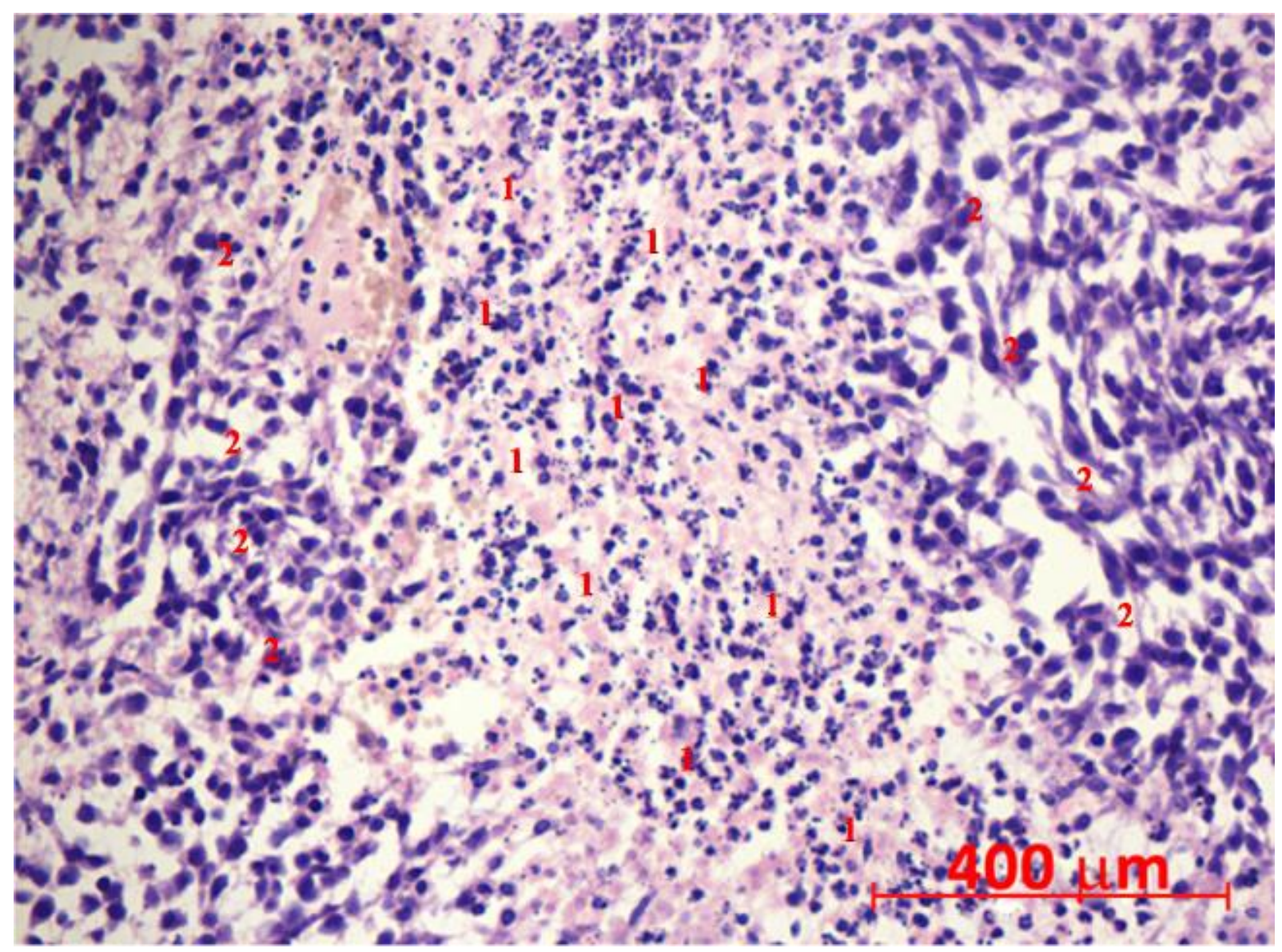

Puc. 42. Инфильтраты в зонах разряжения и некроза опухолевой ткани у крыс

группы «клетки». Размер инфильтрирующих клеткой (1) существенно меньше клеток (2) опухоли. Окраска гематоксилин-эозином

Вероятно, увеличение числа PCNA-позитивных клеток в очаге обусловлено пролиферацией мигрирующих в опухоль ГСК. В пользу данного утверждения свидетельствует резкое увеличение (на) 30 -е сутки наблюдения в опухолевой ткани крыс группы «клетки» количества микроглиоцитов (рис. 45).

Скопления IBA1-позитивных клеток выявлялись в дистрофически измененных участках мозга, непосредственно прилегающих к опухоли и максимально подверженных инвазии и при этом практически отсутствовали в кровеносных сосудах. Количество IBA1-ИР микроглиальных клеток в паренхиме мозга на противоположном полушарии головного мозга у крыс группы «клетки» не имело достоверных различий по сравнению с контрольной (рис. 46). 

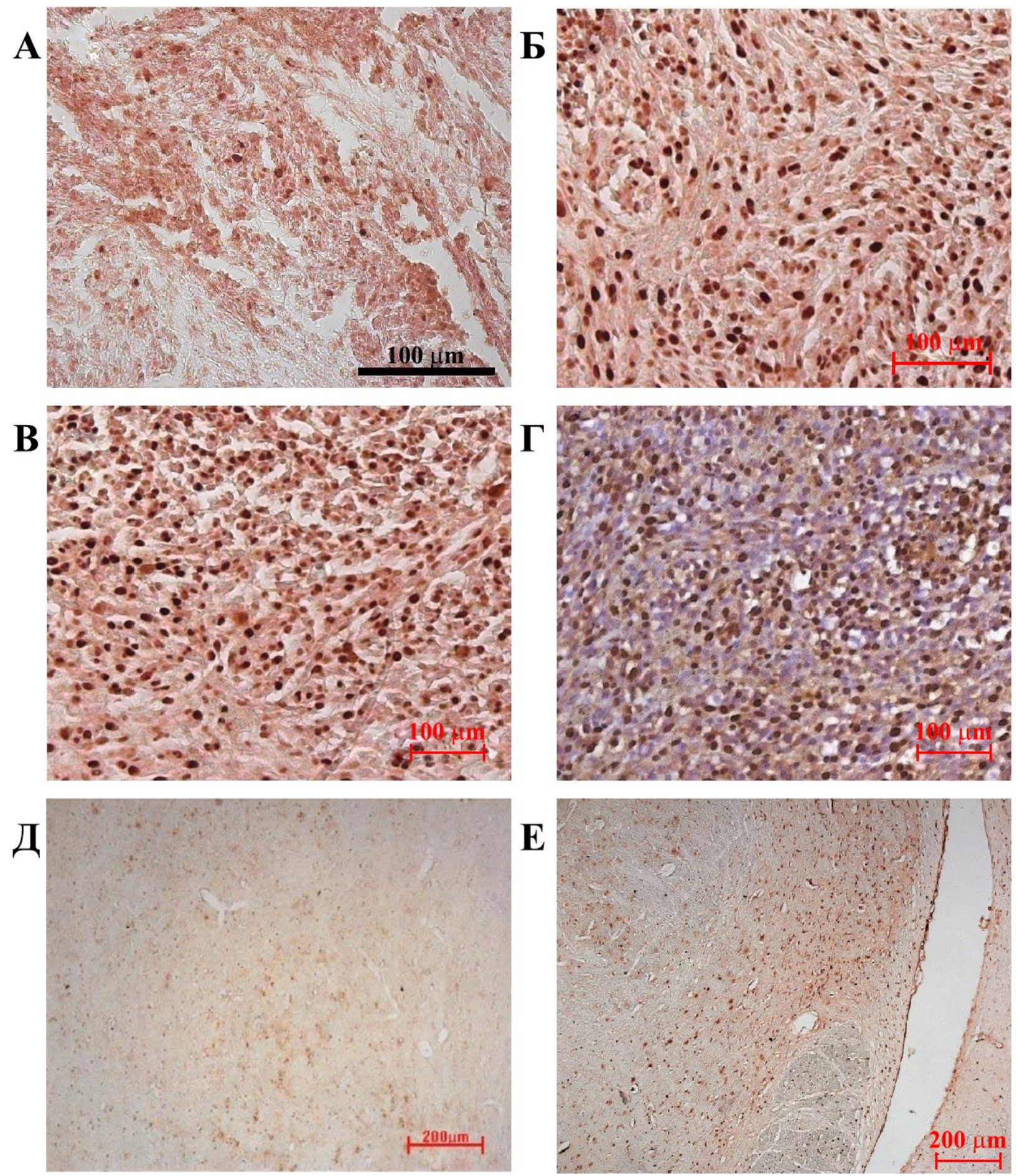

E

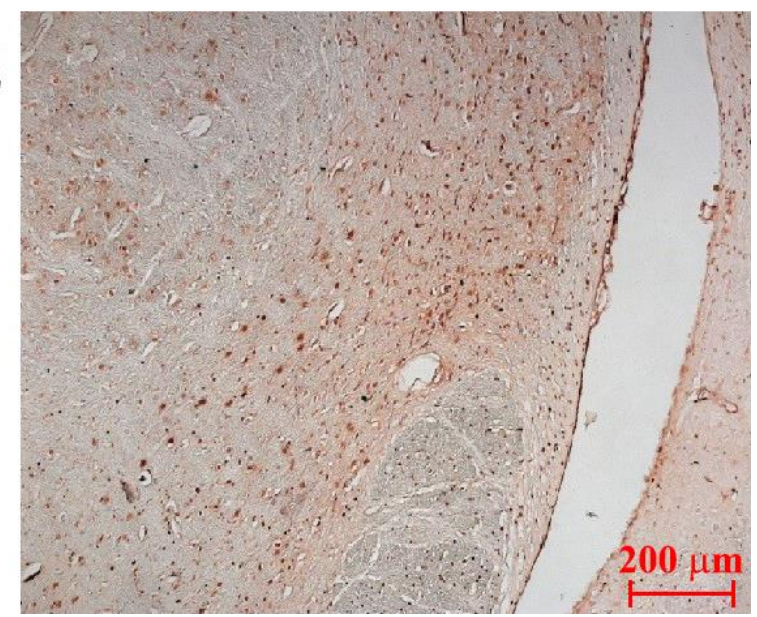

Puc. 43. Неопластическая ткань в мозге экспериментальных животных. Иммуногистохимических реакция на PCNA: A - контрольная группа, 30-е сутки; Б - группа «клетки», 25-е сутки; В - группа «клетки», 30-е сутки. Масштаб 100 мкм; Г - группа «клетки», 30-е сутки, дополнительная окраска гематоксилин-эозином; Д - противоположная сторона полушария контрольных животных; $\mathrm{E}$ - противоположная сторона полушария группы «клетки» 


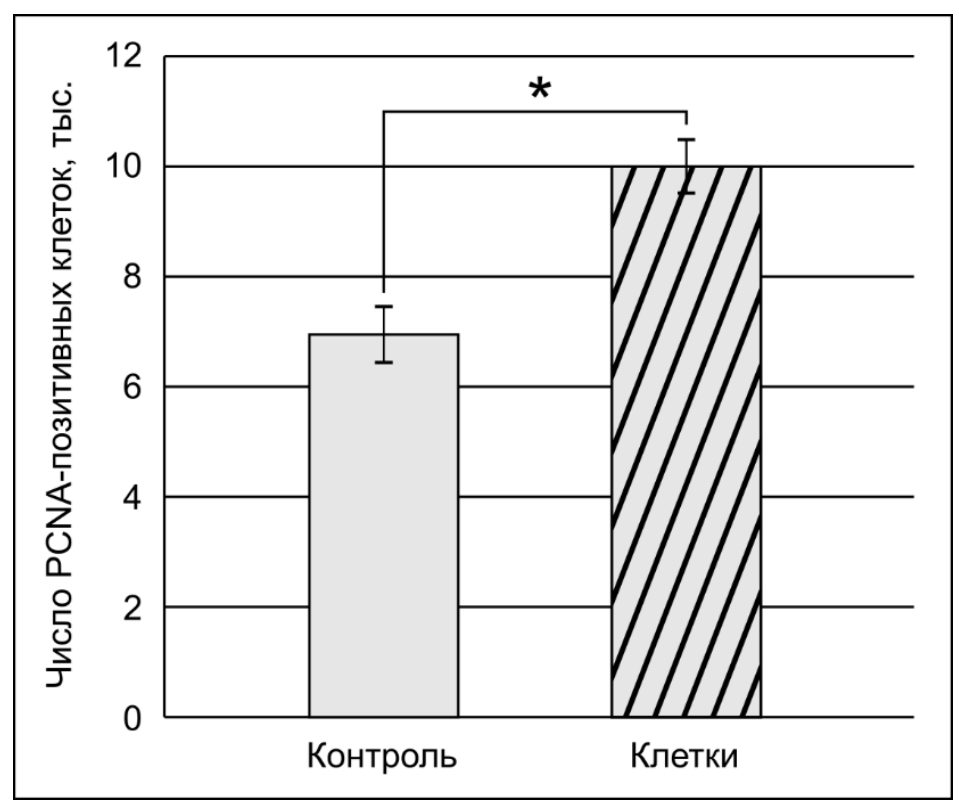

Рис. 44. Соотношение числа PCNA-ИР клеток в опухолевой ткани глиомы С6 в мозге крыс при введении ГСК. По оси ординат количество (тыс.) ИР клеток на микропрепаратах для каждой точки. Указаны $\mathrm{M} \pm$ s.e.m, $\mathrm{N}=30$ для каждой группы; * - достоверные $(\mathrm{p}<0,05)$ в количестве PCNA-ИР между группами

Микроглия/макрофаги в этой связи заслуживают особого внимания. Данный тип клеток составляет более трети всех клеток, рекрутируемых МГБ (Fonseca et al., 2015). Известно, что примитивные макрофаги заселяют мозг на ранних этапах эмбриогенеза и поддерживают популяцию путем пролиферации, стволовые клетки костного мозга в этом процессе участия не принимают. Однако продуцируемые опухолью токсины повреждают гематоэнцефалический барьер, что делает возможным рекрутирование значительного количества моноцитов и стволовых клеток различных типов и оставляет возможность для их трансформации в IBA1+ клетки. Однако биологическая роль таких трансформаций достаточно неоднозначна.

Морфология GFAP-позитивной астроцитарной глии в мозге животных, получивших трансфузию ГСК, не демонстрирует на всем сроке наблюдения принципиальных отличий от животных контрольной группы. Как и в контрольной группе, на 20-е сутки GFAP-позитивные звездчатые клетки концентрировались вокруг очага опухолевой инвазии и практически не обнаруживались в неопластической ткани. К 30-м суткам группировка GFAP-позитивных астроцитов становилась более плотной, однако эти клетки также отсутствовали в опухолевой ткани. При этом у крыс двух сравниваемых групп в ткани мозга противоположного полушария были обнаружены только единичные GFAPпозитивные клетки. 
A

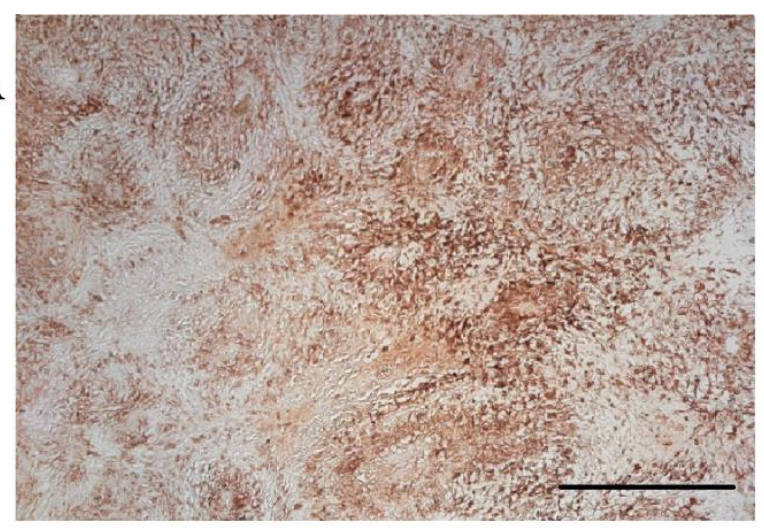

Б

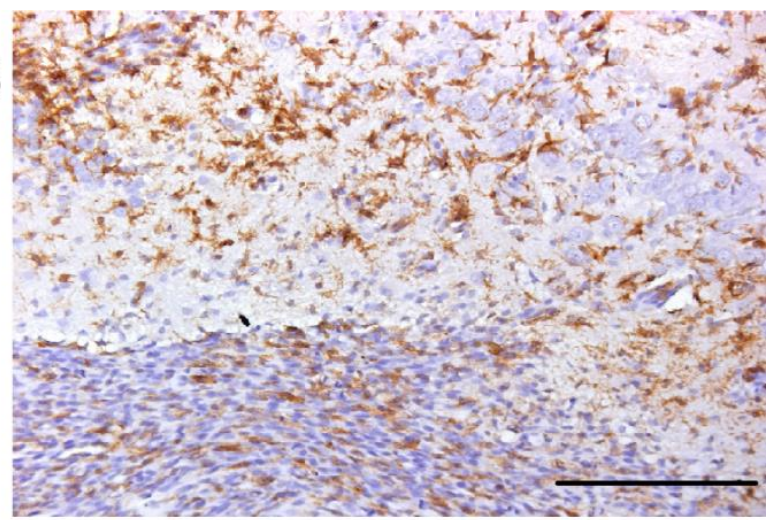

B

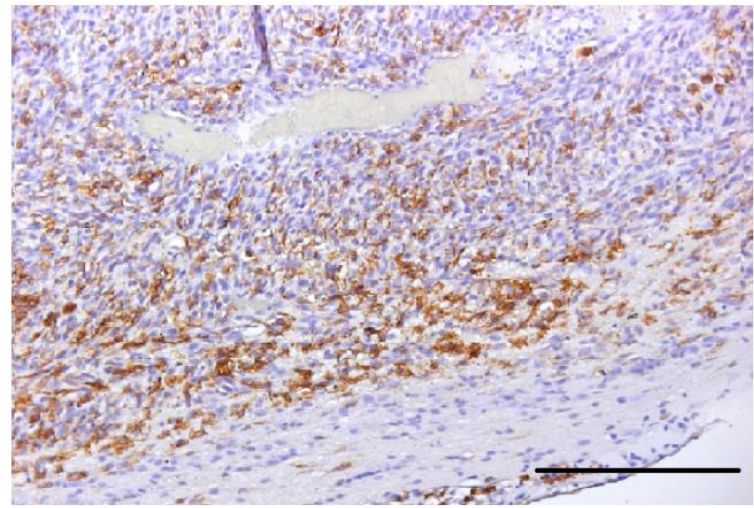

$\Gamma$

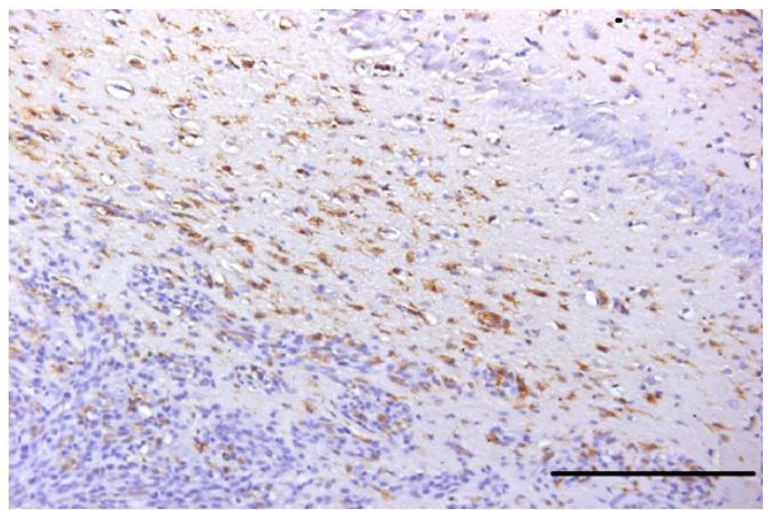

\section{Д}
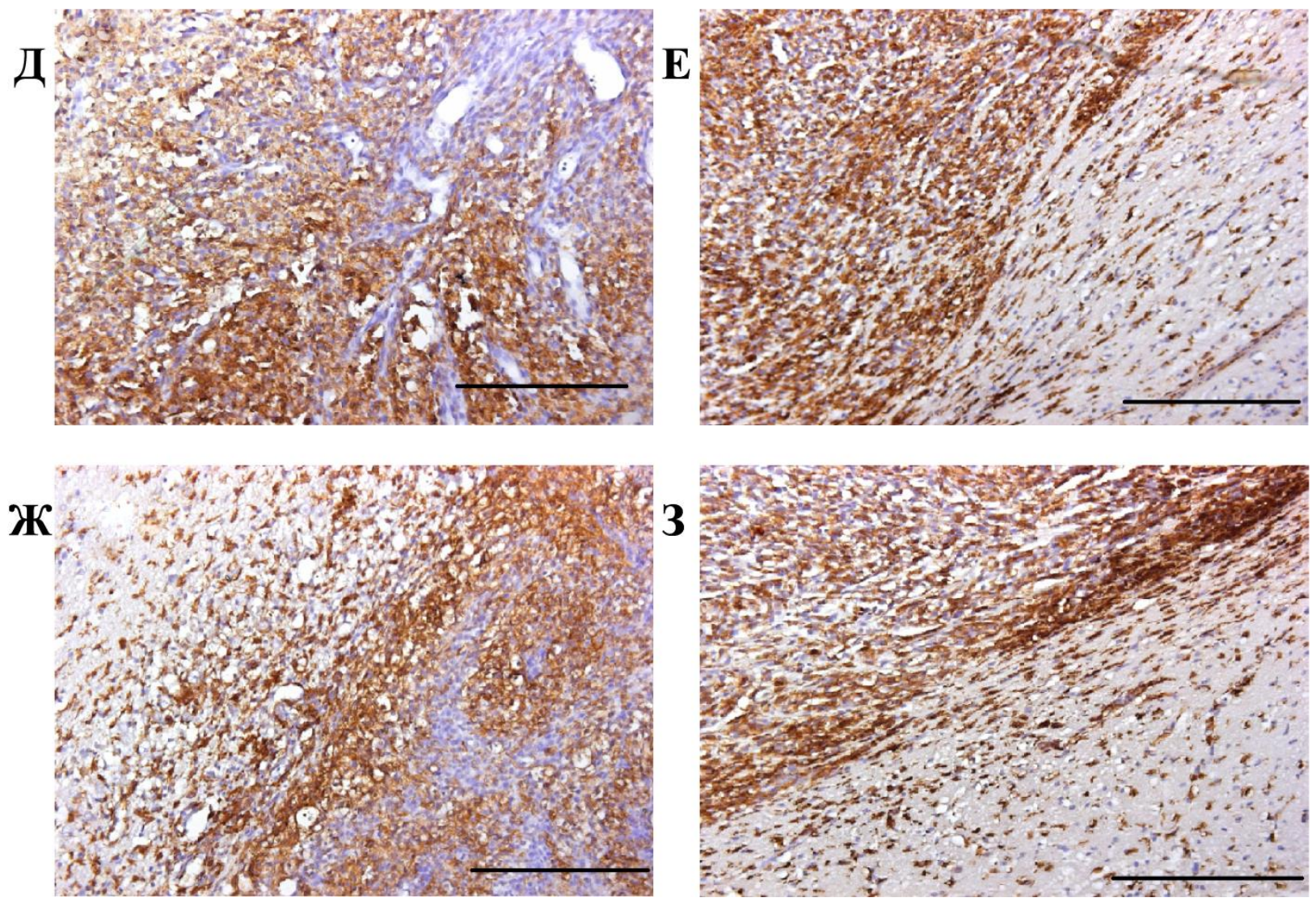

Puc. 45. Иммуногистохимическая реакция на антитела к специфическому белку IBA1:

A-Г, контрольная группа: А - центр опухоли, 30-е сутки; край опухоли: Б - 10 сутки, В - 20-е сутки, Г - 30-е сутки; Д-3, группа «клетки»: Д - центр опухоли, 30-е сутки; край опухоли: E - 10-е сутки, Ж - 20-е сутки, 3 - 30-е сутки. Дополнительная окраска гематоксилин-эозином. Масштаб 200 мкм 


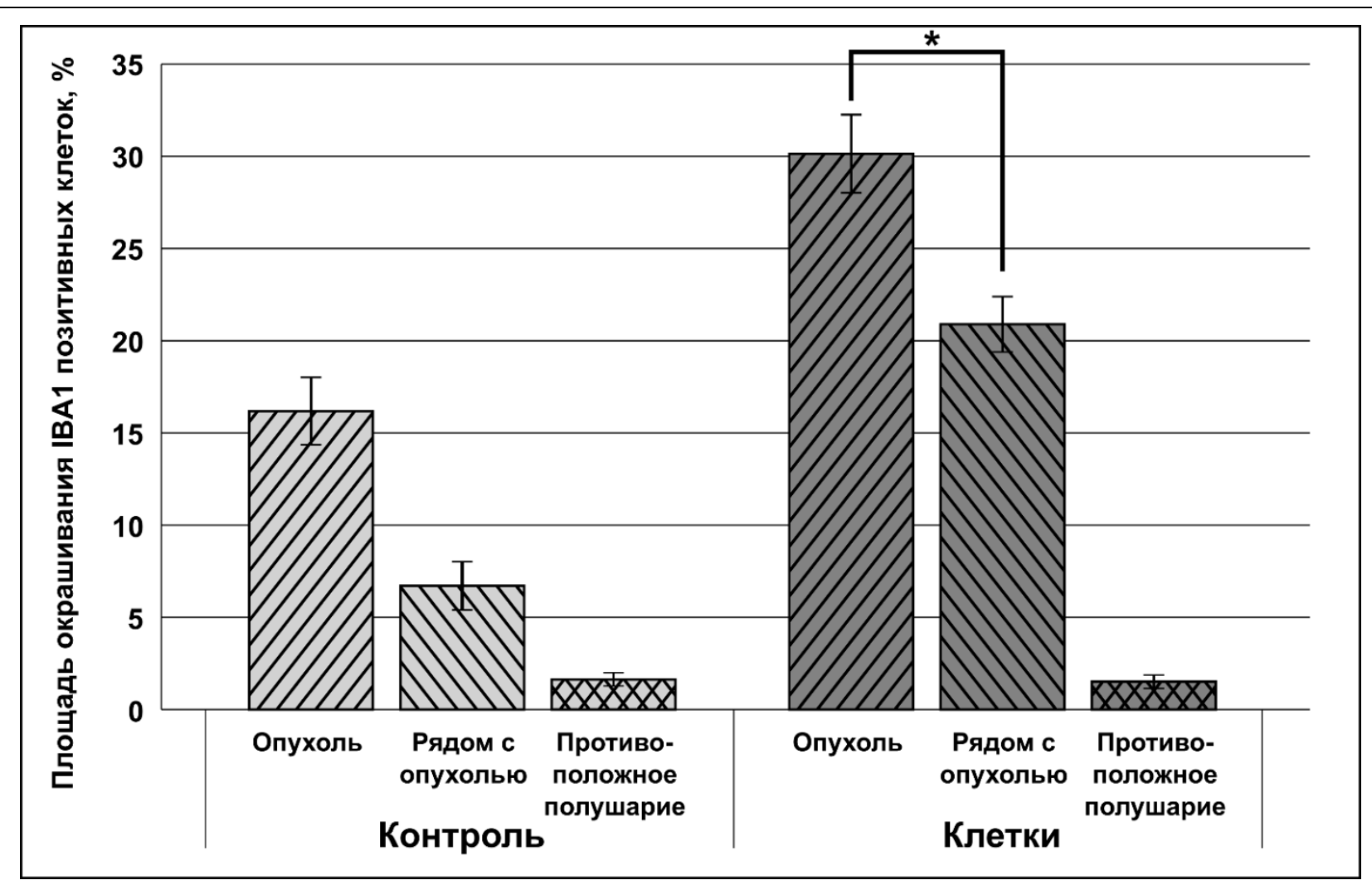

Puc. 46. Сравнительная оценка распределения IBA1 в мозге животных.

По оси абсцисс указан \% площади окрашивания специфическими антителами от площади снимка. Данные представлены в виде $\mathrm{M} \pm$ s.e.m, $\mathrm{N}=30$ для каждой группы. Значком «*» отмечены достоверные отличия (P < 0,05) между площадью IBA $1+$ ткани в опухоли и участках мозга, прилегающих к ним, в группе «клетки» от группы контроля

При анализе влияния трансплантированных ГСК на опухолевый очаг наше внимание привлекло изменение количества висфатина и эндотелина1 в очаге глиомы (рис. 47-50). Висфатин - фермент, который лимитирует скорость биосинтеза NAD, что играет важную роль в энергетическом метаболизме. В клетках глиомы потребность в NAD существенно выше, чем в нормальных клетках ЦНС, при этом степень злокачественности МГБ коррелирует с высокими концентрациями этого агента (Reddy et al., 2008). Висфатин вовлечен в процессы гомеостаза, блокирует процессы апоптоза, стимулирует выживание клеток, обеспечивает накопление висцерального жира, задействован в механизмах нейропротекции и вовлечен в нейрогенез. Данное вещество является аналогом инсулина, биологические эффекты висфатина проявляются в оптимизации процесса утилизации глюкозы, что весьма актуально в условиях ишемии. Однако спектр биологических эффектов этого лиганда намного шире. 

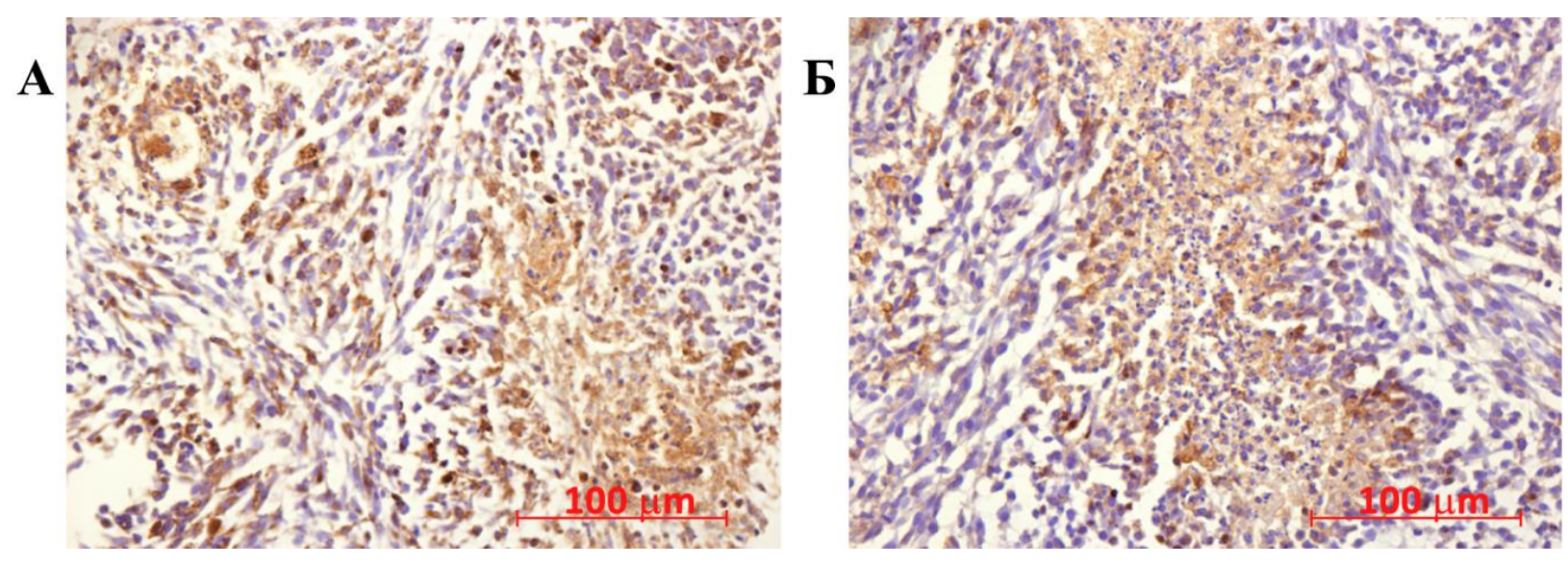

Puc. 47. Распределение висфатина в опухолевой ткани крыс контрольной

группы (А) и группы «клетки» (Б). Иммуногистохимичесакя реакция на висфатин. Докрашивание гематоксилином-эозином

В опухолевых клетках висфатин стимулирует пролиферацию, миграцию, ангиогенез, ремоделирование ВКМ. В очаге глиомы основным источником висфатина являются опухолевые клетки. Он также способен индуцировать процессы миграции НСК, ГСК и высокодифференцированных клеток, индуцируя в очаге продукцию MCP-1 и EGF-2. В моноцитах и макрофагах висфатин стимулирует секрецию интерлейкина 6 и 8, а также TNF $\alpha$. Соотношение площади окрашивания опухолевой ткани у крыс сравниваемых групп представлено на Рис. 48.

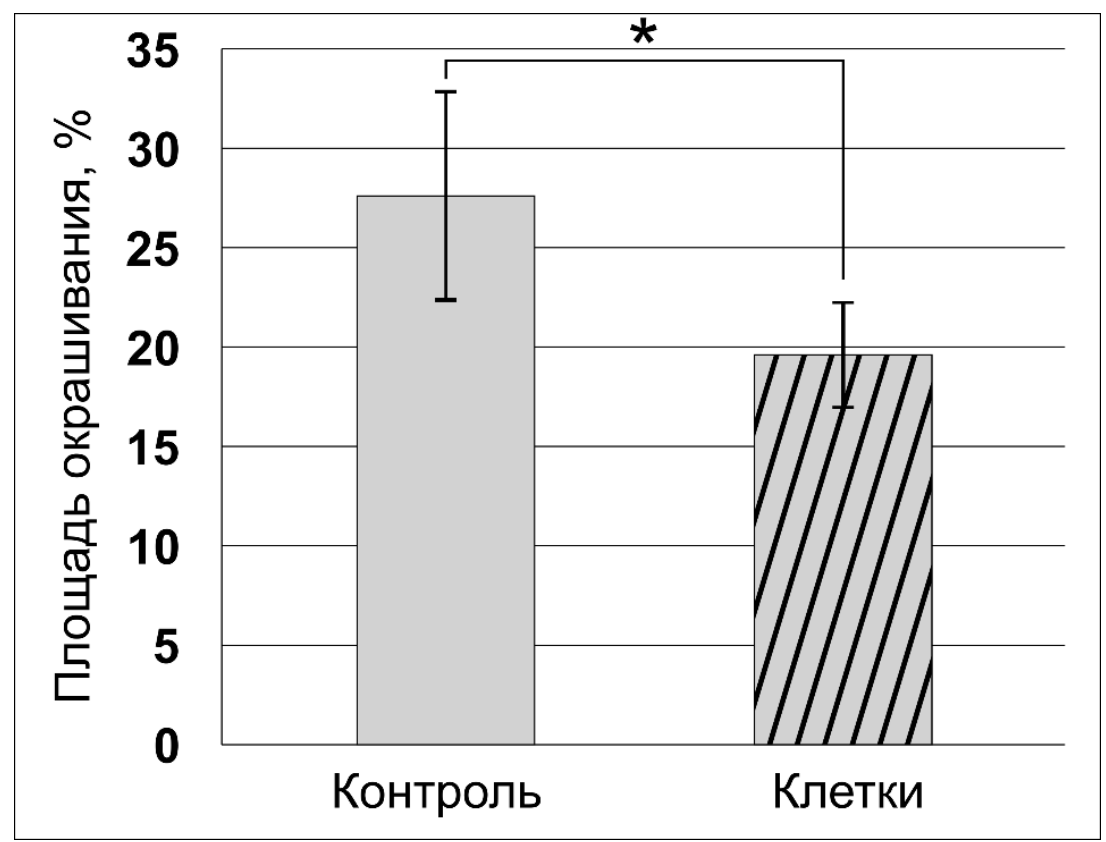

Puc. 48. Суммарная площадь окрашивания опухолевой ткани антителами к висфатину, 30 суток. По оси абсцисс указана площадь окрашивания в \% от суммарной площади. Данные представлены в виде $\mathrm{M} \pm$ s.e.m, $\mathrm{N}=30$ для каждой группы 
Как следует из представленных данных, тенденция к снижению продукции висфатина является одним из биологических эффектов ГСК. Это утверждение становится очевидным на фоне уменьшения размеров опухолевого узла, увеличения выживаемости экспериментальных животных, и обнаруженного в данном исследовании увеличения количества эндотелина-1 в опухолевом очаге (рис. 49).
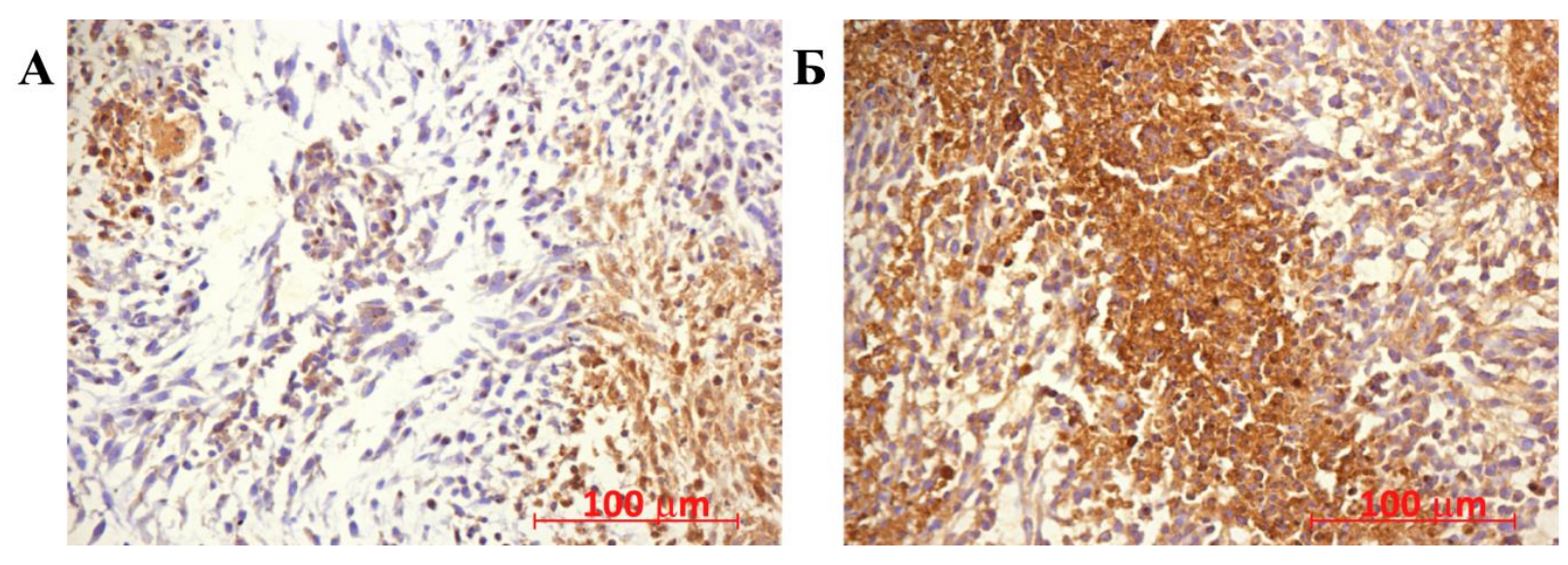

Puc. 49. А и Б. Иммуногистохимическая реакция на антитела к эндотелину-1.

Неопластическая ткань мозга крысы группы «клетки», 30-е сутки эксперимента.

Дополнительная окраска гематоксилином-эозином

Будучи вазоактивным пептидом и мощным вазодилататором с прововоспалительным действием, эндотелин-1 обладает цитостатическими свойствами, конечные эффекты этого лиганда определяются его концентрацией и зависят от локального микроокружения (рис. 50).

В ходе иммуногистохимической характеристики опухолевых узлов мозга крыс с глиомой С6, получивших трансплантацию ГСК, наше внимание привлекли изменения в площади окрашивания опухолевой ткани антителами к TGF- $\beta 1$ у животных сравниваемых групп. Препараты опухолевой ткани мозга крыс контрольной группы активно окрашивались антителами к этому лиганду, при этом TGF- $\beta 1$ был довольно равномерно распределен как в центре, так и на периферии опухоли. Данное распределение TGF- $\beta 1$ в опухолевой ткани крыс, получавших трансплантацию ГСК, сохранялось до 20-30-х суток эксперимента (рис. 51).

У крыс группы «клетки» к этому времени в неопластической ткани появляются многочисленные полости, что закономерно снижает площадь окрашивания микропрепаратов антителами к этому фактору. Весьма вероятно, что обнаруженная тенденция к сокращению площади окрашивания TGF- $\beta 1$ может быть связана с воздействием микроглии. 


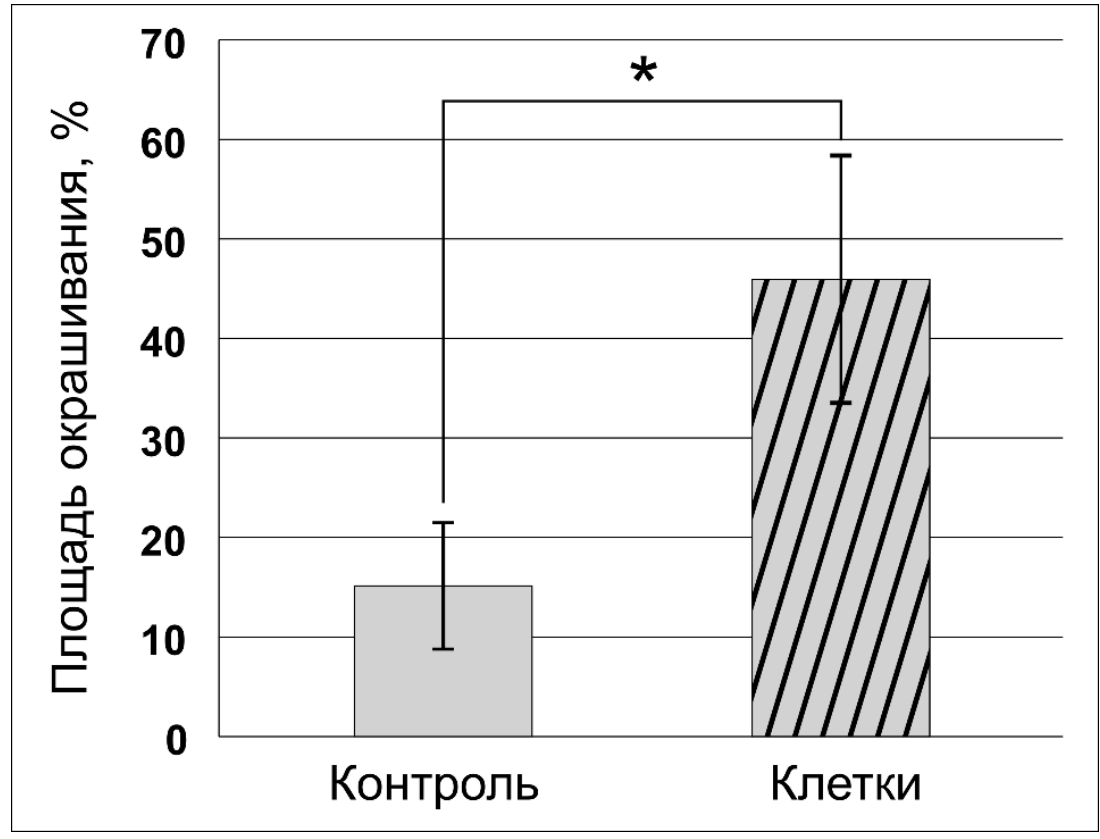

Puс. 50. Суммарная площадь окрашивания опухолевой ткани антителами к эндотелину-1, 30 суток. По оси ординат указана площадь окрашивания в \% от суммарной площади микропрепаратов, сравниваемые данные представлены в виде $\mathrm{M} \pm$ s.e.m, $\mathrm{N}=30$ для каждой группы. Знаком «*» показаны достоверные $(\mathrm{P}<0,05)$ отличия сравниваемых значений в группе «клетки» от контрольной

При морфологическом анализе иммуногистохимических перестроек в опухолевой ткани животных сравниваемых групп обращало на себя внимание значительное скопление на границе опухолевого очага клеток, позитивно окрашивающихся антителами к нестину (рис. 53, A) и рецепторному белку CXCR4 (рис. 53, Б). При анализе распределения нестина и CXCR4+ клеток в сравнении с рис. 39 обращала на себя внимание более плотная группировка клеток на границе неопластического очага. Экспрессия нестина и CXCR4 свойственна как опухолевым клеткам, так и нормальным нейральным и гемопоэтическим стволовым клеткам, что свидетельствует об их способности к миграции, а следовательно, к взаимодействию с клетками других типов.

Однако обращала на себя внимание более плотная группировка нестин- и CXCR4-позитивных клеток в группе «клетки», преимущественно в участках скопления микроглиоцитов, а именно в прилегающих к опухоли участках мозга ИР в отношении TGF- $\beta 1$ и ряда других иммуноцитохимических маркеров.

В ходе морфохимической характеристики края опухолевого очага в группе «клетки» обращала на себя внимание иммунопозитивность к ряду цитокинов (рис. 54). 

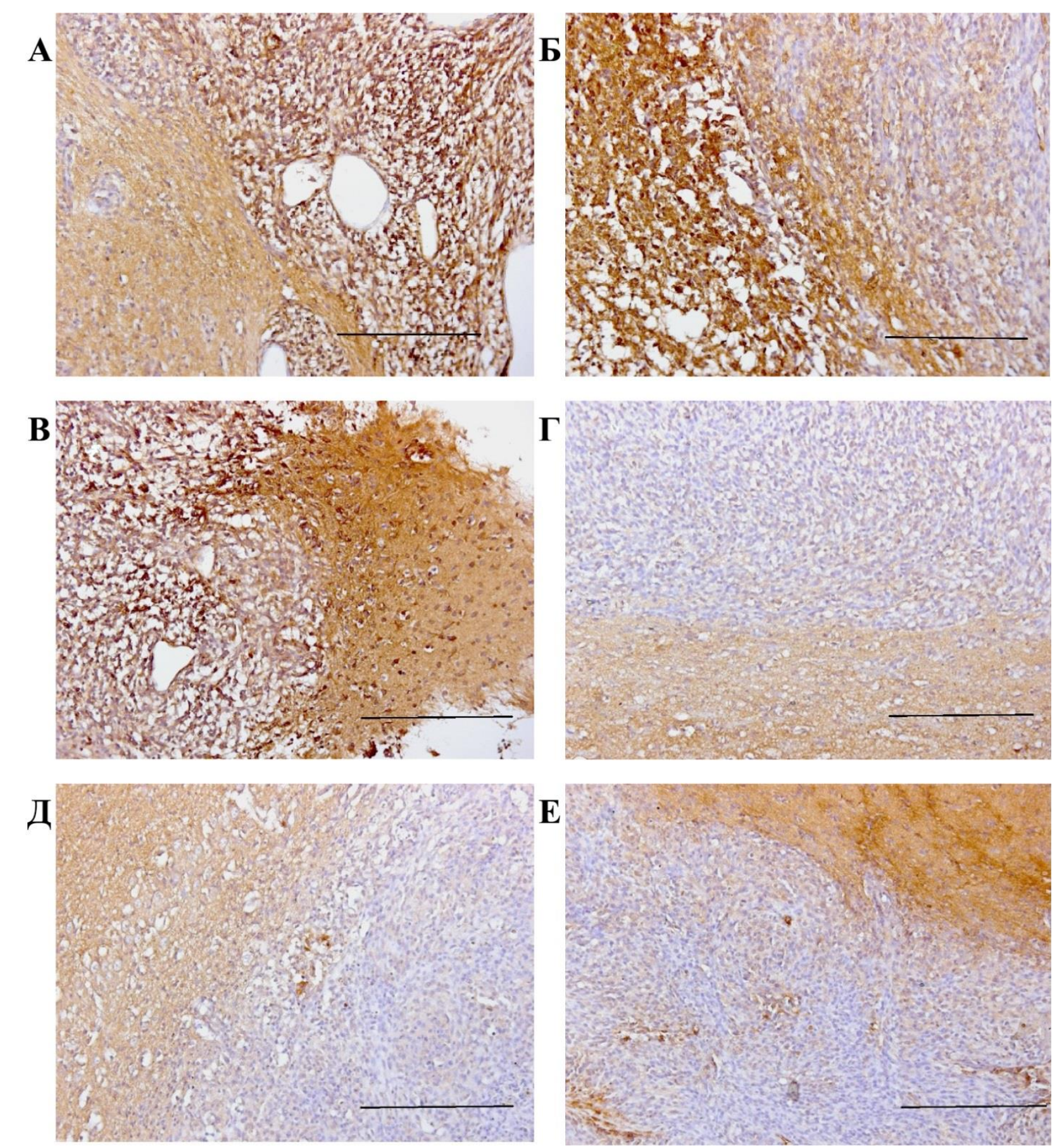

Рuc. 51. Ткань опухоли из мозга крыс, 30-е сутки, иммуногистохимическая реакция на антитела к TGF- $\beta 1$. Препарат дополнительно окрашен гематоксилин-эозином.

Масштаб 100 мкм. А-В. Контрольная группа, маркер распределен в опухолевой ткани. Г-Е. Группа «клетки», единичные включения TGF- $\beta 1$

С учетом сложности объективной количественной оценки влияния ГСК на уровень продукции данных цитокинов и других патогенетически связанных с ними веществ на этапе морфологического исследования было решено ограничиться качественной констатацией наблюдаемых изменений, а количественные данные получить методом иммуноферментного анализа. 


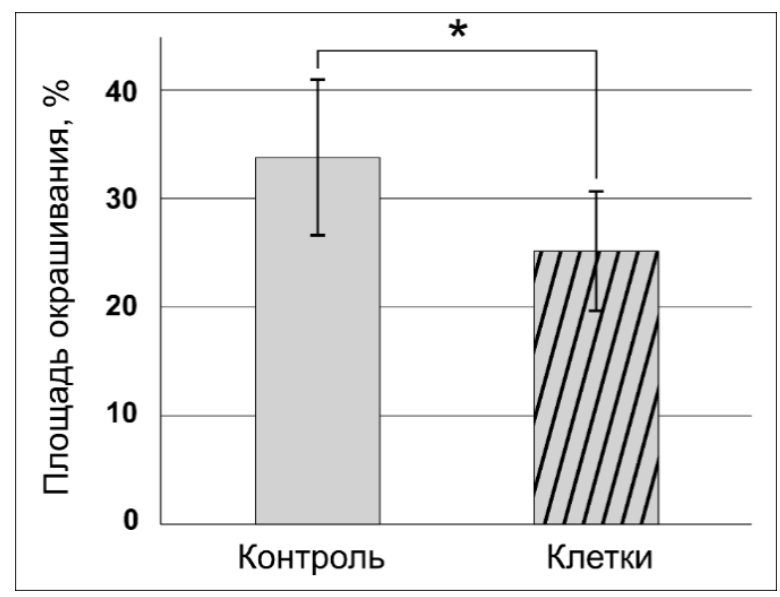

Рuc. 52. Сравнительное распределение иммунореактивности к TGF- $\beta 1$ в опухолевой ткани крыс сравниваемых групп на 30-е сутки. По оси абсцисс указан \% площади окрашивания специфическими антителами к общей площади снимков. Данные представлены в виде $\mathrm{M} \pm$ s.e.m, $\mathrm{N}=$ 30 для каждой группы. Значком «*» отмечены отличия $(\mathrm{p}<0,05)$ между площадью ткани, иммунопозитивной к TGF- $\beta 1$, в центре опухоли в группе «клетки» от контрольной группы
A

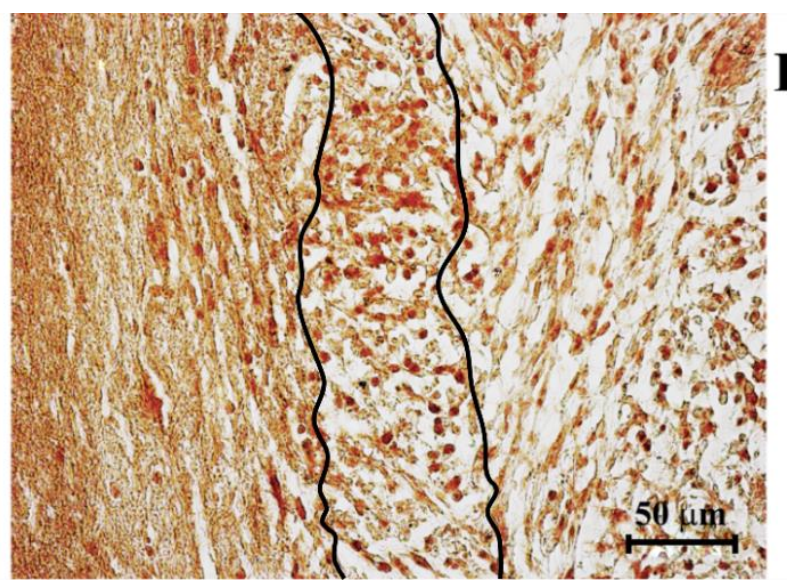

Б

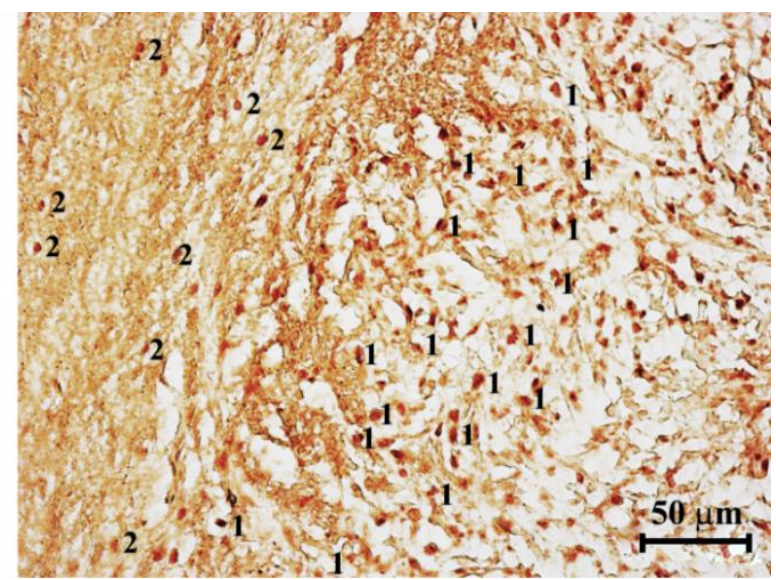

Puc. 53. Край опухоли в мозге крыс группы «клетки», 30 суток.

А - иммуноцитохимическая реакция на антитела к белку стволовых клеток нестину.

Многочисленные нестин-позитивные клетки локализуются в области инвазии неопластических элементов в вещество мозга. Б - иммуноцитохимическая реакция на

белок CXCR4. Клетки, несущие этот рецептор, а следовательно, мигрировавшие, локализуются в области инвазивного роста (1) на краю очага опухоли и частично в ее ткани (2) 


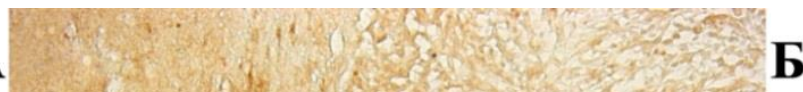

\section{$\mathbf{b}$}
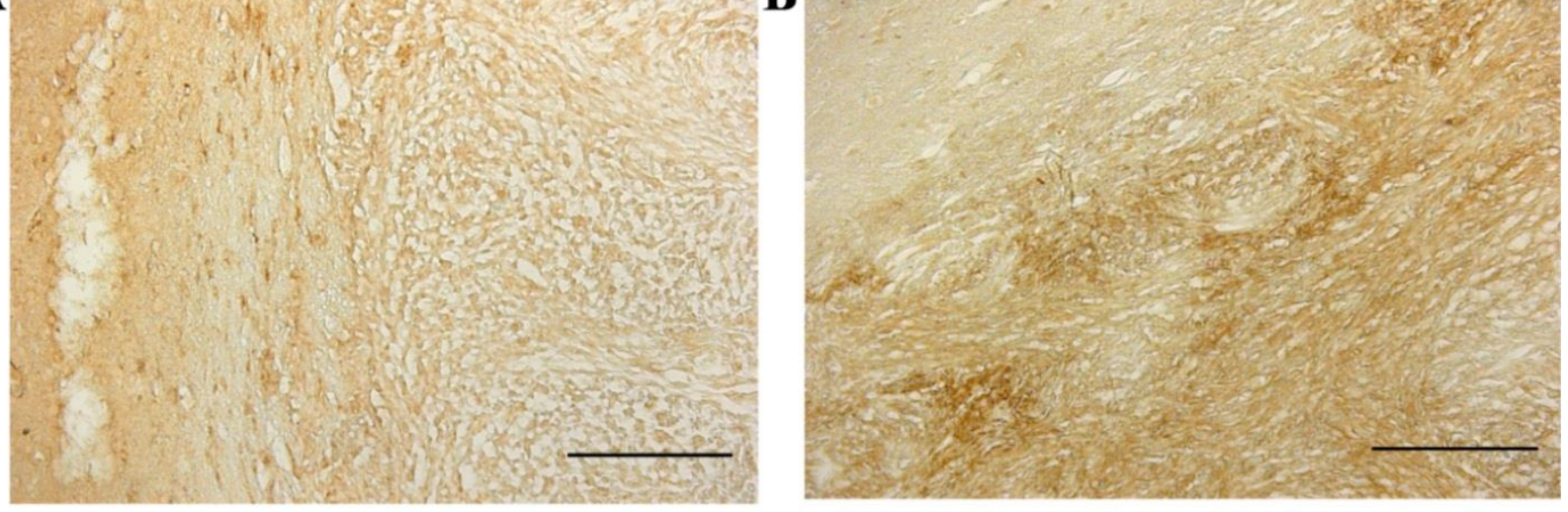

B

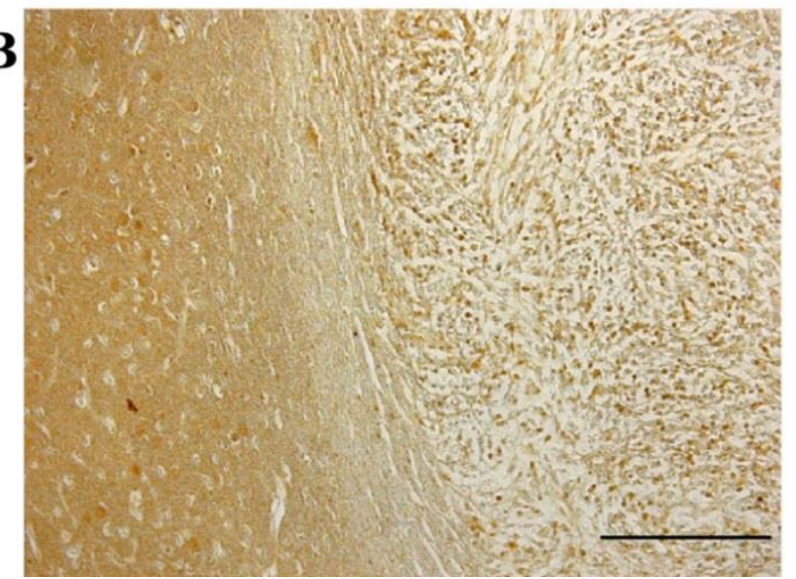

Puc. 54. Край опухолевого очага у крысы группы «клетки», 30 суток.

Иммуногистохимичесая реакция на антитела к интерлейкину-10 (А), фактору некроза опухолей (Б) и интерлейкину-1 (В). Масштаб 100 мкм

\section{4. Иммуноферментный анализ экспрессии цитокинов в вытяжке опухоли и прилежащей ткани мозга у контрольных и экспериментальных животных}

Результаты иммуноферментного анализа опухолевой ткани и прилежащего вещества мозга демонстрируют снижение продукции этого противовоспалительного цитокина (рис. 55).

Одновременно со снижением уровня продукции TGF- $\beta 1$ в опухолевой ткани и прилежащем к ней веществе мозга к 30-м суткам резко снижался уровень продукции противовоспалительного цитокина интерлейкина-10 и промотора воспаления - фактора некроза опухолей $\alpha 1$ (рис. 56, А, Б).

При этом уровень продукции интерлейкина-1 в опухолевой ткани и прилежащем к ней веществе мозга под воздействием трансплантированных клеток не претерпел статистически значимых изменений (рис. 57). 


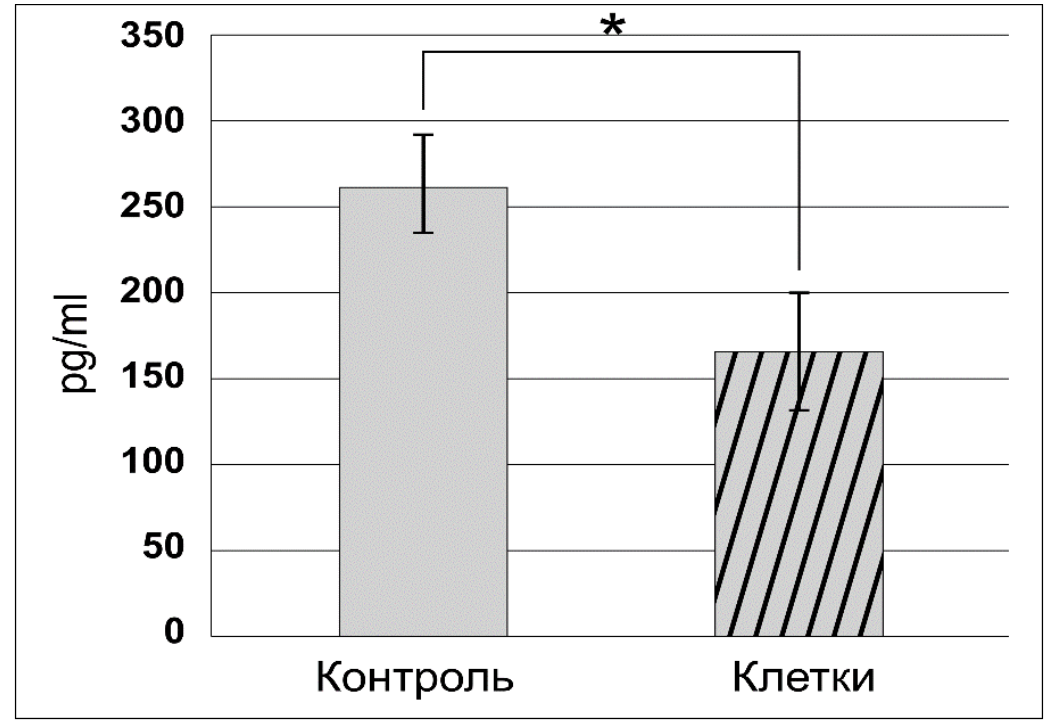

Puc. 55. Продукция TGF- $\beta 1$ в опухоли и прилежащих тканях головного мозга крыс сравниваемых групп, по данным ИФА, на 30-е сутки. По оси ординат указано pg/ml. Данные представлены в виде $\mathrm{M} \pm$ s.e.m, $\mathrm{N}=12$ для каждой группы, * - P $<0,05$
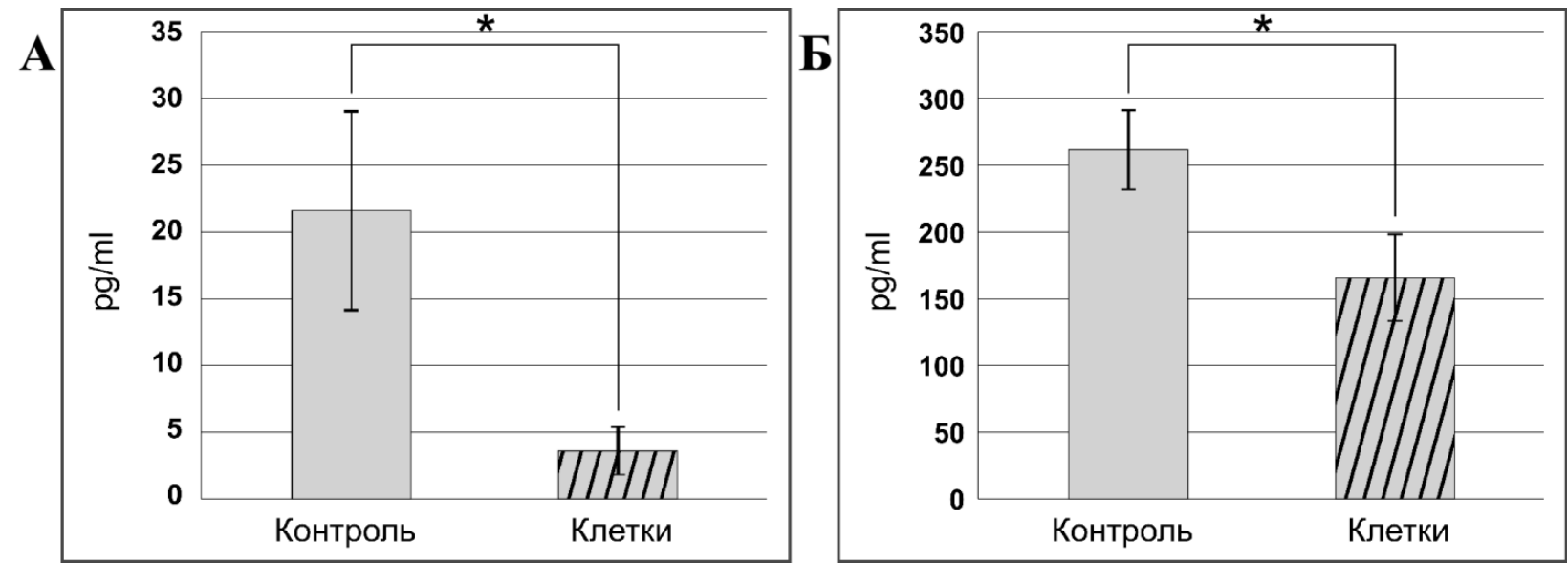

Puc. 56. А - сопоставление уровня продукции интерлейкина-10 в опухоли и прилежащих тканях головного мозга крыс сравниваемых групп, по данным ИФА, на 30-е сутки. По оси ординат указано $\mathrm{pg} / \mathrm{ml}$, данные представлены в виде $\mathrm{M} \pm \mathrm{s} . \mathrm{e} . \mathrm{m}$, $\mathrm{N}=12$ для каждой групп, * - различия достоверны при $\mathrm{p}<0,05$. Б - сопоставление уровня продукции TNF $\alpha 1$ в опухоли и прилежащих тканях головного мозга крыс сравниваемых групп, по данным ИФА, на 30-е сутки. По оси ординат указано pg/ml. Данные представлены в виде $\mathrm{M} \pm$ s.e.m, $\mathrm{N}=12$ для каждой группы, * - различия достоверны при $\mathrm{p}<0,05$ 


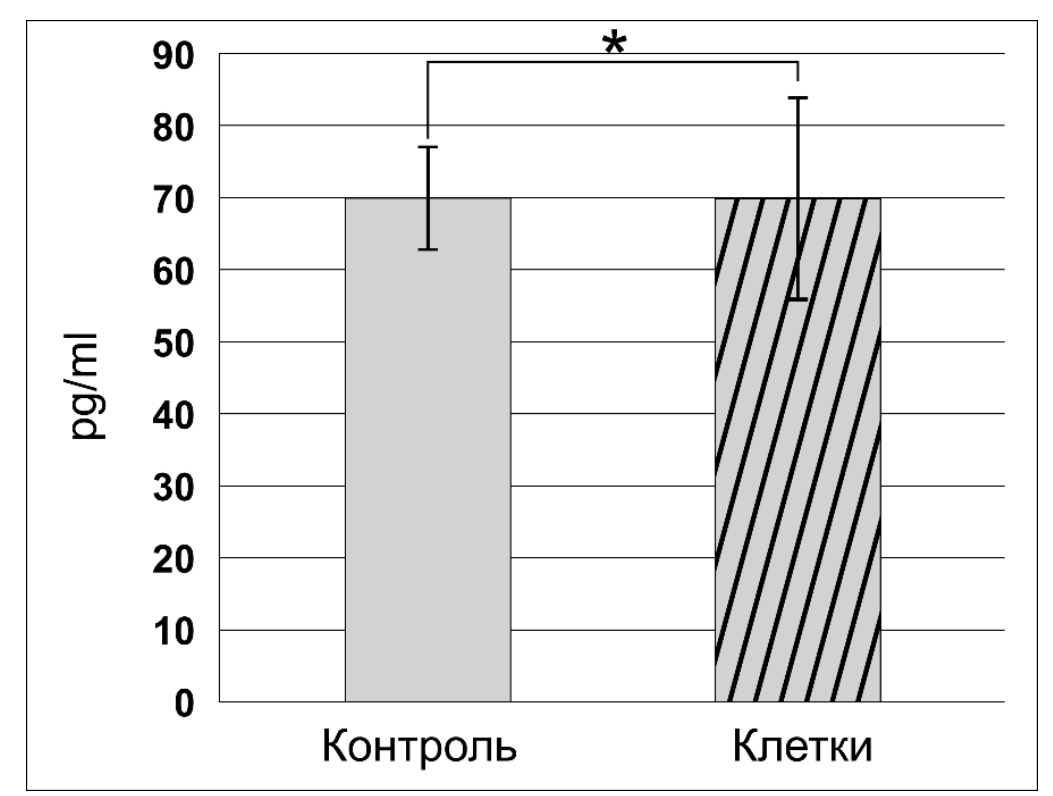

Puc. 57. Сопоставление уровня продукции IL-1 в опухоли и прилежащих тканях головного мозга крыс сравниваемых групп, по данным ИФА, на 30-е сутки. По оси ординат указано $\mathrm{pg} / \mathrm{ml}$. Данные представлены в виде $\mathrm{M} \pm$ s.e.m, $\mathrm{N}=12$ для каждой группы

\section{5. Обсуждение результатов главы 5}

Ранее попытки идентифицировать пути распределения трансплантированных СК разных типов в опухолевой ткани предпринимались на модели аденокарциномы Льюис, опухолях Фишера и Эрлиха, других экспериментальных моделях. Однако авторам удалось идентифицировать в неопластической ткани лишь отдельные клетки, флуоресценция которых соответствовала заданному спектру. Эти результаты принято объяснять малым количеством вводимых клеток, проблемами автофлуоресценции или неадекватностью выбранного типа СК и линий животных для эксперимента.

Большинство исследователей, изучавших миграцию стволовых клеток в организме опухоленосителя, сообщают о преимущественном накоплении трансплантата в потенциальных «нишах» (Aboody et al., 2013), что справедливо и в отношении стволовых клеток костного мозга (Hambardzumyan et al., 2015), но только отчасти нашло подтверждение в нашем эксперименте. При введении стволовых клеток в организм контрольных крыс мы идентифицировали их накопление в желудочках мозга, в области вентрикулярной герминативной зоны и в костном мозге этих животных. Скопления ГСК также наблюдались в селезенке, что, возможно, справедливо для крыс обоих групп, но требует использования соответствующих методов. 
При изучении распределения трансплантированных стволовых клеток в организме экспериментальных и контрольных животных в данном исследовании использован метод маркировки клеток флуоресцентными красителями. Преимуществом метода является простота использования и потенциальная применимость в клинической практике, а также возможность визуализации процесса межклеточной коммуникации. С помощью данного метода продемонстрировано, что при введении стволовых клеток разных типов (ГСК и НСК) в организм крыс с глиобластомой большая часть клеток мигрирует в зону неоплазии и проникает в опухолевую ткань.

Результаты эксперимента позволяют утверждать, что способность привлекать стволовые клетки относится к категории ключевых свойств МГБ наряду с высокой скоростью пролиферации и инвазивным ростом. Неоднократно описана способность МГБ вызывать опустошение герминативных зон мозга и подавлять пролиферацию НСК, что указывает на регуляторную роль этих клеток и высокий противоопухолевый потенциал, что в свете проведенных исследований приобретает принципиально новый биологический смысл.

Отличительной особенностью распределения НСК в мозге животных контрольной группы (без опухоли) является их тропность к герминативным зонам мозга: у интактных животных после внутривенного введения нейральные CD133+ стволовые клетки накапливаются в структурах мозговых желудочков и способны мигрировать в субвентрикулярную область головного мозга. У животных с экспериментальной глиобластомой как нейральные CD 133+, так и гемопоэтические CD34+ стволовые клетки мигрируют в опухоль и накапливаются в очагах инвазивного роста и зонах некроза неопластической ткани.

Как следует из эксперимента, трансплантация ГСК крысам с глиомой С6 приводит к увеличению выживаемости животных данной группы и улучшает их функциональное состояние. При этом морфологический анализ взаимодействия трансплантированных клеток с клетками глиомы выявил ряд важных закономерностей. ГСК оказывают амортизирующее воздействие на течение неопластического процесса, о чем свидетельствует сокращение площади некрозов. Раннее появление некрозов позволяет отнести глиому С6, смоделированную в нашем эксперименте, к категории опухолей высокой степени злокачественности. Новообразования этого типа характеризуются очень высоким уровнем пролиферативной активности.

Заслуживает особого внимания тот факт, что темпы пролиферации неопластических элементов с течением времени падают, однако у крыс 
группы «клетки» отмечен всплеск пролиферативной активности с 20-го по 30-й дни эксперимента, что может быть связано с пролиферацией мигрировавших в опухоль ГСК, трансформирующихся в IBA1+ клетки. Косвенным подтверждением этого служит резкое возрастание количества клеток, иммунопозитивных к антителам против IBA1 в области опухоли в указанные сроки эксперимента (рис. 46).

Глиома характеризуется выраженной способностью привлекать различные клетки, при этом до 30\% клеток, рекрутируемых МГБ, составляют именно микроглиоциты (Hambardzumyan et al., 2015; Fonseca et al., 2015), что нашло подтверждение в нашем исследовании. В естественных условиях основным источником микроглиоцитов/макрофагов до 20-х суток являются собственные ресурсы головного мозга, а моноциты крови до определенного момента не участвуют в этом процессе. В пользу этого аргумента свидетельствует снижение количества микроглиальных клеток с 20-х по 30-е сутки эксперимента. Важно, что при этом область их максимального скопления смещаться от центра опухолевого очага к периферии, обнаруживая четкую тенденцию к уплотнению микроглиальных клеток в участках инвазии. В свою очередь, по краям опухолевого очага, как бы препятствуя миграции микроглии, наблюдается уплотнение астроцитов, которые формируют клеточный барьер, блокирующий продвижение инвазивного процесса в ткань мозга.

Иммобилизация ГСК из депо в костном мозге в системный кровоток существенным образом изменяет архитектуру и естественный стереотип течения опухолевого процесса. Мигрируя в опухоль и взаимодействуя с ее клетками, значительная часть ГСК трансформируется в IBA1-позитивные клетки, которые локализуются в центре опухоли и на ее периферии. Важно, что накопление микроглиоцитов происходит именно в местах локализации мигрировавших сюда трансплантированных клеток. В литературе описаны два субтипа микроглиоцитов M1 и M2 фенотипа, способные как подавлять, так и стимулировать опухолевый процесс, что весьма дискутабельно и нуждается в дальнейшем, более предметном изучении. Противоопухолевые эффекты глии (Fonseca et al., 2015) хорошо известны. Весьма вероятно, что итоговая про- или противоопухолевая функция микроглии определяется влиянием клеточного микроокружения. Аргументом в пользу этой гипотезы является преимущественная локализация IBA1-ИР микроглиоцитов в зонах инвазии клеток глиомы С6 в вещество мозга и их тесная колокализация с клетками, имеющими признаки других, возможно, мигрировавших сюда стволовых клеток. 
Способность трансплантированных ГСК содействовать локальному усилению воспалительной реакции - один из вероятных механизмов противоопухолевого действия СК. Как показано в нашем исследовании, ГСК подавляют продукцию в опухоли противовоспалительного цитокина IL10, несколько усиливают продукцию провоспалительного цитокина IL-1 и достоверно увеличивают количество IBА1-ИР клеток, высокая фагоцитарная активность которых вероятно, и объясняет формирование полостей и уменьшение площади окрашивания микропрепаратов антителами к TGF- $\beta 1$. При этом повышение числа микроглиоцитов в опухоли должно сочетаться с усилением продукции TGF- $\beta 1$, однако в нашем эксперименте этого не наблюдалось, что, вероятно, связанно с тем, что источником TGF- $\beta 1$ является не микроглия, а сами клетки глиомы. В этом ключе демонстративно снижение выработки в опухолевой ткани и окружающей ткани мозга TNF $\alpha 1$, что, вероятно, объясняет стабилизирующее влияние ГСК на рост опухоли и уменьшение площади некрозов.

В контексте противоопухолевых свойств ГСК особого внимания заслуживает обнаруженная тенденция к подавлению продукции висфатина и стимуляция синтеза эндотелина-1 в группе «клетки», что свидетельствует о регуляторном действии трансплантата. Не исключено, что исследование содержания данных маркеров на более ранних этапах опухолевого процесса позволило бы зарегистрировать более рельефную динамику их наработки в очаге неоплазии. Вместе с тем даже минимальные сдвиги в сигнальном микроокружении опухоли могут в комплексе определять ее биологическую активность. Висфатин и эндотелин-1 представляют собой типичные регуляторные вещества, изменения количества которых наиболее полно отражают процессы адаптации и компенсации. Говоря о фундаментальном значении данных трансформаций, нельзя не сказать об их клиническом значении. Трансформация трансплантированных ГСК в клетки микроглии/макрофаги усиливает защитные возможности организма путем стимуляции процесса презентации опухолевых антигенов, что открывает возможности для иммунотерапии.

Таким образом, трансплантация ГСК животным с экспериментальной глиобластомой сопровождается сокращением площади зон некроза, увеличением количества микроглиоцитов опухли и усилением синтеза эндотелина-1, подавлением продукции TGF- $\beta 1$, интерлейкина-10 и (фактора некроза опухоли) $\mathrm{TNF} \alpha 1$ в очаге неоплазии. 


\section{ТРАНСФОРМИРУЮЩИЙ ФАКТОР РОСТА $\beta$ \\ В ПРОЦЕССАХ ВЗАИМОДЕЙСТВИЯ \\ ГЕМОПОЭТИЧЕСКИХ СТВОЛОВЫХ \\ И ОПУХОЛЕВЫХ КЛЕТОК IN VITRO}

Резистентность к лечению связывают с ОСК, занимающими ведущее место в иерархии клеток МГБ. Популяция ОСК гетерогенна, однако инвазивный рост связан не с каким-то одним клоном ОК (Lathia et al., 2015), a с формированием особого «инвазивного» фенотипа ОК и особых условий микросреды, возникающих в ходе межклеточных взаимодействий при участии ряда паракринных факторов (Brown et al., 2017; Wang et al., 2016; Iwadate et al., 2016), среди которых самое пристальное внимание уделяется трансформирующему фактору роста $\beta$ (TGF- $\beta$ ).

Существуют разрозненные данные (Kaur et al., 2015; Goldenberg, 2012; Rodríguez-García et al., 2017; Zhang et al., 2020) о способности TGF- $\beta$ усиливать метастатическую и инвазивную активность глиом, однако лекарств и технологий для эффективного воздействия на эти процессы не существует. Одним из направлений их создания является реализация противоопухолевого потенциала нормальных гемопоэтических стволовых клеток.

Цель данного раздела - показать на модели глиобластомы in vitro роль трансформирующего ростового фактора $\beta$ в процессах взаимодействия опухолевых и гемопоэтических стволовых клеток. Задачи настоящего раздела работы:

1) показать влияние TGF- $\beta 1$ на клетки МГБ;

2) показать морфологические и ультраструктурные особенности клеток МГБ при стимуляции TGF- $\beta 1$;

3) оценить влиние TGF- $\beta 1$ на подвижность клеток МГБ;

4) описать закономерности взаимодействия ГСК с клетками МГБ, предобработанными TGF- $\beta 1$.

\section{1. Влияние TGF-ß1 на клетки глиобластомы}

В работе использована система высокоэффективной роботизированной количественной микроскопии в режиме реального времени.

Под воздействием TGF- $\beta 1$ клетки глиобластомы «распластывались» по поверхности культурального планшета, приобретая очертания, существенно отличающиеся от клеток контрольной культуры (рис. 58). 


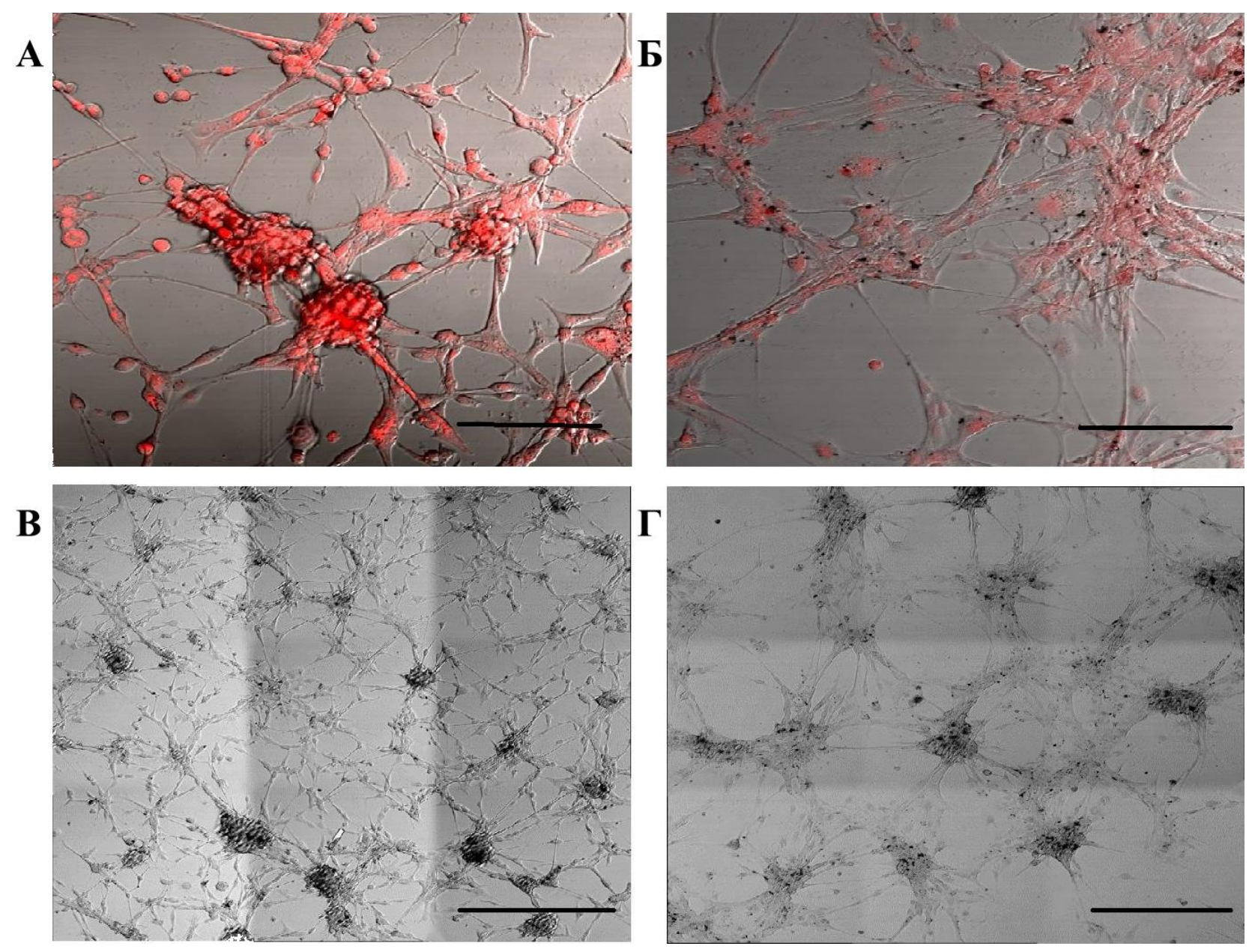

Puc. 58. Воздейстие 10 нг/мл TGF- $\beta 1$ на клетки линии U87 глиобластомы человека: A - контрольная группа; Б - клетки, стимулированные TGF- $\beta 1$. Окраска CMPTX-Red $(\lambda=546 \mathrm{~nm})$, флуоресцентная лазерная микроскопия, масштаб - 400 мкм; В-Г.

Панорамная реконструкция культуры клеток линии U87 глиобластомы до (B) и после (Г) стимуляции TGF- $\beta 1$. Изображение в проходящем свете. Масшаб 400 мкм

При проведении исследования был сделан акцент на работу с живыми клетками, под которыми понималась итоговая сумма распознанных системой Cell-IQ образов клеток в состоянии интерфазы и митоза (Рис. ). При распознавании образов под пролиферирующими клетками обозначались элементы, имеющие отчетливые признаки открепления от субстрата, увеличения объема ядра и клетки в целом, с округлыми контурами клеточной мембраны, светлой цитоплазмой, с отсутствием патологических включений и другими признаками ранней профазы, а также клетки в митозе.

Как следует из эксперимента, в концентрации 10 нг/мл TGF- $\beta 1$ снижал темпы пролиферации клеток глиобластомы (рис. 59). 


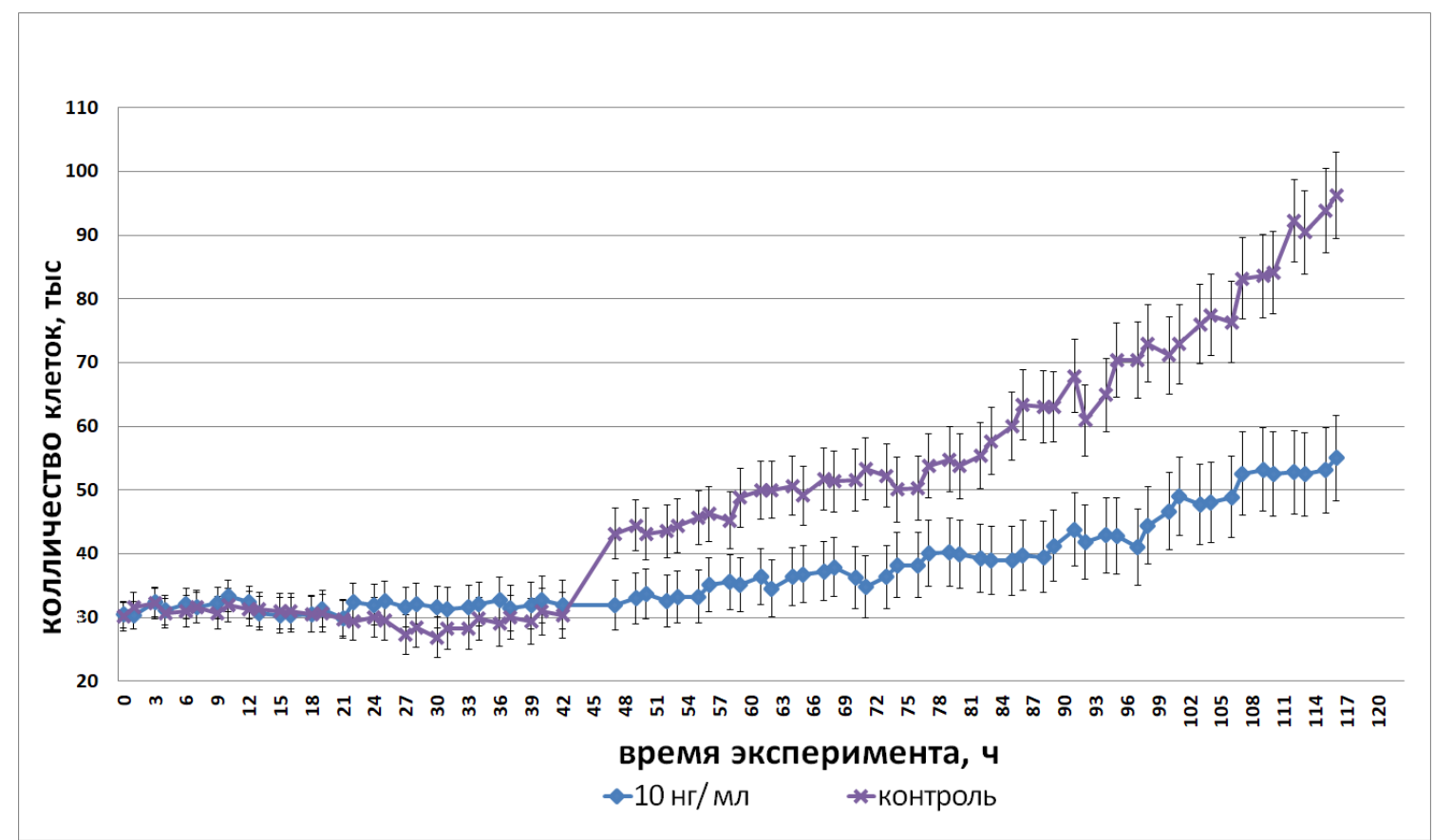

Puc. 59. Влияние 10 нг/мл TGF- $\beta 1$ на клетки линии U87 глиобластомы (ANOVA; $\mathrm{m}=2 ; \mathrm{n}=20 ; \alpha=0,05$ )

\section{2. Морфологические (ультраструктурные) особенности клеток линии U87 глиобластомы после стимуляции TGF-ß1}

Под воздействием 10 нг/мл TGF- $\beta 1$ клетки «распластывались» по плоской поверхности культурального планшета и приобретали фибробластоподобную форму (рис. 60). Клетки глиобластомы в контрольной культуре сохраняли типичную веретеновидную или полигональную форму.

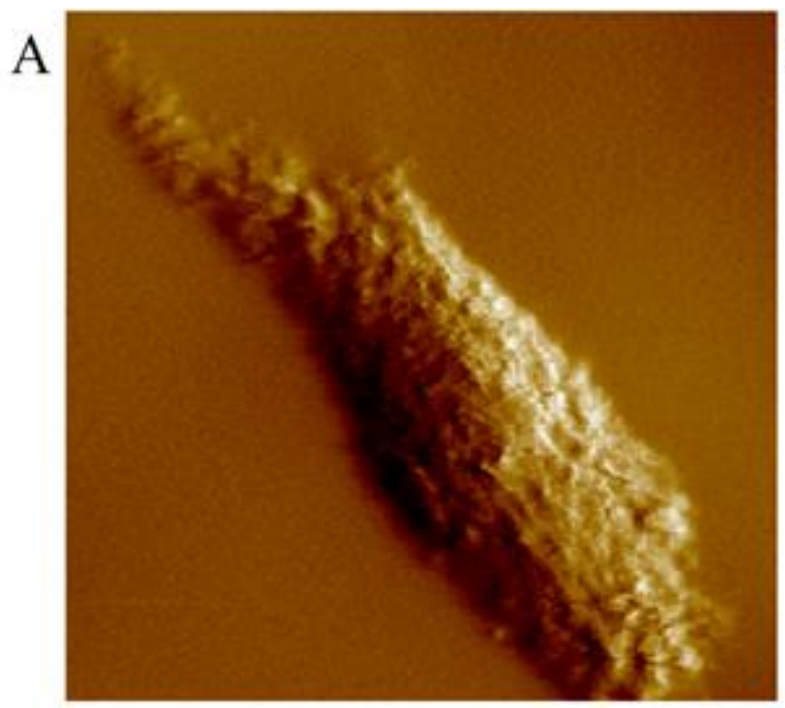

$\overline{7.0 \mu \mathrm{m}}$
Б

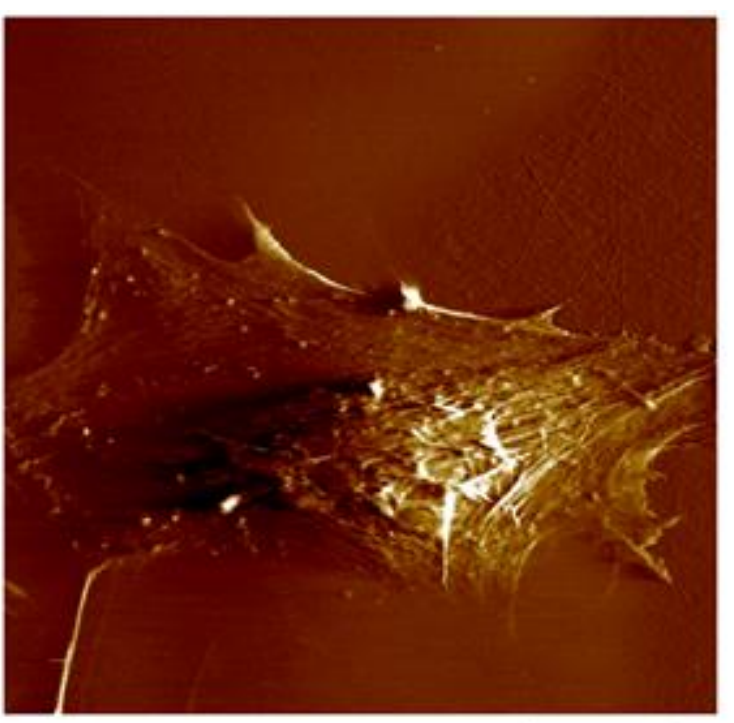

$\overline{7.0 \mu \mathrm{m}}$

Puc. 60. Клетки глиобластомы линии U87: А - контрольная культура; Б - стимуляция 10 нг/мл TGF- $\beta 1$, микроскопия высокого разрешения 
По данным электронной микроскопии, в клетках контрольной культуры глиобластомы визуализировались крупные ядра различной формы и величины с диспергированным хроматином и хорошо конструированным ядрышком (рис. 61, А).
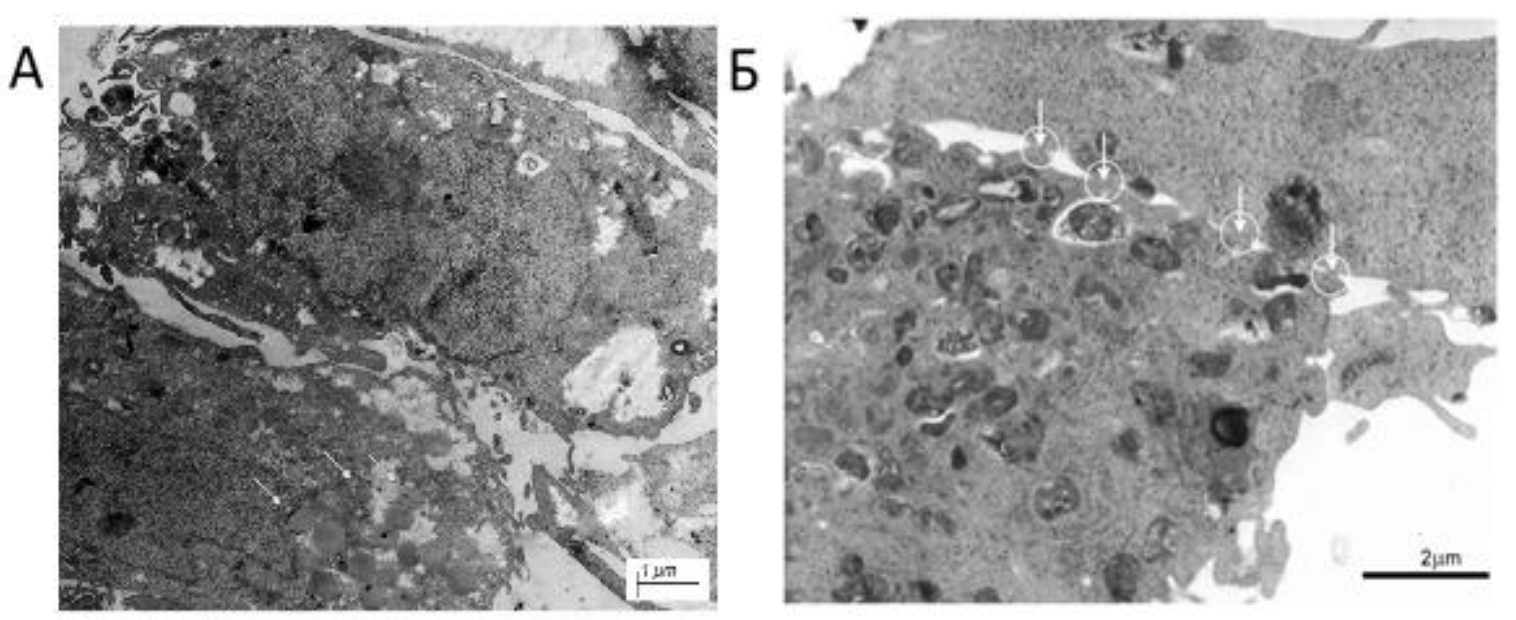

B
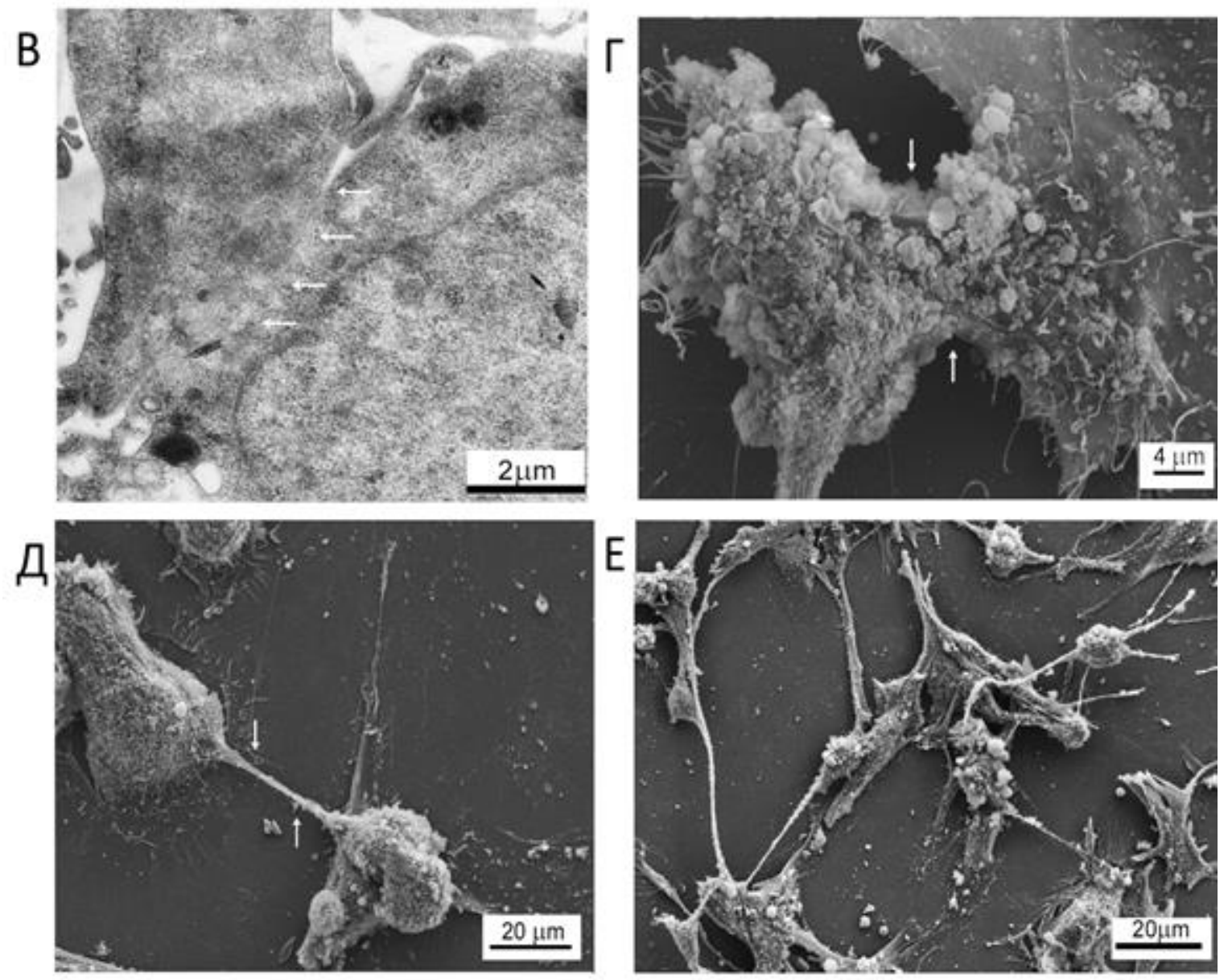

Puc. 61. Клетки линии U87 глиобластомы человека, просвечивающая электронная микроскопия: A - клетка с крупным ядром и хорошо конструированным ядрышком

и включения электронноплотного материала в цитоплазме; Б - адгезивные межклеточные контакты; В, Г - участок цитоплазматического слияния между клетками глиобластомы; Д, Е - контактные мостики между взаимодействующими клетками 
Цитоплазма содержала обширные поля специфического материала с низкой электронной плотностью и дисперсным распределением компонентов, напоминающих углеводные включения в цитоплазме простейших, рядом с которыми располагались округлые объекты, похожие на липидные капли. Соприкасаясь, поверхности клеток формировали адгезивные контакты и контактные пояски (рис. 61, Б) с распределенным между ними рыхлым аморфным матриксом.

В некоторых местах формировались обширные зоны слипания клеток с образованием интердигитаций в виде плотного прилегания клеточных мембран, поверхность которых в некоторых местах растворялась (рис. 61, В, указаны стрелками), образуя участки цитоплазматического слияния, заполненного гомогенным содержимым. Подобные контакты предполагают не только возможность свободного обмена макромолекулами, но и вероятное обобществление внутриклеточных органелл. Участки слияния мембран между взаимодействующим клетками (рис. 61, Г) сочетались с формированием специфических контактных мостиков (рис. 61, Д) и протяженных микротрубок, соединяющих между собой «распластавшиеся» неопластические клетки в сложно организованную структуру (рис. 61, Е).

При стимуляции клеток линии U87 глиобластомы TGF- $\beta 1$ обращало на себя внимание резкое уменьшение или полное исчезновение специфических включений в цитоплазме, напоминающих углеводные поля, уменьшение числа липидных включений и количества межклеточных контактов (рис. 62, что может свидетельствовать об изменении интенсивности внешнесекреторной функции клеток и их условий взаимодействия.
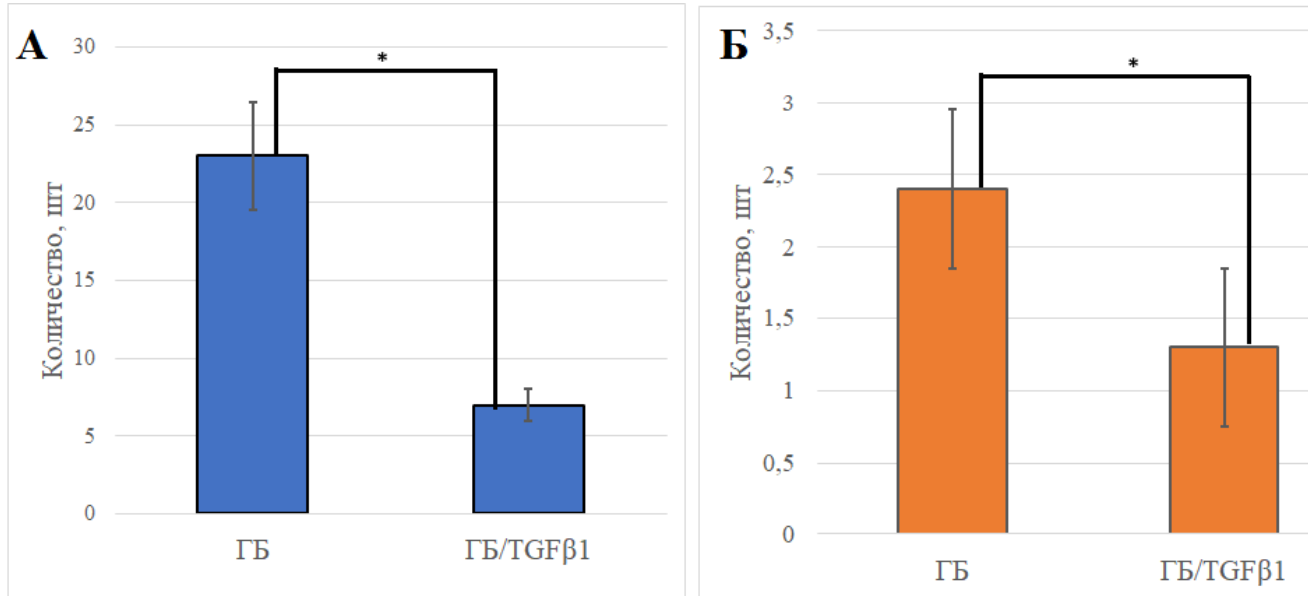

Puc. 62. Количество внутриклеточных липидных включений (А) и межклеточных контактов (Б) при стимуляции клеток глиобластомы TGF- $\beta 1 . *$ * $\mathrm{P}<0,05$; критерий Стьюдента. По вертикальной оси указано число внутрицитоплазматических включений (А) и межклеточных контактов (Б) в поле зрения 


\section{3. Влияние TGF-ק1 на подвижность клеток глиобластомы}

Стимуляция 10 нг/мл TGF- $\beta 1$ сопровождалась резким снижением времени «зарастания царапины» (рис. 63) в клеточном монослое до 27 ч против 45 в контрольной группе, что на фоне снижения динамики роста указывало на возросшую подвижность клеток глиобластомы (рис. 64).

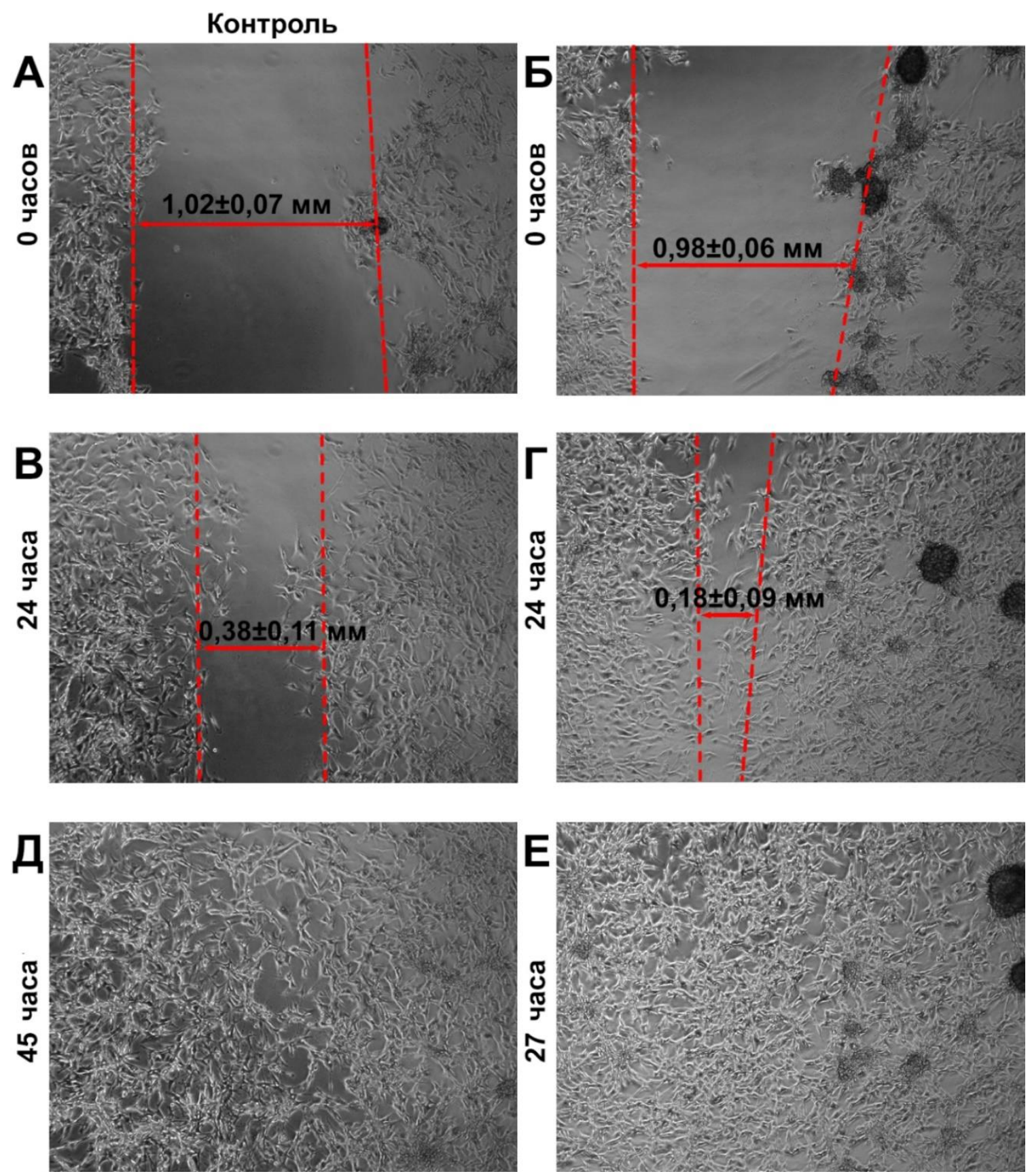

Puc. 63. Анализ миграции клеток в зону «царапины» в клеточном монослое (scratch wound assay) с использованием высокоэффективной количественной роботизированной микроскопии в реальном времени: А, В, Д-клетки контрольной культуры глиобластомы. Полное «зарастание царапины» наблюдается через 45 ч после начала эксперимента; Б, Г,

Е - клетки глиобластомы, культивируемые в среде с содержанием 10 нг/мл TGF- $\beta 1$. Полное «зарастание царапины» наблюдается через 27 ч с момента начала исследования 


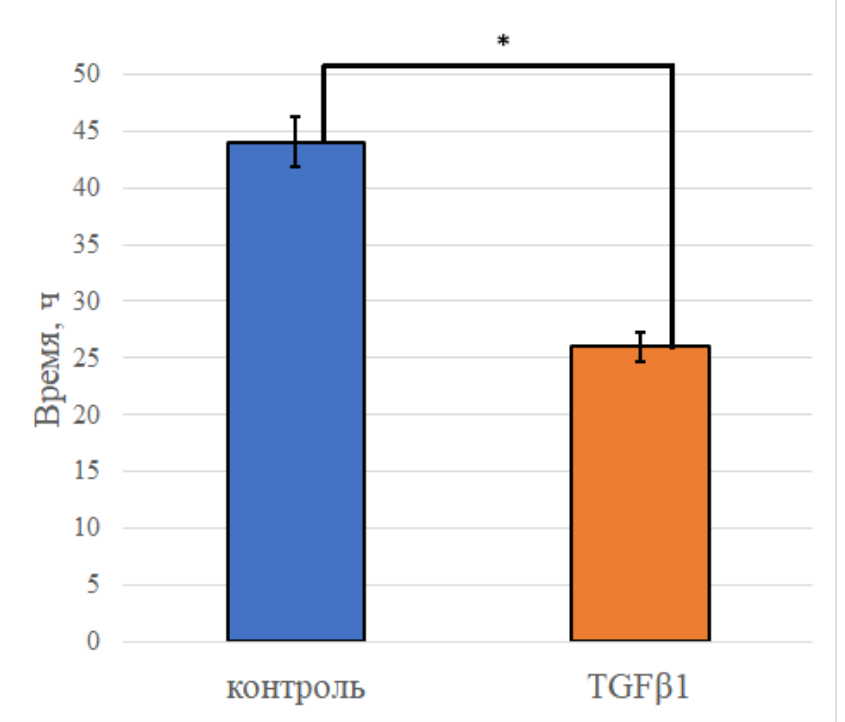

Puc. 64. Результаты анализа миграционной активности клеток линии U87 глиобластомы в зону «царапины» в клеточном монослое $\mathrm{p}<0,05$; критерий Стьюдента

\section{4. Закономерности взаимодействия ГСК с клетками глиобластомы, предобработанными TGF-ק1 in vitro}

Исследование состояло из двух частей:

1) изученеие общих закономерностей взаимодействия ГСК с клетками глиобластомы, предобработанными TGF- $\beta 1$;

2) разработка методов повышения эффективности такого взаимодействия.

\subsection{1. Изученеие общих закономерностей взаимодействия ГСК с клетками глиобластомы, предобработанными TGF-ß1}

Для проведения исследования была сформирована контрольная группа клеток линии U87 глиобластомы человека и культура клеток линии U87 глиобластомы, предобработанных 10 нг/мл в TGF- $\beta 1$. При проведении эксперимента клетки глиобластомы человека культивировали совместно с ГСК костного мозга человека (рис. 65).

Спустя 48 ч в обеих сочетанных культурах на фоне флуоресценции опухолевых клеток, окрашенных CMTPX Red $(\lambda=546 \mathrm{~nm}-$ красная метка), и адгезировавших к ним ГСК, окрашенных CFDA ( $\lambda=488 \mathrm{~nm}$ - зеленая метка), стали появляться зеленые флуоресцентные объекты существенно меньшего диаметра, локализованные как на поверхности, так и, вероятно, внутри клеток глиобластомы (рис. 66). 
A

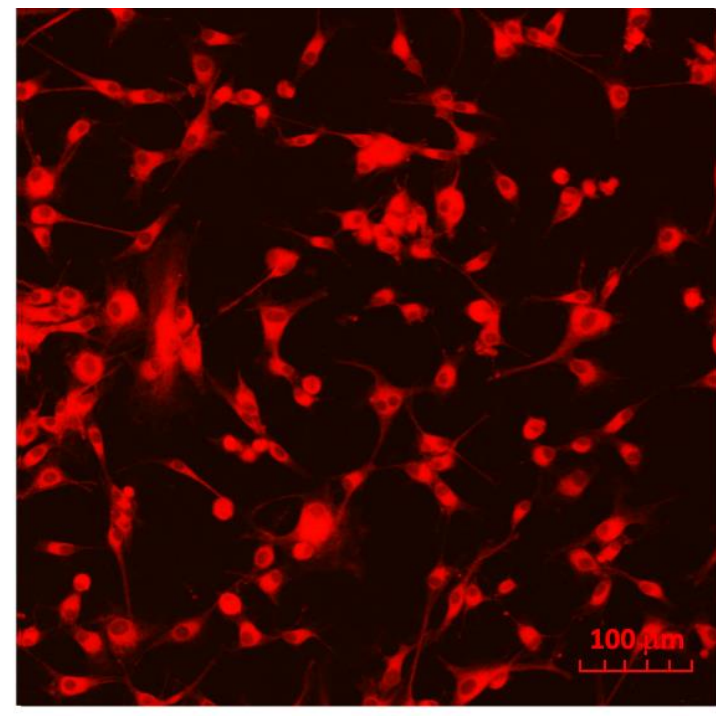

$\mathrm{B}$

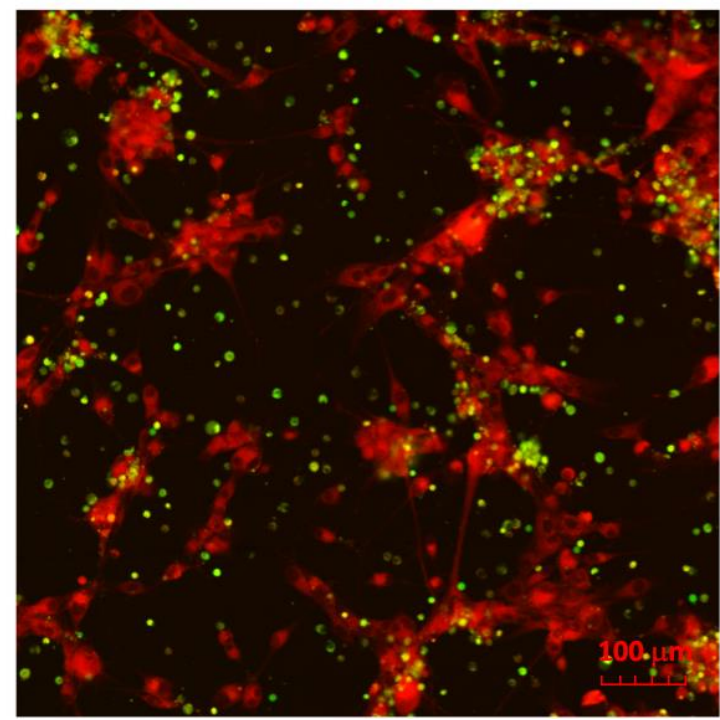

Б

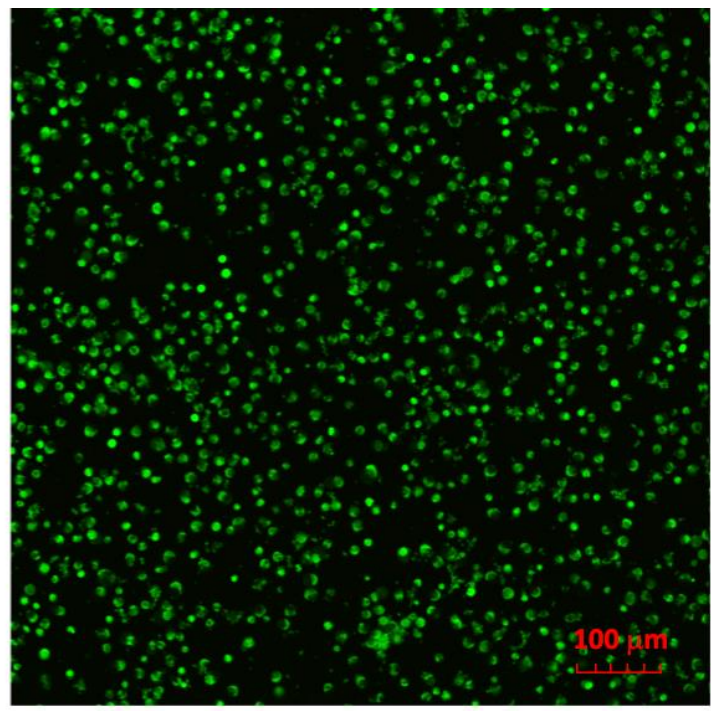

$\Gamma$

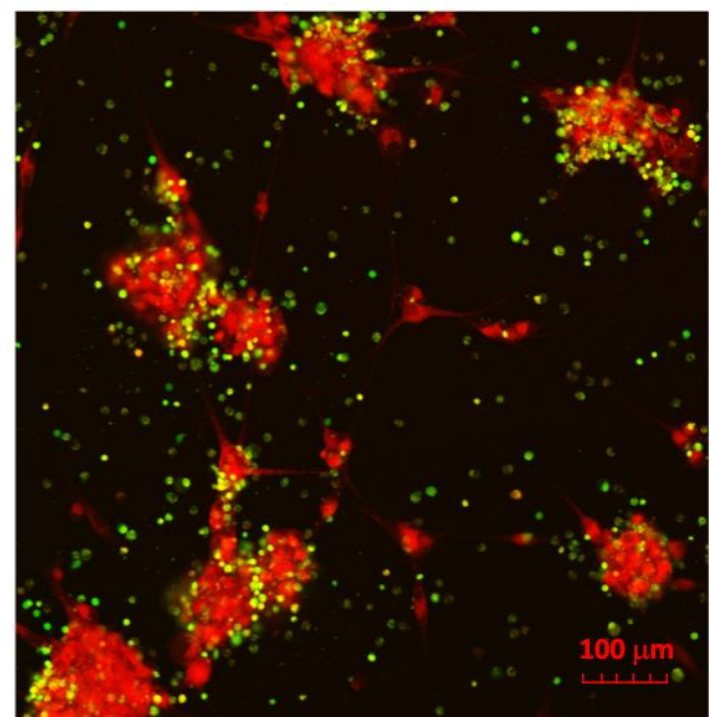

Puc. 65. Клеточные культуры, использованные в эксперименте in vitro, 48 ч.

Клетки глиобластомы окрашены Red CMTPX ( $\lambda=546$ mm, эксцизия / эмиссия 577/602 nm, красный). Флуоресцентная лазерная микроскопия: А - клетки глиобластомы, контрольная культура; Б - ГСК, контроль, окраска Vybrant® CFDA SE $(\lambda=488$, эксцизия / эмиссия 492/517 nm, зеленый); В - сочетанная культура ГСК

с опухолевыми клетками контрольной группы; Г - сочетанная культура ГСК с опухолевыми клетками агрессивного фенотипа

Через 72 ч в спектре свечения ГСК, адгезировавших к клеткам глиобластомы, начинали преобладать желтые тона (рис. 67), что указывает на пересечение спектров флуоресцентного сигнала, красителей CFDA $(\lambda=$ $488 \mathrm{~nm})$ и СМТРX Red $(\lambda=546 \mathrm{~nm})$.

TGF- $\beta 1$ оказывал влияние как на форму отдельных клеток глиобластомы, так на архитектуру клеточного монослоя, которая под воздействием этого цитокина формировала ячеистую структуру, образованную крупными «распластанными» конгламератами, состоящимим из клеток раз- 
личной формы. Контрольная группа характеризовалась немногочисленным хаотичным образованием конгламератов округлой формы, сформированных веретеновидными клетками.
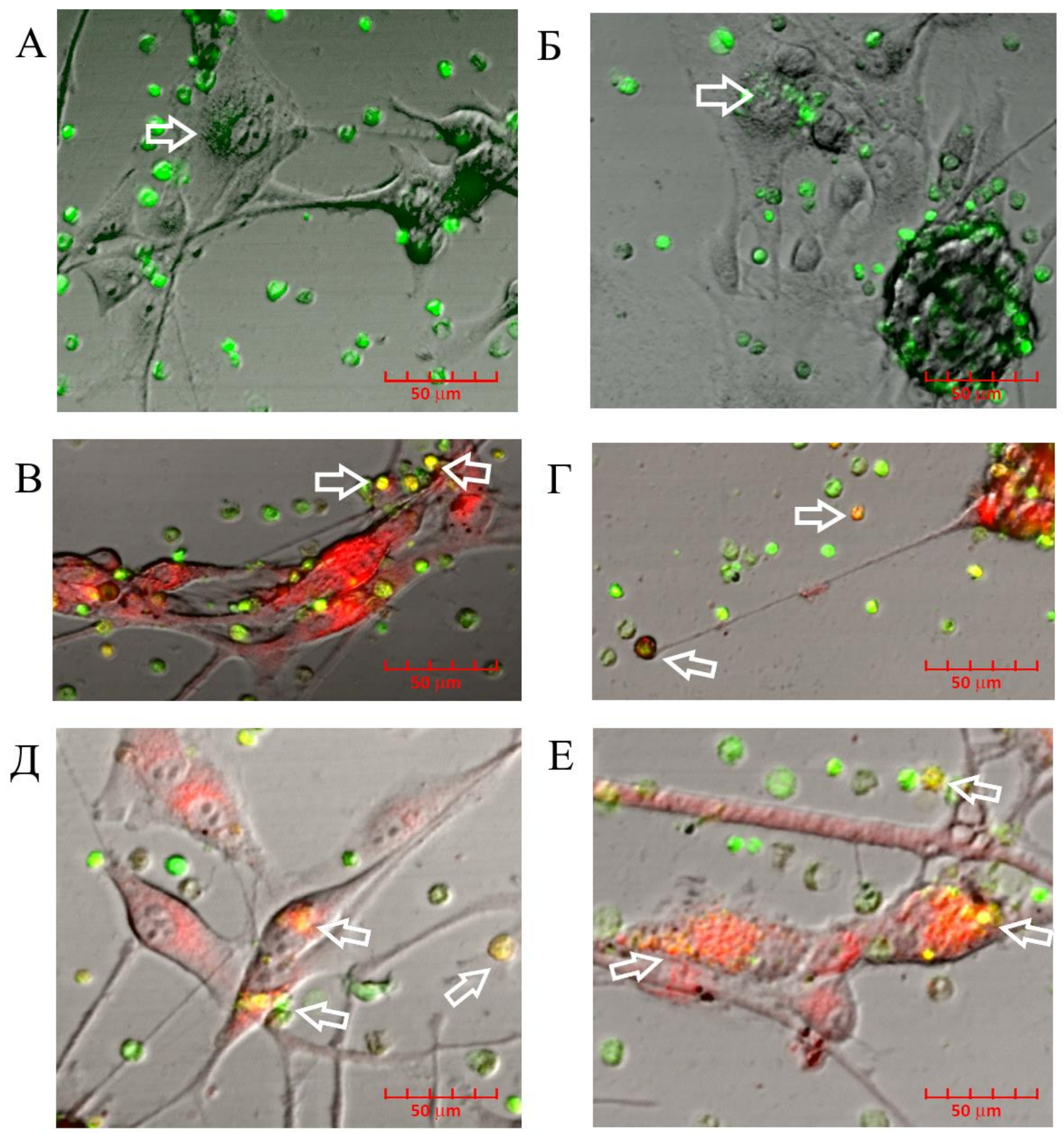

Puc. 66. Сочетанная культура клеток глиобластомы и ГСК. Нормальные ГСК, окраска Vybrant ${ }^{\circledR}$ CFDA SE ( $\lambda=488$, эксцизия/ эмиссия $492 / 517 \mathrm{~nm}$, зеленый). Клетки глиобластомы окрашены Red CMTPX ( $\lambda=546 \mathrm{~nm}$, эксцизия / эмиссия 577/602 nm, красный). Флуоресцентная лазерная микроскопия, Х400. А, В - клетки глиобластомы линии U87 контрольной группы в сочетанной культуре с ГСК; Б, Г - клетки глиобластомы агрессивного фенотипа линии U87 в сочетанной культуре с ГСК; А,

Б - флуоресценция в зеленом спектре. Стрелками указаны клетки, участвующие в обмене флуоресцентными метками 

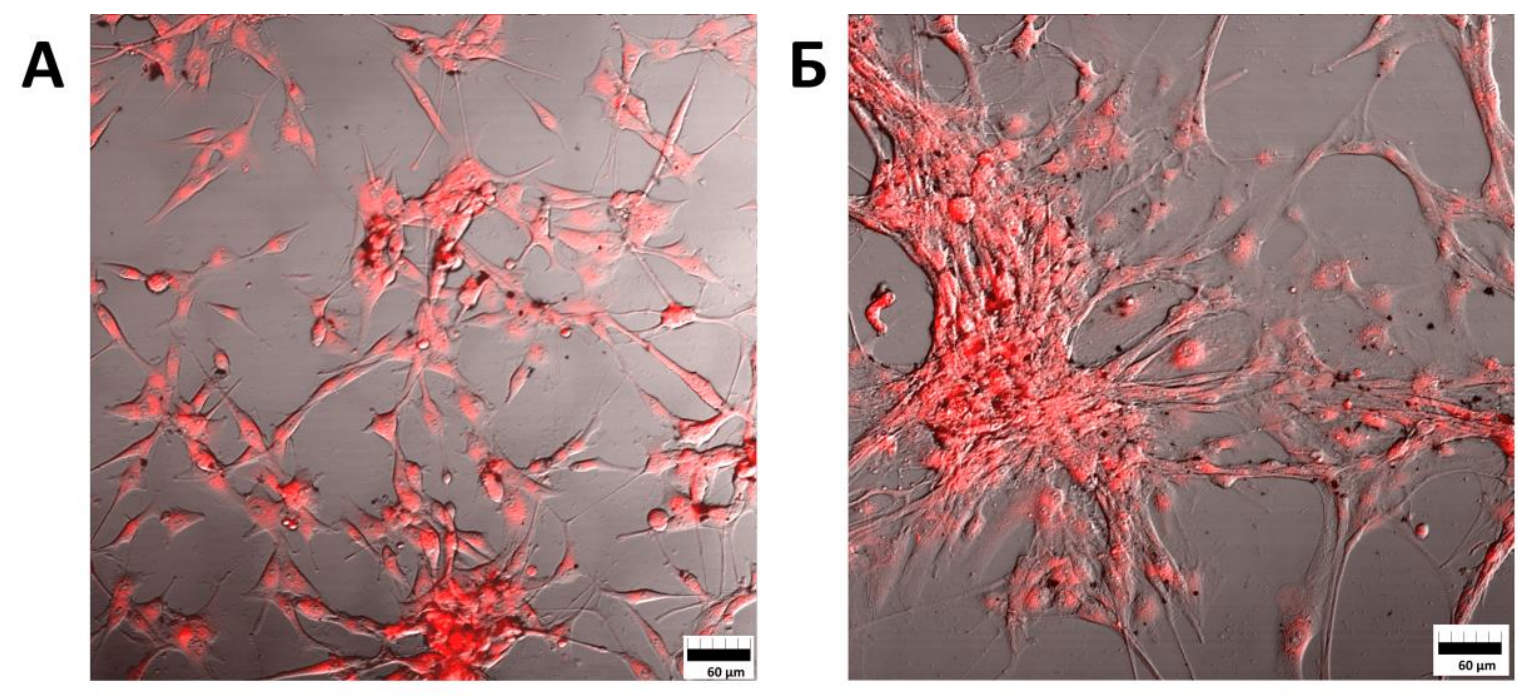

B
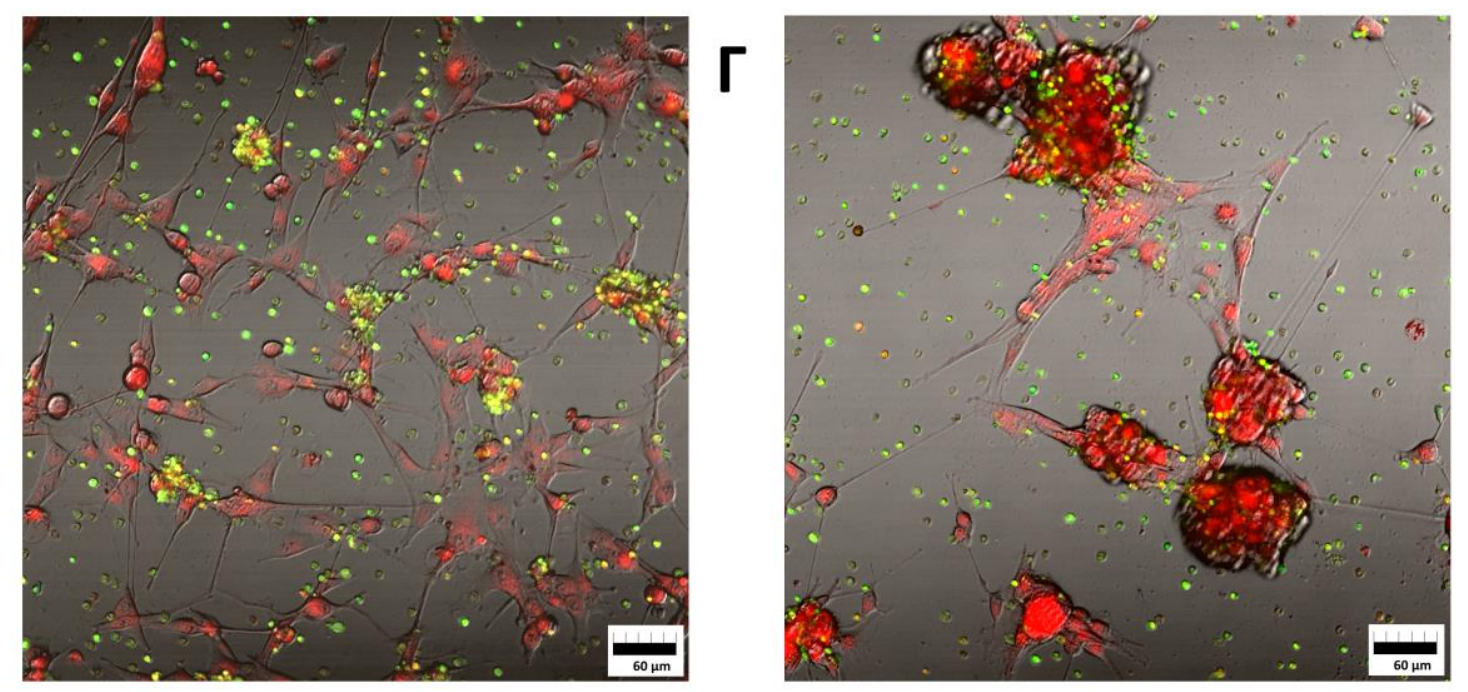

Puc. 67. Сокультура клеток глиобластомы и ГСК. Нормальные ГСК окрашены

Vybrant ${ }^{\circledR}$ CFDA SE ( $\lambda=488$, эксцизия/ эмиссия 492/517 nm, зеленый). Клетки глиобластомы окрашены Red CMTPX ( $\lambda=546$ nm, эксцизия/ эмиссия 577/602 nm, красный). Флуоресцентная лазерная микроскопия, 72 ч эксперимента: A - контрольнь клеток глиобластомы; Б - клетки глиобластомы агрессивного фенотипа линии U87;

B - клетки глиобластомы линии U87 контрольной группы в сочетанной культуре с ГСК; Г - клетки глиобластомы агрессивного фенотипа линии U87 в сочетанной культуре с ГСК

Сокультивирование предобработанных TGF- $\beta 1$ клеток глиобластомы с ГСК приводило к формированию многочисленных плотных конгламератов опухолевых клеток, окруженных ГСК (рис. 68).

По данным проточной цитофлуориметрии, с начала эксперимента отмечено формирование двух монохромных популяций клеток, окрашенных флуоресцентными красителями (Рис. 69). С увеличением времени наблюдения число дубль-позитивных клеток в сочетанной культуре остается постоянным. Спустя 72 ч наблюдений количество дубль-позитивных 
клеток в контрольной сокультуре составляло 93,5 $\pm 11,7 \%$, в сокультуре сравнения $-94,6 \pm 12,2 \%$.
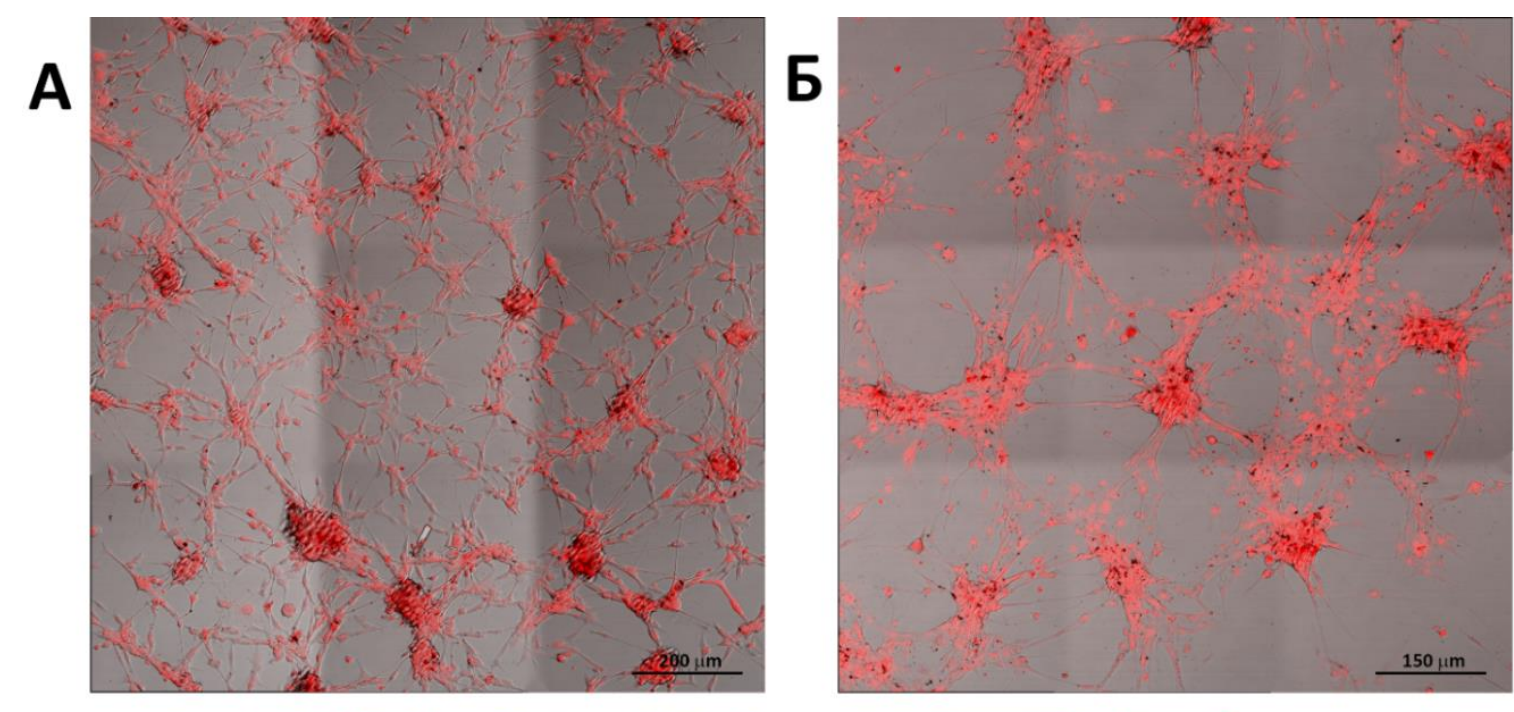

B
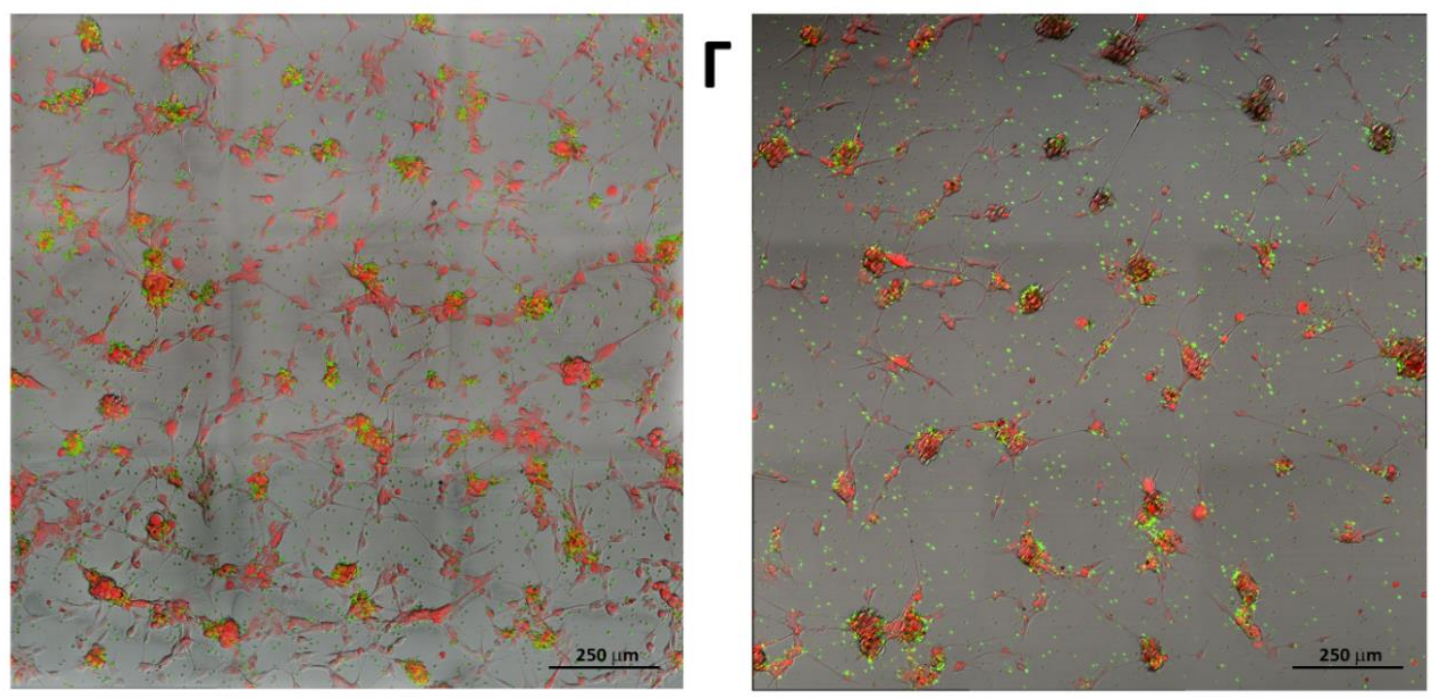

Puc. 68. Сокультура клеток глиобластомы и ГСК, панорамные снимки, состоящие из девяти фотографий, X 200. ГСК окрашены Vybrant ${ }^{\circledR}$ CFDA SE $(\lambda=488$, эксцизия/ эмиссия 492/517 nm, зеленый). Клетки глиобластомы окрашены Red CMTPX ( $\lambda=546 \mathrm{~nm}$, эксцизия/ эмиссия 577/602 nm, красный). 72 ч эксперимента.

Флуоресцентная лазерная микроскопия: А - контроль клеток глиобластомы; Б - клетки линии U87 глиобластомы, предобработанные TGF- $\beta 1$; B - клетки глиобластомы линии U87 контрольной группы в сочетанной культуре с ГСК; Г - клетки глиобластомы агрессивного фенотипа линии U87 в сочетанной культуре с ГСК

Как следует из эксперимента, CD34+CD45+ клетки взаимодействуют с клетками глиобластомы и обмениваются с ними флуоресцентной меткой. Обработка опухолевых клеток TGF- $\beta 1$ не влияет на этот процесс, следовательно, не снижает способности к координированному межклеточному взаимодействию. 


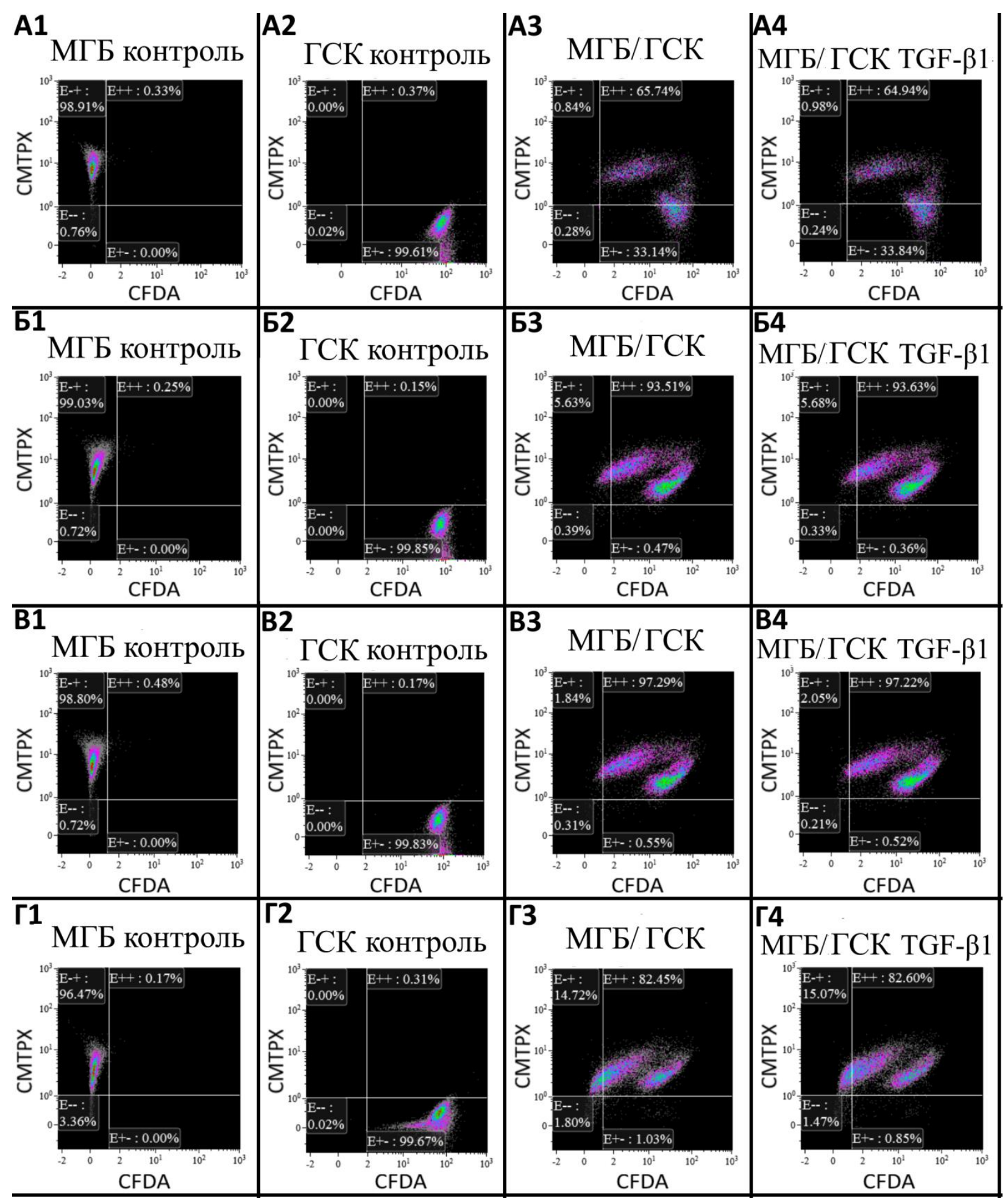

Puc. 69. Гистограммы распределения клеток в культуре глиобластомы, окрашенных красным флуоресцентным красителем с ГСК, окрашенными зеленым флуоресцентным красителем, по данным цитофлуориметрии: А - 24 ч; Б - 48 ч; В - 72 ч; Г - 96 ч. A1, Б1, В1, Г1 - клетки ГСК, окрашенные CellTrackerTM Red CMTPX; A2, Б2, В2, Г2 клетки глиобластомы, окрашенные CFDA SE; A3, Б3, В3, Г3 -культура клеток глиобластомы U87 с ГСК; A4, Б4, В4, Г4 - культура клеток глиобластомы U87 с ГСК в присутствии TGF- $\beta 1$ 
Взаимодействие ГСК с клетками глиобластомы стимулированных 10 нг/мл TGF- $\beta 1$ сопровождалось усилением темпа пролиферации опухолевых клеток до значений, сопоставимых с контрольной группой (рис. 70).

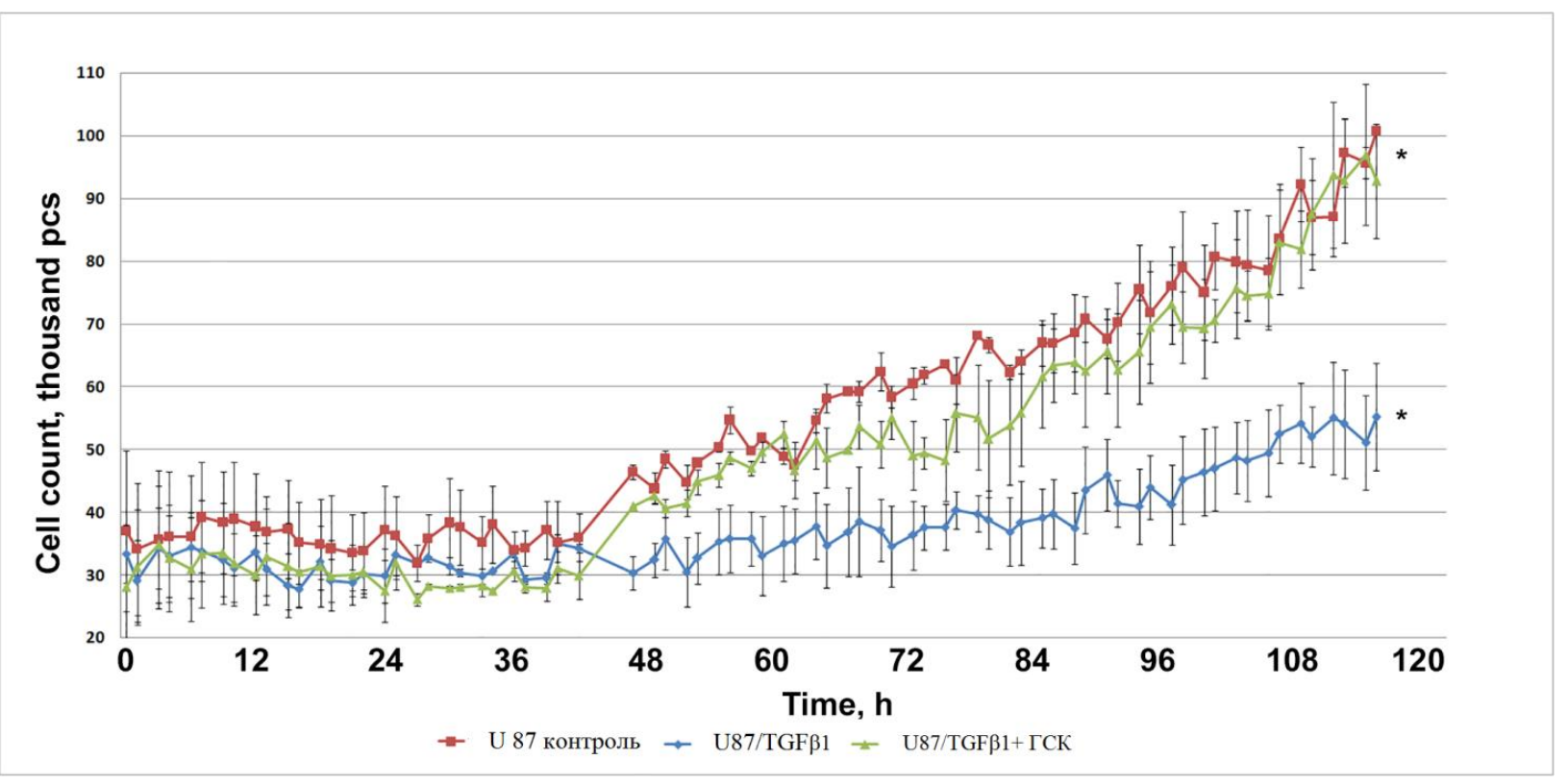

Puc. 70. Динамика роста клеток глиобластомы линии U87 в сочетанной культуре с ГСК. Продолжительность эксперимента - 120 ч. Ошибка первого рода с поправкой на эффект множественных сравнений $<P=0,01<\alpha=0,05 / 4$ по отношению к контролю

Однако выявлено изменение архетиктуры клеточного монослоя и темпов пролиферации опухолевых клеток под воздействием TGF- $\beta 1$ в сочетанной культуре с ГСК, что может свидетельствовать об изменинии взаимодействия опухолевых клеток агрессивного фенотипа с внеклеточным матриксом в присутствии ГСК.

\subsection{2. Разработка методов повышения эффективности взаимодействия ГСК с клетками глиобластомы, предобработанными TGF-ß1 in vitro}

Для проведения эксперимента сформированы два образца, содержащих $10^{4}$ мононуклеарных ККМ человека, 1,8\% которых были иммунопозитивны к антигену CD34, что позволяет считать их ГСК. Первый образец был контрольным, второй образец - 24 ч, инкубировали в среде DMEM, полученной после культивирования клеток МГБ $\left(\mathrm{t} 37^{\circ} \mathrm{C}\right)$ и содержащей $0,01 \mathrm{ng} / \mathrm{mL}$ человеческого интерферона- $\gamma$ (кат. № I3265, Sigma-Aldrich) и $100 \mathrm{ng} / \mathrm{mL}$ липополисахарида Escherichia coli (кат. № O111:B4, SigmaAldrich). Далее контрольные и предварительно обработанные ККМ вно- 
стили в культуру клеток МГБ, предварительно предобработанных TGF- $\beta 1$ (10 нг/мл). Соотношение клеток в сочетанной культуре 1:1. Оценивали скорость пролиферации опухолевых клеток и скорость зарастания царапины в клеточном монослое (рис. 71).
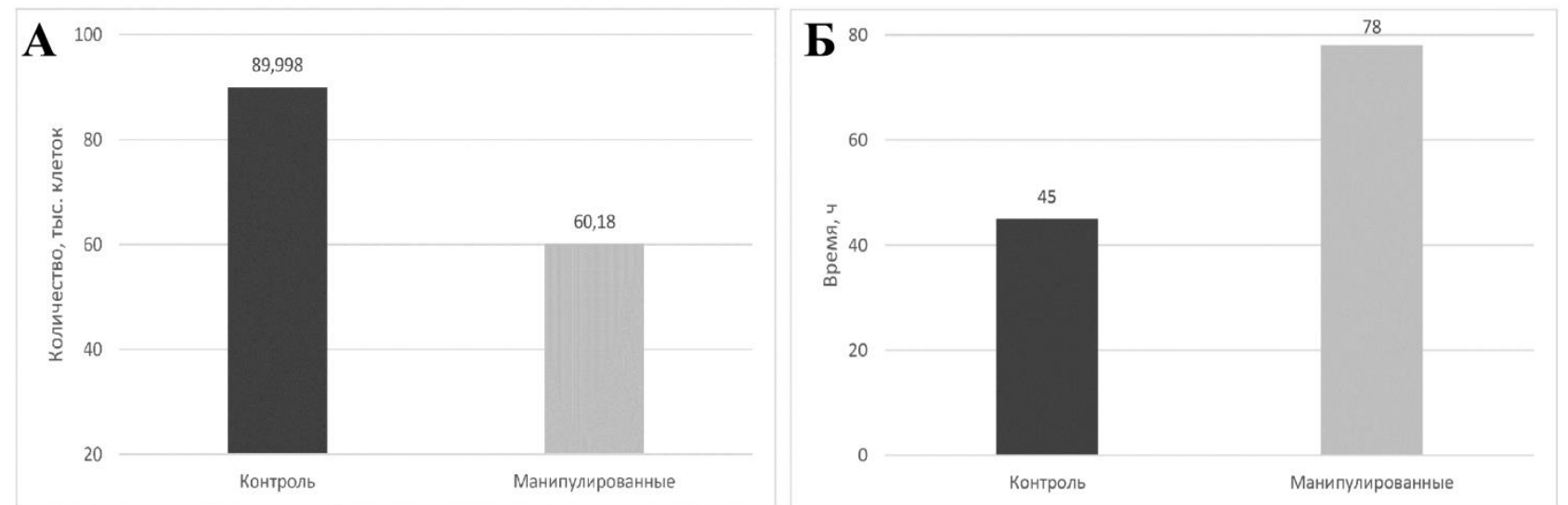

Puc. 71. Скорость пролиферации опухолевых клеток in vitro (A) и время «зарастания царапины» в клеточном монослое (Б) при совместном культивировании контрольных и манипулированных ГСК с клетками глиобластомы, предобработанными TGF- $\beta 1$

Таким образом, мононуклеарные CD45+ KKM, обогащенные ГСК, взаимодействуют с клетками МГБ и обмениваются флуоресцентными метками. Обработка опухолевых клеток TGF- $\beta 1$ не влияет на этот процесс и не снижает способности ККМ к координированному взаимодействию с ОК. В результате взаимодействия ГСК с клетками МГБ, стимулированными 10 нг/мл TGF- $\beta 1$, наблюдается усиление темпа пролиферации ОК до значений, сопоставимых с контрольной группой. Предварительная провоспалительная модификация повышает противоопухолевый потенциал ККМ, что проявляется снижением темпов пролиферации клеток МГБ и уменьшением их подвижности. 


\begin{tabular}{cc}
\hline \multirow{2}{*}{ ТРАНСФОРМИРУЮЩИЙ ФАКТОР РОСТА $\beta$} \\
В ПРОЦЕССАХ ВЗАИМОДЕЙСТВИЯ \\
ГЕМОПОЭТИЧЕСКИ СТВОЛОВЫХ \\
ГЕ \\
И ОПУХОЛЕВЫХ КЛЕТОК IN VIVО \\
\hline
\end{tabular}

\section{1. Материалы и методы проведения иследования}

Эксперимент выполнен на животных с перевитой глиальной опухолью головного мозга. В работе использована экспериментальная модель глиобластомы, описанная в п. 7.1. Животные были разделены на пять групп: 1) контрольная группа $(\mathrm{N}=60) ; 2)$ группа крыс $(\mathrm{N}=30)$, получавших гранулоцитарный колониестимулирующий фактор для иммобилизации мононуклеарных CD45+ ККМ в кровоток (группа «Г-КСФ»). Методика рекрутирования ГСК идентична описанной ранее; 3) группа крыс $(\mathrm{N}=30)$, которым проводили провоспалительную терапию для запуска системной воспалительной реакции путем введения бактериального липополисахарида (LPS) и интерферона- $\gamma$ (IFN $\gamma$ ) (группа «proinflamation therapy», «РТ»); 4) крысы (N = 30), получившие стимуляцию Г-КСФ, с последующей провоспалительной терапией (группа «Г-КСФ+РТ»).

Провоспалительная терапия. Для запуска системной воспалительной реакции крысы в течение семи дней получали внутрибрюшинно 0,5 мл смеси, содержащей липополисахарид E.coli 0,5 мг/кг (серотип O111:B4cat. кат. № L2630 Sigma-Aldrich, Saint Louis, MO, США), и $5 \mu \mathrm{g}$ рекомбинантного крысиного интерферона- $\gamma$ (кат. № I3275 Sigma-Aldrich, Saint Louis, MO, US).

Морфологическое исследование. Ткань мозга крысы получали после декапитации животных. Материал разделяли на две части: одну часть материала использовали для проведения морфологического и иммуногистохимического исследования, вторую часть материала использовали для оценки содержания цитокинов в ткани мозга по описанной ниже методике. Материал для морфологического и иммуногистохимического исследований фиксировали (4\% ПФА) в течение 12 ч с последующей промывкой PBS. Парафиновые срезы головного мозга толщиной 7 мкм депарафинировали и окрашивали гематоксилин-эозином по стандартной методике. Все использованные реагенты - производства компании Sigma-Aldrich (Saint Louis, MO, США).

Иммуногистохимическое исследование. Исследование выполнено по стандартной методике. Первичные антитела против микро- 
глии/макрофаг-специфического белка IBA1 (ab107159), пролиферирующих клеток ядерного антигена PCNA (ab 29) и мембранного белка антиген-представляющих клеток CD86 (ab213044) использованы в соответствии с инструкциями производителя - компании "Аbcam" (США). Вторичные антитела, меченые пероксидазой хрена PI-1000 (anti-rabbit), PI2000 (anti-mouse) использовали в соответствии с инструкциями производителя - компании "Vector Laboratories". Для иммунопероксидазной реакции использовали хромоген «Vector® ${ }^{\circledR}$ NovaRED ${ }^{\circledR}$ Substrate Kit» (Vector Laboratories; SK-4800). Срезы отмывали 0,1 M PBS, обезвоживали, заключали в бальзам и изучали, используя AxioScope A1 (Carl Zeiss, Германия).

Иммуноферментный анализ. Твердофазный иммуноферментный анализ (ИФА) ткани мозга на содержание IL-1 (ab100768), IL-10 (ab100765), TNF $\alpha$ (ab100747) и TGF- $\beta 1$ (ab119558) выполнен с использованием коммерческих наборов фирмы "Аbcam" (США). Мозг крыс извлекали и немедленно замораживали в жидком азоте при $-70{ }^{\circ} \mathrm{C}$. Для анализа брали ткань глиомы с захватом вещества мозга в пределах 5 мм от края. Гомогенаты ткани готовили с использованием буфера: сахароза 0,25 M, Трис-HCl 0,01 М, ЭДТА 0,001 M, HEPES 0,01. Все реагенты - производства компании "Sigma-Aldrich" (Saint Louis, MO, США). Лизирующий буфер добавляли из расчета 5 мл на 1 мг ткани, проводили гомогенизацию ткани, центрифугирование и отбор надосадочной жидкости для анализа. Содержание белка определяли с использованием коммерческого набора «Pierce BCA Protein Assay Kit» (Thermo Scientific). Определение оптической плотности производили при длине волны 450 нм на планшетном спектрофотометре (BioRad xMark).

\section{2. Результаты}

Имплантация клеток глиомы приводила к формированию опухоли, что сопровождалось отеком и деформацией мозговых структур, сглаженностью основных борозд и извилин. Морфологические изменения в мозге контрольных крысс с глиомой С6 соответствовали описанным выше.

На 14-й день наблюдений ткань глиомы была представлена скоплением клеток, формирующих многочисленные кровеносные сосуды, вокруг которых клетки глиомы формировали плотные конгломераты в виде «розеток», ограниченных на периферии очагами некроза. Опухоль характеризовалась высокими темпами пролиферации. PCNA + клетки 
были сосредоточены в опухоли и равномерно распределены в прилежащем к ней веществе мозга, где формировали сателлитные очаги, окруженные плотными скоплениями GFAP+ клеток звездчатой формы с многочисленными отростками. В свою очередь, скопления клеток, иммунореактивных в отношении микроглии/макрофаг-специфического белка IBA1, выявлялись как в ткани опухоли, так и в прилежащем веществе мозга (рис. 25, глава 5)

К 28-му дню основное место в картине глиомы занимали обширные зоны некроза, содержавшие запустевшие микрососуды и немногочисленные клеточные элементы (рис. 24, глава 5). Отмечалось резкое снижение темпа пролиферативных процессов, при этом архитектура реакции астроцитарной глии не претерпела значимых изменений. Количество IBA1+ клеток в области опухолевого узла уменьшалось, образовав уплотнения вдоль границ опухолевого очага. Снижение темпов пролиферации и числа клеток микроглии на фоне интенсивных процессов некроза в центре опухолевого узла сопровождалось увеличением содержания TGF- $\beta 1$ в мозговой ткани. В свете сказанного срок 28 дней был выбран нами в качестве контрольной точки эксперимента (рис. 72).

Стимуляция Г-КСФ крыс II и IV групп с 20 по 27 день сопровождалась увеличением доли CD45+ клеток в общем числе лимфоцитов, рекрутированных в кровеносное русло. При этом среди клеток костного мозга, иммунопозитивных в отношении мембранного антигена CD45, количество HSC-like cells (ГСК-подобные клетки) к 7-м суткам эксперимента критически возросло.

На 28-й день эксперимента у этих животных отмечено значимое увеличение числа PCNA+ клеток в опухоли по сравнению с контролем и группой крыс, получавших только РТ (группа III). Некоторое усиление пролиферации сочеталось с увеличением площади окрашивания узла глиомы антителами против белка микроглии / макрофагов IBA1 (рис. 73).

К 28-му дню наблюдений опухолевой ткани крыс группы II, получивших только стимуляцию костного мозга Г-КСФ, возрастала плотность группиовки IBA1+ клеток как в опухолевой ткани, так и в прилежащем к ней веществе мозга. В противовес «распластанной», звездчатой или кляксообразной форме IBA+ клеток, отмеченных на 14-й день эксперимента в прилежащей ткани мозга, на 28-й день мы наблюдали IBA1+ клетки округлой формы с очень короткими отросткаими. 
Отношение общей площади некроза к общей площади препарата

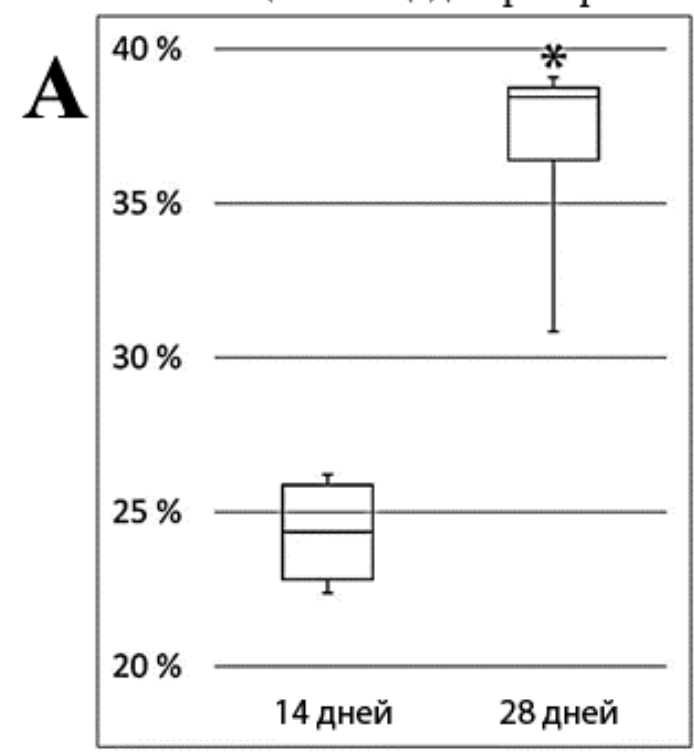

Количество клеток микроглии в экспериментальных образцах

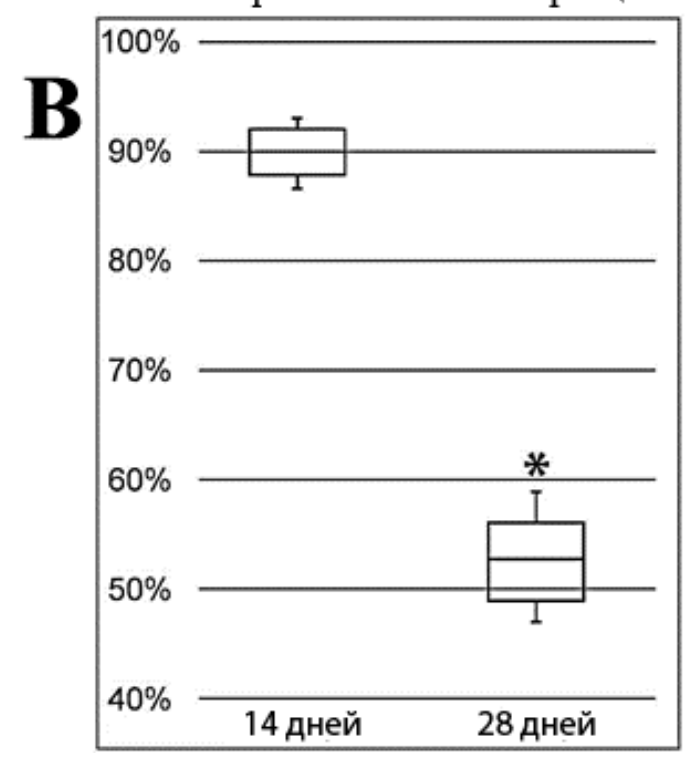

количество PCNA+ клеток в единице площади препарата

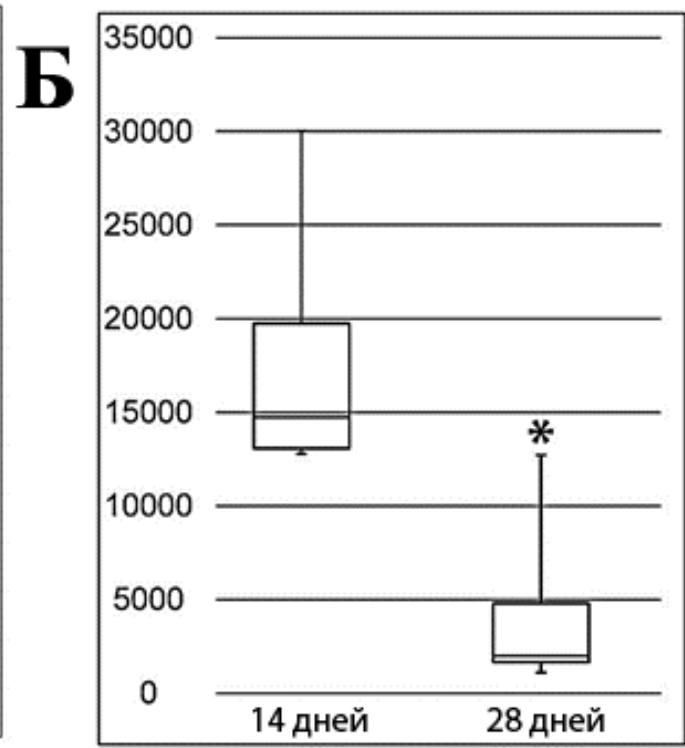

Содержание TGF- $\beta 1$ в культуре

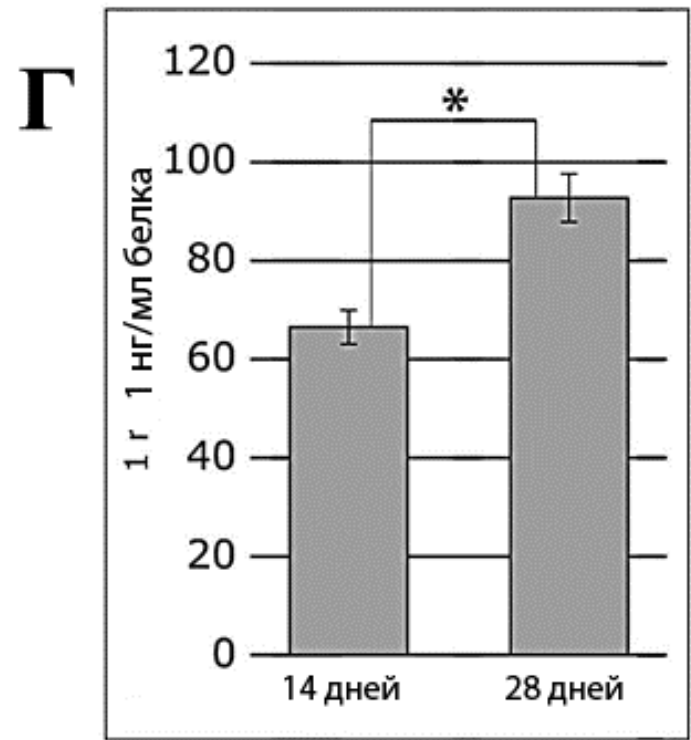

Puc. 72. Динамика морфологических и иммуногистохимических трансформаций опухолевой ткани в мозге крыс контрольной группы с 14 по 28 сутки эксперимента:

А - рост площади некрозов; Б - уменьшение числа пролиферирующих клеток в единице площади препарата; В - уменьшение площади окрашивания антителами против белка микроглии IBA1; Г - увеличение синтеза TGF- $\beta 1$

Картину, аналогичную описанной выше, мы наблюдали как у животных III группы, получивших только провоспалительную терапию, так и у крыс IV группы, получивших Г-КСФ+ IFN $\gamma+$ ЛПС. Принципиальным отличием у последних было только существенно большее количество клеток микроглии в опухолевой ткани крыс IV группы (рис. 74). 

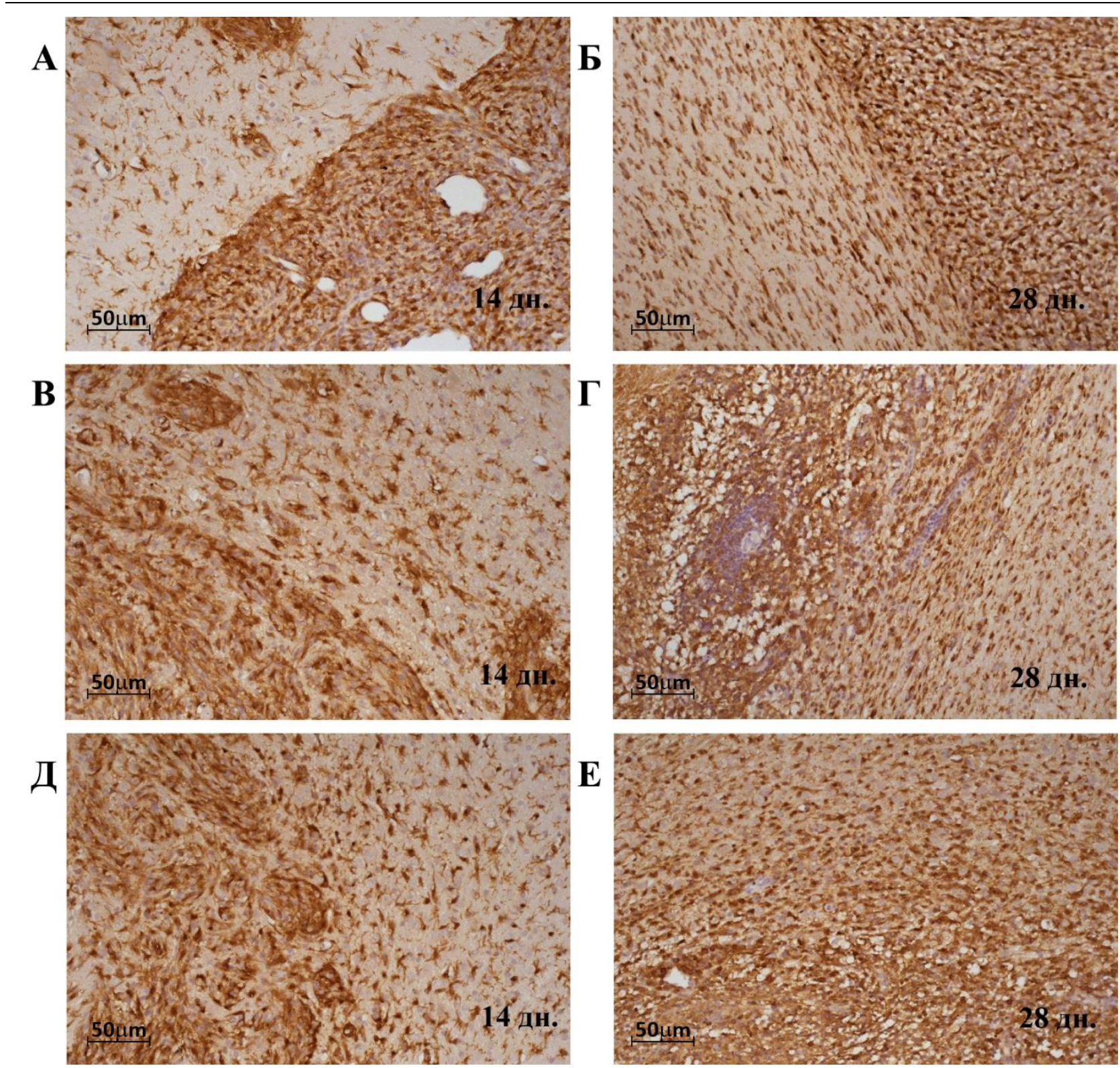

Puc. 73. Неопластическая ткань в мозге крыс с глиомой С6. Окраска антителами против

белка микроглии / макрофагов IBA1: А и Б - группа II, только стимуляция Г-КСФ; В и Г - группа III, только провоспалительная терапия IFN $\gamma+$ ЛПC; Д и Е - группа IV, стимуляция Г-КСФ+ IFN $\gamma+$ ЛПС

Исключительно важно, что увеличение колличества клеток микроглии в опухолевой ткани и веществе мозга, непосредственно прилежащем к опухолевому очагу, у животных II-IV групп сопровождалось поляризацией популяции микроглиоцитов и увеличением в их составе клеток, иммунореактивных в отношении антигена CD86, к 28-му дню эксперимента.

Колличество CD86-иммунореактивных элементов в опухоли и прилежащей к ней ткани мозга у животных I контрольной группы уменьшилось к 28-му дню эксперимента (рис. 75). Они были локализованы среди дистрофически измененного мозгового вещества, усеянного неопластиче- 
скими клетками. В группах II и IV наблюдалась обратная динамика: колличество CD86+ клеток возрастало, более того, отмечалась тенденция к их группировке на границе опухолевой ткани, преимущественно в зоне инвазии, что совпадало с участками локализации мигрировавших сюда мононуклеарных CD45+ клеток костного мозга.

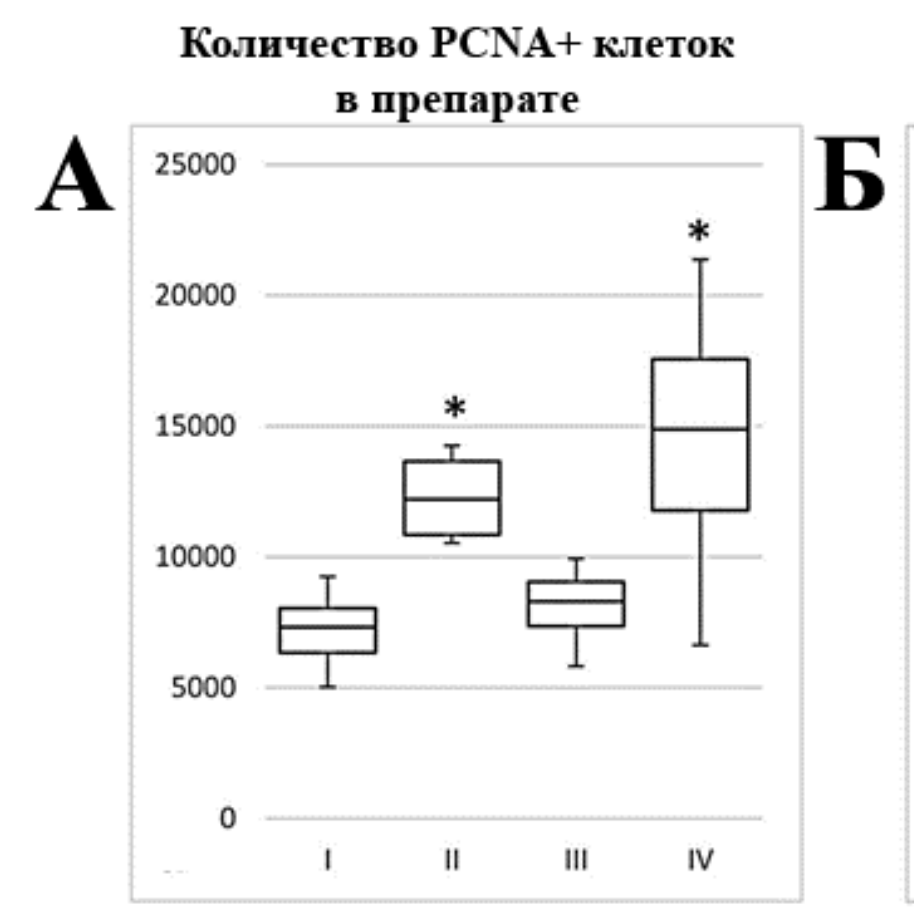

Количество М1 микроглии в опухоли

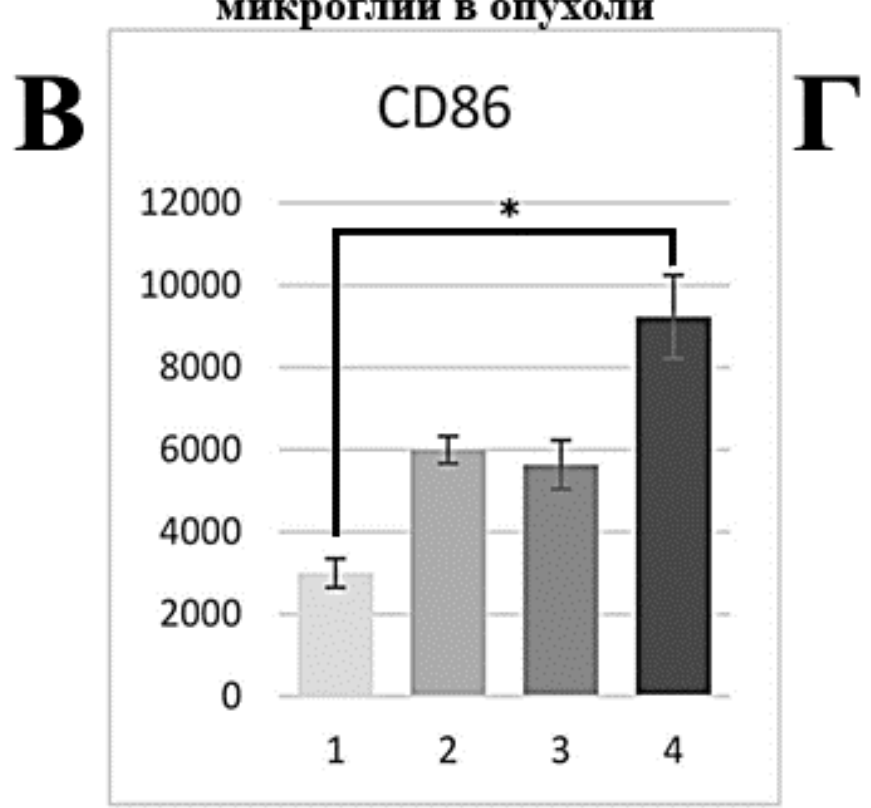

Количество клеток микроглии в препарате

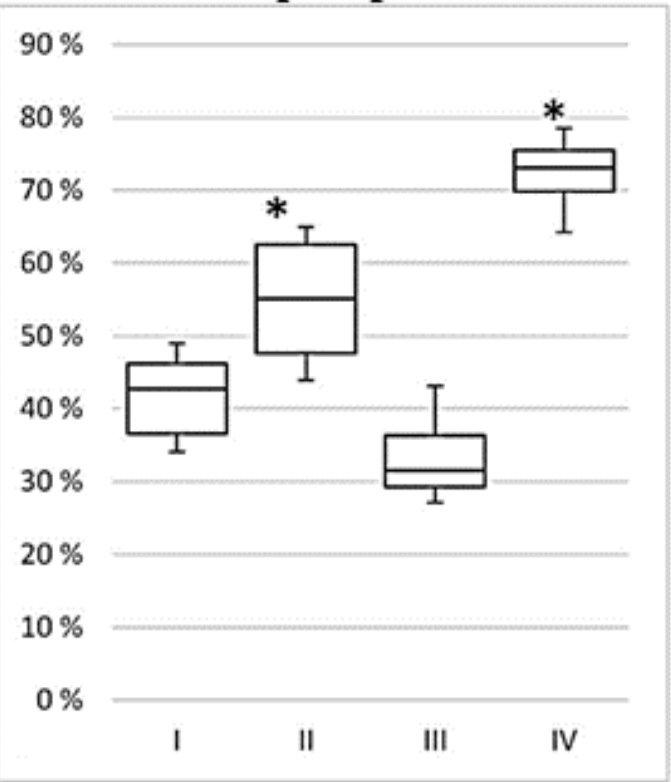

Количество М2 микроглии в опухоли

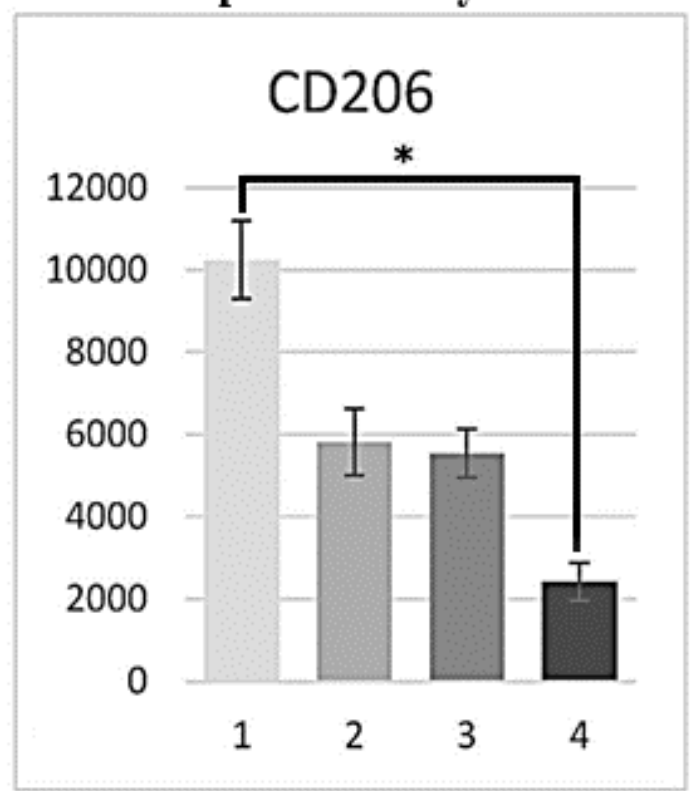

Puc. 74. Динамика морфологических и иммуногистохимических трансформаций опухолевой ткани в мозге крыс сравниваемых групп на 28-е сутки эксперимента: A - увеличение числа пролиферирующих клеток и площади окрашивания антителами против IBA+ клеток микроглии (Б) у крыс II и IV групп; В - уменьшение числа клеток CD86+ и количества CD 206+ элементов 
У животных III группы, получавших провоспалительную терапию и у животных IV группы, где введение Г-КСФ сочеталось с провоспалительной стимуляцией (рис. 75), CD86+ элементы были представлены клетками звездчатой или полигональной формы, крупным телом и очень короткими отростками, контактирующими друг с другом.

Напротив, клетки, иммунопозитивные в отношении 1-го типа маннозного рецептора C - антигена CD206, указывающего на принадлежность макрофагов к М2 фенотипу, в большом количестве выявлялись в опухоли и прилежащей к опухолевому очагу ткани мозга у крыс контрольной группы как на 14-й, так и на 28 день наблюдения (рис. 76 и 77). Их количество несколько снижалось у крыс II группы, получавших Г-КСФ, и группы III, получивших провоспалительную терапию, и было минимальным в группе IV.

Иммуноферментный анализ выявил значительные различия в уровне ключевых про- и противовоспалительных цитокинов у крыс экспериментальных групп. К 28-му дню эксперимента у крыс контрольной группы содержание противовоспалительных цитокинов TGF- $\beta 1$ и IL-10 в опухоли и прилежащей ткани мозга было максимальным (рис. 78, А, Б). В группах II (Г-КСФ) и III (РТ) содержание этих цитокинов достоверно снижалось и достигало минимума у крыс группы IV (G-CSF + PT). Подобный эффект сопровождался резким повышением содержания провоспалительных цитокинов TNF $\alpha$ и IL-1 у животных этой группы (рис. 78, В, Г).

Провоспалительная модификация неопластического очага сопровождалась значимым изменением морфологической картины неопластического процесса, что было особенно заметно при окраске опухолевой ткани антителами против одного из ключевых маркеров эпителиально-мезенхимального перехода - виментина. У крыс I (контрольной) группы виментинпозитивные клетки активно выявлялись в опухолевой ткани (Рис. 79).

К 14-й недели эксперимента у крыс контрольной группы клетки, продуцирующие виментин, были локализованы вдоль границ опухоли (рис. 79, А), откуда многочисленные виментин-позитивные клетки звездчатой и полигональной форм вторгались в вещество мозга (рис. 79, Б), образуя скопления клеточных элементов. У крыс контрольной группы к 28-й неделе эксперимента группировка виментин-позитивных клеток становилась более плотной, клетки округлой и звездчатой форм локализовались в участках мозга, прилежащих к опухоли (рис. 79, В-Г), из которой вторгались в мозговое вещество. 
A

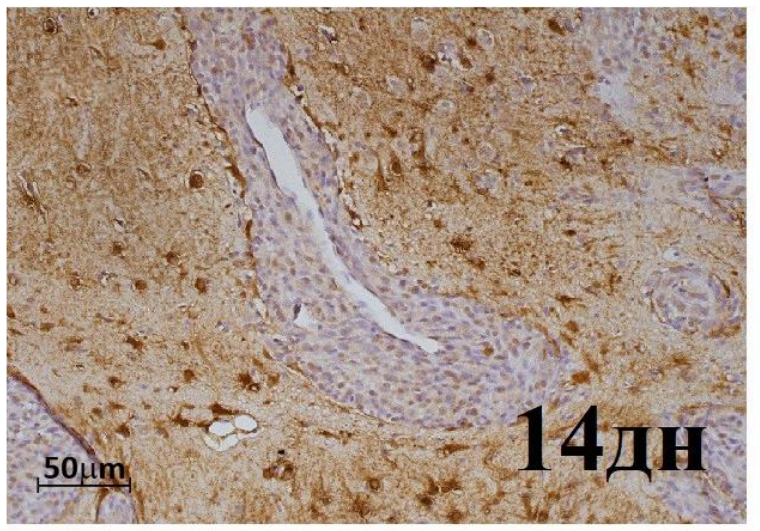

B
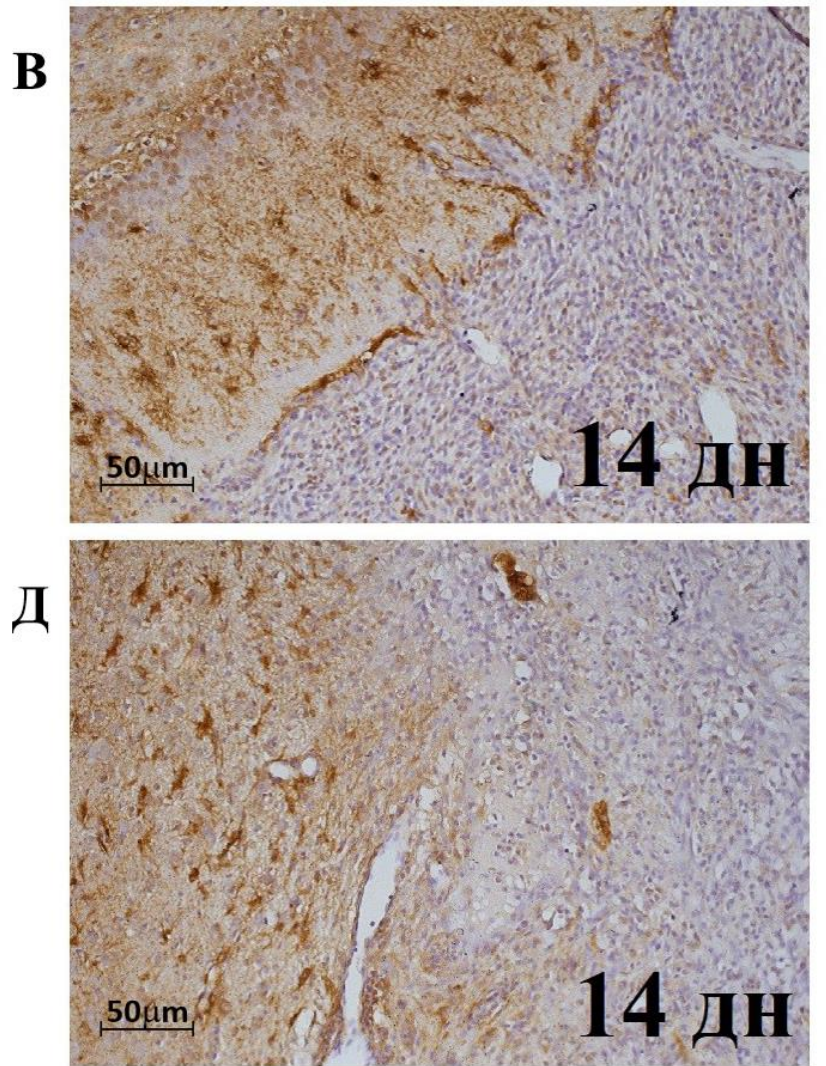

Ж

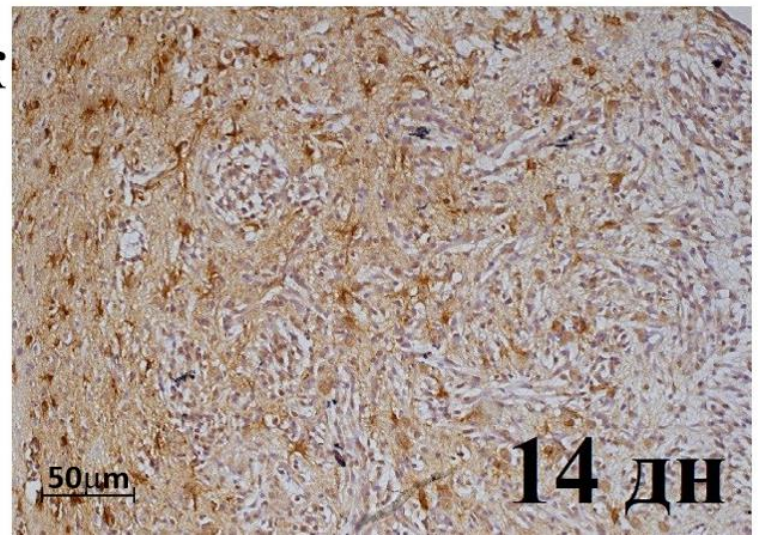

$\mathbf{b}$

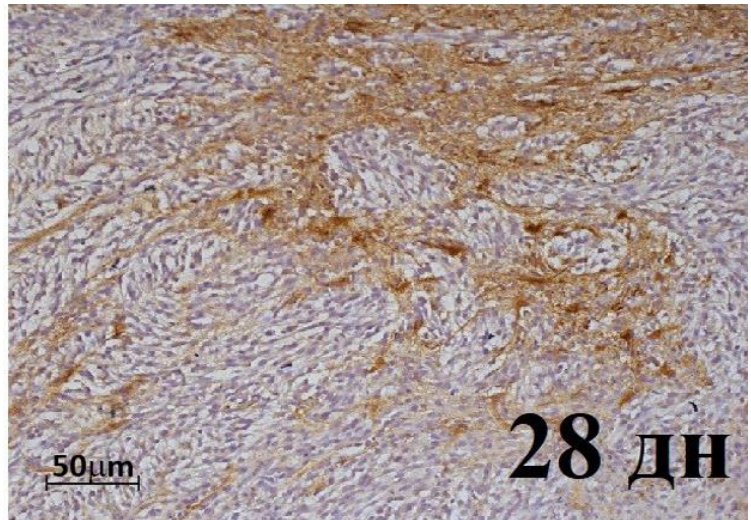

$\Gamma$

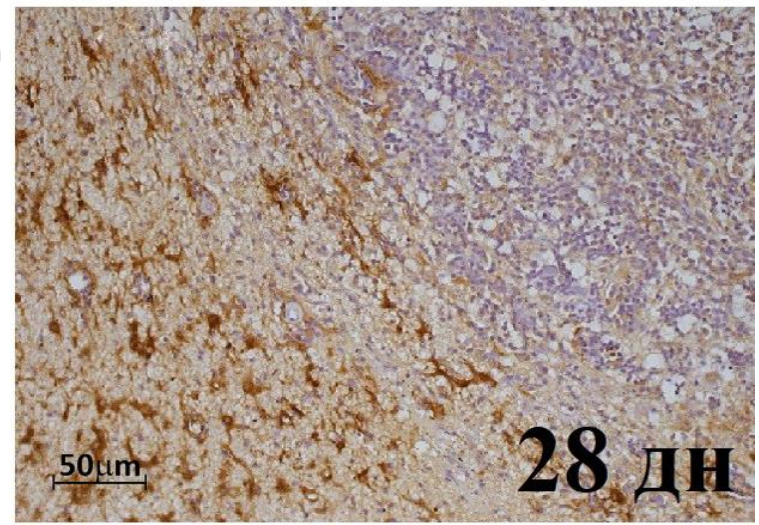

$\mathbf{E}$

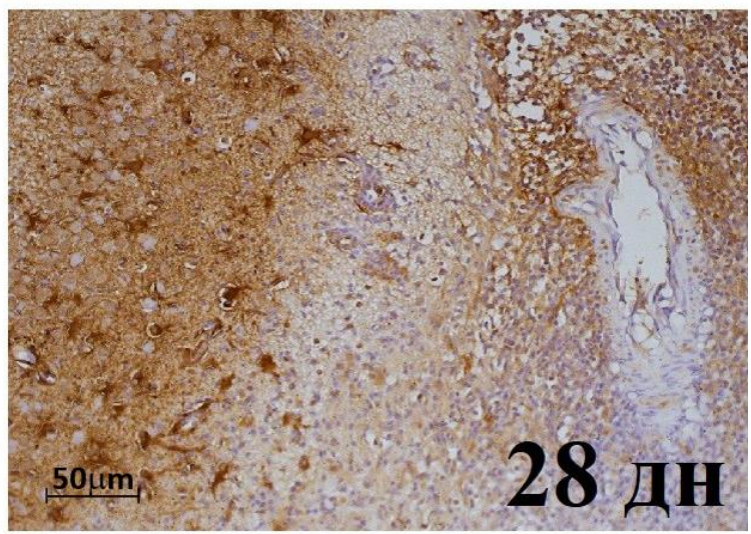

3

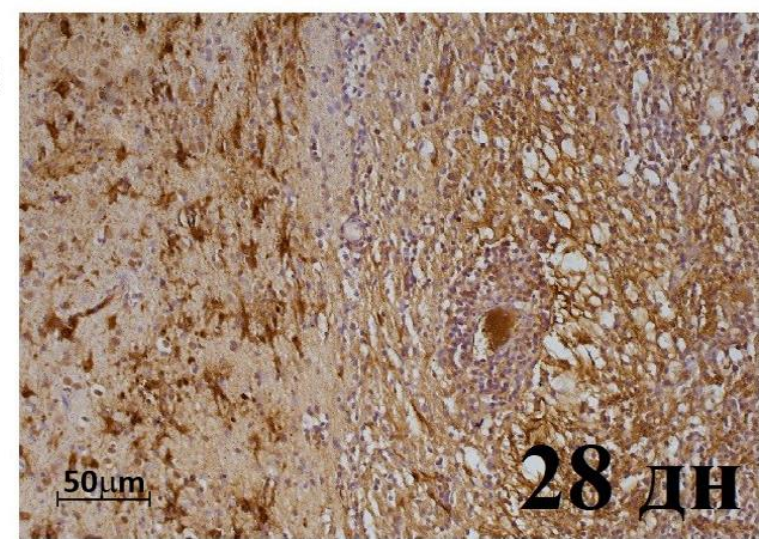

Puc. 75. Опухолевая ткань в мозге крыс с глиомой С6, окраска антителами против CD86 (M1-тип): А и Б - группа I, контрольная; В и Г - группа II, стимуляция Г-КСФ;

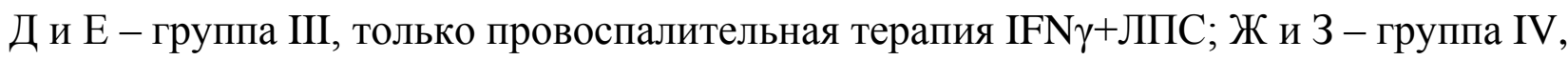

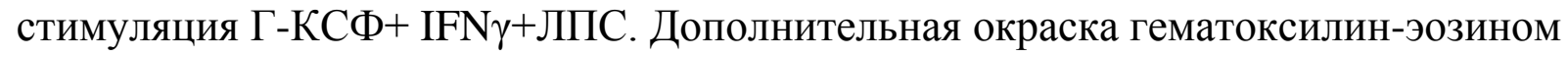




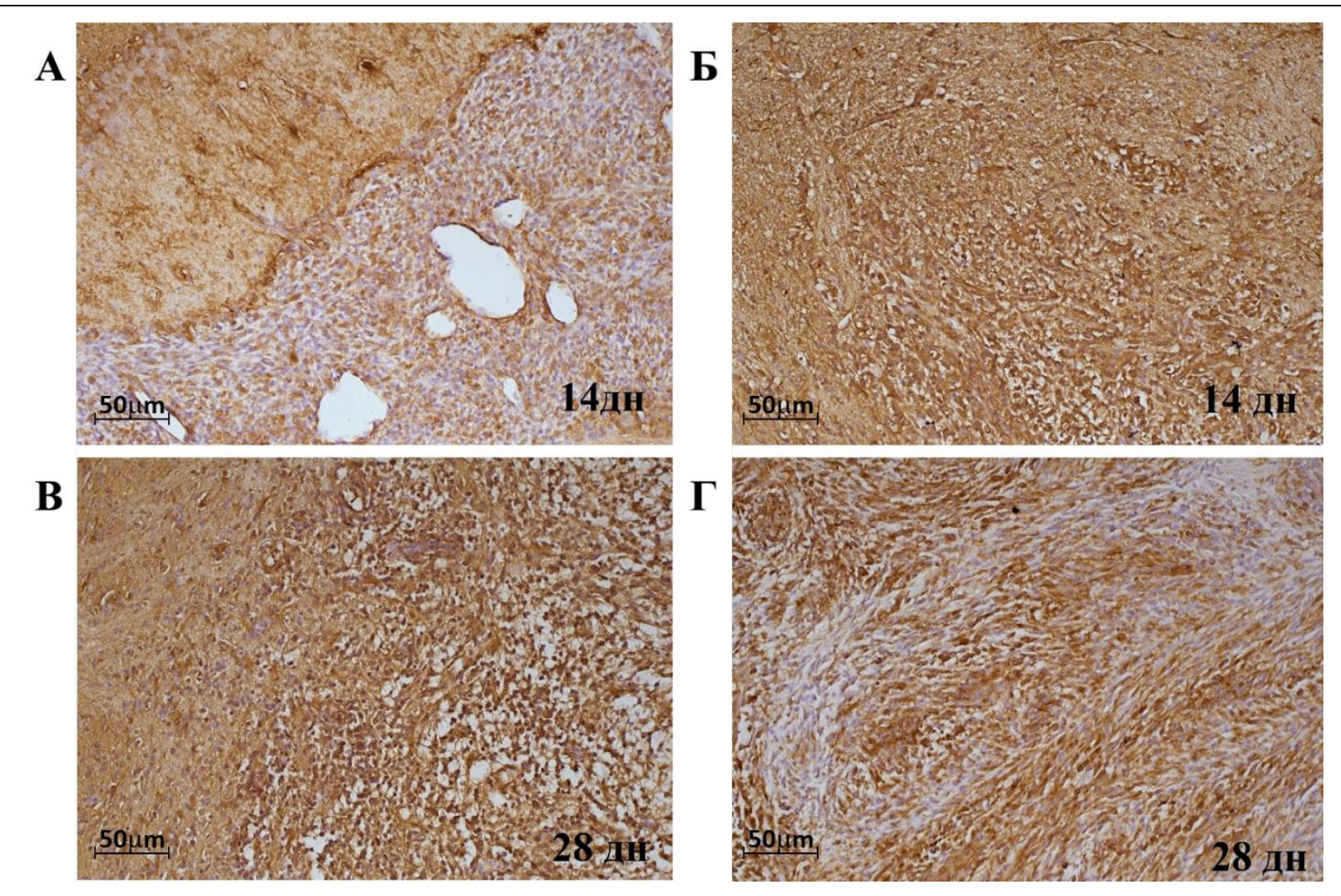

Puc. 76. Неопластическая ткань в мозге крыс с глиомой C6, группа I, контрольная.

Окраска антителами против антигена CD206 - маннозного рецептора C, тип-1, продукта гена MRC1 (противовоспалительный M2 тип); A - край опухоли с прилежащей тканью мозга, 14-е сутки; Б - центр опухолевого узла, 14-е сутки; В - край опухоли с прилежащей тканью мозга, 28-е сутки; Г - центр опухолевого узла, 28-е сутки. Дополнительная окраска гематоксилин-эозином

Картина инвазивного неопластического процесса у животных II-IV групп к 28-му дню наблюдений обнаруживала существенные отличия от контрольной группы (рис. 80).

К 28-му дню наблюдений у всех животных II-IV групп отмечено снижение плотности группировки виментин-позитивных элементов в участках мозга, примыкающих к опухоли. У крыс группы II (Г-КСФ) островковые скопления виментин-позитивных клеток (рис. 80, А, Б) были сосредоточены в прилежащей к опухоли ткани мозга, однако у животных III

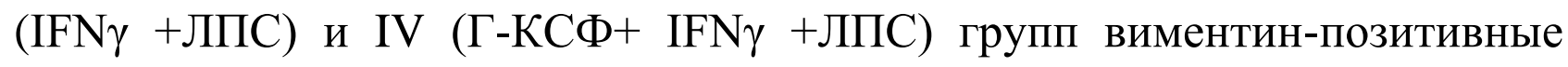
клетки в прилежащей к опухоли ткани мозга всречались существенно реже, при этом граница опухоли становилась более четкой (рис. 80, Д, Е).

Животные всех экспериментальных групп показали повышение показателей выживаемости по сравнению с контрольной группой, од- 
нако наилучшие результаты были зарегистрированы у крыс группы IV (G-CSF+PT) (рис. 81).
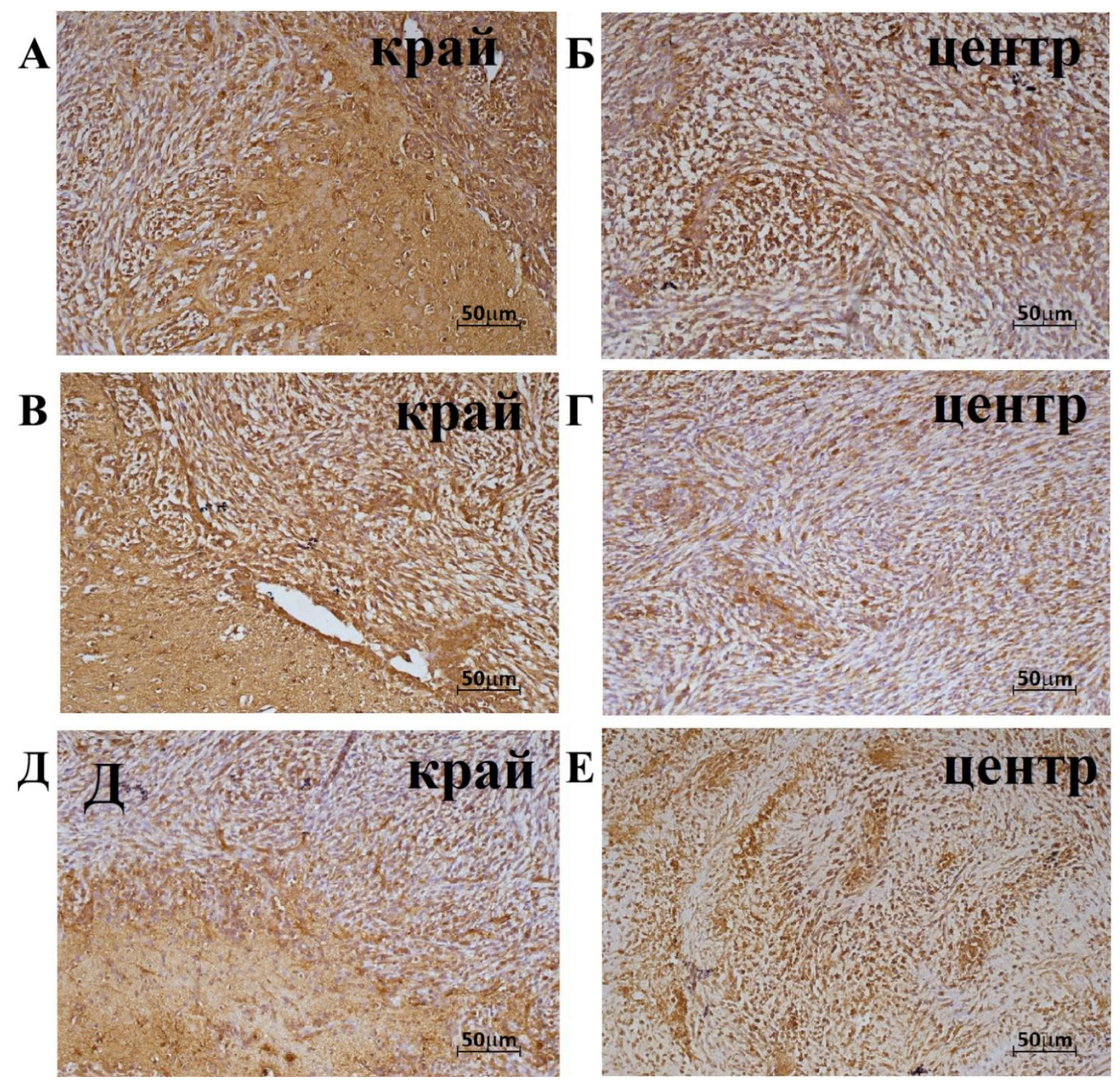

Puc. 77. Неопластическая ткань в мозге крыс с глиомой С6, 28-е сутки эксперимента.

Окраска антителами против антигена CD206 - маннозного рецептора C, тип-1, продукта гена MRC1 (противовоспалительный М2 тип); А и Б - группа II, стимуляция Г-КСФ; В и Г - группа III, провоспалительная терапия IFN- $\gamma+$ ЛПС; Д и Е - группа IV, стимуляция Г-КСФ, IFN $\gamma+$ ЛПС. Дополнительная окраска гематоксилин-эозином 

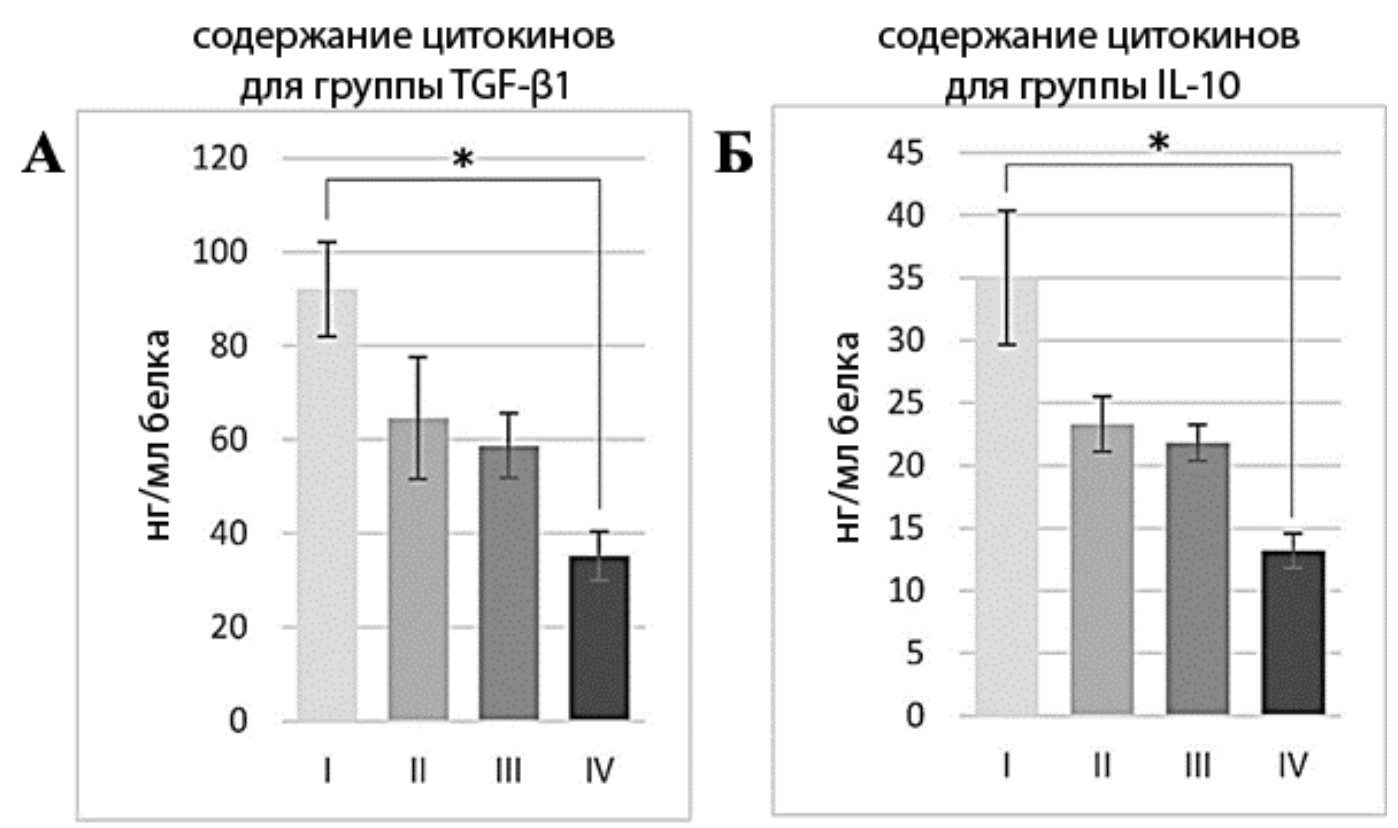

\section{содержание цитокинов}

для группы TNFa
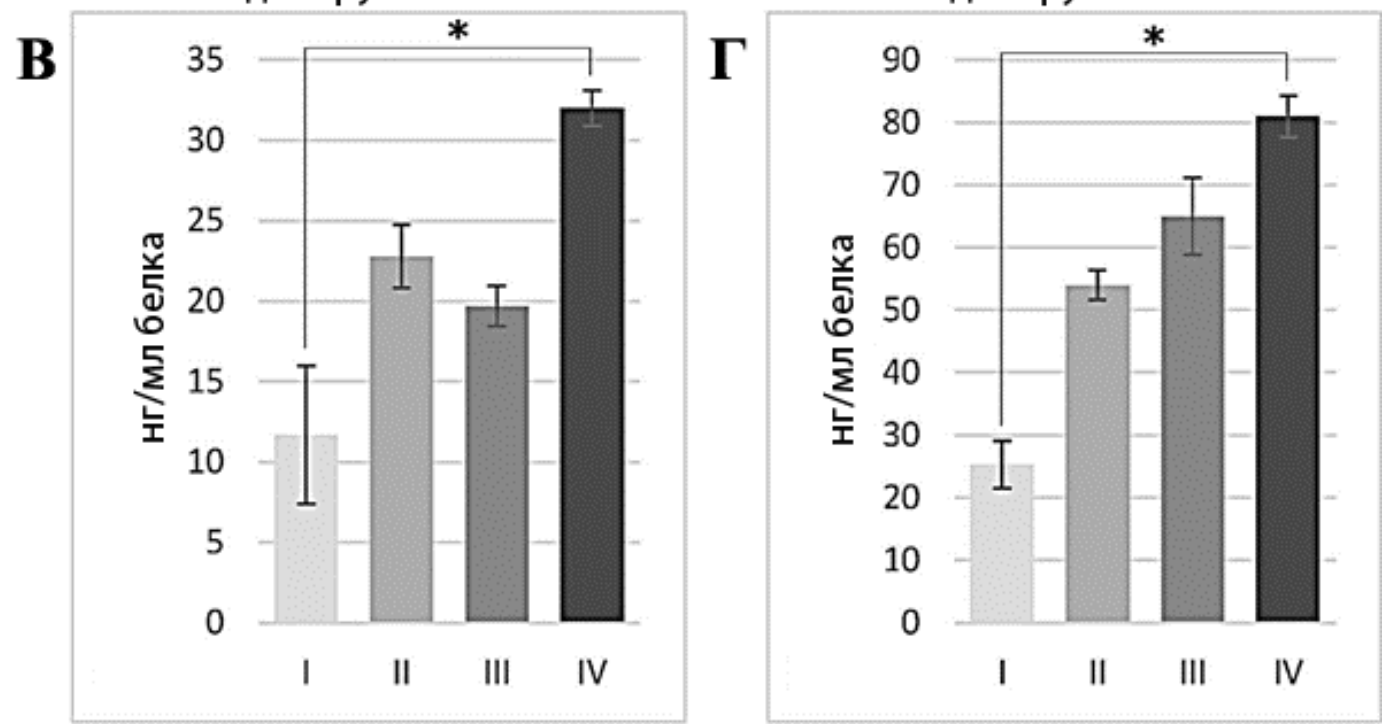

Puc. 78. Результаты иммуноферментного анализа опухолевой ткани на содержание противовоспалительных и провоспалительных цитокинов:

A - TGF- $\beta 1$; Б - интерлейкин-10; В - TNF $\alpha$; Г - интерлейкин-1.

Результаты представлены в виде $\mathrm{M} \pm \mathrm{SEM}$. «*»-различия между группами по сравнению с контрольной группой (группа I) считались достоверными с $\mathrm{p}<0,05$. Результаты представлены в виде $\mathrm{M} \pm \mathrm{SEM}$.

Тест Стьюдента использован для парных образцов 
A

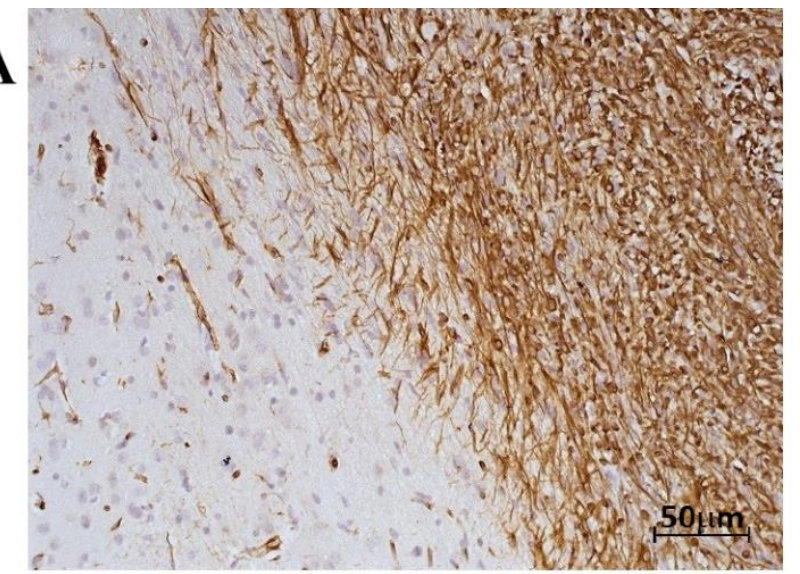

B

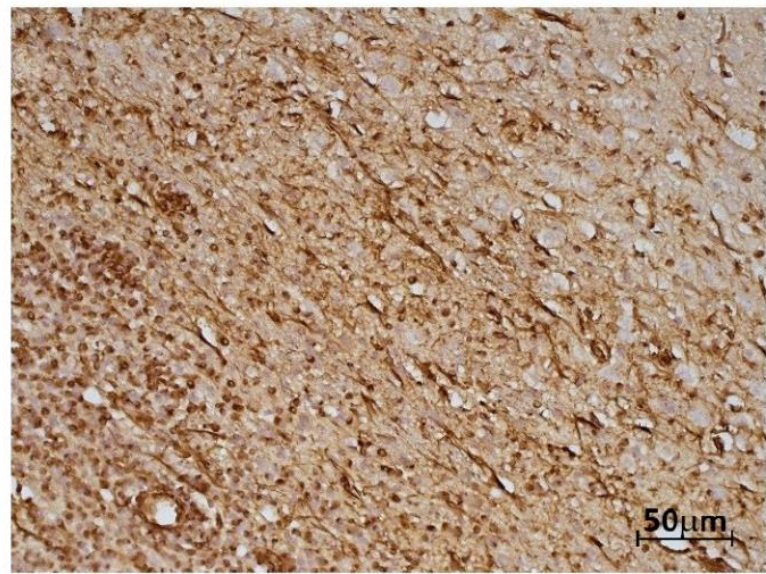

$\mathbf{5}$

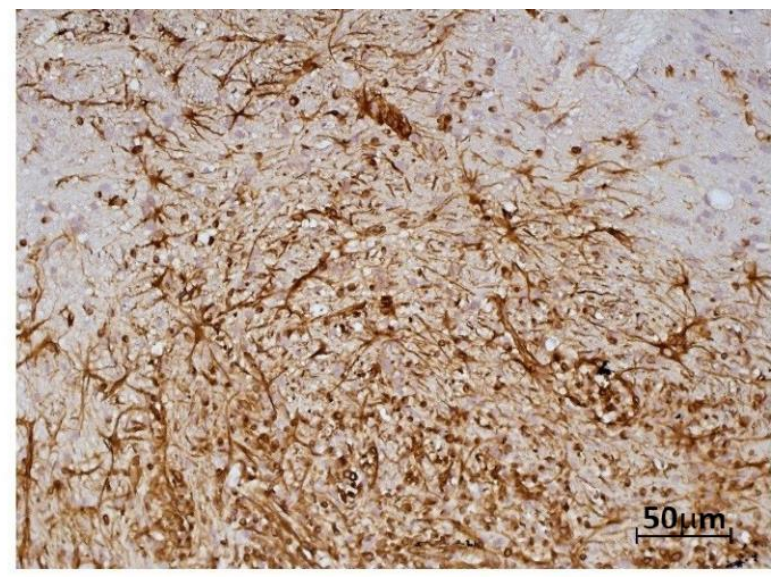

$\Gamma$

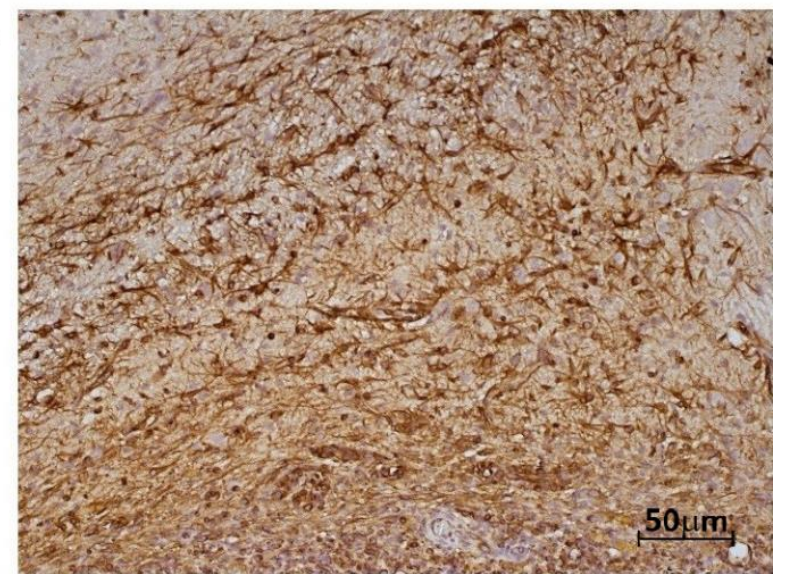

Puc. 79. Неопластическая ткань в мозге крыс глиомой С6, контрольная группа. Окраска антителами против маркера эпителиально-мезенхимального перехода виментина; А и Б - край опухоли с прилежащей тканью мозга, 14-е сутки; В и Г край опухоли с прилежащей тканью мозга, 28-е сутки. Дополнительная окраска гематоксилин-эозином 

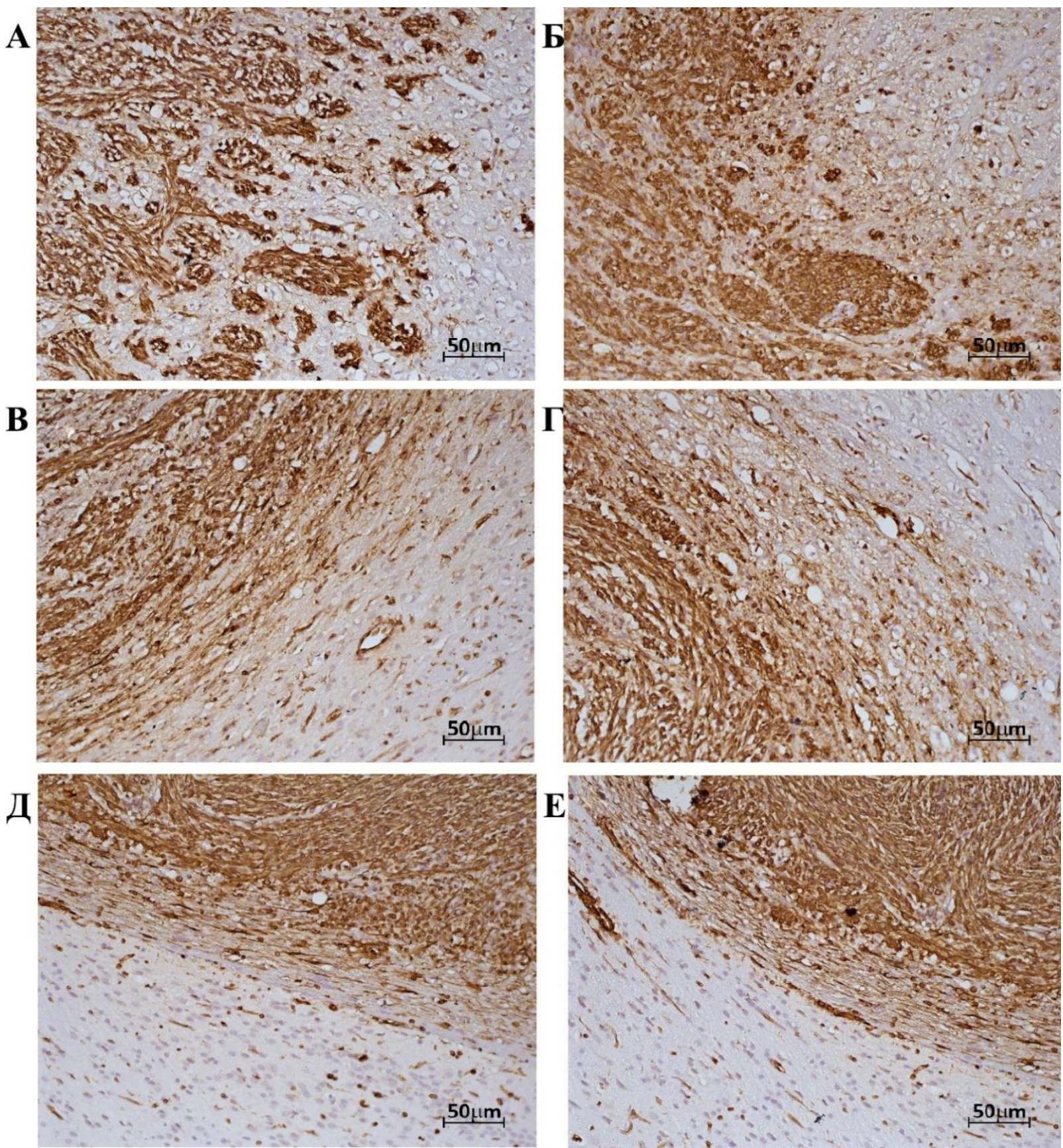

Puc. 80. Неопластическая ткань в мозге крыс с глиомой С6, 28-е сутки. Окраска антителами против маркера эпителиально-мезенхимального перехода - виментина. А и Б - край опухоли с прилежащей тканью мозга, группа II (Г-КСФ); В и Г край опухоли с прилежащей тканью мозга, группа III (INF + ЛПC); Д и Е - край опухоли с прилежащей тканью мозга, группа IV (Г-КСФ+INF $\gamma+Л П C)$.

Дополнительная окраска гематоксилин-эозином 


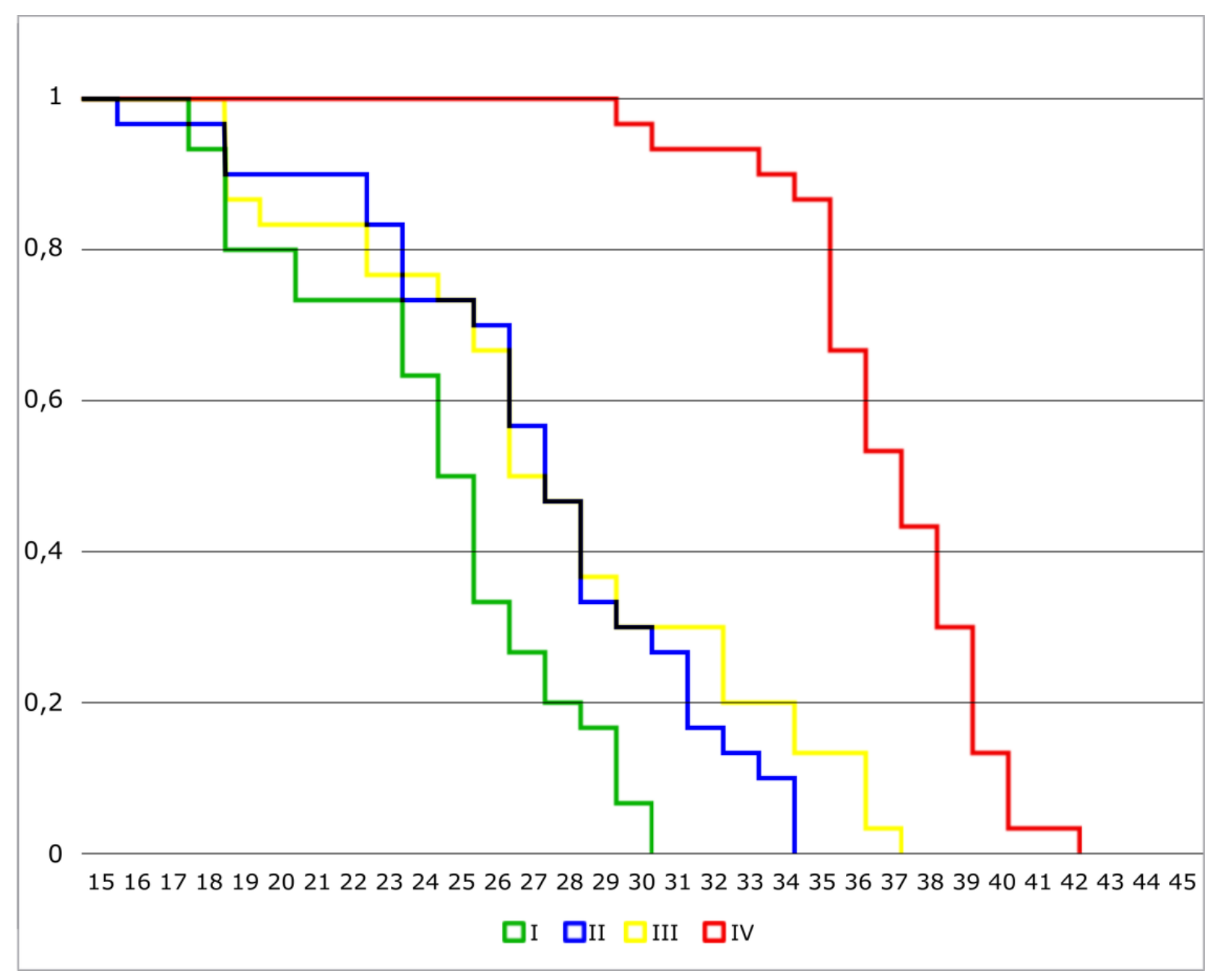

Puc. 81. Кривые выживаемости экспериментальных животных по Каплану-Мейеру. Зеленый маркер - группа I (контроль), синий маркер - группа II (G-CSF), желтый маркер - группа III (PT), красный маркер - группа IV (G-CSF + PT)

\section{3. Обсуждение результатов главы}

Как следует из результатов эксперимента, стереотаксическая имплантация клеток глиомы С6 в мозг иммунокомпетентных крыс породы «Вистар» позволяет сформировать глиальную опухоль, которая воспроизводит основные патофизиологические механизмы развития МГБ и характеризуется инвазивным ростом, высокой скоростью пролиферации раковых клеток, интенсивным ангиогенезом и ранним появлением очагов некроза, что позволяет отнести ее к классу глиом высокой степени злокачественности согласно классификации Duma-Duport, или Grade IV, в соответствие с критериями ВО3.

Исключительно важно, что эта опухоль в своем развитии воспроизводит основные патофизиологические механизмы, характерные для МГБ. Так, несмотря на интенсивный ангиогенез, к 28-м суткам наблюдения 
происходит прогрессирующее увеличение площади зон некроза и снижение темпов пролиферации опухолевых клеток, что косвенно указывает на ключевую роль фактора гипоксии - основного регулятора морфологических изменений в опухолевой ткани.

При проведении эксперимента мы отказались от окраски опухоли антителами к фактору, индуцированному гипоксией (HIF), что связано с большой изученностью вопроса и наличием прямой взаимосвязи между количеством HIF в ткани глиомы и интенсивностью ангиогенеза (Clara et al., 2014). Однако, несмотря на интенсивный ангиогенез, уже на 14-е сутки в опухоли формируются очаги некроза, которые на 28-й день начинают занимать основное место в морфологической картине. При этом опухоль не погибает, а на границе опухоли с веществом мозга наблюдается активная инвазия неопластических клеток и образование их сателлитных очагов.

Обращает на себя внимание тот факт, что пролиферация сохраняется на границах с неизменным веществом мозга, где степень оксигенации выше, чем в центре опухолевого узла. В этом случае именно высокий уровень энергозатратной пролиферации множества клеток опухоли и становится, с одной стороны, причиной гипоксии и формирования очагов некроза, а с другой - индуктором синтеза TGF- $\beta 1$ и VEGF в клетках глиомы. Первый одновременно с противовоспалительными эффектами стимулирует формирование структур межклеточного матрикса, в то время как второй фактор запускает ангиогенез, связанный именно со структурами матрикса и провоцирует тем самым инвазию, что и подтверждается результатами морфологического анализа. Нельзя не отметить, что роль VEGF в процессе провоспалительной модификации опухоли не входила в задачи исследования и требует дальнейшего изучения. Однако уже эти результаты морфологического исследования являются достаточным основанием для углубленного анализа роли TGF- $\beta 1$ в ходе опухолевого процесса и патофизиологического значения усиленной продукции TGF- $\beta 1$ в области инвазивного края опухоли и веществе мозга.

Основным источником TGF- $\beta 1$ в опухолевой ткани являются клетки МГБ (Massague, 2008), некоторую лепту вносят М2-активированные клетки микроглии, продуцирующие TGF- $\beta 1$ вместе с другими противовоспалительными цитокинами. Однако число клеток микроглии в опухоли крыс контрольной группы значительно сокращается к 28-му дню наблюдений, а интенсивность продукции TGF- $\beta 1$ фибробластами в сравнении с неопластическими клетками невелика. Существуют данные, что наряду с клет- 
ками МГБ непосредственное участие в синтезе TGF- $\beta 1$ принимают рекрутированные в опухоль ККМ (Hambardzumyan et al., 2016), но наши данные не подтверждают такую возможность (Bryukhovetskiy, 2016).

Существуют прямые корреляции между уровнем TGF- $\beta 1$ в сыворотке крови и степенью злокачественности глиом (Rich et al., 2003), однако вопрос нельзя считать изученным. В норме этот цитокин индуцирует апоптоз, контролирует пролиферацию и дифференцировку клеток. Помимо этого, по нашим данным, стимуляция TGF- $\beta 1$ ведет к резкому изменению молекулярного профиля клеток МГБ, что проявляется подавлением синтеза адгезионного Е-кадгерина, усилением продукции миграционного $\mathrm{N}$-кадгерина и компонентов актин-миозинового цитоскелета, что полностью согласуется с важнейшей ролью TGF- $\beta 1$ в организации межклеточного матрикса и проявляется усилением синтеза белков мезенхимального фенотипа и матриксных металлопротеиназ (Bryukhovetskiy et al., 2016). В этой связи усиленная продукция TGF- $\beta$ предшествует ангиогенным эффектам VEGF (Krishnan et al., 2015) и потенцирует их, что является важным фактором «зрелости» опухоли и свидетельствует о наличии в ее составе клеток, способных к проникновению в окружающие ткани и органы, а, следовательно, обладающих всей полнотой свойств раковых клеток.

Безусловно, инвазивный рост - главный критерий прогрессирования опухоли, и, по мнению большинства авторов, это свойство МГБ связано не столько с ОК, сколько с опухолевыми стволовыми клетками (ОСК). Именно на поражение ОСК ориентирован огромный арсенал таргетных средств, применение которых (Touat et al., 2018) не привело, однако, к значимому увеличению выживаемости больных МГБ при масштабных клинических исследованиях. Между тем количество ОСК в опухоли всегда сравнительно не велико (Sundar et al., 2014). Они локализованы в нишах и реализуют свойственный им дифференцировочный потенциал в направлении создания неопластической кровеносной сети как основного условия выживания опухоли (Hambardzumyan et al., 2016). И хотя данное исследование напрямую не затрагивает роль ОСК, полученные результаты указывают, что, возможно, их значение в опухолевой прогрессии не столь велико, как считается.

При этом данные собственных исследований указывают на то, что стимуляция TGF- $\beta$ сближает молекулярный фенотип дифференцированных клеток МГБ с ОСК, что позволяет ликвидировать критический разрыв разницу между количеством ОСК и инвазивными свойствами дифференци- 
рованных опухолевых клеток, делая возможным прогрессирование опухоли (Bryukhovetskiy, 2019). В этой связи полученные данные свидетельствуют, что важным путем регуляции инвазивной активности МГБ может стать подавление продукции TGF- $\beta$ в опухоли, что может быть реализовано путем использования противоопухолевого потенциала ГСК и мононуклеарных клеток костного мозга.

Мононуклеарные CD45+ клетки костного мозга активно используются в онкологии более 50 лет. Они применяются после высокодозной химиотерапии для снижения депрессии костного мозга, сокращения риска инфекционных и геморрагических осложнений и восстановления иммунного противоопухолевого ответа. При аллогенной трансплантации клетки этого типа обладают собственным лечебным эффектом благодаря реакции донорских иммунных клеток против остаточной опухоли у больного. Однако во всех случаях для рекрутирования в системный кровоток и последующей иммобилизации клеток этого типа применяется Г-КСФ, использованный в нашем исследовании.

Г-КСФ (Pierce et al., 2017) обладает способностью стимулировать пролиферацию и дифференцировку предшественников нейтрофилов, ускоряет созревание гранулоцитов и их выброс из костного мозга, увеличивает их фагоцитарную и антителозависимую клеточную цитотоксическую активность против опухолевых клеток, усиливает активность естественных киллеров, адгезию нейтрофилов, модулирует экспрессию их рецепторов и их афинность. Г-КСФ является одним из самых мощных агентов (Domingues et al., 2017), рекрутирующих ГСК и прогениторные ККМ в системный кровоток и индуцирующих на них экспрессию рецептора CXCR4 (Saba et al., 2015), детерминирующего миграцию клеток этого типа в опухолевый очаг в ответ на рост градиента концентрации фактора стромальных клеток SDF1 $\alpha$ (Bryukhovetskiy et al., 2015) и еще 80 цитокинов, реализующих этот эффект через соответствующего типа рецепторы, что описано в главах 1 и 3 настоящей работы.

Безусловно, злокачественные опухоли оказывают влияние на локальное, т.е. тканевое микроокружение. Моноциты крови инфильтрируют опухоль и под влиянием сигнальных молекул, секретируемых опухолью (Г-КСФ, гранулоцитарно-макрофагальный фактор роста - КСФ, интерлейкины 4 и 10, трансформирующий ростовой фактор $\beta$ ), дифференцируются в макрофаги с «антивоспалительным» фенотипом и, подавляя антиопухолевый иммунитет и стимулируя формирование новых кровенос- 
ных сосудов, способствуют росту и метастазированию опухоли. Однако здесь целесообразно еще раз вернуться к дизайну исследования.

Значительную часть мононуклеарных клеток, иммобилизированных в кровеносное русло Г-КСФ, составляют ГСК, которые окрашиваются антителами против антигена CD34. Именно этот феномен был основанием для формирования группы II. К сожалению, у большинства авторитетных производителей отсутствуют в продаже антитела против CD34+ антигена ГСК крысы, что, конечно, вызывает определенные сложности, но ценности исследования не снижает. Но, как следует из эксперимента, стимуляция Г-КСФ позволяет не только резко и статистически значимо увеличить долю CD45+ клеток в общем числе лимфоцитов, но и более чем в 19 раз увеличивает в их популяции число CD45+ HSCs-like cells, принадлежащих к боковой популяции, определяемой как ГСК (Telford et al., 2010).

В главе 6 показано, что стволовые клетки человека обладают высокой подвижностью в отношении клеток глиом и карцином in vitro и при внутривенном введении in vivo в организм экспериментальных животных с перевитой глиальной опухолью мозга мигрируют в неопластический очаг, где трансформируются в клетки IBA+ микроглии, обладающей высоким противоопухолевым потенциалом (Bryukhovetskiy et al., 2017).

Теоретически одним из механизмов подавления ОСК является модуляция активности моноцитарно-макрофагальной системы, с использованием ГСК, рекрутируемых Г-КСФ в кровоток человека. Рекрутирование ГСК в системный кровток приводит к резкому увеличению в опухоли числа клеток с маркерами микроглии, что тоже иногда связывают с прогрессированием процесса (Fonseca et al., 2015; Hambardzumyan et al., 2016). Однако морфохимическая модификация узла экспериментальной глиомы в ответ на рекрутирование ГСК и пула CD45+ клеток не всегда сокращает продолжительность жизни крыс с глиомой С6. Решающее значение здесь принадлежит особенностям локализации и качественным параметрам микроглии.

Анализируя данные главы 7, допустимо утверждать, что накопление клеток костного мозга в опухоли обусловлено формированием неопластической кровеносной сети, которая является прямым ответом на стимулирующее воздействие внутриопухолевой гипоксии. Детальное изучение этого вопроса - задача будущего, однако в норме количество ГСК, способных проникнуть через неповрежденный гематоэнцефалический барьер, крайне мало. В естественных условиях защитную функцию в мозге обес- 
печивают резидентные микроглиоциты, происходящие из эмбрионального желточного мешка. Они поддерживают популяцию путем пролиферации, клетки костного мозга в этом процессе не участвуют.

Именно формирование кровеносной сети позволяет МГБ рекрутировать стволовые и прогениторные и другие клетки костного мозга, с последующей их трансформацией в клетки микроглии. Отсюда можно предположить, что наблюдаемое рядом исследователей (Wang et al., 2016) стимулирующее влияние этих клеток на рост опухоли отчасти обусловлено как воздействием привлекающей их гипоксии, так и влиянием особых, иммуносупрессивных цитокинов, без которых невозможно формирование неопластической кровеносной сети и амортизация цитотоксического влияния имунных клеток, проникающих в «забарьерный» орган.

Вероятно, гипоксия активизирует либо предрасполагает к активации макрофагов по альтернативному пути (состояние М2), что повышает их фагоцитарную активность, усиливает синтез интерлейкина 10, TGF- $\beta 1$ и других противовоспалительных цитокинов, запускающих процессы ремоделирования некротизированной ткани (Nusblat et al., 2017), что, вероятно, и объясняет преобладание М2 микроглии в микроокружении клеток МГБ. Клетки этого типа образуют секреторные петли в коллаборации с фибробластами и активно продуцируют TGF- $\beta$ и запускают процессы генерации клеток с фенотипом эпителиально-мезенхимального перехода. В этой связи подавление инвазивной активности клеток МГБ возможно при активации макрофагов по классическому пути (состояние M1), что послужило главным аргументов для создания групп III и IV.

Эффекты, наблюдаемые в группе III, были связаны с двойным стимулирующим воздействием на клетки микроглии, связанные в своем происхождении с моноцитарно-макрофагальным рядом. При этом воздействие LPS реализуется через рецептор врожденного иммунитета TLR4 и приводит к формированию инфламмасомы и секреции после процессинга преформированных провоспалительных цитокинов (IL-1, IL-6, TNF $\alpha$ ), и это полностью подтверждается результатами, приведенными выше. Одновременно главным биологическим эффектом IFN $\gamma$ также является стимуляция всего пула клеток моноцитарно-макрофагального ряда, что выражается в дальнейшем нарастании продукции провоспалительных цитокинов, сборке протеосомного комплекса и экспрессии на мембране адгезионных молекул IBA1 и ко-стимулирующих молекул В7 (CD80/CD86), что вновь находит подтверждение в результатах настоящей работы. 
Как известно, микроглиоциты мозга происходят из эмбрионального желточного мешка, и после закрытия гематоэнцефалического барьера поддерживают свою популяцию путем пролиферации, моноциты и ГСК в этом участия не принимают. Вероятно, этим и объясняется обилие в опухоли PCNA+ клеток, иммунопозитивных в отношении маркеров микроглии на 14-й день эксперимента. Однако этот ресурс быстро истощается, что проявляется уменьшением плотности группировки клеток микроглии на 28-й день наблюдений.

Несколько настораживает отмеченный нами факт некого усиления пролиферативной активности в опухолевой ткани на фоне стимуляции Г-КСФ и провоспалительной терапии. Однако следует принять во внимание, что активированные IFN $\gamma$ макрофаги вновь обретают способность к пролиферации и вряд ли микроглия является исключением из этого правила. Это позволяет предполагать еще один источник роста числа PCNA+ клеток по периферии опухолевого узла у животных группы IV на 28-й день опухолевого роста, а также объясняет компактизацию опухоли и рост числа IBA1+ клеток микроглии по периферии узла и в его толще.

Другим не менее важным эффектом IFN $\gamma$ является торможение продукции противовоспалительных цитокинов, что на примере TGF- $\beta 1$ и IL-10 также находит свое подтверждение в результатах настоящей работы (Рис. 78). При этом комбинированное воздействие Г-КСФ, а также бактериального LPS и IFN $\gamma$ (группа IV) обеспечивает максимальное рекрутирование всех мононуклеров, стимуляцию созревания ГСК в сторону миелоидного ряда, многогранную и глубокую стимуляцию всех (циркулирующих и тканевых) клеток моноцитарно-макрофагального ряда, в том числе и микроглии. Неслучайно именно результаты группы IV по всем тестам обеспечивают получение наиболее четких и убедительных эффектов и позволяют ставить вопрос о возможности экспериментально-клинического исследования в рамках терапии МГБ.

Результаты, полученные для группы IV, а также имееющиеся у нас данные о возможности стимуляции активности металлопротеиназ в клетках микроглии (Bryukhovetskiy et al., 2018) позволяют соединить в целостную картину результаты иммуногистохимии и ИФА с результатами морфологического исследования. Поскольку металлопротеиназы играют крайне существенную роли в ремоделировании матрикса при воспалении, повышение их продукции клетками микроглии может существенно изменить структуру матрикса и снизить скорость неоангиогенеза в опухолевом 
узле, что проявится снижением скорости его роста и повышением выживаемости животных. Это предположение подтверждается также ростом числа IBA1+ клеток микроглии в узле и вокруг него и полностью совпадает с результатами томографии и микроскопического исследования.

Активный ангиогенез, наблюдаемый в процессе роста опухоли (см. главу 5) способствует повреждению гематоэнцефалического барьера, что делает возможным рекрутирование стволовых и прогениторных клеток костного мозга в опухоль, где они восполняют популяцию микроглиоцитов. Однако попадая в иммуносупрессивную среду, формируемую TGF- $\beta$, эти клетки получают альтернативный вектор активации, в пользу чего свидетельствует значительное уменьшение в опухолевой ткани крыс группы Г-КСФ числа клеток, иммунопозитивных в отношении маннозного рецептора CD206 - одного из наиболее ценных признаков альтернативной активации макрофагов (Suzuki et al., 2018; Scodeller et al., 2017).

Принципиально важно, что рекрутирование CD45+ клеток костного мозга в кровеносное русло сопровождается увеличением выживаемости экспериментальных животных. При этом наибольшие показатели выживаемости крыс с глиомой C6 у крыс группы G-CSF+PT свидетельствуют о том, что локальное усиление воспалительной реакции - это ведущий механизм противоопухолевого действия ГСК и всего пула мононуклеарных CD45+ клеток костного мозга.

Таким образом, интенсивность продукции TGF- $\beta 1$ в опухолевой ткани обратно пропорциональна интенсивности процессов пролиферации. Стимуляция экспериментальных животных Г-КСФ рекрутирует ГСК и мононуклеарные CD45+ клетки в системный кровоток и далее в опухоль экспериментальных животных с глиомой С6, что сопровождается усилением процессов микроглиальной пролиферации и обогащением инфильтрации в опухолевой ткани маркерами клеток микроглии. Провоспалительная терапия на фоне стимуляции Г-КСФ вызывает усиление процессов презентации антигена, что сопровождается снижением продукции TGF- $\beta$, ремоделированием опухолевого матрикса и увеличением выживаемости экспериментальных животных. 


\section{ПРОТЕОМИКА СТВОЛОВЫХ И ОПУХОЛЕВЫХ КЛЕТОК}

ОСК - один из краеугольных камней проблемы. В предшествующих главах данной работы довольно много было сказано о роли ОСК в патофизиологии опухолевого процесса, месте ОСК в опухолевой иерархии и о других уникальных свойствах этого типа клеток. И тем не менее ОСК представляются крайне неконкретной целью, которая совсем не похожа на объект противоопухолевой таргетной терапии.

Безусловно, пул ОСК глиобластомы характеризуется высокой гетерогенностью и полиморфизмом иммуноцитохимических маркеров клеточной поверхности, однако самый пристальный анализ современной литературы, проведенный в главе 1, позволяет сделать вывод, что только ОК МГБ иммунореактивные в отношении антигена CD133, стабильно демонстрируют некоторые свойства ОСК. В свете сказанного целью данной главы стало сопоставление молекулярного фенотипа CD133+ ОК МГБ с нормальными стволовыми клетками и CD133-негативными клетками МГБ. Работы были выполнены с использованием современных постгеномных (протеомных) технологий.

Исследование было проведено по четырем ключевым направлениям.

1. Проведен сравнительный анализ протеомных профилей нормальных CD 133+НСК человека, мезенхимальных CD29+, CD44+, CD73+, CD90+ стволовых клеток КМ человека и CD133+ ОСК глиобластомы человека.

2. Проведено сравнительное картирование протеомов CD133+ОСК и CD133-негативных, дифференцированных клеток глиобластомы (ДКГ).

3. Установлены закономерности трансформации молекулярного фенотипа ДКГ при стимуляции TGF- $\beta 1$ и показана стратегическая роль этого цитокина в сближении ряда важнейших параметров протеомного профиля ОСК и ДКГ.

4. Установлены закономерности трансформации протеомного профиля CD133+ ОСК после облучения в дозе 60 Грей. 


\section{1. Сравнительный анализ протеомных профилей нормальных нейральных CD 133+ стволовых клеток человека, мезенхимальных CD29+, CD44+, CD73+, CD90+, CD34- стволовых клеток костного мозга человека и опухолевых (CD133+) стволовых клеток (ОСК) глиобластомы человека}

При разработке дизайна эксперимента исходили из следующей идеальной модели. МГБ - одна из самых агрессивных опухолей ЦНС, в патогенезе которой ключевая роль принадлежит ОСК. Тканеспецифические, регионарные нейральные стволовые клетки (НСК) находятся за ГЭБ и непосредственно вовлечены в патогенез МГБ. Напротив, мезенхимальные стволовые клетки (МСК) костного мозга в условиях сохранного ГЭБ участия в опухолевом процессе не принимают.

Целью исследования явилось проведение сравнительного протеомного картирования ОСК ГБ человека, НСК и МСК человека, для определения степени вовлеченности регионарных стволовых клеток в опухолевый процесс и идентификации универсальных молекулярных механизмов участия всех типов стволовых клеток в неопластическом процессе. Исследование одобрено Этическим комитетом Школы биомедицины ДВФУ (протокол № 2 от 02.08.2015).

Нейральные стволовые клетки человека. Материал предоставлен «ЗАО «Клиника "Нейровита»» (г. Москва, Россия). Перед использованием в эксперименте клетки протестированы на загрязнение микоплазмой с помощью Universal Mycoplasma Detection Kit (ATCC® 30-1012К ${ }^{\mathrm{TM}}$ ). После разморозки материал характеризовали методом проточной цитометрии в отношении антигена CD133 (cat no. 130-105-226; Miltenyi Biotec, Inc.).

Мезенхимальные стволовые клетки человека. Материал предоставлен «ЗАО "Клиника Нейровита"» (г. Москва, Россия). Перед использованием в эксперименте клетки протестированы на загрязнение микоплазмой с помощью Universal Mycoplasma Detection Kit (ATCC® 30-1012K ${ }^{\mathrm{TM}}$ ). МСК характеризовали с помощью проточной цитометрии по экспрессии поверхностных антигенов: CD29+, CD44+, CD73+, CD90+, CD34 -.

Выделение культивированных стволовых клеток глиобластомы человека. В работе использована клеточная линия U-87MG МГБ полученная из Американской коллекции типовых культур (АТСС; кат. № НТВ14 тм). Безусловно, эта клеточная линия не является оригинальной линией 
U-87, созданной в университете Уппсалы (Allen et al., 2016), но представляет собой «дикий» тип человеческой ГБ. Этот факт значительно увеличивает ценность эксперимента, так как глиобластома «дикого» типа составляет более $90 \%$ случаев этой опухоли.

Для выделения глиомасфер использованы клетки, полученные после третьего пассажа с момента получения их от производителя. Перед использованием в эксперименте клетки протестированы на загрязнение микоплазмой с помощью Universal Mycoplasma Detection Kit (ATCC®) 30-1012К ${ }^{\mathrm{TM}}$ ). Клетки линии U87 культивировали в среде DMEM/F12 с пониженным содержанием сыворотки и добавлением L-glutamine; B27; bFGF, 20ng/ml; EGF, 20 ng/ml; Penicillin/Streptomycin, $100 \mathrm{U} / \mathrm{ml}$; Heparin, $5 \mu \mathrm{g} / \mathrm{ml}$. Bce реагенты производства компании Gibco. Культивирование проводили во флаконах Т75, при $37{ }^{\circ} \mathrm{C}$, в атмосфере $5 \% \mathrm{CO}_{2}$. Добавление свежих ростовых факторов проводили каждые 3 дня. Селекцию CD133+ клеток выполняли методом иммуносортинга с использованием магнитных шариков с иммобилизованными на них антителами к CD133 (cat no. 130105-226; Miltenyi Biotec, Inc.).

Методика сравнительного исследования клеточных протеомов. Использована комбинация высокоэффективной жидкостной хроматографии и масс-спектрометрии (ВЭЖХ-МС). Для оценки изменения экспрессии уровней белков применялся метод label-free. Клетки лизировали при помощи Mammalian Cell Lysis Kit (MCL1-1KT, Sigma-Aldrich), образцы очищали от низкомолекулярных соединений, проводили энзиматический гидролиз и по 3 мкл растворов анализировали масс-спектрометрически для контроля проведения трипсинолиза. По окончании реакции содержимое пробирок упаривали досуха при $60{ }^{\circ} \mathrm{C}$, проводили разделение триптических пептидов. Анализ триптических пептидов проводили на нанопроточном хроматографе Dionex Ultimate 3000 (Dionex, Нидерланды) в сочетании с масс-спектрометром LTQ Orbitrap XL (Thermo) с источником ионизации NSI. Разделение пептидов осуществляли на колонке Acclaim C18 PepMap100 (75 мкм х 150 мм, размер зерна 3 мкм, Dionex), снабженной предколонкой. Для идентификации белков масс-спектры конвертировали программой Proteome Discoverer 1.0 (Thermo). Поиск белков проводили с помощью программы Mascot Server 2.3.02 (Matrix Science, Великобритания). Списки идентифицированных белков вместе с хромато-массспектрами загружали в программу Skyline1.2.0.3303. Аннотирование био- 
логических процессов, молекулярных функций, клеточной локализации и сигнальных путей белков проводили с помощью баз PubMed, PANTHER, Gene Ontology и KEGG.

Результаты. После проведения лизиса количество общего белка в ли-

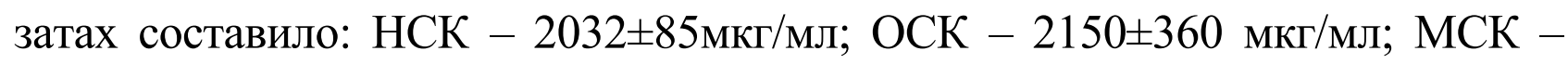
$3198 \pm 281$ мкг/мл. Обработка данных ВЭЖХ проводилась с помощью программы Mascot Server, было идентифицировано 1664 белка во всех пробах. В результате дальнейшей обработки данных программой Skyline были определены уровни:

1) НСК - 1447 белков по 11176 пептидам (молекулярный вес от 3,53 до 3908, 10 кДа);

2) ОСК - 1225 белков по 13674 пептидам (молекулярный вес от 4,60 до 3908, 10 кДа);

3) $\mathrm{MCK}$ - 842 белков по 10932 пептидам (молекулярный вес от 5,02 до 1017,07 кДа).

Динамический диапазон для идентифицированных белков составил 7 порядков. Протеомные карты НСК, МСK и ОСК линии U87 глиобластомы человека приведены на сайте ДВФУ: https://www.dvfu.ru/science/the-rd-results/current-projects-pcpir/14.575.21.0038/

Для проведения сравнительного анализа из данного списка были исключены белки, идентифицированные только в одном типе клеток, что позволило из 1664 белков получить группу сравнения «А» - НСК и ОСК (1052 белка) и группу сравнения «Б»- ОСК и МСК (607 белков). При проведении анализа в группе сравнения «А» обнаружено 63,2 $\pm 11,5 \%$ идентичных белков, что отражают близость морфофункциональных фенотипов НСК и ОСК ГБ человека, имеющих единый источник происхождения, единую нейральноподобную дифференцировку и общую локализацию в мозге. В группе сравнения «Б» выявлено 36,5 $\pm 9,5 \%$ идентичных белков.

Далее из анализа каждой из групп сравнения были исключены все белки, у которых нормализованная сигнальная интенсивность изменилась менее чем в 2 раза. В результате в группе «А» осталось только 637 белков $(38,28 \%)$, в группе «Б» - 425 белков $(25,54 \%)$. Затем на основании баз данных исключили уже ранее известные белки, участвующие в канцерогенезе МГБ, роль которых доказана, что позволило сформировать некую «матрицу подобия», или особый субстрат, объединяющий нормальные стволовые клетки и ОСК. Для дальнейшего анализа выполнили разделе- 
ние идентифицированных белков на функционально значимые кластеры и провели прецизионный анализ протеомных профилей сравниваемых клеточных систем.

\section{Распределение белков на функционально значимые кластеры}

Из белков групп сравнения «А» и «Б» был выделен первый кластер «Рецеетторные белки», представляющий группу протеинов, расположенных на мембранах анализируемых клеток. Всего было отобрано 105 белков, среди которых идентифицировны акцепторные белки 35 сигнальных путей.

Из оставшихся белков выделен второй кластер «Ядерные белки», всего отобрано 146 белков. При анализе данного кластера белков было установлено, что только 22 из них имели сигнальный домен на клеточной мембране.

Третий кластер «Белки сигнальной трансдукции и межклеточной регуляциии〉 содержал 33 белка. При анализе данного кластера белков было выявлено 16 сигнальных путей, из которых только 10 имели сигнальный домен как на мембране, так и в ядре этих клеток: сигнальный путь активации В-клеток, путь Т-клеточной активации, путь воспаления, опосредованный цитокинами, путь гликолиза, путь ангиогенеза, FAS, EGF, FGF сигнальные механизмы, сигнальный путь фокальной адгезии и интегриновый сигнальный путь. Очевидно, это и есть фундаментальные механизмы, которые предопределяют судьбу низкодифференцированых клеток в организме человека.

\section{Прецизионный анализ протеомных профилей сравниваемых клеток}

На данном этапе обработки данных из групп сравнения «А» и «Б» были удалены протеины, участвующие в канцерогенезе МГБ и обеспечивающие быстрое воспроизводство АТФ для поддержки энергетического статуса, синтез макромолекул, работу дыхательной цепи, эффект Варбурга, а также исключены некоторые другие белки. В результате в группах осталось 34 ядерных, 53 мембранных и 10 внеклеточных белков.

Далее были исключены белки цитоскелета и эндоплазматического ретикулума. В результате в группах осталось 19 ядерных, 20 мембранных и 5 внеклеточных белков.

Далее с помощью международных баз данных провели аннотирование сигнальных путей и белок-белковых взаимодействий, что дало возможность идентифицировать сигнальные пути, не трансформированные в 
результате канцерогенеза в ОСК. Сравнение этих данных позволило установить, что не трансформированными в процессе канцерогенеза и общими для всех типов СК являюся сигнальные пути интегринов и фокальной адгезии, предопределяющие взаимодействие с ВКМ.

Итак, как следует из первой части исследования, протеомный профиль CD133+ ОСК МГБ обладает высокой степенью идентичности с нормальными CD133+ НCK (63,2\% белков) и нормальными МСК КМ человека (36,47\% белков). Сигнальный путь фокальной адгезии представляет собой перспективную мишень для воздействия на ОСК.

\section{2. Сравнительное картирование стволовых CD133+ и дифференцированных CD133- клеток глиобластомы}

Протеомный анализ выявил 1990 уникальных белков в образцах CD133+ ОСК и CD133-ДКГ. Всего в образце CD133+ОСК идентифицирован 1891 белок, в образце CD133-ДКГ обнаружено 1748 белков. Идентифицированные белки показали высокий процент совпадения между двумя клеточными популяциями: 1649 белков присутствовали во всех клеточных лизатах, 242 белка были обнаружены только в ОСК и 99 белков наблюдались только в ДКГ. Среди обнаруженных белков 589 имели значительно отличающиеся уровни экспрессии в ОСК $(\mathrm{p}<0,05)$ по сравнению с ДКГ; 358 белков усиливали, а 231 снижал экспрессию.

Большинство идентифицированных белков имели внутриклеточную локализацию, связь с метаболическими и клеточными процессами, были функционально неоднородны и проявляли ферментативную активность (рис. 82, А-Г).

Биоинформационный анализ установил принадлежность 136 дифференциально-экспрессированных белков ОСК к 15 сигнальным путям (Таблица 3).

Среди белков, усиливающих уровень синтеза более чем в 2 раза, в ОСК по сравнению с ДКГ выявлено 100 белков, среди которых 14 белков сигнального пути рецепторного взаимодействия (РВ) с ВКМ, 16 белков сигнального пути фокальной адгезии, 12 белков сигнального пути гликолиза/гликонеогенеза и 12 белков сигнального пути Wnt. Учитывая особую роль сигнальных механизмов взаимодействия с ВКМ в биологии стволовых клеток всех типов, при проведении прецизионного биоинформационного анализа мы решили сосредоточиться на этих механизмах. 
A

- Клеточные части - Органелль

॥ Макромолекулярный комплекс " Мембрана

- Другое

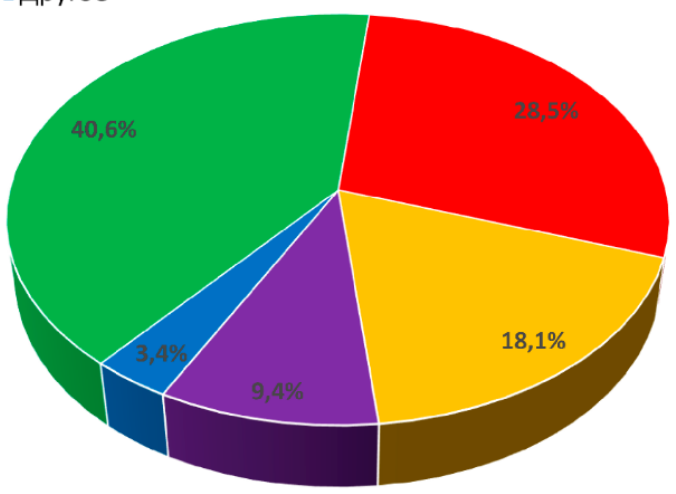

- Метаболические процессы - Клеточные процессы

- Расположение "Биологическая регуляция

- Ответ на раздражители = Клеточные компоненты организации биогенеза - Развитие - Другое

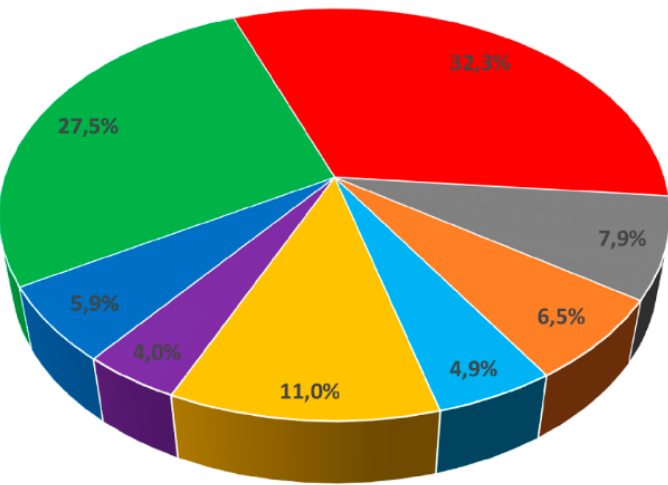

B - Связывание нүклеиновых кислот $=$ Гидролаза

- Оксидоредуктаза

- Модулятор энзимов $=$ Белки цитоскелета $=$ Трансфераза

$\Gamma$

- Факторы транскрипции = Молекулы сигналинга " Другое

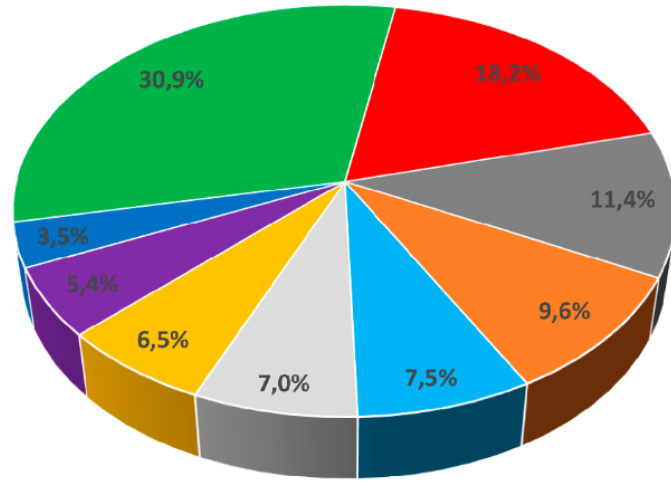

$\Gamma$ - Связывание

- Каталитическое действие - Активность структурных молекул = Транспортная активность - Рецепторная активность - Другое

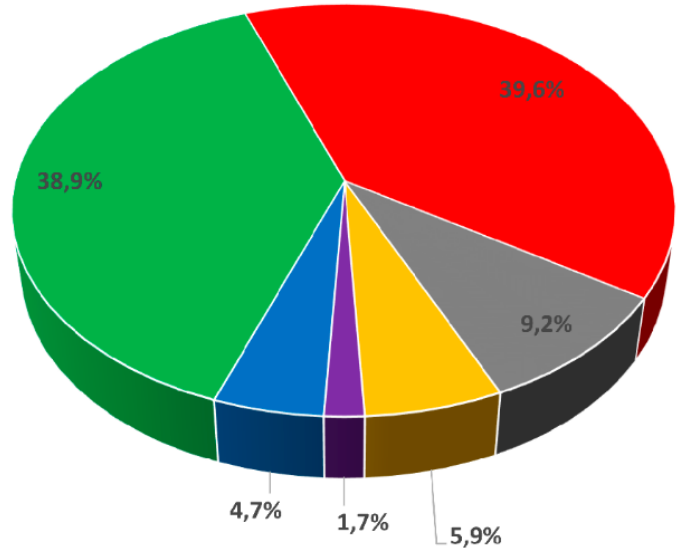

Puc. 82. Молекулярно-биологическая характеристика протеома CD133+ OCK линии U87MГ глиобластомы человека: А - локализация; Б - отношение к биологическим процессам; В - функциональный класс; Г - биологическая активность идентифицированных белков

Таблиияа 3

Принадлежность дифференциально экспрессированных белков CD133+ ОСК к внутриклеточным путям сигнальной трансдукции

\begin{tabular}{|l|c|c|}
\hline \multicolumn{1}{|c|}{ Сигнальный путь } & $\begin{array}{c}\text { Общее число иденти- } \\
\text { фицированных белков } \\
(\mathrm{n})\end{array}$ & $\begin{array}{c}\text { Белки, усиливаю- } \\
\text { щие уровень синте- } \\
\text { за > 2 раза (n) }\end{array}$ \\
\hline Адгезивных контактов & 4 & 4 \\
\hline Апоптоза & 7 & 4 \\
\hline Молекул клеточной адгезии & 6 & 6 \\
\hline Клеточного цикла & 4 & 3 \\
\hline Хемокинов & 5 & 14 \\
\hline $\begin{array}{l}\text { Рецепторного взаимодействия с } \\
\text { ВКМ }\end{array}$ & 14 & \\
\hline
\end{tabular}


Окончание табл. 3

\begin{tabular}{|l|c|c|}
\hline Фокальная адгезия & 26 & 16 \\
\hline Щелевых контактов & 5 & 4 \\
\hline Гликолиза/гликонеогенеза & 13 & 12 \\
\hline Сигнальный путь инсулина & 6 & 1 \\
\hline Интегриновый сигнальный путь & 5 & 2 \\
\hline МАРК & 9 & 3 \\
\hline Регуляции актинового цитоскелета & 11 & 7 \\
\hline Плотных контактов & 9 & 8 \\
\hline Wnt & 12 & 12 \\
\hline
\end{tabular}

Таблийа 4

Белки фокальной адгезии, экспрессия которых усилена более чем в два в ОСК по сравнению с ДКГ

\begin{tabular}{|l|l|c|}
\hline \multicolumn{1}{|c|}{ ID } & Международное наименование белка & $\begin{array}{c}\text { Отношение } \\
\text { ОСК/ДКГ }\end{array}$ \\
\hline ARHGAP35 & Rho GTPase activating protein 35 & 2.80 \\
\hline CAPN2 & Calpain 2 & 2.27 \\
\hline COL6A1 & Collagen type VI alpha 1 chain & 8.46 \\
\hline COL6A3 & Collagen type VI alpha 3 chain & 4.31 \\
\hline CTNNB1 & Catenin beta 1 & 13.98 \\
\hline DIAPH1 & Diaphanous related formin 1 & 6.12 \\
\hline FN1 & Fibronectin 1 & 4.41 \\
\hline ITGA2 & Integrin subunit alpha 2 & 3.90 \\
\hline ITGA5 & Integrin subunit alpha 5 & 3.62 \\
\hline ITGB1 & Integrin subunit beta 1 & 4.50 \\
\hline ITGB3 & Integrin subunit beta 3 & 3.24 \\
\hline ITGAV & Integrin alpha-V & 5.07 \\
\hline LAMB1 & laminin subunit beta 1 & 8.84 \\
\hline LAMC1 & laminin subunit gamma 1 & 3.87 \\
\hline MAPK1 & Mitogen-activated protein kinase 1 & 2.67 \\
\hline ZYX & Zyxin & 2.28 \\
\hline \multicolumn{2}{|l|}{$*$ - данные представлены в нормализованных масс-спектрометрических единицах. }
\end{tabular}

Исключительно важно, что значительная часть белков сигнального пути фокальной адгезии является компонентами тотально апрегулированного сигнального пути РВ-ВКМ. При этом среди белков, усиливших уровень синтеза в ОСК по сравнению с ДКГ более чем в два 
раза, уровень синтеза коллаген aVIa1 (COL6A1) и ламинина $\beta 1$ (LAMB1) был увеличен в 8 раз (табл. 4).

Таблица 4

Белки сигнального пути рецепторного взаимодействия
с внеклеточным матриксом, эксперссия которых усилена более чем в 2 раза в ОСК по сравнению с ДКГ

\begin{tabular}{|l|l|c|}
\hline \multicolumn{1}{|c|}{ ID } & \multicolumn{1}{|c|}{ Международное наименование белка } & $\begin{array}{c}\text { Отношение } \\
\text { ОСК/ДКГ }\end{array}$ \\
\hline CD44 & CD44 antigen & 2.5 \\
\hline HMMR & Hyaluronan-mediated motility receptor & 2.2 \\
\hline COL1A1 & Collagen type $1 \alpha 1$ & 2.8 \\
\hline COL1A2 & Collagen type 1 & 3.2 \\
\hline COL6A1 & Collagen type VI $\alpha 1$ chain & 8.4 \\
\hline COL6A3 & Collagen type VI $\alpha 3$ chain & 4.3 \\
\hline FN1 & Fibronectin 1 & 4.1 \\
\hline LAMB1 & Laminin subunit $\beta 1$ & 8.8 \\
\hline LAMC1 & Laminin subunit $\gamma 1$ & 3.8 \\
\hline ITGA2 & Integrin subunit $\alpha 2$ & 3.9 \\
\hline ITGA5 & Integrin subunit $\alpha 5$ & 3.6 \\
\hline ITGAV & Integrin $\alpha$ V & 5.0 \\
\hline ITGB1 & Integrin subunit $\beta 1$ & 4.5 \\
\hline ITGB3 & Integrin subunit $\beta 3$ & 3.2 \\
\hline
\end{tabular}

* - данные представлены в нормализованных масс-спектрометрических единицах.

Итак, гиперэкспрессия белков сигнального пути РВ-ВКМ - важнейшая характеристика протеома ОСК ГБ.

Представляется еще более важным, что такая картина сочетается с усилением синтеза белков сигнального пути гликолиза/гликонеогенеза, обеспечивающего выживание клеток в условиях гипоксии, и wntсигнального пути - ключевого эмбрионального механизма регуляции дифференцировочного потенциала мультипотентных клеток всех типов (табл. 5).

Допустимо предположить, что если дифференцировочный потенциал появляется у клетки в условиях жесткого гипоксичекого преконденционирования, то и вектор реализации такого потенциала определяется именно фактором гипоксии. В этой связи гиперэкспрессия белков сигнального пути PB-ВКМ является особо важным условием, позволяющим 
ОСК установить продуктивные взаимоотношения с ВКМ, а, следовательно, выжить.

Таблица 5

\section{Белки wnt-сигнального пути апрегулированные в ОСК} по сравнению с ДКГ

\begin{tabular}{|l|l|c|}
\hline \multicolumn{1}{|c|}{ ID } & \multicolumn{1}{|c|}{ Международное наименование белка } & $\begin{array}{c}\text { Отношение } \\
\text { ОСК/ДКГ }\end{array}$ \\
\hline APC & Adenomatous polyposis coli & $\uparrow^{*}$ \\
\hline CACYBP & Calcyclin binding protein & 2.0 \\
\hline CSNK2A2 & Casein kinase 2 alpha 2 & 5.2 \\
\hline CSNK2B & Casein kinase 2 beta & 12.2 \\
\hline CTBP1 & C-terminal binding protein 1 & 3.4 \\
\hline CTBP2 & C-terminal binding protein 2 & 2.2 \\
\hline CTNNB1 & Catenin beta 1 & 13.9 \\
\hline DAAM1 & Dishevelled associated activator of morphogenesis 1 & 6.5 \\
\hline CUL1 & Cullin 1(CUL1) & 3.3 \\
\hline RAC2 & $\begin{array}{l}\text { Ras-related C3 botulinum toxin substrate 2 (rho } \\
\text { family, small GTP binding protein Rac2 }\end{array}$ & 1.6 \\
\hline RHOA & Ras homolog family member A & 1.9 \\
\hline RUVBL1 & RuvB like AAA ATPase 1 & 3.2 \\
\hline \multicolumn{2}{|c|}{$*-$ данные представлены в нормализованных масс-спектрометрических единицах. }
\end{tabular}

Итак, принципиальные отличия молекулярного фенотипа CD133+OCK от ДКГ заключаются в тотальном усилении синтеза белков сигнальных путей PB - BKM (среди которых CD44, HMMR, COL1A1, COL1A2, COL6A1, COL6A3, FN1, LAMB1, LAMC1, ITGA2, ITGA5, ITGAV, ITGB1, ITGB3) и Wnt (среди которых АРC, CACYBP, CSNK2A2, CSNK2B, CTBP1, СТВР2, CTNNB1, DAAM1, CUL1, RAC2, RHOA, RUVBL1).

Идентифицированные белки могут быть использованы в качестве мишеней для прецизионной противоопухолевой терапии, ориентированной против ОСК. Приоритетными мишенями для поражения РВ-ВКМ в ОСК являются белки COL6A1 и LAMB1, уровень синтеза которых усилен более чем в 8 раз. Приоритетными мишенями для поражения wnt-каскада в ОСК является белок CTNNB1 - уровень его синтеза увеличен более чем 13 раз. 


\section{3. Сравнительный анализ ключевых параметров протеом ОСК и ДКГ, обработанных TGF-ß1}

Опухолевые клетки в количестве $50 \quad 000$ засевали в лунку 6-луночной плашки и культивировали при $37^{\circ} \mathrm{C}, 5 \% \mathrm{CO}_{2}$ до достижения $30 \%$ конфлюэнтности в среде DMEM/F12, содержащей $10 \%$ FBS, 1\% 200MM L-глутамина, 20 мM HEPES. Затем клетки промывали раствором HBSS и переводили на бессывороточную среду DMEM/F12 с добавлением TGF- $\beta 1$ в концентрации 5 нг/мл на 72 ч. Клетки монослойной культуры снимали и осаждали центрифугированием (1500 об/мин в течение 10 мин), супернатант удаляли, клетки ресуспендировали в 3 мл PBS (pH 7,4). Промывку клеток PBS повторяли еще два раза. Получение лизатов опухолевых клеток, их очистку от низкомолекулярных соединений и иные манипуляции проводили по методике, описанной выше.

В ходе протеомного анализа ДКГ, стимулированных TGF- $\beta$, было идентифицировано 2400 белков, из которых 2197 протеинов детектировались во всех клеточных лизатах: 40 белков выявлено только в контрольных DGCs, 163 белка - только в клетках, предобработанных TGF- $\beta 1$. Cpeди идентифицированных белков при стимуляции TGF- $\beta 1$ только 610 значимо ( $\mathrm{p}<0,05)$ изменили уровень синтеза: 488 усиливали, 122 снижали экспрессию.

Среди белков, значимо изменивших экспрессию в ДКГ обработанных TGF- $\beta 1$, идентифицированы маркеры ЭМП: Е-кадгерин (CDH1), оклюдин (OCLN), клаудин 1 (CLDN1). Среди апрегулированных белков выявлены N-кадгерин (CDH2), виментин (VIM), витронектин (VTN), компоненты актин-миозинового комплекса и матриксные металлопротеиназы MMP2, MMP9, MMP14, ADAMTS1 (табл. 6).

Биоинформационный анализ выявил 19 белков сигнального пути рецепторного взаимодействия с ВКМ, из которых 13 белков: гликопротеин CD44 (CD44), гиалуронан-опосредованный рецептор клеточной подвижности (HMMR), коллагены I (COL1A2), VIa1 (COL6A1) и VIa3 (COL6A3), фибронектин (FN1), ламинины $\beta 1$ (LAMB1) и $\gamma 1$ (LAMC1), ингегрины $\alpha 2$ (ITGA2), $\alpha 5$ (ITGA5), $\alpha \mathrm{V}$ (ITGAV), $\beta 1$ (ITGB1) и $\beta 3$ (ITGB3), а также 3 белка, активирующих этот сигнальный каскад: киндлин 2 (fermitin family homolog 2, FERMT2), лизилоксидаза 2 (lysyl oxidase homolog 2, LOXL2), диацетилаза гистонов 2 (histone deacetylase 2, HDAC2) и фибриллин 1 
(FBN1) в ДКГ, стимулированных TGF- $\beta 1$, усиливали синтез до значений, сопоставимых с ОСК (Таблица 7).

Таблийа 6

Экспрессия белков эпителиально-мезенхимального перехода

в дифференцированных клетках глиобластомы линии U87MG после стимуляции TGF-ß1

\begin{tabular}{|c|c|c|}
\hline ID & Международное название белка & 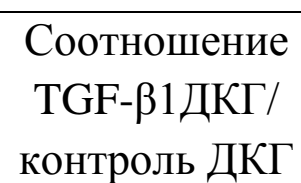 \\
\hline CDH1 & Е-кадгерин & $\downarrow^{*}$ \\
\hline OCLN & Окклюдин & $\downarrow^{*}$ \\
\hline CLDN1 & Клаудин 1 & 0,6 \\
\hline $\mathrm{CDH} 2$ & N-кадгерин & $\uparrow^{*}$ \\
\hline VIM & Виментин & 2,8 \\
\hline VTN & Витронектин & $\uparrow^{*}$ \\
\hline Actl6a & Актиноподобный белок 6А & 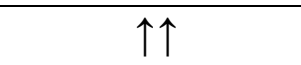 \\
\hline Actn1 & Актин, $\alpha 1$ & 2,0 \\
\hline ARPC3 & $\begin{array}{l}\text { Актиноподобный родственный белок } 2 / 3 \text { ком- } \\
\text { плексная субединица } 3\end{array}$ & 2,3 \\
\hline MYBPC3 & Миозин-связывающий белок C, сердечный & 5,7 \\
\hline Myo1C & Миозин IC & 2,8 \\
\hline MYO5A & Миозин VA (тяжелая цепь 12, миоксин) & $\uparrow$ \\
\hline Myo7a & Миозин VIIA & $\uparrow$ \\
\hline MMP2 & Матриксная металлопептидаза 2 & 2,8 \\
\hline MMP9 & Матриксная металлопептидаза 9 & 3,1 \\
\hline MMP14 & Матриксная металлопептидаза 14 & 2,2 \\
\hline ADAMTS1 & $\begin{array}{l}\text { ADAM матриксная металлопептидаза тром- } \\
\text { боспондинового типа } 1\end{array}$ & $\uparrow$ \\
\hline
\end{tabular}

Итак, стимуляция TGF- $\beta 1$ в свою очередь индуцирует экспрессию в ДКГ маркеров эпителиально-мезенхимального перехода, белков актинмиозинового комплекса и металлопротеиназ ВКМ - MMP2, ММР9, MMP14, ADAMTS1, что сопровождается повышением уровня синтеза 13 белков сигнального пути рецепторного взаимодействия с ВКМ (CD44, HMMR, COL1A2, COL6A1, COL6A3, FN1, LAMB1, LAMC1, ITGA2, ITGA5, ITGAV, ITGB1, ITGB3) и трех белков, активизирующих такое вза- 
имодействие FERMT2, HDAC2 и FBN1 в дифференцированных клетках глиобластомы до уровня ОСК.

Таблийа 7

Белки сигнального пути РВ-ВКМ, усиливающие синтез в ДКГ после стимуляции TGF-ß до значений, сопоставимых с ОСК

\begin{tabular}{|c|c|c|c|}
\hline ID & Международное название белка & $\begin{array}{c}\text { Соотноше- } \\
\text { ниеCD133 }{ }^{+} \mathrm{O} \\
\mathrm{CK} / \mathrm{CD} 133^{-} \\
\text {ДКГ }\end{array}$ & $\begin{array}{l}\text { Соотношение } \\
\text { ДКГ TGF- } \beta 1 / \\
\text { ДКГ' контроль }\end{array}$ \\
\hline CD44 & Гликопротеин CD44 & 2,5 & 2,3 \\
\hline HMMR & $\begin{array}{l}\text { Гиалуронан-опосредованный ре- } \\
\text { цептор клеточной подвижности }\end{array}$ & 2,2 & 2,3 \\
\hline Col15a1 & Коллаген XV типа, $\alpha 1$ субединица & - & 2.5 \\
\hline COL1A1 & Коллаген I типа, $\alpha 1$ субединица & 2,8 & - \\
\hline COL1A2 & Коллаген I типа & 3,2 & 3,6 \\
\hline COL6A1 & Коллаген VI типа, $\alpha 1$ субединица & 8,4 & 8,6 \\
\hline COL6A3 & Коллаген VI типа, $\alpha 3$ субединица & 4,3 & 4,5 \\
\hline COL7A1 & Коллаген VII типа, $\alpha 1$ субединица & - & 5,7 \\
\hline FN1 & Фибронектин I типа & 4,1 & 4,2 \\
\hline FNDC3B & $\begin{array}{l}\text { Фибронектин III типа, домен, со- } \\
\text { держащий белок 3В }\end{array}$ & - & 2,3 \\
\hline LAMB1 & Ламинин $\beta 1$ субединица & 8,8 & 8,2 \\
\hline LAMC1 & Ламинин $\gamma 1$ субединица & 3,8 & 3,7 \\
\hline ITGA2 & Ламинин $\alpha 2$ субединица & 3,9 & 4,1 \\
\hline ITGA5 & Ламинин $\alpha 5$ субединица & 3,6 & 3,5 \\
\hline ITGA8 & Интегрин $\alpha 8$ субединица & - & 2.2 \\
\hline ITGAV & Интегрин $\alpha \mathrm{V}$ субединица & 5,0 & 4,5 \\
\hline ITGAX & Интегрин $\alpha$ Х субединица & - & 2,2 \\
\hline ITGB1 & Интегрин $\beta 1$ субединица & 4,5 & 4,5 \\
\hline ITGB3 & Интегрин $\beta 3$ субединица & 3,2 & 3,4 \\
\hline
\end{tabular}

Уровень синтеза матриксной металлопротеиназы LOXL2 в OCK усилен более чем 9 раз по сравнению с ДКГ. Этот параметр принципиально не изменяется при стимуляции TGF- $\beta 1$. Белок LOXL2 является маркером ОСК глиобластомы человека. 
Белки, активирующие сигнальный путь РВ-ВКМ, усиливающие уровень синтеза в ДКГ после стимуляции TGF- $\beta$ до значений, сопоставимых с ОСК

\begin{tabular}{|c|c|c|c|}
\hline ID & $\begin{array}{c}\text { Международное название } \\
\text { белка }\end{array}$ & $\begin{array}{c}\text { Соотношение } \\
\text { CD133+ОСК/C } \\
\text { D133ДКГ }\end{array}$ & $\begin{array}{l}\text { Соотношение } \\
\text { ДКГ TGF- } \beta 1 / \\
\text { ДКГ'контроль } \\
\end{array}$ \\
\hline FERMT2 & $\begin{array}{l}\text { Ферментинового семейства } \\
\text { гомолог } 2, \text { киндлин } 2\end{array}$ & 3,5 & 3,2 \\
\hline LOXL2 & Лизил оксидазы гомолог 2 & 9,0 & 1,3 \\
\hline HDAC2 & Диацетилаза гистонов 2 & 1,7 & 1,5 \\
\hline FBN1 & Фибриллин 1 & 6,2 & 5,1 \\
\hline
\end{tabular}

\section{4. Сравнительный анализ ключевых параметров} протеома CD133+ ОСК МГБ человека до

\section{и после экспериментального облучения}

В работе использованы клетки линии Т98-G МГБ человека (American Type Culture Collection (ATCC®) CRL-1690M). «IDH-дикая» T98-G линия характеризуется низким уровнем метилирования гена MGMT и высоким содержанием фермента прямой репарации ДНК О6-метилгуанин метилтрансферазы. По данным проточной цитометрии, более $90 \%$ этой клеточной культуры иммунопозитивны в отношении антигена CD133.

Клетки культивировали в 6-луночных планшетах, заполненных средой DMEM с 10\%-ной эмбриональной телячьей сывороткой, пенициллином / стрептомицином (100 U/ml, 100X (cat. no. 15240062, Gibco, ThermoFisher scientific, US) при $37{ }^{\circ} \mathrm{C} \quad\left(\begin{array}{llll}5 \% & \mathrm{CO}_{2}\end{array}\right)$. Все реагенты производства компании "Gibco" (Thermo Fisher Scientific, Inc.). Линия протестирована на контаминацию микоплазмой с помощью Universal Mycoplasma Detection Kit (ATCC® 30-1012K ${ }^{\mathrm{TM}}$ ).

Клетки МГБ подвергали дистанционному облучению с применением гамма-терапевтической установки «Рокус-М» (г. Санкт-Петербург, Россия) использующей кобальт 60 в качестве источника радионуклидного излучения. За одну фракцию достигали дозы 6 Грей и выполняли 8 фракций с интервалом 72 ч до достижения суммарной дозы 48 Грей. Количество живых клеток в культуре составляло $70 \pm 12,5 \%$. Дальнейшее увеличение дозы до 60 Гр не сопровождалось значимыми изменениями 
данной цифры. Для получения лизатов для протеомного картирования использовали только живые клетки МГБ. Лизаты готовили согласно описанной выше методике (см. раздел 8.1).

Используя протеомный анализ триптических пептидов, с помощью программного обеспечения "MaxQuant" было идентифицировано 978 белков. Дополнительная обработка данных с помощью программы "Perseus" идентифицировала в первом образце (облученные клетки - 60 Гр) 957 белков, а во втором, контрольном образце - 945 белков. Идентифицированные протеины показали высокий процент перекрытия для двух клеточных популяций: 924 белка (94\% из 978 белков) были обнаружены во всех клеточных лизатах, 6 белков - только в облученных клетках, а 2 белка только в контрольных клетках.

Из всех идентифицированных ДЭБ (p < 0,05) были 70 белков, уровень синтеза которых в облученных клетках увеличивался более чем в 2 раза. Исходя из логики, описанной в главе 3 , было идентифицировано 18 ДЭБ, уровень синтеза которых был увеличен в 3 раза, однако особое внимание было уделено семи протеинам, увеличившим уровень синтеза в 4 раза и более (табл. 8).

Таблий 8

Дифференциально экспрессированные белки, экспрессия которых в CD133+ клетках МГБ, получивших облучение в дозе 60 Грей, усилена более чем 4 раза

\begin{tabular}{|l|l|c|}
\hline $\begin{array}{c}\text { Название } \\
\text { гена }\end{array}$ & \multicolumn{1}{|c|}{ Международное название белка } & $\begin{array}{c}\text { Облучение/ } \\
\text { контроль }\end{array}$ \\
\hline ERC1 & ELKS/RAB6-interacting/CAST family member 1 & 9,5 \\
\hline NARG1L & $\begin{array}{l}\text { NMDA receptor regulated 1-like; N-alpha-acetyltransferase } \\
15\end{array}$ & 6,3 \\
\hline PLCD3 & Phospholipase C, delta 3 & 5,7 \\
\hline ROCK2 & Rho-associated, coiled-coil containing protein kinase 2 & 4,5 \\
\hline SARNP & SAP domain containing ribonucleoprotein & 4,2 \\
\hline TMSB4X & $\begin{array}{l}\text { Thymosin-like 2 (pseudogene); thymosin-like 1 (pseudo- } \\
\text { gene); thymosin beta 4, X-linked }\end{array}$ & 4,1 \\
\hline YTHDF2 & $\begin{array}{l}\text { YTH domain family, member 2; YTH domain family, } \\
\text { member 3 }\end{array}$ & 6,8 \\
\hline
\end{tabular}

Прецизионный биоинформационный анализ выявил принадлежность девяти ДЭБ белков, идентифицированных в облученных клетках МГБ 
( $\mathrm{p}<0,05)$, к сигнальному каскаду, ассоциированному с протеасомами (табл. 9).

Таблиия 9

Детерминанты протеасом, экспрессия которых отличается

более чем в два раза в облученных клетках МГБ

по сравнению с контрольной группой

\begin{tabular}{|l|l|c|}
\hline $\begin{array}{c}\text { Название } \\
\text { гена }\end{array}$ & \multicolumn{1}{|c|}{ Международное название белка } & $\begin{array}{c}\text { Облучение/ } \\
\text { контроль }\end{array}$ \\
\hline PSMA2 & Proteasome (prosome, macropain) subunit, alpha type, 2 & 3,2 \\
\hline PSMA3 & Proteasome (prosome, macropain) subunit, alpha type, 3 & 2,3 \\
\hline PSMA4 & Proteasome (prosome, macropain) subunit, alpha type, 4 & 2,2 \\
\hline PSMB2 & Proteasome (prosome, macropain) subunit, beta type, 2 & 2,3 \\
\hline PSMB3 & Proteasome (prosome, macropain) subunit, beta type, 3 & 2,9 \\
\hline PSMB7 & Proteasome (prosome, macropain) subunit, beta type, 7 & 3,5 \\
\hline PSMC3 & Proteasome (prosome, macropain) 26S subunit, ATPase, 3 & 3,3 \\
\hline PSMD1 & $\begin{array}{l}\text { Proteasome (prosome, macropain) 26S subunit, non- } \\
\text { ATPase, 1 }\end{array}$ & 2,4 \\
\hline PSMD3 & $\begin{array}{l}\text { Proteasome (prosome, macropain) 26S subunit, non- } \\
\text { ATPase, 3 }\end{array}$ & 3,9 \\
\hline
\end{tabular}

Итак, облучение в дозе 60 Грей усиливает в CD133+ клетках МГБ синтез белков ERC1, NARG1L, PLCD3, ROCK2, SARNP, TMSB4X и YTHDF2 более чем в 4 раза. При этом достоверно более чем 2 раза возрастает уровень синтеза белков протеасом (PSMA2, PSMA3, PSMA4, PSMB2, PSMB3, PSMB7, PSMC3, PSMD1, PSMD3).

\section{5. Обсуждение результатов главы 8}

\subsection{1. Обсуждение результатов сравнительного картирования}

\section{стволовых и опухолевых клеток}

Сопоставив протеомный профиль белков ОСК, выделенной из глиобластомы человека, с протеомными профилями: а) нормальных, тканеспецифичных для нервной системы НСК и б) МСК костного мозга человека, которые локализованы за ГЭБ, мы идентифицировали 1664 белка, из которых 63,2\% идентичны в НСК и ОСК и 36,47\% подобны МСК и ОСК. Для нас было особенно важно, что ОСК ГБ и нормальная НСК - это клетки, локализованные за ГЭБ и имеющие единый гистогенетический источник в ЦНС. 
Высокий процент белков, идентичных в ОСК и НСК, свидетельствует о вовлеченности регионарных стволовых клеток в неопластический процесс и служит важным аргументом в пользу идеи происхождения рака из регионарных стволовых клеток (Lathia et al., 2015; Gimple et al., 2019). Основываясь на представленных выше фактах высокой подвижности НСК в отношении клеток ГБ и способности нормальных стволовых клеток взаимодействовать с клетками ГБ, обмениваться с ними флуоресцентной меткой, допустимо предположить, что столь высокий процент общих белков НСК и ОСК указывает на существование особого механизма прогрессирования ГБ, связанного с вовлечением в неопластический процесс регионарных стволовых клеток.

На существование именно такого механизма указывает присутствие только 36,47\% белков, подобных в МСК и ОСК. Остальные белки в ОСК глиобластомы U87 связанны с опухолевым процессом. Первоначально предполагали, что все идентифицированные нами «общие» белки представляют собою некую «матрицу подобия» и ОСК - это и есть тот «здоровый» и «видоспецифичный» белковый клеточный субстрат, который остался сохранным в ОСК.

Исходя из данных 2014 г. мы предполагали, что эти белки могут стать основой для разработки метода персонализированного, таргетного управления ключевыми функциями ОСК, и проаннотировали белки этого типа клеток, которые не пострадали в результате неопластической трансформации клетки, распределив их на мембранные, секретируемые и ядерные. Такой подход не является личной инициативой авторов, а скорее, продиктован спецификой объекта исследования, разрешающими возможностями метода и возможностями современных баз биологической информации.

В частности, анализируя «матрицы подобия», мы не смогли в полном объеме идентифицировать важный кластер - «цитоплазматические белки», связывающие «ядерный» и «мембранный» компоненты внутриклеточных путей сигнальной трансдукции. Помимо этого, исходя из соображений достоверности, из анализа каждой из групп сравнения мы исключили все белки, у которых нормализованная сигнальная интенсивность изменилась менее чем в 2 раза, что, безусловно, исключает влияние некоторых уникальных белков. В частности, в данную, безусловно, идеализированную выборку, не попал wnt-сигнальный путь важнейший молекулярный механизм регуляции активности стволовых 
клеток всех типов, что потребовало проведения дополнительных исследований.

Полученные данные позволили идентифицировать в ОСК ряд путей сигнальной трансдукции, не пострадавших в результате опухолевой трансформации и общих для стволовых клеток всех типов. Наше дальнейшее внимание привлекли сохранные сигнальный пути активации Вклеток, путь Т-клеточной активации, путь воспаления, опосредованного цитокинами, путь гликолиза, путь ангиогенеза, FAS, EGF, FGF - сигнальные механизмы, сигнальный путь фокальной адгезии и интегриновый сигнальный путь.

Анализируя эти механизмы, нельзя не обратить внимание, что путь активации В-клеток, путь Т-клеточной активации и путь воспаления, опосредованного цитокинами, наиболее характерны для клеток иммунной системы важнейшего регулятора процессов репарации и регенерации в многоклеточном организме. Очевидно, что нормальная стволовая клетка использует именно эти пути для взаимодействия с клетками иммунной системы, что указывает на исключительно важную роль таких взаимодействий.

Наше внимание привлек сигнальный путь воспаления, опосредованного цитокинами, который, весьма возможно, задает главный вектор, предопределяющий судьбу нормальных и патологически измененных низкодифференцированных клеток в процессе воспаления. Вероятно, конечный выбор определяется провоспалительными или иммуносупрессивными цитокинами. На основании данных предшествующих экспериментов можно предположить, что в иммуносупрессивной среде оптимизируются энергетические процессы в опухолевых клетках, подавляется FAS-сигнализация, формируются ансамбли взаимодействующих клеток, продуцирующих EGF- и FGFлиганды, запускаются процессы ангиогенеза и прогрессирования опухоли. Но стратегически важным условием для реализации именно такого сценария является установление продуктивных взаимодействий между стволовыми клетками и внеклеточным матриксом (ВКМ).

В этой связи сигнальный путь интегринов, который большей частью совпадает с путем фокальной адгезии, представлял наибольший интерес. Вопервых, сигнальный путь фокальной адгезии можно рассматривать как путь

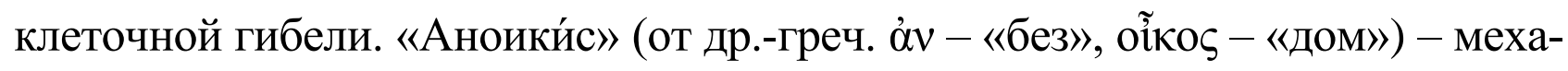
низм гибели «бездомной» клетки путём апоптоза, которая наступает в ответ на утрату связи с ВКМ. Данный механизм активируется при связывании 
классического провоспалительного цитокина - фактора некроза опухоли $\alpha$ (TNF $\alpha$ ) с FAS-рецептором, внутриклеточный сигнальный домен которого, как показывают наши исследования, остается сохранным в нормальных и опухолевых стволовых клетках. Взаимодейстие TNF $\alpha / F a s$ приводит к сборке сигнального комплекса, индуцирующего смерть (death-inducing signalling complex, DISC), который запускает апоптоз.

Воздействие на FAS систему исключительно перспективно. Описаны примеры (Chen et al., 2017; Kumar et al., 2015) подавления роста опухолей путем активации TNFa/Fas сигнального пути, и этот эффект опосредован моноцитами и гранулоцитами, инфильтрирующими опухоль. Безусловно, опухолевая клетка - это патологически измененная клетка, и рассуждая о ее поведении в провоспалительной среде, необходимо принимать во внимание и мутации компонентов сигнального пути FAS, и мутации компонентов других сигнальных путей.

\subsection{2. Обсуждение результатов сравнительного картирования ОСК и ДКГ}

Основываясь на этой логике, во второй части нашей работы выполнен сравнительный анализ молекулярных фенотипов ОСК и ДКГ. В качестве отправной точки нами был выбран протеом ОСК линии U-87MG глиобластомы человека, изолированной из глиомасфер по эксперссии антигена CD133. Как следует из данных анализа протеомных профилей, ОСК представляет собой уникальную живую систему, обладающую живучестью, на что указывает усиление синтеза белков сигнальных путей гликолиза/гликонеогенеза. Гипоксический тип метаболизма является одной из важнейших характеристик клеток злокачественных опухолей, но особенно он характерен для клеток «дикого» типа ГБ (Allen et al., 2016). Столь значительные отличия протеомного профиля ОСК от ДКГ свидетельствуют о том, что в процессе селекции на бессывороточных средах с пониженным содержанием глюкозы создаются условия, идентичные таковым внутри узла ГБ, что обеспечивает отбор клеток, обладающих уникальными морфогенными и сигнальными свойствами.

В пользу этого аргумента указывает апрегуляция множества белков сигнального пути Wnt - ключевого эмбрионального механизма регуляции плюрипотентности стволовых клеток (табл. 5). На обсуждении этого феномена нужно остановиться более подробно. 
К сожалению, распространенное мнение о тотальной активации wntсигнального каскада в ОСК не подтвердилось в нашем эксперименте. Wntлиганды, рецепторы "Frizzled", корецепторы LRP5/6 и другие канонические белки этого каскада не показали значимого увеличения экспрессии. Однако гиперэкспрессированные компоненты wnt-сигнального пути в ОСК формировали довольно специфическую картину.

Белок - APC (Adenomatous Polyposis Coli) - достоверно гиперэкспрессирован в ОСК по сравнению с ДКГ. Наиболее часто данный феномен встречается именно МГБ (Nikuseva-Martić et al., 2007). Мутация гена, кодирующего этот белок, является одним из компонентов синдрома Теркота, играющего стратегическое значение в патогенезе МГБ (Dipro et al., 2012).

Экспрессия CacyBP/SIP (Calcyclin-связывающего белка, взаимодействующего с Siah-1) в ОСК выше (в 2,0 раза), чем в ДКГ. Белок не является компонентом канонического wnt-каскада, но имеет важное значение для пролиферации, дифференцировки, апоптоза и организации цитоскелета, транскрипции и убиквитинирования, регулирует деградацию $\beta$-катенина. Высокие уровни СасуBP / SIP характерны для клеток wnt-управляемых опухолей желудка и толстой кишки, а также для нейронов. Белок является одним из компонентов сигнального пути Р53, который стратегически важен для МГБ.

Высокие уровни СасуВР / SIP важны для пролиферации ОСК (Yan et al., 2018), где он является антагонистическим белком р27-селективного ингибитора циклин-зависимой киназы 1B. СасуBP / SIP может использоваться как маркер состояния клеточной популяции МГБ и быть перспективной мишенью для регуляции ОСК.

Casein kinase 2 (CK2), компонент канонического сигнального пути Wnt / $\beta$-catenin, регулирует клеточный цикл, апоптоз и транскрипцию. $\mathrm{CK} 2$, как и белок АРC, является важнейшим компонентом «комплекса деградации» $\beta$-катенина. Одновременно этот фермент участвует в модерации сигналинга NF-кB в клетках МГБ (Nitta et al., 2015). В нашей работе были идентифицированы две каталитические субъединицы: CSNK2A2 $(\mathrm{CK} 2 \alpha)$ и CSNK2B (CK2 $\beta)$, которые были увеличены в ОСК по сравнению с ДКГ в 5,24 и 12,21 раза. СК2 $\alpha$ является мультинодулярным регулятором сигнального пути Wnt/ $\beta$-catenin, экспрессия этого белка увеличивается во многих опухолях, субъединицы CSNK2A2 и CSNK2B могут быть использованы как мишени для регуляции ОСК в комплексной терапии МГБ. 
Cul1 является одним из белков wnt-сигнального пути. Уровень синтеза куллина в OCК в 3,39 раза выше, чем в ДКГ. Белки Cull участвуют в различных внутриклеточных процессах, включая пролиферацию, дифференцировку и апоптоз.

Белки Rac2, RhoA и DAAM1 - компоненты неканонической Wntсигнализации. Также они являются компонентами сигнального пути адгезивных контактов. Rac-белки - подсемейство Rho малых GTPases. Функция этого семейства включает модификацию актинового цитоскелета, пролиферацию и регуляцию ключевых свойств стволовых клеток. Rac2 является маркером более агрессивных типов МГБ (Lai et al., 2017). Наше исследование показало, что количество Ras2 в клетках CD133 + увеличилось в 1,67 раза. Rho GTPases принадлежат к суперсемейству Ras, и эти белки (RhoA, Rac1 и Cdc42) поддерживают трансформацию клеточного цитоскелета во время ЭМП. RhoA активно экспрессируются в клетках GBM, способствуя миграции и инвазии раковых клеток. Наше исследование показало, что количество RhoA в ОСК увеличилось в 1,94 раза.

C-концевые связывающие белки (CtBP) имеют две изоформы: CtBP1 и CtBP2, которые являются частью сигнального пути Wnt / $\beta$-catenin и других молекулярных механизмов, определяющих развитие злокачественных опухолей, инвазию опухолевых клеток, апоптоз и ответ на терапию. Уровни экспрессии СТВР1 и СТВР2 в ОСК усилены в 3,42 и 2,24 раза по сравнению с ДКГ. Белок СtВР в комплексах с белком АРС регулирует активность $\beta$-катенина и моделирует активность оси TCF4/ LEF, активирует целевые гены самообновления ОСК (Dcona et al., 2017).

RUVBL1 (Pontin52) является одним из белков сигнального пути Wnt, который необходим для роста и жизнеспособности опухолевых клеток. Уровень RUVBL1 был значительно выше в ОСК по сравнению с ДКГ. Белок играет ключевую роль в клеточном цикле, митозе, ремоделировании хроматина, регуляции транскрипции и развития, репарации ДНК и апоптозе. Важно, что белки CtBP и RUVBL1 регулируют экспрессию генов в ядре ОСК совместно с SMAD - сигнальным каскадом, активным фактором которого является TGF- $\beta$, роль которого в патогенезе МГБ очевидна.

$\beta$-катенин является ключевым элементом wnt-сигнального пути, связанного с самообновлением стволовых клеток. Согласно экспериментальным данным, экспрессия $\beta$-катенина (изоформы CTNNB1) в ОСК увеличена в 13,9 раза по сравнению с ДКГ. Этот факт имеет решающее значение в ис- 
следовании. Ингибирование $\beta$-катенина в клетках U87 подавляет их миграционную активность, синтез этого белка играет решающую роль в инвазии, выживании и пролиферации (Kahlert et al., 2015) ОСК и способности клеток МГБ формировать глиомасферы in vitro (Kierulf-Vieira et al., 2015).

Особенностью данного исследования является усиление синтеза компонентов (АРC, СК2 $\alpha, \mathrm{CK} 2 \beta)$ «комплекса деградации $\beta$-катенина»на фоне многократного увеличения содержания самого $\beta$-катенина в ОСК. В норме эти величины обратно зависимы. Усиление продукции АРС и СК2 на фоне высокого содержания $\beta$-катенина в ОСК явно свидетельствуют о наличии WNT-лиганда в глиомасфере. Кроме того, апрегуляция белков «деградационного комплекса» наводит на мысль, что $\beta$-катенин может быть связан с клеточной мембраной, где он координирует процессы межклеточного взаимодействия в глиомасфере.

Особого внимания заслуживает тот факт, что $\beta$-катенин (CTNNB1) является одним из компонентов сигнального пути адгезивных контактов, гиперэкспрессия которых на фоне высокого содержания $\beta$-катенина и других wnt-белков описана (Nikuseva-Martić et al., 2007) как одна из ключевых особенностей клеток МГБ. Тесная связь между усилением синтеза белков сигнальных путей адгезионных контактов и белков wht-сигнального пути, вероятно, обясняется спецификой пролиферации ОСК в глиомасфере, где усиление контактного взаимодействия индуцирует выход клеток из глиомасфер, их дифференцировку и формирование монослоя.

Здесь опять целессобразно вернуться к фокальной адгезии. Инвазия главное свойство ГБ, и в этой связи именно фокальная адгезия является регулятором поведения ОСК, что требует особого внимания к вопросу. Для проникновения опухолевых клеток через ВКМ, что, собственно, составляет основную суть процесса инвазии, опухолевые клетки изначально прикрепляются к его компонентам. В формировании клеточно-матриксных контактов ключевая роль принадлежит интегринам - рецепторам, которые обеспечивают рецепторное взаимодействие с ВКМ, осуществляя трандукцию сигнала «внутрь» и «наружу».

Проведение сигнала «наружу» клетки координирует афинный статус интегриновых рецепторов, которые, связываясь с ВКМ, формируют фокальную «адгезивную бляшку», в результате чего клетка прикрепляется, выживает и реорганизует цитоскелет, что необходимо для амебоидной миграции в ткани. В свою очередь, трансдукция сигнала «внутрь», активи- 
зирует все внутриклеточные сигнальные механизмы фокальной адгезии, координирующие основные жизненные процессы, обеспечивая включение программ миграции или ангиогенеза.

В пользу высоких инвазивных возможностей ОСК свидетельствует апрегуляция 14 белков сигнального рецепторного взаимодействия с ВКМ. Такой молекулярный арсенал позволяет ОСК быстро запустить инвазивный процесс, что подтверждают экспериментальные данные (Singh et al., 2003) об исключительной онкогенности этих клеток. Однако запуск опухолевого процесса и прогрессирование МГБ - это не синонимы.

Если исходить из предположения, что количество ОСК в опухоли сравнительно невелико (Gimple et al., 2019), то прогрессирование МГБ, а следовательно, проникновение ОК в окружающие ткани за пределы первичного опухолевого узла возможно только при условии преодоления определенного количественно-качественного порога, что становится возможным благодаря селекции биохимических изменений, которые претерпевают ДКГ под воздействием иммуносупрессивных цитокинов, в фокусе самого пристального внимания TGF- $\beta$.

B норме TGF- $\beta$ индуцирует апопто3, контролирует пролиферацию и дифференцировку клеток. Стимуляция TGF- $\beta 1$ ведет к резкому изменению молекулярного профиля ДКГ в виде подавления синтеза адгезионного Е-кадгерина, усиления продукции миграционного N-кадгерина, апрегуляции компонентов актин-миозинового комплекса, белков мезенхимального фенотипа и матриксных металлопротеиназ.

В пользу исключительно продуктивной межклеточной коллаборации в опухолевом очаге свидетельствует значительное усиление синтеза в ДКГ 19 белков сигнального пути рецепторного взаимодействия с ВКМ, среди которых 13 белков увеличивают уровень синтеза более чем в 2 раза, достигая значений, сопоставимых с ОСК, что отчасти позволяет рассматривать клетки этого типа в качестве своеобразной «матрицы», детерминирующей свойства ДКГ агрессивного фенотипа.

\subsection{3. Обсуждение результатов сравнительного анализа ключевых параметров протеома ОСК и ДКГ обрабобанных TGF-ß1}

При сравнительном анализе протеомов ДКГ, стимулированных TGF$\beta$ и ОСК, нами обнаружено резкое усиление продукции гликопротеина CD44 - рецептора гиалуроновой кислоты и опосредованного гиалурона- 
ном рецептора подвижности (HMMR), что является ключевым фактором для инвазии (Mooney et al., 2016).

Антиген CD44 в контексте полученных данных особенно интересен. В клетках, выделенных из глиомасфер, колличество элементов ИР в отношении антигена CD44 сравнительно невелико. Однако в эксперименте in vivo к 28-му дню наблюдений отмечен рост количества клеток ИР в отношении антигена CD44, который рассматривают (Goffart et al., 2017) как признак агрессивного фенотипа ОК. В этой связи появление этого маркера на поверхности клеток глиомы на 28-й день эксперимента подтверждает возросшую мобильность OK, вызванную стимуляцией TGF- $\beta$.

В эксперименте (Brown et al., 2016) имплантация CD44+ клеток в мозг животных позволяла быстро запустить инвазивный процесс, при этом формирование объемных опухолей было возможно только при наличии среди имплантируемых клеток CD133-ИР морфологических элементов.

Результаты настоящего исследования показали, что содержание белка CD44 в OCK было в 2,5 раза выше, чем в ДКГ, при этом стимуляции TGF- $\beta$ увеличивает уровень синтеза этого белка в 2,3 раза по сравнению с интактными ДКГ.

HMMR является онкогеном, который играет важную роль в развитии солидной опухоли. Он сильно активируется в тканях глиомы человека, особенно в МГБ. Белок HMMR создает комплекс с CD44 и после связывания с гиалуроновой кислотой активирует внутриклеточные сигнальные пути, регулирующие пролиферацию и инвазию ОСК. Ингибирование HMMR подавляет и радиосенсибилизирует клетки МГБ. Результаты настоящего исследования показали, что экспрессия HMMR в OCK была в 2,2 раза выше по сравнению с экспрессией в ДКГ, что свидетельствует о высокоинвазивной природе этих клеток. В ДКГ после стимуляции ТGF- $\beta$, уровень синтеза этого белка возрастает в 2,3 раза.

Особое внимание заслуживают компоненты ВКМ: коллаген, фибронектин и ламинин, синтез которого является обязательным компонентом комплексной программы инвазивного роста. В настоящем исследовании продемонстрирована высокая (более чем в 2 раза) экспрессия коллагенов I и IV типов в ОСК по сравнению с таковыми в ДКГ. При этом стимуляция дифференцированных опухолевых клеток TGF- $\beta$ приводила к усилению уровня синтеза трех субъедениц коллагена COL1A2, COL6A1 и COL6A3 до уровня, сопоставимого с ОСК. 
Коллаген I (COL1A2) типа, регулируемого в OCK, в 3,2 раза сильнее по сравнению с ОСК стимулирует дифференцированные клетки TGF- $\beta$ и усиливает синтез этого белка в 3,6 раза. Данный протеин является молекулярно-ориентированным маркером при раке желудка и простаты. Подавление гена COL1A2 угнетает процессы инвазии и метастазирования опухолей желудочно-кишечного тракта.

Collagen type VI $\alpha 1$ chain (COL6A1) апрегулирован в OCK в 8,4 раза по сравнению с ДКГ, однако стимуляция опухолевых клеток TGF- $\beta$ усиливает синтез этого белка более чем в 8 раз. Апрегуляция COL6A1 в клетках МГБ ассоциируется с резистентностью к лечению и является одним из самых значимых маркеров инвазивных глиальных опухолей.

Фибронектин 1 (FN1) является ключевым компонентом ВКМ. Повышенные уровни экспрессии FN1 выявлены у большинства пациентов с ГБ. Повышенная продукция FN1 модулирует адгезию, пролиферацию, дифференцировку и химиорезистентность ОСК. Результаты настоящего исследования показали, что экспрессия этого белка в ОСК была в 4,1 раза выше, чем в DGCs. При этом стимуляция TGF- $\beta$ увеличивает уровень синтеза FN 1 в опухолевых клетках в 4,2 раза.

Экспрессия субъединиц $\beta$ (LAMB1) и $\gamma$ (LAMC1) ламининов была выше в 8,8 и 3,8 раза соответственно в ОСК по сравнению с таковой в ДКГ. Стимуляция клеток ГБ TGF- $\beta 1$ приводит к усилению продукции этих молекул ламинина в 8,2 и 3,7 раза соответственно.

При связывании с коллагеном, ламинином и фибронектином происходит перестройка цитоплазматического домена интегриновых рецепторов с образованием адгезивной бляшки, необходимой для амебоидной миграции клеток в окружающие ткани. В этой связи наблюдаемое нами обогащение репертуара интегриновых рецепторов клеточной поверхности представляется одним из важнейших компонентов общей картины изменений, наблюдаемых при формировании агессивного фенотипа.

Обогащение репертуара интегриновых рецепторов при стимуляции TGF- $\beta$ показано нами на модели клеток линии A549 аденокарциномы легких и МГБ человека (Shevchenko, 2017). В данном исследовании особо отметим значительное увеличение содержания в ДКГ агрессивного фенотипа 5 - белков, которые достигают значений, сопоставимых с ОСК.

Субъединица интегрина 2 (ITGA2) участвует в прогрессировании инвазивных опухолей, включая меланому, способствует выживанию и ин- 
вазии клеток рака предстательной железы и является маркером инвазивно активных клеток - предшественников трофобласта. Текущее исследование показало, что ОСК имели в 3,9 раза более высокую экспрессию ITGA2 по сравнению с таковой в ДКГ. Стимуляция опухолевых клеток TGF- $\beta$ увеличивает уровень синтеза этого белка в 4,1 раза.

Субъединица интегрина 5 (ITGA5) является маркером неблагоприятного прогноза при раке пищевода и колоректальной аденокарциноме, положительно регулирует клеточную стволовость при трижды негативном раке молочной железы и поддерживает образование глиомасфер in vitro и миграцию клеток ГБ. Результаты текущего исследования показали, что CSC имели 3,6-кратную повышенную экспрессию ITGA5 по сравнению с DGC. При этом стимуляция опухолевых клеток TGF- $\beta$ увеличивает уровень синтеза этого белка в 3,5 раза.

Интегрин V (ITGAV) активируется в первичных опухолевых клетках головного мозга и метастазах меланомы, рака легких, почек и молочной железы. ITGAV регулирует биологические эффекты TGF- $\beta$ через SMADзависимый механизм, индуцирует дифференцировку ОСК при взаимодействии с компонентами ЕСМ. Эти белки играют важную роль в позиционировании клеток-предшественников при миграции нейробластов из субвентрикулярной зоны мозга в обонятельную луковицу. Текущее исследование показало, что экспрессия ITGAV в OCK в 5 раз выше, чем в ДКГ. Стимуляция опухолевых клеток TGF- $\beta$ увеличивает уровень синтеза этого белка в 4,5 раза. Данные белки являются важнейшими рецепторами витронектина, фибронектина, фибриногена, ламинина и других компонентов ЕСМ.

Уровни экспрессии субъединицы интегрина $\beta 1$ (ITGB1) и субъединицы интегрина $\beta 3$ (ITGB3) также были увеличены в ОСК в 4,5 и 3,24 раза соответственно. Стимуляция опухолевых клеток TGF- $\beta$ увеличивает уровень синтеза этого белка в 4,5 и 3,4 раза по сравнению с интактными дифференцированными опухолевыми клетками. Уровень синтеза ITGB1 усилен в клетках ГБ, резистентной к бевацизумабу, а эффективность антиангиогенной терапии возрастает при подавлении этой мишени. Усиленная продукция ITGB3 характеризует клетки МГБ, выделенные из богатых витронектином гипоксических зон опухоли и обладающие высокой инвазивной и метастатической активностью. Экспрессию этих белков в клетках колоректального рака предложено рассматривать в числе молекулярных маркеров отдаленных метастазов в мозг. 
Итак, стимуляция дифференцированных опухолевых клеток TGF- $\beta$ сопровождается апрегуляцией ряда белков сигнального пути рецепторного взаимодействия с ВКМ, что сближает их молекулярный фенотип с ОСК. Однако сходство молекулярных фенотипов на этом не заканчивается. Более тонкий биоинформационный анализ выявил ряд белков, активирующих сигнальный путь РВ-ВКМ, которые апрегулируется в ДКГ после стимуляции TGF- $\beta$, достигая значений, сопоставимых с ОСК.

FERMT2 является важным регулятором активности интегрина в межклеточных взаимодействиях, который модулирует опосредованную интегрином адгезию и инвазию ОК, а также участвует в канцерогенезе и прогрессировании опухолей. Результаты настоящего исследования показали, что ОСК имели 3,5-кратное увеличение экспрессии FERMT2 по сравнению с ДКГ. Стимуляция опухолевых клеток TGF- $\beta$ увеличивает уровень синтеза этого белка в 3,2 раза по сравнению с интактными ДКГ.

LOXL2 является секретируемой медь-зависимой аминооксидазой семейства LOX; его субстраты - коллаген и эластин. Повышенная экспрессия LOXL2 в клетках различных типов рака коррелирует со снижением показателей выживаемости у пациентов и связана с инвазивной и метастатической активностью рака молочной железы, гепатоцеллюлярной аденокарциномы, клеток рака предстательной железы и некоторых других агрессивных опухолей. Текущий анализ выявил 9-кратное увеличение экспрессии LOXL2 в OCK по сравнению с таковым в ДКГ. Однако стимуляция опухолевых клеток TGF- $\beta$ значительно повышает уровень синтеза этого белка в ДКГ по сравнению с интактными ДКГ, что указывает на особую роль этого фермента в биологии ОСК.

Поэтомy LOXL2 может быть заметным маркером OCK и многообещающей терапевтической мишенью. Уровень экспрессии LOXL2 позитивно регулируется индуцируемыми гипоксией факторами, а повышенная экспрессия часто наблюдается в инвазивных опухолях молочной железы, головы и шеи. Следовательно, значительное увеличение экспрессии LOXL2, наблюдаемое в OCK в настоящем исследовании, указывает на то, что этот белок может играть роль в опухолевых процессах в клетках данного типа. LOXL2 изменяет структуру гистонов, способствуя развитию метастазов и инвазии.

Уровень экспрессии LOXL2 коррелирует с экспрессией HDAC2, что указывает на то, что эти белки могут играть синергетическую онкогенную 
роль. В настоящем исследовании экспрессия HDAC2 была в 1,7 раза выше в ОСК по сравнению с таковой в ДКГ. При этом стимуляция опухолевых клеток TGF- $\beta$ увеличивает уровень синтеза этого белка в 1,5 раза до значений, сопоставимых в ОСК.

FBN1 представляет собой белок семейства фибриллинов, который участвует в поддержании плюрипотентности нормальных эмбриональных стволовых клеток и ОСК и обеспечивает биологическое действие TGF- $\beta$. Было обнаружено, что уровень экспрессии FBN1 в OCK в 6,21 раза выше, чем в ДКГ. Стимуляция опухолевых клеток TGF- $\beta$ увеличивает уровень синтеза этого белка в 5,1 раза до значений, сопоставимых в ОСК. Таким образом, стимуляция TGF- $\beta$ подавляет пролиферацию, увеличивает подвижность и формирует агрессивный молекулярный фенотип клеток МГБ, который характеризуется переключением адгезионных Е-кадгеринов на миграционные N-кадгерины, продукцию маркеров тканей мезодермального происхождения, усиленивает синтез белков актин-миозинового комплекса, продукцию матриксных металлопротеаз и апрегуляцию 19 белков сигнального пути рецепторного взаимодействия с внеклеточным матриксом, из которых 13 белков увеличивают уровень синтеза более чем в 2 раза, достигая значений, сопоставимых с ОСК. Формирование агрессивного фенотипа клеток МГБ сопровождается усилением синтеза молекул, непосредственно взаимодействующих с апрегулированными белками.

Экспрессия LOXL2 более чем в 9 раз выше в OCK по сравнению с ДКГ, из чего можно заключить, что ОСК имеют высокоинвазивную природу и что данный белок может быть важным маркером ОСК и многообещающей мишенью для устранения этих клеток в МГБ. Вероятно, клетки фенотипа CD133+ LOXL2+ занимают особое место в иерархии клеток МГБ, а продукция этого маркера отличает клетки агрессивного фенотипа от ОСК, что должно обязательно учитываться при выборе мишеней для целевой терапии.

\subsection{4. Обсуждение результатов сравнительного анализа ключевых параметров протеома СD133+ ОСК МГБ человека до и после экспериментального облучения}

Белок ERC1, или ELKS/RAB6 - взаимодействующий белок одного семейства CAST - продукт экспрессии гена ERC1 под воздействием облучения усиливает уровень синтеза в 9,5 раза. Белок входит в группу RIM-связанных белков, регулирующих эллектрическую активность пре- 
синаптических $\mathrm{Ca}^{+2}$ каналов (Kaeser, 2011), в клетках млекопитающих направляет белок RAB6A в меланосомы, принимает участие в транспорте продуктов внутриклеточного синтеза из аппарата Гольджи к плазматической мембране вдоль сети микротрубочек.

По данным базы белок-белковых взаимодействий, STRING (https://string-db.org) - продукт гена ERC1 - взаимодействует с транскрипционным фактором NF-k $\beta$, контролирующим экспрессию генов иммунного ответа, апоптоза, клеточного цикла и репарации ДНК. Помимо этого данный белок является компонентом системы убиквитин-зависимого внутриклеточного протеолиза и неразрывно связан с реакцией на стресс и репарацией ДНК. Существуют данные (Astro et al., 2016) о вовлеченности этого белка в регуляцию процесса фокальной адгезии и микромеханических свойств опухолевых клеток, активацию сигналинга TGF- $\beta$ и MAPK. Критически высокое содержание белкового продукта ERC1-гена в облученных клетках, вероятно, указывает на активизацию именно этих процессов. Публикации о роли этого белка в клетках МГБ фактически отсутствуют.

NMDA (N-метил-D-аспартат)-рецептор регулируемый белок 1 продукт экспрессии гена NARG1L - под влиянием облучения усиливает уровень синтеза в 6,3 раза. Данный белок известен как антиген рака желудка 19. По данным базы белок-белковых взаимодействий, STRING (https://string-db.org) - продукт гена NARG1L - вовлечен в процессы васкуляризации, гемопоэза, нейронального роста и развития. Есть данные (Sugiura et al., 2001) об участии белка в передаче сигналов между нейронами и в дифференцировке потомков НСК в нейроны. Публикации о роли данного белка в клетках МГБ отсутствуют.

Фосфолипаза С дельта 3 - продукт экспрессии гена PLCD3. Coдержание этого белка в клетках МГБ после экспериментального облучения возрастает в 5,7 раза. Данный ген - член семейства фосфолипаз C, катализирующих гидролиз 4,5-бисфосфата фосфатидилинозитола с образованием вторичных мессенджеров диацилглицерина и 1,4,5трисфосфата инозита, которые опосредуют различные клеточные ответы на внеклеточные стимулы, индуцируя протеинкиназу С и повышая концентрации цитозольного Са ${ }^{2+}$. Белок вовлечен в пролиферацию, миграцию и инивазию ОК назофарингеальной карциномы (Liu et al., 2018), экспрессия гена PLCD3 ассоциирована с низкой выживаемостью больных раком поджелудочной железы (Zhou et al., 2019). 
В контексте проблемы МГБ пристального внимания заслуживает сообщение (Raimo et al., 2016) о способности белков семейства фосфолипазы C индуцировать M1 и M2 поляризацию макрофагов при взаимодействии с ОК. Высокое содержание PLCD3 изоформы фосфолипазы С в опухолевых клетках, солокализованных с М2-активированными макрофагами нуждается в тщательном изучении применительно к МГБ. Клетки МГБ линии T-98G, использованные в эксперименте, иммунопозитивны в отношении антигена CD133 - ключевого маркера ОСК. Избыточное содержание в них PLCD3, вероятно, является одним из компонентов системы межклеточных взаимодействий ОСК в иммуносупрессивной среде (см. глава 1), которые играют ключевую роль в патогенезе МГБ. Косвенно на это указывает отмеченное (Raimo et al., 2016) снижение содержания PLCD3 в OK после стимуляции LPS. В свете сказанного представляет интерес сообщение (Lin et al., 2001) о подавлении в клетках МГБ уровня синтеза этого белка цАМФ и кальцием.

Rho-ассоциированная протеин-киназа 2 - продукт экспрессии гена ROCK2 - в облученных клетках МГБ усиливает уровень синтеза в 4,5 раза. По данным Gene Cards (https://www.genecards.org), этот белок является ключевым регулятором актинового цитоскелета и клеточной полярности, непосредственно участвует в механизмах фокальной адгезии к ВКМ, модуляции циркадных ритмов и сигналинге $\mathrm{Ca}^{+2}$, является негативным регулятором VEGF индуцированного ангиогенеза.

По данным базы KEGG (https://www.kegg.jp), Rho-ассоциированная протеин-киназа 2 является компонентом сигнальных путей плотных межклеточных контактов, Wnt, активации тромбоцитов, регуляции актинового цитоскелета, цАМФ, фокальной адгезии и некоторых других внутриклеточных механизмов. Взаимоотношения с wnt-сигналингом довольно специфические, белок ROCK2 является компонентом не канонического wntсигнального пути, экспрессия некоторых компонентов которого значимо усиленна в ОСК (табл. 5).

Рибонуклеопротеин, содержащий SAP-домен, - продукт экспрессии гена SARNP, в облученных клетках МГБ усиливает уровень синтеза в 4,2 раза. По данным базы белок-белковых взаимодействий, STRING (https://string-db.org) - продукт гена SARNP - связывает одноцепочечную и двухцепочечную ДНК, является компонентом TREX (TRanscription-EXport) комплекса, участвует в транскрипционном или трансляционном контроле 
роста клеток, метаболизме и канцерогенезе. Негативно регулирует экспрессию одного из ключевых маркеров ЭМП адгезионного Е-кадгерина (Kang et al., 2020). Публикации о роли этого белка в клетках МГБ отсутствуют.

Тимозин $\beta 4$ - продукт экспрессии гена TMSB4X - в облученных клетках МГБ усиливает уровень синтеза в 4,1 раза. Тимозин $\beta 4$ играет важную роль в организации цитоскелета, связывает и изолирует актиновые мономеры и ингибирует полимеризацию актина. Введение тимозина $\beta 4$ способствует миграции клеток, образованию кровеносных сосудов, созреванию стволовых клеток, выживанию различных типов клеток и снижению продукции провоспалительных цитокинов (Philp \&Kleinman, 2010), что формирует важные условия для выживания клеток МГБ. Данный белок обладает исключительно сильным противовоспалительным действием в отношении нейтрофилов (Young et al 1999) и, вероятно, является модулятором биологических эффектов кортикостероидов в клетках.

По данным литературы (Makowiecka et al., 2019), тимозин $\beta 4$ вовлечен в процессы фокальной адгезии, миграции и инвазии клеток меланомы человека. Более того, тимозин $\beta 4$ и TGF- $\beta$ рассматривают (Morita \& Hayashi, 2018) как два критически значимых фактора ЭМП, которые обеспечивают прогрессирование рака всех типов. Однако публикации о роли данного белка в клетках МГБ практически отсутствуют.

YTH N6-метиладенозин РНК-связывающий белок 2 - продукт экспрессии гена YTHDF2 - в облученных клетках МГБ усиливает уровень синтеза в 6,8 раза. Данный ген входит в суперсемейство ҮТН. Белковый домен ҮТН, является консервативным для всех эукариот и его консервативная С-концевая область играет критическую роль в передаче цитозольных Са-сигналов в ядро, регулируя экспрессию генов. Но функции белка гораздо шире. Он регулирует стабильность мРНК провоспалительных генов, участвуя в регуляции воспаления. Нокдаун YTHDF2 (Yu et al., 2019) значительно увеличивает индуцированную LPS-экспрессию TNF- $\alpha$, IL-1 $\beta$ и других провоспалительных цитокинов.

Итак, белки, значительно усилившие экспрессию после облучения клеток МГБ, напрямую связаны с кальциевой сигнализацией, увеличением подвижности ОК, усилением взаимодействия с ВКМ и подавлением воспалительных стимулов микроокружения. Это клетки, располагающие сложными механизмами активной модификации микроокружения в иммуносупрессивном ключе, клетки активной миграции и борьбы. 
Значимая апрегуляция девяти белков протеасом заслуживает особо пристального внимания (табл. 9). Процесс убиквитин-зависимой деградации белка в протеасоме является энергозависимым и требует расхода энергии АТФ, количество которой в ОК в условиях лучевого повреждения и окислительного стресса крайне невелико. Однако ОК идут на усиление синтеза этих белков, что указывает на исключительную важность процесса деградации белков в протеасоме, необходимое для выживания клеток. Протеасомы ликвидируют внутриклеточные циклины и другие белки, предопределяющие движение клеток через контрольные точки клеточного цикла, что подавляет пролиферацию и сохраняет ОК под воздействием облучения. Протеасомы разрушают окисленные белки, например, протеасомы клеточного ядра регулируются поли(АДФ-рибоза)-полимеразами (PARP) и разрушают окисленные гистоны (Bader \& Grune, 2006), без которых снижается эффективность репарации ДНК. Повреждене генома порождает активный синтез белка р53, известного как «страж генома», запускающий апоптоз. Теоретически активация протеасом просто необходима для разрушения р53 и сохранения ОК. Протеасомы регулируют активность и утилизируют транскрипционный фактор NF-кB (Adams, 2003), активирующий синтез провоспалительных цитокинов и иммунный ответ, a также подавляют пролиферацию лейкоцитов при воспалении (BenNeriah, 2002).

В большинстве клеток подавление протеасом индуцирует апоптоз, в этой связи уже известные препараты - лактацистин, бортезомиб, ритонавир и относительно новое вещество - маризомиб (Manton et al., 2016) имеют большие терапевтические перспективы. Гипотетически подавление протеасом способно резко повысить уровень окислительного стресса, снизить эффективность репарации ДНК, индуцируя геномною нестабильность ОК. Однако стратегия применения этих препаратов при МГБ нуждается в корректировке.

Таким образом, исследование позволяет сделать несколько выводов:

1. Идентичны $63,2 \%$ белков в НСК и ОСК и $36,47 \%$ белков в МСК и ОСК. Сигнальный каскад фокальной адгезии является сохранным во всех типах СК.

2. ОСК отличаются от ДКГ тотальным усилением экспрессии белков сигнального пути PB-BKM и Wnt. Приоритетными мишенями для поражения этих сигнальных путей являются белки COL6A1, LAMB1 и CTNNB1. 
3. Стимуляция TGF- $\beta 1$ индуцирует в ДКГ экспрессию белков актинмиозинового комплекса и матриксных металлопротеиназ 2, 9, 14 и ADAMTS1. При этом 13 белков сигнального пути PB-BKM (CD44, HMMR, COL1A2, COL6A1, COL6A3, FN1, LAMB1, LAMC1, ITGA2, ITGA5, ITGAV, ITGB1, ITGB3) и 3 белка, активизирующих РВ-ВКМ (FERMT2, HDAC2 и FBN1) в ДКГ усиливают экспрессию до уровня ОСК.

4. Белок LOXL2 является маркером OCK МГБ человека.

5. Облучение в дозе 60 Грей усиливает в ОСК синтез белков ERC1, NARG1L, PLCD3, ROCK2, SARNP, TMSB4X и YTHDF2 более чем в 4 раза. При этом более чем 2 раза возрастает уровень синтеза белков протеасом (PSMA2, PSMA3, PSMA4, PSMB2, PSMB3, PSMB7, PSMC3, PSMD1, PSMD3). 


\begin{tabular}{|c|c|}
\hline 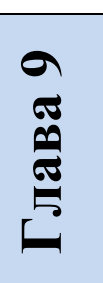 & $\begin{array}{c}\text { ПРОТИВООПУХОЛЕВАЯ ЭФФЕКТИВНОСТЬ } \\
\text { ПРОИЗВОДНЫХ МОРСКИХ АЛКАЛОИДОВ КАК } \\
\text { ПОТЕНЦИАЛЬНЫХ ЛЕКАРСТВЕННЫХ СРЕДСТВ } \\
\text { ДЛЯ АДРЕСНОЙ ДОСТАВКИ В КЛЕТКИ МГБ }\end{array}$ \\
\hline
\end{tabular}

Согласно существующему стандарту (Stupp et al., 2017) основная ставка в лечении больных МГБ делается на химиотерапию (глава 2). Принципиально важно, что химиотерапия, направленная на продление жизни больного после рецидива опухоли, проводится после предшествующего курса комплексного лучевого и лекарственного лечения. В этой связи рецидивирующая МГБ - это опухоль, обладающая высокой степенью резистентности к генотоксической химиотерапии. Ключевым препаратом для лечения МГБ является TMZ (глава 2), однако в подавляющем большинстве случаев его эффективность в отношении рецидивирующей опухоли низкая. В этой связи разработка новых лекарственных средств, превосходящих или усиливающих цитотоксическую эффективность TMZ в отношении клеток радиорезистентной МГБ - одно из важнейших направлений решения проблемы.

С 2014 г. в фокусе нашего пристального внимания находится группа низкомолекулярных соединений, в основе которых лежит пентациклическая система пиридо[1,2-a:3,4-b']дииндола, наиболее изученным представителем которой является красный пигмент фаскаплизин, - бисиндольный алкалоид (Bharate et al., 2012; Segraves et al., 2004; Wang et al., 2019), впервые выделенный из морской губки Fascaplysinopsis spp.

В основе комплексного противоопухолевого действия фаскаплизина лежит способность к интеркаляции ДНК в сочетании с образованием активных комплексов с циклин-зависимыми киназами 4 и, возможно, 6 типов (глава 2), подавление сигнального пути PI3K/AKT/mTOR, запуск апоптоза по митохондриальному пути, индукция аутофагии и антиангиогенное действие.

Фаскаплизин оказывает выраженное цитотоксическое действие в отношении клеток глиом и карцином, но его цитотоксический эффект уступает TMZ. В поисках решения проблемы мы синтезировали ряд производных фаскаплизина, два из которых получены впервые. 


\section{1. Дизайн исследования}

На первом этапе исследования применялись 4 производных пиридо [1,2-a:3,4-b']дииндола. Фаскаплизин использовался для сравнения. Изучалось воздействие in vitro различных концентраций тестируемых веществ $(0,5$ мкM; 0,05 мкМ; 0,005 мкМ) на клетки глиомы С6 в количестве $2 \times 10^{4}$ клеток МГБ, которые) высаживали в лунки 24-луночного планшета, заполненные средой DMEM содержащей $10 \%$ эмбриональную телячью сыворотку и $100 \mathrm{U} / \mathrm{ml}$, антибиотик-антимикотик 100X. Клетки культивировали при стандартных условиях - $37^{\circ} \mathrm{C}\left(\begin{array}{lll}5 \% & \mathrm{CO}_{2}\end{array}\right)$. Все используемые реагенты производства компании "Gibco" (ThermoFisher scientific, US).

На втором этапе исследования для фармакологического тестирования соединений лидеров - 7-фенилфаскаплизина, 3-бромфаскаплизина и 9-бромфаскаплизина - выбрана наиболее соответствующая концентрация $0,5 \mu \mathrm{M}$. Для оценки цитотоксической эффективности TMZ в отношении клеток МГБ линии T98-G, обладающей низкой чувствительностью к TMZ (Valtorta et al., 2017; Paul-Samojedny et al., 2016), использована концентрация $500 \mu \mathrm{M}$ соответствующая IC50 для данной опухоли.

На третьем этапе исследования для выработки радиорезистентности клетки линии T98-G ГБ человека подвергали дистанционному облучению с использованием гамма-терапевтической установки «Рокус-М» (г. СанктПетербург, Россия), использующую кобальт - 60 в качестве источника радионуклидного излучения. За одну фракцию достигали дозы 6 Грей и выполняли 8 фракций с интервалом 72 ч до достижения суммарной дозы

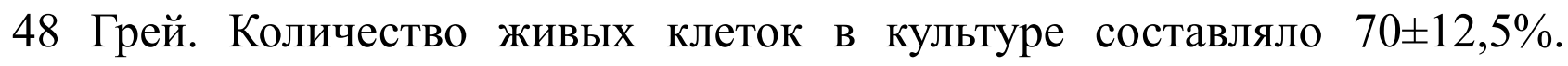
Дальнейшее увеличение дозы до 60 Грей не сопровождалось значимыми изменениями данной цифры.

\section{2. Материалы и методы}

Опухолевые клетки. В работе использованы клетки низкодифференцированной инвазивной глиомы C6, клетки линии U-87MG и T98G МГБ человека (ATCC; cat no. HTB-14M). Клетки крысиной глиомы C6 (American Type Culture Collection, ATCC®; cat no. CCL-107) линии U-87MG глиобластомы человека получены из. Глиома С6 является одной из самых адекватных и востребованных моделей ГБ экспериментальных животных (Grobben et al., 2002). Глиобластома линии U-87 не является оригинальной 
МГБ, полученной в Унивеситете Уппсала, но, очевидно, является агрессивной глиобластомой «дикого» типа, которая составляет более $90 \%$ случаев этого заболевания (Allen et al., 2016).

Клетки линии T98-G глиобластомы человека получены от производителя (ATCC® CRL-1690ТМ). Эта линия характеризуется низкой чувствительностью к TMZ (Lee et al., 2016; Valtorta et al., 2017; PaulSamojedny et al., 2016), что в первую очередь связано с низким уровнем метилирования гена MGMT и высоким содержанием фермента О6-метилгуанин-(ДНК)-метилтрансферазы, что позволяет смоделировать состояние опухоли сразу после комплексной лучевой и химиотерапии.

Все клетки культивировали в 6-луночных планшетах, заполненных средой DMEM - Dulbecco's Modified Eagle Medium (DMEM) - с 10\%-ной эмбриональной телячьей сывороткой (FBS) c пенициллином / стрептомицином (100 U/ml, Antibiotic-Antimitotic 100X (cat. no. 15240062, Gibco, ThermoFisher scientific, US) при $37{ }^{\circ} \mathrm{C}\left(5 \% \mathrm{CO}_{2}\right)$. Все химические вещества были получены от компании "Gibco" (Thermo Fisher Scientific, Inc.). Клетки культивировали до достижения 80\% конфлюэнтности, пассировали в соотношении 1:3 и использовали в эксперименте после третьего пассажа с момента получения от производителя. Все клеточные линии протестированы на контаминацию микоплазмой с помощью Universal Mycoplasma Detection Kit (ATCC ${ }^{\circ}$ 30-1012K ${ }^{\mathrm{TM}}$ ).

Тестируемые вещества. В работе использован синтетический фаскаплизин и производные пиридо[1,2-a:3,4-b']дииндола: 7-фенилфаскаплизин, 3хлорфаскаплизин, 3-бромфаскаплизин, 9-бромфаскаплизин (рис. 83). Фаскаплизин, 3-бромфаскаплизин и 9-бромфаскаплизин были получены в три стадии согласно ранее разработанному методу (Zhidkov et al., 2007), из соответствующих галогенпроизводных триптамина и фенилуксусной кислоты. Спектральные характеристики продуктов идентичны таковым для природных алкалоидов.

3-хлорфаскаплизин был синтезирован по аналогичному методу (Zhidkov et al., 2007), исходя из триптамина и 2,4-дихлорфенилуксусной кислоты. Структура была подтверждена методами масс-спектрометрии и ЯМРспектроскопии на ядрах 1Н и 13С. Масс-спектр (АРCI), m/z: 409/411 (1:0.3) (M+). Спектр ЯМР-1Н (400 МГц, MeOH-d4) d: 9.36 (д, J = 5.8, 1Н, Н-6), 8.97 (д, J = 5.8, 1Н, H-7), 8.53 (д, J = 1.3, 1Н, H-4), 8.50 (д, J = 7.8, 1Н, Н-8), 8.02 (д, J $=7.8,1 \mathrm{H}, \mathrm{H}-1), 7.90$ (т, J = 7.6, 1Н, Н-10) 7.82 (д, 1Н, J = 7.6, 1Н, H-11), 7.77 
(дд, J1 = 7.8, J2 = 1.3, 1Н, Н-2), 7.54 (т, J = 7.6, 1Н, Н-9). Спектр ЯМР-13С (100 МГц, МeOH-d4) d: 180.2, 149.5, 148.2, 142.9, 138.7, 138.6, 137.3, 135.4, 135.1, $132.8,132.5,131.5,127.1,126.9,126.4,122.7,120.5,116.3$

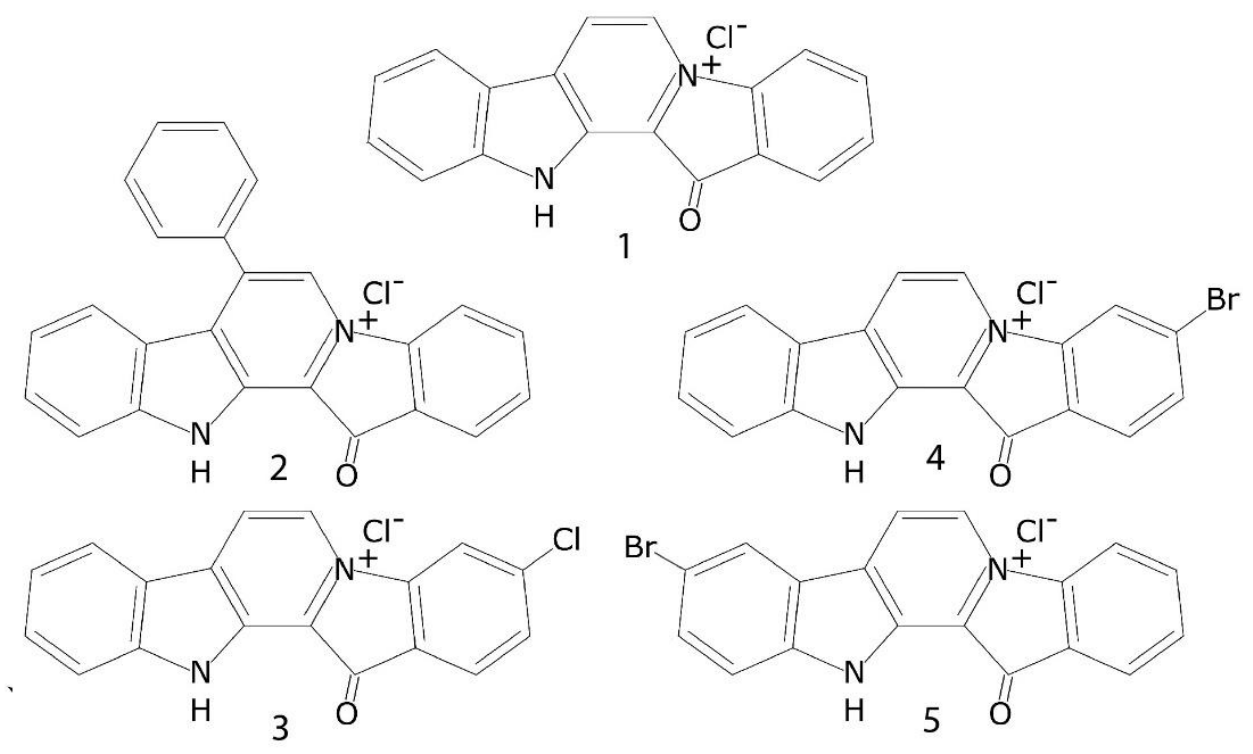

Рис. 83. Исследуемые соединения: фаскаплизин (1); 7-фенилфаскаплизин (2);

3-хлорфаскаплизин (3); 3-бромфаскаплизин (4); 9-бромфаскаплизин (5)

7-фенилфаскаплизин был получен по аналогичному методу (Zhidkov et al., 2007) в две стадии, из индиго. Масс-спектр (АРCI), m/z: $347\left(\mathrm{M}^{+}\right)$. Спектр ЯМР ${ }^{1} \mathrm{H}$ (400 МГц, МеOH-d4): 7.64 (д, 1Н), 7.73-7.77 (м, 4H), 7.80-7.85 (м, 4Н), 7.95 (т, 1Н), 8.38 (д, 1Н), 9.35 (с, 1Н). Спектр ЯМР ${ }^{13} \mathrm{C}$ (100 МГц, MeOH-d4) d: 181.9, 147.7, 147.4, 138.2, 137.7, 137.0, 134.3, 133.8, $132.2,131.6,130.5,129.5,129.2,126.5,125.6,124.5,122.9,121.2,119.7$, 115.6, 113.6.

Метод проточной цитофлюориметрии. На первом этапе применяли метод, основанный на использовании двух флуоресцентных красителей TMRM и DRAQ7. Живые клетки обладают яркой флуоресценцией по каналу TMRM, но не накапливают DRAQ7. Клетки, находящиеся на ранних стадиях апоптоза, слабо флуоресцируют по каналу TMRM, но окрашиваются DRAQ7.

Аликвоты объемом 100 мкл клеточной суспензии инкубировали с 20x раствором TMRM в финальной концентрации 150 нM (Thermo, США). Образцы инкубировали в течение 20 минут при $37{ }^{\circ} \mathrm{C}$ в атмосфере $5 \% \mathrm{CO}_{2}$ в защищенном от света месте и по завершении инкубации отмывали избытком физраствора, содержащего 2\% FBS. В полученную клеточную 
суспензию вносили 5 мкл рабочего раствора красителя DRAQ7 (Beckman Coulter, США) и проводили цитометричекий учет. Для каждого из образцов анализировали не менее 15000 событий. По завершении инкубации к образцам добавляли по 100 мкл забуференного физраствора и анализировали на проточном цитофлуориметре "BD Accuriтм C6" (BD Biosciences, CША).

При исследовании влияния производных фаскаплизина на фазы клеточного цикла опухолевых клеток использовали красители пропидия йодид (PI, Biolegend, США) и диамидино-2-фенилиндола (DAPI, Biolegend, США). В процессе окрашивания клеточный осадок ресуспендировали в 100 мкл забуференного физраствора, к полученной клеточной суспензии добавляли 900 мкл раствора этанола $\left(70 \%,-20{ }^{\circ} \mathrm{C}\right)$ в соотношении 1:9. Далее пробы 1 ч выдерживали при $-20{ }^{\circ} \mathrm{C}$. Для окраски ДНК использовали раствор DAPI (BioLegend, США) в конечной концентрации 10 мкг/мл. Инкубацию с красителем осуществляли в течение 20 мин при комнатной температуре в темноте. По завершении инкубации к образцам добавляли по 200 мкл забуференного физраствора и анализировали на проточном цитофлуориметре "Navios"TM" (BeckmanCoulter, CША). Для каждого из образцов анализировали не менее 10000 событий. Чтобы отличить одиночные клетки от агрегатов и в последующем удалить их из анализа, использовали сочетания пикового и интегрального сигналов флуоресценции DAPI. Результаты получали в виде распределения клеток по фазам G0/G1, $\mathrm{S}$ и $\mathrm{G} 2 / \mathrm{M}$, выраженном в процентах от общего числа проанализированных клеток. Для анализа данных цитометрического анализа использовано программное обеспечение "Kaluza ${ }^{\mathrm{TM}}$ Software", "10 UserNetworkPack" (FullVersion) и "ModFit TL" (Verity Software House, США).

На втором и третьем этапах эксперимента для ранних признаков апоптоза к 100 мкл клеточной суспензии $\left(2 \times 10^{6}\right.$ клеток/мл) добавляли 20 кратный рабочий раствор DiOC6(3) ("Invitrogen", US), получая конечную концентрацию красителя, равную 20 нМ. После внесения красителя образцы тщательно перемешивали и инкубировали в течение 20 мин при $37{ }^{\circ} \mathrm{C}$ в атмосфере $5 \% \mathrm{CO}_{2}$ в защищенном от света месте. По завершении инкубации образцы отмывали избытком PBS, содержащим 2\% FBS (8 мин при 300 g), после чего супернатант декантировали, а клеточный осадок переводили в 100 мкл свежего PBS. В полученную клеточную суспензию вносили 10 мкл раствора диамидино-2-фенилиндола (DAPI), получая финальную концентрацию DAPI, равную 1 мкг/мл. После этого образцы ин- 
кубировали в темноте в течение 10 мин при комнатной температуре и вносили в образцы по 200 мкл PBS.

Для каждого из образцов анализировали не менее 50000 одиночных клеток. Чтобы отличить одиночные клетки от агрегатов и в последующем дискриминировать агрегаты из анализа, использовали сочетания сигналов по прямому и боковому светорассеянию - интенсивность пикового против интенсивности интегрального сигнала по FS или SS, а также время полета против интенсивности интегрального сигнала FS или SS. Анализ полученных результатов проводили при помощи программного обеспечения "CytExpert"TM" (Beckman Coulter, США).

Статистическую обработку полученных результатов проводили с использованием пакета программ "GraphPadPrism 4.00". Данные обрабатывали с помощью дисперсионного анализа ANOVA, сравнение разностей средних проводили по методу Тьюки и выражали в виде средних значений \pm стандартное отклонение. Различия считали достоверными при $\mathrm{p}<0,05$.

\section{3. Результаты}

Первый этап эксперимента. Во всех образцах после 6 ч инкубации наблюдали появление ранних признаков апоптоза, на что указывало ослабление свечения по каналу TMRM. Спустя 24 ч было отмечено увеличение числа флюоресцирующих объектов (апоптотических телец), накапливающих краситель DRAQ7, что является признаком олигонуклеосомной деградации ДНК и наступления «поздних» стадий апоптоза. Через 48 ч цитотоксическое действие тестируемых соединений в отношении клеток глиомы С6 превосходило действие незамещенного фаскаплизина, а в образцах, содержащих 0,5 мкМ 3-бромфаскаплизина, было отмечено уменьшение количества живых клеток глиомы С6 уже через 6 ч инкубации (рис. 84, А). К 48 ч данный эффект заметно усиливался. В свою очередь, цитотоксическая активность 7-фенилфаскаплизина несколько уступала 3-бромфаскаплизину, но достоверно превосходила другие протестированные соединения (рис. 84, А).

В образцах, содержащих 0,05 мкМ тестируемых производных, к 12 ч эксперимента 3-бромфаскаплизин показал цитотоксическую активность, уступающую незамещенному фаскаплизину (рис. 84, Б). К 24 ч наибольшая цитотоксическая активность была отмечена у 7-фенилфаскаплизина и 3хлорфаскаплизина, которая сохранялась к 48 ч эксперимента (рис. 84, Б). 


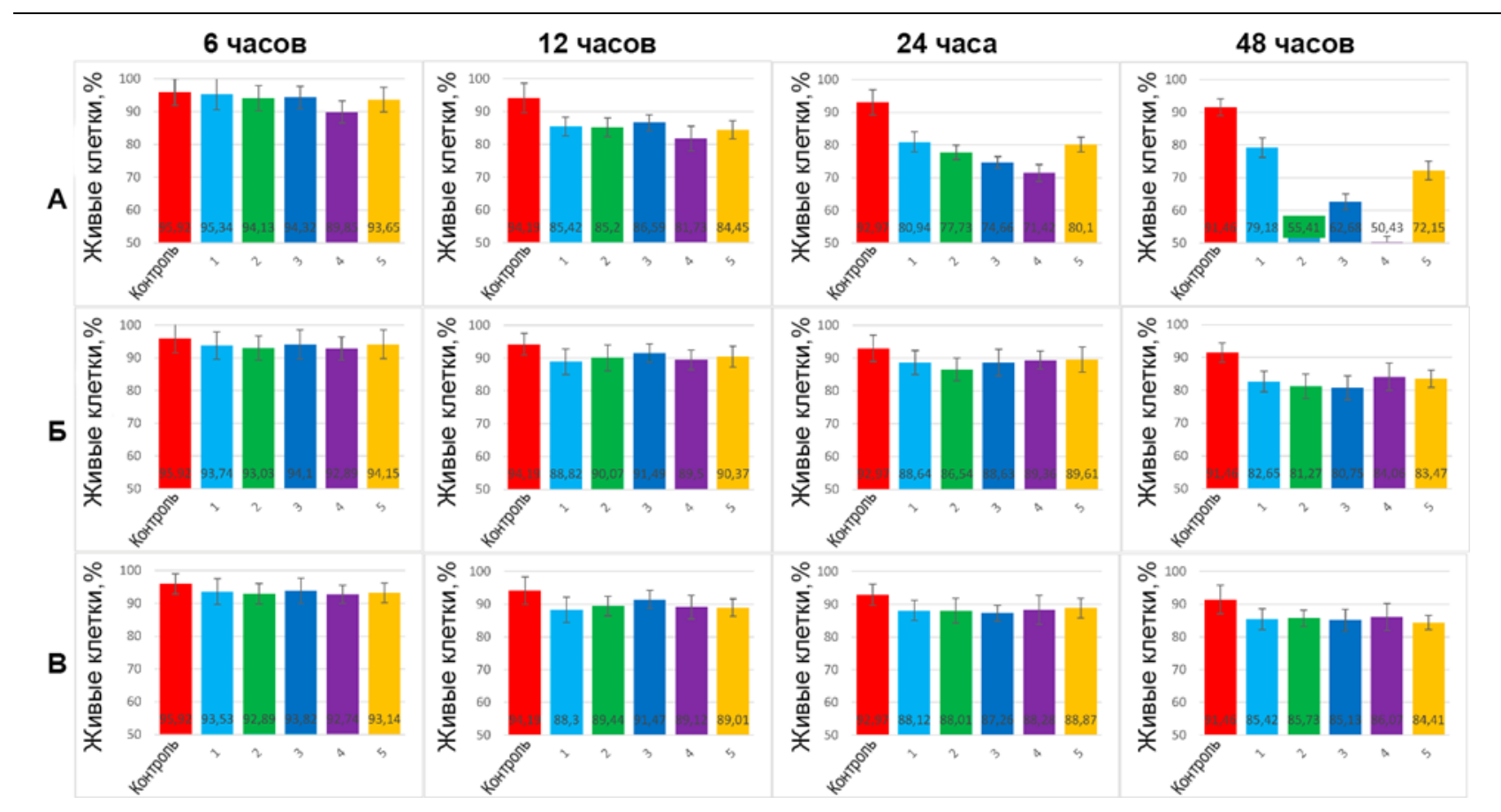

Puc. 84. Влияние фаскаплизина (1), 7-фенилфаскаплизина (2),

3-хлорфаскаплизина (3), 3-бромфаскаплизина (4), 9-бромфаскаплизина (5) на клетки глиомы С6. Окрашивание проводилось катионным липофильным красителем ТMRM и ДНК-связывающим красителем DRAQ7. Концентрация тестируемых веществ:

А - 0,5 мкМ; Б - 0,05 мкМ; В - 0,005 мкМ. Контрольные точки - 6, 12, 24, 48 ч

В концентрации 0,005 мкМ в образцах с незамещенным фаскаплизином отмечен слабый цитостатический эффект, который к 12 ч сменялся на цитотоксический (рис. 84, В). Аналогичная динамика была характерна и для остальных производных. Спустя 24 ч экспозиции гибель клеток глиомы в присутствии 3-хлорфаскаплизина была более выражена, чем в других образцах исследуемой группы. По результатам 48 ч инкубации 9-бромфаскаплизин в концентрации 0,005 мкМ показал наибольшую цитотоксическую активность в отношении глиомы С6 in vitro (рис. 84, В).

Присутствие производных фаскаплизина оказывало выраженное воздействие на жизненный цикл опухолевых клеток (рис. 85). При 6-часовой экспозиции наблюдалось характерное для всех пяти веществ снижение числа клеток в фазе G0/G1 и возрастание по сравнению с данными контроля количества клеток в $\mathrm{S}$ фазе.

На данной контрольной точке уменьшение пролиферации было незначительное и только при максимальной концентрации исследуемых веществ. Наибольшее цитостатическое действие показал 3-хлорфаскаплизин. 


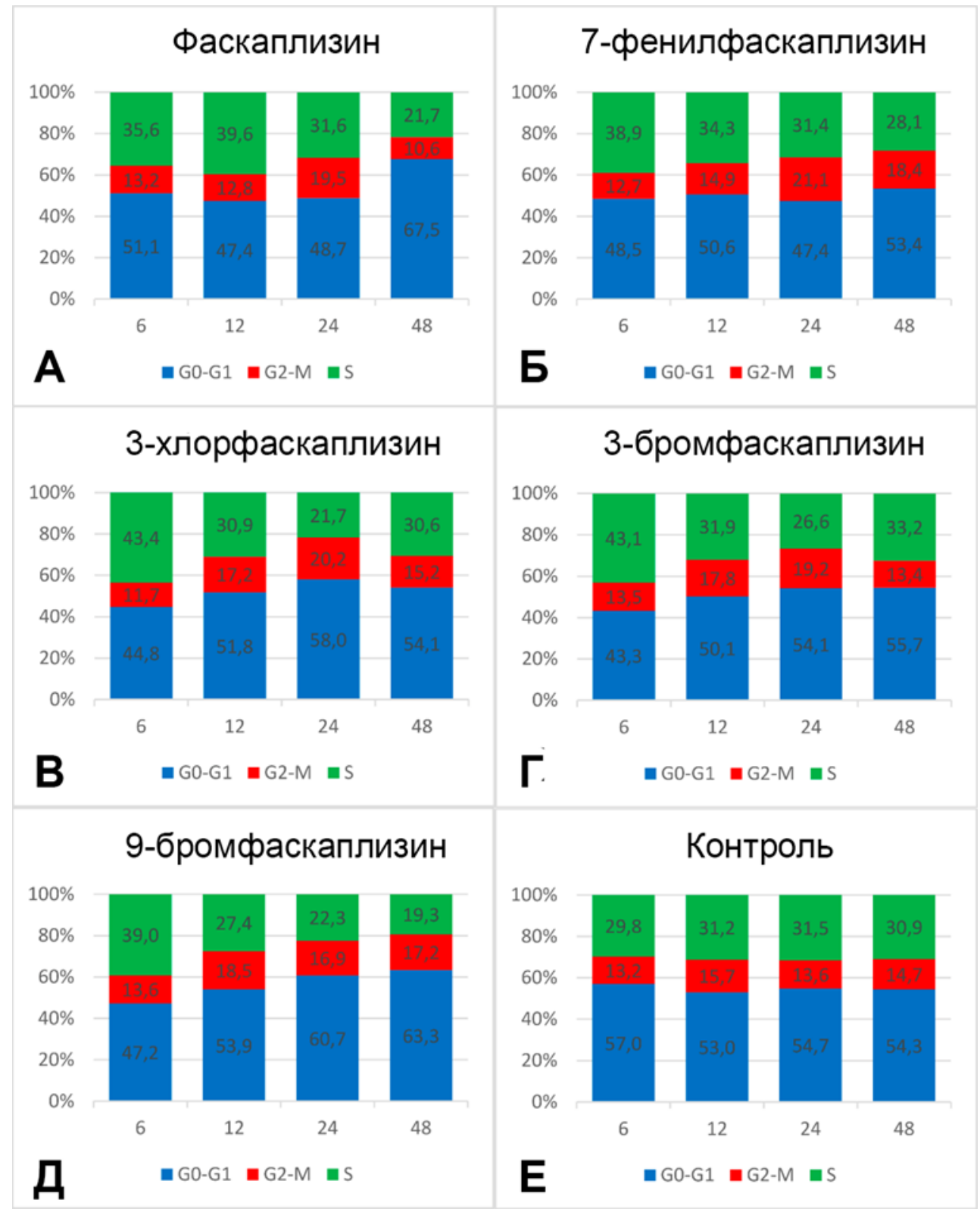

Puc. 85. Распределения клеток глиомы С6 (процентное соотношение)

по фазам клеточного цикла $\left(\mathrm{G}_{0}-\mathrm{G}_{1}, \mathrm{~S}, \mathrm{G}_{2}-\mathrm{M}\right)$ под действием тестируемых соединений в концентрации 0,5 мкМ

После 12 ч инкубации клеток глиомы в присутствии 0,5 мкМ производных фаскаплизина было отмечено увеличение числа клеток, вошедших в S фазу. Подобные данные свидетельствуют о первичном цитостатическом эффекте всех пяти веществ за счет накопления клеток в $\mathrm{S}$-периоде и блокады митоза, однако с уменьшением числа живых клеток происходило увеличение клеток в фазе G0/G1 в образцах, содержавших исследуемые алкалоиды. Так, к 48 ч инкубации в культурах клеток глиомы, содержавших 0,5 мкМ незамещенного фаскаплизина, зафиксировано наибольшее количество клеток в фазе G0/G1. 
Второй этап эксперимента. Спустя 24 ч наблюдений количество живых клеток МГБ линии U-87MG в среде, содержащей незамещенный фаскаплизин, было сопоставимо с контрольной группой (рис. 86, А), при этом в культуральной среде, содержащей производные фаскаплизина, также не было существенных различий в количестве живых клеток. Спустя 48 ч эксперимента в лунках планшета, содержащего 3-бромфаскаплизин, было отмечено резкое снижение числа живых клеток (рис. 86, Б). Цитотоксическое действие 9-бромфаскаплизина было менее выраженным, но тем не менее количество живых клеток в лунках с данным веществом достоверно отличалось от контроьной группы. Спустя 72 ч цитотоксический эффект 3-бромфаскаплизин достигал максимума (рис. 86, В), обнаруживая достоверные отличия от 9-бромфаскаплизина, 7-фенилфаскаплизина и незамещенного фаскаплизина.

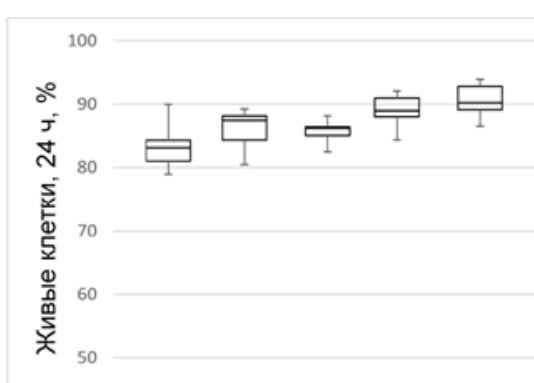

A
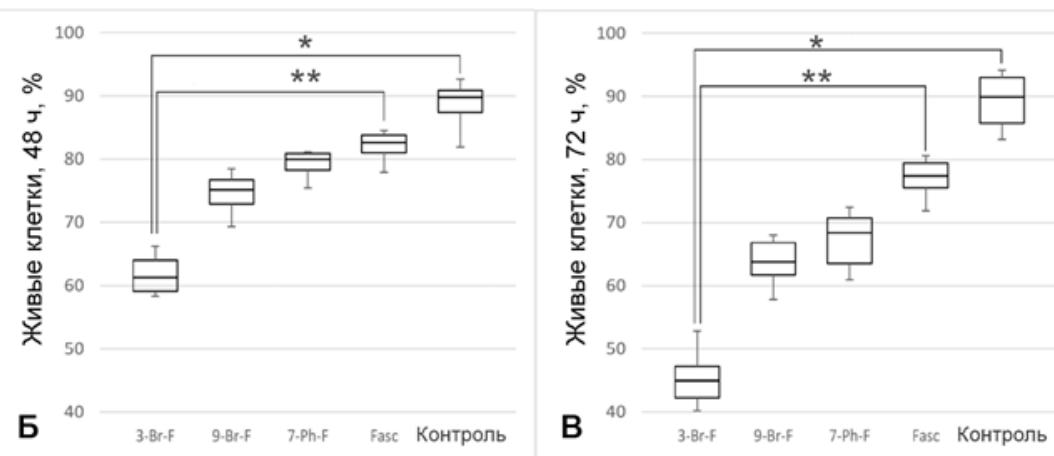

Puc. 86. Цитотоксическая эффективность производных фаскаплизина в отношении клеток линии U-87MG глиобластомы человека: А - 24 ч, Б - 48 ч, В - 72 ч

Третий этап эксперимента. TMZ оказывал выраженное цитотоксическое действие на необлученные клетки МГБ линии T98-G (рис. 87, А), которое было очевидно уже к 24 ч наблюдений, а через 48 ч сопровождалось гибелью более половины популяции клеток ГБ. Цитотоксическое действие производных фаскаплизина к этому времени было не столь очевидно. Эффективность 9-бромфаскаплизина была сопоставима с контрольной группой. В культуре, содержащей 3-бромфаскаплизин, наблюдалось достоверное уменьшение числа живых клеток ГБ (рис. 87, Б), однако цитотоксическая эффективность TMZ была более очевидной и достигала максимума к 72 ч наблюдений (рис. 87, В).

Напротив, цитотоксическая эффективность 9-бромфаскаплизина в отношении предварительно облученных клеток ГБ была сопоставима с TMZ (рис. 88, А). Однако к 48 ч наблюдений количество живых клеток ГБ в среде с 9-бромфаскаплизином стабилизировалось (рис. 88, Б), а в среде, 
содержащей TMZ и 3-бромфаскаплизин, продолжало снижаться. Через 72 ч (рис. 88, В) цитотоксическая эффективность 3-бромфаскаплизина в отношении культуры облученных клеток ГБ достоверно отличалась от контрольной группы и была сопоставима с TMZ.
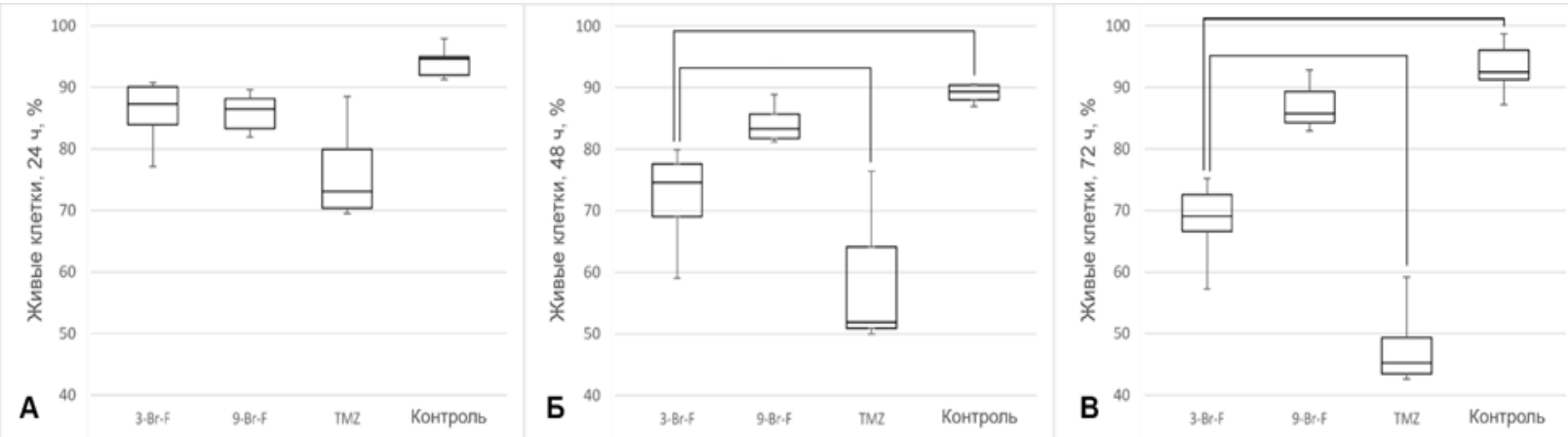

Puс. 87. Цитотоксическая эффективность производных фаскаплизина в отношении клеток линии T98-G глиобластомы человека: А - 24 ч, Б - 48 ч, В -72 ч

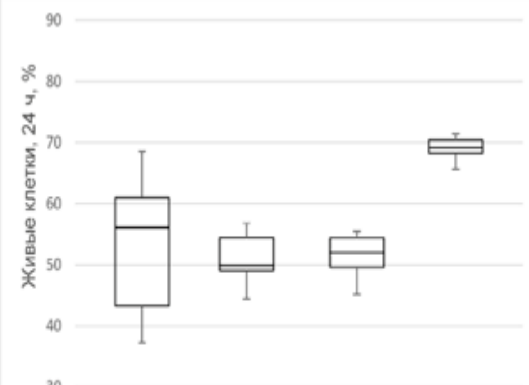

$A^{3}$

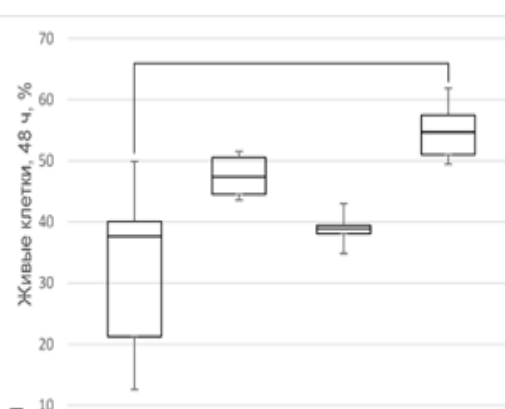

$\mathbf{5}^{10}$

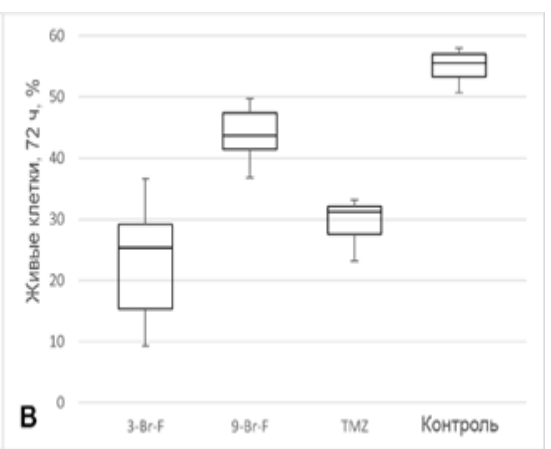

Puc. 88. Цитотоксическая эффективность производных фаскаплизина в отношении клеток линии T98-G глиобластомы человека, предварительно получивших облучение в дозе 48 Грей: А - 24 ч, Б - 48 ч, В - 72 ч

\section{Обсуждение}

Цитотоксическое действие фаскаплизина показано в отношении многих видов злокачественных опухолей, однако его активность в отношении глиальных опухолей мозга практически не изучалась. В этом ключе проведенное исследование не только открывает возможности выявления более активного соединения, но и указывает на необходимость более детального изучения механизмов взаимодействия этого вещества с его молекулярными мишенями, отвечающими за процессы пролиферации и роста опухолевых клеток.

Согласно полученным данным фаскаплизин и его синтетические производные обладают выраженным цитотоксическим действием в отношении клеток опухолей мозга. Характер действия данных алкалоидов свя- 
зан в разной степени со временем экспозиции и концентрацией действующего вещества.

В настоящем исследовании для большинства тестируемых соединений максимальный эффект достигался при концентрации 0,5 мкМ, однако фаскаплизин и 9-бромфаскаплизин при концентрации 0,005 мкМ показали не меньший эффект, чем при концентрации 0,05 и 0,5 мкМ после 48 ч инкубации, что свидетельствует о зависимости эффекта от времени экспозиции. Весьма вероятно, что время экспозиции в данном случае представляется куда более важным, чем прямое цитотоксическое действие вещества. Очевидно, цитотоксический эффект фаскаплизина и его производных 3-бромфаскаплизина и 9-бромфаскаплизина обусловлен преимущественно временем воздействия соединений на культуру клеток глиомы, так как к 48 ч инкубации количество живых клеток резко уменьшается на всем диапазоне концентрации.

Согласно литературным данным индукция апоптоза с участием фаскаплизина вызвана подавлением процесса образования активных комплексов CDK 4 и 6 с циклином D1 (Kumar et al., 2015), что в итоге вызывает арест клеточного цикла в фазе $\mathrm{G}_{1}$ и запуск апоптоза. Однако данный механизм не является единственным; воздействие на другие ферменты, вовлеченные в жизненные процессы опухолевых клеток, также представляет интерес для дальнейшего изучения.

Как показано в нашем эксперименте, воздействие производных фаскаплизина удлиняет S-фазу клеточного цикла глиомы C6, при этом к 24 ч эксперимента деления клеток не происходит. Этот эффект одинаково выражен в образцах с незамешенным фаскаплизином и некоторыми его производными (3-хлорфаскаплизином, 7-фенилфаскаплизином, 3-бромфаскаплизином). Не менее важно, что на первых часах инкубации под влиянием тестируемых соединений количество опухолевых клеток в фазе $\mathrm{G}_{0}$ сокращается. Однако воздействие тестируемых веществ, цитотоксическая активность которых уступает действию соединений-лидеров (3-бромфаскаплизина и 7фенилфаскаплизина), вызывает увеличение числа клеток в фазах $\mathrm{G}_{0}-\mathrm{G}_{1}$ к концу эксперимента. Этот эффект сохраняется и в образцах, содержащих незамещенный фаскаплизин, где наблюдается существенное снижение числа клеток в фазах $\mathrm{G}_{2}-\mathrm{M}$ и $\mathrm{S}$. Данные наблюдения свидетельствуют о том, что при снижении числа живых клеток происходит резкое увеличение числа клеток в фазе $\mathrm{G}_{0}-\mathrm{G}_{1}$ к 48 ч наблюдений. Очевидно, резкое возрастание числа клеток в 
фазе $\mathrm{G}_{0}$ представляет собой одну из моделей ответа неопластических клеток на воздействие цитостатиков, что необходимо учитывать при назначении противоопухолевой терапии.

Результаты эксперимента открывают возможности для создания новых химиопрепаратов на основе протестированных соединений. Важно, что активность изучаемых морских алкалоидов в разной степени зависит от дозы и времени воздействия. Оперируя этими параметрами, можно обеспечить снижение общей токсичности химиотерапии или повысить ее эффективность путем создания комбинации из нескольких соединений, например, в одной биодеградируемой капсуле. Адресная доставка такого препарата к очагу неоплазии позволит эффективно уничтожать пролиферирующие опухолевые клетки, в то же время воздействуя на покоящиеся клетки и препятствуя тем самым возникновению рецидива заболевания.

Лидером среди протестированных соединений является 3-бромфаскаплизин. Для всех производных фаскаплизина сохраняется зависимость цитотоксического действия от времени экспозиции вещества. Основным механизмом гибели опухолевых клеток является апоптоз, что доказано в многочисленных предшествующих исследованиях (Kuzmich et al., 2010; Bryukhovetskiy et al., 2017) и подтверждается данными цитометрии.

Результаты нашего эксперимента свидетельствуют о высокой цитотоксической эффективности TMZ в отношении клеток ГБ. Данный препарат обоснованно считают золотым стандартом химиотерапии опухолей мозга (Omuro et al., 2013), при этом цитотоксическая эффективность TMZ coхраняется как до, так и после облучения. Нельзя не отметить, что клеточная линия T98-G (Lee et al., 2019; Valtorta et al., 2017; Paul-Samojedny et al., 2016) ГБ человека не обладает высокой чувствительностью к TMZ и содержит значительное число клеток, экспрессирующих мембранный антиген CD133главный иммуноцитохимический маркер раковых стволовых клеток.

В данной работе мы отказались от свойственного большинству исследований акцента на клетки данного типа, поскольку высокая пластичность и способность к быстрой и эффективной репарации генетического аппарата (Wegner et al., 2019; Rajal et al., 2014) вообще является отличительной особенностью МГБ. Эта способность наглядно проявляется в снижении чувствительности клеток, облученных МГБ, к ТMZ. При этом исключительно важно, что 3-бром и 9-бромфаскаплизин существенно уступают в цитотоксической эффективности TMZ в отношении необлу- 
ченных клеток ГБ и оказывают сопоставимое и даже превосходящее TMZ цитотоксическое действие в отношении опухолевых клеток, предварительно облученных в дозе 48 Гр.

Нельзя не отметить, что радиорезистентность опухолевых клеток, выработанная после первого курса комбинированного химиолучевого лечения по поводу МГБ, служит одной из важнейших причин неудовлетворительных результатов лечения. Сутью этого феномена является как активация механизмов репарации ДНК (Erasmus et al., 2018), так и индукция синтеза стратегически важных ферментов, обеспечивающих прохождение опухолевой клеткой контрольных точек клеточного цикла. В этой связи уместно предположить, что именно мультитаргетное действие синтетических производных фаскаплизина позволяет этим соединениям подавлять TMZ-резистентные опухолевые клетки.

Результаты эксперимента открывают возможности для создания новых химиопрепаратов на основе протестированных соединений. Безусловным лидером в нашем эксперименте является 3-бромфаскаплизин, однако и 9-бромфаскаплизин нельзя считать менее перспективным соединением. Теоретически существует возможность повысить эффективность эрадикации клеток МГБ путем комбинации из нескольких соединений, например, в одной биодеградируемой капсуле. Адресная доставка такого препарата в опухолевый очаг позволит эффективно уничтожать радиорезистентные опухолевые клетки, препятствуя тем самым возникновению рецидива заболевания и продлевая жизнь больного.

Таким образом, цитотоксическая эффективность протестированных соединений превосходит незамещенный фаскаплизин. Наилучшей способностью убивать клетки глиомы С6 обладают 3-бромфаскаплизин и 7-фенилфаскаплизин. Цитотоксическое действие данных соединений носит дозозависимый характер и возрастает с увеличением времени экспозиции. Производные фаскаплизина воздействуют на все фазы жизненного цикла неопластических клеток, при этом число живых клеток в фазе $\mathrm{G}_{0}$ под воздействием 3-бромфаскаплизина и 7-фенилфаскаплизина остается минимальным. Цитотоксическая эффективность 3-бромфаскаплизина в отношении клеток линии U-87 MG МГБ превосходит незамещенный фаскаплизин. В свою очередь, цитотоксическая эффективность 3-бромфаскаплизина в в отношении клеток линии T98-G ГБ уступает TMZ, а в отношении клеток линии T98-G ГБ с выработанной радиорезистентностью превосходит TMZ. 


\section{БИОМЕДИЦИНСКИЕ КЛЕТОЧНЫЕ ПРОДУКТЫ И ТЕХНОЛОГИИ ДЛЯ РЕГУЛЯЦИИ ФУНКЦИЙ СТВОЛОВЫХ КЛЕТОК В КОМПЛЕКСНОЙ ТЕРАПИИ МГБ: РЕАЛЬНОСТЬ И ПЕРСПЕКТИВЫ}

Лечение опухолей мозга - одна из самых концептуальных проблем современной клинической медицины и фундаментальной науки. Именно эта проблема наиболее ярко обозначает реальные границы наших возможностей в борьбе с раком, прямо указывает на существующие недостатки и диктует необходимость поиска новых системных решений, без которых невозможно движение вперед. Целью данного заключительного раздела монографии является критический анализ проделанной работы, систематизация данных, расстановка акцентов и выделение приоритетных путей решения проблемы в будущем.

Любая концепция будущего неразрывно связана с прошлым, однако точкой отсчета всегда является сегодняшний день. В главе 1 настоящей работы уделено довольно много внимания истории вопроса. Проблема лечения опухолей мозга - объективно сложная и молодая, особый интерес к ней сформировался в конце XX в. с появлением методов исследований, адекватных сложности изучаемого объекта.

Сегодня совершенно очевидно, что МГБ - это собирательный термин, объединяющий гетерогенную группу первичных, главным образом, нейроэктодермальных опухолей мозга, для которых степень дифференцировки морфологических элементов обратно пропорциональна скорости их пролиферации.

Корнем анализируемой проблемы принято считать нормальные НСК и нейральные прогениторные клетки, населяющие герминативные зоны мозга млекопитающих и человека. Весьма вероятно, что спровоцированные канцерогенами мутации происходят изначально именно в клетках этого типа. В этом есть своя логика: скорость пролиферации нейральных стволовых и прогениторных клеток (Altman et al., 2019) - одна из самых высоких в мозге, а быстро пролиферирующая клетка - идеальный объект мутагенеза, но это только одна из точек зрения.

Как следует из экспериментов, описанных в главе 4, CD133+HCK, способны мигрировать к ОК различных типов, однако обладают повышенной подвижностью в отношении клеток МГБ. Вектор миграционной 
активности СК обратно пропорционален степени дифференцировки ОК и более выражен между клетками имеющими единый источник происхождения в ЦНС. Иными словами, НСК обладают высокой подвижностью в отношении $\mathrm{CD} 133+$ клеток МГБ, что, вероятно, и обясняет особую роль НСК в патогенезе МГБ.

Опираясь на перечисленные факты, можно с уверенностью сказать, что, действительно, НСК имеют самое непосредственное отношение к МГБ. В данном исследовании показано, что нормальные CD133+ HCK и CD133+ ОСК глиобластомы человека демонстрируют сходство более чем 60\% внутриклеточных белков, обнаруживая при этом значительные отличия от нормальных СК костного мозга. Но этот факт не стоит переоценивать: СК с индуцированной плюрипотентностью, полученные в эксперименте (Phanstiel et al., 2011) путем эпигенетического перепрограмирования соматических клеток, тоже демонстрируют высокое сходство протеомных профилей, при этом их происхождение более чем очевидно.

В контексте индуцированной плюрипотентности необходимо обратить внимание на феномен ЭМП. Ведущим индуктором ЭМП является гипоксия. Именно в результате ЭМП происходит два принципиально важных события. Во-первых, формируется инвазивный фенотип ОК, во- вторых, формируется популяция индуцированных ОСК. Вероятно, это плюрипотентные клетки, поскольку показана (Mathieu et al., 2013) возможность формирования тератом содержащих элементы всех трех зародышевых листков - эктодермы, мезодермы и энтодермы при имплантации клеток де-дифференцированных гипоксией в организм иммунодефицитных мышей.

В свою очередь, именно при индуцированной плюрипотентности востанавливается эмбриональная длина теломеров, и такая клетка способна пролиферировать, не будучи связана лимитом Хайфлика (West \&Vaziri, 2010), что особо важно для ОСК. Весьма вероятно, в патогенезе МГБ задействованы оба механизма появления ОСК, что и порождает уникальные свойства данной опухоли.

Определенный свет в этом вопросе могла бы пролить молекулярная онкогенетика. В главе 1 описана богатая палитра мутаций и иных молекулярно-генетических сбоев и поломок, выявленных в клетках МГБ. Но, несмотря на такое внимание к проблеме молекулярно-генетические подходы к классификации МГБ разработаны очень слабо, в первую очередь, ввиду объективной сложности вопроса. Между тем грандиозные достижения в 
области создания клеток с индуцированной плюрипотентностью однозначно указыввают на то, что «стволовость» это, скорее, понятие из сферы эпигенетики. В этой связи совершенно не принципиально, в каких именно клетках ЦНС произошли мутации. Важно, что с момента формирования клона ОК его развитие идет по пути наращивания темпов пролиферации, которая применительно к клеткам МГБ является очень высокой.

Высокая скорость пролиферации ОК - узловая точка проблемы. Быстрый рост опухоли среди высокодифференцированных клеток ЦНС сопровождается выделением токсических метаболитов, которые повреждают и убивают нейроны. Увеличивающаяся опухоль сдавливает вещество мозга, нарушает кровообращение и ликвородинамику, способствует развитию отека и дислокационных явлений.

Быстро умножающееся число ОК порождает гипоксию и запускает механизмы селекции, отбирающие самые жизнеспособные клоны ОК. Пролиферация и гипоксия - это две стороны одной медали. С одной стороны, высокая скорость деления ОК порождает гипокию, а с другой стороны, именно гипоксия привлекает в опухоль многочисленные неопухолевые клетки, в первую очередь, стволовые клетки костного мозга, взаимодействуя с которыми опухоль приобретает свои уникальные качества.

В первую очередь, это касается взаимоотношений ОК с астроцитами и клетками микроглии. Как показано в настоящей работе, астроциты активно мигрируют к опухолевому очагу и окружают его (рис. 38, А) формируя некий демаркационный «вал», отграничивающий опухоль от ткани мозга, а также образуя многочисленные скопления клеток астроцитарной глии наподобие редутов, или линий обороны, рассредоточенных на некотором удалении от первичного очага подобно волнам от камня, брошенного в воду (рис. 38, Г).

В процессе роста опухоли астроциты (рис. 38 , Д) активно взаимодействуют с клетками микроглии. Первые окружают растущую опухоль, вторые инфильтрируют ее ткань (рис. 35, Б) и, взаимодействуя с ОК, активизируют процессы презентации антигенов (рис. 75 А, Б) и продукцию провоспалительных цитокинов. Вероятно, это важнейшее препятствие на пути экспорта неопластического процесса в вещество мозга. Преодоление этого барьера становится возможным благодаря селекции ОК, резистентных к гипоксии, которая индуцирует в них продукцию ключевого иммуносупрессивного цитокина - TGF- $\beta 1$. 
В ранние сроки развития опухоли продукция TGF- $\beta 1$ сосредоточнена в области ее инвазиивного края (рис. 39, В) в зоне максимального контакта с астроцитарной глией и микроглиальными клетками. В дальнейшем опухоль оптимизирует свой клеточный состав и накапливает необходимое количество ОК, способных к продукции TGF- $\beta 1$, что проявляется накоплением этого цитокина в неопластической ткани (рис. 55).

Лавинообразный синтез TGF $\beta$ и IL10 и других иммуносупрессивных цитокинов не позволяет глиоцитам и мигрирующим в опухоль иммуноцитам локализовать процесс, а запуск процессов ЭМП, индуцированный TGF$\beta$, ведет к появлению инвазивного фенотипа ОК, что иллюстрирует переход неопластического процесса в новую, качественно иную плоскость.

Итак, быстрая пролиферация низкодифференцированных ОК в окружении высоко дифференцированных и практически не пролиферирующих или слабо пролиферирующих клеток и тканей ЦНС создает опухоли оптимальные условия для развития. Астроциты и клетки микроглии не способны сдержать опухолевый процесс, да и ресурсы этого типа клеток ограничены, а продукция ОК иммуносупрессивных цитокинов подавляет их активное сопротивление, выключает воспаление, запускает ЭМП и формирует инвазивный фенотип ОК. Дальнейшие события, такие как активный ангиогенез и повреждение ГЭБ, рекрутирование неопухолевых клеток и кластеризация опухолевой ткани под воздействием гипоксии являются вторичными.

Следовательно, мутантные НСК, сформированные в результате ЭМП опухолевые клетки с индуцированным дифференцировочным потенциалом и рекрутированные нормальные СК костного мозга составляют гетерогенный пул СК глиобластомы. Клетки этого типа способны взаимодействовать друг с другом, с дифференцированными ОК и многочисленными не опухолевыми клетками мигрирующими в неопластический очаг. Стратегически важной задачей СК глиобластомы является запуск процессов ангиогенеза, именно с этого момента проблема становится нерешаемой.

Ранняя диагностика МГБ практически невозможна. Клиническая картина опухоли неспецифична, более того, все современные подходы к диагностике и лечению МГБ упираются в необходимость регулярного МРТобследования. Исключительно актуальна идея поиска маркеров для ранней диагностики МГБ, которые могли бы указать на необходимость МРТ. Однако объективно таких маркеров, которые позволили бы диагностировать МГБ 
на основании исследования образцов крови, не существует. Повышение уровня белка в ликворе, увеличение содержания TGF- $\beta$ в крови и ликворе (Rich, 2003), повышение титра нейроспецифических белков и другие маркеры активного патологического процесса являются неспецифическими.

В свете сказанного диагноз МГБ всегда поздний. Инфильтрация вещества мозга ОК в процессе инвазивного роста МГБ исключает возможность радикального решения вопроса согласно хирургическим канонам онкологии. Операция не обеспечивает полной эрадикации ОК, более того, современные способы хирургического лечения глиом пока несильно продвинулись в этом направлении.

И тем не менее целесообразность элиминации максимально возможного количества ОК очевидна, так как она обеспечивает декомпрессию мозга, позволяет уточнить диагноз, провести прицельное облучение, ввести лекарство в зону поражения, а обширное повреждение ГЭБ расширяет возможности лекарственной терапии. При этом возможности современной хирургии в лечении таких больных далеко не исчерпаны и будут развиваться.

В контексте разговора о будущем целесообразно снова упомянуть технологию «кибер-нож». К сожалению, эффективность этой технологии пока оставляет желать лучшего, о чем прямо сказано в главе 2. Однако если присмотреться к ней более внимательно, исключив результаты лечения больных с низким функциональным статусом по шкале Карновского, результаты очень старых и соматически тяжелых больных, то по при условии высоких доз облучения в сочетании с адекватной лекарственной поддержкой (Morris et al., 2019) общая выживаемость была 31 месяц против 13,3 месяца в контрольной группе.

Данные о 20-месячной медиане выживаемости больных, получивших лечение с использованием технологии «гамма-нож» (Guseynova et al., 2018), указывают на ее высокую перспективу. Условием успеха этой технологии является возможность подвести большую дозу облучения локально в область контакта опухоли с веществом мозга, тем самым обеспечив эффективную эрадикацию ОК. Именно эта технология представляеся особенно перспективной и, вероятно, ее развитие на базе принципа «тоге cyber - less knife», сформулированного Джеффри Богартом (Bogart, 2007), определит будущее хирургической помощи в нейроонкологии.

Технология кибер-ножа иллюстрирует логичный переход от операции к лучевой терапии. Продолжительность жизни больного МГБ корре- 
лирует с дозой полученной радиации, достигающей 60-70 Гр (Stupp et al., 2005; Stupp et al., 2014; Stupp et al., 2019). Действительно, попытки повышения эффективности лучевой терапии с использованием протонной терапии и нейтрон-захватной терапии пока не привели к очевидному успеху. Однако сообщения (Mizumoto et al., 2016; Mizumoto et al., 2015) о потенциальной эффективности этого метода в комбинации с $\gamma$-облучением заслуживают внимания и является довольно интересными (глава 2). Возможности лучевой терапии в лечении МГБ на сегодняшний день еще не исчерпаны, предел не достигнут, и этот метод будет развиваться не только путем комбинации с радиохирургией, но и за счет дополнений метода лучевой терапии адекватной фармакологической поддержкой.

Фармакологическое сопровождение лучевой терапии играет не менее важную роль, чем само облучение. Современный стандарт комплексного лечения МГБ, по протоколу Роджера Ступпа (Stupp et al., 2005), предписывает больному сочетать облучение и прием TMZ. Такая тактика является абсолютно правильной, однако эффективность TMZ резко снижается после облучения, как это показано в нашей работе (рис. 87 и 88), что требует назначения средств, препятствующих адаптации к облучению.

В главе 2 приведена обширная дискуссия по поводу оптимизации существующих методов противоопухолевой генотоксической терапии с использованием уже имеющихся химических соединений. Однако протеомный анализ облученных ОК (табл. 9) довольно однозначно указывает, что одним из путей повышения эффективности лучевой терапии является использование ингибиторов протеасом, белковые компоненты которых резко усиливают уровень синтеза в облученных ОК. Безусловно, эта гипотеза требует проверки в эксперименте, однако необходимость персонализированного подхода к лечению более чем очевидна.

Кроме того, ввиду снижения эффективности TMZ в отношении клеток МГБ после облучения целесообразно дополнять химиотерапию второй линии более эффективными цитотоксическими средствами. В нашей работе был сделан акцент на синтетические производные морского алкалоида фаскаплизина. Как следует из эксперимента (рис. 88), цитотоксическая эффективность 3-бромфаскаплизина превосходит незамещенный фаскаплизин и по эффективности сопоставима с TMZ и даже частично его превосходит.

Однако дело не столько в 3-бромфаскаплизине, сколько в том, что цитотоксическое действие TMZ в отношении радиорезистентных ОК мо- 
жет быть усилено лекарственными средствами, обладающими другим, более эффективным механизмом генотоксического действия. Противоопухолевое действие фаскаплизина связано с интеркаляцией ДНК. Сегодня эффект такой терапии может быть воспроизведен за счет таких препаратов, как доксирубицин и даунорубицин. При этом производные нитрозомочевины (Wick et al., 2015), рекомендованные для оптимизации второй линии химиотерапии МГБ, воздействуют на те же самые молекулярные механизмы, что и TMZ.

В нашей работе довольно часто звучит тема ГЭБ, что неслучайно. Теоретически и практически очень важно вводить лекарственные препараты в обход ГЭБ, используя такие способы, как интратекальное введение, или хирургическое введение во время реоперации в область постэктомического деффекта. Вероятно, следует ожидать усиления эффекта лечения при использовании липосомальных форм препаратов, функционализированные антителами против белков LOXL2, COL6A1, LAMB1 и CTNNB1 экспрессированных в ОСК.

В свою очередь, антиангиогенные препараты должны остаться компонентами второй линии лечения, но здесь целесообразно обратить внимание на усиление экспрессии отдельных белков wnt-сигнального каскада в ОСК, без подавления которого антиангиогенная терапия просто не будет эффективна.

И тем не менее описанные приемы обеспечивают лишь временный эффект, конечно, он позволит выиграть время, которое не имеет цены. Однако цитотоксическое воздействие на ОК быстро порождает адаптивный ответ в виде активизации процессов репарации ДНК и селекции ОК, которые лучше всего этой способностью обладают.

Принято считать, что лучшей способностью к репарации ДНК характеризуются ОСК, и это фактически аксиома нейроонкологии. ОСК посвещена серьезная литература. Теоретические и эксприментальные исследования по этой тематике предпринимаются нашим коллективом с 2014 года, и тем немеее, вопрос остается открытым.

Термин ОСК откровенно неудачный, это весьма гетерогенный пул ОК, большая часть которых никакой истинной «стволовости» не демонстрирует, а способны лишь к частичной редифференцировке, преимущественно в эндотелиальные клетки. Вероятно, этот термин возник в результате развития цитометрических технологий, сделавших возможным полу- 
чение лабораторных образцов ОК определенного изотипа (Singh et al 2003), который показал высокую онкогенность при имплантации в мозг экспериментальным животным. Однако термины «опухоль-инициирующие клетки» (Cancer - Initiating Cells) или «раковые стволово-подобные клетки» (Cancer Stem-Like Cells) так и не прижились.

Экстраполяция результатов экспериментальных данных в клинику привела к закреплению этого термина, который приобрел настолько концептуальный оттенок, что скорее напоминают мистический танк «Белый тигр» из одноименного фильма российского режисера Карена Шахназарова, чем четко обозначенный объект таргетной терапии. Но несмотря на всю эту лирику совершенно очевидно, что без контроля над ОСК никакого прогресса в направлении лечения больных МГБ ожидать не иследует.

Первая линия комплексного лечения по протоколу Роджера Ступпа (Stupp et al., 2005), в принципе, никак не направлена против ОСК, она ориентрована против всех ОК в целом, часть из которых, вероятно, и будет ОСК. Эта проблема возникает только при рецидиве опухоли, причем появляется «внезапно», обнаруживая полное отсутствие всяких подходов к воздействию на нее.

Одним из способов воздействия на ОСК принято считать иммунотерапию (ИТ), и в этой связи целесообразно еще раз вернуться к результатам работ, описанных в главе 8. Среди множества дифференциально экспрессированных белков ОСК особого внимание заслуживает белок ERC1, усиливающий уровень синтеза более чем в 9 раз в клетках, подвергнутых облучению. ОСК после лучевой терапии более чем 4 раза усиливают уровень экспрессии белков противовоспалительного кластера NARG1L, PLCD3, ROCK2, SARNP, TMSB4X и YTHDF2. Гиперэкспрессия гена TMSB4X в облученных клетках - очень важный факт. Белок TMSB4X обладает сильным противовоспалительным эффектом в отношении нейтрофилов (Young et al., 1999) и является модулятором биологических эффектов кортикостероидов.

Итак, ОСК после курса облучения, в принципе, представляют собой ОК, которые способны противостоять влиянию ИТ. Настоящее исследование ярко иллюстрирует причину, по которой современная ИТ бессильна против МГБ. В этой связи подход к данной проблеме должен быть качественно иной. Как следует из главы 8 , ОСК в отличие от ДКГ характеризуются критически усиленной экспрессией белков РВ-ВКМ, что сближает их с нормальными СК. Вероятно, это «ахилесова пята» МГБ. 
В настоящей работе (глава 8) проведено картирование протеомных профилей нормальных и опухолевых СК, показанно, что во всех типах СК сохранными являются внутриклеточные сигнальные пути, обеспечивающие рецепторное взаимодействие с ВКМ.

Вероятно, именно эффективность взаимодействия с ВКМ определяет судьбу всех СК, которая, в свою очередь, сильно зависит от сопутствующего клеточного микроокружения, формирующего «нишу» СК. После облучения ОСК обладают еще более высоким потенциалом взаимодействия с ВКМ и способностью формировать иммуносупрессивное микроокружение. В этой связи дестабилизацию взаимоотношений ОСК с ВКМ следует считать самой перспективной задачей и важнейшим направлением пролонгации ремиссии при МГБ.

Решение этой задачи возможно с использованием качественно новых биомедицинских клеточных продуктов (БМКП) и технологий, созданных на основе ККМ, обогащенных ГСК. Основу этого утверждения составляют факты, показанные в данной работе.

ГСК - другие по происхождению СК, нежели НСК, однако они обладают высокой подвижностью в отношении ОК, при этом модификация состава взаимодействующих клеток или предшествующее воздействие на клетки приводит к развитию специфических форм взаимно ориентированных влияний внутри клеточных популяций и сопровождается закономерными модуляциями в их пространственном микроокружении.

Принято считать, что миграция СК в область повреждения тканей и органов это репаративный феномен (глава 3). Считается, что синтез SDF-1 $\alpha$ и других хемоатрактантов, привлекающих ГСК, запускается хемокинами семейства HIF, источником которых являются поврежденные ткани. Однако наши экспериментальные данные (глава 4) свидетельствуют о том, что источником сигналов, индуцирующих миграцию НСК и ГСК, являются сами клетки МГБ, что указывает именно на первостепенную роль ОК в этом процессе.

На первостепенную роль ОК в процессах взаимодействия с нормальными СК указывает и высокая подвижность клеток МГБ в отношении ГСК, мигрирующих в культуральную вставку. Как показано в эксперименте (глава 4), клетки МГБ активно перемешались в пределах культуральной вставки и как бы «собирали» мигрирующие к ним ГСК, которые адгезировали к поверхности ОК, словно грозди винограда. Данный факт 
свидетельствуют в пользу существования сложных атрактивных и персмиссивных взаимоотношений между СК и ОК и указывает на большее значение нормальных СК в биологии злокачественных опухолей.

Здесь необходимо вернуться к истории. Безусловно, факт адгезии СК к OK показан для МСK костного мозга (Nakamizo et al., 2005) и эндотелиальных CK (Moore et al., 2004). Но особого внимания заслуживает феномен адгезии НСК к клеткам глиальных опухолей, подмеченный в работах научного коллектива Карен Эбоди (Aboody et al., 2000; Aboody et al., 2013). Мигрируя к клеткам глиом, НСК адгезировали к ним «оседлав, in piggy back fashion» (Aboody et al., 2000). Логично предположить, что такой способ контактного взаимодействия создает оптимальные условия для обмена информацией, поскольку любое взаимодействие живых систем - это обмен информацией.

Феномен адгезии ГСК к ОК продемонстрирован и в настоящей работе. Показано, что ГСК адгезируют к клеткам крысиной глиомы линии С6, клеткам МГБ линии U87, клеткам рака легких и молочной железы. Важным этапом контактного взаимодействия является перенос флуоресцентной метки между ГСК и ОК, что означает трансфер белков, связывающих клеточный краситель. Активный обмен флуоресцентным материалом между ГСК и ОК разных линий указывает на стереотипность подобных взаимоотношений в данной системе.

Механизмы, обеспечивающие обмен флуоресцентной меткой в ходе контактных взаимодействий, пока не до конца ясны. Это может быть слияние клеток, которое довольно хорошо описано на модели взаимодействия MCK с OCK глиом (Sun et al., 2015) или между клетками глиомы и фибробластами (Mercapide et al., 2012). Обмен информационными молекулами возможен через экзосомы (Xu et al., 2015), на что указывает появление на наших препаратах многочисленных микровезикул, диаметр которых существенно меньше ГСК. В свою очередь, возможно формирование структурно-функционального синцития между взаимодействующими клетками, при котором обособленные участки цитоплазмы клеток связываются между собой цитоплазматическими мостиками (Godlewski et al., 2015).

Факт взаимодействия между ГСК и ОК имеет важное значение для понимания процессов канцерогенеза. Вероятно, взаимодействуя с патологически измененными клетками, в том числе ОК, нормальные ГСК накапливают не свойственные им белки, что лежит в основе аутоимунных синдромов, в ряде случев сопровождающих опухолевые процессы. В свою 
очередь, определенные параметры протеома ГСК могут быть использованы для ранней диагностики МГБ и других видов рака.

Как следует из главы 4 настоящей работы, ГСК обладают противоопухолевым потенциалом, который возрастает с увеличением колличества этого типа клеток. При соотношении 3 ГСК к 1 ОК пролиферация последней становится невозможной. Поскольку этот эксперимент был выполнен без какого либо цитокинового сопровождения, то данный эффект является иллюстрацией именно регуляторной функции ГСК и может быть связан с механизмом «вето» ГСК (Reisner et al., 2003), при котором происходит формирование взаимной толерантности при контактном взаимодействии. Не менее важна возможность прямого эпигенетического перепрограммирования в процессе взаимодействия ГСК и ОК.

Способность СК взаимодействовать с ОК позволяет рассматривать НСК и ГСК в качестве перспективного средства доставки в опухоль суицидальных генов, например ТР 53, и онколитических вирусов. Высокая подвижность НСК в отношении глиом позволила назвать (Carvalho et al., 2019) клетки этого типа «троянским конем» для МГБ, однако это только одно из возможных направлений использования СК в терапии МГБ. Наилучшей способностью индуцировать подвижность СК обладают именно ОСК, что позволяет предположить, что противоопухолевая клеточная терапия может быть эффективна именно против этого типа ОК.

Однако здесь необходимо снова повторить мысль, сформулированную выше. ОСК - понятие динамическое, буквально оно означает способность группы ОК в определенный момент времени и в определенных условиях к выполнению ряда профильных функций - репарации ДНК, пролиферации, построению кровеносного русла и т.д. В тот момент, когда такие условия резко меняются, например, под влиянием терапии, будь это суицидальные гены, вирусы или таргетные препараты, формируются новые условия, в которых возникают новые ОК с функциями ОСК.

В теории этот процесс может быть бесконечным, пока в мозге больного сохраняется осаточная опухолевая ткань. Более того, обсуждается мысль (Gimple et al., 2019; Sharifzad et al., 2019), что все клетки рецидивирующей МГБ обладают свойствами ОСК, что, вероятно, недалеко от истины.

В этой связи гораздо более целесообразно, чтобы терапевтический потенциал ГСК был интегрирован в единую стратегию лечения МГБ, целью которой является не столько тотальное уничтожение ОК, сколько мо- 
делирование микроокружения ОСК, которое должно быть строго провоспалительным.

Источником для создания таких БМКП и технологий может стать лейкоконцентрат мононуклеарных CD45+ клеток, рекрутируемых в кровоток при стимуляции Г-КСФ. В настоящем исследовании in vivo показано (глава 5), что значительная часть мононуклеарных CD45+ клеток KM, обогащенных ГСК, после введения в кровоток иммуносупрессивных крыс с глиомой С6 мигрирует в очаг глиомы в головном мозге, накапливается в области инвазивного роста опухоли и проникает в зоны некроза.

Факт подобного поведения CD45+ клеток, в том числе ГСК, становится понятен, если учесть наличие на их поверхности рецептора CXCR4 (англ. "C-X-C chemokine receptor type 4"; CD184) - рецептор хемокинов, который индуцирует хемотаксис клеток в ответ на связывание с хемокином CXCL12 или SDF-1 $\alpha$. Безусловно, источником сигналов для трансплантированных клеток КМ являются поврежденные ткани, продуцирующие SCF-1 $\alpha$. В пользу этого аргумента указывает скопление клеток, несущих рецептор CXC-R4 (рис. 53), в зону инвазивного роста глиомы.

Введение Г-КСФ экспериментальным животным с глиомой С6 сопровождается рекрутированием CD45+ мононуклеарных клеток КМ в системный кровоток. Количество СК или клеток «боковой популяции» среди всей фракции CD45+ возрастает до 30\%, что очень много (рис. 31). При рекрутировании мононуклеарных клеток КМ человека количество ГСК среди них составляет 1,5-2\%, а основная масса этих клеток представлена Т- и Влимфоцитами и моноцитами, предшественниками тканевых макрофагов.

В свете сказанного к наблюдаемым нами феноменам нужно подходить критически. Во-первых, всплеск пролиферативной активности в опухолевой ткани крыс с глиомой С6, наблюдаемый в группе «клетки» (рис. 28), вероятно, связан с пролиферацией ГСК, рекрутированных в кровоток и мигрировавших в опухоль. Во-вторых, что наиболее вероятно, попадая в условия иммуносупрессивной микросреды опухолевого очага, такие клетки оказываются вовлеченными в неопластический процесс и используются опухолью. В-третьих, пролиферация - ключевое свойство злокачественных глиом, и совсем не удивительно, что опухоль реагирует на появление новых клеточных элементов подобным образом.

Факт усиления пролиферативных процессов в опухолевой ткани под воздействием СК КМ нельзя назвать позитивным, даже несмотря на то, 
что нами показана способность ГСК угнетать жизненные функции ОК (глава 4). Однако представляется очень важным, что ГСК мигрируют в опухоль в сопровождении многочисленных иммуноцитов, чем, вероятно, и объясняется резкое возрастание числа Iba1-позитивных клеток в опухоли к 30-м суткам эксперимента.

Как следует из главы 2, клетки микроглии происходят из эритромиелоидных предшественников желточного мешка и после закрытия ГЭБ поддерживают популяцию путем пролиферации. При необходимости ресурсы головного мозга восполняются за счет иммобилизации микроглиоцитов из других отделов ЦНС, что показано на примере крыс контрольной группы (рис. 35).

Под действием токсинов и продуцируемых опухолью ангиогенных факторов, формирующих кровеносное русло, происходит повреждение ГЭБ, что делает возможным рекрутирование ГСК, гемопоэтических прогениторов, моноцитарно-дендритных клеток и собственно моноцитов. Трансформация этих элементов (Iba1+ микроглиально-подобные клетки) весьма вероятна (Zhihong \& Hambardzumyan, 2018) и показана в нашем исследовании.

В нашем эксперименте стимуляция крыс Г-КСФ сопровождалась увеличением площади окрашивания микропрепаратов антителами к Iba1. B противовес этому на 30-е сутки количество в Ibal+ клеток в опухолевом очаге и окружающих его тканях мозга крыс контрольной группы резко сокращалось, что указывает на связь между этими явлениями. Но особого внимания заслуживают изменения профиля продукции цитокинов в ткани глиомы С6.

Опухолевая ткань характеризуется определенным уровнем продукции ключевых цитокинов (рис. 54), при этом в фокусе нашего пристального внимания были IL-10 (рис. 54, A), TNF $\alpha$ (рис. 54, Б) и IL (рис. 54, В) и конечно, TGF- $\beta 1$ (рис. 55). При введении Г-КСФ крысам с глиомой С6 отмечалось снижение содержания в опухоли противовоспалительных цитокинов IL-10 и TGF $\beta-1$, в то время как содержание TNF $\alpha$ тоже снизилось, а IL-1 достоверно не изменилось. Данные обстоятельства указывают на недостаточность только одного рекрутирования СК для провоспалительной модификации микроокружения ОК, однако наше внимание привлекло резкое снижение содержания в опухоли TGF- $\beta 1$ (рис. 55).

Как следует из эксперимента, стимуляция TGF- $\beta 1$ вызывает резкое изменение формы ОК, которые быстро «распластываются» по поверхно- 
сти культурального планшета, приобретая особую, фибробластоподобную форму (рис. 60). Изменение формы ОК сопровождается подавлением пролиферации, уменьшением числа контактов с соседними клетками и снижением количества внутриклеточных включений (рис. 62).

Уменьшение числа внутриклеточных включений, напоминающих липидные капли и углеводные поля (рис. 61, А), следует обяснять усилением функции внешней секреции, что непосредственно связано с возросшей подвижностью ОК (рис. 63) и проявляется уменьшением времени «зарастания царапины» в клеточном монослое. Увеличение клеточной подвижности в сочетании с приобретением ОК миграционного фенотипа и снижением темпа пролиферации указывает на особую роль TGF- $\beta 1$ в запуске процессов инвазивного роста МГБ.

Как показано в нашей работе, мононуклеарные ККМ, обогащенные ГСК, взаимодействуют с клетками МГБ, предобработанными TGF- $\beta 1$. Стимуляция TGF- $\beta 1$ не оказывает значимого влияния на интенсивность процессов обмена флуоресцентной меткой (рис. 69). Данный факт представляет особый интерес. Если предположить, что к активному обмену флуоресцентной меткой с ОК способны не все CD45+ клетки, а только ГСК, как это показанно в главе 4, то данный факт становится относительно понятным, поскольку колличество ГСК в лейкоконцентрате характеризуется относительным постоянством.

В свою очередь, обмен флуоресцентной меткой в ходе взаимодействия ГСК и ОК происходит в иммуносупрессивной среде, вызванной TGF- $\beta 1$, при этом значительное количество CD45+ иммуноцитов в обоих случаях не оказывает агрессивного воздействия на ОК. Возможно, это связано с наличием у ОК механизмов уклонения от иммунного контроля или, что более вероятно, отсутствием у иммуноцитов информации относительно тактики взаимодействия с ОК. В этой связи особенно важно, что в ходе взаимодействия ГСК с ОК, предобработанными TGF- $\beta 1$, отмечается возврат темпов пролиферации клеток МГБ до уровня контрольных значений, что, возможно, связано с дестабилизацией системы адгезивных взаимоотношений ОК с поверхностью планшета.

В этой связи особого внимания заслуживает тот факт, что культивирование CD45+ клеток человека в культуральное среде, полученной после культивирования клеток МГБ и содержащей интерферон- $\gamma$ и бактериальный LPS, сопровождается увеличением эффективности противоопухоле- 
вого межклеточного взаимодействия с подавлением скорости пролиферации и подвижности ОК (рис. 71).

В свете полученных данных подавление продукции TGF- $\beta 1$ в опухолевом очаге, наблюдаемое нами при стимуляции экспериментальных животных Г-КСФ (рис. 55), вероятно, является ключевым компонентом реализации противоопухолевого потенциала мононуклеарных клеток КМ, обогащенного ГСК. В этой связи провоспалительная терапия в виде стимуляции крыс с глиомой С6 интерфероном- $\gamma$ и бактериальным LPS вслед за введением Г-КСФ, вероятно, является главным условием реализации противоопухолевого потенциала клеток КМ.

Действительно, такая комбинированная стимуляция крыс с перевитой глиомой С6 в нашем эксперименте сопровождалась увеличением Iba+ клеток микроглии в зоне инвазии именно у крыс группы Г-КСФ+ интерферон- $\gamma+$ бактериальный LPS (глава 7). Важно, что такая стимуляция также сопровождается некоторым увеличением пролиферативной активности в опухоли (рис. 74, А), при этом синхронно возрастает и площадь окрашивания микропрепаратов антителами против Iba1-маркера микроглиально-подобных клеток (рис. 74, Б), что отчасти объясняет наблюдаемый феномен.

Синхронно с увеличением числа микроглиально-подобных клеток мы наблюдаем их поляризацию в провоспалительном M1-направлении, о чем свидетельствуют увеличение клеток, иммунореактивных к белку CD86 и снижение числа клеток иммунореактивных в отношении антигена CD206 (рис. 74, В и Г). Как следует из анализа микропрепаратов (рис. 76 и 77), CD86+ клетки локализованы главным образов в зоне инвазии опухоли в ткань мозга, они «распластаны» и активно контактируют как с ОК, так и друг с другом. Учитывая, что именно в зоне инвазии опухоли в ткань мозга (рис. 38) локализованы активированные клетки астроцитарной глии, то, безусловно, эти клетки тоже вносят определенный вклад в рост опухоли.

Комбинация провоспалительной терапии с использованием интерферона- $\gamma$ и бактериального LPS с рекрутированием CD45+ клеток КМ в системный кровоток ведет к модификации профиля экспрессии цитиокинов в неопластическом очаге (рис. 78) в виде снижения уровня синтеза IL-10 и TGF- $\beta 1$, к усилению синтеза провоспалительных цитокинов IL-1 и TNF $\alpha$ и, что особенно важно, к снижению площади окрашивания микропрепаратов антителами против одного из важнейших маркеров ЭМП - виментина (рис. 80). 
Итак, рекрутирование CD45+ клеток KM в кровоток животных с глиомой С6 в сочетании с провоспалительной стимуляцией изменяет архитектуру и стереотип течения неопластического процесса. В опухоли значительно возрастает количество в Iba1+ клеток, которые локализуются в местах распределения мигрировавших сюда клеток КМ. В свою очередь, на границе опухоли наблюдается уплотнение лучистых глиоцитов, которые формируют клеточный барьер, препятствующий продвижению опухолевого процесса в ткань мозга. Провоспалительная модификация микроокружения ОК подавляет продукцию TGF- $\beta 1$ OK, что сопровождается увеличением выживаемости животных (рис. 81).

Выше изложенные факты свидетельствуют о биологической и экспериментальной обоснованности новых методологических подходов к лечению МГБ. Использование этих подходов на практике позволяет создать новую группу противоопухолевых БМКП, целью которых является модуляция микроокружения ОСК, дестабилизация взаимоотношений ОСК и ВКМ и разрушение иерархии ОК. Безусловно, появление в арсенале врача-онколога БМКП расширяет возможности традиционной терапии опухолей и формирует качественно новый подход к лечению больных МГБ.

Можно ли дополнить такую терапию более традиционными средствами ИТ опухолей, например, дендритными вакцинами и культурами цитотоксических лимфоцитов? Безусловно, этот вопрос требует предметного изучения в эксперименте, но весьма вероятно, что именно так и следует сделать. В качестве мишеней тут целесообразно выбрать белок LOXL2 уровень синтеза которого в ОСК по сравнению с ДКГ был увеличен более чем в 9 раз, и белок $\beta$-катенин - ключевой компонент сигнального пути wnt, уровень синтеза которого в ОСК по сравнению с ДКГ увеличен более чем в 13 раз. На эти мишени обязательно должна быть направлена прецизионная ИТ с использованием персонализированных дендритных вакцин, цитотоксических лимфоцитов или моноклональных антител.

Другим возможным спосбом ИТ могут стать БМКП, представляющие собой ДВ или культуру ЦТЛ, обогащенную экзосомами, продуцируемыми донорскими ГСК и МСК в условиях провоспалительной стимуляции. Принцип такой ИТ описан в главе 3 данной работы, где теоретически сформулирована концепция БМКП, сочетающиего возможности ДВ и таргетного препарата, подавляющего экспрессию ряда ключевых генов методом РНК-интерференции. 
Однако принцип таргетности лечения не следует гиперболизировать. Даже самое точное воздействие на компоненты сигнального пути фокальной адгезии или РВ-ВКМ в ОСК ничего не стоит без подавления продукции TGF- $\beta$. Как показано в нашей работе, стимуляция TGF- $\beta$ индуцирует синтез в ДКГ миграционного N-кадгерина, виментина, витронектина, компонентов актин-миозинового комплекса и матриксные металлопротеиназы MMP2, MMP9, MMP14, ADAMTS1. При этом уровень продукции ключевых белков сигнального пути РВ-ВКМ достигает значений, сопоставимых с ОСК, в том числе белков COL6A1 и LAMB1. Вполне возможно, что это и есть так называемый качественно-количественный переход, непосредственно активизирующий инвазивные процессы. В этой связи центральной задачей терапии является подавление продукции TGF- $\beta 1$, а не какие-то другие цели, хотя данный факт требует дальнейшего изучения.

Как должна быть построена провоспалительная терапия? Вопрос этот не простой и, конечно, ответ на него возможен только в эксперименте. С теоретических позиций после первого курса комбинированного лечения включащего облучение и химиотерапию возможно рекрутирование клеток КМ в системный кровоток с использованием Г-КСФ, на фоне провоспалительной стимуляции. Однако эффективность такого лечения вряд ли будет велика, поскольку предшествующая химиотерапия довольно губительно влияет на клетки ККМ.

Вероятно, если у пациента есть банкированный КМ, то введение мононуклеарных CD45+ клеток на фоне провоспалительной стимуляции может стать методом выбора. Однако в абсолютном большинстве случаев таких резервов у больного не будет, и тогда основу лечения должны составить БМКП аллогенного КМ, способные вызывать реакцию «трансплантант- против хозяина».

Несмотря на довольно большую работу, этот факт в нашем исследовании только обозначен, но говоря именно о будущем, допустимо предположить, что именно БМКП аллогенного КМ в перспективе станут основным инструментом лечения МГБ.

Аргументов в пользу такого рода предположений много. Главным среди этих аргументов является невозможность радикального удаления МГБ. В онкогематологии трансплатация аллогенного костного мозга применяется после высокодозной химиотерапии, которая должна быть в достаточной степени противоопухолевой и иммуносупрессивной, что понят- 
но. Однако чем больше в организме больного остаточной опухолевой ткани, тем меньше потребность использовать сверхтоксические режимы кондиционирования, тем больше целесообразна ставка на реакцию «трансплантант против опухоли».

Как показывает весь мировой опыт лечения больных МГБ, облучение и химиотерапия пока не справляются с задачей уничтожения ОК в мозге больных МГБ. В этой связи, возможно, следует идти не по пути нарашивания доз цитостатиков, а сделать ставку на препраты алогенного костного мозга и спопутствующей аллогенной трансплантации провоспалительной модификации ВКМ. Поскольку ОСК проявляют максимум своих потенций именно в ангиогенезе, то вероятно, такая терапия должна проводиться в неразрывной связке с антиангиогенными препаратами, ингибиторами wnt-сигналинга, и атакой на TGF- $\beta$.

Как долго нужно продолжать такую терапию? Этот вопрос не имеет однозначного ответа. Хроническое воспаление ведет к формированию фиброзной капсулы или гранулемы с интенсивным отложением кальция на периферии, как это наблюдается в случае туберкулемы. Как правило, срок формирования первичной туберкулемы составляет 1-3 года. Кальциноз, формирование фиброзной сумки и инкапсуляция неопластического очага применительно к МГБ может стать решением проблемы, что, вероятно, и является целью такой терапии.

Итак, мобилизованные мононуклеарные CD45+ клетки KM, обогащенные ГСК, представляют собой исключительно перспективную платформу для создания БМКП. ГСК, которые составляют не многочисленную, но критически важную часть данного продукта, обладают способностью направленной миграции в опухолевый очаг и взаимодействию с ОК, в процессе которого способны оказать репрограммирующее воздействие на ОСК. В свою очередь, многочисленные иммуноциты, входящие в состав лейкоконцентрата, могут быть использованы для создания культур ЦТЛ и ДВ. В условиях аллотрансплантации они могут быть использованы для запуска реакции «трансплантант против хозяина» с целью провоспалительной модификации микроокружения ОСК, дестабилизации отношений ОСК с ВКМ, разрушения патологически измененного ВКМ и инкапсуляции опухолевого процесса. 


\section{ЗАКЛЮЧЕНИЕ}

Лечение опухолей мозга - одна из самых сложных задач медицины. Настоящее исследование посвящено МГБ, однако наработанный материал применим ко всем первичным и метастатическим новообразованиям мозга. Ни для кого не секрет, что крайне низкие результаты лечения опухолей мозга обусловлены использованием устаревших подходов к лечению, старых лекарственных препаратов и технологий. Однако модернизация этих стратегий и методик требует решения ряда фундаментальных задач, которые, несмотря на усилия авторов, в настоящей работе только обозначены.

Нами проанализирована специфика механизмов терапевтической резистентности МГБ человека, предпринята попытка систематизации и научно-теоретического обоснования новых подходов к созданию биомедицинских клеточных препаратов для персонифицированной терапии глиальных опухолей мозга.

Впервые с использованием современных методов молекулярной и клеточной биологии изучены закономерности миграции СК к клеткам различных линий in vitro. Установлено, что миграция нейральных стволовых клеток к CD133+ клеткам глиобластомы более выражена по сравнению с их подвижностью в отношении клеток иного происхождения.

У животных с глиомой С6 трансплантированные ГСК мигрируют в опухоль и накапливаются в очагах инвазии и некроза неопластической ткани. В условиях in vitro выявлена способность ГСК человека адгезировать к клеткам глиальных опухолей, замедляя темпы их пролиферации. Процесс межклеточного взаимодействия сопровождается переносом флуоресцентного цитоплазматического материала ГСК в ОК, что более выражено у клеток линии С6 в сравнении с CD133+ клетками линии U87. Установлено, что накопление ГСК в опухолевом очаге in vivo сопровождается подавлением продукции TGF-1 $\beta$ и увеличением числа iba- $1+$ глиальных клеток.

Мононуклеарные клетки КМ, обогащенные ГСК, взаимодействуют с клетками МГБ и обмениваются с ними флуоресцентной меткой. Обработка опухолевых клеток TGF- $\beta 1$ не влияет на этот процесс и не снижает их способности к межклеточному взаимодействию. Совместно культивирование ГСК с клетками МГБ, стимулированными 10 нг/мл TGF- $\beta 1$, сопровождается усилением темпа пролиферации ОК, но предварительная про- 
воспалительная модификация повышает противоопухолевый потенциал ГСК, что проявляется снижением темпов пролиферации и уменьшением подвижности клеток МГБ.

Стимуляция экспериментальных животных Г-КСФ рекрутирует ГСК и мононуклеарные CD45+ клетки в системный кровоток и далее в опухоль экспериментальных животных с глиомой С6, что сопровождается усилением процессов микроглиальной пролиферации и обогащением инфильтрации в опухолевой ткани маркерами клеток микроглии. Провоспалительная терапия на фоне стимуляции Г-КСФ вызывает усиление процессов презентации антигена, что сопровождается снижением продукции TGF- $\beta$, ремоделированием опухолевого матрикса и увеличением выживаемости экспериментальных животных.

С использованием протеомного анализа показана идентичность 63,2\% белков НСК и ОСК и 36,47\% белков в МСК и ОСК. Сигнальный каскад фокальной адгезии является сохранным во всех типах СК. ОСК отличаются от ДКГ тотальным усилением экспрессии белков сигнального пути PB-BKM и Wnt. Приоритетными мишенями для поражения этих сигнальных путей являются белки COL6A1, LAMB1 и CTNNB1. Обработка TGF- $\beta 1$ стимулирует в ДКГ экспрессию белков актин-миозинового комплекса и матриксных металлопротеиназ 2, 9, 14 и ADAMTS1. При этом 13 белков сигнального пути PB-BKM (CD44, HMMR, COL1A2, COL6A1, COL6A3, FN1, LAMB1, LAMC1, ITGA2, ITGA5, ITGAV, ITGB1, ITGB3) и 3 белка, активизирующих PB-BKM (FERMT2, HDAC2 и FBN1) в ДКГ, усиливают экспрессию до уровня ОСК.

Белок LOXL2 является маркером OCK МГБ человека. Облучение в дозе 60 Грей усиливает в ОСК синтез белков ERC1, NARG1L, PLCD3, ROCK2, SARNP, TMSB4X и YTHDF2 более чем в 4 раза. При этом более чем 2 раза возрастает уровень синтеза белков протеасом (PSMA2, PSMA3, PSMA4, PSMB2, PSMB3, PSMB7, PSMC3, PSMD1, PSMD3).

Наилучшей способностью убивать клетки глиомы С6 обладают 3-бромфаскаплизин и 7-фенилфаскаплизин. Цитотоксическое действие этих соединений носит дозозависимый характер и возрастает с увеличением времени экспозиции. Производные фаскаплизина воздействуют на все фазы жизненного цикла неопластических клеток, при этом число живых клеток в фазе $\mathrm{G}_{0}$ под воздействием 3-бромфаскаплизина и 7-фенилфаскаплизина остается минимальным. Цитотоксическая эффективность 3-бром- 
фаскаплизина в отношении клеток линии U-87 MG ГБ превосходит незамещенный фаскаплизин. В свою очередь, цитотоксическая эффективность 3-бромфаскаплизина в отношении клеток линии T98-G ГБ уступает TMZ, а в отношении клеток линии T98-G ГБ с выработанной радиорезистентностью превосходит TMZ.

Как показывает исследования, ГСК способны к взаимодействию с ОК, в том числе с ОСК, и обладают огромным противоопухолевым потенциалом, реализация которого определяется влиянием локального микроокружения, что само по себе дает ответ на вопрос о путях воздействия на ОСК. Пристального внимания заслуживает феномен обмена флуоресцентной меткой между ГСК и ОСК, что указывает на принципиальную диагностическую ценность изменений протеома ГСК не только при раке, но, вероятно, и при множестве других заболеваний. Возможно, именно ГСК в недалеком будущем станут главным объектом диагностики и лечения наиболее сложных онкологических заболеваний и других, тяжелых социально-значимых заболеваний.

Предел возможностей хирургии сегодня еще не достигнут. Безусловно, она всегда была, есть и будет царицей медицинских наук, однако сегодня хирургия мозга уже идет не столько по пути удаления, сколько путем реконструкции, стимуляции, регуляции и адаптации. И в этом плане биомедицинские клеточные препараты и технологии должны стать логическим продолжением скальпеля хирурга, именно об этом свидетельствуют результаты данной работы.

Однако как бы привлекательны бы ни были полученные результаты, повлиять на реальное положение дел они смогут только тогда, когда войдут в аренал простого врача, что требует высокого уровня стандартизации и систематизации всей имеющейся информации, разработки и клинической апробации новых алгоритмов и стратегий лечения МГБ. Итогом этой работы станет появление принципиально нового типа медицины - биомедицины.

Развитие биомедицинских клеточных, геномных и постгеномных технологий уже провозглашено в числе приоритетов национального развития науки в России и в мире. Это означает, что «нужно бежать со всех ног, чтобы только оставаться на месте, а чтобы куда-то попасть, надо бежать как минимум вдвое быстрее», - эта фраза Люиса Кэрролла в наши дни актуальна как никогда. Будущее принадлежит биомедицине, это очевидно. 


\section{СПИСОК ЛИТЕРАТУРЫ}

1. Aasland D, Götzinger L, Hauck L et al. Temozolomide Induces Senescence and Repression of DNA Repair Pathways in Glioblastoma Cells via Activation of ATR-CHK1, p21, and NF-кB. Cancer Res. 2019;79(1):99-113.

2. Aboody KS, Brown A, Rainov NG et al. Neural stem cells display extensive tropism for pathology in adult brain: evidence from intracranial gliomas. Proc Natl Acad Sci U S A. 2000 Nov 7;97(23):12846-51.

3. Adams V, Späte U, Kränkel $N$ et al. Nuclear factor-kappa B activation in skeletal muscle of patients with chronic heart failure: correlation with the expression of inducible nitric oxide synthase. Eur J Cardiovasc Prev Rehabil. 2003;10(4):273-7.

4. Ahmed EM, Bandopadhyay G, Coyle B, Grabowska A. A HIFindependent, CD133-mediated mechanism of cisplatin resistance in glioblastoma cells. Cell Oncol (Dordr). 2018; 41(3):319-328.

5. Ahmed K, Koval A, Xu J, Bodmer A, Katanaev VL. Towards the first targeted therapy for triple-negative breast cancer: Repositioning of clofazimine as a chemotherapy-compatible selective Wnt pathway inhibitor. Cancer Lett. 2019;449:45-55.

6. Alcantara Llaguno SR, Xie X, Parada LF. Cell of Origin and Cancer Stem Cells in Tumor Suppressor Mouse Models of Glioblastoma. Cold Spring Harb Symp Quant Biol. 2016; 81:31-36.

7. Aldape K, Zadeh G, Mansouri S et al. Glioblastoma: Pathology, Molecular Mechanisms and Markers. Acta Neuropathol. 2015;129(6):829-48.

8. Allen M, Bjerke M, Edlund $\mathrm{H}$ et al. Origin of the U87MG glioma cell line: Good news and bad news. Sci Transl Med. 2016;8(354):354re3.

9. Altmann C, Keller S, Schmidt MHH. The Role of SVZ Stem Cells in Glioblastoma. Cancers (Basel). 2019;11(4):448.

10. Álvarez-Satta M, Moreno-Cugnon L, Matheu A. Primary Cilium and Brain Aging: Role in Neural Stem Cells, Neurodegenerative Diseases and Glioblastoma. Ageing Res Rev. 2019; 52:53-63.

11. Angelastro JM, Lamé MW. Overexpression of CD133 promotes drug resistance in C6 glioma cells. Mol Cancer Res. 2010;8(8):1105-15.

12. Anthony BA, Link DC. Regulation of hematopoietic stem cells by bone marrow stromal cells. Trends Immunol. 2014;35(1):32-7. 
13. Astro V, Tonoli D, Chiaretti $\mathrm{S}$ et al. Liprin- $\alpha 1$ and ERC1 control cell edge dynamics by promoting focal adhesion turnover. Sci Rep. 2016;6:33653.

14. Bader N, Grune T. Protein oxidation and proteolysis. Biol Chem. 2006; 387(10-11):1351-1355.

15. Bady P, Kurscheid S, Delorenzi M et al. Epub 2018 Jan 24.The DNA Methylome of DDR Genes and Benefit From RT or TMZ in IDH Mutant LowGrade Glioma Treated in EORTC 22033. Acta Neuropathol. 2018;135(4):601-615.

16. Bao L, Li X, Lin Z. PTEN overexpression promotes glioblastoma death through triggering mitochondrial division and inactivating the Akt pathway. J Recept Signal Transduct Res. 2019;39(3):215-225.

17. Bao S, Wu Q, McLendon RE et al. Glioma stem cells promote radioresistance by preferential activation of the DNA damage response. Nature. 2006;444(7120):756-60.

18. Bastida-Ruiz D, Van Hoesen K, Cohen M. The Dark Side of Cell Fusion. Int J Mol Sci. 2016;17(5):638.

19. Benitez JA, Ma J, D'Antonio M, Boyer A et al. PTEN regulates glioblastoma oncogenesis through chromatin-associated complexes of DAXX and histone H3.3. Nat Commun. 2017;8:15223.

20. Ben-Neriah Y. Regulatory functions of ubiquitination in the immune system. Nat Immunol. $2002 ; 3(1): 20-6$.

21. Berendsen S, van Bodegraven E, Seute T et al. Adverse prognosis of glioblastoma contacting the subventricular zone: Biological correlates. PLoS One. 2019 11;14 (10): e0222717.

22. Bharate SB, Manda S, Mupparapu N et al. Chemistry and biology of fascaplysin, a potent marine-derived CDK-4 inhibitor. Mini Rev Med Chem. 2012;12(7):650-64.

23. Bhawe KM, Aghi MK. Microarray Analysis in Glioblastomas. Methods Mol Biol. 2016;1375:195-206.

24. Bischof J, Westhoff MA, Wagner JE et al. Cancer stem cells: The potential role of autophagy, proteolysis, and cathepsins in glioblastoma stem cells. Tumour Biol. 2017; 39 (3):1010428317692227.

25. Blumenthal DT, Gorlia T, Gilbert MR et al. Is more better? The impact of extended adjuvant temozolomide in newly diagnosed glioblastoma: a secondary analysis of EORTC and NRG Oncology/RTOG. Neuro Oncol. 2017;19(8):1119-1126. 
26. Blumenthal DT, Kanner AA, Aizenstein O et al. Surgery for Recurrent High-Grade Glioma After Treatment with Bevacizumab. World Neurosurg. 2018;110:e727-e737.

27. Bogdahn U, Hau P, Stockhammer G et al. Targeted therapy for highgrade glioma with the TGF- $\beta 2$ inhibitor trabedersen: results of a randomized and controlled phase IIb study. Neuro Oncol. 2011;13(1):132-42.

28. Bonnet D, Dick JE. Human acute myeloid leukemia is organized as a hierarchy that originates from a primitive hematopoietic cell. Nat Med. 1997;3(7):730-7.

29. Boutet A, De Frutos CA, Maxwell PH et al. Snail Activation Disrupts Tissue Homeostasis and Induces Fibrosis in the Adult Kidney. EMBO J. 2006;25(23):5603-13.

30. Bradshaw A, Wickremsekera A, Tan ST et al. Cancer Stem Cell Hierarchy in Glioblastoma Multiforme. Front Surg. 2016;3:21.

31. Braun K, Ahluwalia MS. Treatment of Glioblastoma in Older Adults. Curr Oncol Rep. 2017;19(12):81.

32. Bräutigam E, Lampl C, Track C et al. Re-irradiation of recurrent glioblastoma as part of a sequential multimodality treatment concept. Clin Transl Oncol. 2019;21(5):582-587.

33. Brown DV, Daniel PM, D'Abaco GM et al. Coexpression analysis of CD133 and CD44 identifies proneural and mesenchymal subtypes of glioblastoma multiforme. Oncotarget. 2015;6(8):6267-80.

34. Brown DV, Filiz G, Daniel PM, Hollande F et al. Expression of CD133 and CD44 in glioblastoma stem cells correlates with cell proliferation, phenotype stability and intra-tumor heterogeneity. PLoS One. 2017;12(2):e0172791.

35. Bogart JA. Stereotactic body radiotherapy for poor-risk lung cancer: "more cyber, less knife?". Cancer J. 2007;13(2):75-7.

36. Bryukhovetskiy A, Shevchenko V, Kovalev S et al. To the novel paradigm of proteome-based cell therapy of tumors: through comparative proteome mapping of tumor stem cells and tissue-specific stem cells of humans. Cell Transplant. 2014;23 Suppl 1:S151-70.

37. Bryukhovetskiy I, Manzhulo I, Mischenko P et al. Cancer Stem Cells and Microglia in the Processes of Glioblastoma Multiforme Invasive Growth. Oncol Lett. 2016;12(3):1721-1728. 
38. Bryukhovetskiy I, Shevchenko V, Arnotskaya N et al. Transforming Growth Factor- $\beta$ Mimics the Key Proteome Properties of CD133 - Differentiated and CD133 + Cancer Stem Cells in Glioblastoma. Int Rev Neurobiol. 2020;151:219-242.

39. Cai L, Kirchleitner SV, Zhao D et al. Glioblastoma Exhibits InterIndividual Heterogeneity of TSPO and LAT1 Expression in Neoplastic and Parenchymal Cells. Int J Mol Sci. 2020;21(2):612.

40. Caja L, Bellomo C, Moustakas A. Transforming Growth Factor $\beta$ and Bone Morphogenetic Protein Actions in Brain Tumors. FEBS Lett. 2015; 589(14):1588-97.

41. Cammarata FP, Torrisi F, Forte GI et al. Proton Therapy and Src Family Kinase Inhibitor Combined Treatments on U87 Human Glioblastoma Multiforme Cell Line. Int J Mol Sci. 2019;20(19):4745.

42. Chen S, Guan X, Wang LL et al. Fascaplysin Inhibit Ovarian Cancer Cell Proliferation and Metastasis Through Inhibiting CDK4. Gene. 2017;635:3-8.

43. Chen Z, Hambardzumyan D. Immune Microenvironment in Glioblastoma Subtypes. Front Immunol. 2018; 9:1004.

44. Chi Y, Zhu S, Wang C et al. Glioma homing peptide-modified PEGPCL nanoparticles for enhanced anti-glioma therapy. J Drug Target. 2016;24(3):224-32.

45. Chute JP. Stem cell homing. Curr Opin Hematol. 2006;13(6):399-406.

46. Colak S, Ten Dijke P. Targeting TGF- $\beta$ Signaling in Cancer. Trends Cancer. 2017; 3(1):56-71.

47. Colwell N, Larion M, Giles AJ et al. Hypoxia in the Glioblastoma Microenvironment: Shaping the Phenotype of Cancer Stem-Like Cells. Neuro Oncol. 2017;19(7):887-896.

48. Crespo I, Vital AL., Gonzalez-Tablas M et al. Molecular and Genomic Alterations in Glioblastoma Multiforme. Am J Pathol. 2015;185(7):1820-33.

49. Crespo I, Vital AL., Nieto AB et al. Detailed characterization of alterations of chromosomes 7, 9, and 10 in glioblastomas as assessed by singlenucleotide polymorphism arrays. J Mol Diagn. 2011;13(6):634-47.

50. Da Ros M, De Gregorio V, Iorio AL et al. Glioblastoma Chemoresistance: The Double Play by Microenvironment and Blood-Brain Barrier. Int J Mol Sci. 2018; 19 (10): 2879.

51. Dcona MM, Morris BL, Ellis KC, Grossman SR. CtBP- an emerging oncogene and novel small molecule drug target: Advances in the understanding 
of its oncogenic action and identification of therapeutic inhibitors. Cancer Biol Ther. 2017;18(6):379-391.

52. De Bacco F, D'Ambrosio A, Casanova E et al. MET inhibition overcomes radiation resistance of glioblastoma stem-like cells. EMBO Mol Med. 2016 May 2;8(5):550-68.

53. Degl'Innocenti A, di Leo N, Ciofani G. Genetic Hallmarks and Heterogeneity of Glioblastoma in the Single-Cell Omics Era. Adv Ther (Weinh). 2020; 3(1):1900152.

54. Deng Q, Hou J, Feng L et al. PHF19 promotes the proliferation, migration, and chemosensitivity of glioblastoma to doxorubicin through modulation of the SIAH1/ $\beta$-catenin axis. Cell Death Dis. 2018;9(11):1049.

55. Di Raimo T, Leopizzi M, Mangino $G$ et al. Different expression and subcellular localization of Phosphoinositide-specific Phospholipase C enzymes in differently polarized macrophages. J Cell Commun Signal. 2016;10(4):283-293.

56. Dijksterhuis JP, Arthofer E, Marinescu VD et al. High levels of WNT$5 \mathrm{~A}$ in human glioma correlate with increased presence of tumor-associated microglia/monocytes. Exp Cell Res. 2015;339(2):280-8.

57. Ding L, Morrison SJ. Haematopoietic stem cells and early lymphoid progenitors occupy distinct bone marrow niches. Nature. 2013;495(7440):231-5.

58. Diplas BH, He X, Brosnan-Cashman JA et al. The genomic landscape of TERT promoter wildtype-IDH wildtype glioblastoma. at Commun. 2018;9(1):2087

59. Dirkse A, Golebiewska A, Buder T et al. Stem Cell-Associated Heterogeneity in Glioblastoma Results From Intrinsic Tumor Plasticity Shaped by the Microenvironment. Nat Commun. 2019;10(1):1787.

60. Doan NB, Nguyen HS, Al-Gizawiy MM et al. Acid ceramidase confers radioresistance to glioblastoma cells. Oncol Rep. 2017;38(4):1932-1940.

61. Doetsch F, Caillé I, Lim DA et al. Subventricular zone astrocytes are neural stem cells in the adult mammalian brain. Cell. 1999;97(6):703-16.

62. Domingues MJ, Nilsson SK, Cao B. New agents in HSC mobilization. Int J Hematol. 2017;105(2):141-152.

63. Duesberg P, Li R. Multistep carcinogenesis: a chain reaction of aneuploidizations. Cell Cycle. 2003;2(3):202-10.

64. Duesberg PH. Are cancers dependent on oncogenes or on aneuploidy? Cancer Genet Cytogenet. 2003;143(1):89-91.

65. Duffau H. Glioblastoma in 2017. Rev Infirm. 2017; 66(228):16-18. French. 
66. Dvorak HF. Tumor Stroma, Tumor Blood Vessels, and Antiangiogenesis Therapy. Cancer J. 2015 Jul-Aug;21(4):237-43.

67. Dvorak HF. Tumors: wounds that do not heal-redux. Cancer Immunol Res. 2015;3(1):1-11.

68. Erasimus H, Gobin M, Niclou S, et al. DNA repair mechanisms and their clinical impact in glioblastoma. Mutation Research, Reviews in Mutation Research. 2016; 769, 19-35.

69. Eriksson PS, Perfilieva E, Björk-Eriksson T et al. Neurogenesis in the adult human hippocampus. Nat Med. 1998;4(11):1313-7.

70. Esaki S, Nigim F, Moon E et al. Blockade of transforming growth factor- $\beta$ signaling enhances oncolytic herpes simplex virus efficacy in patientderived recurrent glioblastoma models. Int J Cancer. 2017;141(11):2348-2358.

71. Fabregat I, Fernando J, Mainez J, Sancho P. TGF-beta signaling in cancer treatment. Curr Pharm Des. 2014;20(17):2934-47.

72. Fan H, Lu S. Fusion of human bone hemopoietic stem cell with esophageal carcinoma cells didn't generate esophageal cancer stem cell. Neoplasma. 2014;61(5):540-5.

73. Fiscon G, Conte F, Licursi V et al. Computational identification of specific genes for glioblastoma stem-like cells identity. Sci Rep. 2018;8(1):7769.

74. Fonseca AC, Amaral R, Garcia C et al. Microglia in Cancer: For Good or for Bad? Adv Exp Med Biol. 2016; 949:245-261.

75. Fortunato JT, Reys B, Singh P, Pan E. Brainstem Glioblastoma Multiforme in a Patient with NF1. Anticancer Res. 2018;38(8):4897-4900.

76. Friedman HS. Temozolomide in Early Stages of Newly Diagnosed Malignant Glioma and Neoplastic Meningitis. Semin Oncol. 2000;27(3 Suppl 6):35-40.

77. Fulton B, Short SC, James A et al. PARADIGM-2: Two parallel phase I studies of olaparib and radiotherapy or olaparib and radiotherapy plus temozolomide in patients with newly diagnosed glioblastoma, with treatment stratified by MGMT status. Clin Transl Radiat Oncol. 2017; 8:12-16.

78. Futakuchi M, Lami K, Tachibana Y, Yamamoto Y, Furukawa M, Fukuoka J. The Effects of TGF- $\beta$ Signaling on Cancer Cells and Cancer Stem Cells in the Bone Microenvironment. Int J Mol Sci. 2019;20(20):5117.

79. Gabriely G, Wheeler MA, Takenaka MC, Quintana FJ. Role of AHR and HIF-1 $\alpha$ in Glioblastoma Metabolism. Trends Endocrinol Metab. 2017;28(6):428-436. 
80. Gabrusiewicz K, Li X, Wei J et al. Glioblastoma stem cell-derived exosomes induce M2 macrophages and PD-L1 expression on human monocytes. Oncoimmunology. 2018; 7(4):e1412909.

81. Gabrusiewicz K, Li X, Wei J, Hashimoto Y et al. Glioblastoma stem cell-derived exosomes induce M2 macrophages and PD-L1 expression on human monocytes. Oncoimmunology. 2018;7(4):e1412909.

82. Gage FH. Mammalian neural stem cells. Science. 2000;287(5457):1433-8.

83. Galanis E, Anderson SK, Miller CR et al. Phase I/II trial of vorinostat combined with temozolomide and radiation therapy for newly diagnosed glioblastoma: results of Alliance N0874/ABTC 02. Neuro Oncol. 2018;20(4):546-556.

84. Gallo-Oller G, Vollmann-Zwerenz A, Meléndez B et al. P144, a Transforming Growth Factor beta inhibitor peptide, generates antitumoral effects and modifies SMAD7 and SKI levels in human glioblastoma cell lines. Cancer Lett. 2016;381(1):67-75.

85. Gao X, Deeb D, Jiang H et al. Synthetic triterpenoids inhibit growth and induce apoptosis in human glioblastoma and neuroblastoma cells through inhibition of prosurvival Akt, NF-kappaB and Notch1 signaling. J Neurooncol. 2007;84(2):147-57.

86. Gardner LB, Li Q, Park MS et al. Hypoxia Inhibits G1/S Transition Through Regulation of p27 Expression. J Biol Chem. 2001;276(11):7919-26.

87. Gersey Z, Osiason AD, Bloom L et al. Therapeutic Targeting of the Notch Pathway in Glioblastoma Multiforme. World Neurosurg. 2019;131:252263.e2.

88. Gerstner ER. ACT IV: the final act for rindopepimut? Lancet Oncol. 2017; 18(10):1294-1296.

89. Gerstner ER. ACT IV: The Final Act for Rindopepimut? Lancet Oncol. 2017;18(10):1294-1296.

90. Gibson VB, Benson RA, Bryson KJ et al. A novel method to allow noninvasive, longitudinal imaging of the murine immune system in vivo. Blood 2012; 119:2545-2551.

91. Gilbert MR, Wang M, Aldape KD et al. Dose-dense temozolomide for newly diagnosed glioblastoma: a randomized phase III clinical trial. J Clin Oncol. 2013;31(32):4085-91.

92. Gimple RC, Bhargava S, Dixit D, Rich JN. Glioblastoma stem cells: lessons from the tumor hierarchy in a lethal cancer. Genes Dev. 2019;33(1112):591-609. 
93. Gimple RC, Bhargava S, Dixit D, Rich JN. Glioblastoma stem cells: lessons from the tumor hierarchy in a lethal cancer. Genes Dev. 2019;33(1112):591-609.

94. Godlewski J, Krichevsky AM, Johnson MD et al., 2015. Belonging to a network--microRNAs, extracellular vesicles, and the glioblastoma microenvironment. Neuro Oncol. 2015; 17(5):652-62.

95. Goffart N, Lombard A, Lallemand F et al. CXCL12 mediates glioblastoma resistance to radiotherapy in the subventricular zone. Neuro Oncol. 2017;19(1):66-77.

96. Goffart N, Lombard A, Lallemand F et al. CXCL12 mediates glioblastoma resistance to radiotherapy in the subventricular zone. Neuro Oncol. 2017;19(1):66-77.

97. Goldenberg DM. Horizontal transmission of malignancy by cell-cell fusion. Expert Opin Biol Ther. 2012;12 Suppl 1:S133-9.

98. Gong M, Yu B, Wang J et al. Mesenchymal Stem Cells Release Exosomes That Transfer miRNAs to Endothelial Cells and Promote Angiogenesis. Oncotarget. 2017;8(28):45200-45212.

99. Goodwin CR, Rath P, Oyinlade O et al. Crizotinib and erlotinib inhibits growth of c-Met(+)/EGFRvIII(+) primary human glioblastoma xenografts. Clin Neurol Neurosurg. 2018; 171:26-33.

100. Grande MT, Sánchez-Laorden B, López-Blau C et al. Snail1-induced partial epithelial-to-mesenchymal transition drives renal fibrosis in mice and can be targeted to reverse established disease. Nat Med. 2015;21(9):989-97.

101. Greenbaum A, Hsu YM, Day RB et al. CXCL12 in early mesenchymal progenitors is required for haematopoietic stem-cell maintenance. Nature. 2013;495(7440):227-30.

102. Guan X, Vengoechea J, Zheng S et al. Molecular Subtypes of Glioblastoma Are Relevant to Lower Grade Glioma. PLoS One. 2014;9(3):e91216.

103. Gujar AD, Le S, Mao DD et al. An NAD+-dependent Transcriptional Program Governs Self-Renewal and Radiation Resistance in Glioblastoma. Proc Natl Acad Sci U S A. 2016 Dec 20;113(51):E8247-E8256.

104. Guseynova K, Liscak R, Simonova G, Novotny J Jr. Gamma knife radiosurgery for local recurrence of glioblastoma. Neuro Endocrinol Lett. 2018;39(4):281-287.

105. Hambardzumyan D, Bergers G. Glioblastoma: Defining Tumor Niches. Trends Cancer. 2015; 1(4):252-265. 
106. Hambardzumyan D, Gutmann DH, Kettenmann H. The role of microglia and macrophages in glioma maintenance and progression. Nat Neurosci. 2016;19(1):20-7.

107. Hamilton G. Cytotoxic effects of fascaplysin against small cell lung cancer cell lines. Mar Drugs. 2014;12(3):1377-89.

108. Heerboth S, Housman G, Leary M et al. EMT and tumor metastasis. Clin Transl Med. 2015; 4:6.

109. Hefnawy A, Khalil IA, El-Sherbiny IM. Facile Development of Nanocomplex-In-Nanoparticles for Enhanced Loading and Selective Delivery of Doxorubicin to Brain. Nanomedicine (Lond). 2017;12(24):2737-2761.

110. Herrlinger U, Tzaridis T, Mack F et al. Lomustine-temozolomide combination therapy versus standard temozolomide therapy in patients with newly diagnosed glioblastoma with methylated MGMT promoter (CeTeG/NOA-09): a randomised, open-label, phase 3 trial. Lancet. 2019;393(10172):678-688.

111. Hirschmann-Jax C, Foster AE, Wulf GG et al. A Distinct "Side Population" of Cells With High Drug Efflux Capacity in Human Tumor Cells. Proc Natl Acad Sci U S A. 2004; 101 (39):14228-33.

112. Hörmann A, Chaudhuri B, Fretz H. DNA binding properties of the marine sponge pigment fascaplysin. Bioorg Med Chem. 2001; 9(4):917-21.

113. $\mathrm{Hu} \mathrm{Q}, \mathrm{Gao} \mathrm{X}, \mathrm{Gu} \mathrm{G}$ et al. Glioma therapy using tumor homing and penetrating peptide-functionalized PEG-PLA nanoparticles loaded with paclitaxel. Biomaterials. 2013; 34 (22):5640-50.

114. Huang R, Zong X. Aberrant cancer metabolism in epithelialmesenchymal transition and cancer metastasis: Mechanisms in cancer progression. Crit Rev Oncol Hepatol. 2017; 115:13-22.

115. Inocencio J, Frenster JD, Placantonakis DG. Isolation of Glioblastoma Stem Cells With Flow Cytometry. Methods Mol Biol. 2018;1741:71-79.

116. Inocencio J, Frenster JD, Placantonakis DG. Isolation of Glioblastoma Stem Cells with Flow Cytometry. Methods Mol Biol. 2018;1741:71-79.

117. Iwadate Y. Plasticity in Glioma Stem Cell Phenotype and Its Therapeutic Implication. Neurol Med Chir (Tokyo). 2018;58(2):61-70.

118. Iwatsuki M, Mimori K, Fukagawa T et al. The clinical significance of vimentin-expressing gastric cancer cells in bone marrow. Ann Surg Oncol. 2010;17(9):2526-33.

119. Iwatsuki M, Mimori K, Yokobori T et al. Epithelial-mesenchymal Transition in Cancer Development and Its Clinical Significance. Cancer Sci. 2010;101(2):293-9. 
120. Jackson CM, Choi J, Lim M. Mechanisms of immunotherapy resistance: lessons from glioblastoma. Nat Immunol. 2019;20(9):1100-1109.

121. Jakovlevs A, Vanags A, Gardovskis J, Strumfa I. Molecular Classification of Diffuse Gliomas. Pol J Pathol. 2019;70(4):246-258.

122. Jawhari S, Ratinaud MH, Verdier M. Glioblastoma, hypoxia and autophagy: a survival-prone 'ménage-à-trois'. Cell Death Dis. 2016;7(10):e2434.

123. Jing D, Zhang Q, Yu H et al. Identification of WISP1 as a novel oncogene in glioblastoma. Int J Oncol. 2017;51(4):1261-1270.

124. Johansson AC, La Fleur L, Melissaridou S, Roberg K. The relationship between EMT, CD44(high) /EGFR(low) phenotype, and treatment response in head and neck cancer cell lines. J Oral Pathol Med. 2016;45(9):640-646.

125. Kaeser PS, Deng L, Wang Y et al. RIM proteins tether Ca2+ channels to presynaptic active zones via a direct PDZ-domain interaction. Cell. 2011;144(2):282-95.

126. Kahlert UD, Suwala AK, Koch K et al. Pharmacologic Wnt Inhibition Reduces Proliferation, Survival., and Clonogenicity of Glioblastoma Cells. J Neuropathol Exp Neurol. 2015;74(9):889-900.

127. Kaina B, Christmann M. DNA repair in personalized brain cancer therapy with temozolomide and nitrosoureas. DNA Repair (Amst). 2019;78:128-141.

128. Kang GJ, Park MK, Byun HJ et al. SARNP, a participant in mRNA splicing and export, negatively regulates E-cadherin expression via interaction with pinin. J Cell Physiol. 2020; 235(2):1543-1555.

129. Karpel-Massler G, Westhoff MA, Kast RE et al. Erlotinib in Glioblastoma: Lost in Translation? Anticancer Agents Med Chem. 2011;11(8):748-55.

130. Katakowski M, Chopp M. Exosomes as Tools to Suppress Primary Brain Tumor. Cell Mol Neurobiol. 2016;36(3):343-52.

131. Kaur M, Bell T, Salek-Ardakani S, Hussell T. Macrophage adaptation in airway inflammatory resolution. Eur Respir Rev. 2015;24(137):510-5.

132. Kavanagh DP, Kalia N. Hematopoietic stem cell homing to injured tissues. Stem Cell Rev Rep. 2011;7(3):672-82.

133. Kawamura Y, Takouda J, Yoshimoto K, Nakashima K. New Aspects of Glioblastoma Multiforme Revealed by Similarities Between Neural and Glioblastoma Stem Cells. Cell Biol Toxicol. 2018;34(6):425-440.

134. Kellner S, DeMott MS, Cheng CP et al. Oxidation of phosphorothioate DNA modifications leads to lethal genomic instability. Nat Chem Biol. 2017;13(8):888-894. 
135. Kendall SE, Najbauer J, Johnston HF et al. Neural stem cell targeting of glioma is dependent on phosphoinositide 3-kinase signaling. Stem Cells. 2008; 26(6):1575-86.

136. Kenney-Herbert E, Al-Mayhani T, Piccirillo SG et al. CD15 Expression Does Not Identify a Phenotypically or Genetically Distinct Glioblastoma Population. Stem Cells Transl Med. 2015;4(7):822-31.

137. Khoei S, Shoja M, Mostaar A, Faeghi F. Effects of Resveratrol and Methoxyamine on the Radiosensitivity of Iododeoxyuridine in U87MG Glioblastoma Cell Line. Exp Biol Med (Maywood). 2016;241(11):1229-36.

138. Kierulf-Vieira KS, Sandberg CJ, Grieg Z et al. Wnt inhibition is dysregulated in gliomas and its re-establishment inhibits proliferation and tumor sphere formation. Exp Cell Res. 2016;340(1):53-61.

139. King HO, Brend T, Payne HL et al. RAD51 Is a Selective DNA Repair Target to Radiosensitize Glioma Stem Cells. Stem Cell Reports. 2017;8(1):125-139.

140. Kitahara CM, Wang SS, Melin BS et al. Association Between Adult Height, Genetic Susceptibility and Risk of Glioma. Int $\mathbf{J}$ Epidemiol. 2012;41(4):1075-85.

141. Kitange GJ, Mladek AC, Schroeder MA et al. Retinoblastoma Binding Protein 4 Modulates Temozolomide Sensitivity in Glioblastoma by Regulating DNA Repair Proteins. Cell Rep. 2016;14(11):2587-98.

142. Klughammer J, Kiesel B, Roetzer $\mathrm{T}$ et al. The DNA methylation landscape of glioblastoma disease progression shows extensive heterogeneity in time and space. Nat Med. 2018; 24(10):1611-1624.

143. Kondo Y, Katsushima K, Ohka F et al. Epigenetic Dysregulation in Glioma. Cancer Sci. 2014;105(4):363-9.

144. Kreth S, Thon N, Kreth FW. Epigenetics in Human Gliomas. Cancer Lett. 2014; 342(2):185-92.

145. Krishnan S, Szabo E, Burghardt I et al. Modulation of cerebral endothelial cell function by TGF- $\beta$ in glioblastoma: VEGF-dependent angiogenesis versus endothelial mesenchymal transition. Oncotarget. 2015;6(26):22480-95.

146. Kulason KO, Schneider JR, Chakraborty S et al. Superselective intraarterial cerebral infusion of cetuximab with blood brain barrier disruption combined with Stupp Protocol for newly diagnosed glioblastoma. J Exp Ther Oncol. 2018;12(3):223-229.

147. Kumar MS, Armenteros-Monterroso E, East P et al. Retraction: HMGA2 Functions as a Competing Endogenous RNA to Promote Lung Cancer 
Progression. Curr Neuropharmacol. 2020 May 28. doi: 10.2174/1570159X18666200528142429. Online ahead of print.

148. Kuzmich AS, Fedorov SN, Shastina VV et al. The Anticancer Activity of 3- And 10-bromofascaplysins Is Mediated by caspase-8, -9, -3-dependent Apoptosis. Bioorg Med Chem. 2010;18(11):3834-40

149. Lai YJ, Tsai JC, Tseng YT et al. Small G protein Rac GTPases regulate the maintenance of glioblastoma stem-like cells in vitro and in vivo. Oncotarget. 2017;8(11):18031-18049.

150. Lan X, Jörg DJ, Cavalli FMG et al. Fate mapping of human glioblastoma reveals an invariant stem cell hierarchy. Nature. 2017;549(7671):227-232.

151. Lasorella A, Sanson M, Iavarone A. FGFR-TACC gene fusions in human glioma. Neuro Oncol. $2017 ; 19(4): 475-483$.

152. Lassman AB, Pugh SL, Gilbert MR et al. Phase 2 Trial of Dasatinib in Target-Selected Patients With Recurrent Glioblastoma (RTOG 0627 Randomized, Double-Blind, Placebo-Controlled, Multicenter Phase II Study of Onartuzumab Plus Bevacizumab Versus Placebo Plus Bevacizumab in Patients With Recurrent Glioblastoma: Efficacy, Safety, and Hepatocyte Growth Factor and O6-Methylguanine-DNA Methyltransferase Biomarker Analyses. J Clin Oncol. 2017;35(3):343-351.

153. Lathia JD, Mack SC, Mulkearns-Hubert EE et al. Cancer stem cells in glioblastoma. Genes Dev. 2015;29(12):1203-17.

154. Laval B, Maurizio J, Kandalla PK et al. C/EBP $\beta$-Dependent Epigenetic Memory Induces Trained Immunity in Hematopoietic Stem Cells. Cell Stem Cell. 2020 May 7;26(5):657-674.e8.

155. Lee SY, Jeong EK, Ju MK et al. Induction of metastasis, cancer stem cell phenotype, and oncogenic metabolism in cancer cells by ionizing radiation. Mol Cancer. 2017;16(1):10.

156. Lee YK, Lee KW, Kim $M$ et al. Chelidonine Induces CaspaseDependent and Caspase-Independent Cell Death through G(2/M) Arrest in the T98G Human Glioblastoma Cell Line. Evid Based Complement Alternat Med. 2019 May;2019:6318179.

157. Lehmann S, Te Boekhorst V, Odenthal J et al. Hypoxia Induces a HIF-1-Dependent Transition from Collective-to-Amoeboid Dissemination in Epithelial Cancer Cells. Curr Biol. 2017;27(3):392-400.

158. Lei R, Li J, Liu F et al. HIF-1 $\alpha$ Promotes the Keloid Development Through the Activation of TGF- $\beta /$ Smad and TLR4/MyD88/NF- $\kappa$ B Pathways. Cell Cycle. 2019 Dec;18(23):3239-3250. 
159. Lesueur P, Lequesne J, Grellard JM et al. Phase I/IIa Study of Concomitant Radiotherapy With Olaparib and Temozolomide in Unresectable or Partially Resectable Glioblastoma: OLA-TMZ-RTE-01 Trial Protocol. BMC Cancer. 2019;19(1):198.

160. Lewellis SW, Knaut H. Attractive guidance: how the chemokine SDF1/CXCL12 guides different cells to different locations. Semin Cell Dev Biol. 2012;23(3):333-40.

161. Li P, Wu M. Epigenetic Mechanisms of Glioblastoma. Glioblastoma [Internet]. Brisbane (AU): Codon Publications; 2017. Chapter 3. DOI: https://doi.org/10. 15586/codon. glioblastoma.2017.ch3

162. Lin FG, Cheng HF, Lee IF et al. Downregulation of phospholipase C delta3 by cAMP and calcium. Biochem Biophys Res Commun. 2001;286(2):274-80.

163. Linkous A, Balamatsias D, Snuderl M et al. Modeling PatientDerived Glioblastoma with Cerebral Organoids. Cell Rep. 2019;26(12):32033211.e5.

164. Liu T, Xu H, Huang M et al. Circulating Glioma Cells Exhibit Stem Cell-like Properties. Cancer Res. 2018;78(23):6632-6642.

165. Liu W, Liu X, Wang L et al. PLCD3, a flotillin2-interacting protein, is involved in proliferation, migration and invasion of nasopharyngeal carcinoma cells. Oncol Rep. 2018; 39(1):45-52.

166. Liu Y. Leptomeningeal Carcinomatosis From Gastric Cancer Successfully Treated by the Intrathecal Methotrexate Plus Temozolomide and Simultaneous Radiotherapy: Case Report and Literatures Review. Cancer Biol Ther. 2017;18(10):761-764.

167. Lizarte Neto FS, Rodrigues AR, Trevisan FA et al., 2019. MicroRNA-181d associated with the methylation status of the MGMT gene in Glioblastoma multiforme cancer stem cells submitted to treatments with ionizing radiation and temozolomide. Brain Res. 2019 1720: 146302.

168. Louis DN, Perry A, Reifenberger G et al. The 2016 World Health Organization Classification of Tumors of the Central Nervous System: a summary. Acta Neuropathol. 2016 Jun;131(6):803-20.

169. Louis DN. The Next Step in Brain Tumor Classification: "Let Us Now Praise Famous Men"... or Molecules? Acta Neuropathol. 2012;124(6):761-2.

170. Lourenco S, Teixeira VH, Kalber T et al. Macrophage migration inhibitory factor-CXCR4 is the dominant chemotactic axis in human mesenchymal stem cell recruitment to tumors. J Immunol. 2015; 194(7):3463-74. 
171. Lu W, Lin C, King TD et al. Silibinin inhibits Wnt/ $\beta$-catenin signaling by suppressing Wnt co-receptor LRP6 expression in human prostate and breast cancer cells. Cell Signal. 2012; 24(12):2291-6.

172. Lucas B, Pérez LM, Gálvez BG. Importance and regulation of adult stem cell migration. J Cell Mol Med. 2018;22(2):746-754.

173. Lukas RV, Wainwright DA, Ladomersky E et al. Newly Diagnosed Glioblastoma: A Review on Clinical Management. Oncology (Williston Park). 2019;33(3):91-100.

174. Makowiecka A, Malek N, Mazurkiewicz E et al. Thymosin $\beta 4$ Regulates Focal Adhesion Formation in Human Melanoma Cells and Affects Their Migration and Invasion. Front Cell Dev Biol. 2019;7:304.

175. Manton CA, Johnson B, Singh M et al. Induction of cell death by the novel proteasome inhibitor marizomib in glioblastoma in vitro and in vivo. Sci Rep. 2016;6:18953.

176. Maraka S, Janku F. BRAF Alterations in Primary Brain Tumors. Discov Med. 2018; 26 (141):51-60.

177. Massacesi C, Di Tomaso E, Urban P et al. PI3K inhibitors as new cancer therapeutics: implications for clinical trial design. Onco Targets Ther. 2016; 9:203-10.

178. Matias D, Dubois LG, Pontes B et al. GBM-Derived Wnt3a Induces M2-Like Phenotype in Microglial Cells Through Wnt/ $\beta$-Catenin Signaling. Mol Neurobiol. 2019;56(2):1517-1530.

179. Matias D, Predes D, Niemeyer Filho P et al. Microglia-glioblastoma interactions: New role for Wnt signaling. Biochim Biophys Acta Rev Cancer. 2017;1868(1):333-340.

180. Méndez-Ferrer S, Michurina TV, Ferraro F et al. Mesenchymal and haematopoietic stem cells form a unique bone marrow niche. Nature. 2010;466(7308):829-34.

181. Mentkevich GL, Dolgopolov IS, Popa AV et al. Blood stem cell transplantation in pediatric oncology. Vestn Ross Akad Med Nauk. 2001;(9):89-92. Russian

182. Mercapide J, Anzanello F, Rappa G, Lorico A. Relationship Between Tumor Cell Invasiveness and Polyploidization. PLoS One. 2012;7(12):e53364.

183. Mercapide J, Rappa G, Lorico A. The intrinsic fusogenicity of glioma cells as a factor of transformation and progression in the tumor microenvironment. Int J Cancer. 2012; 131 (2):334-43. 
184. Mercatelli N, Galardi S, Ciafrè SA. MicroRNAs as Multifaceted Players in Glioblastoma Multiforme. Int Rev Cell Mol Biol. 2017;333:269-323.

185. Milkina E, Ponomarenko A, Korneyko $M$ et al. Interaction of hematopoietic CD34+ CD45+ stem cells and cancer cells stimulated by TGF- $\beta 1$ in a model of glioblastoma in vitro. Oncol Rep. 2018;40(5):2595-2607.

186. Miska J, Lee-Chang C, Rashidi A et al. HIF-1 $\alpha$ Is a Metabolic Switch between Glycolytic-Driven Migration and Oxidative PhosphorylationDriven Immunosuppression of Tregs in Glioblastoma. Cell Rep. 2019;27(1):226-237.

187. Mizumoto M, Yamamoto T, Ishikawa E et al. Proton beam therapy with concurrent chemotherapy for glioblastoma multiforme: comparison of nimustine hydrochloride and temozolomide. J Neurooncol. 2016;130(1):165-170.

188. Mizumoto M, Yamamoto T, Takano S et al. Long-term survival after treatment of glioblastoma multiforme with hyperfractionated concomitant boost proton beam therapy. Pract Radiat Oncol. 2015;5(1):e9-16.

189. Mooney KL, Choy W, Sidhu S et al. The role of CD44 in glioblastoma multiforme. J Clin Neurosci. 2016;34:1-5.

190. Morita T, Hayashi K. Tumor Progression Is Mediated by Thymosin- $\beta 4$ through a TGF $\beta / M R T F$ Signaling Axis. Mol Cancer Res. 2018;16(5):880-893.

191. Morris SL, Zhu P, Rao M et al. Gamma Knife Stereotactic Radiosurgery in Combination with Bevacizumab for Recurrent Glioblastoma. World Neurosurg. 2019;127:e523-e533.

192. Muldoon LL, Pagel MA, Netto JP, Neuwelt EA. Intra-arterial Administration Improves Temozolomide Delivery and Efficacy in a Model of Intracerebral Metastasis, but Has Unexpected Brain Toxicity. J Neurooncol. 2016;126(3):447-54.

193. Murnyák B, Kouhsari MC, Hershkovitch R et al. PARP1 Expression and Its Correlation With Survival Is Tumour Molecular Subtype Dependent in Glioblastoma. Oncotarget. 2017;8(28):46348-46362.

194. Nabors LB, Portnow J, Ammirati M et al. Central Nervous System Cancers, Version 1.2015. J Natl Compr Canc Netw. 2015;13(10):1191-202.

195. Nahomi RB, Nagaraj RH. The role of HIF-1 $\alpha$ in the TGF- $\beta 2-$ mediated epithelial-to-mesenchymal transition of human lens epithelial cells. J Cell Biochem. 2018; 119(8):6814-6827.

196. Nakamizo A, Marini F, Amano T et al. Human bone marrow-derived mesenchymal stem cells in the treatment of gliomas. Cancer Res. 2005; 65(8):3307-18. 
197. Nam JY, de Groot JF. Treatment of Glioblastoma. J Oncol Pract. 2017;13(10):629-638.

198. Neagu MR, Reardon DA. Rindopepimut vaccine and bevacizumab combination therapy: improving survival rates in relapsed glioblastoma patients? Immunotherapy. 2015; 7(6): 603-6.

199. Nervi B, Link DC, DiPersio JF. Cytokines and hematopoietic stem cell mobilization. J Cell Biochem. 2006;99(3):690-705.

200. Nguyen HS, Shabani S, Awad AJ et al. Molecular Markers of Therapy-Resistant Glioblastoma and Potential Strategy to Combat Resistance. Int J Mol Sci. 2018; 19 (6): 1765.

201. Nikuseva-Martić T, Beros V, Pećina-Slaus N et al. Genetic changes of CDH1, APC, and CTNNB1 found in human brain tumors. Pathol Res Pract. 2007;203(11):779-87.

202. Noch EK, Ramakrishna R, Magge R. Challenges in the Treatment of Glioblastoma: Multisystem Mechanisms of Therapeutic Resistance. World Neurosurg. 2018;116:505-517.

203. Nusblat LM, Carroll MJ, Roth CM. Crosstalk between M2 macrophages and glioma stem cells. Cell Oncol (Dordr). 2017 ;40(5):471-482.

204. Oberoi RK, Parrish KE, Sio TT et al. Strategies to improve delivery of anticancer drugs across the blood-brain barrier to treat glioblastoma. Neuro Oncol. 2016;18(1):27-36.

205. Oh TI, Lee JH, Kim S et al. Fascaplysin Sensitizes Anti-Cancer Effects of Drugs Targeting AKT and AMPK. Molecules. 2017;23(1):42.

206. Omuro A, DeAngelis LM. Glioblastoma and other malignant gliomas: a clinical review. JAMA. 2013 Nov 6;310(17):1842-50.

207. Or-Geva N, Reisner Y. Exercising 'veto' power to make haploidentical hematopoietic stem cell transplantation a safe modality for induction of immune tolerance. Regen Med. 2015;10(3):239-42.

208. Or-Geva N, Reisner Y. The evolution of T-cell depletion in haploidentical stem-cell transplantation. Br J Haematol. 2016;172(5):667-84.

209. Or-Geva N, Reisner Y. The role of donor-derived veto cells in nonmyeloablative haploidentical HSCT. Bone Marrow Transplant. 2015;50 Suppl 2:S14-20.

210. Osswald M, Jung E, Sahm F et al. Brain tumour cells interconnect to a functional and resistant network. Nature. 2015;528(7580):93-8. 
211. Ouanouki A, Lamy S, Annabi B. Anthocyanidins inhibit epithelialmesenchymal transition through a TGF $\beta / \mathrm{Smad} 2$ signaling pathway in glioblastoma cells. Mol Carcinog. 2017; 56(3):1088-1099.

212. Passarin MG, Moretto G, Musso AM. Intrathecal liposomal cytarabine in combination with temozolomide in low-grade oligoastrocytoma with leptomeningeal dissemination. J Neurooncol. 2010; 97(3):439-44.

213. Patel AP, Tirosh I, Trombetta JJ et al. Single-cell RNA-seq highlights intratumoral heterogeneity in primary glioblastoma. Science. 2014;344(6190):1396-401.

214. Paul-Samojedny M, Łasut B, Pudełko A et al. Methylglyoxal (MGO) inhibits proliferation and induces cell death of human glioblastoma multiforme T98G and U87MG cells. Biomed Pharmacother. 2016;80:236-243.

215. Pecchia I, Dini V, Ricci-Vitiani L, Biffoni M et al. Glioblastoma stem cells: radiobiological response to ionising radiations of different qualities. Radiat Prot Dosimetry. 2015;166(1-4): 374-8.

216. Peters KB, Lipp ES, Miller E et al. Phase I/II trial of vorinostat, bevacizumab, and daily temozolomide for recurrent malignant gliomas. J Neurooncol. 2018; 137(2):349-356.

217. Philp D, Kleinman HK. Animal studies with thymosin beta, a multifunctional tissue repair and regeneration peptide. Ann N Y Acad Sci. 2010;1194:81-6.

218. Phanstiel DH, Brumbaugh J, Wenger CD et al. Proteomic and phosphoproteomic comparison of human ES and iPS cells. Nat Methods. 2011; 8(10): $821-827$

219. Pierce H, Zhang D, Magnon C et al. Cholinergic Signals from the CNS Regulate G-CSF-Mediated HSC Mobilization from Bone Marrow via a Glucocorticoid Signaling Relay. Cell Stem Cell. 2017;20(5):648-658.e4.

220. Pitter KL, Tamagno I, Alikhanyan K et al. Corticosteroids compromise survival in glioblastoma. Brain. 2016;139(Pt 5):1458-71.

221. Pohl SG, Brook N, Agostino M et al. Wnt signaling in triple-negative breast cancer. Oncogenesis. 2017; 6(4):e310.

222. Poon CC, Sarkar S, Yong VW, Kelly JJP. Glioblastoma-associated microglia and macrophages: targets for therapies to improve prognosis. Brain. 2017;140(6):1548-1560.

223. Prionisti I, Bühler LH, Walker PR, Jolivet RB. Harnessing Microglia and Macrophages for the Treatment of Glioblastoma. Front Pharmacol. 2019; 10:506. 
224. Quezada C, Torres Á, Niechi I et al. Role of extracellular vesicles in glioma progression. Mol Aspects Med. 2018;60:38-51.

225. Ramalho MJ, Andrade S, Loureiro JA, do Carmo Pereira M. Nanotechnology to improve the Alzheimer's disease therapy with natural compounds. Drug Deliv Transl Res. 2020; 10(2):380-402.

226. Rasmussen RD, Gajjar MK, Tuckova L et al. Author Correction: BRCA1-regulated RRM2 Expression Protects Glioblastoma Cells From Endogenous Replication Stress and Promotes Tumorigenicity. Nat Commun. 2018;9(1):5396.

227. Reardon DA, Nabors LB, Mason WP et al. Phase I/randomized phase II study of afatinib, an irreversible ErbB family blocker, with or without protracted temozolomide in adults with recurrent glioblastoma. Neuro Oncol. 2015;17(3):430-9.

228. Reardon DA, Nabors LB, Mason WP et al. Phase I/randomized Phase II Study of Afatinib, an Irreversible ErbB Family Blocker, With or Without Protracted Temozolomide in Adults With Recurrent Glioblastoma. Neuro Oncol. 2015;17(3):430-9.

229. Reddy PS, Umesh S, Thota B et al. PBEF1/NAmPRTase/Visfatin: a potential malignant astrocytoma/glioblastoma serum marker with prognostic value. Cancer Biol Ther. 2008; 7 (5):663-8.

230. Reisner Y, Or-Geva N. Veto cells for safer nonmyeloablative haploidentical HSCT and CAR T cell therapy. Semin Hematol. 2019;56(3):173-182.

231. Revoltella RP, Menicagli M, Campani D. Granulocyte-macrophage colony-stimulating factor as an autocrine survival-growth factor in human gliomas. Cytokine. 2012; 57 (3): 347-59.

232. Rich JN. The role of transforming growth factor-beta in primary brain tumors. Front Biosci. 2003; 8:e245-60.

233. Rodríguez-García A, Samsó P, Fontova P et al. TGF- $\beta 1$ targets Smad, p38 MAPK, and PI3K/Akt signaling pathways to induce PFKFB3 gene expression and glycolysis in glioblastoma cells. FEBS J. 2017;284(20):3437-3454.

234. Rossi JF, Céballos P, Lu ZY. Immune precision medicine for cancer: a novel insight based on the efficiency of immune effector cells. Cancer Commun (Lond). 2019; 39(1):34.

235. Roy LO, Poirier MB, Fortin D. Chloroquine inhibits the malignant phenotype of glioblastoma partially by suppressing TGF-beta. Invest New Drugs. 2015;33(5):1020-31. 
236. Rozmyslowicz T, Majka M, Kijowski J et al. Platelet- and megakaryocyte-derived microparticles transfer CXCR4 receptor to CXCR4-null cells and make them susceptible to infection by X4-HIV. AIDS. 2003;17(1):33-42.

237. Saadatpour L, Fadaee E, Fadaei S et al. Glioblastoma: exosome and microRNA as novel diagnosis biomarkers. Cancer Gene Ther. 2016;23(12):415-418.

238. Saba F, Soleimani M, Kaviani S et al. G-CSF Induces Up-Regulation of CXCR4 Expression in Human Hematopoietic Stem Cells by BetaAdrenergic Agonist Hematology. 2015;20(8):462-468.

239. Sahariah P, Másson M. Antimicrobial Chitosan and Chitosan Derivatives: A Review of the Structure-Activity Relationship. Biomacromolecules. 2017;18(11):3846-3868.

240. Sankowski R, Böttcher C, Masuda T et al. Mapping microglia states in the human brain through the integration of high-dimensional techniques. Nat Neurosci. 2019; 22(12):2098-2110.

241. Sareddy GR, Kesanakurti D, Kirti PB, Babu PP. Nonsteroidal AntiInflammatory Drugs Diclofenac and Celecoxib Attenuates Wnt/ $\beta$-catenin/Tcf Signaling Pathway in Human Glioblastoma Cells. Neurochem Res. 2013;38(11):2313-22.

242. Sarkaria JN, Hu LS, Parney IF et al. Is the Blood-Brain Barrier Really Disrupted in All Glioblastomas? A Critical Assessment of Existing Clinical Data. Neuro Oncol. 2018; 20 (2):184-191.

243. Sasaki A. Microglia and brain macrophages: An update. Neuropathology. 2017; 37(5):452-464.

244. Sattiraju A, Sai KKS, Mintz A. Glioblastoma Stem Cells and Their Microenvironment. Adv Exp Med Biol. 2017;1041:119-140.

245. Scartoni D, Amelio D, Palumbo P et al. Proton therapy re-irradiation preserves health-related quality of life in large recurrent glioblastoma. J Cancer Res Clin Oncol. 2020; 146 (6):1615-1622.

246. Scheithauer BW, Fuller GN, VandenBerg SR. The 2007 WHO Classification of Tumors of the Nervous System: Controversies in Surgical Neuropathology. Brain Pathol. 2008;18(3):307-16.

247. Schiffer D, Annovazzi L, Casalone C et al. Glioblastoma: Microenvironment and Niche Concept. Neurol Sci. 2018; 39(7):1161-1168.

248. Schiffer D, Mellai M, Bovio E et al. Glioblastoma niches: from the concept to the phenotypical reality. Neurol Sci. 2018;39(7):1161-1168. 
249. Scodeller P, Simón-Gracia L, Kopanchuk S et al. Sci Rep. 2017;7(1):14655.

250. Segerman A, Niklasson M, Haglund $C$ et al. Clonal Variation in Drug and Radiation Response Among Glioma-Initiating Cells Is Linked to Proneural-Mesenchymal Transition. Cell Rep. 2016;17(11):2994-3009.

251. Segraves NL, Robinson SJ, Garcia D et al. Comparison of fascaplysin and related alkaloids: a study of structures, cytotoxicities, and sources. J Nat Prod. 2004; 67(5):783-92.

252. Seidel C, Kortmann RD. Corticosteroids compromise survival in glioblastoma patients after radio- and chemotherapy. Strahlenther Onkol. 2017;193(11):982-983. German

253. Seo S, Jeon HY, Kim H. Comparison of Cellular Transforming Activity of OCT4, NANOG, and SOX2 in Immortalized Astrocytes. DNA Cell Biol. 2017;36(11):1000-1009.

254. Seystahl K, Wick W, Weller M et al. Therapeutic options in recurrent glioblastoma--An update. Crit Rev Oncol Hematol. 2016; 99:389-408.

255. Sharifzad F, Ghavami S, Verdi J et al. Glioblastoma cancer stem cell biology: Potential theranostic targets. Drug Resist Updat. 2019;42:35-45.

256. Sharma A. Role of stem cell derived exosomes in tumor biology. Int J Cancer. 2018; 142(6):1086-1092.

257. Sharma HS, Muresanu DF, Castellani RJ et al. Pathophysiology of blood-brain barrier in brain tumor. Novel therapeutic advances using nanomedicine. Int Rev Neurobiol. 2020;151:1-66.

258. Sharma HS, Muresanu DF, Castellani RJ et al. Pathophysiology of blood-brain barrier in brain tumor. Novel therapeutic advances using nanomedicine. Int Rev Neurobiol. 2020;151:1-66.

259. Shevchenko V, Arnotskaya N, Korneyko M et al. Proteins of the Wnt Signaling Pathway as Targets for the Regulation of CD133+ Cancer Stem Cells in Glioblastoma. Oncol Rep. 2019;41(5):3080-3088.

260. Shevchenko V, Arnotskaya N, Pak O et al. Molecular determinants of the interaction between glioblastoma CD133+ cancer stem cells and the extracellular matrix. Int Rev Neurobiol. 2020;151:155-169.

261. Sidlik-Muskatel R, Reisner Y. Toward safer haploidnetical hematopoietic stem cell transplantation. Bone Marrow Transplant. 2019;54(Suppl 2):733-737.

262. Singh SK, Clarke ID, Terasaki M et al. Identification of a cancer stem cell in human brain tumors. Cancer Res. 2003;63(18):5821-8. 
263. Singh SK, Hawkins C, Clarke ID et al. Identification of Human Brain Tumour Initiating Cells. Nature. 2004;432(7015):396-401.

264. Sofias AM, Dunne M, Storm G, Allen C. The battle of "nano" paclitaxel. Adv Drug Deliv Rev. 2017;122:20-30.

265. Stadlbauer A, Zimmermann M, Oberndorfer S et al. Vascular Hysteresis Loops and Vascular Architecture Mapping in Patients With Glioblastoma Treated With Antiangiogenic Therapy. Sci Rep. 2017;7(1):8508.

266. Stritzelberger J, Distel L, Buslei R et al. Acquired temozolomide resistance in human glioblastoma cell line U251 is caused by mismatch repair deficiency and can be overcome by lomustine. Clin Transl Oncol. 2018;20(4):508-516.

267. Stupp R, Brada M, van den Bent MJ et al. High-grade glioma: ESMO Clinical Practice Guidelines for diagnosis, treatment and follow-up. Ann Oncol. 2014;25 Suppl 3:iii93-101.

268. Stupp R, Lukas RV, Hegi ME. Improving survival in molecularly selected glioblastoma. Lancet. 2019;393(10172):615-617.

269. Stupp R, Mason WP, van den Bent MJ et al. Radiotherapy plus concomitant and adjuvant temozolomide for glioblastoma. $\mathrm{N}$ Engl $\mathrm{J}$ Med. 2005;352(10):987-96.

270.Stupp R, Taillibert S, Kanner A et al. Effect of Tumor-Treating Fields Plus Maintenance Temozolomide vs Maintenance Temozolomide Alone on Survival in Patients With Glioblastoma: A Randomized Clinical Trial. JAMA. 2017;318(23):2306-2316.

271.Stupp R, Taillibert S, Kanner A et al. Effect of Tumor-Treating Fields Plus Maintenance Temozolomide vs Maintenance Temozolomide Alone on Survival in Patients With Glioblastoma: A Randomized Clinical Trial. JAMA. 2017;318(23):2306-2316.

272. Sugiura N, Patel RG, Corriveau RA. N-methyl-D-aspartate receptors regulate a group of transiently expressed genes in the developing brain. J Biol Chem. 2001;276(17):14257-63.

273. Sun C, Zhao D, Dai X et al. Fusion of Cancer Stem Cells and Mesenchymal Stem Cells Contributes to Glioma Neovascularization. Oncol Rep. 2015;34(4):2022-30.

274. Sundar SJ, Hsieh JK, Manjila S et al. The role of cancer stem cells in glioblastoma. Neurosurg Focus. 2014;37(6):E6.

275. Suzuki Y, Shirai M, Asada K et al. Macrophage mannose receptor, CD206, predict prognosis in patients with pulmonary tuberculosis. Sci Rep. 2018;8(1):13129. 
276. Syed V. TGF- $\beta$ Signaling in Cancer. J Cell Biochem. 2016;117(6):1279-87.

277. Tabet A, Jensen MP, Parkins CC et al. Designing Next-Generation Local Drug Delivery Vehicles for Glioblastoma Adjuvant Chemotherapy: Lessons From the Clinic. Adv Healthc Mater. 2019 Feb; 8(3):e1801391.

278. Taspinar M, Ilgaz S, Ozdemir $M$ et al. Effect of LomeguatribTemozolomide Combination on MGMT Promoter Methylation and Expression in Primary Glioblastoma Tumor Cells. Tumour Biol. 2013;34(3):1935-47.

279. Telford WG. Stem cell side population analysis and sorting using DyeCycle violet. Curr Protoc Cytom. 2010; Chapter 9:Unit9.30.

280. Thakkar JP, Dolecek TA, Horbinski C et al. Epidemiologic and Molecular Prognostic Review of Glioblastoma. Cancer Epidemiol Biomarkers Prev. 2014;23(10):1985-96.

281. Tong WW, Tong GH, Liu Y. Cancer stem cells and hypoxiainducible factors. Int J Oncol. 2018;53(2):469-476.

282. Tong WY, Alnakhli M, Bhardwaj R et al. Delivery of siRNA in vitro and in vivo using PEI-capped porous silicon nanoparticles to silence MRP1 and inhibit proliferation in glioblastoma. J Nanobiotechnology. 2018;16(1):38.

283. Torres Á, Arriagada V, Erices JI et al. FK506 Attenuates the MRP1Mediated Chemoresistant Phenotype in Glioblastoma Stem-Like Cells. Int J Mol Sci. 2018; 19 (9): 2697.

284. Touat M, Idbaih A, Sanson M, Ligon KL. Glioblastoma Targeted Therapy: Updated Approaches From Recent Biological Insights. Ann Oncol 2017; 28(7):1457-1472.

285. Tuazon JP, Castelli V, Lee JY et al. Neural Stem Cells. Adv Exp Med Biol. 2019;1201:79-91.

286. Tupitsyn NN, Yaryghin VN, Bryukhovetskiy AS et al. Immunophenotypic peculiarities of mobilized stem (CD34+) cells in blood from patients with severe spinal cord injury. J Biol Regul Homeost Agents. 2006; 20(1-2):36-40.

287. Umphlett M, Shea S, Tome-Garcia J et al. Widely metastatic glioblastoma with BRCA1 and ARID1A mutations: a case report BMC Cancer. 2020;20(1):47.

288. Urhie O, Turner R, Lucke-Wold B et al. Glioblastoma Survival Outcomes at a Tertiary Hospital in Appalachia: Factors Impacting the Survival of Patients Following Implementation of the Stupp Protocol. World Neurosurg. 2018 Jul;115:e59-e66. 
289. Valtorta S, Lo Dico A, Raccagni I et al. Oncotarget. 2017;8(68):113090-113104.

290. Verhaak RG, Hoadley KA, Purdom E et al. Integrated Genomic Analysis Identifies Clinically Relevant Subtypes of Glioblastoma Characterized by Abnormalities in PDGFRA, IDH1, EGFR, and NF1. Cancer Cell. 2010;17(1):98-110.

291. Vick NA, Khandekar JD, Bigner DD. Chemotherapy of brain tumors. Arch Neurol. 1977 Sep;34(9):523-6.

292. Waitkus MS, Diplas BH, Yan H. Biological Role and Therapeutic Potential of IDH Mutations in Cancer. Cancer Cell. 2018;34(2):186-195.

293. Wang D, Berglund A, Kenchappa RS et al. BIRC3 is a novel driver of therapeutic resistance in Glioblastoma. Sci Rep. 2016;6:21710.

294. Wang G, Wang JJ, Fu XL et al. Advances in the targeting of HIF-1 $\alpha$ and future therapeutic strategies for glioblastoma multiforme (Review). Oncol Rep. 2017;37(2):657-670.

295. Wang J, Liu J, Meng H et al. Neural stem cells promote glioblastoma formation in nude mice. Clin Transl Oncol. 2019 Nov;21(11):1551-1560.

296. Wang W, Zhao Z, Wu F et al. Bioinformatic analysis of gene expression and methylation regulation in glioblastoma. $\mathbf{J}$ Neurooncol. 2018;136(3):495-503.

297. Wang Y, Kong X, Guo Y et al. Continuous dose-intense temozolomide and cisplatin in recurrent glioblastoma patients. Medicine (Baltimore). 2017;96(10):e6261.

298. Wang Y, Liu S, Wei X et al. Non-small cell lung cancer leptomeningeal metastases treated with intrathecal therapy plus osimertinib and temozolomide and whole-brain radiation therapy: a case report. Onco Targets Ther. 2018;11:4733-4738.

299. Wang Y, Zhou CJ, Liu Y. Wnt Signaling in Kidney Development and Disease. Prog Mol Biol Transl Sci. 2018; 153:181-207.

300. Wegner RE, Abel S, Horne ZD et al. National Trends in Radiation Dose Escalation for Glioblastoma. Radiat Oncol J. 2019;37(1):13-21.

301. Weil S, Osswald M, Solecki G et al. Tumor microtubes convey resistance to surgical lesions and chemotherapy in gliomas. Neuro Oncol. 2017;19(10):1316-1326.

302. Weller M, Butowski N, Tran DD et al. Rindopepimut with temozolomide for patients with newly diagnosed, EGFRvIII-expressing glioblas- 
toma (ACT IV): a randomised, double-blind, international phase 3 trial. Lancet Oncol. 2017 Oct;18(10):1373-1385.

303. Weller M, Cloughesy T, Perry JR, Wick W. Standards of care for treatment of recurrent glioblastoma--are we there yet? Neuro Oncol. 2013;15(1):4-27.

304. Weller M, Le Rhun E, Preusser M et al. How we treat glioblastoma. ESMO Open. 2019; 4(Suppl 2):e000520.

305. West MD, Vaziri H. Back to Immortality: The Restoration of Embryonic Telomere Length During Induced Pluripotency. Regen Med. 2010;5(4):485-8.

306. Wick A, Desjardins A, Suarez C et al. Phase 1b/2a study of galunisertib, a small molecule inhibitor of transforming growth factor-beta receptor I, in combination with standard temozolomide-based radiochemotherapy in patients with newly diagnosed malignant glioma. Invest New Drugs. 2020 Mar 5. doi: 10.1007/s10637-020-00910-9. Online ahead of print.

307. Wick W, Naumann U, Weller M. Transforming growth factor-beta: a molecular target for the future therapy of glioblastoma. Curr Pharm Des. 2006;12(3):341-9.

308. Widel M. Radionuclides in Radiation-Induced Bystander Effect; May It Share in Radionuclide Therapy? Neoplasma. 2017;64(5):641-654.

309. Wilcox JA, Ramakrishna R, Magge R. Immunotherapy in Glioblastoma. World Neurosurg. 2018;116:518-528.

310. Wirsching HG, Galanis E, Weller M. Glioblastoma. Handb Clin Neurol. 2016;134:381-97.

311. Wohlfart S, Gelperina S, Kreuter J. Transport of drugs across the blood-brain barrier by nanoparticles. J Control Release. 2012;161(2):264-73.

312. Wurmser AE, Gage FH. Stem cells: cell fusion causes confusion. Nature. 2002; 416 (6880):485-7.

313. Yan S, Li A, Liu Y. CacyBP/SIP inhibits the migration and invasion behaviors of glioblastoma cells through activating Siah1 mediated ubiquitination and degradation of cytoplasmic p27. Cell Biol Int. 2018;42(2):216-226.

314. Yang SW, Zhang ZG, Hao YX et al. HIF-1 $\alpha$ Induces the EpithelialMesenchymal Transition in Gastric Cancer Stem Cells Through the Snail Pathway. Oncotarget. 2017; 8(6):9535-9545.

315. Yang Y, Cai Y, Zhang Y et al. Exosomes Secreted by AdiposeDerived Stem Cells Contribute to Angiogenesis of Brain Microvascular Endo- 
thelial Cells Following Oxygen-Glucose Deprivation In Vitro Through MicroRNA-181b/TRPM7 Axis. J Mol Neurosci. 2018;65(1):74-83.

316. Yankelevich M, Savasan S, Dolgopolov I et al. Small Split Doses of CD34+ Peripheral Blood Stem Cells to Support Repeated Cycles of Nonmyeloablative Chemotherapy. Case Rep Oncol Med. 2017;2017:4184879.

317. Yin L, Gao Y, Zhang X et al. Niclosamide Sensitizes TripleNegative Breast Cancer Cells to Ionizing Radiation in Association With the Inhibition of Wnt/ $\beta$-catenin Signaling. Oncotarget. 2016;7(27):42126-42138.

318. Young JD, Lawrence AJ, MacLean AG et al. Thymosin beta 4 sulfoxide is an anti-inflammatory agent generated by monocytes in the presence of glucocorticoids. Nat Med. 1999 ;5(12):1424-7.

319. Yu R, Li Q, Feng Z et al. m6A Reader YTHDF2 Regulates LPSInduced Inflammatory Response. nt J Mol Sci. 2019; 20(6):1323.

320.Zaitsev S, Sharma HS, Sharma A et al. Pro-inflammatory modification of cancer cells microsurroundings increases the survival rates for rats with low differentiated malignant glioma of brain. Int Rev Neurobiol. 2020;151:253-279.

321. Zaitsev S, Sharma HS, Sharma A et al. Pro-inflammatory modification of cancer cells microsurroundings increases the survival rates for rats with low differentiated malignant glioma of brain. Int Rev Neurobiol. 2020;151:253-279.

322.Zang C, Liu X, Li B et al. IL-6/STAT3/TWIST inhibition reverses ionizing radiation-induced EMT and radioresistance in esophageal squamous carcinoma. Oncotarget. 2017; 8(7):11228-11238.

323. Zeng C, Zhang Y, Park SC et al. CD34(+) Liver Cancer Stem Cells Were Formed by Fusion of Hepatobiliary Stem/Progenitor Cells with Hematopoietic Precursor-Derived Myeloid Intermediates. Stem Cells Dev. 2015;24(21):2467-78.

324. Zhang J, Xiao X, Zhang X, Hua W. Tumor Microenvironment Characterization in Glioblastoma Identifies Prognostic and Immunotherapeutically Relevant Gene Signatures. J Mol Neurosci. 2020;70(5):738-750.

325. Zhang LN, Kong CF, Zhao D et al. Fusion with mesenchymal stem cells differentially affects tumorigenic and metastatic abilities of lung cancer cells. J Cell Physiol. 2019; 234 (4):3570-3582.

326. Zhang M, Herion TW, Timke C et al. Trimodal glioblastoma treatment consisting of concurrent radiotherapy, temozolomide, and the novel TGF$\beta$ receptor I kinase inhibitor LY2109761. Neoplasia. 2011;13(6):537-49. 
327.Zhang N, Hong B, Zhou C et al. Cobalt Chloride-induced Hypoxia Induces Epithelial-mesenchymal Transition in Renal Carcinoma Cell Lines. Ann Clin Lab Sci. 2017; 47(1):40-46.

328. Zhao C, Wang H, Xiong C, Liu Y. Hypoxic glioblastoma release exosomal VEGF-A induce the permeability of blood-brain barrier. Biochem Biophys Res Commun. 2018; 502 (3):324-331.

329. Zhao D, Najbauer J, Garcia E et al. Neural stem cell tropism to glioma: critical role of tumor hypoxia. Mol Cancer Res. 2008;6(12):1819-29.

330. Zhen Y, Zhao S, Li Q et al. Arsenic trioxide-mediated Notch pathway inhibition depletes the cancer stem-like cell population in gliomas. Cancer Lett. 2010;292(1):64-72.

331. Zhidkov ME, Smirnova PA, Tryapkin OA et al. Total Syntheses and Preliminary Biological Evaluation of Brominated Fascaplysin and Reticulatine Alkaloids and Their Analogues. Mar Drugs. 2019;17(9):496.

332.Zhou X, Liao X, Wang X et al. Noteworthy prognostic value of phospholipase $\mathrm{C}$ delta genes in early stage pancreatic ductal adenocarcinoma patients after pancreaticoduodenectomy and potential molecular mechanisms. Cancer Med. 2020; 9(3): 859-871.

333. Zhou XD, Wang XY, Qu FJ et al. Detection of cancer stem cells from the C6 glioma cell line. J Int Med Res. 2009;37(2):503-10. 
Aвmopbl:

Брюховецкий Игорь Степанович, доктор медицинских наук, заместитель проректора по медицинским вопросам ДВФУ, директор Департамента фундаментальной медицины, заведующий лабораторией молекулярной и клеточной нейробиологии Школы биомедицины ДВФУ;

Брюховецкий Андрей Степанович, доктор медицинских наук, профессор, генеральный директор 3АО «Клиника "Нейровита"»; Хотимченко Юрий Степанович, доктор биологических наук, профессор, директор Школы биомедицины ДВФУ;

Пак Олег Игоревич, кандидат медицинских наук, главный врач Медицинского центра ДВФУ, проректор по медицинским вопросам ДВФУ;

Шевченко Валерий Евгеньевич, доктор биологических наук, профессор, главный научный сотрудник лаборатории онкопротеомики НИИ канцерогенеза НМИЦ онкологии им.Н.Н. Блохина (г. Москва);

Зайцев Сергей Викторович, младший научный сотрудник лаборатории молекулярной и клеточной нейробиологии Школы биомедицины ДВФУ;

Ляхова (Выговская) Ирина Александровна, младший научный сотрудник лаборатории молекулярной и клеточной нейробиологии Школы биомедицины ДВФУ 
Научное издание

Брюховецкий Игорь Степанович, Брюховецкий Андрей Степанович, Хотимченко Юрий Степанович и др.

\title{
ГЛИОБЛАСТОМА И СТВОЛОВЫЕ КЛЕТКИ КОСТНОГО МОЗГА
}

\author{
Монография \\ Редактор И.А. Гончарук \\ Компьютерная верстка и дизайн обложки Е.П. Давыгора
}

Подписано в печать 28.08 .2020 г. Формат $60 \times 84$ / 16. Усл. печ. л. 14,76 .

Тираж 500 экз. (1-й завод 1-50). Заказ 185.

Дальневосточный федеральный университет

690922, Приморский край, г. Владивосток, о. Русский, п. Аякс, 10.

Отпечатано в Дальневосточном федеральном университете 690922, Приморский край, г. Владивосток, о. Русский, п. Аякс, 10.

(Типография Издательства ДВФУ, 690091, г. Владивосток, ул. Пушкинская, 10) 